NUREG-0278

$$
\text { Vol. } 2
$$

\title{
TECHNOLOGY, SAFETY, AND COSTS OF DECOMMISSIONING A REFERENCE NUCLEAR FUEL REPROCESSING PLANT
}

Battelle Pacific Northwest Laboratory for

U. S. Nuclear Regulatory Commission 


\section{NOTICE}

This report was prepared as an account of work sponsored by the United States Government. Neither the United States nor the United States Nuclear Regulatory Commission, nor any of their employees, nor any of their contractors, subcontractors, or their employees, makes any warranty, express or implied, nor assumes any legal liability or responsibility for the accuracy, completeness or usefulness of any information, apparatus, product or process disclosed, nor represents that its use would not infringe privately owned rights.

Available from

National Technical Information Service

Springfield, Virginia 22161

Price: Printed Copy $\$ 14.00$; Microfiche $\$ 3.00$

The price of this document for requesters outside of the North American Continent can be obtained from the National Technical Information Service. 


\section{DISCLAIMER}

This report was prepared as an account of work sponsored by an agency of the United States Government. Neither the United States Government nor any agency Thereof, nor any of their employees, makes any warranty, express or implied, or assumes any legal liability or responsibility for the accuracy, completeness, or usefulness of any information, apparatus, product, or process disclosed, or represents that its use would not infringe privately owned rights. Reference herein to any specific commercial product, process, or service by trade name, trademark, manufacturer, or otherwise does not necessarily constitute or imply its endorsement, recommendation, or favoring by the United States Government or any agency thereof. The views and opinions of authors expressed herein do not necessarily state or reflect those of the United States Government or any agency thereof. 


\section{DISCLAIMER}

Portions of this document may be illegible in electronic image products. Images are produced from the best available original document. 


\title{
TECHNOLOGY, SAFETY, AND COSTS OF DECOMMISSIONING A REFERENCE NUCLEAR FUEL REPROCESSING PLANT
}

\author{
K. J. Schneider and C. E. Jenkins, Study Coordinators \\ and \\ $\checkmark$ R. E. Rhoads \\ J. Mishima \\ P. J. Pelto \\ L. P. Williams \\ R. I. Smith \\ E. C. Watson \\ I. F. Nemec \\ G. H. Winson \\ J. F. Johnson \\ E. S. Murphy
}

Manuscript Completed: September 1977

Date Published: October 1977
Battelle Pacific Northwest Laboratory
Battelle Boulevard
Richland, WA 99352

Prepared for

Division of Engineering Standards

Office of Standards Development

U. S. Nuclear Regulatory Commission

Under Contract No. EY-76-C-06-1830 
0 


\section{CONTENTS}

A. FACILITY DESCRIPTION . . . . . . . . . . . . . . . . A-1

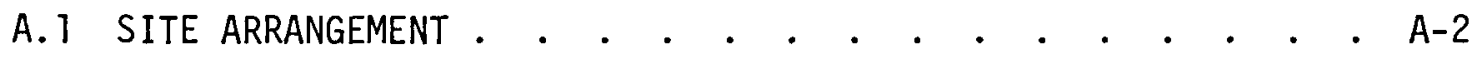

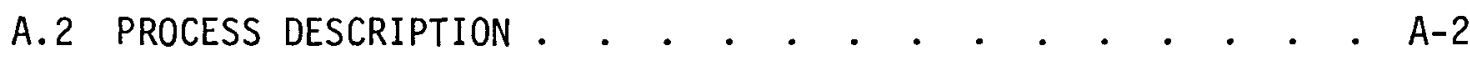

A.3 MAIN PROCESS BUILDING EQUIPMENT AND STRUCTURES . • • • . A-17

A.3.1 Remote Process Cel1. . . . . . . . . . . . A-17

A.3.2 Remote Maintenance and Scrap Cell . . . . . . . A-26

A.3.3 Uranium Product Cell . . . . . . . . . . . A-30

A.3.4 Intermediate Level Cell . . . . . . . . . . A-35

A.3.5 High Level Cell . . . . . . . . . . . . . A-44

A.3.6 High-Intermediate Level Cel1. . . . . . . . . A-49

A.3.7 Plutonium Product Cel1. . . . . . . . . . . A-57

A.3.8 Plutonium Nitrate Storage and Loadout. . . . . A-63

A.3.9 Control Room Area (CRA) . . . . . . . . . . A-69

A.3.10 Galleries. . . . . . . . . . . . . . A-69

A.3.11 Stations • . . . . . . . . . . . . . . A-71

A.3.12 Sample and Analytical Cell (SAC) . . . . . . A-74

A.3.13 Decontamination Facilities . . . . . . . . . A-75

\begin{tabular}{l} 
A.4 FUEL RECEIVING AND STORAGE STATION STRUCTURES \\
AND EQUIPMENT \\
\hline
\end{tabular}

A.5 LIQUID RADIOACTIVE WASTE STORAGE FACILITY. • • • . • . A-76

A.5.1 High-Level Liquid Waste Storage (HLLW) . . . . . A-76

A.5.2 Intermediate-Level Liquid Waste Storage (ILLW). . . A-87

A.5.3 Waste Tank Equipment Gallery (WTEG) . . . . . . A-91

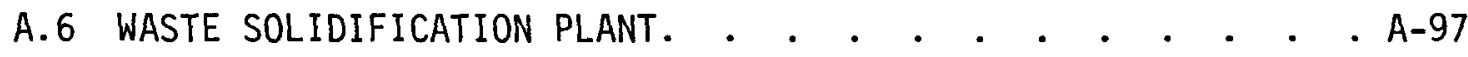


A.6.1 Waste Vitrification Cell . . . . . . . . . A-97

A.7 AUXILIARY PROCESS SYSTEMS AND SERVICE AREAS . . . . . . A-106

A.7.1 Ventilation System . . . . . . . . . .A-106

A.7.2 Water Reservoir . . . . . . . . . . . .A-115

A.7.3 Electrical Power System . . . . . . . . . A-115

A.7.4 Fire Protection System. . . . . . . . . . .A-116

A.7.5 Hot and Cold Laboratory Area (HCLA) . . . . . .A-118

B. RESIDUAL RADIOACTIVITY INVENTORY ESTIMATES . . . . . . . .

B. 1 KEY ASSUMPTIONS . . . . . . . . . . . . . . . . . B-1

B.2 REFERENCE FUEL AND HIGH-LEVEL WASTE. • . • • • • • • B-2

B.3 ESTIMATES OF RADIOACTIVITY LEVELS IN THE PROCESS

B.4 ESTIMATES OF RADIOACTIVITY LEVELS IN HLLW and ILLW
STORAGE TANKS AFTER PLANT SHUTDOWN . . . . . B-9

B.4.1 Radioactivity Levels in Waste Solutions . . . . B-12

B.4.2 Solution Remaining in Tanks . . . . . . . B-12

B.4.3 Radioactivity Adhering to Internals . . . . . B-12

B.4.4 Radioactivity on the Tank Bottoms . . . . . . B-13

B.5 ESTIMATES OF RADIOACTIVITY LEVELS IN HLLW AND ILLW STORAGE

TANKS FOLLOWNG CHEMICAL DECONTAMINATION . . . . . . . B-13

B.5.1 Radioactivity Estimates in the Layaway Mode. . . . B-17

B.5.2 Radioactivity Estimates in the Protective Storage Mode . . . . . . . . . . . . . B-17

B.5.3 Radioactivity Estimates in the Dismantlement Mode. . B-17

B.6 WASTE SOLIDIFICATION PLANT RADIONUCLIDE INVENTORIES • • • B-17

C. REFERENCE SITE - DESCRIPTION AND CONTAMINATION LEVELS . . . . c c-1

C.1 SITE LOCATION . . . . . . . . . . . . . . . . C-1

C.2 DEMOGRAPHY . . . . . . . . . . . . . . . . . . C-2 
C. 3 LAND USE.

C.4 WATER USE . . . . . . . . . . . . . . . . . C-3

C.5 GEOLOGY . . . . . . . . . . . . . . . . . C-4

C.6 HYDROLOGY . . . . . . . . . . . . . . . . . C -5

C.7 METEOROLOGY. . . . . . . . . . . . . . . . . C-10

C.8 ECOLOGY. . . . . . . . . . . . . . . . . . C-14

C.8.1 Terrestrial Ecology. . . . . . . . . . . C-14

C.8.2 Aquatic Ecology . . . . . . . . . . . C-17

C.9 RADIOLOGICAL CHARACTERISTICS . . . . . . . . . . . C-19

C.9.1 Natural Occurring Radiation . . . . . . . . C-19

C.9.2 Radionuclides from Nuclear Weapons Testing . . . . C-21

C.9.3 Radionuclides from Plant Operation. . . . . . C-21

D. DERIVATION OF RESIDUAL CONTAMINATION LEVELS . . • • . . • . D-1

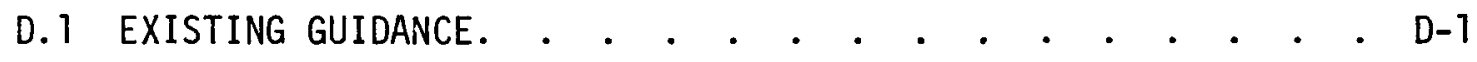

D.2 TECHNICAL APPROACH . . . . . . . . . . . . . D - . 5

D.2.1 Residual Radioactive Contamination Levels . . . . D-5

D.2.2 Dose Calculations . . . . . . . . . . D-6

D.2.3 Allowable Residual Contamination Levels . . . . . D-7

REFERENCES. • • • • • • • • • • • • • • • • • . D-22

E. DECOMMISSIONING MODE DETAIL . . . . . . . . . . . . . . E-1

E.1 QUALITY ASSURANCE PROGRAM . . . . . . . . . . . . . . E-1

E.2 DECONTAMINATION METHODS. . . . . . . . . . . . . E-4

E.2.1 Chemical Decontamination Procedures . . . . E-4

E.2.2 Mechanical Decontamination Techniques. . . . . E-7 
E.3 DISMANTLEMENT MODE SUPPORTING INFORMATION. . . . . . . E-14

E.3.1 Equipment Removal Operations in the Process

Cells of the Main Process Building. . . . . . E-14

E.3.2 Sequence of Events for Filter Niche Decontamination . . . . . . . . . . E-36

E.3.3 Sequence of Events for the Dismantlement of the Liquid Waste Storage Facility. . . . . . . E-37

E.3.4 Dismantlement Details for the Waste Solidification Plant . . . . . . . . . E-45

E.3.5 Sequence of Events for Fuel Receiving and Storage Station Decontamination . . . . . . . . . E-48

E.3.6 Special Equipment and Material Requirements. . . E-51

E.4 PROTECTIVE STORAGE MODE SUPPORTING INFORMATION • • • • • E-75

E.4.1 Procedures for Sealing Contaminated Areas . . . E-75

E.4.2 Decontamination and Isolation Procedures for Gloveboxes, Hoods and the Sample and Analytical Cells. . . . . . . . . . E-76

E.4.3 Sequence of Events for Placing the Fuel Receiving and Storage Station in Protective Storage.

E.4.4 Sequence of Events for Placing the Waste Solidification Plant in Protective Storage. . . . E-79

E.4.5 Sequence of Events for Placing the Fuel Receiving and Storage Station in Protective Storage . . . E-80

E.5 LAYAWAY MODE SUPPORTING INFORMATION. . . . . . . . . E-83

E.6 DECOMMISSIONING WASTES AND WASTE DISPOSAL. . . . . . . E-84

E.7 DECOMMISSIONING MANPOWER REQUIREMENTS . . . . . . • . E-91

E.7.1 Staff Labor Job Descriptions. . . . . . . . E-9]

E.7.2 Details of Decommissioning Worker Manpower Requirements . . . . . . . . . . . . . . E-93

E.8 COST ESTIMATE DETAILS . . . . . . • • • • • . . . . E-114 
E.8.1 Labor and Subcontractor Cost Details . . . . .E-114

E.8.2 Special Equipment Costs . . . . . . . . .E-121

E.8.3 Waste Management Cost . . . . . . . . . . .E-123

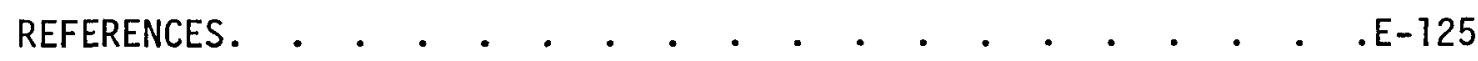

F. DECOMMISSIONING SAFETY ASSESSMENT DETAILS. . . . . . . . . . F-1

F.1 KEY ASSUMPTIONS USED IN THE SAFETY ASSESSMENT • • • • •

F.2 SAFETY IMPACTS OF DECOMMISSIONING ACTIVITIES. . . . . . F-2

F.2.1 Releases of Radioactive Material to the Environment . . . . . . . . . . . . . F-4

F.2.2 Occupational Radiation Exposure. . . . . . . . F-48

F.2.3 Hazardous Chemical Releases During Decommissioning Operations. . . . . . . . . . . . . . . F-48

F.2.4 Construction/Industrial Accidents . . . . . . . F-53

F.3 TRANSPORTATION SAFETY . . . . . . . . . . . . . . F-54

F.3.1 Procedures and Standards for Transporting Radioactive Wastes . . . . . . . . . . . F-54

F.3.2 Radiological Transportation Safety Impacts . . . . F-57

F.3.3 Nonradiological Transportation Safety Impacts . . . F-62

F.4 RADIATION DOSE MODELS . . . . . . . . . . . . . . . F-63

F.4.1 Models for Estimating Normal Radiation dose to Man . F-63

F.4.2 Model and Calculations for Radiation Exposure

Rates in Process Cells. . . . . . . . . . F-74

F.4.3 Application of Radiation Dose Models . . . . . . F-75

F.4.4 Effection of Radioactive Decay on Radiation Dose Calculations . . . . . . . . . . F-85

REFERENCES. • • • • • • • • • • • • • • • • . . F-94 
VOLUME 2

\section{FIGURES}

Figure

A.1-1 Plot Plan Complex. . . . . . . . . . . . . . . A-3

A.2-1 Overall Process Flowsheet for the Barnwell

Nuclear Fuel Plant . . . . . . . . . . . . . A-7

A.2-2 Effluent and Waste Treatment Process Flow Diagram

for the Reference Fuel Reprocessing Plant. . . . . . . A-12

A.2-3 High and Intermediate-Level Waste Vitrification

Flow Diagram . . . . . . . . . . . . . . A-14

A.3-1 General Arrangement of Main Process Building and

Fuel Receiving and Storage Station Grade Level . . . . . A-19

A.3-2 General Arrangement of Main Process Building and Fuel

Receiving and Storage Station Upper Elevations . . . . . A-21

A.3-3 General Sections Through Main Process Building and

Fuel Receiving and Storage Stations. . . . . . . . A-23

A.3-4 Remote Process Cell Equipment Arrangement Plan . . . . A-27

A.3-5 Remote Process Cell Equipment Arrangement Overal1

Section . . . . . . . . . . . . . . . A-29

A.3-6 Remote Maintenance and Scrap Cel1 - Equipment

Arrangement Plan . . . . . . . . . . . . . . A-31

A.3-7 Remote Maintenance and Scrap Cel1 - Equipment

Arrangement Sections. . . . . . . . . . . . . A-33

A.3-8 Uranium Product Cell Equipment Arrangement . . . . . . A-37

A.3-9 Uranium Product Cell (UPC) - Equipment

Arrangement Elevation . . . . . . . . . . . A-39

A.3-10 Intermediate Level Cell - Equipment
Arrangement Plans. . . . . . . . . . . . A-41

A.3-12 High Level Cell - Equipment Arrangement Plans . . . . . A-45

A.3-13 High Level Cell - Equipment Arrangement Elevation • . . A-47 
A.3-14 High Intermediate Level Cell - Equipment Arrangement Plans.

A.3-15 High Intermediate Level Cell - Equipment Arrangement Elevation

A.3-16 High Intermediate Level Cell (HILC) Equipment Arrangement Elevation

A.3-17 Plutonium Product Cel1 - Equipment Arrangement Plans.

A.3-18 Plutonium Product Cell Equipment Elavation . . . . . A-61

A.3-19 Plutonium Nitrate Storage and Loadout Area . . . . . A-65

A.3-20 Plutonium Nitrate Storage and Loadout Area . . . . A-67

A.4-1 Plan Arrangement Fuel Receiving and Storage Station.

A.4-2 Sections - Fuel Receiving and Storage Station . . . . A-79

A.5-1 HLLW Storage Tank Section Schematic. . . . . . . . A-83

A.5-2 Partial Section of HLLW Tank . . . . . . . . . A-85

A.5-3 Coal and Ballast Tank Supports . . . . . . . . A-86

A.5-4 ILLW Storage Tank Schematic . . . . . . . . . A-89

A.5-5 Waste Tank Equipment Gallery - Equipment Arrangement Plan . . . . . . . . . . . . . . A-93

A.5-6 Waste Tank Equipment Gallery - Equipment Arrangement Plan and Sections. . . . . . . . . A-95

A.6-1 Conceptual Waste Solidfication Plant - Plan View . . . A-98

A.6-2 Conceptual Waste Solidification Plant-Section AA . . . A-99

A.6-3 Conceptual Waste Solidification Plant-Section BB . . . A-100

A.6-4 Conceptual Waste Solidification Plant-Section CC . . . .A-101

A.6-5 Canister Decontamination Cell. . . . . . . . . .A-105

A.7-1 Air Flow Diagram Ventilation System. . . . . . . .A-109

A.7-2 Blower Station Building. . . . . . . . . . . A-113 
C.6-1 Recorded Daily Average and Extreme River Flows at the Reference Site . . . . . . . . . . . . C-6

C.6-2 Daily Average and Extreme Water Temperatures at the Reference Site. . . . . . . . . . . . . . C-8

C.6-3 Liquid Effluents Dilution for the Reference River . . . . C-9

C.7-1 Average ( $\left(\mathbb{Q} / Q^{\prime}\right)$ Values Versus Distance in a Sector from the Reference River Site . . . . . . . . C-13

E.3-1 Location of Penetrations for HLLW Tank Decontamination . . E-41

E.3-2 Waste Tank Vault Top Penetrations . . . . . . . . . E-42

E.3-3 Plasma Arc Torch Schematic Diagram . . . . . . . . E-54

E.3-4 Arc Saw Schematic Diagram . . . . . . . . . E-59

E.3-5 Hydraulic Concrete Spalling Device (Rock Splitter). . . E-60

E.3-6 Typical Linear Shaped Charge Section . . . . . . . . E-62

E.3-7 Portable Filtered Ventilation Enclosure . . . . . . . E-64

E.3-8 Sketch of Shielded Working Platform. . . . . . . . . E-65

E.3-9 Conceptual Sketch of the Shielded Working Cage . . . . . E-70

E.3-10 Schematic Diagram of Electropolishing Cell . . . . . . E-74

F.4-1 First Year Radiation Dose for a Reference Release from the Remote Process Cell. . . . . . . . . . . . F-86

F.4-2 Fifty Year Radiation Dose Commitment for A Reference Release from the Remote Process Cell . . . . . . . . . F-87

F.4-3 First Year Radiation Dose for a Reference Release for a High-Level Waste Storage Tank. . . . . . . . . F-88

F.4-4 Fifty Year Radiation Dose Commitment for a Reference Release from a High-Level Waste Storage Tank . . . . . . . . F-89

F.4-5 First Year Radiation Dose for a Reference Release from the Plutonium Product Cell . . . . . . . . . . . . . F-90

F.4-6 Fifty Year Radiation Dose Commitment for a Reference Release from the Plutonium Product Cell . . . . . . . . . F-91 
F.4-7 First Year Radiation Dose for a Reference Release from the Waste Solidification Plant. . . . . . . . . . . F-92

F.4-8 Fifty Year Radiation Dose Commitment for a Reference Release from the Waste Solidification Plant. . . . . . . . F-93 


\section{TABLES}

\section{VOLUME 2}

\section{TABLE}

A.1-1 Major BNFP Radioactive Processing Facilities. . . . . . A-2

A.4-1 Major Equipment - Fuel Receiving and Storage Station . . A-80

A.6-1 Major WSP Areas and Associated Function . . . . . . .A-102

A.6-2 Major Waste Solidification Plant Equipment . . . . . .A-103

A.7-1 Summary of Types of Ventilation Filters in the

Reference FRP . . . . . . . . . . . . . . . .A-107

B.2-1 Nuclide Radioactivity of Spent LWR Fuel at Time of

Reprocessing at Shutdown, and as a Function of Time

After Plant Shutdown. . . . . . . . . . . B-3

B.2-2 Radioactivity in High-Level Liquid Waste from Spent

LWR Fuel Reprocessed 1.5 Years After Reactor Discharge . . B-6

B.3-1 Estimated Inventory of Major Radionuclides in Cells of Main

Process Building After Shutdown and Before Chemical

Decontamination . . . . . . . . . . . . B-8

B.3-2 Estimated Inventory of Major Radionuclides on Process Cell

Walls and External Surfaces of Equipment in Process Cells

After Chemical Decontamination . . . . . . . . B-10

B.4-1 Estimated Inventory of Radionuclides in a HLLW Storage

Tank After Removal of Waste . . . . . . . . . . B-11

B.5-1 Estimated Inventory of Radionuclides in a HLLW Storage Tank After Removal of Waste and Chemical Decontamination

for the Layaway Mode. . . . . . . . . . . . . B-14

B.5-2 Estimated Inventory of Radionuclides in a HLLW Storage Tank After Removal of Waste and Chemical Decontamination for the Protective Storage Mode . . . . . . . . . B-15

B.5-3 Estimated Inventory of Radionuclides in a HLLW Storage Tank After Removal of Waste and Chemical Decontamination for the Dismantling Mode . . . . . . . . . . B-16

B.6-1 Radioactivity of HLLW in WSP at Various Times . . . . . B-18 
$\underline{\text { TABLES }}$

B.6-2 Estimated inventory of Major Radionuclides in Cells of WSP After Shutdown . . . . . . . . . . . B-20

B.6-3 Estimated Inventory of Major Radionuclides on WSP Ce11 Walls and External Equipment Surfaces After Chemical Decontamination

C.6-1 Population Distribution Around the Reference Ful1

Cycle Site. . . . . . . . . . . . . . . C- 2

C.7-1 Monthly Temperature Statistics . . . . . . . . . C 7

C.7-2 Mean Monthly Relative Humidity . . . . . . . . . C-10

C.8-1 Wild1ife Considered to Be Rare, Endangered or Threatened Within the Reference Site . . . . . .C- 15

C.8-2 Some Important Mammals that Occur Near the Study Site. . . C- 16

C.9-1 Estimated Annual Radioactive Atmospheric Release from a $1500 \mathrm{MT} / \mathrm{yr}$ Ful1 Reprocessing Plant . . . . . . . . C- 23

C.9-2 Estimated Activity of Radionuclides on the FRP Site Over a 30-yr Operating Lifetime . . . . . . . . . . C-24

D.1-1 U.S. Public Health Service Recommendations for Reducing External Exposure Due to Radioactive Contamination . . . . . . . . . . . . . . . . D-2

D.2-1 Isotopic Composition of Radioactive Surface Contamination in the Reference FRP. . . . . . . . . . . . . . D-9

D.2-2a Maximum Annual Dose to Selected Organs of Reference. Site is Decommissioned at Shutdown.. . . . . . . D-10

D.2-2b Maximum Annual Dose to Selected Organs of Reference. Site is Decommissioned 10 years After Shutdown... . . D-11

D.2-2c Maximum Annual Dose to Selected Organs of Reference. Site is Decommissioned 30 Years After Shutdown . . . . D-12

D.2-2d Maximum Annual Dose to Selected Organs of Reference. Site is Decommissioned 100 Years After Shutdown. . . . D-13 
TABLES

D.2-3a Maximum Annual Dose to Selected Organs of Reference.

Site is Decommissioned at Shutdown - Conditional Release. . D-14

D.2-3b Maximum Annual Dose to Selected Organs of Reference.

Site is Decommissioned 10 Years After Shutdown - Conditional

D.2-3c Maximum Annual Dose to Selected Organs of Reference.

Site is Decommissioned 30 Years After Shutdown - Conditional

Release

D.2-3d Maximum Annual Dose to Selected Organs of Reference.

Site is Decommissioned 100 Years After Shutdown -

Conditional Release.

D.2-4a Maximum Annual Dose to Selected Organs of Reference.

Facility Decommissioned at Shutdown. . . . . . . . . D-18

D.2-4b Maximum Annual Dose to Selected Organs of Reference.

Facility Decommissioned 10 Years After Shutdown. . . . . D-19

D.2-4c Maximum Annual Dose to Selected Organs of Reference.

Facility Decommissioned 30 Years After Shutdown. . . . D-20

D.2-4d Maximum Annual Dose to Selected Organs of Reference.

Facility Decommissioned 100 Years After Shutdown . . . . D-21

E.2-1 Concrete and Steel Removal Methods . . . . . . . . . E-9

E.2-2 Types of Explosives for Use in Dismantlement. . . . . . E-11

E.3-1 UPC - Order of Removal of Major Pieces of Equipment . . . E-17

E.3-2 ILC - Order of Removal of Major Pieces of Equipment • . . E-18

E.3-3 HILC - Order of Removal of Major Pieces of Equipment . . . E-22

E.3-4 HLC - Order of Removal of Major Pieces of Equipment . . . E-24

E.3-5 PPC - Order of Removal of Major Pieces of Equipment . . . E-28

E.3-6 RPC - ORder of Removal of Major Pieces of Equipment . . . E-33

E.3-7 RMSC - Order of Removal of Major Pieces of Equipment . . . E-34 
TABLES

E.3-8 Special Tools, Equipment, and Materials for Decommissioning

E.3-9 Special Materials.

E.3-10 Typical Conditions for Plasma Arc Wetting of Stainless Steel . . . . . . . . . . . . E-57

E.6-1 Concrete Rubble from Dismantlement . . . . . . . . . E-85

E.6-2 Stainless Steel Liners from Dismantlement. • • • • • . E-86

E.6-3 Equipment from Dismantlement . . . . . . . . . . . E-87

E.6-4 Stainless Steel Piping from Dismantlement. . . . . . . E-88

E.6-5 HEPA and Roughing Filters from Dismantlement. . . . . . E-89

E.7-1 Decommissioning Worker Manpower for Dismantlement . . . . E-94

E.7-2 Decommissioning Worker Manpower for Protective Storage • .E-102

E.7-3 Decommissioning Worker Manpower for Layaway . • . . . . E-109

E.8-1 Employee Pay Scales and Owner Costs Used to Calculate Decommissioning Labor Costs . . . . . . . . . . .E-116

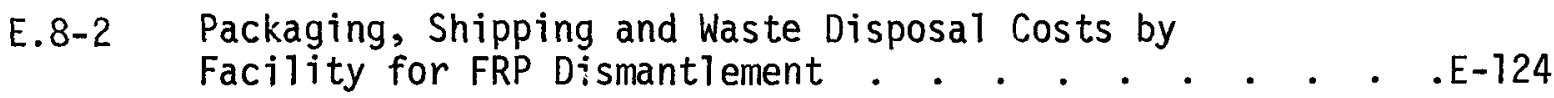

F.2-1 Estimated Release of Radioactive Material for Normal Decommissioning Activities. . . . . . . . . . . . F-4

F.2-2 Estimated Radioactivity Released from Postulated Decommissioning Accidents . . . . . . . . . . . . F-33

F.2-3 Estimated Occupational Radiation Doses for Immediate Dismantlement . . . . . . . . . . . . . . . . F-49

F.2-4 Inventory of Stable End-Products After Decay of All Residuals from Decontamination Procedures. . . . . . . F-54

F.2-5 Construction/Industrial Accidents . . . . . . . . . F-54

F.3-1 Quantity Limits for the Seven Transport Groups . . . . . F-55

F.3-2 Transportation Accident Severity Categories . . . . . . F-60

F.3-3 Nonradiation Transportation Accident Statistics. • • . . F-62 
F.4-1 Consumption Rates of Feed and Water by Farm Animals . . . F-68

F.4-2 Plant Concentration Factors and Animal Product

Transfer Coefficients

F.4-3 Calculation of Fractions of Hydrogen and Carbon in

Environmental Media, Vegetation, and Animal Products . . . F-70

F.4-4 Unit Release from FRP During Decommissioning (Typified

by the Remote Process Cel1) . . . . . . . . F-76

F.4-5 Unit Release from the FRP During Decommissioning (Typified

by the High-Level Liquid Waste Tanks) . . . . . . . F-76

F.4-6 Unit Release from the FRP During Decommissioning (Typified

by the Plutonium Product $\mathrm{Cel1}$ ) . . . . . . . . F-77

F.4-7 Unit Release from the FRP During Decommissioning (Typified

by Waste Solidification Plant) . . . . . . . . F-77

F.4-8 Parameters Used for Calculation of Radiation Doses from

Consumption of Foods. . . . . . . . . . . . . . F-78

F.4-9 Chronic Radiation Doses and Dose Commitments to the

Maximum Public Individual Due to 100-Meter High Releases

Typified by Those in the Remote Process Cel1. . . . . . F-79

F.4-10 Chronic Radiation Doses and Dose Commitments to the

Maximum Public Individual from 100-Meter High Releases

Typified by Those from the High Level Liquid Waste Tanks. . F-80

F.4-11 Chronic Radiation Doses and Dose Commitments to the

Maximum Public Individual from 100-Meter High Releases

Typified by Those from the Plutonium Product Cel1 . . . : F-80

F.4-12 Chronic Radiation Doses and Dose Commitments to the

Maximum Public Individual from 100-Meter High Releases

Typified by Those from the Waste Solidification Plant. . F-81

F.4-13 Chronic Radiation Doses and Dose Commitments to the

Large Population Groups from 100-Meter High Releases

Typified by Those from the Remote Process Cel1 . . . . . F-81

F.4-14 Chronic Radiation Doses and Dose Cormitments to the Large Population Group from 100-Meter High Releases

Typified by Those from the High Level Liquid Waste Tanks. F-82

F.4-15 Chronic Radiation Doses and Dose Commitments to the Large Population Group from 100-Meter High Releases

Typified by Those from the Plutonium Product Cel1 . . . . F-82

F.4-16 Chronic Radiation Doses and Dose Commitments to the Large Population Group from 100-Meter High Releases

Typified by Those from the Waste Solidification Plant. . . F-83 
F.4-17 Radiation Doses and Dose Commitments to the Maximum Public Individual from 100-Meter High Releases Typified by Those from the Remote Process Cel1 . . . . . . . F-84

F.4-18 Radiation Doses and Dose Commitments to the Maximum Public Individual from 100-Meter High Accidental

Releases Typified by Those form the High Level Liquid Waste Tanks

F.4-19 Radiation Doses and Dose Commitments to the Maximum Public Individual from 100-Meter High Accidental Releases Typified by Those from the Plutonium Product Cell . F-85

F.4-20 Radiation Doses and Dose Commitments to the Maximum Public Individual from 100-Meter High Accidental Releases Typified by Those from the Waste Solidification Plant.

G.4-1 Annual Sinking Fund Payments (Option II)

G.4-2 Annual Adjustments to the Prepaid Sinking Fund (Option III) 


\section{FACILITY DESCRIPTION}

Major features of the reference plant for reprocessing LWR spent fuel are presented in Volume 1, Section 5. This appendix describes in more detail the portions of the facility that are important to decommissioning and the Purex chemical process used in the reference facility.

The Barnwe1l Nuclear Fuel Plant was selected as the reference facility for this study. Construction of major portions of this facility has been completed and nonradioactive testing has been carried out. The plant capacity (5 MTHM/day) and design concepts are believed to be representative of reprocessing plants that may be operated in the future. Two other commercial reprocessing plants have been constructed in the United States. The Nuclear Fuel Services Plant in New York was operated for several years, but has been shut down because of licensing difficulties encountered when a capacity expansion program was undertaken. The General Electric Plant at Morris, IL encountered technical difficulties before startup. The future disposition of that plant is unknown. Exxon Nuclear Corporation has plans to construct a reprocessing plant in Tennessee. Design details of the plant are still being worked out.

Much of the detailed plant design information contained in this appendix has been extracted from the Barnwell Final Safety Analysis Report. (1) A conceptual design for a waste solidification plant has been developed for this study since designs for the waste solidification facility at Barnwell have not been finalized. The existing $U_{6}$ conversion facility and solid radioactive waste storage area, the planned plutonium dioxide conversion facility and nonradioactive portions of the facility are not conceptually decommissioned in this study. Detailed descriptions of these facilities are therefore not presented.

This appendix is divided into seven main sections. Section A.l presents an overview of the plant layout. Details of the process description are 
given in Section A.2. Sections A.3 through A.7 present details of structures and equipment in the main process building, fuel receiving and storage station, liquid waste storage complex, waste solidification plant and auxiliary process systems and service areas.

\section{A. 1 SITE ARRANGEMENT}

A plot plan of the reference reprocessing plant is shown in Figure A.1-1. The major portions of the facility included in this study are: 1) the main process building, 2) the fuel receiving and storage station, 3) the liquid waste storage system, 4) the waste solidification plant, and 5) radioactive support areas and nonradioactive support areas that are a non-separable part of the radioactive areas. A listing of the major structures with their overall dimensions is given in Table A.1-1.

TABLE A.1-1. Major BNFP Radioactive Processing Facilities

Structural Identification

Fuel Receiving and

Storage Station

Main Process Building

Control Room Area/Plutonium Nitrate Storage and Loadout (CRA/PNSL)

Waste Tank Equipment Gallery (WTEG)

Waste Tank Cells (WTC)

Waste Solidification

Plant (WSP)
Plan

Dimensions (m) Height (m)

$45 \times 45$

$36 \times 68$

$20 \times 25$

$31 \times 34$

Circular

18m Diam

$26 \times 29$
28

26

18

12

11

18
Foundation Type

Embedment Depth (m)

\section{A.2 PROCESS DESCRIPTION}

The reference reprocessing plant uses the Purex chemical process to separate the uranium and plutonium from spent LWR fuel. The Purex recovery process has been in large scale use for 20 years and is used, with minor 


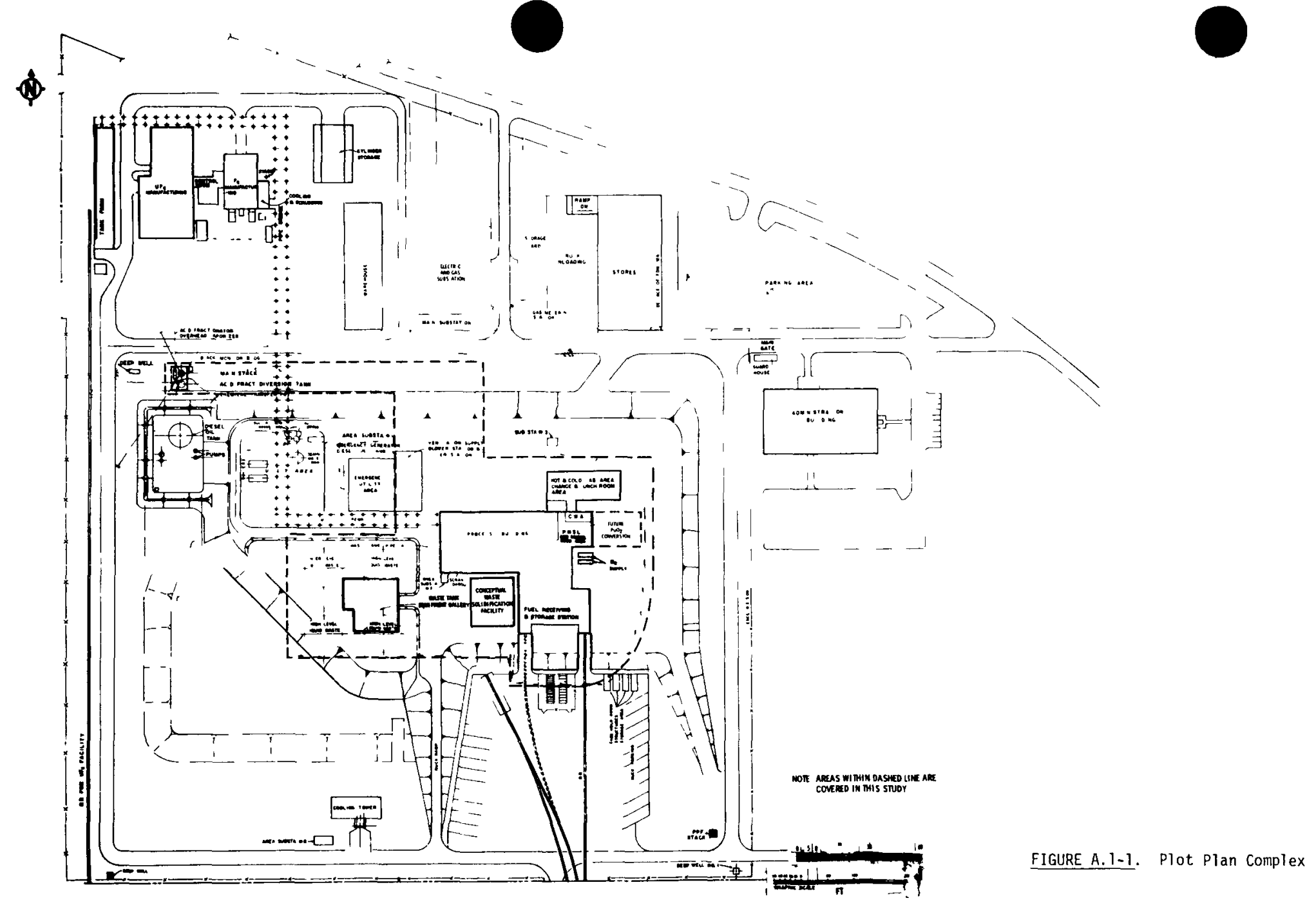


0$$
\text { . }
$$

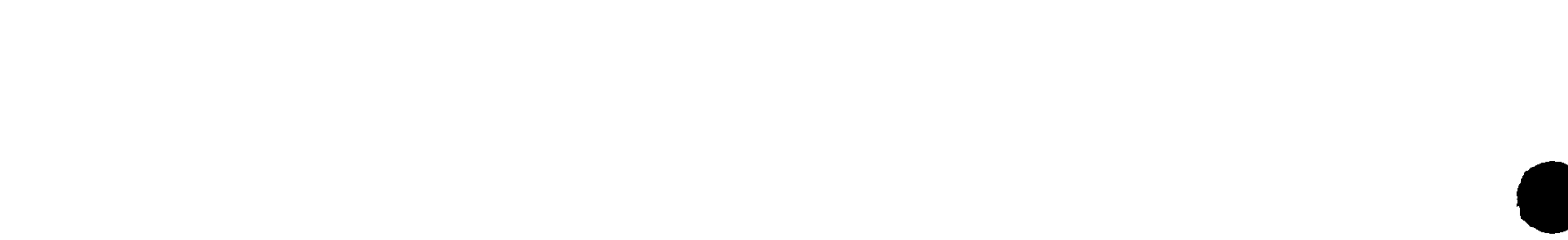

.

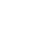

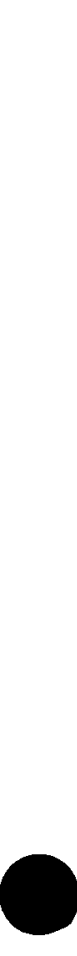


variations, by most of the reprocessing plants now operating throughout the world. A simplified block diagram of the process used in this study is shown in Volume 1, Figure 5.2-1. A detailed flow diagram is given in Figure A.2-1.

The process description presented in this section provides background information on the types of operational activities carried out in the plant and provides a basis for estimation of residual radioactivity inventories presented in Appendix B. It is also useful to indicate the kinds of decommissioning activities that are possible or necessary within the facility.

- Cask Handling

The irradiated fuel assemblies arrive at the plant in shielded casks. The cask and transport vehicle are monitored for outside contamination and washed to remove outside dirt. The cask is removed from the carrier and the condition of the fuel and cask coolant is determined. The cask is vented and the primary coolant is replaced if necessary.

The cooled cask is transported by the cask handling crane to the cask unloading pool (CUP) where it is submerged in the water and lowered to the bottom of the pool. The top of the cask is opened and the contained fuel is removed (all under water). The fuel is placed in storage canisters that are moved to the fuel storage pool (FSP) for retention until the fuel is scheduled for reprocessing.

\section{- Fuel Shearing and Dissolution}

The fuel shearing and dissolution processes are generally called "headend" operations. The fuel assemblies are remotely transferred from the storage pool to the feed mechanism of the mechanical shear after a full batch has been accumulated. Here the fuel assemblies are chopped into small segments ( 5 to $12 \mathrm{~cm}$ long) to expose the fuel to the dissolvent. The fuel segments fail into the dissolver containing hot 3 to 8 molar (M) nitric acid which dissolves virtually all the uranium, plutonium, and nongaseous fission products. Gadolinium nitrate is added to the dissolver solution to prevent nuclear criticality excursions. The undissolved cladding hulls remain in the dissolver basket. The cladding hulls are rinsed, monitored for fissile material, packaged, and transferred to the interim underground waste storage area for 
0 


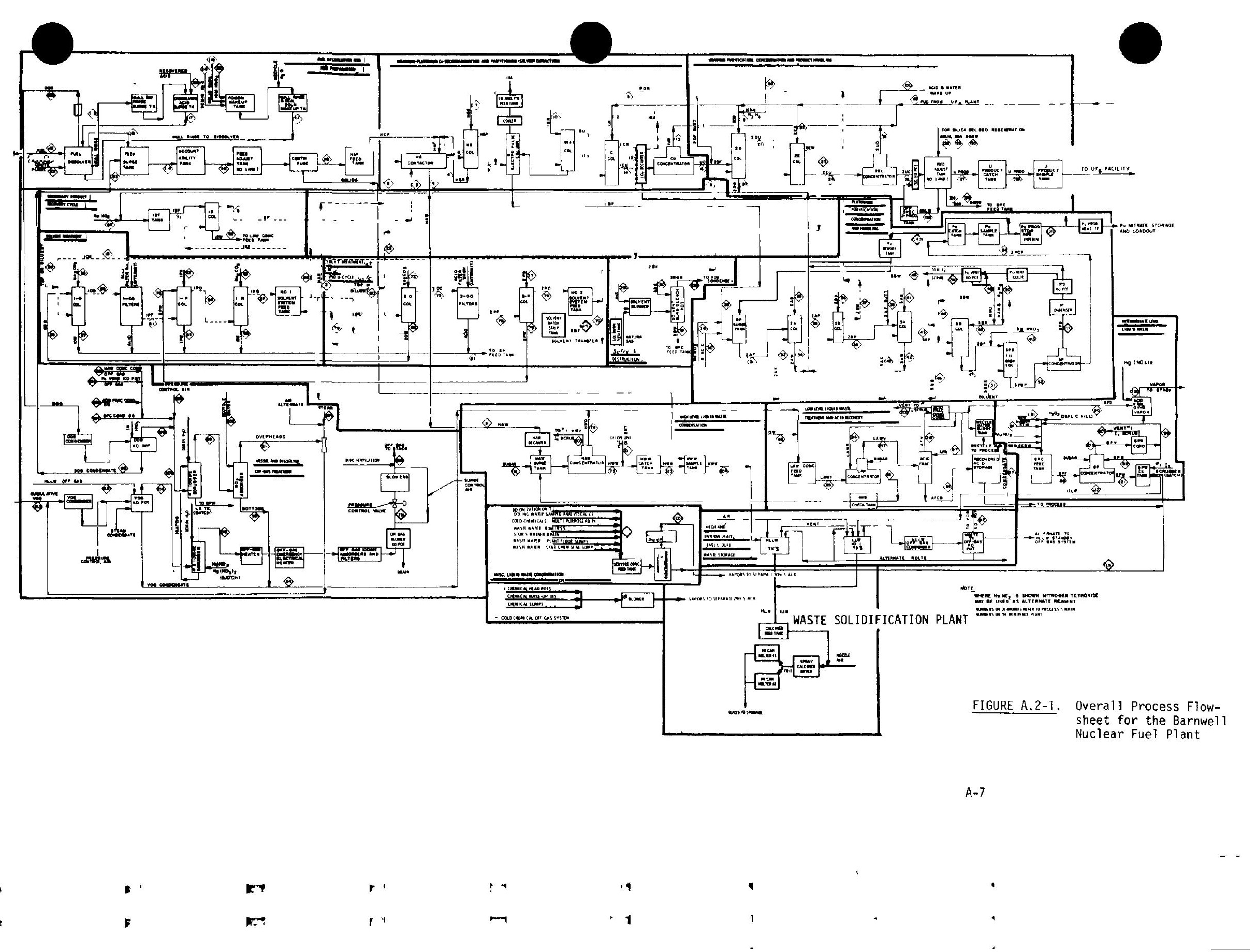


ventual shipment offsite. Gases generated during dissolution are channeled to the off-gas treatment system to remove particulates, radioiodine, and nitrogen oxides.

The dissolver solution is transferred to tanks for uranium and plutonium accountability sampling and final acid adjustment to 2 to $3 \mathrm{M}$ nitric acid before feeding to the solvent extraction process. The solution is centrifuged to remove fine solids which are sent to the high-level waste storage system.

\section{- Solvent Extraction Cycles}

The acid-adjusted and centrifuged solution is sent to the first solvent extraction cycle where it is contacted counter-currently in a 10-stage centrifugal contactor with an organic solution of $30 \%$ tributyl phosphate (TBP) in normal paraffin hydrocarbon diluent (dodecane). The organic solution preferentially extracts the tetravalent plutonium and hexavalent uranium, leaving about $95 \%$ of the fission products in the aqueous solution. The organic solution from the centrifugal contactor passes through a pulsed scrub column where a $3 \mathrm{M}$ aqueous nitric acid solution removes about $96 \%$ of the extracted fission products and is recycled back to the centrifugal contactor. The aqueous solution leaving the centrifugal contactor contains about $99.9 \%$ of the fission products and about $0.5 \%$ of the uranium and plutonium, and is sent to a highlevel waste concentrator. The organic solution from the pulsed scrub column is then joined by organic raffinates (wastes) from the plutonium purification sections and passes through a partitioning column where tetravalent plutonium is electrochemically reduced to the less extractable trivalent state. This enables the plutonium to be stripped into an aqueous nitric acid solution containing hydrazine as a holding chemical reductant, all within the same electrochemical device. The organic solution passes through the final first cycle column where the uranium is stripped into acidified water (about 0.01M nitric acid).

The aqueous strip solution is concentrated from $0.3 \mathrm{M}$ uranium to $1.5 \mathrm{M}$ uranium, adjusted with nitric acid, and sent to the second uranium solvent extraction cycle where it is again preferentially extracted by another $30 \%$ TBP organic solution in a pulsed column. Before leaving this column, the organic solution containing the uranium is scrubbed with 2.3M nitric acid solution 
which removes the extracted fission products (mostly zirconium-niobium and ruthenium). Hydroxylamine nitrate and hydrazine are also added to the scrub solution to chemically reduce the residual plutonium to remove the less extractable trivalent plutonium into the aqueous stream. Uranium is stripped from the organic solution in another pulsed column, using acidified water $(0.01 \mathrm{M}$ nitric acid). This solution is concentrated from $0.4 \mathrm{M}$ uranium to $1.5 \mathrm{M}$ uranium by boiling off some of the water. Finally, the concentrated uranium solution from the second cycle is passed through silica gel beds to remove residual zirconium-niobium. Uranyl nitrate product solution is analyzed and transferred to the onsite $U_{6}$ conversion facility.

Plutonium in the aqueous stream leaving the partitioning column in the first cycle is reoxidized to the extractable tetravalent state with a nitrite chemical and sent to the second plutonium solvent extraction cycle. Here, it is preferentially extracted into the TBP organic solution in another pulsed extraction column. In the top portion of the same column, the organic stream is scrubbed with 1.0M nitric acid solution to remove extracted ruthenium and zirconium-niobium. The organic stream passes through a strip column where tetravalent plutonium is transferred to an aqueous stream of dilute $(0.3 \mathrm{M})$ nitric acid.

The extraction-scrubbing sequence is repeated in a third plutonium cycle for further decontamination from fission products. To effect a higher plutonium product concentration, the plutonium is reduced in the third strip column by hydroxylamine nitrate to the more readily strippable trivalent state. A TBP organic scrub solution is added to remove residual uranium from the plutonium aqueous stream as it leaves the third strip column. The plutonium nitrate solution is washed with an organic stream of diluent to remove traces of TBP. Final concentration of the plutonium product stream from $60 \mathrm{~g} \mathrm{Pu} / 1 \mathrm{iter}$ to $250 \mathrm{~g} \mathrm{Pu} /$ iter is accomplished by boiling off water and nitric acid in a titanium concentrator. The plutonium product solution is analyzed and stored in tanks with a nuclear criticality-safe geometry before transfer to the plutonium dioxide conversion facility. 


\section{Organic Solvent Treatment}

The organic solvent waste streams from the first and partition cycles are washed with successive dilute aqueous solutions of sodium carbonate, nitric acid, and sodium carbonate to remove organic degradation products by extraction or precipitation. Precipitated solids are removed by filtration. Fresh TBP or diluent is added as required to maintain the 30\% TBP concentration and the total solvent inventory.

The organic solvent waste stream from the second uranium cycle is treated similarly, except the second alkaline wash is omitted. This solvent extractant is kept in a separate system. Degraded solvent is burned.

\section{- Secondary Product Recovery}

The aqueous raffinate (waste) streams from the plutonium and uranium cycles are treated with a nitrite salt or $\mathrm{NO}_{2}$ gas to adjust the plutonium and uranium valence to +4 and passed through a secondary recovery solvent extraction cycle. Here, they are processed in a pulse column where residual uranium and plutonium are recovered by extraction into a TBP-organic solution. The uranium and plutonium are recycled back to the first (codecontamination) cycle for decontamination and recovery. The aqueous raffinate stream is concentrated in a low-level process waste concentrator.

\section{- Effluent and Waste Treatment}

A block flow diagram of the effluent and waste treatment systems in the reference facility is presented in Figure A.2-2. The radioactive aqueous waste streams from all the solvent extraction cycles are concentrated in the highlevel and/or low-level waste concentrators. The acidic concentrated bottoms from high-level waste concentration are stored for an interim period in cooled stainless steel waste tanks, and the overheads are passed through a low-level waste concentrator and then to a distillation (fractionation) column to recover most of the nitric acid as a 12M solution. The overheads (primarily water) are then recycled as process water, or sampled and released to the stack from a vaporizer. The $12 \mathrm{M}$ recovered acid is used in the process where the residual radioactivity can be tolerated. 


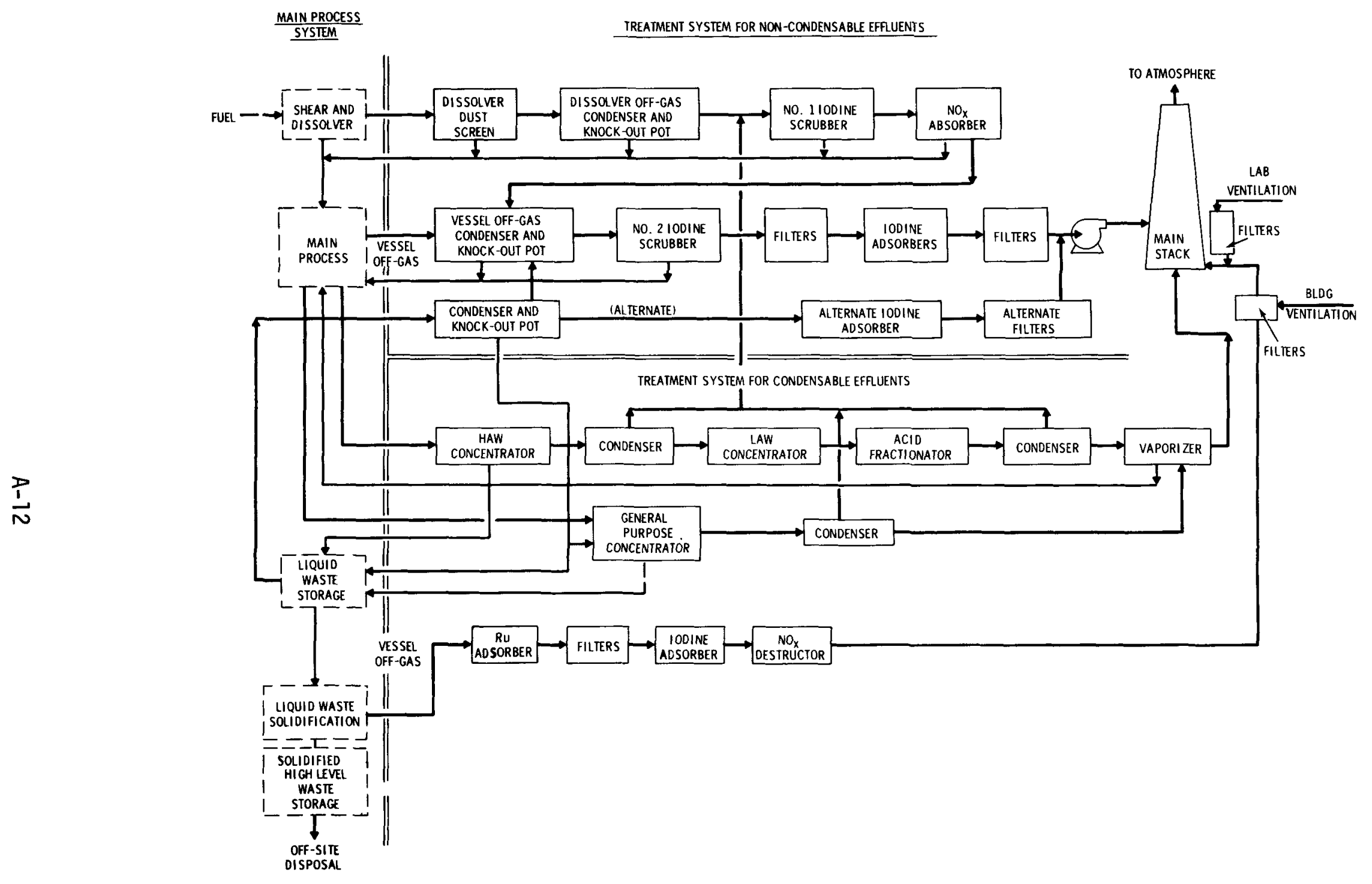

FIGURE A.2-2. Effluent and Waste Treatment Process Flow Diagram for the Reference Fuel Reprocessing Plant 
Miscellaneous liquid process waste streams containing salts and radioactivity $(\sim 1 \mathrm{C} / \mathrm{l})$ are acidified and concentrated in a general purpose concentrator to approximately $50 \mathrm{Ci} / \mathrm{l}$ as intermediate-level liquid waste. The concentrator bottoms are stored in an uncooled stainless steel waste tank as intermediate-level liquid waste and the condensed overheads are vaporized to the stack.

Other miscellaneous low-level liquid waste streams such as waste water from fuel storage, plant floor sumps, nonradioactive chemicals, etc., are sent to a service concentrator where the water is evaporated out through a separate, short stack and the concentrated solution is stored with the remaining intermediate-level liquid waste.

off gases from the dissolver are scrubbed with circulating mercuric nitrate-nitric acid solution to remove radioactive iodine, then treated in an absorber to convert nitrogen oxides to nitric acid suitable for recycling. The dissolver vessel off-gas streams are combined and passed through a second iodine scrubber containing mercuric nitrate, then through iodine adsorber beds, and finally through high-efficiency filters before release to the main stack.

High- and intermediate-level liquid wastes are solidified in the waste solidification plant (WSP). The spray calciner/in-can melter process under development at PNL is utilized conceptually in the WSP to solidify the waste liquid from the reference reprocessing plant. The waste solidification process flow sheet (Figure A.2-3) consists of four basic steps: (1) calcination; (2) vitrificaiton; (3) canister handling; and (4) effluent treatment. These steps are discussed further below.

\section{Calcination}

The spray calciner decomposes the chemicals in the liquid waste to a calcine powder of metal oxides and process off gas. HLLW and ILLW from the interim storage tanks are mixed in the calciner feed tank and pumped through an internal-mixing pneumatic atomizing nozzle at the top of the spray drying chamber. The fine waste droplets leaving the nozzle are dried and calcined to an oxide powder as they fall through a cylindrical chamber with its wall heated to $700^{\circ} \mathrm{C}$ by a multizone electrical resistance-heated furnace. The oxide powder falls out of the bottom of the spray drier at a temperature of about $300^{\circ} \mathrm{C}$. 

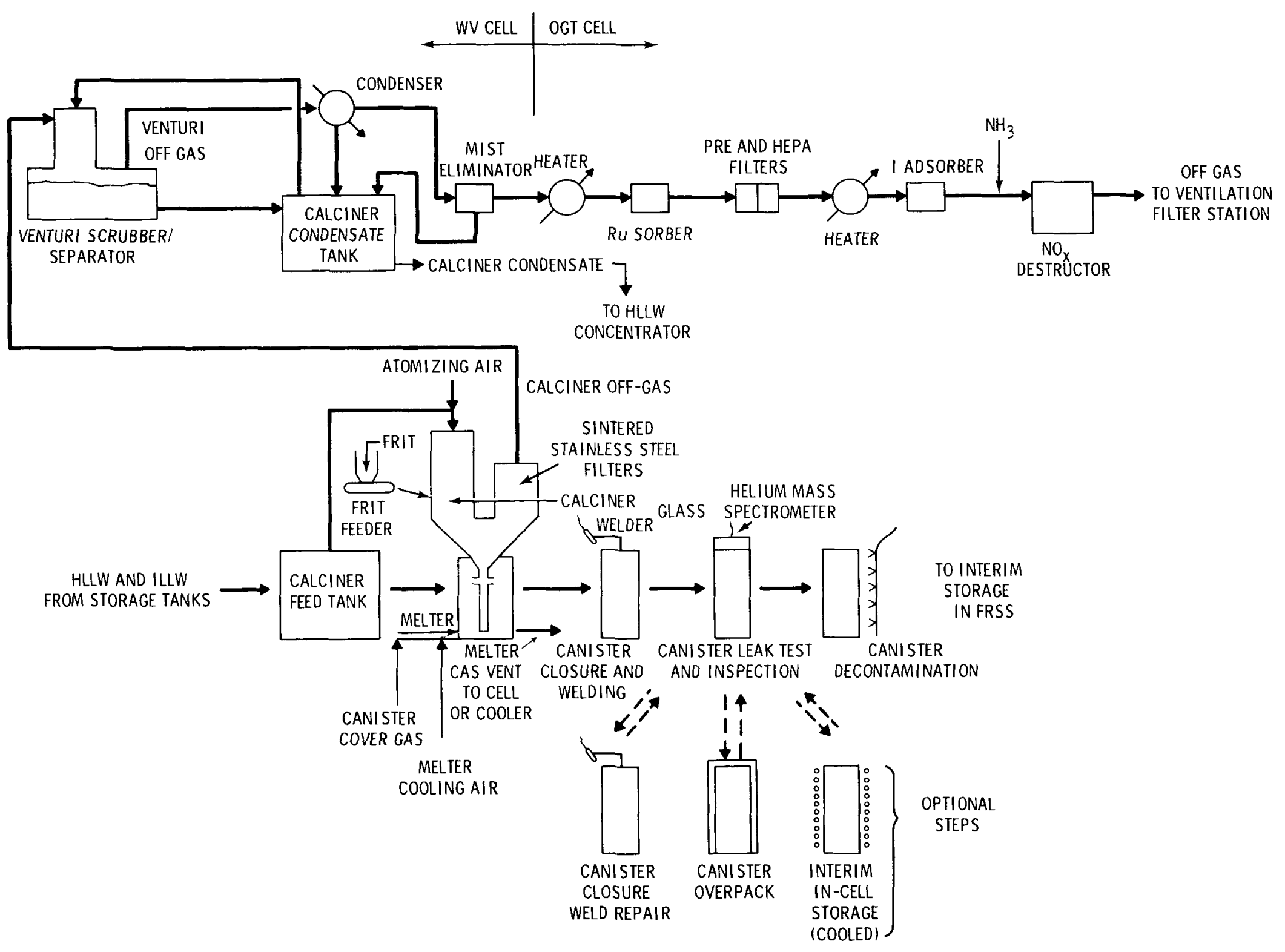

FIGURE A.2-3. High and Intermediate-Level Liquid Waste Vitrification Flow Diagram 
Granular glass frit is metered into the cone at the calciner bottom at a rate proportional to the feed rate to the calciner. For BNFP wastes, one part by weight of HLLW and ILLW calcine is added to about two parts of frit and dropped down a loading chute into a canister for melting. When one canister is full, a diverter valve routes the calcine-frit mix to a second preheated canister.

\section{Vitrification}

The mixture of waste powder and frit falls through a flow diverter valve, into a 304L stainless steel canister contained in the retort (secondary container) of one of the two multizoned electrical resistance heated melter furnaces. The mixture is heated to melting at about $1050^{\circ} \mathrm{C}$. As the melt level rises, heating of the furnace zones below the melt level is terminated and cooling air is blown on the outer wall of the retort, cooling the glass to temperatures below $800^{\circ} \mathrm{C}$. During the filling of the waste canister with glass, the space between the retort and the canister is purged with an inert gas such as argon to reduce oxidation of the canister.

\section{Canister Handling}

The filled and cooled canister is removed from the calciner connections and a lid is placed on the canister. A pre-packaged helium source is placed in the canister prior to closure to provide helium for later leak testing. The filled canister is moved to the seal welding and inspection station.

The canister lid is seal welded with an automatic welder using the Tungsten Inert Gas process. The canister weld is helium leak checked with a mass spectrometer and the canister is visually inspected for flaws or damage. The external surfaces of the filled canister are then decontaminated with medium pressure water and/or steam sprays to remove loose contamination. The canister is then moved to interim storage in the air-cooled racks in the WVC before being transferred to the fuel storage water pool in the FRSS for temporary storage and shipment offsite to a Federal repository.

\section{Effluent Treatment}

The primary sources of process effluents are calciner and melter off gas, canister cooling air, retort purge gas and canister decontamination solutions. 
Other effluents from the process area include cell ventilation air, vessel ventilation air and solutions from periodic process cell chemical decontamination.

Airborne effluents from the waste solidification process are treated in the WSP prior to return to the FRP ventilation system for final HEPA filtration and release. (See Figure A.2-3). The combined calciner and melter off gas is filtered by sintered stainless steel filters to remove bulk entrained calcine. Less than 0.1 weight percent (wt\%) of the calcine passes through the filters. About $2 \%$ of the fission product ruthenium is volatilized and escapes the calciner as does most of any tritium and halogens (i.e., fluorine, bromine, chlorine and iodine) reaching the calciner. The balance of the radionuclides remain in the calcine. The calcine filters are periodically blown back with air pulses to remove the accumulation of calcine dusts.

The calciner off gas from the sintered stainless filters is subjected to a series of process operations to remove particulates, volatilized ruthenium, halogens and other condensible gases, and $\mathrm{NO}_{\mathrm{X}}$. These off-gas treatment steps include the following:

- quenching in an acid spray tower of a venturi scrubber to cool the gases and remove particulates,

- condensing to separate the condensible gases and aerosols from noncondensible gases; excess condensation is sent to the HLLW concentrator in the FRP,

- mist elimination to further remove aerosols from noncondensible gases,

- adsorption to remove most of the remaining ruthenium from noncondensible gases,

- HEPA filtration to further remove aerosols from noncondensible gases,

- removal of iodine and other halogens from noncondensible gases by adsorption on silver zeolite, and

- destruction of $\mathrm{NO}_{x}$ in the noncondensible gases by passing through a heated catalyst in the presence of excess ammonia.

The canister cooling air and the retort purge inert gas are vented to the cell, combined with the cell ventilation air and filtered to remove radioactive 
articulates before release to the final filtration system for the fuel reprocessing plant. The WVC air filtration system includes one stage of roughing filters followed by two stages of HEPA filters. The treated vessel off gases are combined with the cell ventilation air for final treatment in the VFS and release through the main stack.

Some cell or equipment decontamination is required periodically during production operations. Typical solutions used include steam, water, nitric acid, caustic, potassium permanganate and tartaric acid. These solutions are collected in the cell sump and process tanks, transferred to a waste accumulation tank for sampling, and combined with the HLLW.

\section{A.3 MAIN PROCESS BUILDING EQUIPMENT AND STRUCTURES}

This section contains details of the structures and equipment located in the main process building. Information is generally presented as a brief narrative with details in accompanying engineering drawings of the Barnwell Nuclear Fuel Plant. Plan and elevation views of the main process building are presented in Figures A.3-1 through A.3-3. These figures show building layout; major dimensions of the main process cells auxiliary process areas, operating areas and maintenance areas. Wall thicknesses and major process cell access penetrations are also shown.

Other details of the process cell operating characteristics and equipment layout are presented in Sections A.3-] through A.3-8. Auxiliary process areas, operating areas and maintenance facilities are discussed in Sections A.3-9 through A.3-13.

\section{A.3.1 Remote Process Cell}

The remote process cell (RPC) is a high-level radiation cell used primarily for head-end mechanical process operations and initial chemical processing. All maintenance and some operations activities in the cell are performed remotely. 
0 


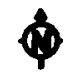

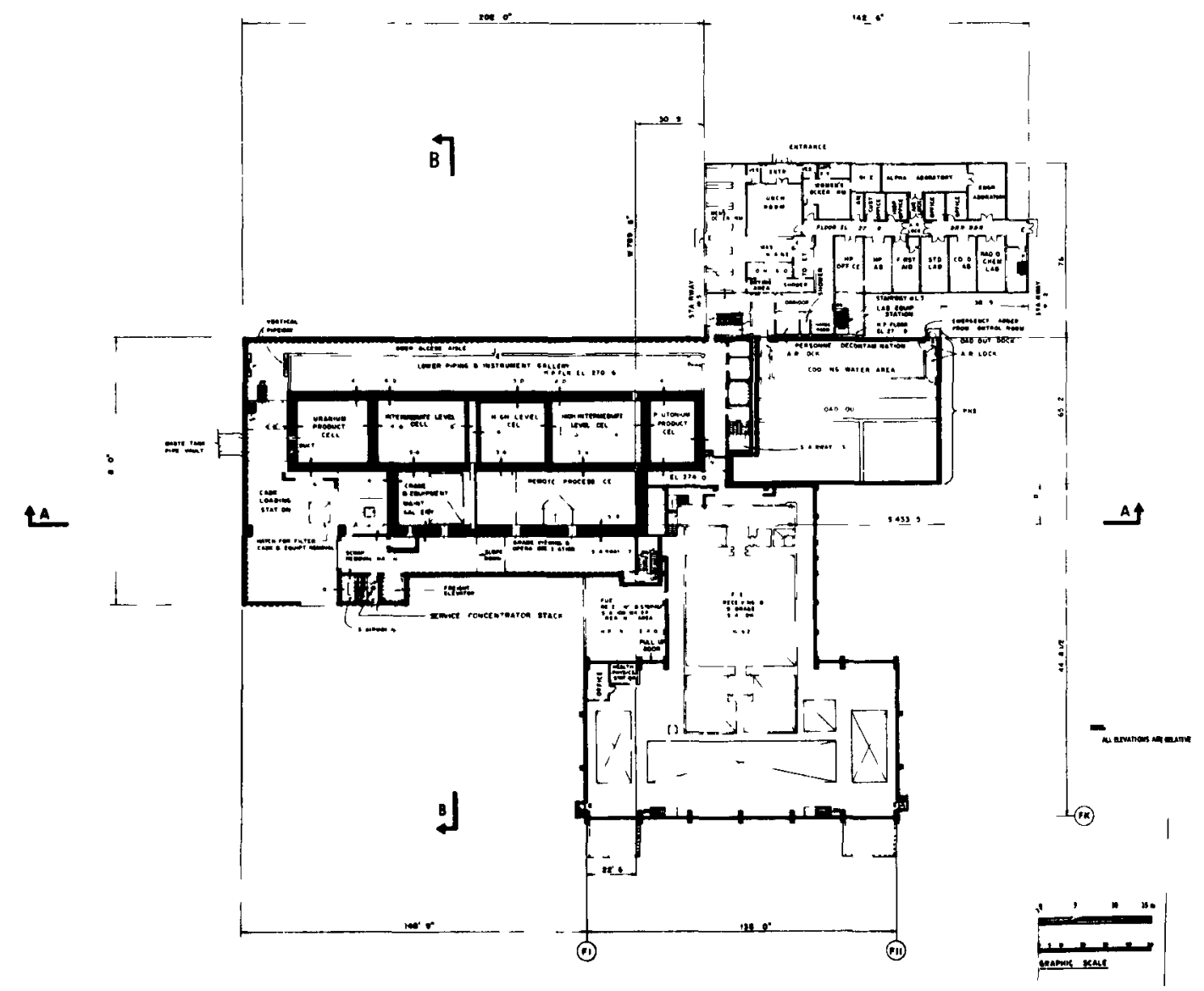

FIGURE A.3-1. General Arrangement of

Main Process Building and

Fuel Receiving and Storage

Station Grade Level

A-19

10

1 
•

• 


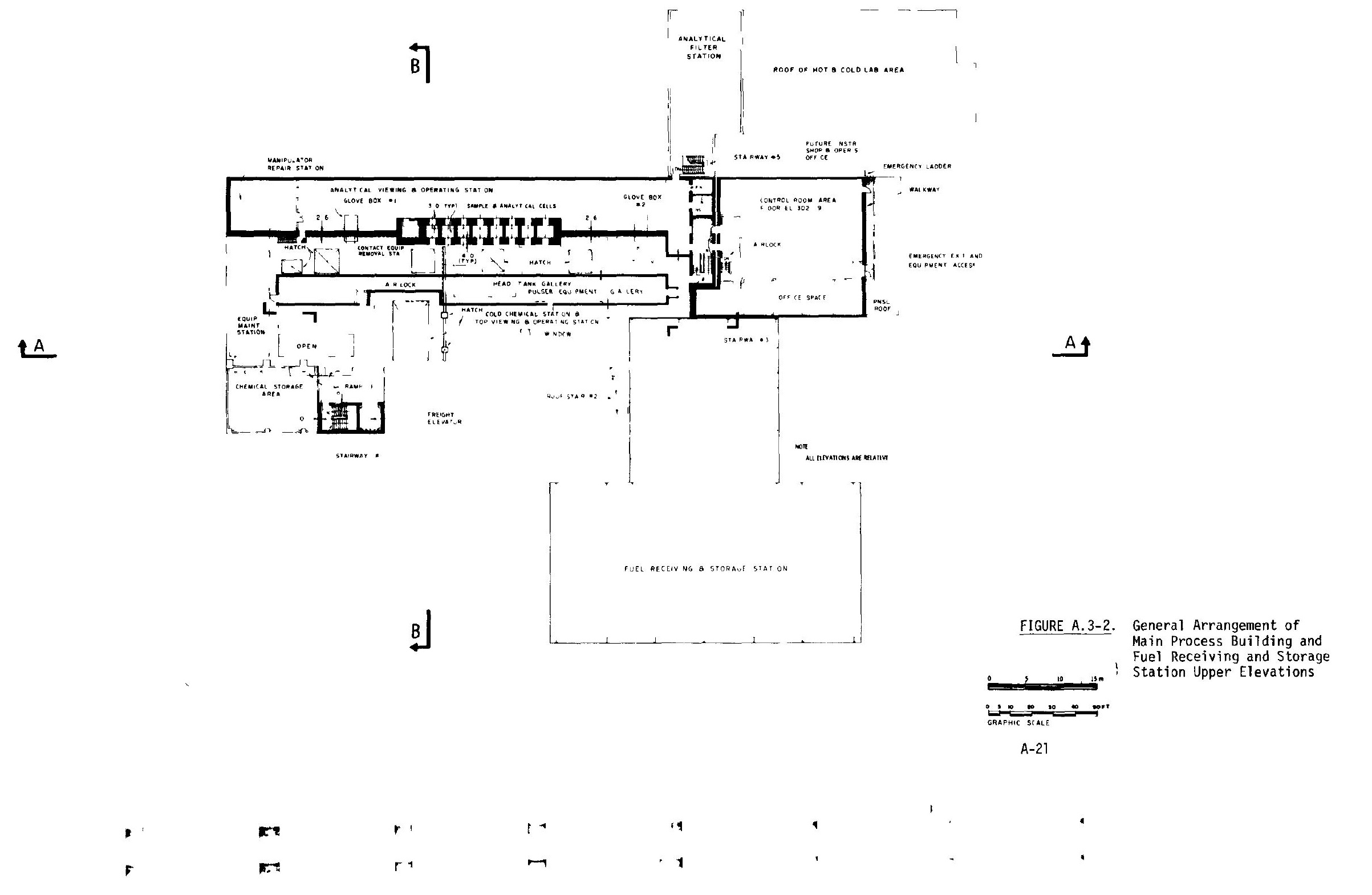


0

0 

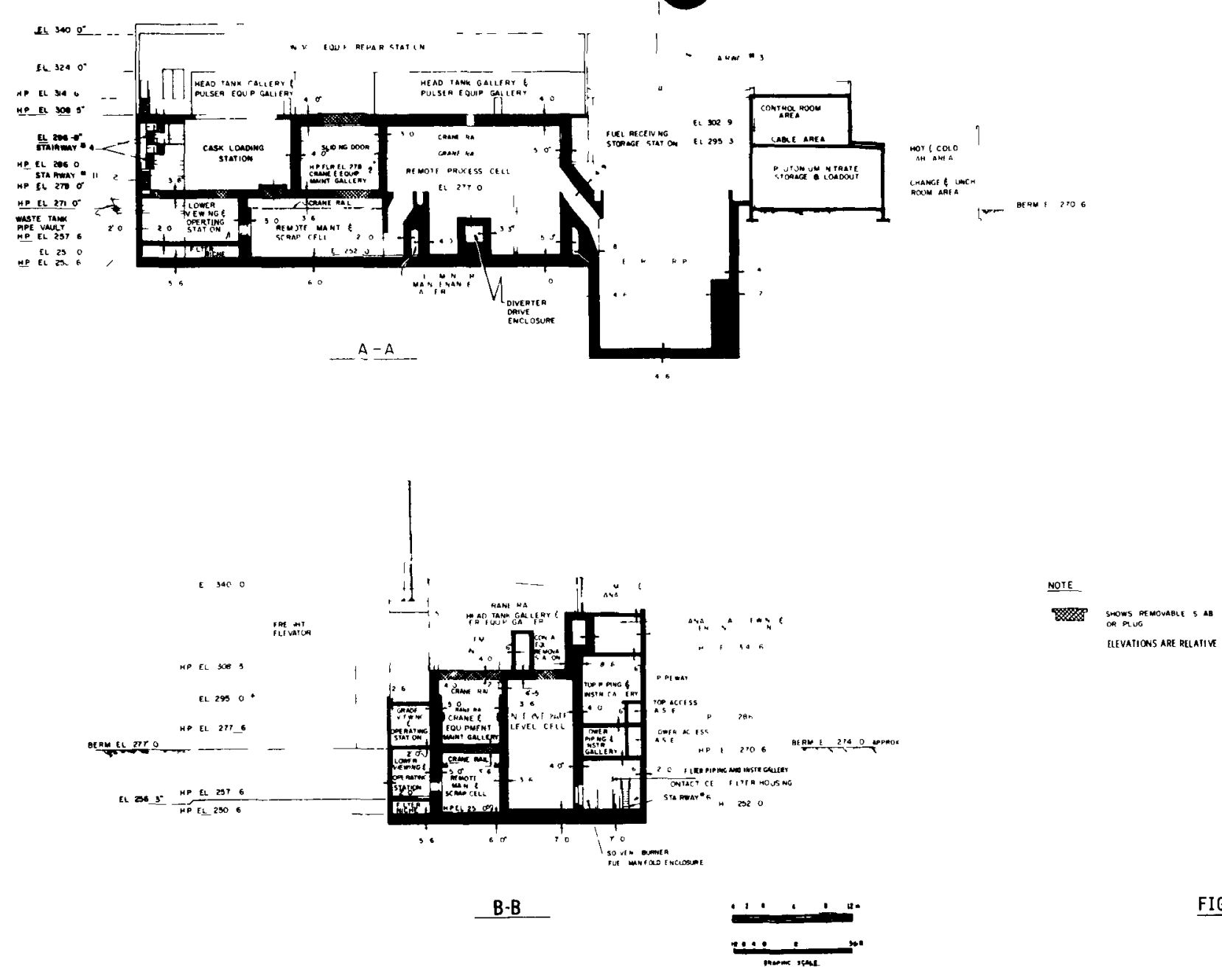

FIGURE A.3-3. General Sections Through Main Process Building and Fuel Receiving and Storage Stations 
•

•

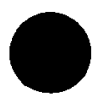


Details of the cell structure and equipment layout are presented in Figures A.3-4 and A.3-5. Overall dimensions of process equipment in the RPC are presented in Appendix E, Table E.3-6. The major equipment items in the cell are:

- fuel shear

- sheared fuel diverter

- fuel dissolvers (3)

- high-level liquid waste concentrator

- entrance to cladding hull monitor and dump

- maintenance crane and power manipulator

Most of the process equipment in the cell is constructed of $304 \mathrm{~L}$ stainless steel. The HLLW concentrator has a titanium vessel and jacket. The cell floor and lower walls are lined with 304 L stainless steel to contain spills of process solutions. The stainless steel liner is welded to anchors in the underlying concrete. The anchors are spaced on about $0.5 \mathrm{~m}$ centers. This construction is typical of all stainless steel liners in the facility. Spilled process solutions may be transferred from the cell sumps to the ILLW system or returned to the process. Exposed concrete surfaces in the cell are coated with an acid-resistant phenolic paint system such as Amercoat 90 or Phenoline 305.

A wheel-mounted shielding door connects the RPC with the crane and equipment maintenance gallery (CEMG). The door opens and closes horizontally from a pocket in the wall to permit the crane and power manipulator to be moved into the CEMG for maintenance and to remove process equipment to the remote maintenance and scrap cell (RMSC) for maintenance or disposal. A hatch in the RPC floor near the shielding door provides access to the cladding hull monitor. Another hatch in this area is used to transfer leached hulls to the RMSC for packaging and transfer to the onsite bunker storage area.

\section{A.3.2 Remote Maintenance and Scrap Cel1}

The remote maintenance and scrap cell (RMSC) is used for remote handling and packaging of cladding hulls and other radioactive scrap, and for remote decontamination and repair of process equipment. 
0

0 

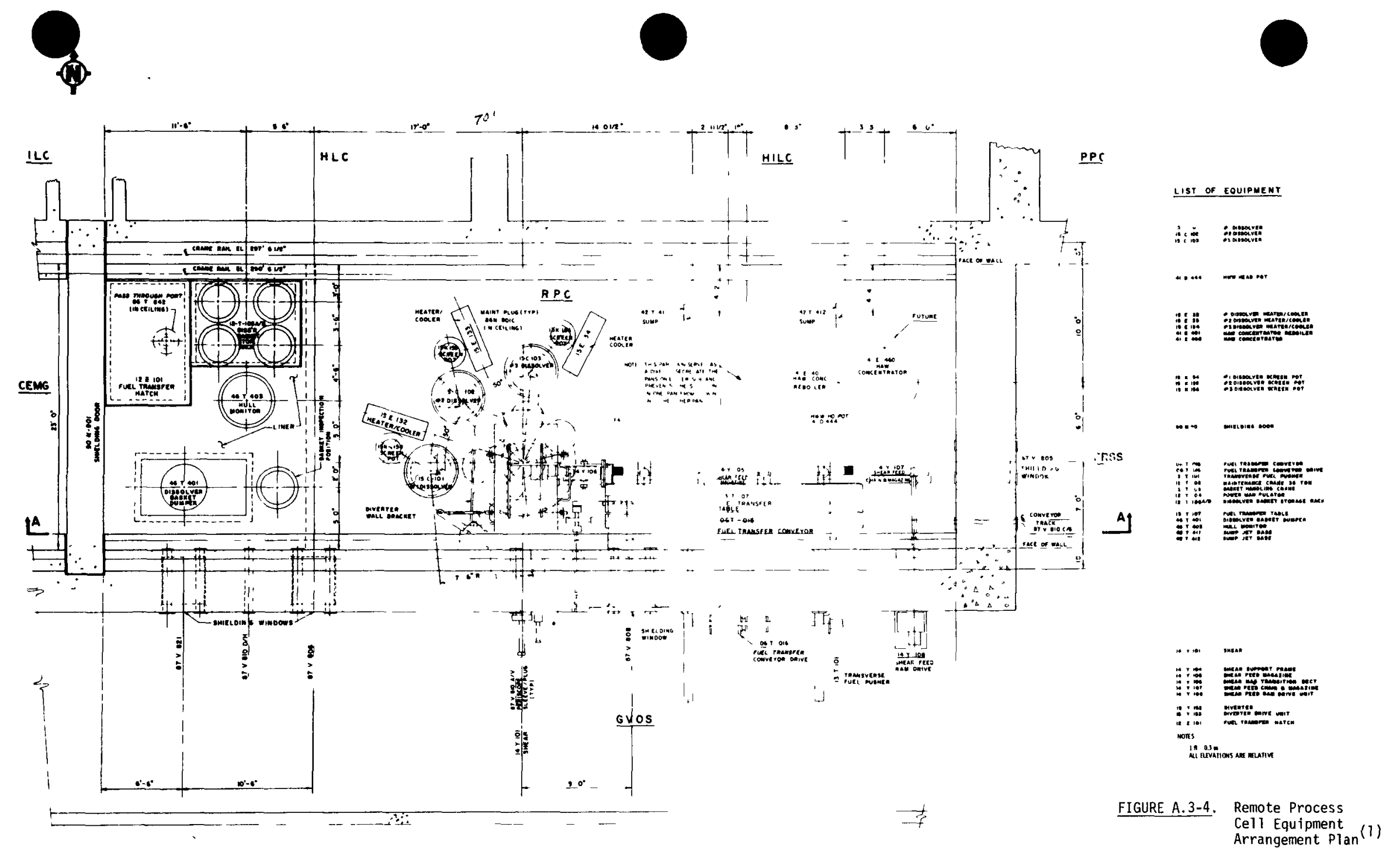
•

0

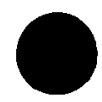




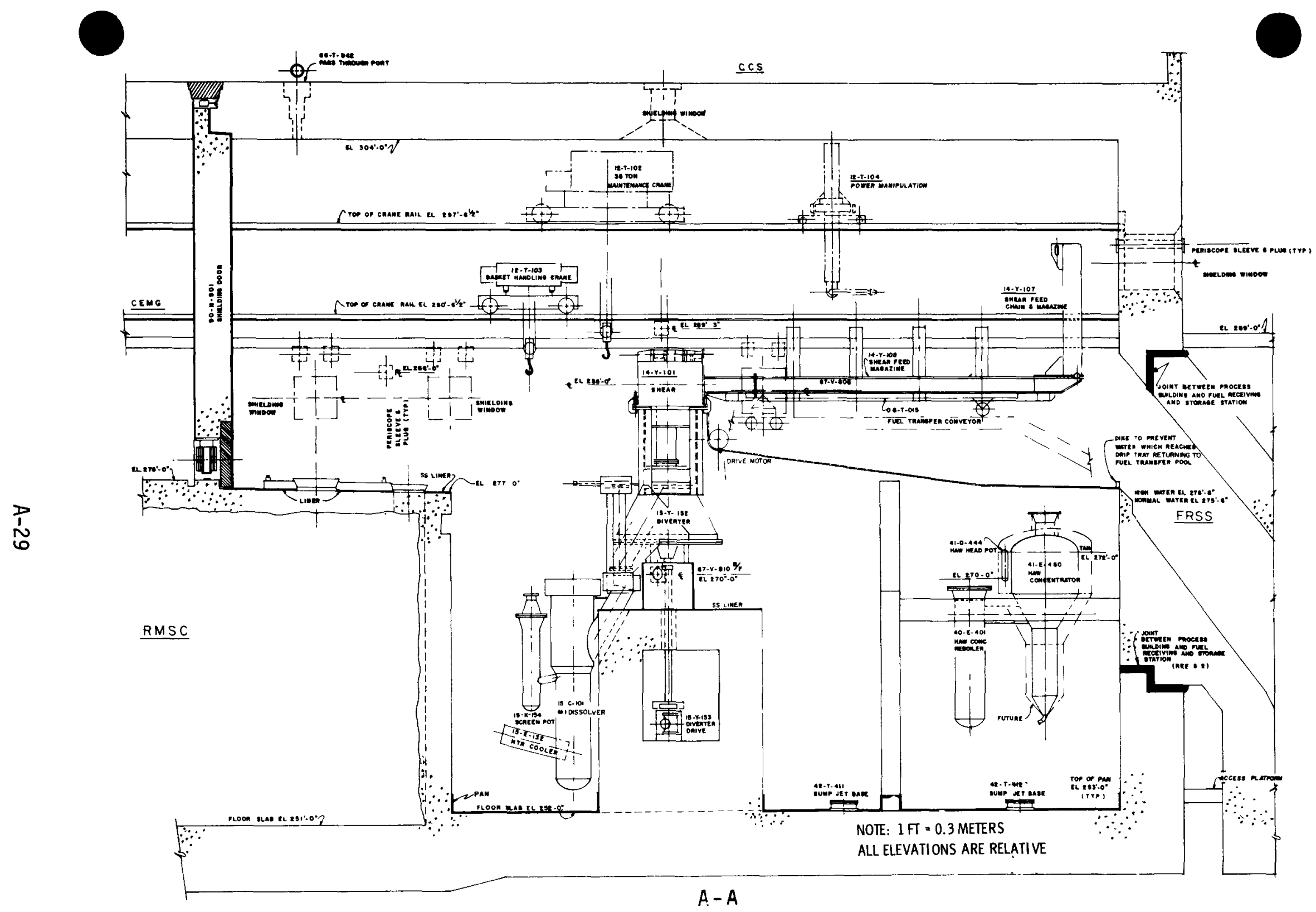

FIGURE A.3-5. Remote Process Cell Equipment Arrangement Overall Section (1) 
Details of the cell structure and equipment layout are presented in Figures A.3-6 and A.3-7. Overall dimensions of the RMSC process equipment are presented in Appendix E, Table E.3.7.

The major equipment in the cell is:

- dissolver basket dumper

- cladding hull disposal containers

- cladding huli transfer can

- remote crane and power manipulator

- SAC waste chute and retainer

- shielding windows and master-slave manipulators

The walls and floor of the RMSC are lined with 5-mm-thick 304L stainless steel. The ceiling is concrete coated with phenolic paint. All structural steel work, crane rails, fittings anchorages, clips and embedded metal items are $304 \mathrm{~L}$ stainless steel, stainless-clad carbon steel, or phenolic-painted carbon steel.

Shielding windows in the RMSC walls allow direct viewing of operations in the cell. A shielded hatch connects the RMSC with the cask loading station (CLS) for removal of packaged waste. Removable ceiling plugs connect the RMSC and the CEMG.

Stainless steel piping (including installed spares) associated with utilities, decontamination equipment, and ventilation, is provided through wall penetrations in the cell. The decontamination facilities permit decontamination of equipment in the cell and internal decontamination of the cell. Equipment can be removed to the CEMG for contact maintenance after in-cell decontamination.

\section{A.3.3 Uranium Product Cell}

The uranium product cell (UPC) contains equipment for purification of the uranium product stream and the cleanup system for uranium processing solvent. Process operations are performed remotely. Equipment maintenance and repair is performed by contact methods following chemical decontamination of the process equipment and cell surfaces. 


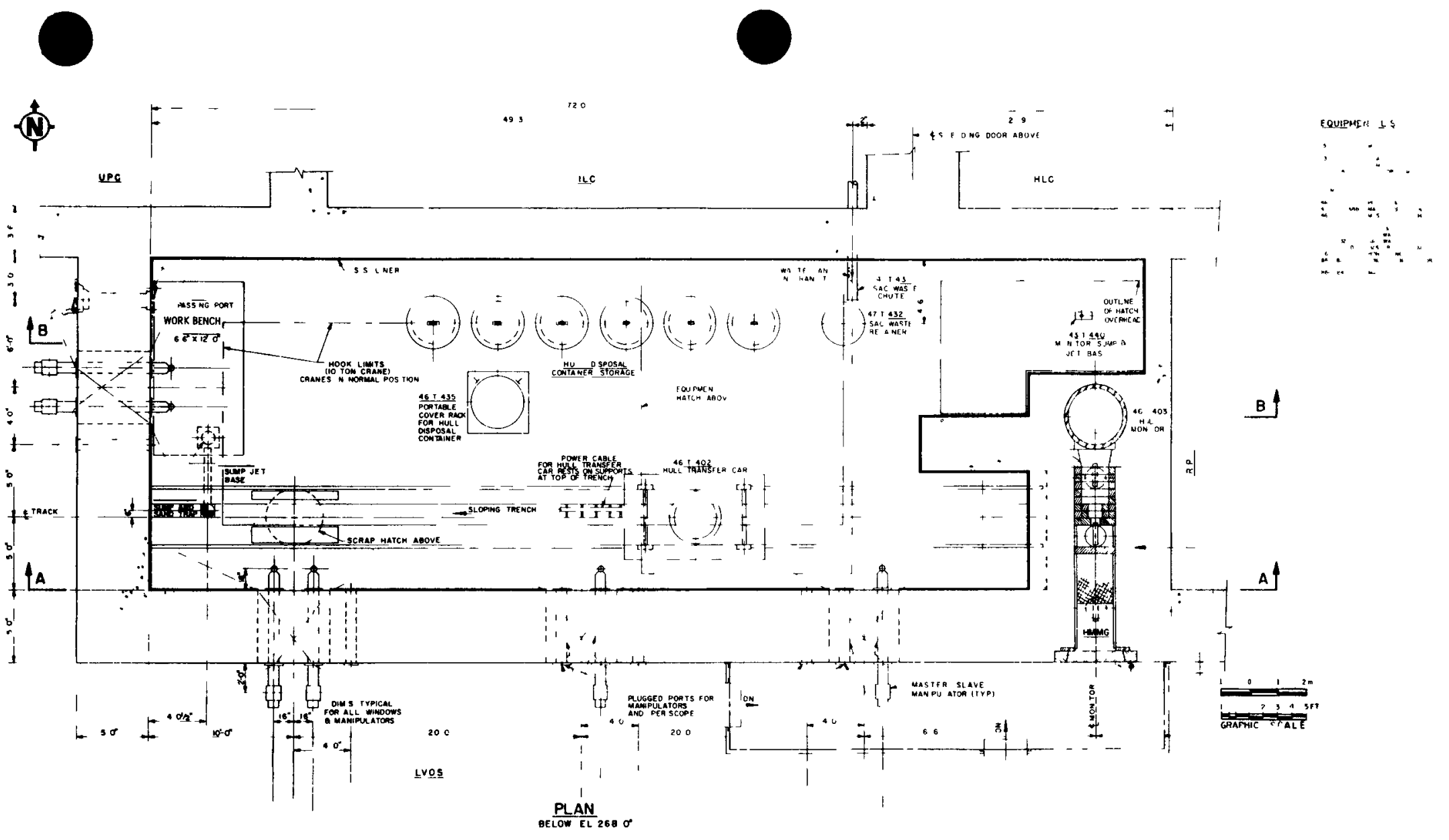

FIGURE A.3-6. Remote Maintenance and Scrap Cell -

Equipment Arrangement 
0

0<smiles>O</smiles> 


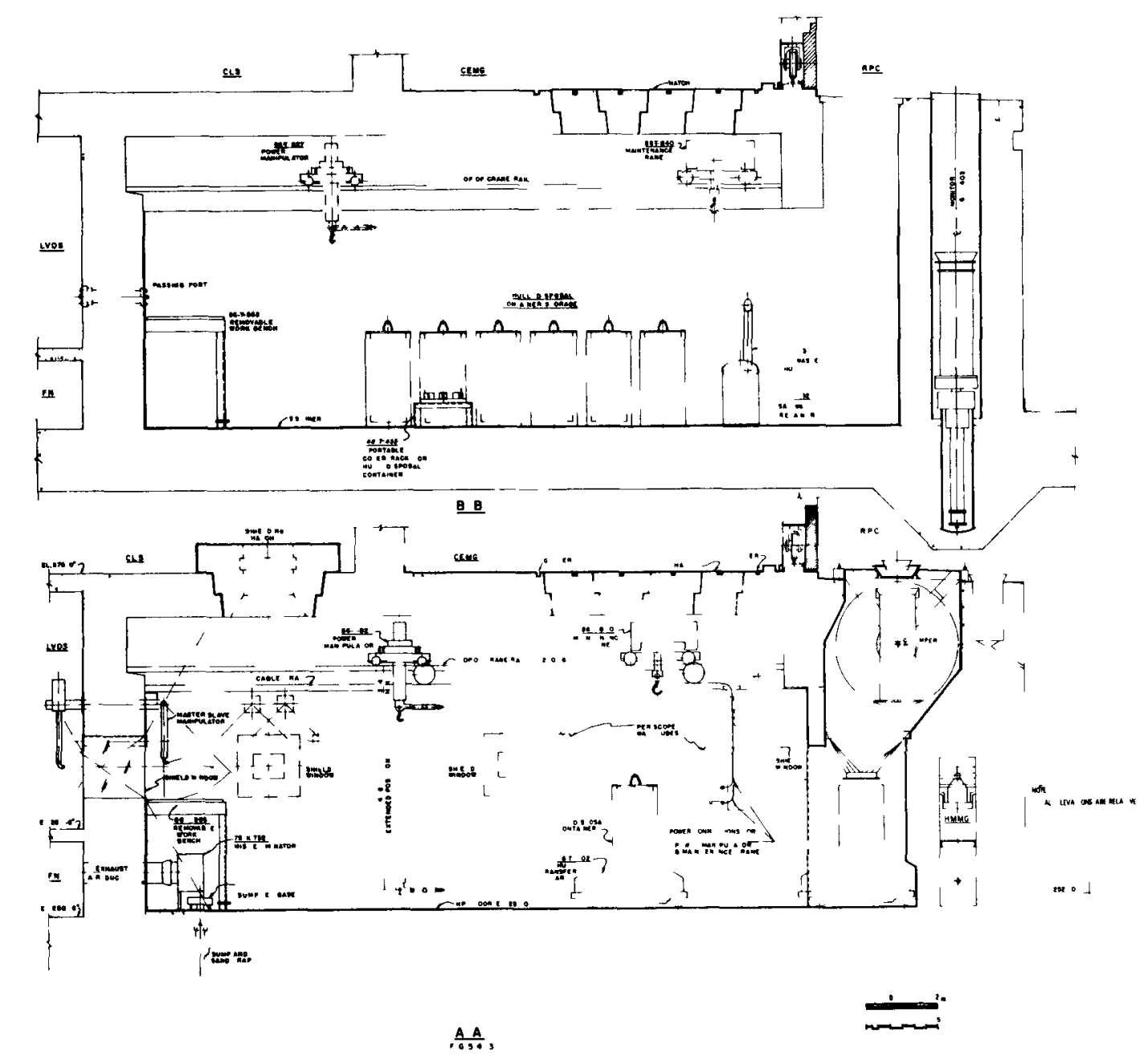

FIGURE A 3-7 Remote Maintenance and Scrap Cell - tquipment 
•

0

0 
Details of the cell structure and equipment layout are presented in Figures A.3-8 and A.3-9. Overall dimensions of process equipment in the UPC are presented in Appendix E, Table E.3-1. Process equipment in the UPC is typically constructed of $304 \mathrm{~L}$ stainless steel. A stainless steel floor pan with a sump is provided in the cell to catch spills of process solutions for removal. Concrete surfaces are coated with phenolic paint.

There are three main access penetrations to the cell. A shielded personnel access door connects the UPC with the filter piping and instrument gallery (FPIG). Two removable concrete hatches in the cell ceiling provide access from the contact equipment removal station (CERS).

\section{A.3.4 Intermediate Level Cell}

The intermediate level cell (ILC) contains equipment for vessel off-gas treatment, spent solvent treatment and combustion, acid recovery, and low-level liquid waste concentration. A11 operating activities are carried out remotely. Contact maintenance is used after appropriate chemical decontamination.

Details of the cell structure and equipment layout are presented in Figures A.3-10 and A.3-11. Equipment overall dimensions are given in Appendix E, Table E.3-2. The major equipment located on the cell includes:

- acid fractionator

- $\mathrm{NO}_{2}$ absorber

- waste solvent burner

- low-level waste concentrator

- iodine scrubbers (2)

Most process equipment and piping in the cell are constructed of $304 \mathrm{~L}$ stainless steel. The acid fractionator and LAW concentrator and reboiler are titanium, and the waste solvent burner is inconel. The cell is equipped with a 304L stainless steel floor pan and sump to collect spills of process solutions for removal. Concrete surfaces are coated with phenolic paint. Access to the cell is through a shielding door to the FPIG and a removable concrete ceiling hatch to the CERS. 
0

0 


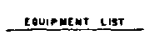

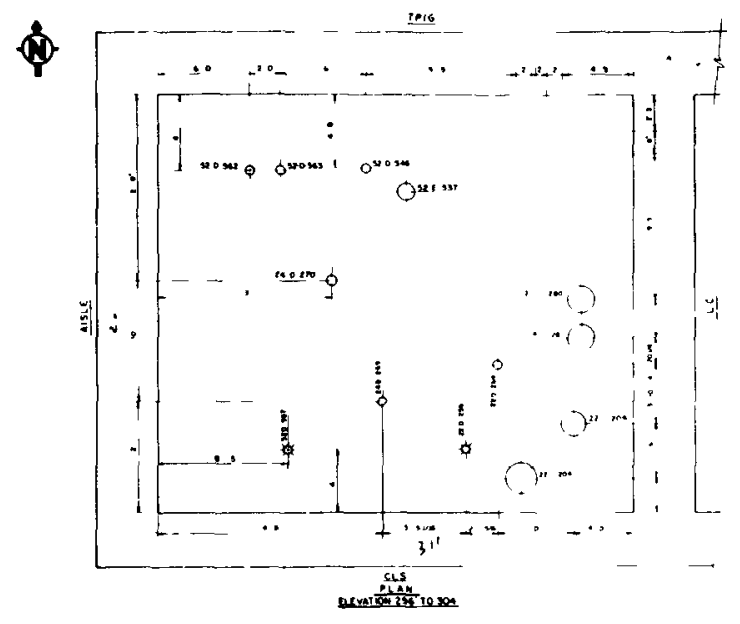

P:

Ai:i: in

,

证

sti

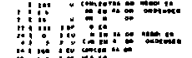

$\because:=\therefore:=$
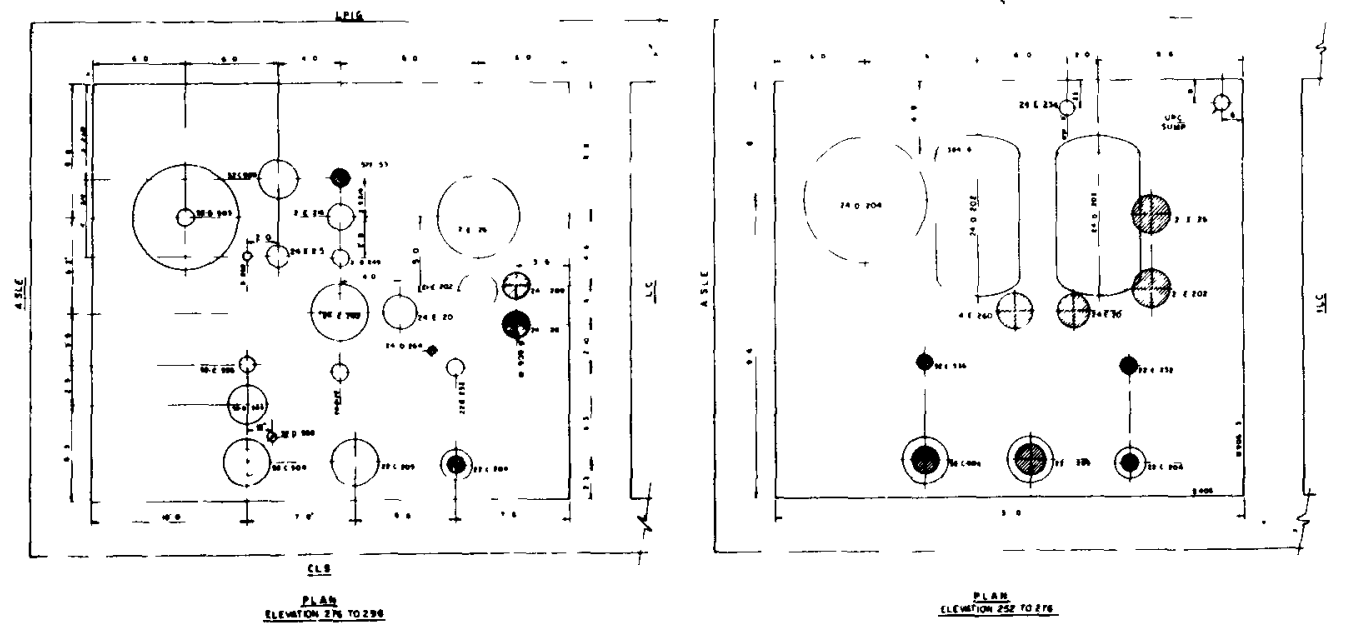

1.

FIGURE A.3-8. Uranium Product Cell Equipment Arrangement 
0

0

0 


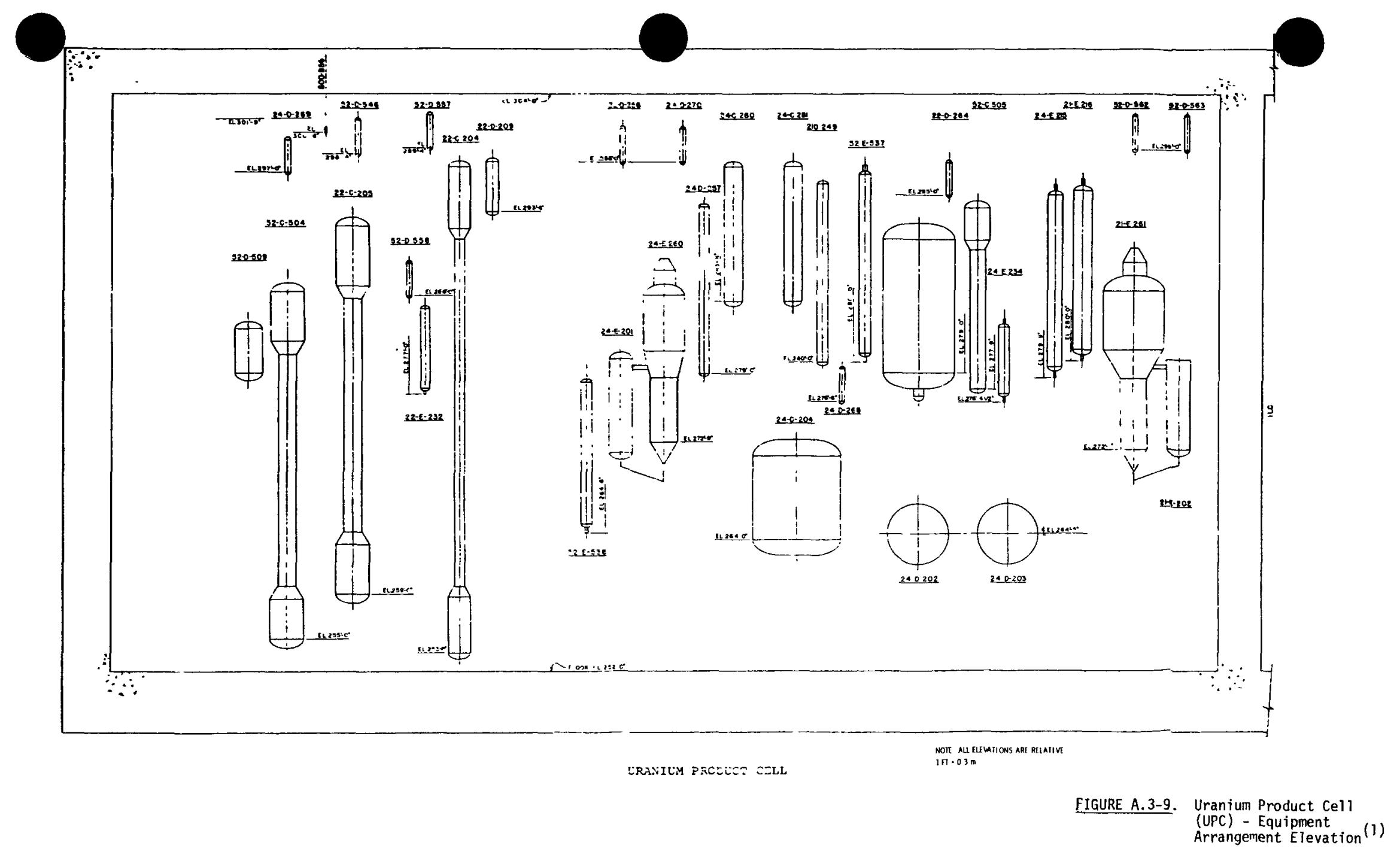


0

0

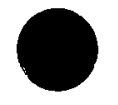




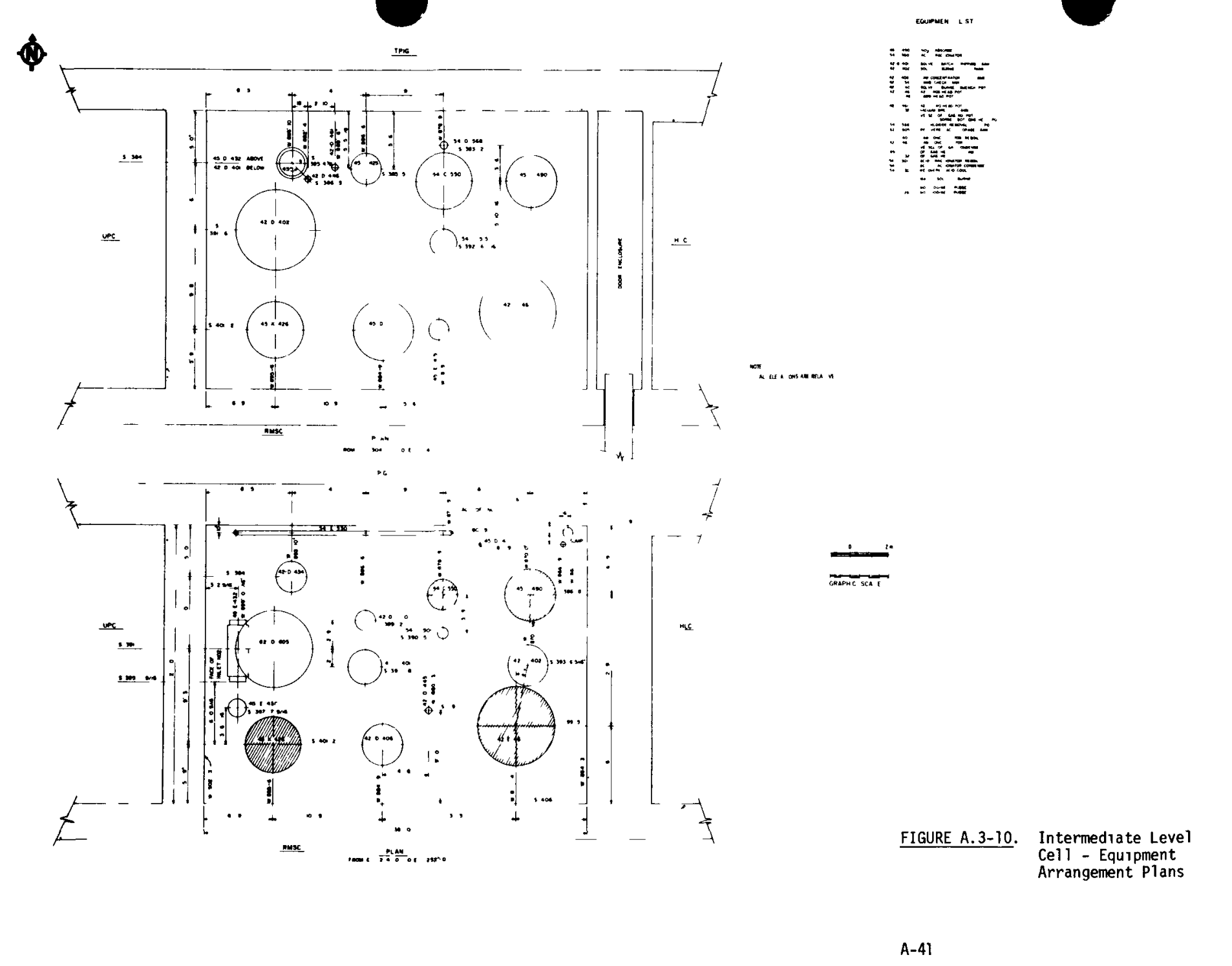


•

•

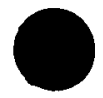


CERS.

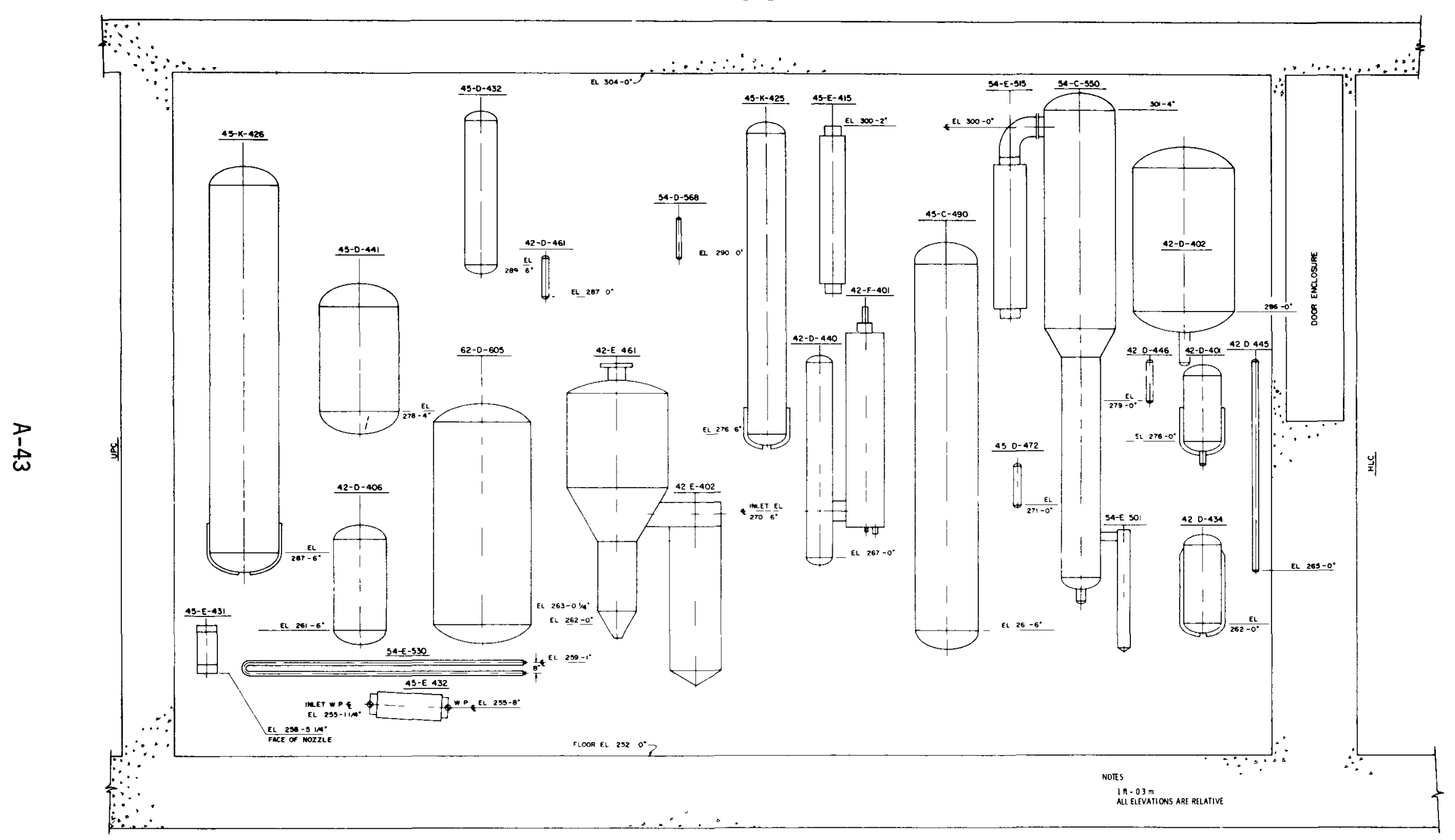

INTERMEDIATE LEVEL CELL

FIGURE A.3-11. Intermediate-Leve1 Cel1 (ILC) - Equipment Arrangement Elevation 


\section{A.3.5 High Level Cell}

The high level cell (HLC) contains equipment for accountability of uranium and plutonium, chemical adjustment and centrifuging of the main process stream from the dissolvers, and handling high- and intermediate-level waste solutions. The cell is designed for remote operation and contact maintenance.

Details of the cell structures and equipment layout are presented in Figures A.3-12 and A.3-13. Process equipment overall dimensions are given in Appendix E, Table E.3-4.

The major process equipment in the cell includes:

- feed centrifuge

- dissolver surge, transfer and flush accumulation tanks (7)

- general purpose concentrator tank

- high-activity waste (HAW) catch and surge tanks (3)

- feed adjustment and surge tanks (3)

- accountability tank

Cell equipment is constructed almost entirely of 304L stainless steel. The cell is equipped with a stainless steel floor pan and sump to catch spills of process solutions. Concrete surfaces are coated with phenolic paint. Access to the cell is through a shielding door to the FPIG and a removable concrete ceiling hatch to the CERS. 
4

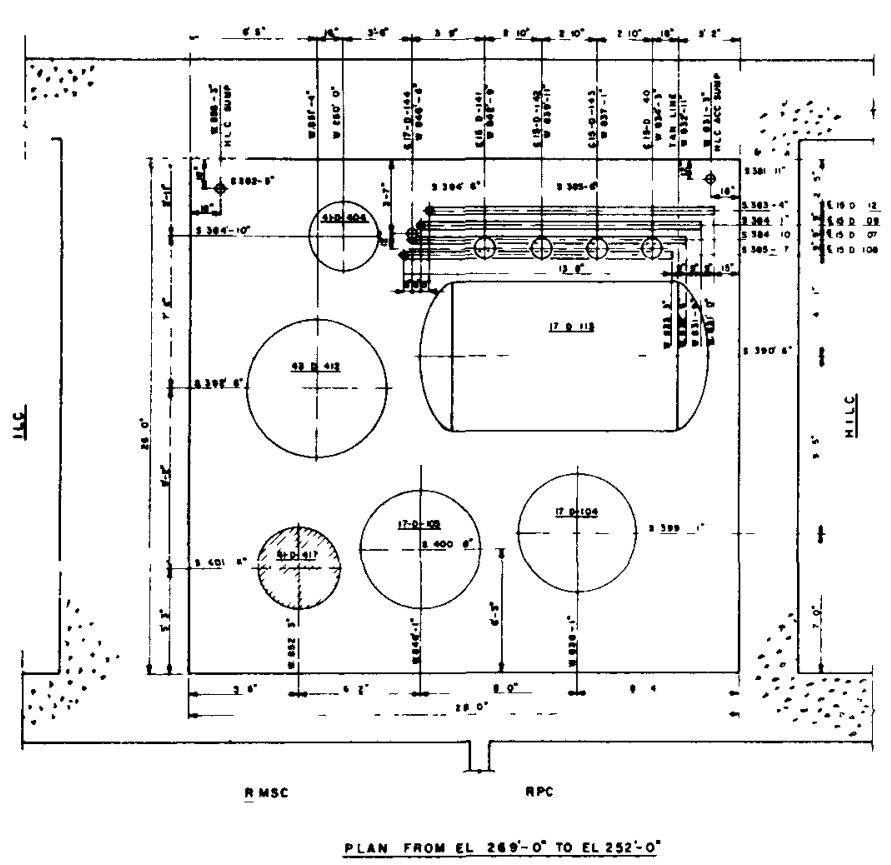

LP1E
IP16

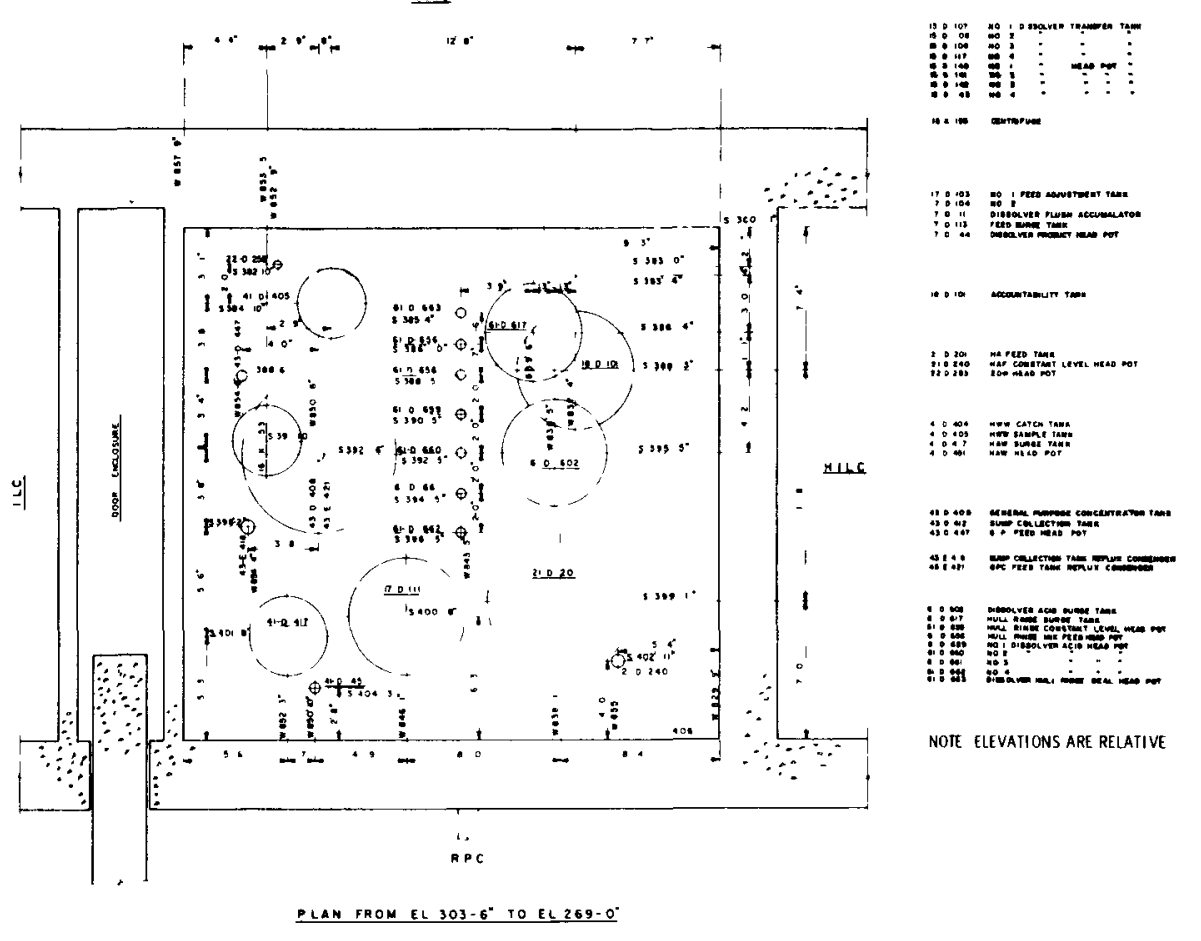

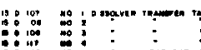

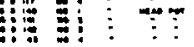

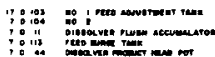

EOUIPMENT LIST

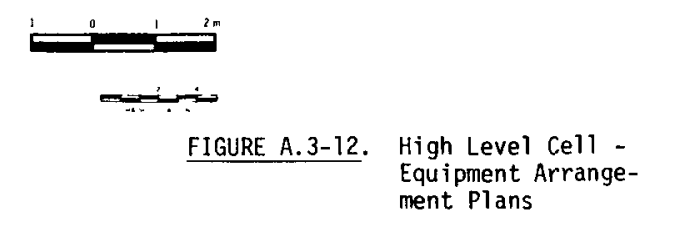

$\begin{array}{lll}m & 1 & 1 \\ 1+1 & -1\end{array}$


0

0

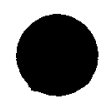


-

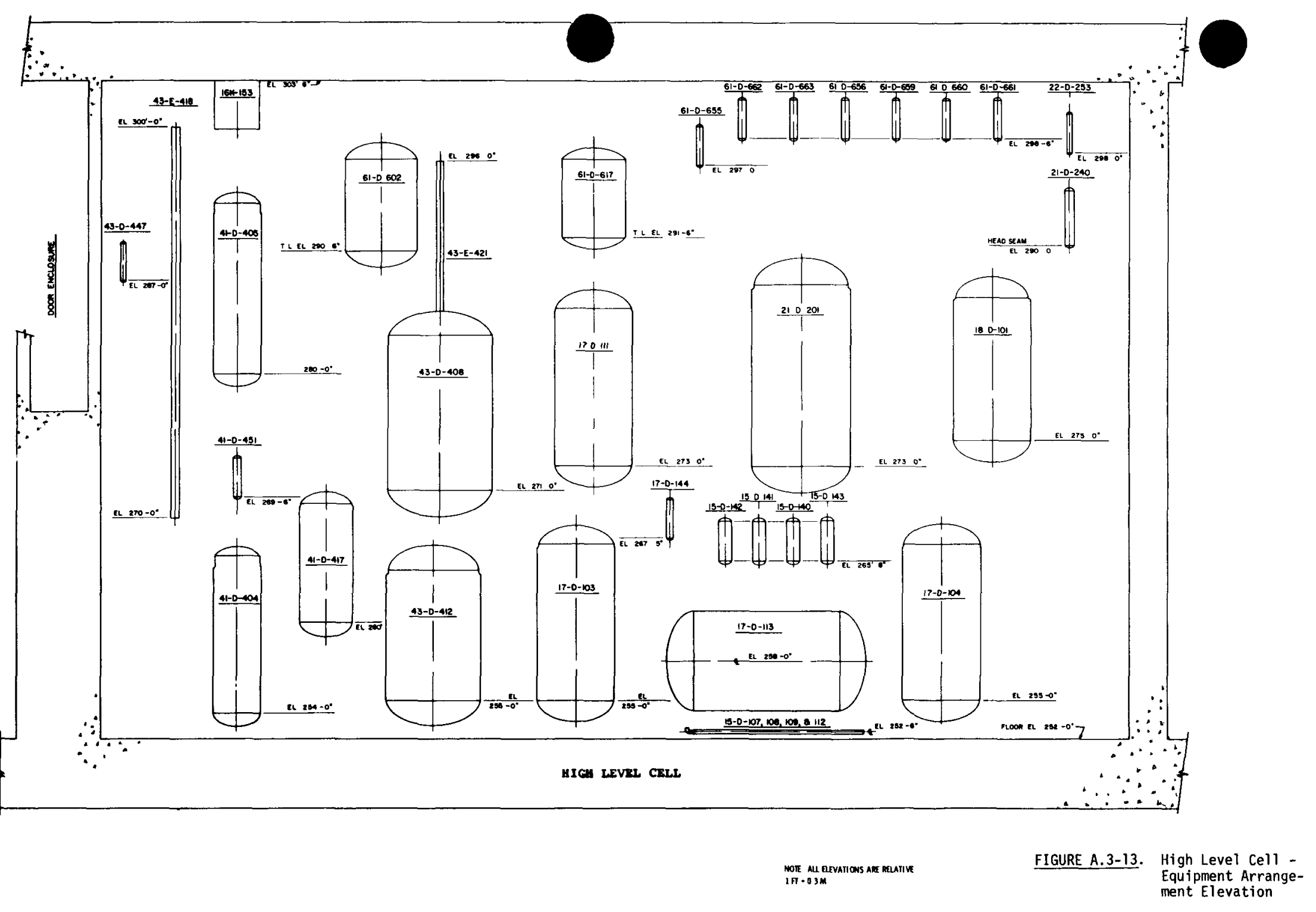

$m$
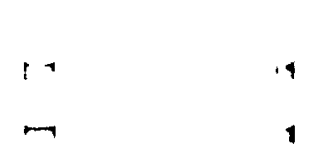
0

0

O 


\section{A.3.6 High-Intermediate Level Cell}

The high-intermediate level cell (HILC) contains equipment for solvent extraction of uranium and plutonium from fission products, separation of uranium from plutonium, concentrating intermediate-level liquid wastes and solvent cleanup and storage. The cell is designed for remote operation and contact maintenance.

Details of the cell structures and equipment layout are presented in Figures A.3-14 through A.3-16. Equipment overal1 dimensions are presented in Appendix E, Table E.3-3.

Major process equipment located in the cell include:

- HA centrifuga 1 contactor

- IB electropulse column

- HS column

- IBX and IC columns solvent cleanup pulse columns (4)

- general purpose concentrator

- dissolver off-gas condenser

- solvent feed tank

The HA centrifugal contactor and $1 B$ electropulse columns are installed in removable shield plugs in the cell ceiling. Nonradioactive portions of this equipment are located in the contact equipment removal station above the HILC.

Most of the process equipment in the HILC is constructed of stainless steel. The IB electropulse column has titanium and platinum internals. The cell is equipped with a stainless steel floor pan and sump to collect spills of process solutions. Concrete surfaces are coated with phenolic paint. Access to the cell is through a shielding door to the FPIG and a removable concrete ceiling hatch to the CENS. 
- 

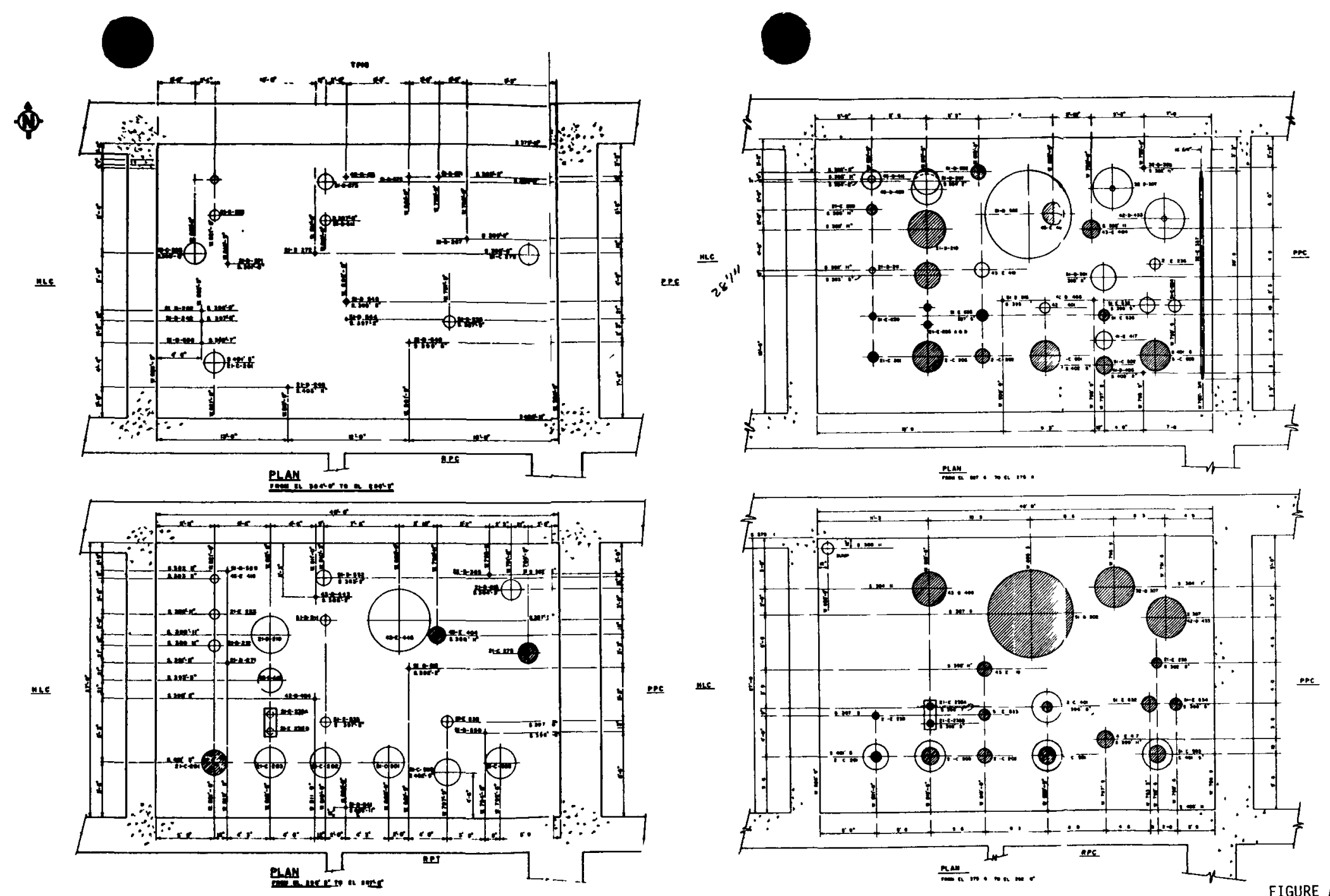

FIGURE A.3-14. High Intermediate Level Cel1 - Equip ment Arrangement
Plans $(1)$
震

I:

$\because \equiv$

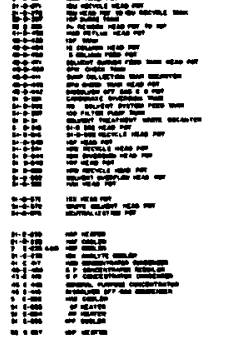
NOTE AU AEVATIONS ARE REATIVE
IT $03 \mathrm{M}$
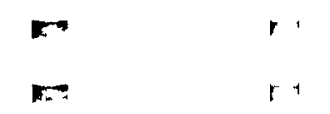

1 
0

0

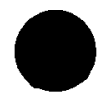




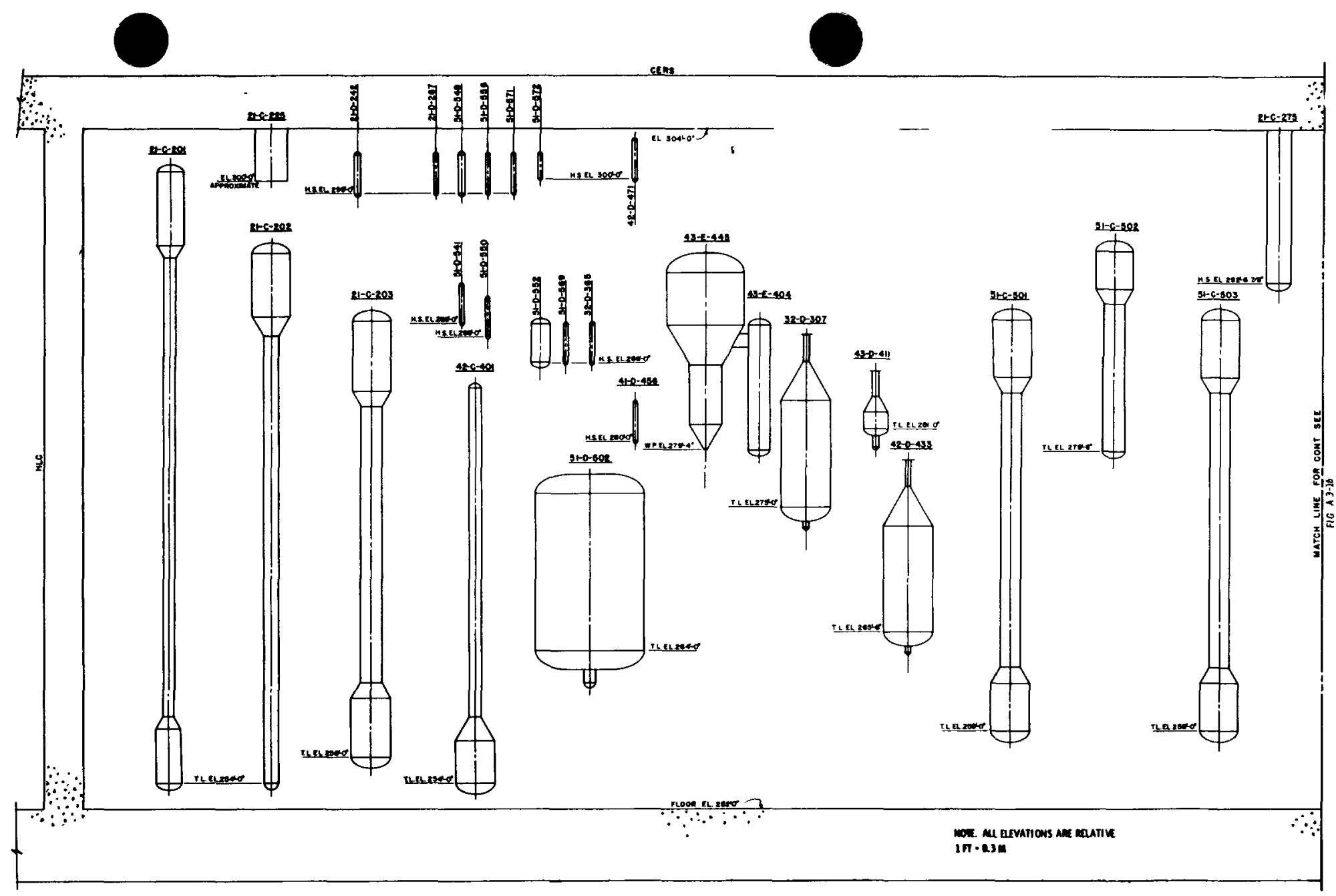

FIGURE A.3-15. High Intermediate LeveI Cell - Equipment Arrangement Elevation( 1 ) 
○

0

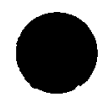




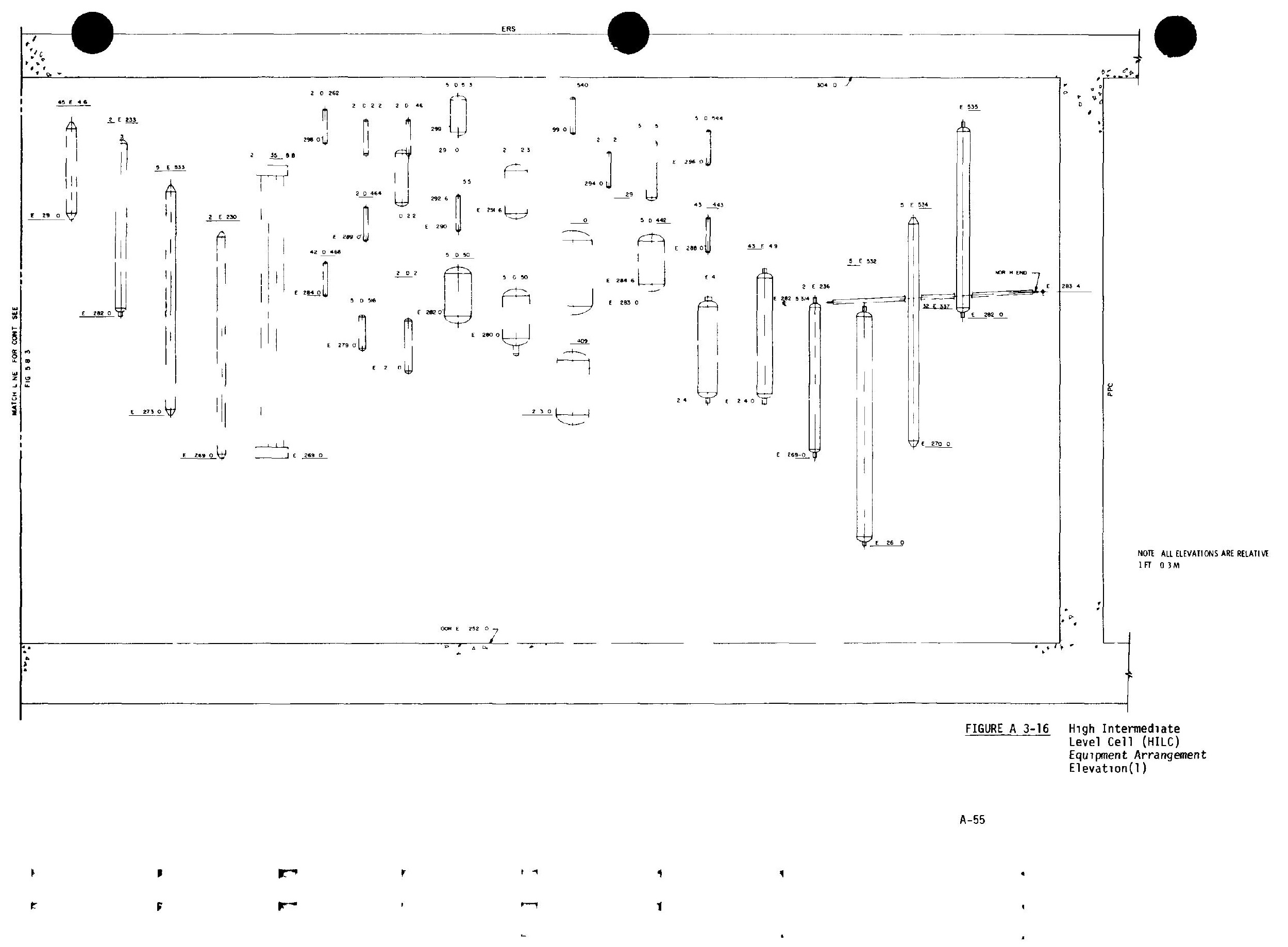


0

0

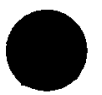




\section{.3.7 Plutonium Product Cell}

The plutonium product cell (PPC) contains equipment for purification, concentration and short-time hold-up of the plutonium product stream. The ce11 is designed for remote operation and contact maintenance.

Details of the cell structures and equipment layout are presented in Figures A.3-17 and A.3-18. Equipment overall dimensions are given in Appendix E, Table E.3-5. Major equipment located in the cell includes:

- plutonium purification pulse columns (4)

- plutonium nitrate concentrator

- plutonium transfer pumps (4)

- plutonium nitrate storage, sample and catch tanks (6)

A11 equipment is designed with a geometry that prevents a plutonium nuclear criticality excursion. The plutonium transfer pumps are located in an isolated "pump niche" for easier maintenance access.

Equipment in the PPC is constructed of $304 \mathrm{~L}$ stainless steel. The cell is provided with a $304 \mathrm{~L}$ stainless steel floor pan and sump with nuclear criticalitysafe geometry to collect spills of process solutions for recycle or removal. Access to the cell is through a shielding door to the FPIG and a concrete ceiling hatch to the CERS. A shielding door to the pump niche is also provided. 
0

0 

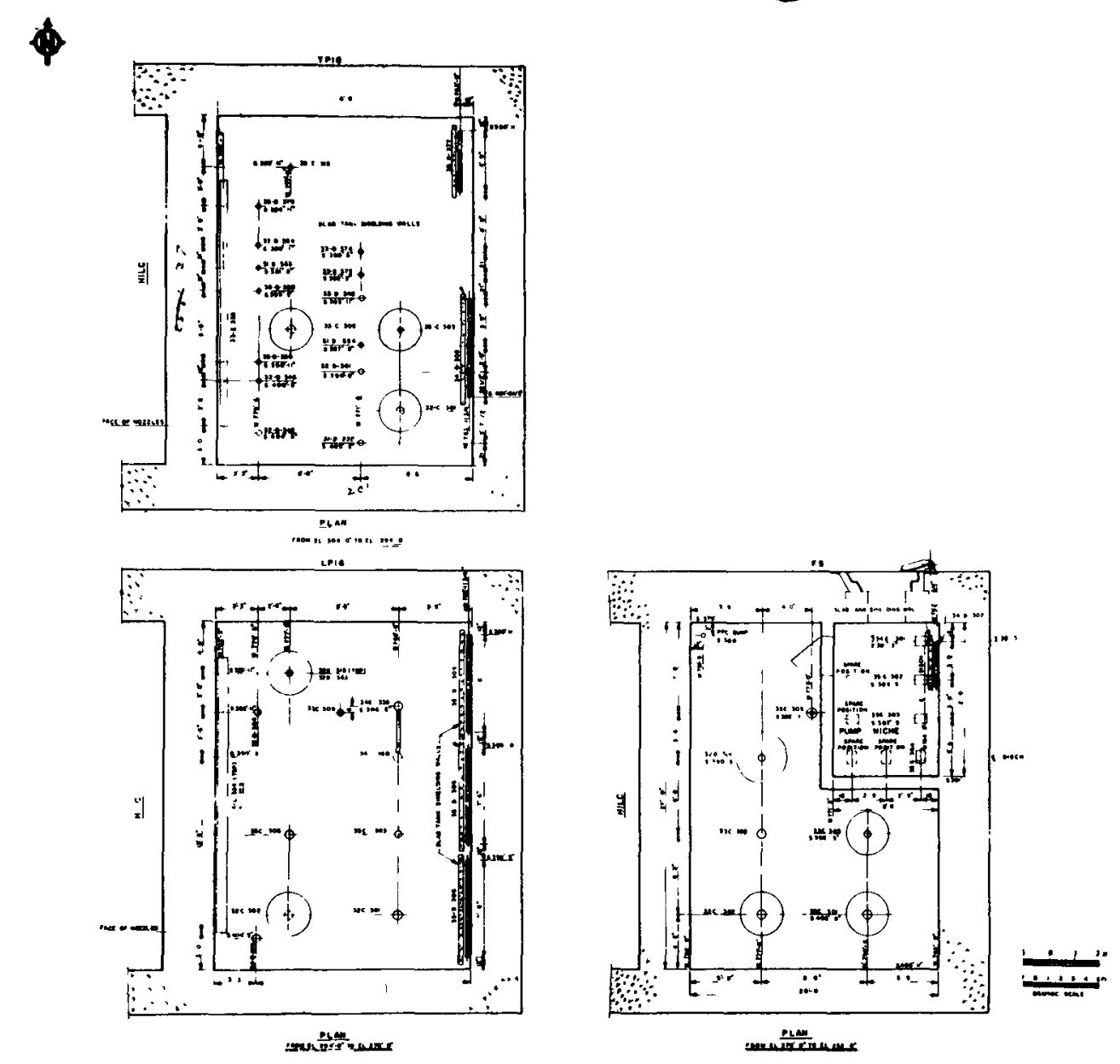
0

0<smiles>O</smiles> 


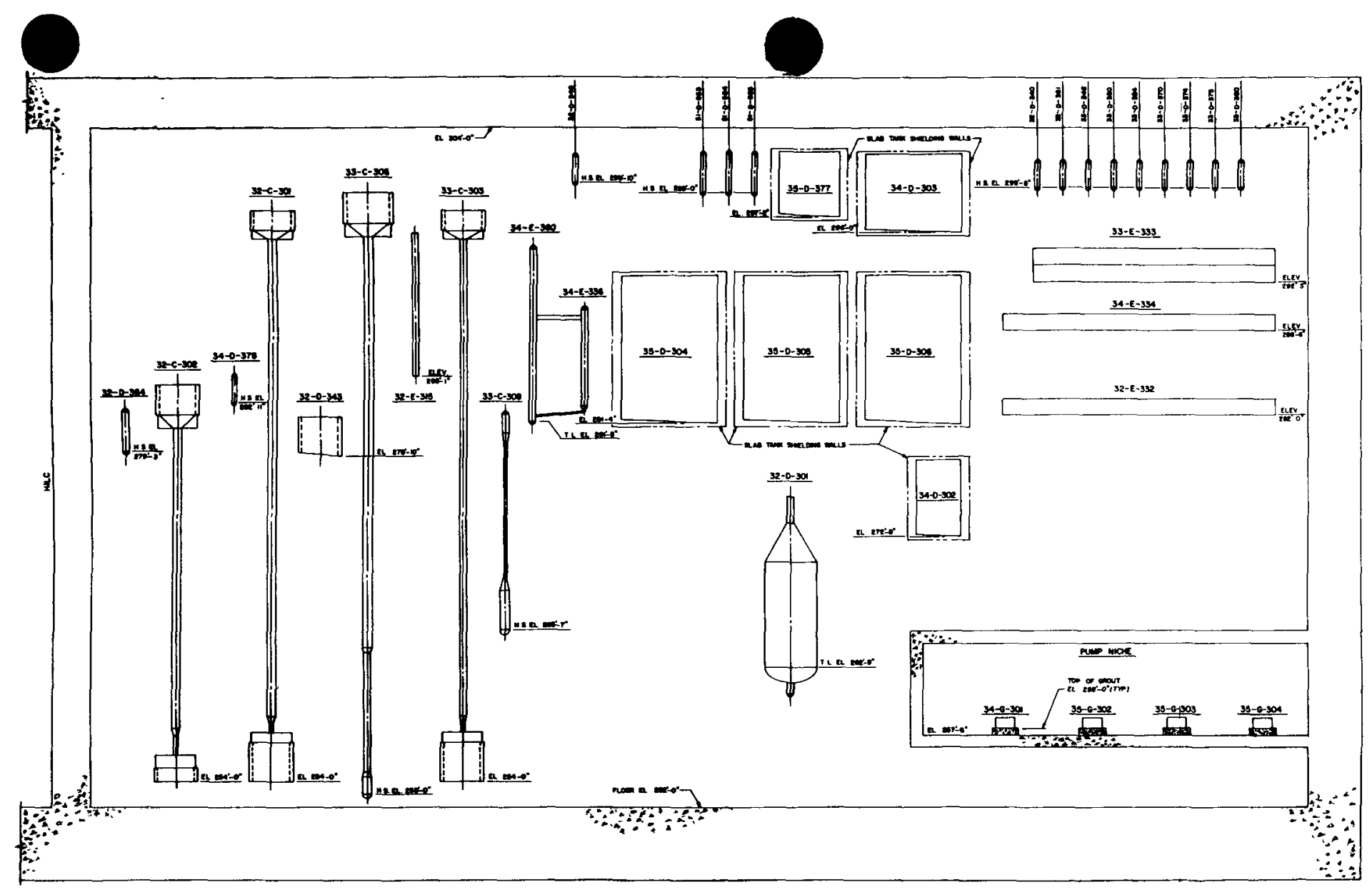

pronourun papouce cels

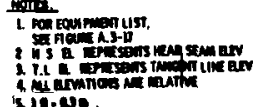

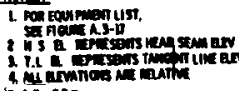$$
\text { ising }
$$

FIGURE A.3-18

Plutonium Product Cell
Equipment Elevation 
0

0 


\subsection{Plutonium Nitrate Storage and Loadout}

The plutonium nitrate storage and loadout (PNSL) area consists of the plutonium nitrate operating station (PNOS), two plutonium nitrate storage cells (PNC), plutonium nitrate control area (PNCA) and the cooling water area (CWA). These facilities contain the following:

- hardware, cells, glove boxes, and equipment for the safe transfer of plutonium directly to the PNSL glove boxes for loadout and transfer to the $\mathrm{PuO}_{2}$ conversion facility,

- equipment for handling and moving plutonium nitrate shipping containers,

- slab tanks (48) and auxiliary equipment for extended storage of plutonium nitrate solution,

- water-chilled heat exchanger equipment and HEPA filtration for cooling air recirculated through the PNCS,

- radiation alarms, air sampling, and monitoring equipment,

- glove box fire detection and extinguishing equipment,

- safety and process control instrumentation,

- ventilation exhaust filtration and ducting.

Equipment layout and facility arrangement in the PNSL is shown in Figures A.3-19 and A.3-20. The PNOS houses the glove box loadout system, pump maintenance glove box, sample glove box, and ventilation equipment for the plutonium nitrate storage cells. The glove boxes and storage cells drain to a sump with a geometry that prevents nuclear criticality. Spilled solutions can be transferred from the sump to the plutonium rework tank in the plutonium product cell (PPC). Other storage and metering tanks in the PPC are connected by an all-welded and jacketed transfer system to the PNSL storage tanks and loadout glove box. 
0

0 

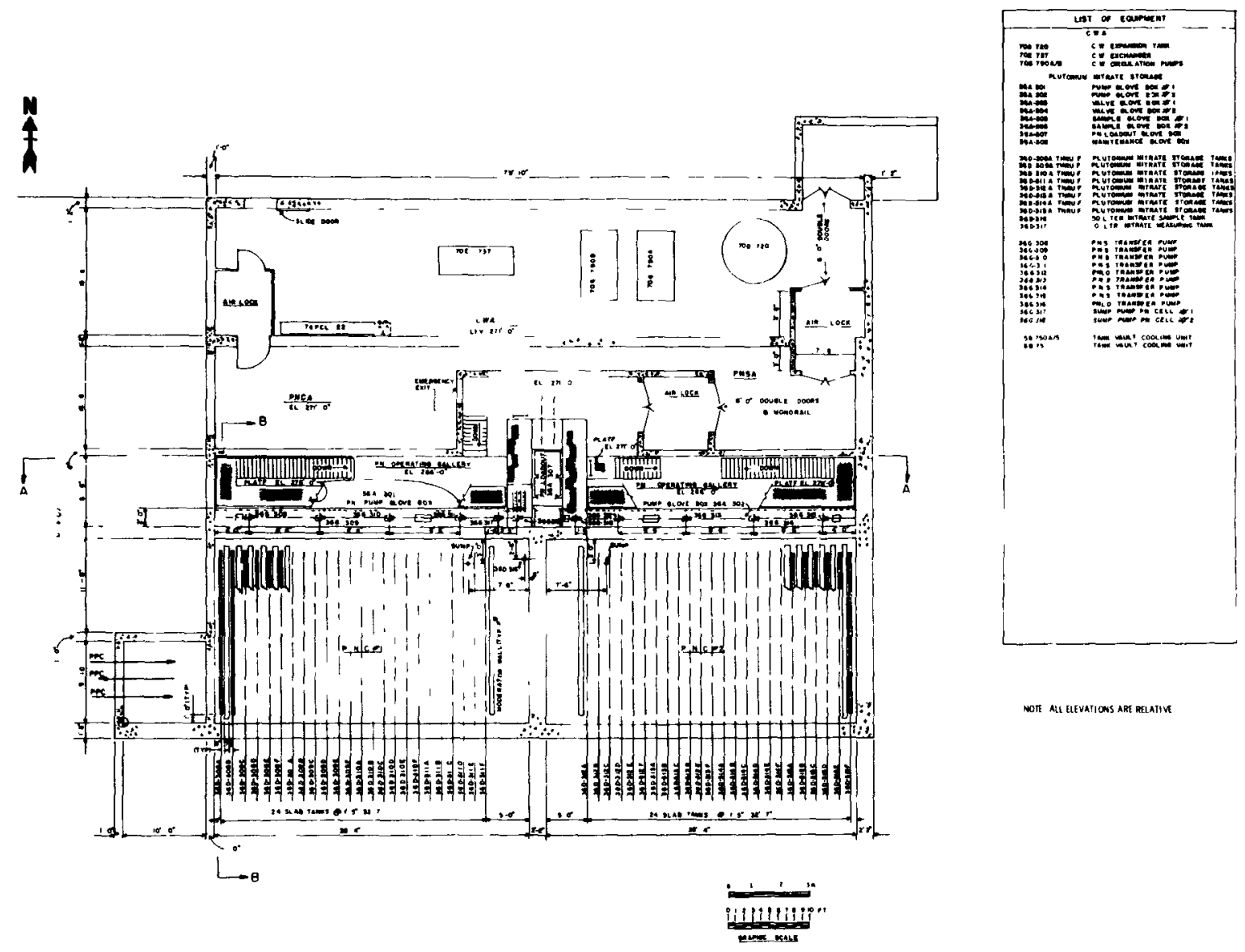


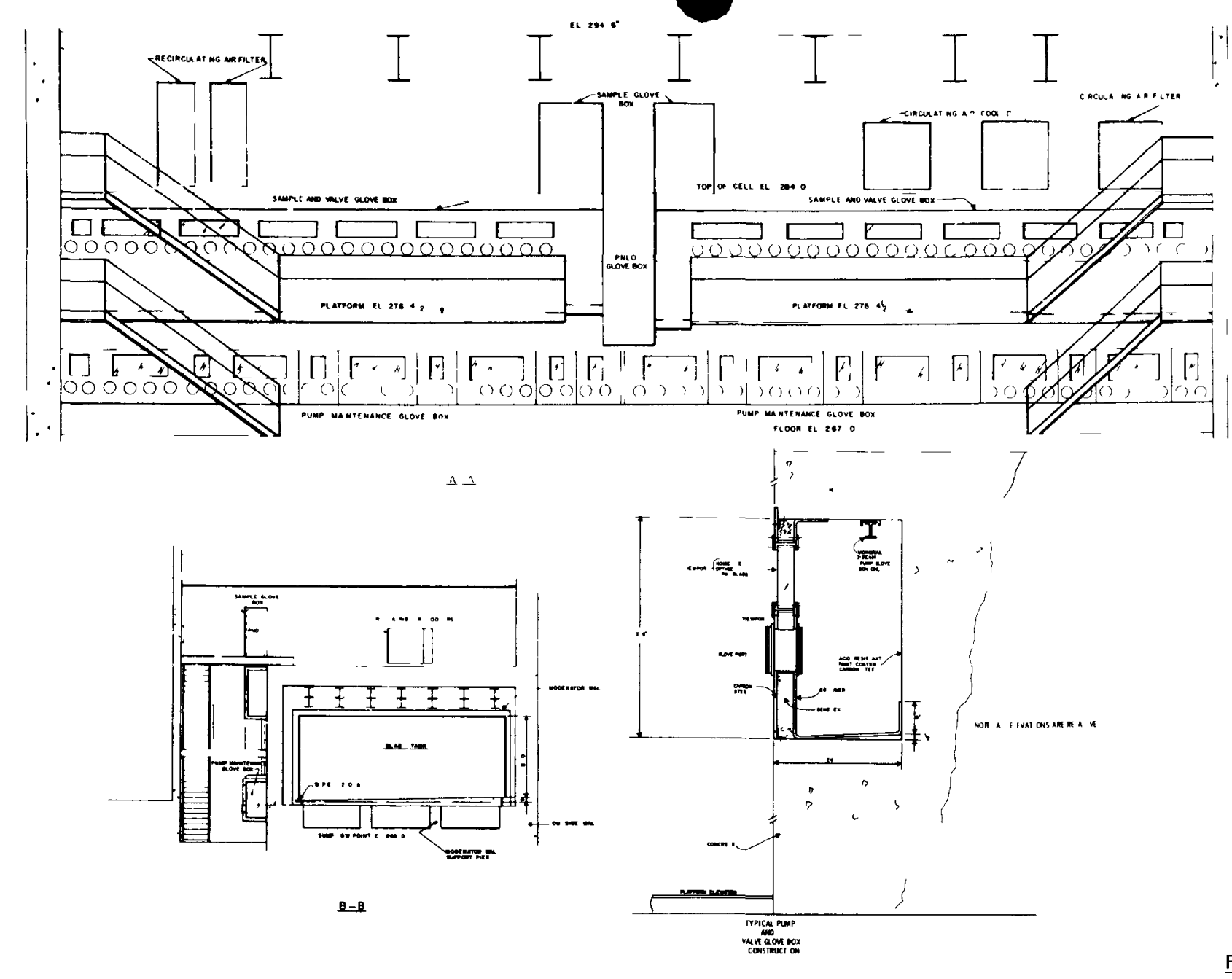

FIGURE A.3-20. Plutonium Nitrate Storage and Loadout Area 
•

•

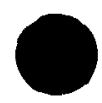


The PNC contains the vessels and piping required for extended storage of plutonium product. The reinforced concrete walls and roof are covered with a chemical-resistant protective coating. The cell floor liner is a $304 \mathrm{~L}$ stainless steel tray that is designed to contain the contents of any vessel in the cel1. The PNC provides storage for $8000 \mathrm{~kg}$ of plutonium in $3 \mathrm{M}$ nitric acid solution with a maximum concentration of 250 grams of plutonium per liter.

\section{A.3.9 Control Room Area (CRA)}

The central control room houses the process control instrumentation for the main reprocessing plant, as well as the display and monitoring panels of all safety-related instruments within the facility. The control room also serves as the communications center from which operators can be directed to perform manual functions.

The CRA consists of:

- main process control room

- offices

- utility and storage space

- instrument and electronic equipment room

- instrument shop area

- static inverter and battery rooms.

An instrument shop for the repair and calibration of noncontaminated electronic instrumentation is located below the control room office area. Rooms containing the static inverters (convert emerging battery power to alternating current), batteries, and special analysis electronics and relay panels are also located in this area. An electrical cable distribution room is provided immediately below the control room to provide space for wire and cable routing.

\section{A.3.10 Galleries}

The major galleries in the facility are shown in the overall views of the process building presented in Figures A.3-1 through A.3-3 and 5.3-2 and 5.3-3 in Volume 1 . The galleries in the main process building enclose and protect piping, process support equipment, and instrumentation components. Many are routinely occupied by operating personnel. The main galleries are described separately below. 
- Head Tank Gallery/Pulser Equipment Gallery (HTG/PEG)

The combined HTG/PEG is located above and provides services to the process cells. This gallery is constructed of reinforced concrete with $0.5 \mathrm{~m}$ thick walls to provide biological shielding for personnel. Additional local biological shielding is provided in the cell around high-radioactivity head pots. Air pulsers for the solvent extraction columns, recovered acid tanks, recycled water tanks, and the cold off-gas (COG) blower are located within the gallery.

- Top Piping and Instrument Gallery (TPIG)

The TPIG is located at the upper level of the face of the contact maintenance process cells at an elevation corresponding generally to the top onethird of these cells. This gallery contains piping, valves, and process control instruments to serve the adjacent cells. Access to these devices is provided by internal gallery walkways at three elevations. Access to the gallery is via the top access aisle (TAA) through two air locks at the back end of the gallery. Access to equipment is provided at the level of the internal gallery walkways.

- Lower Piping and Instrument Gallery (LPIG)

The LPIG is located directly below the TPIG and at the mid-level of the face of the contact maintenance process cells. This gallery contains piping, valves, and process control instruments necessary to the operation of the adjacent cells. Access to the gallery is through the adjacent lower access aisle (LAA) through an air lock entrance at each end of the gallery.

- Filter Piping and Instrument Gallery (FPIG)

The FPIG is located directly below the LPIG. The gallery is isolated by walls and air locks from adjacent areas to minimize the spread of contamination.

This gallery contains piping, valves, and process control instruments necessary for the operation of the adjacent cells. The FPIG also contains the contact cell ventilation air filter housing, SAC filter housings, PPC filter housing, the 2.7 atmosphere (25 psig) steam system, and miscellaneous pumps. The FPIG provides access to these items as well as pipe and electrical chases. Access to this gallery is via the east stairwell, or the LVOS through air locks. Access to the UPC, ILC, HLC, and PPC is provided from this area thro shielding doors into each cell. 
- Crane and Equipment Maintenance Gallery (CEMG)

Contact maintenance is performed on the cranes serving the RPC in this gallery. The CEMG is also a staging area where equipment items entering and leaving the RPC may be prepared or maintained by contact means when radioactivity levels permit. The CEMG is part of the main process cell complex, immediately adjacent to the RPC. The two areas are separated by a shielding door. Roughly half of the floor and roof areas are made up of removable shield plugs. Removal of floor plugs provides access to the RMSC. Access to the equipment maintenance station (EMS) is provided by removal of roof plugs.

The special equipment in the CEMG includes the crane rails, the crane maintenance access platforms, an ultrasonic cleaning tank $\left(0.5 \mathrm{~m}^{3}\right.$ capacity), a shielding viewing window, a shielding personnel access door, a workbench, and a lifting device for the floor plugs.

\section{- Service Concentrator Gallery (SCG)}

The SCG is located in the lower viewing and operating station (LVOS). The gallery, which houses service concentrator equipment, is isolated by walls and air locks from adjacent areas to minimize the spread of contamination. Access is through an air lock from the LVOS. Floor, walls, and ceiling are concrete. The floor and walls are covered with acid-resistant paint up to a height of $0.9 \mathrm{~m}$. Floor drains are provided to the feed tank to route any leakage back to the service concentrator or for transfer to the general purpose concentrator.

- Hull Monitor Maintenance Gallery (HMMG)

The HMMG, located between the RPC and the RMSC, provides a shielded area for maintenance of the hull monitor and drive assembly. Access is from the LVOS. The floor, walls, and ceiling are painted concrete.

\section{A.3.11 Stations}

The major stations in the facility are shown in the overall views of the main process building presented in Figures A.3-1 through A.3-3 in this volume and 5.3-2 and 5.3-3 in Volume 1. The major stations are described in more detail below. 
- Cold Chemical Station (CCS)

The CCS houses the vessels, piping, and flow control systems required to make up, store, and transfer nonradioactive process solutions to the radioactive processing areas. The CCS is located at the highest operating level of the facility. The floor is concrete painted with Amercoat, and the walls are painted carbon steel.

\section{- Cask Loading Station (CLS)}

The CLS contains the facilities for safely removing loaded solid scrap disposal containers from the remote maintenance and scrap cell (RMSC), and securing them in their shielding cask for transport to the onsite underground solid waste storage area. Empty disposal containers also enter the RMSC from the CLS.

A portable stainless steel cask wipe-down decontamination pan is provided in the CLS in lieu of a permanent liner pan. If necessary, casks are set in this pan for final decontamination prior to transfer to the solid waste storage area.

- Viewing and Operating Stations

Viewing and operating stations contain equipment for observing, operating, and maintaining the adjacent remote maintenance process cells. The four viewing and operating stations (lower, grade, analytical, and top--LVOS, GVOS, AVOS and TVOS, respectively) are described below.

The LVOS is an area approximately $4.9 \mathrm{~m}$ wide which bounds the RMSC on the south side and west end, and the lower portion of the RPC on the south. It is separated from these areas by a concrete wal1 $1.5 \mathrm{~m}$ thick. The principal functions performed from the LVOS are loading of leached hulls in interim burial containers and remote maintenance of equipment. Four $0.6-\mathrm{m}$ by $0.7-\mathrm{m}$ lead glass, oil-filled shielding windows are installed in the concrete wall for observation of activities within the RMSC. Two master-slave manipulator wall tubes and one periscope wall tube are located at each shielding window. An additional periscope wall tube is provided for viewing the hull dumping operation. A port for passing items into or out of the RMSC is located in the east wall of the LVOS. 
The GVOS is an area approximately $4.9 \mathrm{~m}$ wide by $40 \mathrm{~m}$ long, separated from the south side of the RPC and CEMG by a concrete wal1 $1.5 \mathrm{~m}$ thick. Operation of the fuel shear mechanism and subsequent transport of leached hulls to the hull dumper are conducted from this area. Remote maintenance in the CEMG is also performed from the GVOS.

Three lead-glass, oil-filled shielding windows are provided for the RPC and one for the CEMG. Master-slave manipulator penetrations are located at each shielding window and two periscope sleeves are provided in the RPC wall. Control panels and auxiliary equipment for the fuel shear mechanisms and fuel transfer conveyor are also located in this area.

The AVOS is an area approximately $5.1 \mathrm{~m}$ wide by $55 \mathrm{~m}$ long, located north of the eight sample and analytical cells. It is separated from these cells by a concrete wall $0.9 \mathrm{~m}$ thick. Operations in the SACs are conducted from the AVOS through a shielding window and two master-slave manipulators installed in each cell. Glove boxes for taking samples from the UPC, PPC, and ILC are also located in the AVOS.

The TVOS is a $4 \mathrm{~m}$ diameter, circular area in the cold chemical station (CCS). The prime function of the TVOS is to provide top viewing of RPC operations. A shielding window is provided in the center of the TVOS floor for this purpose. There are also four penetrations in the TVOS floor for supplying auxiliary services to the RPC.

\section{- Contact Equipment Removal Station (CERS)}

The contact equipment removal station (CERS) provides access into the contact-maintained cells. Materials may be installed in and removed from these cells through shielding hatches in the cell ceilings. The CERS is located on the top level of the main process building immediately above the contactmaintained cells. It extends for the full length of the row of contactmaintained cells, but covers only a little over half of their width. The area is served by a 55 metric ton overhead bridge crane that also passes over the head tank gallery/pulser equipment gallery (HTG/PEG) and the cold chemical station (CCS). The crane does not have access to the portion of the CERS above the plutonium product cell hatch. The feed centrifuge, the centrifugal confactor and their electrical controllers, and the rectifier power supply for the electropulse column are located in the CERS. 


\section{- Equipment Maintenance Station (EMS)}

The EMS is located above the CEMG. It is the final decontamination and repair location where materials from the cells are repaired, prepared for transfer out of the building for other work, or packaged for transfer to the underground waste storage area. The EMS is on the top floor of the process building. Concrete shield plugs in the floor of the area provide access to the CEMG. A steel hatch permits access to the CLS. A 55 metric ton crane traverses the EMS and is utilized for major lifts. Operations in this area are associated with occasional maintenance activities and repair of equipment removed from process areas. Equipment from the cells is decontaminated remotely in the RMSC, and by contact means in the CEMG before being brought to the EMS.

\section{A.3.12 Sample and Analytical Cell (SAC)}

The SAC provides a shielded area for remote sampling and analysis of highly radioactive materials from the process cells. The SAC is divided into eight compartments, each having master-slave manipulators and viewing windows. The compartments are separated by shielding to permit working for limited periods inside one compartment without decontaminating adjacent compartments. A 304L stainless steel liner covers the floor of each compartment and extends part way up the wall. A floor drain to the general purpose concentrator is provided in each compartment for liquid waste.

Access to each compartment is through a manualiy operated door in the rear. Small equipment items and samples are transferred between compartments on a manualiy operated intercompartment conveyor. A power hoist is used to transport large items of equipment from compartment to compartment. Equipment is admitted to and removed from the cell via a transfer drawer. The drawer is located in a glove box in the air lock at the west end of the cell.

Two SAC compartments contain samplers and equipment for remote sampling of the process streams and tanks. One compartment contains sample storage facilities and equipment for disposal of surplus samples to a recovery tank. Another compartment has facilities to transfer equipment to and from the cell via the transfer drawer, and a scrap chute to the remote maintenance and scrap cell (RMSC) for disposal of canned solid waste. Two compartments contain equipment for remote radiochemical analyses. Included in another compartment is 
equipment for decontaminating samples and preparing weighed dilutions of samples to be analyzed in the HCLA. Decontaminated and diluted samples are transferred to the hot and cold laboratory area (HCLA) via a pneumatic transfer system. Equipment for process chemistry studies is in the final compartment.

\section{A.3.13 Decontamination Facilities}

A central decontamination solution mixing and distribution system is provided in the cold chemical station for the contact-maintained cells. The system is composed of mixing tanks, heating coils, and pumps. Decontamination solutions are distributed from the control system throughout the process building and injected into process equipment through manually assembled, external, temporary connections to existing penetrations. Internal recirculation is possible within process equipment, and air-sparge mixing is provided in most tanks.

Internal decontamination of equipment located in a contact-maintained cell is performed by flushing the equipment with decontamination solutions. When external decontamination is required, a decontamination solution fog is sprayed into the cell and on the equipment and cell surfaces through ten 13.6-atm, $2 \mathrm{l} / \mathrm{min}$ spray nozzles installed in the cell ceiling. Rotating spray nozzles are then lowered into the cell for washing. Final decontamination is accomplished by personnel who enter under carefully controlled radiation safety conditions and procedures.

Equipment that is to be removed from a remotely maintained cell to the crane and equipment maintenance gallery (CEMG) is normally flushed internally in place and is then transferred to the CEMG or the remote maintenance and scrap cell (RMSC) for final decontamination. Equipment that is not to be returned to service is transferred to the underground waste storage area for interim storage and eventual offsite disposal.

\section{A.4 FUEL RECEIVING AND STORAGE STATION STRUCTURES AND EQUIPMENT}

The FRSS is designed to receive and store irradiated fuel elements from LWRs and to temporarily store and transfer for shipment the canisters of solidified high-level waste. The spent fuel assemblies are received in shielded casks by either truck or rail, and unloaded under water. Waste canisters are 
loaded under water into rail casks for offsite shipment. The fuel elements waste canisters are stored under water to provide cooling and shielding.

A stainless steel liner covers all wetted surfaces in the FRSS to the highest water mark. Major structures in the FRSS were illustrated in Figures A.3-1 through A.3-3. Plan and elevation views of the FRSS are shown in Figures A.4-1 and A.4-2. Table A.4-1 lists the major equipment in the fuel receiving and storage station.

\section{A.5 LIQUID RADIOACTIVE WASTE STORAGE FACILITY}

Liquid waste from the FRP is classified as either high-level liquid waste (HLLW), intermediate-level liquid waste (ILLW), or nonradioactive liquid waste. The HLLW and ILLW are stored onsite in stainless steel tanks for no longer than 5 years (typically 1.3 years in this study) before being solidified in the waste solidification plant.

The liquid waste storage system is assumed to consist of a waste tank equipment gallery (WTEG), three HLLW storage tanks and one ILLW tank. Radioactive liquids are transferred from the main process building to the WTEG through underground pipe vaults and distributed to the tanks through underground lines via the diverter cell in the WTEG. Radioactive liquids are also transferred from the waste tanks to the Waste Solidification Plant through an underground pipe vault. The WTEG provides all equipment and services necessary to operate the waste tank farm.

\section{A.5.1 High-Level Liquid Waste Storage (HLLW)}

The HLLW system provides for the safe interim storage of high-level liquid wastes. Each HLLW tank is $16.5 \mathrm{~m}$ in diameter by $6.1 \mathrm{~m}$ high with a capacity of $1,135,000$ liters $(300,000 \mathrm{gal})$ assuming $10 \%$ freeboard. Each HLLW tank is contained within an underground, cylindrical, stainless steel lined, concrete vault. A vault is $18.3 \mathrm{~m}$ in diameter and $7.6 \mathrm{~m}$ high. The floor, walls, and top are $1.2 \mathrm{~m}, 0.9 \mathrm{~m}$, and $1.7 \mathrm{~m}$ thick, respectively. 


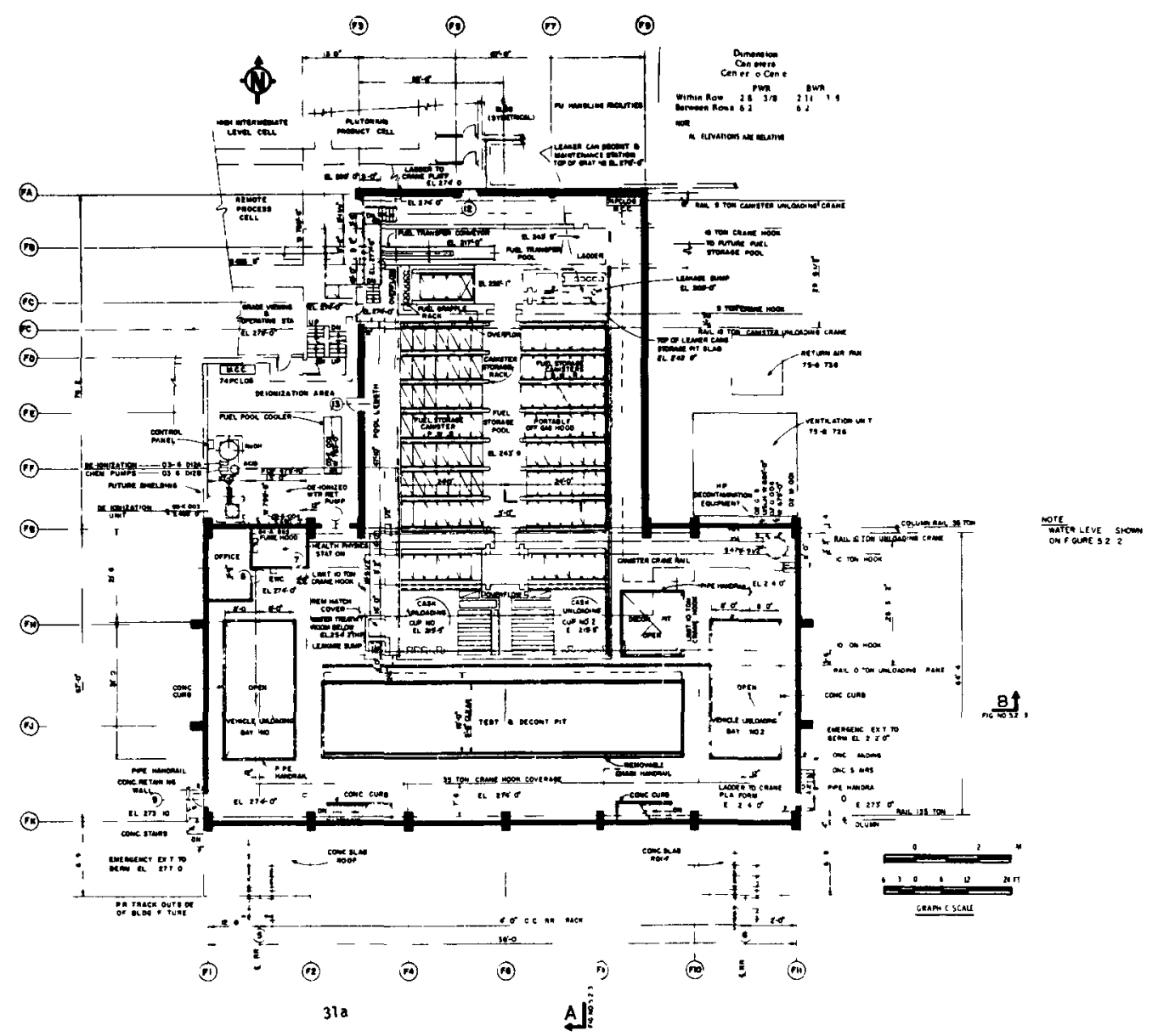


-

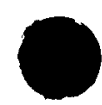




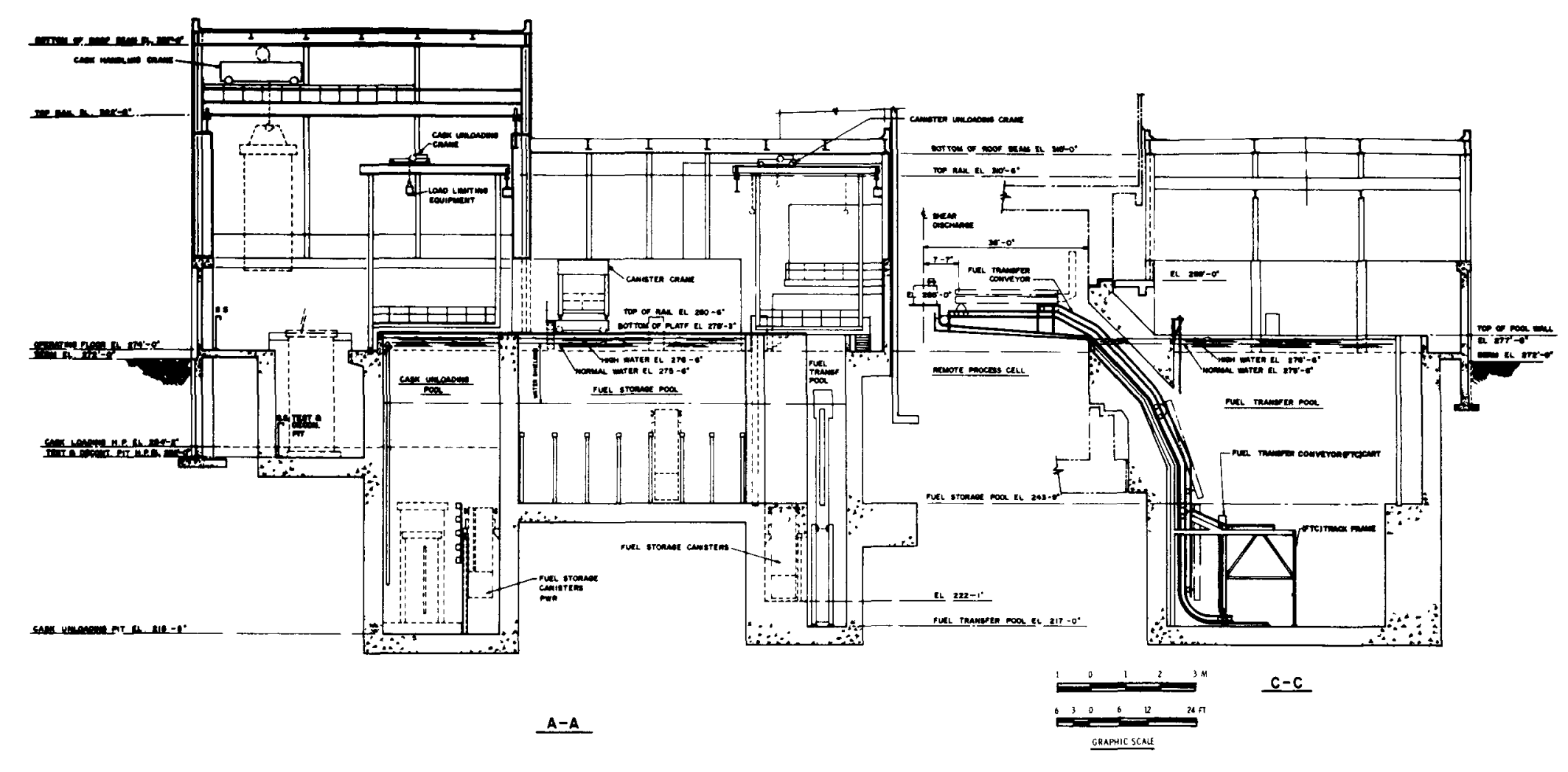

NOTE: ALL ELEVATIONS ARE RLLATIVE

FIGURE A.4-2. Sections - Fuel Receiving and Storage Station 
TABLE A.4-1. Major Equipment - Fuel Receiving and Storage Station

Name
Fuel pool cooler
Fuel pool recirculating
pumps
Filtered demineralizer
water return pump

water return pump

Mud filter

Fuel pool filter

Deionization unit

Cask head support racks

Fuel canister storage racks

Fuel storage canisters for PWR fuel

Support racks for cans with leaking fuel

pins

Fuel storage canisters for BWR fuel

Control rod cluster

storage rack

Storage racks for solidified high-level waste canisters

Cask handling crane

Cask handling crane

Cask crane

Cansiter unloading

crane

Fuel transfer conveyor
Material

Heat Transfer Plates 316 SS

Casings and shafts - 316 SS impellers - bronze

316 SS (casing, impeller and shaft

304L SS (vessel and filter elements)

$304 L$ SS

304L SS

6061-T6 aluminum (embedded supports in contact with pool water are $304 \mathrm{~L}$ SS

5083 aluminum

Stainless steel and carbon steel coated with epoxy paint

5083 aluminum

Stainless steel

Aluminum

Hoisting cable - Stainless steel

Hoisting cable - Stainless steel

Hoisting cable - Stainless steel

Hoisting cable - Stain-

less steel

304L Stainless steel

\begin{tabular}{|c|c|}
\hline Dimensions & Capacity \\
\hline-- & $7000 \mathrm{~kW}$ \\
\hline--- & 3800 liters/min \\
\hline--- & 1100 liters/min \\
\hline--- & --- \\
\hline-- & $\begin{array}{l}\text { Rated at } 1100 \text { liters } / \\
\text { min and will remove } \\
95 \% \text { of all particles } \\
5 \text { microns in size or } \\
\text { larger }\end{array}$ \\
\hline
\end{tabular}

$0.9 \mathrm{~m}$ dia $\times 0.9 \mathrm{~m}$ deep resin bed

Occupies a plan area of $2.7 \times 2.7 \mathrm{~m}$ (in each CUP)

$6.25 \mathrm{~m}$ Length $4.5 \mathrm{~m} \mathrm{High}$ on $2 \mathrm{~m}$ Center

$--$

$1.5 \mathrm{~m} \mathrm{~L} \times 0.3 \mathrm{~m} \mathrm{~W}$

$2.1 \mathrm{~m} \mathrm{~L} \times 0.6 \mathrm{~m} \mathrm{~W}$

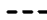

$3 \mathrm{~mL} \times 0.5 \mathrm{~mW} \times 3.7 \mathrm{~m} \mathrm{H}$

4 cans

7 canister/rack

8 fuel assemblies

3 cans each

4 cans each

18 assemblies

$\begin{array}{ll}-- & 123 \mathrm{MT} \\ -- & 9 \mathrm{MT} \\ -- & 13.6 \mathrm{MT} \\ & 13.6 \mathrm{MT} \\ & 1 \text { assembly }\end{array}$


The major equipment in an HLLW tank is illustrated in Figure A.5-1. A cross section of the tank and internals is shown in Figure A.5-2. Each HLLW tank contains the following equipment:

- $485-\mathrm{cm}$ diameter cooling coils

- 18 air-operated ballast tanks around the perimeter of the tank

- 9 air-operated ballast tanks in the main part of the tank

- 22 air lift circulators

- 5 steam-operated ejector pumps (empty-out jets)

- water-seal type pressure/vacuum relief system

- multiple external temperature sensing points

- 10 instrument dip tubes to measure liquid level and specific gravity

The HLLW tanks are supported off the sloping floor of the vault by strips of stainless steel $1.3 \mathrm{~cm}$ thick by $2.5 \mathrm{~cm}$ wide. This provides space under a tank to facilitate drainage in the unlikely event of a leak. The waste tank vault liner is $6 \mathrm{~mm}$ thick 304L stainless steel. The vault liner covers the vault floor and extends $5.5 \mathrm{~m}$ up the vault walls. It provides a liner for the vault sump and will contain all the contents of a leaking waste tank.

Cooling water is supplied to an HLLW storage tank via six 15.2-cm diameter supply headers. Each header supplies eight individual $5-\mathrm{cm}$ schedule 80 stainless steel coils, for a total of 48 coils. The headers and coils are $304 \mathrm{~L}$ stainless steel.

The six banks of eight coils each wind in a helical fashion throughout the tank and terminate in six $15.2-\mathrm{cm}$ return headers. The coils of $5-\mathrm{cm}$ pipe average $225 \mathrm{~m}$ in length. The total length of $5-\mathrm{cm}$ pipe in each tank is $10.8 \mathrm{~km}$.

The HLLW tanks are provided with vigorous agitation to minimize the settling of solids from the waste solution. Ballast tanks periodically sweep the tank floor with a horizontal motion. Air lift circulators provide active vertical circulation of the tank's contents on a continuous basis. Coil and ballast tank supports are shown in Figure A.5-3. 
- 


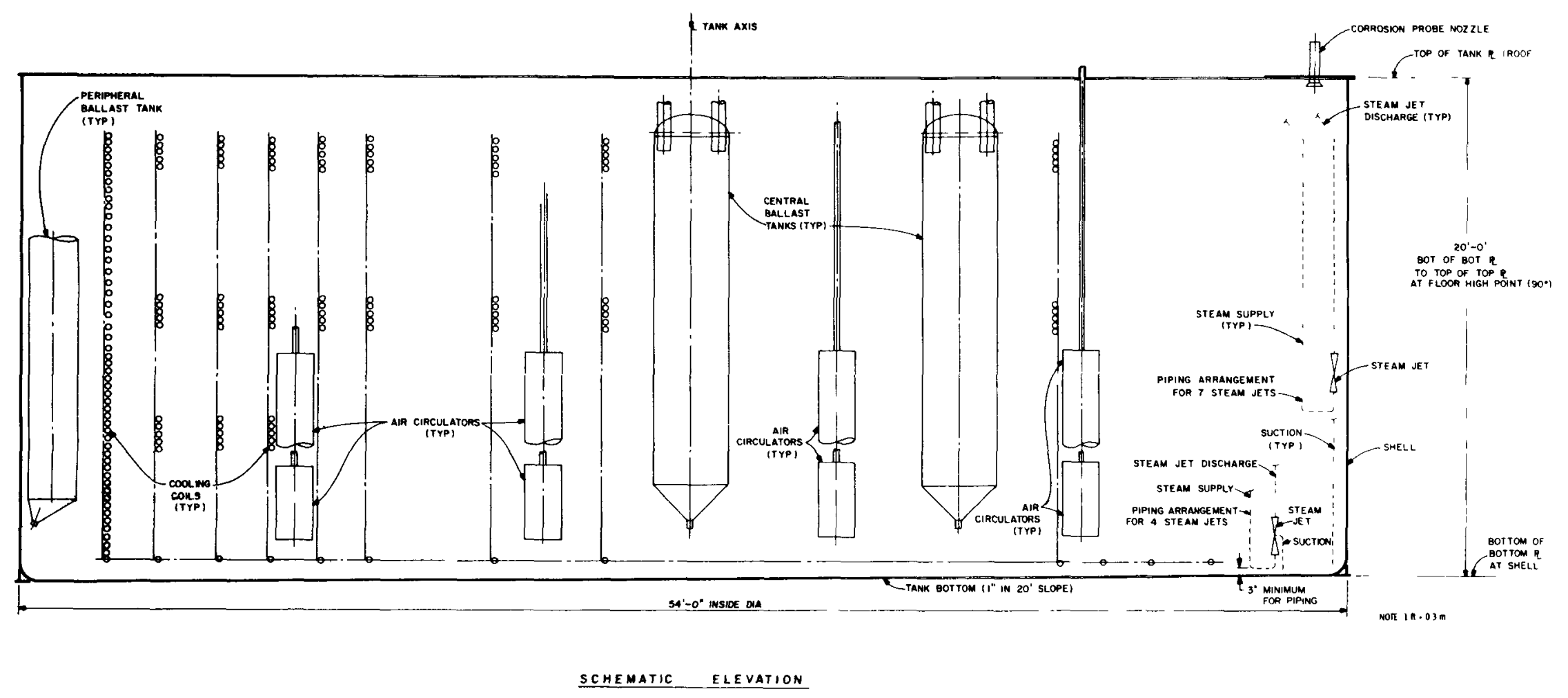

FIGURE A.5-1. HLLW Storage Tank Section Schematic 
-

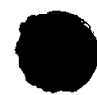




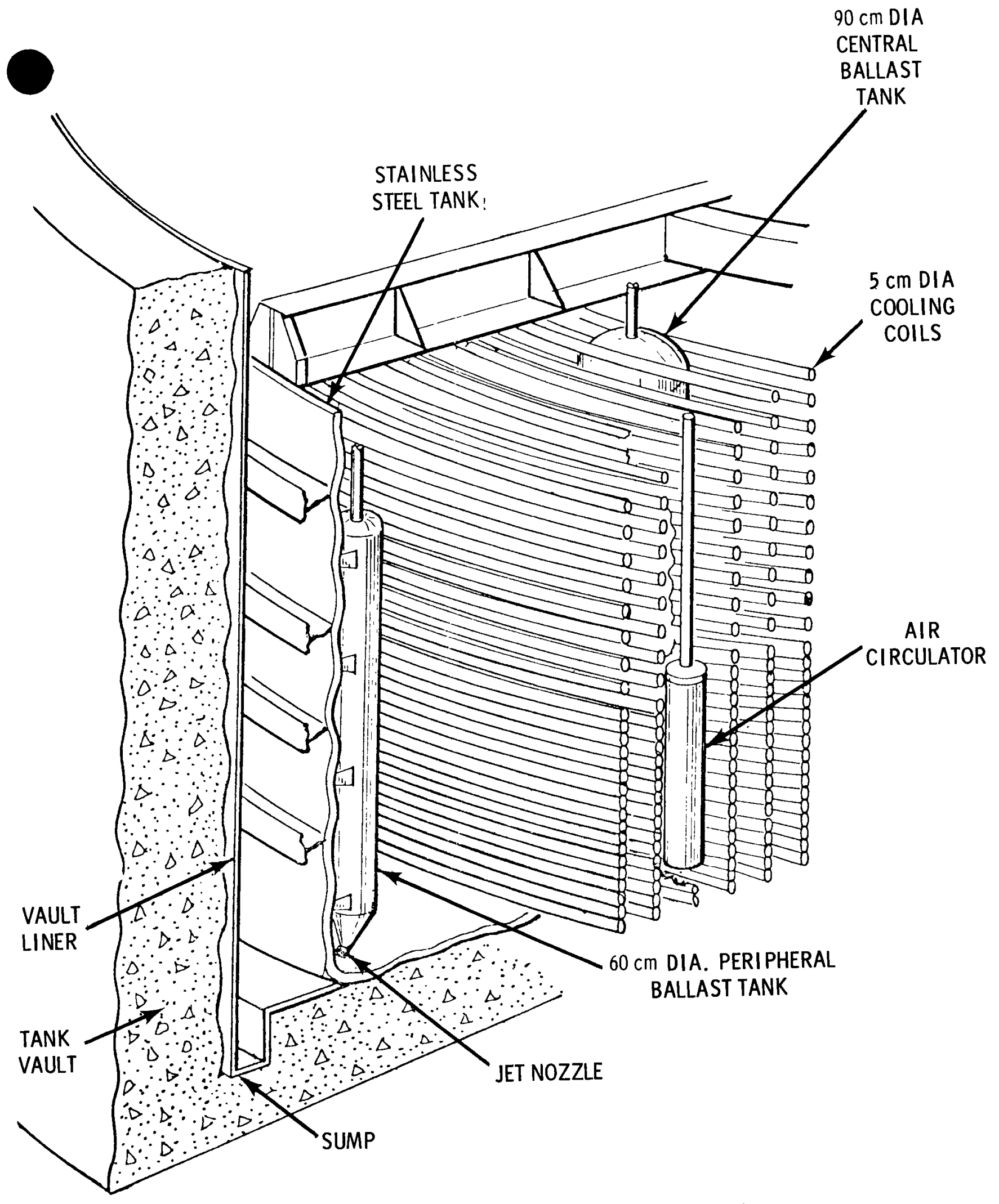

FIGURE A.5-2. Partial Section of HLLW Tank (1) 


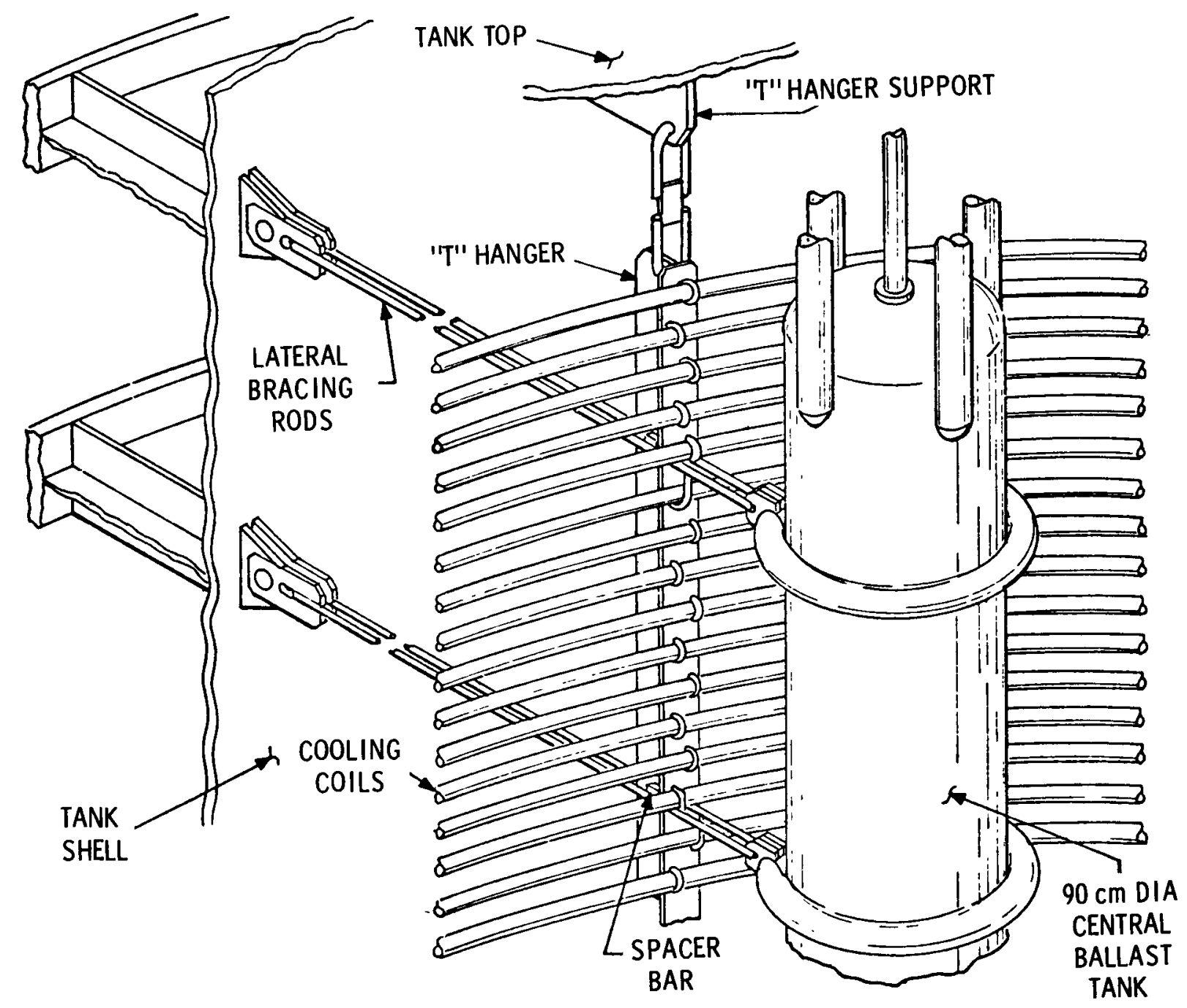

FIGURE A.5-3. Coal and Ballast Tank Supports (1) 
The 18 peripheral ballast tanks are spaced equally around the inside of the circumference of the waste tank. The ballast tanks are approximately $4.9 \mathrm{~m}$ long and $60 \mathrm{~cm}$ in diameter and are attached vertically to the waste tank walls. The bottom section of each ballast tank tapers to a cone that terminates in a venturi nozzle with a throat diameter of $3.8 \mathrm{~cm}$.

The HLLW waste tanks are each vented through a $60-\mathrm{cm}$ dome located on the top of the tank. The dome contains internal baffle plates to minimize the entrainment into the tank off-gas system. The waste tank off gas is carried from the vent dome to the tank off gas treatment system by a $25-\mathrm{cm}$ diameter vent line. Condensed liquid from the off gas returns to the tank by gravity but can be routed to other locations by air lifts.

Waste solutions are transferred between the WTEGs and the waste tanks through pipe lines contained within concrete, stainless steel-lined pipe trenches above the waste tanks. The transfer piping is constructed of $304 \mathrm{~L}$ stainless steel. Two $7.6-\mathrm{cm}$ pipes transfer the HLLW from the main process building to the HLLW rotary diverter located beneath the WTEG. One of the two pipes acts as a spare.

\section{A.5.2 Intermediate-Level Liquid Waste Storage (ILLW)}

A schematic drawing of an ILLW tank is shown in Figure A.5-4. The ILLW tank walls, tank vaults and tank support system are identical in construction to HLLW tanks.

No cooling coils, air lift circulators or ballast tanks are provided in the ILLW tanks. The ILLW tanks are equipped with an air sparge system to moderately agitate the waste and minimize settling of particulates on the tank bottom. The ILLW sparger consists of four sections of $7.6-\mathrm{cm}$ diameter pipe that form a cross, centered in the middle of the tank. The four branches of the sparger, are $7.3 \mathrm{~m}$ long and are supported $5 \mathrm{~cm}$ from the floor of the tank. Air is supplied to the center of the sparger assembly via a $5-\mathrm{cm}$ diameter pipe at $8.4 \mathrm{~m}^{3} / \mathrm{min}$. The ILLW tank is assumed to be operated normally about onehalf full, with process wastes being added as the contents of the tank are removed for solidification with the high-level waste. The ILLW tank has a minal working capacity of $1,135,000$ \& $(300,000$ gal). 
○ 


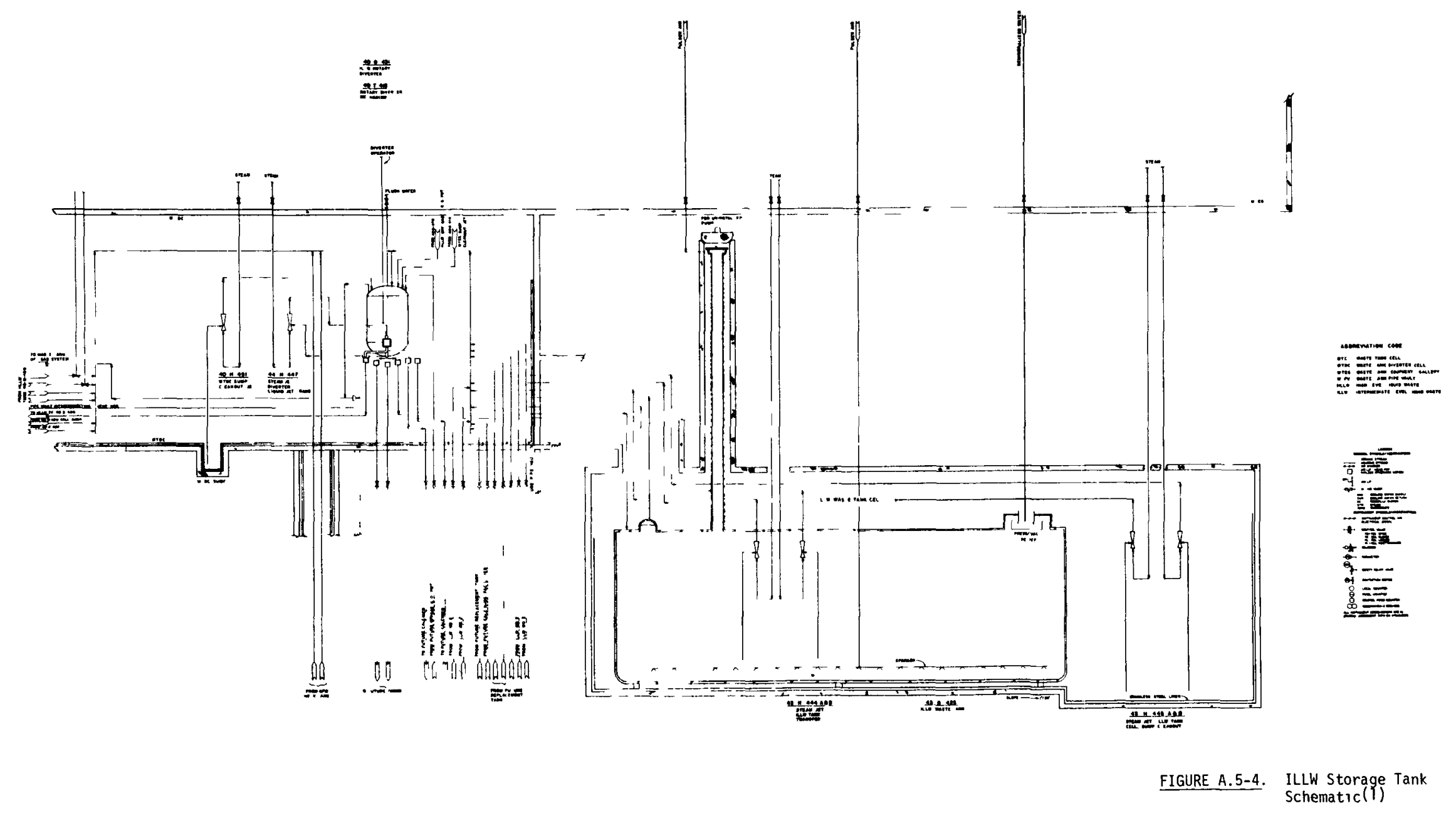

A-89 
-

0

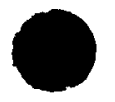




\section{A.5.3 Waste Tank Equipment Gallery (WTEG)}

The WTEG provides services and utilities necessary to operate the liquid waste storage complex. The WTEG equipment arrangement plan and elevation views are shown in Figures A.5-5 and A.5-6. The WTEG is a building approximately $30 \mathrm{~m}$ square, divided into three main sections: a cold (nonradioactive) area, an intermediate area, and a hot (high radiation level) area.

The cold area of the WTEG houses the instrumentation required by the waste tank complex. This instrumentation includes liquid level recorders, specific gravity recorders, tank temperature recorders, and pressure recorders. The ventilation and heating of the cold area are consistent with the design criteria used for areas requiring full-time personnel occupancy.

The intermediate area of the WTEG provides al1 the utilities and services required by the waste storage complex, except off-gas treatment and instrumentation. Included in this area are the waste tank heat rejection system, the sampling system, the air lift circulator controls, the ballast tank air supply system, and the ballast tank control system. The intermediate area also houses the emergency steam generator.

The ventilation system for the intermediate area is sufficient to remove the heat generated by the equipment located in the area and to maintain a temperature of $37^{\circ} \mathrm{C}$ or less.

The high radiation area of the WTEG houses the off-gas treatment system of the liquid waste storage complex. This equipment includes the HLLW condenser, knockout pot, auxiliary superheater, iodine adsorber and HEPA filter module. A total of $355 \mathrm{~m}^{3} / \mathrm{min}(12,700 \mathrm{cfm})$ of exhaust air passes to a walk-in filter bank in the WTEG, where single stages of roughing and HEPA filtration take place. From there, the air flows to the VFS where a second stage of HEPA filtration occurs before discharge through the main stack.

The HLLW and ILLW rotary diverters are located in a small concrete vault beneath the off-gas treatment area of the WTEG. The diverters are used to direct the flow of waste solutions from the main process building to the tanks, between tanks or from the tanks to the WSP. The diverter consists of a small receiver tank, with a movable drain spout, and six receiver funnels to route che waste. 



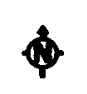

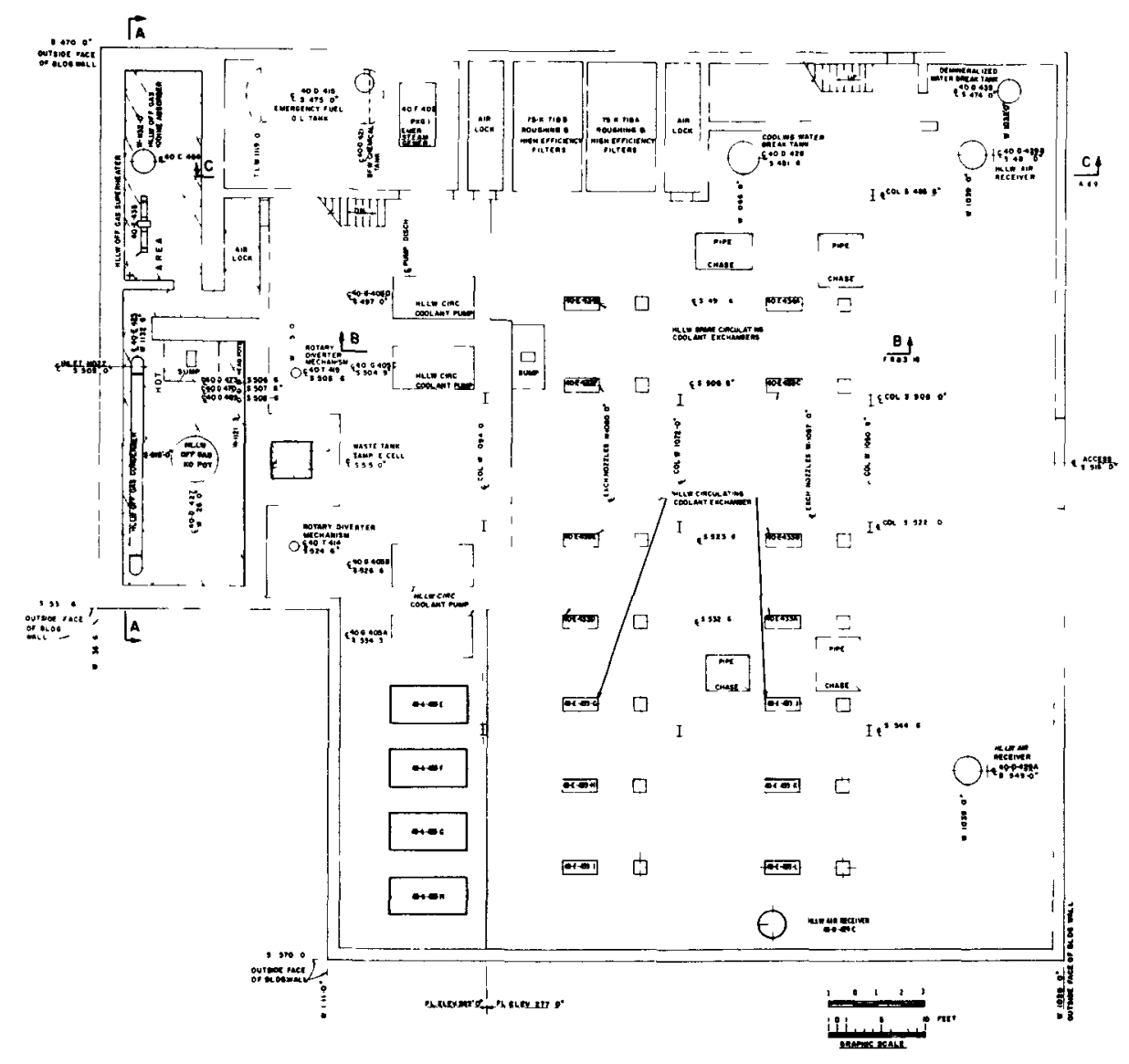

couretertions

葚

粠)

(1)

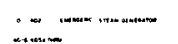

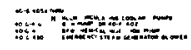

:ت:

if $=$

NoTE

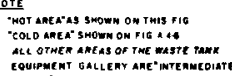

FIGURE A.5-5. Waste Tank Equipment Gallery -

Equi pment Arrangement 
0

0

0 
离

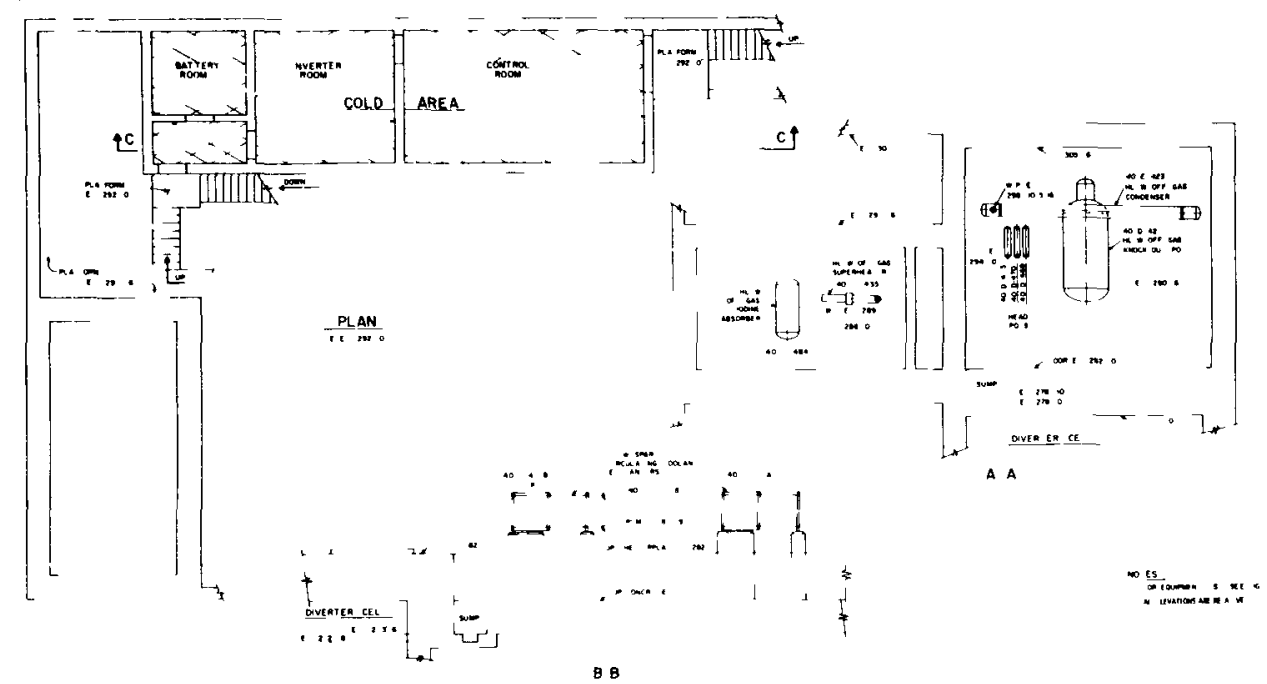

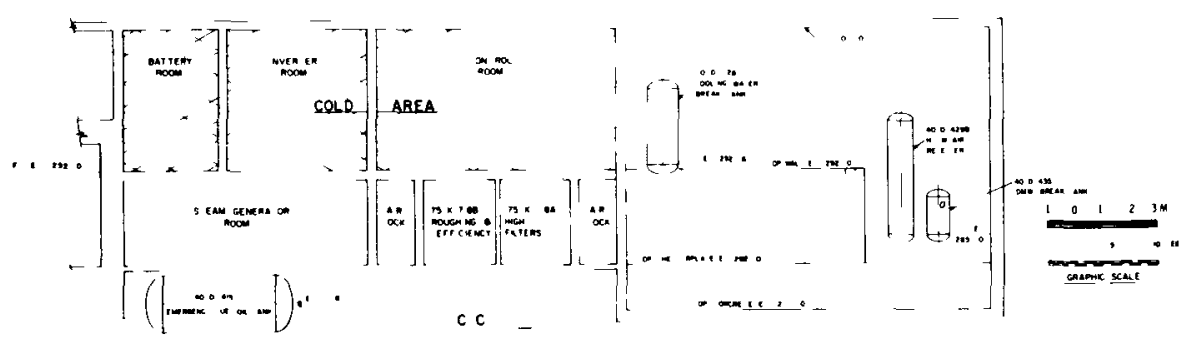


$\bullet$

$\bullet$ 


\section{A. 6 WASTE SOLIDIFICATION PLANT}

This section presents details of the conceptual waste solidification plant (WSP) design developed for this study. The WSP is postulated to be located adjacent to the main process building and the fuel receiving and storage station. (See Figure A.1-1.) It receives liquid high- and intermediate-level wastes from the waste tank farm complex through a stainless steel-lined pipe trench, converts the liquids to a containerized vitrified solid and transfers canisters of solidified waste to the FRSS through a water-filled trench. The solidified high-level waste is stored temporarily in the FRSS before being shipped offsite for disposal in a Federal repository.

Plan and elevation views of the WSP are presented in Figures A.6-1 through A.6-4. These figures show the overall arrangement of the process cells and operating areas in the WSP and the location of major equipment in the waste solidification process cells. General characteristics of the process cells and operating areas are presented in Table A.6-1. Further details concerning the waste solidification process cells are presented below.

\section{A.6.1 Waste Vitrification Cell}

The waste vitrification cell contains the process equipment required to calcine and vitrify the high- and intermediate-level waste from the waste tank farm and to seal and inspect the filled canisters of high-level waste. Equipment for preliminary treatment of process vessel off gases is also located in this cell. All operations and maintenance activities in the WVC are carried out remotely. The cell is provided with four shielding windows, four sets of master-slave manipulators, and two remote cranes to perform remote operations in the cell.

Major equipment located in the WVC includes:

- calciner feed tank

- calciner and furnace

- in-can melter and furnaces (2)

- calciner off-gas filters

- canister storage racks

- canister welding and inspection equipment 


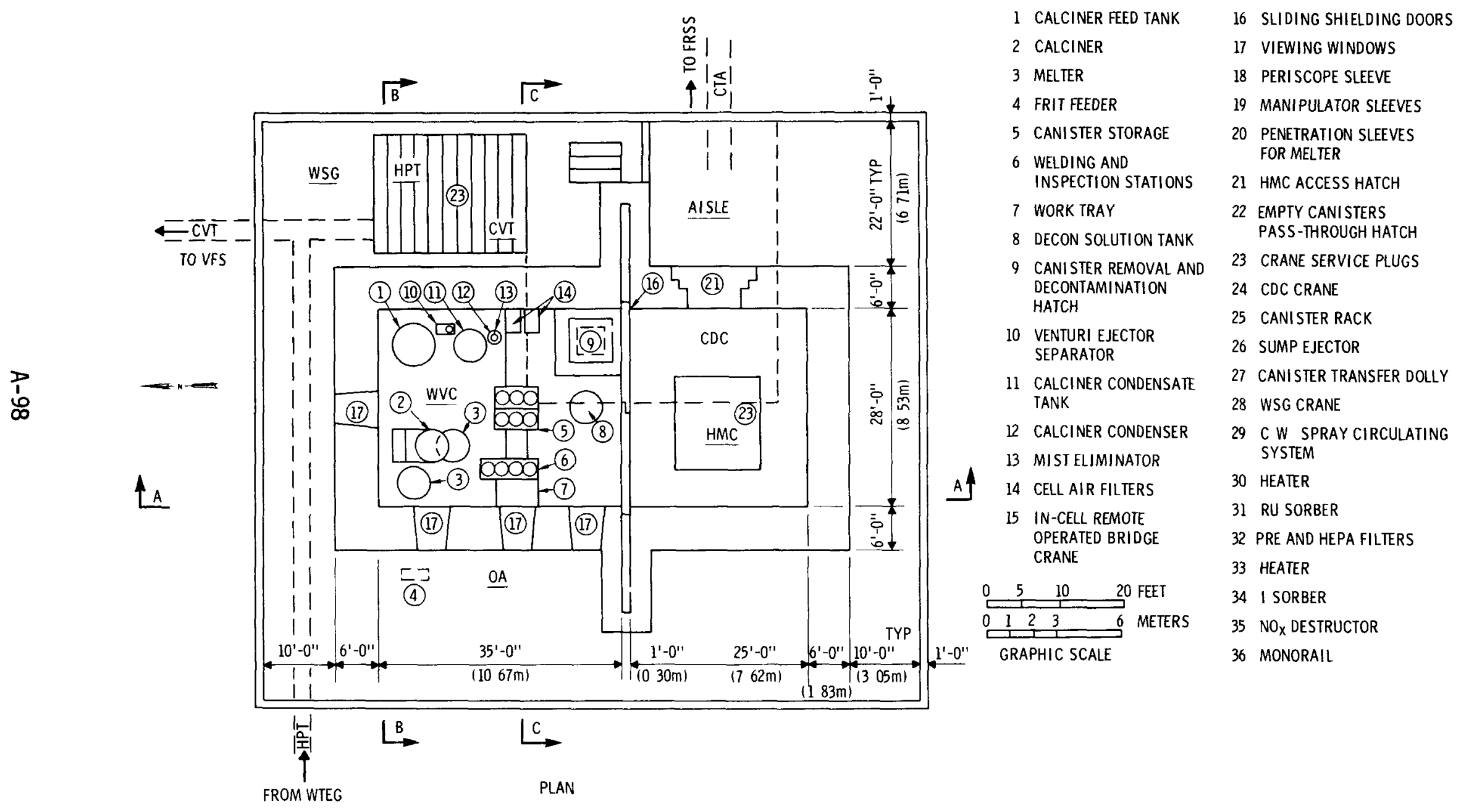

FIGURE A.6-1. Conceptual Waste Solidification Plant - Plan View 


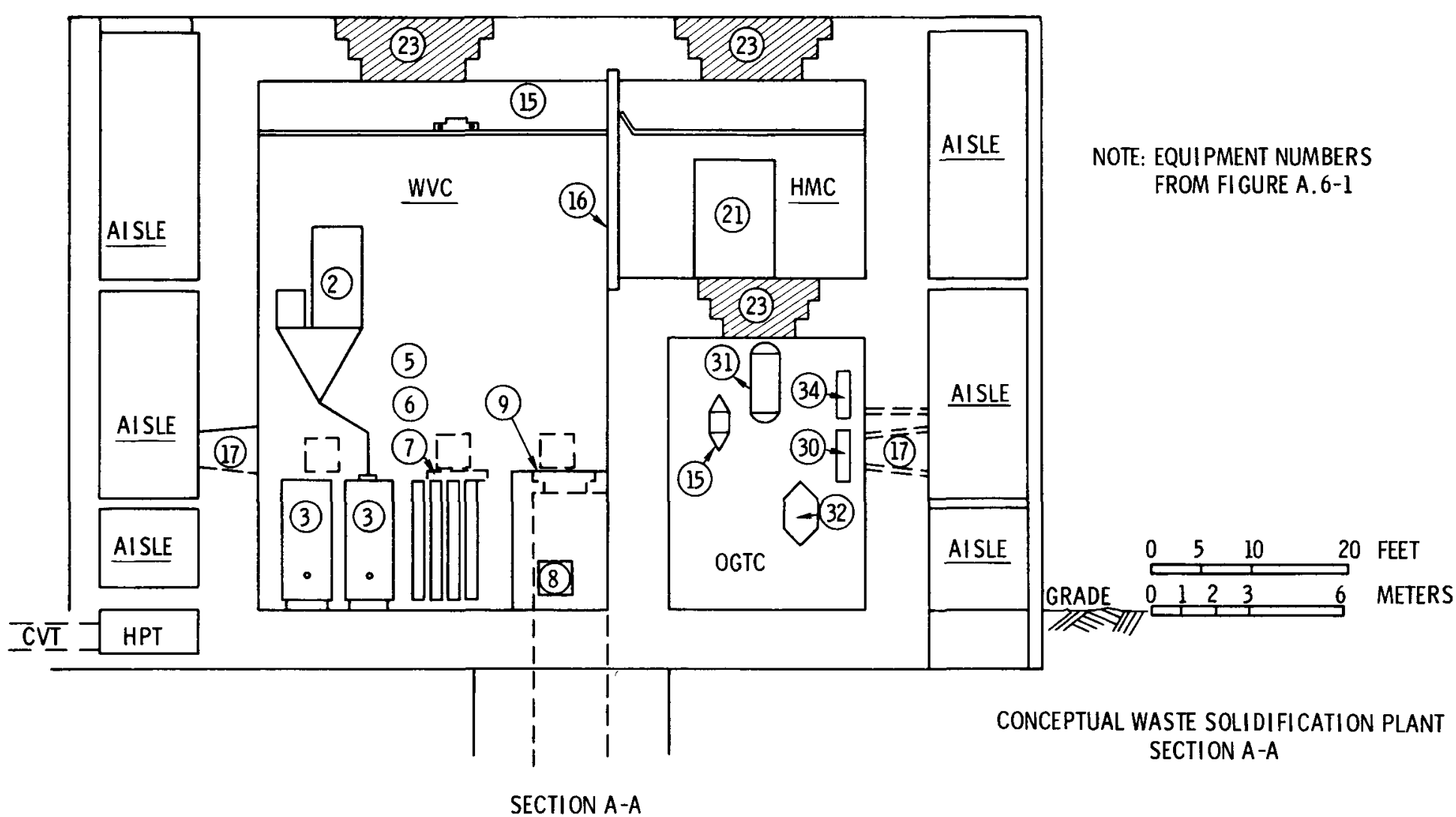

FIGURE A.6-2. Conceptual Waste Solidification Plant-Section AA 
$\frac{7}{8}$
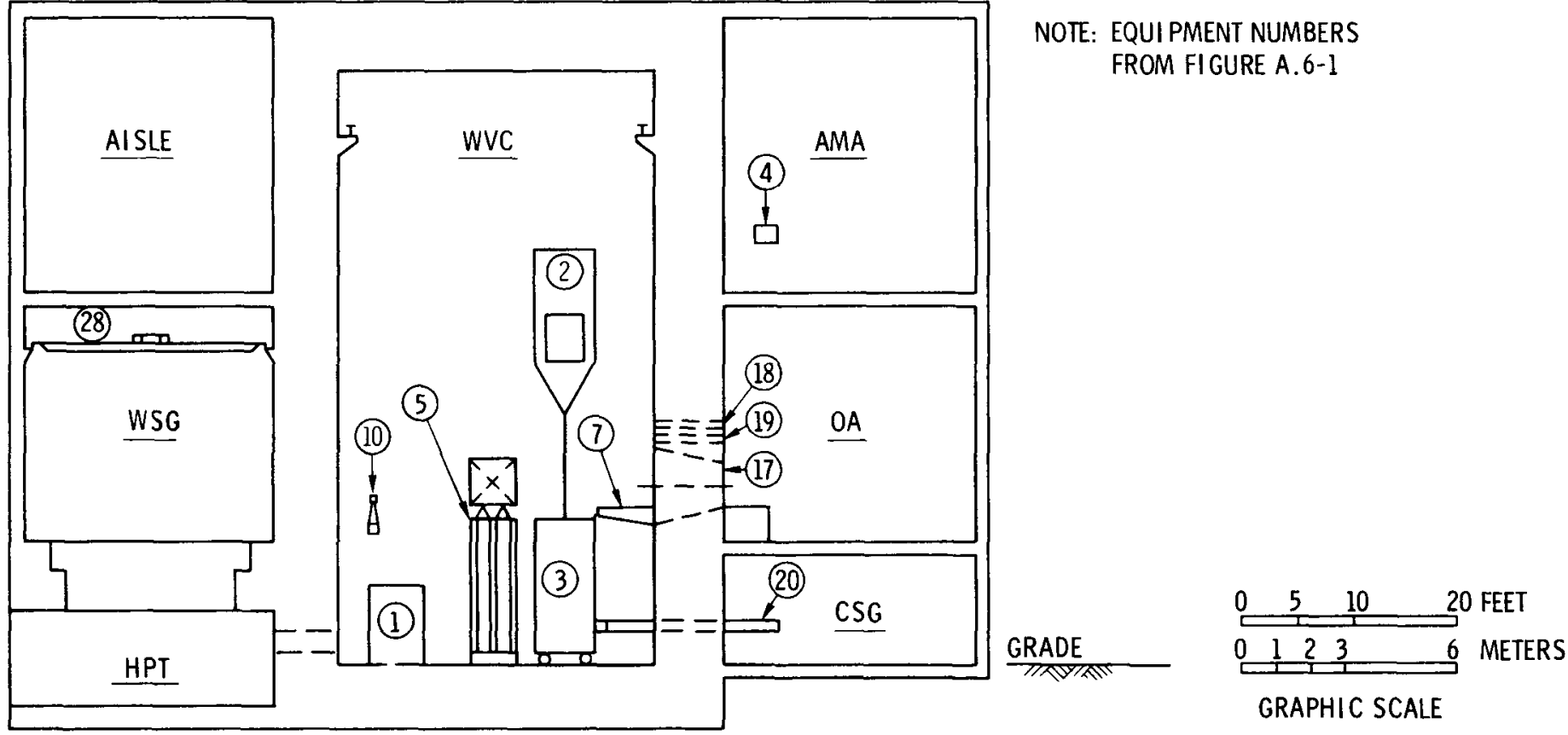

SECTION B-B

FIGURE A.6-3. Conceptual Waste Solidification Plant-Section BB 


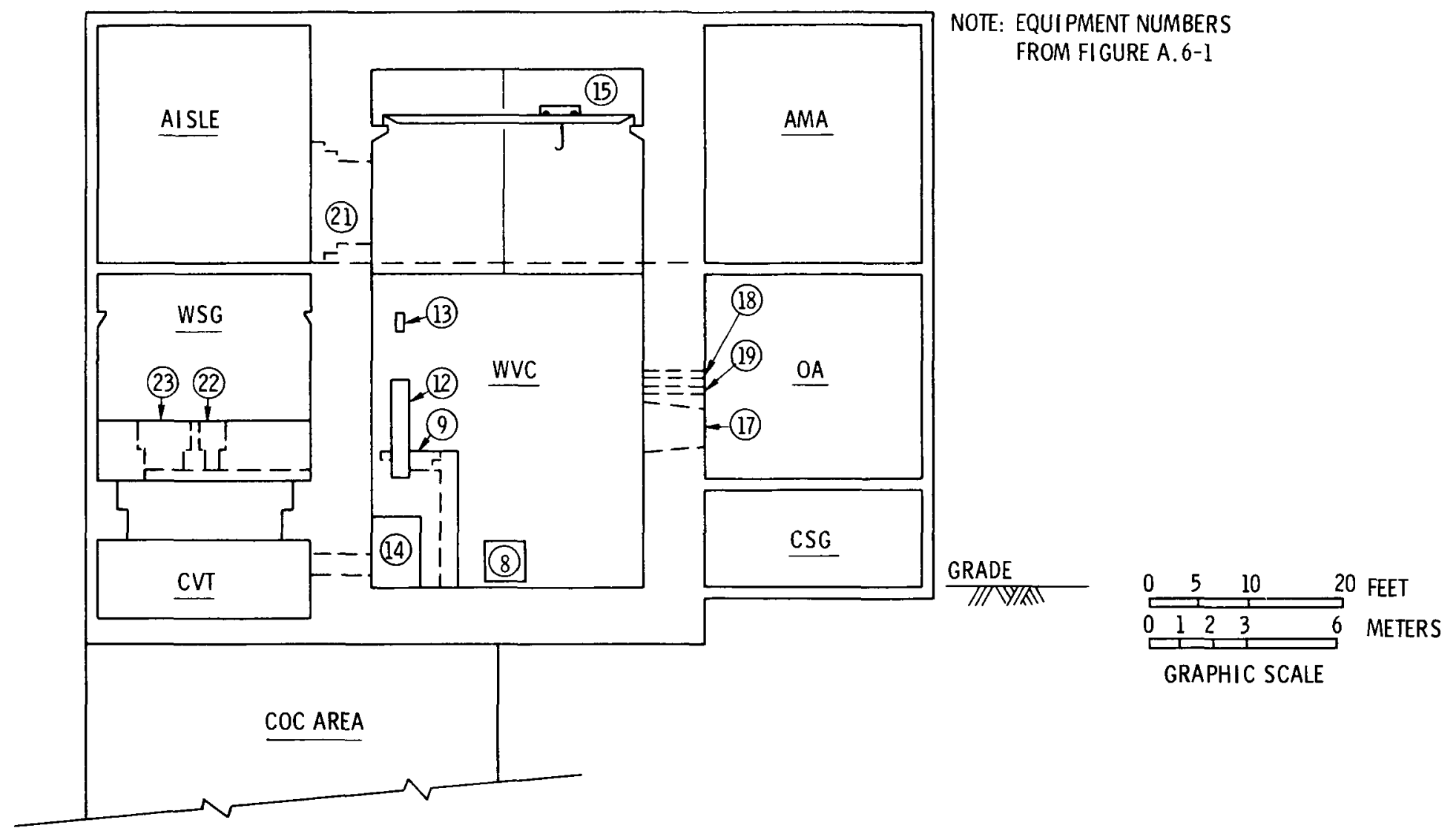

FIGURE A.6-4. Conceptual Waste Solidification Plant-Section CC 
TABLE A.6-1. Major WSP Areas and Associated Function

\begin{tabular}{|c|c|c|c|c|}
\hline Area & Process Function & $\begin{array}{l}\text { Dimensions } \\
\text { (meters) }\end{array}$ & $\begin{array}{l}\text { Surface } \\
\text { Area }\left(\mathrm{m}^{2}\right) \\
\end{array}$ & Remarks \\
\hline $\begin{array}{l}\text { Waste Vitrification Cell } \\
\text { (WVC) }\end{array}$ & $\begin{array}{l}\text { Calcine, vitrify HLLW in cans; } \\
\text { seal, test and clean cans }\end{array}$ & $8.53 \times 10.67 \times 18$ & 873 & 304L SS Liner \\
\hline $\begin{array}{l}\text { Canister Decontamination } \\
\text { Cell (CDC) }\end{array}$ & $\begin{array}{l}\text { Move canisters into and out of } \\
\text { WVC. Clean external surfaces of } \\
\text { filled cans. Access to canister } \\
\text { transfer canal leading to water } \\
\text { storage basin and loadout cranes }\end{array}$ & $9.1 \times 12 \times 6.1$ & 476 & 304L SS Liner \\
\hline $\begin{array}{l}\text { Cell Ventilation Tunnel } \\
\text { (CVT) }\end{array}$ & $\begin{array}{l}\text { Route air from cells to ventila- } \\
\text { tion filter station }\end{array}$ & $\begin{array}{l}1 \text { Dia } \times 100 \text { (duct) } \\
2.2 \times 6.7 \times 7 \text { (sump) }\end{array}$ & $\begin{array}{r}90 \\
155\end{array}$ & 304L SS Liner \\
\hline Hot Pipe Trench (HPT) & $\begin{array}{l}\text { Route radioactive solutions } \\
\text { between the WTEG and the WVC }\end{array}$ & $0.6 \times 0.6 \times 100$ & 240 & 304L SS Liner \\
\hline Operating Area (OA) & $\begin{array}{l}\text { Process control and monitoring } \\
\text { for CDC and WVC }\end{array}$ & $6.7 \times 6 \times 18$ & 241 & \\
\hline $\begin{array}{l}\text { Hot Maintenance Cel1 } \\
\text { (HMC) }\end{array}$ & $\begin{array}{l}\text { Crane and equipment repair } \\
\text { access to OGTC }\end{array}$ & $8.53 \times 7.62 \times 6$ & 323 & 304L SS Liner \\
\hline $\begin{array}{l}\text { Warm Service Gallery } \\
\text { (WSG) }\end{array}$ & $\begin{array}{l}\text { New canisters lowered into } \\
\text { CDC access to CVT, HPT and } \\
\text { VOG Blowers }\end{array}$ & $6.7 \times 7.62 \times 18$ & 618 & $\begin{array}{l}\text { Phenolic painted } \\
\text { concrete walls } \\
\text { and floor }\end{array}$ \\
\hline $\begin{array}{l}\text { Cell Service Gallery } \\
\text { (CSG) }\end{array}$ & $\begin{array}{l}\text { Contains cold equipment, ser- } \\
\text { vices and controls for welder } \\
\text { air supply retort purge gas, } \\
\text { melter umbilical control } \\
\text { motors }\end{array}$ & $6.7 \times 3 \times 30$ & 622 & \\
\hline $\begin{array}{l}\text { Aqueous Make Up Area } \\
\text { (AMA) }\end{array}$ & $\begin{array}{l}\text { Contains frit storage and feed } \\
\text { system, chemical solutions } \\
\text { make up materials storage }\end{array}$ & $7.62 \times 6.7 \times 8.3$ & 340 & \\
\hline $\begin{array}{l}\text { Offgas Treatment Cell } \\
\text { (OGTC) }\end{array}$ & Calciner Offgas Treatment & $4.57 \times 10 \times 18$ & 6.6 & 304L SS Liner \\
\hline
\end{tabular}


Process equipment is constructed primarily of $304 \mathrm{~L}$ stainless steel. The retorts inside the in-can melter furnaces are constructed of Hastelloy $X$. Ceramic and soft-packed insulation is used in the calciner and in-can melter furnaces. Further details of major equipment in the WVC (and OGTC) are given in Table A.6-2.

The WVC walls and floor are lined with 6 -mm-thick 304L stainless steel. Cell equipment is mounted on ears, yokes or racks fixed to the cell walls and guides or supports on the floor. The in-can melters move on rails on the cell floor. A cell sump collects spills of process solutions for transfer to the calciner feed tank.

\section{TABLE A.6-2. Major Waste Solidification Plant Equipment}

\begin{tabular}{|c|c|c|c|}
\hline Equipment & Material & Dimensions (Meters) & Capacity \\
\hline Calciner Feed Tank & $0.65 \mathrm{~cm} 304 \mathrm{~L} \mathrm{SS}$ & $1.83 \times 2.1$ & $5700 \ell$ \\
\hline Calciner and Furnace & $0.65 \mathrm{~cm} 310 \mathrm{SS}$ & 0.92 ID $\times 3.05$ & $240 \ell$ \\
\hline Melter and Furnace (2) & $\begin{array}{l}\text { SS (Hastelloy } x \\
\text { Retort) }\end{array}$ & $0.92 \mathrm{ID} \times 3.36$ & $75 \mathrm{~kg}$ glass $/ \mathrm{hr}$ \\
\hline Frit Feeder & Abrasion Resistant & $1225 \mathrm{~kg}$ of frit & $55 \mathrm{~kg} / \mathrm{hr}$ \\
\hline Calciner Condensate Tank & $0.65 \mathrm{~cm} 304 \mathrm{~L} \mathrm{SS}$ & $1.6800 \times 1.53$ & $3400 \ell$ \\
\hline Decontamination Solution Tank & $0.65 \mathrm{~cm} 304 \mathrm{~L} \mathrm{SS}$ & $1.2200 \times 1.22$ & $1420 \ell$ \\
\hline Canister Storage Rack & 304L SS & $1.83 \times 1.83 \times 3.36$ & 3 empty, 3 full cans \\
\hline $\begin{array}{l}\text { Cell Air Filters (Two } \\
\text { Assemblies) }\end{array}$ & 304L SS Housing & $0.61 \times 1.22 \times 2.44$ & $2.88 \mathrm{~m}^{3} / \min$ \\
\hline Welding \& Inspection Stations & 304L SS Rack & $0.61 \times 1.22 \times 3.66$ & $50 \mathrm{~kW}$ cooling \\
\hline Calciner Condenser & $304 \mathrm{~L}$ SS & $\begin{array}{l}19.5 \mathrm{~m}^{2} \text { Transfer } \\
\text { Surface }\end{array}$ & $\begin{array}{l}3.6 \mathrm{l} / \mathrm{min} \text { of } 2.2 \mathrm{M} \\
\mathrm{HNO}_{3}\end{array}$ \\
\hline Calciner Scrubber Separator & 304 LSS & $\begin{array}{l}0.15 \mathrm{~m} \text { Ejector Ven- } \\
\text { turi }\end{array}$ & $6370 \mathrm{sl} / \mathrm{min}$ \\
\hline Condenser Mist Eliminator & $304 \mathrm{~L}$ SS & $0.10 \times 0.30$ & $2435 \mathrm{~s} \ell / \mathrm{min}$ \\
\hline Off-gas Heating & $304 \mathrm{~L}$ SS & $0.15 \times 2.44$ & $1375 \mathrm{~s} \ell / \mathrm{min}$ \\
\hline Ruthenium adsorber & $304 \mathrm{~L}$ SS & $0.6610 \times 1.83$ & $2070 \mathrm{sl} / \mathrm{min}$ \\
\hline Pre- \& HEPA Offgas Filters & 304L SS Case & $0.36 \times 0.36 \times 1.5$ & $3.5 \mathrm{~m}^{3} / \mathrm{min}$ \\
\hline Iodine Adsorber & 304L SS Vessel & $0.11 \times 0.24 \times 1.37$ & $2.07 \mathrm{~m}^{3} / \mathrm{min}$ \\
\hline NO $x$ Sorbtion Tower & $304 \mathrm{~L}$ SS & $2.100 \times 10.7$ & $2.07 \mathrm{~m}^{3} / \mathrm{min}$ \\
\hline${ }_{N O}^{*}$ Destructor & 304L SS & $0.3 \times 0.92$ & $15 \mathrm{~kW}$ electric heater \\
\hline
\end{tabular}


Access to the WVC is through the shielding doors to the hot maintenance cell and through the canister decontamination cell. Cell equipment is transferred to the HMC for maintenance and repair. Empty and filled canisters enter and leave the WVC through the CDC.

\section{A.6.2 Canister Decontamination Cell}

The canister decontamination cell (CDC) contains equipment to decontaminate filled and sealed solidified high-level waste canisters and to transfer them to the FRSS for temporary storage. A section view of the CDC is presented in Figure A.6-5. Filled canisters enter the CDC through a hatch from the WVC. The CDC is equipped with sprays supplied with decontamination solution from a medium pressure pump connected to the decontamination solution tank. Decontaminated canisters are transferred to a monorail crane or cart in the waterfilled can transfer aisle for transfer to the FRSS.

\section{A.6.3 Hot Maintenance Cell}

The hot maintenance cell (HMC) contains equipment for remote maintenance and decontamination of WSP equipment. The HMC is also used to prepare failed equipment for transfer to the onsite underground waste storage area. The HMC is equipped with shielding windows, master-slave manipulators and remote decontamination equipment. Some contact maintenance of the WVC crane may also be carried out in the HMC after appropriate chemical decontamination.

The HMC walls and floor are lined with $304 \mathrm{~L}$ stainless steel. Access to the HMC is through the shielding door from the WVC and a removable floor plug to the OGTC. A shielding door provides access to the operating aisle.

\section{A.6.4 0ff-Gas Treatment Cell}

The off-gas treatment cell (OGTC) contains equipment to remove ruthenium, iodine, oxides of nitrogen and particulates from the WSP process off-gas streams. Primary equipment located in the OGTC includes:

- off-gas heater

- ruthenium adsorber

- off-gas filters

- iodine adsorber

- $\mathrm{NO}_{\mathrm{x}}$ destructor 


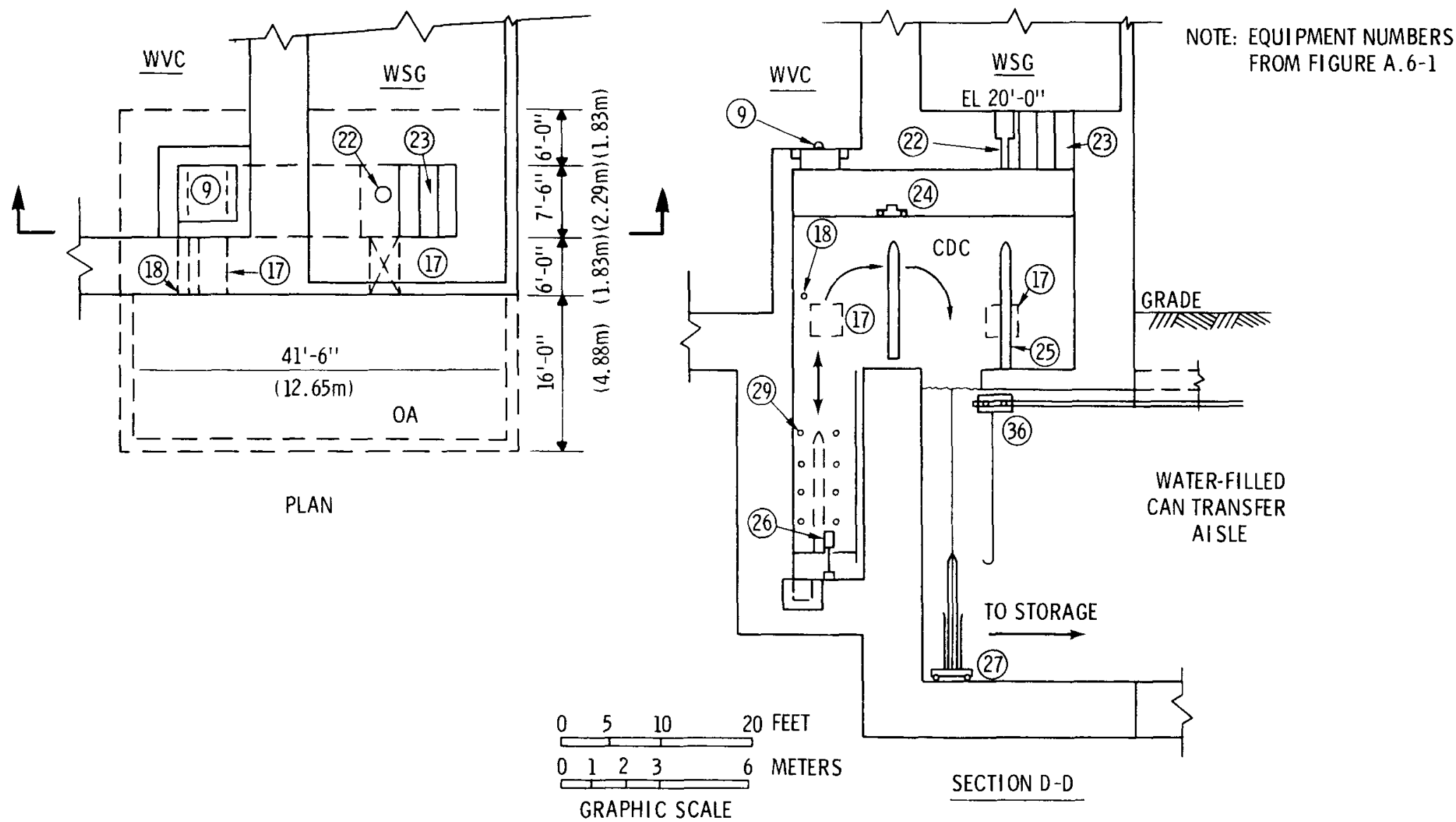

FIGURE A.6-5. Canister Decontamination Ce11 
The treated off-gas stream is routed from the OGTC via the cell ventil tion trench (CVT) to the ventilation filter station for final filtration before release through the plant stack. The off-gas blowers for the WSP are located in the CVT. Ducts carrying the treated off gas pass through the hot pipe trench where they are cooled by hot ventilation air before the off gas is released to the CVT.

Equipment in the OGTC is constructed primarily of stainless steel. The cell walls and floor are also lined with stainless steel. A cell sump is provided to collect spills and chemical decontamination solutions for transfer to the calciner feed tank.

\section{A.7 AUXILIARY PROCESS SYSTEMS AND SERVICE AREAS}

This section contains amplifying information on the auxiliary process systems and service areas that provide necessary services to the main process functions of the facility. The facility ventilation system, water reservoir, electrical power systems, fire protection system and laboratory facilities are described.

\section{A.7.1 Ventilation System}

The ventilation system and its flow paths are designed to confine and channel any airborne radioactive particulate matter to treatment systems (filters) and away from personnel. The system provides for personnel protection and comfort by channeling air from clean zones to zones of successively higher potential contamination. The air also provides cooling to process cells before it exhausts from the cell areas through filters and blowers to the main stack. Ventilation system filter efficiencies used in this study are summarized in Table A.7-1.

- Main Process Building

Fresh air is supplied to various areas of the main process building at a flow rate of about $2600 \mathrm{~m}^{3} / \mathrm{min}(92,000 \mathrm{cfm})$ by the ventilation supply blower of the main process building. Air is distributed through galvanized steel ducts. Stainless steel is used for exhaust ducting to facilitate decontamination should it be required and to ensure maximum integrity for the cell 
exhaust lines. Figure A.7-1 shows schematically the flow pattern through the building. The cell design temperatures in the figure are maximum temperatures. Air flow is generally from clean areas, i.e., those with the least potential for radioactive contamination where the ambient pressure is slightly above atmospheric ( $+6 \mathrm{~mm}$ water), to areas with increasing potential for contamination. Air is exhausted from the cells through two stages of HEPA filters by two of the three process building exhaust blowers. The system pressure is reduced as air is passed from entry to exhaust. An ambient pressure of $-5 \mathrm{~cm}$ of water is maintained in the cells, where the highest contamination potential exists. Air from the system is exhausted to the atmosphere through the 100-meter main stack.

TABLE A.7-1. Summary of Types of Ventilation Filters in the Reference FRP

\begin{tabular}{|c|c|c|c|c|}
\hline Area of Service & $\begin{array}{r}\text { Filtra } \\
\text { Efficiency } \\
\text { Roughing(a) }\end{array}$ & $\begin{array}{l}\text { ion } \\
\text { percent } \\
\text { HEPAt } \\
\end{array}$ & $\begin{array}{c}\text { Mode of } \\
\text { Filter Exchange }\end{array}$ & $\begin{array}{l}\text { Building Area } \\
\text { Location }\end{array}$ \\
\hline $\begin{array}{l}\text { Lab Fume Hood and Glove } \\
\text { Box Exchanger Filter }\end{array}$ & $80-85$ & 99.95 & Bag-out & AFS \\
\hline Pu Glove Box Inlet & $80-85$ & 99.95 & Bag-out & PNSL \\
\hline Pu Glove Box Exhaust & $80-85$ & 99.95 & Bag-out & PNSL \\
\hline AFS Final Tilers & $80-85$ & 99.95 & $\begin{array}{l}\text { Walk-in bank, contact } \\
\text { exchange }\end{array}$ & AFS \\
\hline Pu Glove Box Filter & $80-85$ & 99.95 & Bag-out & PNSL \\
\hline $\begin{array}{l}\text { Waste Tank Equipment } \\
\text { Gallery }\end{array}$ & $80-85$ & 99.95 & $\begin{array}{l}\text { Walk-in bank, contact } \\
\text { exchange }\end{array}$ & WTEG \\
\hline PPC & $80-85$ & $99.95^{(c)}$ & Bag-out & FPIG \\
\hline SAC & $80-85$ & 99.95 & Bag-out & FPIG \\
\hline Contact Cells & $80-85$ & 99.95 & $\begin{array}{l}\text { Walk-in bank, contact } \\
\text { exchange }\end{array}$ & FPIG \\
\hline RPC & $80-85$ & 99.95 & $\begin{array}{l}\text { Special housing contact } \\
\text { or remote exchange }\end{array}$ & $\begin{array}{l}\text { Filter Niche } \\
\text { below LVOS }\end{array}$ \\
\hline RMSC & $80-85$ & 99.95 & $\begin{array}{l}\text { Special housing contact } \\
\text { or remote exchange }\end{array}$ & $\begin{array}{l}\text { Filter Niche } \\
\text { below LVOS }\end{array}$ \\
\hline WVC & $80-85$ & $99.95^{(c)}$ & $\begin{array}{l}\text { Special housing, remote } \\
\text { exchange }\end{array}$ & wVC \\
\hline OGTC & $80-85$ & 99.95 & $\begin{array}{l}\text { Special housing, remote } \\
\text { exchange }\end{array}$ & OGTC \\
\hline AMC & $80-85$ & 99.95 & $\begin{array}{l}\text { Special housing, remote } \\
\text { exchange }\end{array}$ & HMC \\
\hline VFS Final Filters & $80-85$ & 99.95 & $\begin{array}{l}\text { Walk-in bank, contact } \\
\text { exchange }\end{array}$ & VFS \\
\hline
\end{tabular}

(a) Efficiency when new and tested in accordance with NBS dust method at rated filter flow.

(b) Assumed overall installed efficiency of HEPA bank when tested with nonradioactive DOP of 0.7 micrometer mean particle size.

(c) Filter banks have two filters each in series, with individual filter efficiencies of $99.95 \%$. 
-

0 


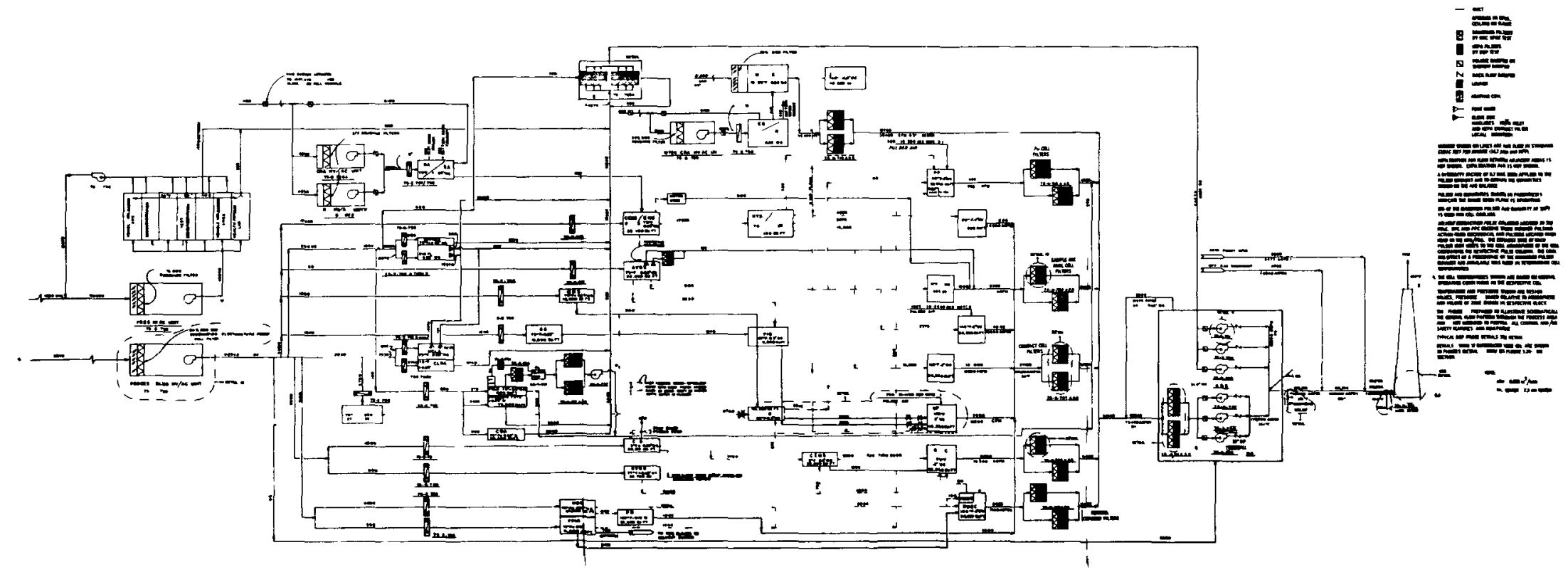

FIGURE A 7-1 Air Flow Diagram Ventilation System

A- 109 
- 
The filter housings for the RPC and the RMSC are located in the FN beneath the floor of the LVOS. The housings are monitored routinely for radiation so that replacement of the filters can be accomplished before radiation levels exceed a calculated safe level, allowing for the time required for replacement. In cases where the radiation level prevents contact replacement, a filter disposal cask (containing suitable shielding for handling radiation levels up to $1000 \mathrm{rem} / \mathrm{hr}$ on the filters) is provided and the housing design permits remote shielded filter replacement and disposal. Rails for a monorail hoist to handle shield plugs and casks are provided over the access port to each filter housing.

Bag-out type filters are provided for cells where the exhaust filters are not expected to become contaminated to gamma radiation levels greater than $1 \mathrm{R} / \mathrm{hr}$, but where the contamination of the filter may be as high as $100 \mathrm{dpm} / 100 \mathrm{~cm}^{2}$ with alpha radiation. Included are the exhausts from the plutonium product cell and the sample and analytical cells. Filters for these systems are exchanged by contact means. The contaminated filter is contained in a plastic bag that is never opened to the operating area. Such bagged filters are stored temporarily in the underground solid waste storage area and eventually shipped to a Federal waste repository for disposal.

Heating coils are mounted in the supply air ducts to the various parallel supply air branches to provide individual temperature control in the various areas. The coils are generally electric, but where large heat loads are involved, steam coils are used.

- Control Room Area (CRA)

Ventilation for the CRA is independent of ventilation for the remainder of the process building, except for an exfiltration route to the cold chemical station. Two packaged units, mounted on the roof of the control room, provide heating, ventilating, and air conditioning for the area, holding its pressure at $+6 \mathrm{~mm}$ water with respect to atmospheric pressure. Each unit is on a separate emergency electric power supply to ensure uninterrupted ventilation to the control room, even during a loss of normal electrical power. 


\section{- Fuel Receiving and Storage Station (FRSS)}

The FRSS also has a separate heating, ventilating, and air conditioning system. It is independent of the process building system except for one interconnection between the systems through an exhaust duct $(0.5 \mathrm{~m}$ diam.) from the FRSS to the analytical filter station. This line exhausts about $50 \mathrm{~m}^{3} / \mathrm{min}(1800 \mathrm{cfm})$ from the FRSS. The FRSS system is operated as a recirculating system of about $2400 \mathrm{~m}^{3} / \mathrm{min}(84,000 \mathrm{cfm})$ with fresh air makeup of $50 \mathrm{~m}^{3} / \mathrm{min}$ to control the ambient pressure to be equal to atmospheric pressure.

\section{- Ventilation Filter Station (VFS)}

The VFS contains filters through which a 11 process ventilation system air passes for final particulate removal before discharge to the main plant stack. Air flows from the process building to the VFS through above-grade ductwork.

As shown in Figure A.7-2, the VFS is a concrete room within the blower station. The VFS is divided, in its long dimension, into two walk-in filter banks. Each bank is further subdivided by structural framework, to two areas where one stage of roughing and one stage of HEPA filters are mounted. Air enters the room on one side, passes through the filters, leaves the room on the other side, and travels to the suction of the main process building exhaust blowers. Half the flow of air, or approximately $900 \mathrm{~m}^{3} / \mathrm{min}(33,000 \mathrm{cfm})$ is filtered by each half of the filter bank. There are 39 roughing and 39 HEPA filters in each of the two banks of final filters. The filter banks are in walk-in rooms with entrances through air-locks. Filters are exchanged manually. Because of the upstream HEPA filters, filter radioactivity levels at this location are expected to be low during replacement. The structural framework supporting the filters is stainless steel, and the interior concrete is coated with an acid resistant paint to permit washdown of the housing for decontamination. The VFS drains to a sump from which liquids can be transferred to the service concentrator.

- Analytical Filter Station (AFS)

The analytical filter station contains filters through which air from analytical areas (HCLA fume hoods and glove boxes) and other areas (FSP and FTP, HPL, CLRA, PPSA and CWA) passes for final particulate removal before discharge to the main plant stack. 


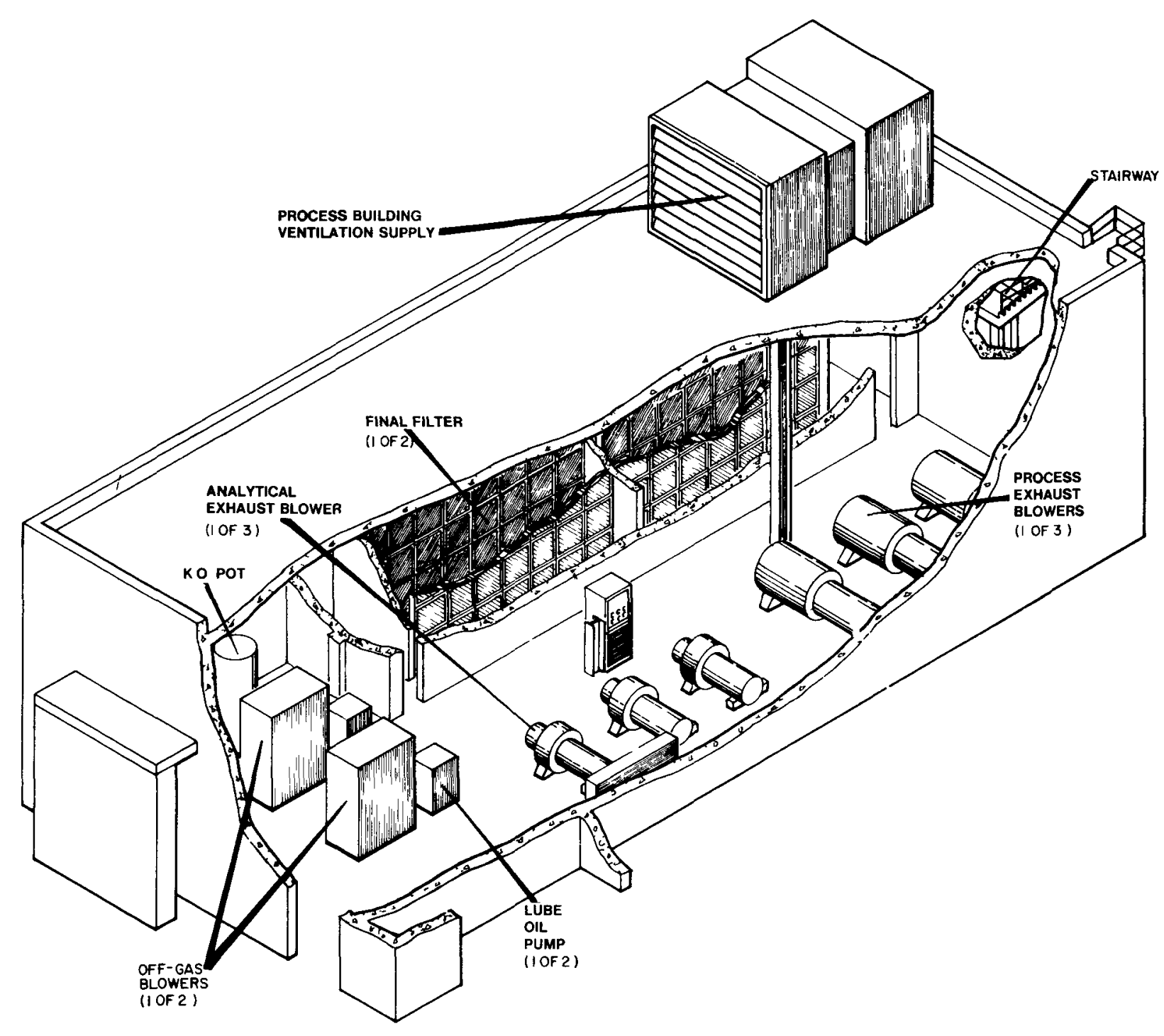

FIGURE A.7-2. Blower Station Building(1) 
The AFS is a concrete curbed, steel structure located above the HCLA. The AFS is divided into two filter banks. Each bank is further subdivided by structural framework supporting one stage of roughing and one stage of HEPA ute filters. Air enters the unit on one side, passes through the filters, leaves the unit on the other side, and travels to the suction of the analytical exhaust blowers. Half the flow of air, or approximately $680 \mathrm{~m}^{3} / \mathrm{min}(24,000 \mathrm{cfm})$ is filtered by each half of the filter bank.

The filter bank is in a walk-in room with access through air-locks. Filters are changed manualiy. Because of the upstream HEPA filters on the glove boxes, filter radioactivity levels at this location are expected to be low during replacement.

The structural framework supporting the filters is stainless steel and the interior walls are coated with acid resistant paint to permit washdown of the housing for decontamination. The AFS drains to the hot and cold laboratory waste catch tank for disposition.

\section{- Filter Niche}

The filter niche houses roughing and HEPA filters from the RPC and RMSC, iodine prefilters and silver zeolite iodine adsorbers. Each HEPA stage is assumed to remove $99.95 \%$ of the particles from the air stream and the silver zeolite beds are assumed to remove $99.9 \%$ of the radioiodine in the off-gas stream.

The filter niche is located in the basement of the process building below the lower viewing and operating station (LVOS). The LVOS is shielded by high density concrete $0.6 \mathrm{~m}$ thick above the niche. Access to equipment installed in the niche is through concrete shield plugs in the floor of the LVOS. Radiation (gamma) monitors can be installed through the floor to determine the radioactivity level of the filters. At a filter contamination level of $1000 \mathrm{R} / \mathrm{hr}$, the LVOS shielding will reduce the radiation level in the LVOS to less than $1 \mathrm{mR} / \mathrm{hr}$. The filter niche is lined with $304 \mathrm{~L}$ stainless steel and sloped to collection points to permit chemical decontamination when required.

\section{- Waste Solidification Plant}

The WSP receives cell supply ventilation air from the blower station returns it to the VFS for final filtration. The WVC, HMC and OGTC are each 
provided with exhaust air filters. Exhaust air from the WVC passes through a roughing filter and two stages of HEPA filtration before release to the VFS. Single stages of roughing and HEPA filters are provided for the other two cells. Exhaust air from the CDC flows directly to the WVC where it is conibined with WVC ventilation air. The WSP process vessel off gas is treated separateiy in the OGTC and combined with filtered exhaust from the WSP cells for final filtration in the VFS.

- Main Stack

The main stack is a structure $100 \mathrm{~m}$ tall and $2.4 \mathrm{~m}$ in diameter, constructed of carbon steel. It is insulated on the outside and supported with guy wires. A 2-m diameter duct runs above ground from the ventilation filter station to the stack. The nitric acid fractionator overhead diversion tank and vaporizer are located adjacent to the stack. The fractionator overheads are vaporized into the air stream entering the stack from the VFS and released.

\section{A.7.2 Water Reservoir}

The onsite water reservoir receives liquid nonradioactive effluents from the FRP and is designed to fulfill the following purposes:

1. Provide emergency cooling water in the event that both commercial and emergency electrical power to the primary water supply system is lost.

2. Serve as a monitoring point for impurities in the liquid effluents from the plant.

3. Serve as a conditioning pond for liquid effluents if necessary.

4. Provide the primary source of fire fighting water.

\section{A.7.3 Electrical Power Systems}

- Normal Power

Normal electrical power is fed to the facility from the commercial substation by two transformers each feeding a main breaker with a capacity of 2000 amperes. The main breakers distribute power at 120 amperes through twelve breakers. A breaker of 2000 amperes capacity is also provided to cross-connect the two main breakers. Distribution cables from the feeder

eakers are in underground plastic conduit. The conduit is encased in concrete. Cables feeding safety-related systems are also encased in structural 
concrete underground conduit. Distribution cables to safety-related loads within buildings are in rigid galvanized steel or stainless steel conduits. Two independent electrical power systems, physically separated, are provided to ensure that the severing of a single cable will not interrupt the system.

\section{- Emergency Power}

The emergency electrical power system is designed to meet emergency situations by providing power to essential loads. Emergency power is supplied by two independent diesel engine-driven generators. Each generator has a continuous rating of $2200 \mathrm{~kW}$. Each generator feeds a separate substation through automatically operated circuit breakers. Both units start automatically upon loss of normal power, and reach rated loading speed and voltage within 10 seconds. After both generators have operated for about 12 seconds, one of the generators may be shut down and the emergency load handled by only one generator. The unit withdrawn from operation serves as backup.

The emergency power system is located in the emergency utility area. (EVA). Each generator is located in a separate room with the emergency bus and generator battery located within an adjacent room.

- Direct Current Power Systems

An uninterruptable power supply is provided for instrumentation in the main control room, the waste tank equipment gallery area and the waste solidification plant.

\section{A.7.4 Fire Protection System}

Fire detection and protection systems at the facility are designed to provide early detection and rapid control of fires to ensure safety of personnel, integrity of radioactivity confinement systems, and to minimize equipment and facility damage. The selection of specific fire protection systems was based on the probability of fire, occupancy of the area, types of fire that could occur, and potential consequences of a fire.

Plant personnel are alerted to a fire by a local alarm and an alarm signal carried by a plant-wide public address system. Fire detectors provide rapid response time and are able to sense combustion in its incipent stage. The operational status of all fire protection systems is displayed central in the process control room. This area is occupied at all times. 
The normal water supply required for the fire protection system is augmented by a backup well-water supply. A fire-water loop provides water to sprinklers in building areas and to strategically located hydrants, with hose stations for general area coverage.

Automatic fire detection and suppression for protection of personnel, facilities, and material exterior to cells is provided by a fixed detector and sprinkler installation. Automatic fire detection and manual suppression capabilities are provided in areas of low fire potential. This includes most of the areas in the facility.

An automatic suppression system, using bromotrifluoromethane (Halon 1301) as the suppression agent is installed in each of the following cells:

- uranium product cell

- intermediate-level cell

- high intermediate-level cell

- high-level cell

- plutonium product cell.

The system provides early detection and rapid automatic suppression. Each cell has a dual system. Automatic detection devices are located in cell exhaust ducts (immediately outside the cells). Each system incorporates one smoke detector and one combination rate-of-rise and fixed-temperature detector. Both detectors in a system must actuate for automatic release of suppressant. Each detector in each system indicates an alarm condition both locally and in the control room. Manual suppressant release capability is provided at the discretion of the control room operator.

Fire detection for the control room area and the associated cable distribution room below is provided by smoke detectors in each area which alarm in the control room. Fire suppression is accomplished manually by the use of portable extinguishers augmented by water, if necessary.

The AFS and the VFS are equipped with automatic suppression systems that can be actuated manually. Exhaust air ducts to filter stations are equipped with debris screens to intercept larger airborne burning debris before it can 
enter the air plenum. Detection is provided by a smoke detector and a combination of rate-of-rise and fixed-temperature detectors. Both detectors must be in an alarm condition simultaneously to actuate the water supply. Suppression is accomplished by spraying water as a fine mist on the debris screens.

\section{A.7.5 Hot and Cold Laboratory Area (HCLA)}

The HCLA is shown in the plan view of the facility (Figure A.3-1). The two-story laboratory complex is composed of 13 individual laboratories that are equipped to provide specific types of analyses or services. One laboratory is equipped for receiving samples from the SAC.

The laboratories are equipped with fume hoods and glove boxes. Samples and equipment are transferred from the fume hoods to the glove boxes through interchange compartments. Bag-out ports are provided on the glove boxes for removal of contaminated waste and equipment. Reagent lines are installed in the glove boxes to deliver chemical reagents to the glove box from storage bottles in the fume hoods.

The fume hoods are lined with $304 \mathrm{~L}$ stainless steel. The glove boxes are constructed of 304L stainless steel, except in the plutonium product laboratory, emission spectroscopy preparation laboratory, and emission spectroscopy laboratory, where some boxes are lined with teflon-coated carbon steel.

Waste drains from the sinks, fume hoods, and glove boxes are routed to the laboratory waste catch tank or fume hood drain tank.

A special alpha laboratory includes two special glove boxes designed for confinement of concentrated alpha-emitting radioiostopes. These glove boxes permit installation, operation, and maintenance of equipment for working with alpha-contaminated materials. The laboratory also contains one conventional glove box line. The boxes are lined with stainless steel. 


\section{REFERENCE}

1. Final Safety Analysis Report, Barnwell Nuclear Fuel Plant, Separations Facility, Volumes 1 through 5 . (Plus amendments) 
0

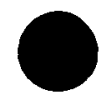




\section{APPENDIX B}

\section{RESIDUAL RADIOACTIVITY INVENTORY ESTIMATES}

This appendix presents estimates of the radioactivity remaining in the facility at shutdown. Methods used to calculate these estimates are also presented. The radioactivities are based on a hypothetical fuel mixture, assumed to represent fuels currently expected to be available for reprocessing in the year 2000. Residual radionuclide estimates are necessary to calculate expected radiation exposure levels in the facility at shutdown.

\section{B.1 KEY ASSUMPTIONS}

The estimate of radioactivity in various areas of the plant were calculated based on a number of assumptions. Calculated estimates are believed to be reasonable when compared to radioactivity levels encountered in work at Hanford. Because these inventories are only estimates, the radiation exposure levels presented in Section 5.7 are shown as ranges. The reference spent nuclear fuel mixture is based on:

- a reactor distribution of $1 / 3$ BWR, $2 / 3$ PWR (by electrical output)

- an average PWR exposure of 31,800 MWd/MTHM (peak PWR exposure of 33,000 MWd/MTHM)

- an average BWR exposure of 25,300 MWd/MTHM (peak BWR exposure of 26,000 MWd/MTHM).

- an average total exposure (PWR and BWR) of 29,300 MWd/MTHM

- a total feed of $13.5 \%$ first Pu recycle, $2.5 \%$ second $\mathrm{Pu}$ recycle, $7.4 \%$ first $U$ recycle, $0.7 \%$ second $U$ recycle, and the remaining as first cycle uranium.

In addition to the isotopic effects of $U$ and $P u$ recycle, low exposure first core discharges were explicitly included in calculations of the isotopic content of the spent reference fuel. 
Estimates of the residual radionuclide inventories in the various plant process areas are based on:

- 1/30 of the total contamination inventory is held up in the plant each year over the 30-year operating life of the plant,

- spent fuel cooling time is 1.5-years (after reactor discharge) at the time of reprocessing,

- a plant operating philosophy stressing continuous housecleaning and cleanup of all spills and accumulations of materials in all cells during normal plant operation is assumed. Such a philosophy would be consistent with maintaining ALARA levels to plant operating and maintenance personnel,

- no unnecessary contaminated materials or debris from plant operation are left in facility after shutdown, and

- HLLW is stored 1.3 to 2.6 years (after reprocessing) before solidification (i.e., the tank of high-level waste being solidified contains a mixture of waste produced between 1.3 and 2.6 years before solidification).

\section{B.2 REFERENCE FUEL AND HIGH-LEVEL WASTE}

Table B.2-1 presents the total radioactivity in curies/metric ton of heavy metal ( $\mathrm{Ci} / \mathrm{MTHM}$ ), charged to reactors, of the reference irradiated fuel mixture. The column labeled "Radioactivity at Time of Reprocessing" represents the radioactivity of 1 MTHM of the reference fuel mixture 1.5 years after discharge from the reactor. It was assumed that $70 \%$ of the ${ }^{3} \mathrm{H}$ present in the reference fuel would remain in the spent fuel solution after removal of the cladding hulls. The column labeled "Radioactivity at Time of Shutdown" represents the radioactivity of 1 MTHM of fuel mixture held up in the plant over its 30-year life (1/30 MTHM held up per year). The remaining columns depict the decay of this held-up material at various times after the plant is shut down. 
TABLE B.2-1. Nuclide Radioactivity of Spent LWR Fuel at Time of Reprocessing, at Shutdown, and as a Function of Time After Plant Shutdown

\begin{tabular}{|c|c|c|c|c|c|c|c|c|}
\hline $\begin{array}{l}\text { Nuclide } \\
\text { Fission Products }\end{array}$ & $\begin{array}{l}\text { Radioactivity at } \\
\text { Time of }(a) \\
\text { Reprocessing }\end{array}$ & $\begin{array}{l}\text { Radioactivity at } \\
\text { Time of } \\
\text { Shutdown (b) FRP }\end{array}$ & $\frac{\text { Decay of }}{10}$ & $\frac{\text { Materials } \mathrm{H}}{20}$ & $\frac{\text { Held Up in } P}{30}$ & $\begin{array}{l}\text { Plant (TIme } \\
\frac{100}{100}\end{array}$ & $\begin{array}{l}\text { After Shutdown } \\
\frac{500}{1}\end{array}$ & $\frac{\text { In Years) }}{1000}$ \\
\hline $3_{H}(c, e)$ & $297 E+2$ & -- & --- & -- & -- & -- & -- & -- \\
\hline${ }^{14}{ }_{c}(e)$ & $566 \mathrm{E}-1$ & $\ldots$ & $\ldots$ & $\ldots$ & $\ldots$ & $\ldots$ & $\ldots$ & ..- \\
\hline${ }^{79} \mathrm{Se}$ & $342 E-1$ & $341 E-1$ & $341 \mathrm{E}-1$ & $341 E-1$ & $341 E-1$ & $341 E-1$ & $340 E-1$ & $338 E-1$ \\
\hline${ }^{87} \mathrm{Rb}$ & $160 E-5$ & $160 E-5$ & $160 E-5$ & $160 E-5$ & $160 E-5$ & $160 \mathrm{E}-5$ & $160 E-5$ & $160 E-5$ \\
\hline${ }^{90} \mathrm{Sr},{ }^{90}{ }_{Y}(\mathrm{~d})$ & $121 E+5$ & $858 \mathrm{E}+4$ & $670 \mathrm{E}+4$ & $524 E+4$ & $380 E+4$ & $728 E+3$ & $378 E-1$ & $167 E-6$ \\
\hline${ }^{93} L r$ & 16 & 16 & 16 & 16 & 16 & 16 & 16 & 16 \\
\hline $93 m_{\mathrm{Nb}}$ & $237 E-1$ & 9 02E-1 & 118 & 135 & 145 & 16 & 16 & 16 \\
\hline${ }^{99} \mathrm{Tc}$ & 1 $28 \mathrm{E}+1$ & $128 \mathrm{E}+1$ & $128 E+1$ & $128 \varepsilon+1$ & $128 \mathrm{E}+1$ & $128 E+1$ & $128 \mathrm{E}+1$ & $128 \mathrm{E}+1$ \\
\hline${ }^{106} \mathrm{Ru},{ }^{106} \mathrm{Rh}$ & $372 E+5$ & $180 E+4$ & $182 E+1$ & $184 \mathrm{E}-2$ & $167 E-5$ & 00 & 00 & 00 \\
\hline${ }^{107} \mathrm{Pd}$ & $118 \mathrm{E}-1$ & $118 \mathrm{E}-1$ & $118 E-1$ & $118 \mathrm{E}-1$ & $118 \mathrm{E}-1$ & $118 \mathrm{E}-1$ & $118 E-1$ & $118 \mathrm{E}-1$ \\
\hline $110 \mathrm{~m}_{\mathrm{Ag}}$ & $817 E+2$ & $272 \mathrm{E}+1$ & $123 E-3$ & $556 \mathrm{E}-8$ & $255 E-12$ & 00 & 00 & 00 \\
\hline${ }^{110} \mathrm{Ag}$ & $106 E+2$ & 354 & $160 \mathrm{E}-4$ & $723 E-9$ & $317 \mathrm{E}-13$ & 00 & 00 & 00 \\
\hline $113 m_{c d}$ & $104 E+1$ & 540 & 329 & 200 & 118 & $382 E-2$ & $962 \mathrm{E}-11$ & 00 \\
\hline & 329 & $108 \mathrm{E}-1$ & $434 E-6$ & $174 \mathrm{E}-10$ & 00 & 00 & 00 & 00 \\
\hline${ }^{121 m_{S n}}$ & $497 \mathrm{E}-4$ & $435 E-4$ & $397 E-4$ & $362 E-4$ & $333 E-4$ & $175 \mathrm{E}-4$ & $455 E-6$ & $477 \mathrm{E}-8$ \\
\hline${ }^{125} \mathrm{Sb}$ & $588 E+3$ & $764 E+2$ & $586 E+1$ & 450 & $317 E-1$ & $545 E-9$ & 00 & 00 \\
\hline${ }^{125 \mathrm{~m}_{\mathrm{Te}}}$ & $244 E+3$ & $316 E+2$ & $243 E+1$ & 187 & $128 \mathrm{E}-1$ & $226 \mathrm{E}-9$ & 00 & 00 \\
\hline${ }^{126} \mathrm{Sn},{ }^{126 m_{S b}}$ & 110 & 110 & 110 & 110 & 310 & 110 & 110 & 109 \\
\hline${ }^{126} \mathrm{Sb}$ & $543 E-1$ & $5 \quad 43-1$ & $542 E-1$ & $542 E-1$ & $542 \mathrm{E}-1$ & $542[-1$ & $541 E-1$ & $539 \mathrm{E}-1$ \\
\hline $129 \mathrm{I}$ & $349 \mathrm{E}-2$ & $349 \mathrm{E}-2$ & $349 E-2$ & $349 E-2$ & $349 \mathrm{E}-2$ & $349 E-2$ & $349 \mathrm{E}-2$ & $349 \mathrm{E}-2$ \\
\hline${ }^{134} \mathrm{Cs}$ & $119 E+5$ & $118 E+4$ & $401 E+2$ & $136 E+1$ & $467 E-1$ & $245 E-11$ & 00 & 00 \\
\hline${ }^{135} \mathrm{Cs}$ & $312 \mathrm{E}-7$ & $312 E-1$ & $312 E-1$ & $312 E-1$ & $312 \mathrm{E}-1$ & $312 \varepsilon-1$ & $312 \mathrm{E}-1$ & $312 E-1$ \\
\hline${ }^{137} \mathrm{Cs}$ & $928 E+4$ & $669 E+4$ & $531 E+4$ & $422 E+4$ & $333 E+4$ & $664 E+3$ & $645 \mathrm{E}-1$ & $622 E-6$ \\
\hline $137 \mathrm{~m}_{\mathrm{Ba}}$ & $868 E+4$ & $626 E+4$ & $497 E+4$ & $394 E+4$ & $317 \mathrm{E}+4$ & $621 E+3$ & $603 E-1$ & $581 E-6$ \\
\hline${ }^{144} \mathrm{Ce},{ }^{144} \mathrm{Pr}$ & $488 E+5$ & $182 E+4$ & 246 & $330 \mathrm{E}-4$ & 4 67E-8 & 00 & 00 & 00 \\
\hline${ }^{147} \mathrm{Pm}$ & $693 E+4$ & $873 E+3$ & $620 E+2$ & $440 E+1$ & 200 & $284 E-8$ & 00 & 00 \\
\hline${ }^{151} \mathrm{Sm}$ & $120 E+3$ & $107 E+3$ & $988 \mathrm{E}+2$ & $913 E+2$ & $850 E+2$ & $482 E+2$ & $199 \mathrm{E}+1$ & $372 E-1$ \\
\hline${ }^{152} E_{U}$ & $156 \mathrm{E}+1$ & 740 & 415 & 233 & 150 & $230 \mathrm{E}-2$ & $213 E-12$ & 00 \\
\hline${ }^{153} \mathrm{Gd}$ & 595 & $190 \mathrm{E}-1$ & $5 \quad 44 E-6$ & $156 \mathrm{E}-10$ & 00 & 00 & 00 & 00 \\
\hline${ }^{154} \mathrm{Eu}$ & $608 E+3$ & $340 E+3$ & $221 E+3$ & $143 E+3$ & $917 E+1$ & $448 E+1$ & $134 \mathrm{E}-6$ & $520 \mathrm{E}-16$ \\
\hline${ }^{155} \mathrm{Eu}$ & $419 E+3$ & $365 E+2$ & 793 & $172 E-1$ & $300 E-3$ & $859 \mathrm{E}-15$ & 00 & 00 \\
\hline $166 m_{\mathrm{Ho}}$ & $669 \mathrm{E}-4$ & $663 E-4$ & $659 \mathrm{E}-4$ & $655 \mathrm{E}-4$ & $650 E-4$ & $626 \mathrm{E}-4$ & $497 E-4$ & $372 \mathrm{E}-4$ \\
\hline Subtotal FP & $139 \mathrm{E}+6$ & $282 E+5$ & $176 \mathrm{E}+5$ & $138 \mathrm{E}+5$ & $107 E+5$ & $207 E+4$ & 4 OOE+] & $188 \mathrm{E}+1$ \\
\hline Actinides & & & & & & & & \\
\hline $\begin{array}{r}227 \mathrm{Ac},{ }^{233_{\mathrm{Ra}}} \\
219_{\mathrm{Rn}}, 215_{\mathrm{Po}} \\
211_{\mathrm{Pb}}, 211_{\mathrm{Bf}} \\
207 \mathrm{Tl},{ }^{227} \mathrm{Th}\end{array}$ & $773 E-6$ & $460 E-5$ & $720 E-5$ & $982 E-5$ & $128 \mathrm{E}-4$ & $313 E-4$ & $140 E-3$ & $284 E-3$ \\
\hline $\begin{array}{l}{ }^{228} \mathrm{Th},{ }^{224} \mathrm{Ra} \\
220_{\mathrm{Rn}}, 216_{\mathrm{Po}} \\
212_{\mathrm{Pb}},{ }^{212} \mathrm{Bi}\end{array}$ & $319 E-2$ & $131 E-1$ & $128 \mathrm{E}-1$ & $118 \mathrm{E}-1$ & $102 E-1$ & $548 \mathrm{E}-2$ & $116 E-3$ & $954 E-6$ \\
\hline 212 po & $340 E-3$ & $140 \mathrm{E}-2$ & $136 E-2$ & $126 E-2$ & $1 \quad 11 E-2$ & $584 E-3$ & $124 E-4$ & 1 02E-6 \\
\hline${ }^{208} \mathrm{Tl}$ & $1.91 \mathrm{E}-3$ & $789 \mathrm{E}-3$ & $767 \mathrm{E}-3$ & $708 \mathrm{E}-3$ & $620 \mathrm{E}-3$ & $329 E-3$ & $699 \mathrm{E}-5$ & $573 \mathrm{E}-7$ \\
\hline
\end{tabular}


TABLE B.2-1. (Continued)

\begin{tabular}{|c|c|c|c|c|c|c|c|c|}
\hline $\begin{array}{l}\text { Nuclide } \\
\text { Actinides } \\
\end{array}$ & $\begin{array}{l}\text { Radioactivity at } \\
\text { Time of }(a) \\
\text { Reprocessing }\end{array}$ & $\begin{array}{c}\text { Radioactivity at } \\
\text { Time of } \\
\text { Shutdown (b) FRP }\end{array}$ & $\frac{\text { Decay of }}{10}$ & $\frac{\text { Materials }}{20}$ & Held up in & $\begin{array}{c}\text { Plant (Time } \\
100\end{array}$ & $\begin{array}{c}\text { After Shutdown } \\
500\end{array}$ & $\frac{\text { in Years) }}{1000}$ \\
\hline${ }^{230} \mathrm{Th}$ & $1.28 E-5$ & $7.57 \mathrm{E}-5$ & $1.30 \mathrm{E}-4$ & $1.95 \mathrm{E}-4$ & $2.85 E-4$ & $1.03 E-3$ & 8. $32 \mathrm{E}-3$ & $1.85 \mathrm{E}-2$ \\
\hline $231 \mathrm{~Pa}$ & $1.07 E-5$ & $1.58 E-5$ & $1.92 \mathrm{E}-5$ & $2.26 E-5$ & $2.67 E-5$ & $4.97 E-5$ & $1.86 E-4$ & $3.55 E-4$ \\
\hline${ }^{234} \mathrm{~Pa}$ & $3.15 E-4$ & $3.16 E-4$ & $3.15 E-4$ & $3.15 E-4$ & 3. $15 E-4$ & $3.15 E-4$ & $3.15 E-4$ & $3.15 E-4$ \\
\hline $232 \mathrm{U}$ & $1.19 E-2$ & $2.14 E-2$ & 2. $10 \mathrm{E}-2$ & $1.92 \mathrm{E}-2$ & $1.70 \mathrm{E}-2$ & $8.88 E-3$ & $1.89 \mathrm{E}-4$ & $1.54 \mathrm{E}-6$ \\
\hline $233_{U}$ & $3.89 \mathrm{E}-5$ & $6.52 \mathrm{E}-5$ & $8.35 E-5$ & $1.02 E-4$ & $1.27 E-4$ & $2.79 \mathrm{E}-4$ & $1.81 \mathrm{E}-3$ & $4.65 E-3$ \\
\hline $234 \mathrm{U}$ & $3.36 E-1$ & $5.54 E-1$ & $6.89 \mathrm{E}-1$ & $8.14 E-1$ & $9.40 \mathrm{E}-1$ & 1.53 & 2.33 & 2.37 \\
\hline${ }^{235} \mathrm{U},{ }^{231} \mathrm{Th}$ & $3.18 \mathrm{E}-2$ & 3. $18 \mathrm{E}-2$ & $3.18 \mathrm{E}-2$ & $3.18 \mathrm{E}-2$ & 3.19E-2 & $3.20 E-2$ & $3.22 \mathrm{E}-2$ & $3.26 \mathrm{E}-2$ \\
\hline $236 \mathrm{U}$ & $2.64 E-1$ & $2.64 E-1$ & $2.64 \mathrm{E}-1$ & $2.65 \mathrm{E}-1$ & $2.65 \mathrm{E}-1$ & $2.66 \mathrm{E}-1$ & $2.75 \mathrm{E}-1$ & $2.85 \mathrm{E}-1$ \\
\hline $237 u$ & 3.48 & 2.35 & 1.47 & $9.21 E-1$ & $5.00 \mathrm{E}-1$ & $2.18 \mathrm{E}-2$ & $4.38 E-5$ & $4.20 E-5$ \\
\hline 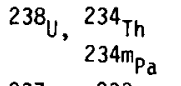 & $9.45 E-1$ & $9.45 \mathrm{E}-1$ & $9.45 E-1$ & $9.45 \mathrm{E}-1$ & $9.45 \mathrm{E}-1$ & $9.45 E-1$ & $9.45 \mathrm{E}-1$ & $9.45 \mathrm{E}-1$ \\
\hline${ }^{237} \mathrm{~Np},{ }^{233} \mathrm{~Pa}$ & $8.00 E-1$ & $8.28 \mathrm{E}-1$ & $8.54 \mathrm{E}-1$ & $8.86 \mathrm{E}-1$ & $9.30 \mathrm{E}-1$ & 1.18 & 2.28 & 2.96 \\
\hline${ }^{236} \mathrm{Pu}$ & $3.22 \mathrm{E}-1$ & $4.42 \mathrm{E}-2$ & $3.88 \mathrm{E}-3$ & $3.41 \mathrm{E}-4$ & $1.40 E-5$ & $1.22 \mathrm{E}-12$ & 0.0 & 0.0 \\
\hline${ }^{238} \mathrm{Pu}$ & $5.54 E+3$ & $4.99 E+3$ & $4.62 E+3$ & 4. $27 E+3$ & $3.96 \mathrm{E}+3$ & $2.30 E+3$ & $1.09 E+2$ & 2.97 \\
\hline${ }^{239} \mathrm{Pu}$ & $3.59 E+2$ & $3.59 E+2$ & $3.59 \mathrm{E}+2$ & $3.58 \mathrm{E}+2$ & $3.58 E+2$ & $3.58 E+2$ & $3.54 E+2$ & $3.50 \mathrm{E}+2$ \\
\hline${ }^{240} \mathrm{Pu}$ & $7.32 E+2$ & $7.39 \mathrm{E}+2$ & $7.41 E+2$ & $7.43 E+2$ & $7.43 E+2$ & $7.42 \mathrm{E}+2$ & 7. $12 \mathrm{E}+2$ & $6.77 \mathrm{E}+2$ \\
\hline${ }^{241} \mathrm{Pu}$ & $1.75 E+5$ & $9.39 E+4$ & $5.88 E+4$ & $3.68 \mathrm{E}+4$ & $2.00 E+4$ & $8.71 E+2$ & 1.75 & 1.68 \\
\hline${ }^{242} \mathrm{Pu}$ & 3.90 & 3.90 & 3.90 & 3.90 & 3.90 & 3.90 & 3.90 & 3.90 \\
\hline${ }^{241} \mathrm{Am}$ & $7.09 \mathrm{E}+2$ & $3.41 E+3$ & $4.55 E+3$ & $5.22 E+3$ & $5.60 E+3$ & $5.71 E+3$ & $3.03 E+3$ & $1.36 E+3$ \\
\hline $242 \mathrm{~m}$ Am, ${ }^{242} \mathrm{Am}$ & $9.70 E+1$ & $9.08 \mathrm{E}+1$ & $8.68 E+1$ & $8.28 E+1$ & $7.46 \mathrm{E}+1$ & $5.76 \mathrm{E}+1$ & 9.28 & $9.50 \mathrm{E}-1$ \\
\hline${ }^{243} \mathrm{Am},{ }^{239} \mathrm{~Np}$ & $9.46 \mathrm{E}+1$ & $9.46 \mathrm{E}+1$ & $9.44 \mathrm{E}+1$ & $9.44 E+1$ & $9.43 E+1$ & $9.36 \mathrm{E}+1$ & $9.04 \mathrm{E}+1$ & $8.64 E+1$ \\
\hline${ }^{242} \mathrm{Cm}$ & $9.89 E+3$ & $2.49 \mathrm{E}+2$ & $3.56 \mathrm{E}+1$ & $3.40 \mathrm{E}+1$ & $3.20 E+1$ & $2.36 \mathrm{E}+1$ & 3.81 & $3.90 \mathrm{E}-1$ \\
\hline${ }^{243} \mathrm{Cm}$ & 9.74 & 7.16 & 5.77 & 4.64 & 3.50 & $8.21 E-1$ & $1.42 \mathrm{E}-4$ & $2.82 E-9$ \\
\hline${ }^{244} \mathrm{Cm}$ & $7.15 \mathrm{E}+3$ & $4.25 E+3$ & $2.90 E+3$ & $1.98 E+3$ & $1.20 E+3$ & $9.24 \mathrm{E}+1$ & $2.06 \mathrm{E}-5$ & $1.76 \mathrm{E}-13$ \\
\hline${ }^{245} \mathrm{Cm}$ & 1.82 & 1.82 & 1.82 & 1.82 & 1.82 & 1.81 & 1.75 & 1.68 \\
\hline${ }^{246} \mathrm{Cm}$ & $3.41 E-1$ & $3.41 \mathrm{E}-1$ & $3.40 E-1$ & $3.40 \mathrm{E}-1$ & $3.39 E-1$ & $3.36 \mathrm{E}-1$ & 3. $16 \mathrm{E}-1$ & $2.94 \mathrm{E}-1$ \\
\hline${ }^{247} \mathrm{Cm},{ }^{243} \mathrm{Pu}$ & $3.58 \mathrm{E}-6$ & $3.58 \mathrm{E}-6$ & $3.58 \mathrm{E}-6$ & $3.58 \mathrm{E}-6$ & $3.58 E-6$ & $3.58 E-6$ & $3.58 \mathrm{E}-6$ & $3.58 \mathrm{E}-6$ \\
\hline${ }^{248} \mathrm{Cm}$ & $7.45 E-6$ & $7.45 E-6$ & $7.45 \mathrm{E}-6$ & $7.45 E-6$ & $7.45 E-6$ & $7.45 E-6$ & $7.44 E-6$ & $7.43 E-6$ \\
\hline${ }^{249} \mathrm{Cf}$ & $9.87 E-5$ & $1.28 \mathrm{E}-4$ & $1.27 E-4$ & $1.24 E-4$ & $1.20 \mathrm{E}-4$ & $1.06 \mathrm{E}-4$ & $4.82 E-5$ & $1.80 E-5$ \\
\hline${ }^{250} \mathrm{Cf}$ & $3.44 \mathrm{E}-4$ & $1.72 E-4$ & $1.01 E-4$ & $5.97 E-5$ & $3.33 E-5$ & $8.62 E-7$ & $4.91 \mathrm{E}-13$ & 0.0 \\
\hline${ }^{251} \mathrm{Cf}$ & $3.47 \mathrm{E}-6$ & $3.43 E-6$ & $3.41 \mathrm{E}-6$ & $3.38 \mathrm{E}-6$ & 3. $33 \mathrm{E}-6$ & 3. $18 \mathrm{E}-6$ & $2.34 \mathrm{E}-6$ & $1.59 \mathrm{E}-6$ \\
\hline${ }^{252} \mathrm{Cf}$ & $3.37 E-4$ & $4.29 \mathrm{E}-5$ & $3.13 \mathrm{E}-6$ & $2.28 \mathrm{E}-7$ & $1.67 \mathrm{E}-8$ & 0.0 & 0.0 & 0.0 \\
\hline $\begin{array}{l}\text { Subtotal } \\
\text { Actinides }\end{array}$ & $1.99 E+5$ & $1.08 E+5$ & $7.22 E+4$ & $4.96 E+4$ & $3.21 E+4$ & $1.03 E+4$ & $4.32 E+3$ & $2.49 E+3$ \\
\hline Total & $1.59 E+6$ & $3.90 \mathrm{E}+5$ & $2.48 E+5$ & $1.88 E+5$ & 1. $39 E+5$ & $3.10 E+4$ & $4.36 E+3$ & $2.51 E+3$ \\
\hline
\end{tabular}

(a) Radioactivity based on:

- Mixture of fuels expected to be reprocessed in the year 2000

- Reactor distribution of $1 / 3$ BWR, 2/3 PWR (by electrical output)

- Average PWR exposure of 31,800 MWD/MTHM (peak PWR exposure of 33,000 MND/MTHM)

- Average total exposure (PWR and BWR) of 29,300 MWD/MTHM

- Total feed of $13.5 \%$ first Pu recycle, $2.5 \%$ second Pu recycle

- Total feed of $7.4 \%$ first $U$ recycle, $0.7 \%$ second $U$ recycle, 1.5 year aging time before reprocessing

(b) Based on 1 MTHM fuel held up over 30 year life of plant (1/30 MTHM held up per year) expected reprocessing plant inventories are shown in Table B.3-1

(c) $70 \%$ of initial tritium assumed to remain with fuel after leaching of fuel from cladding

(d) When isotopes are grouped, radioactivities shown are total for group

(e) Carbon-14 (an activation product) and tritium are assumed not to be held up in the plant, but are present in the spent fuel at time of reprocessing. 100\% of $\mathrm{C}$ isotopes are assumed to be separated during reprocessing 
Table B.2-2 presents an estimate of the radioactive constituants in high-level liquid waste generated from reprocessing the reference fuel, assuming that $0.5 \%$ of the plutonium and uranium, $0.1 \%$ of the iodine, none of the ${ }^{14} \mathrm{C}$, and $\mathrm{a} 1 \mathrm{l}$ of the remaining nongaseous fission products are present. Radioactivity at the time of reprocessing includes a 1.5-year cooling period after discharge from the reactor. Radioactivity of the major isotopes in the high-level waste is also shown as a function of time after reprocessing.

\section{B.3 ESTIMATES OF RADIOACTIVITY LEVELS IN THE MAIN PROCESS BUILDING AFTER PLANT SHUTDOWN}

Table B.3-1 contains an estimate of the amounts of radioactive contaminants in the process cells after shutdown. The values shown represent the radioactivity after post-operations flushings and are calculated from information presented in Table B.2-1. These estimates include amounts held up inside equipment, on external surfaces of equipment, and on cell walls. For the RPC, HILC, RMSC, and HLC, it was assumed that $90 \%$ of the radioactivity in the cell was on the inside of cell equipment. For the UPC and ILC, 50\% of the cell inventory was assumed to be on equipment internals. For the remainder of the cells, contamination was assumed to be mainly on the external surfaces of equipment and on the cell walls.

For amounts on external surfaces of equipment and on cell walls, the estimates were based on postulated leaks from the most radioactive stream in each cell over the operating life of the plant. As a basis for the calculation of radionuclide levels only, it was assumed that liquid solutions equivalent to a film $0.01 \mathrm{~mm}$ thick would adhere to the surface of walls and equipment in the vicinity of a leak. About $85 \%$ of this contamination was assumed to be on the concrete walls and $15 \%$ on stainless steel equipment. This estimate does not include the buildup of large quantities of process material or debris in the cells because these were assumed to be cleaned up as a part of normal housecleaning procedures during plant operation. 


\section{TABLE B.2-2. Waste Radioactivity of Spent LWR Fuel Reprocessed 1.5 Years After Reactor Discharge(a)}

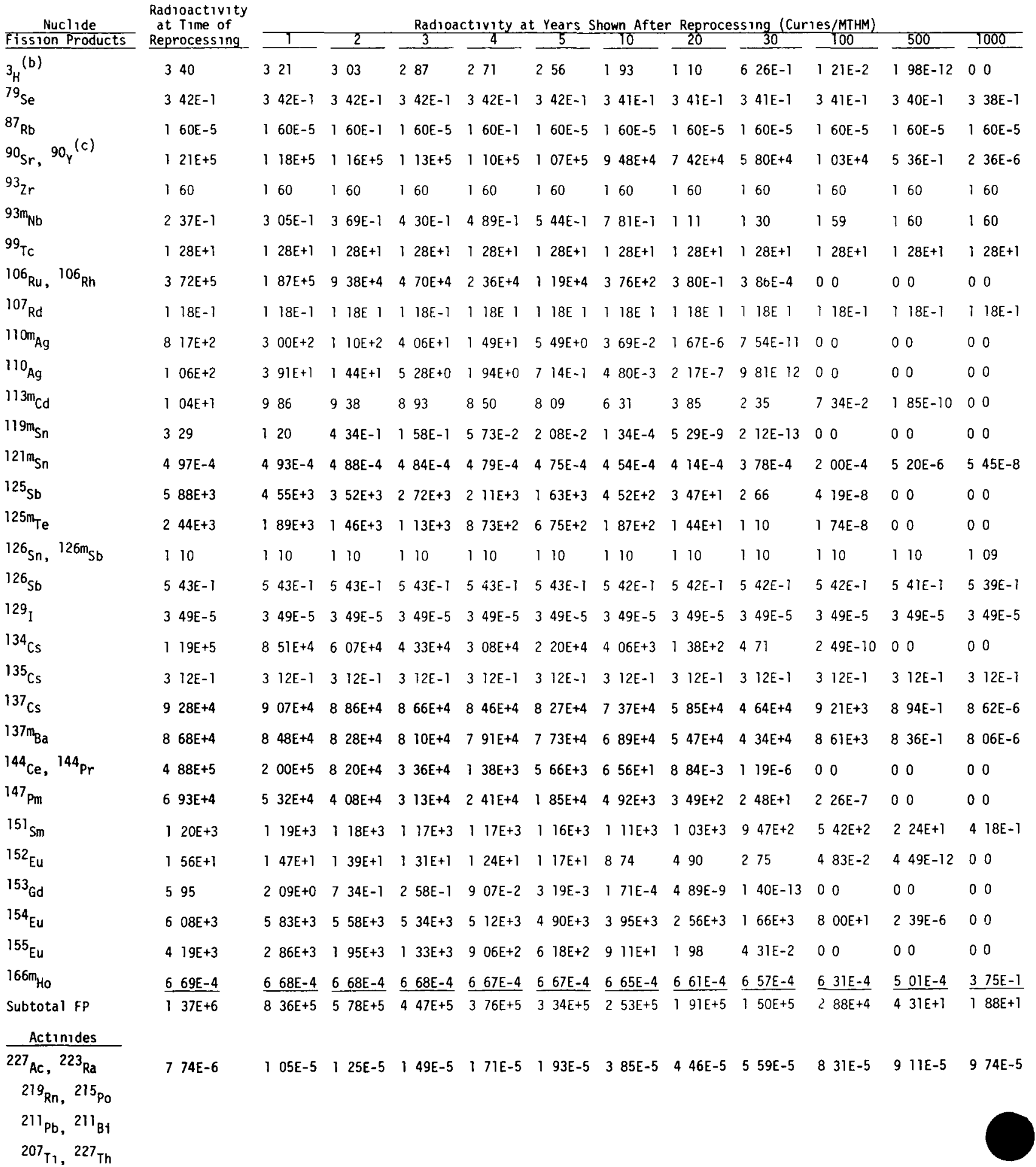




\section{TABLE B.2-2. (Continued)}

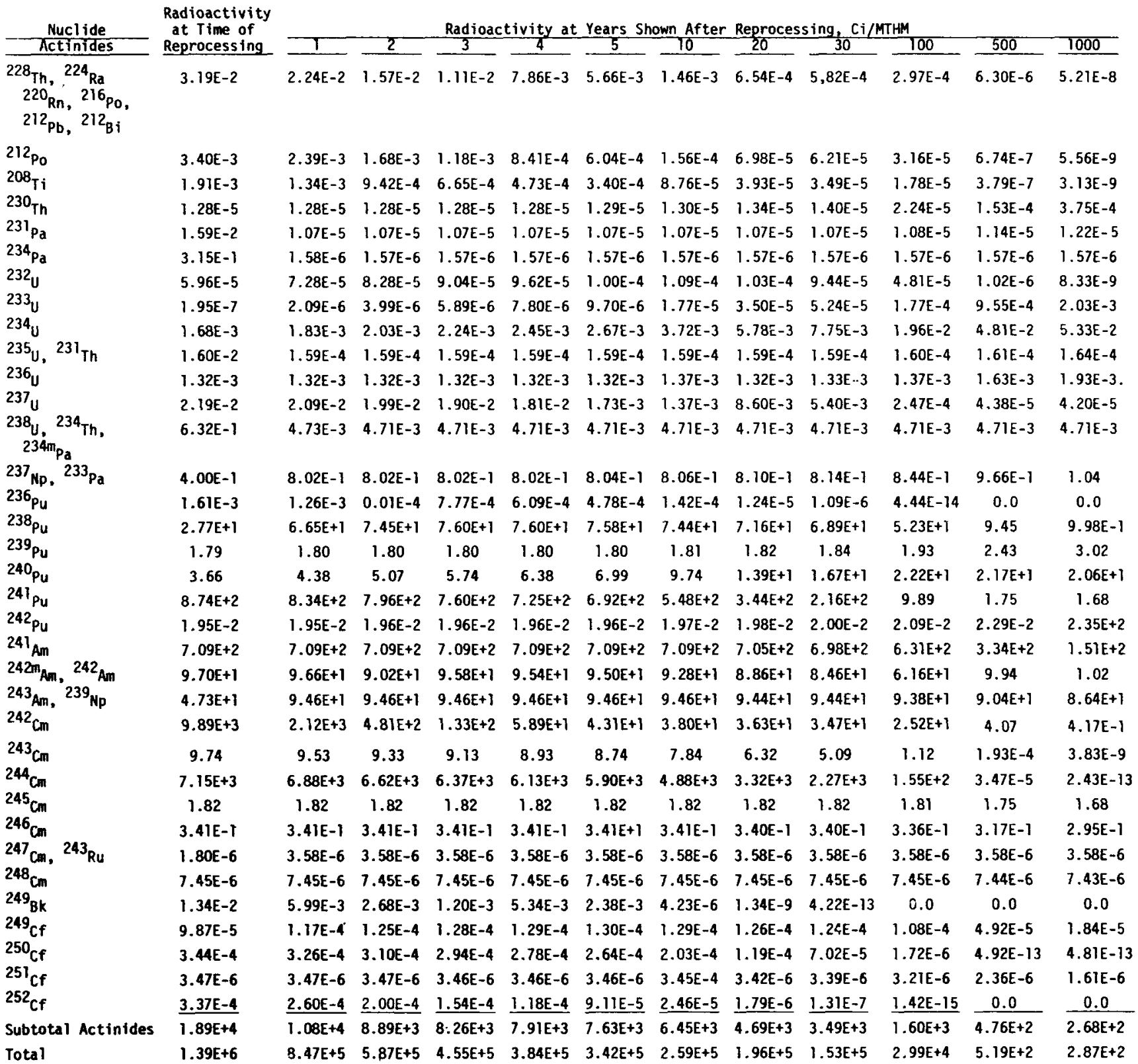

\footnotetext{
(a) Based on reference fuel (See Table B.1-1 Notes)

(b) $10 \%$ of Tritium present in HLLW

(c) When isotopes are grouped, radioactivities shown are total for the group.
} 


\section{TABLE B.3-1. Estimated Inventory of Major Radionuclides in Cells of Main Process Building After Shutdown and Before Chemical Decontamination}

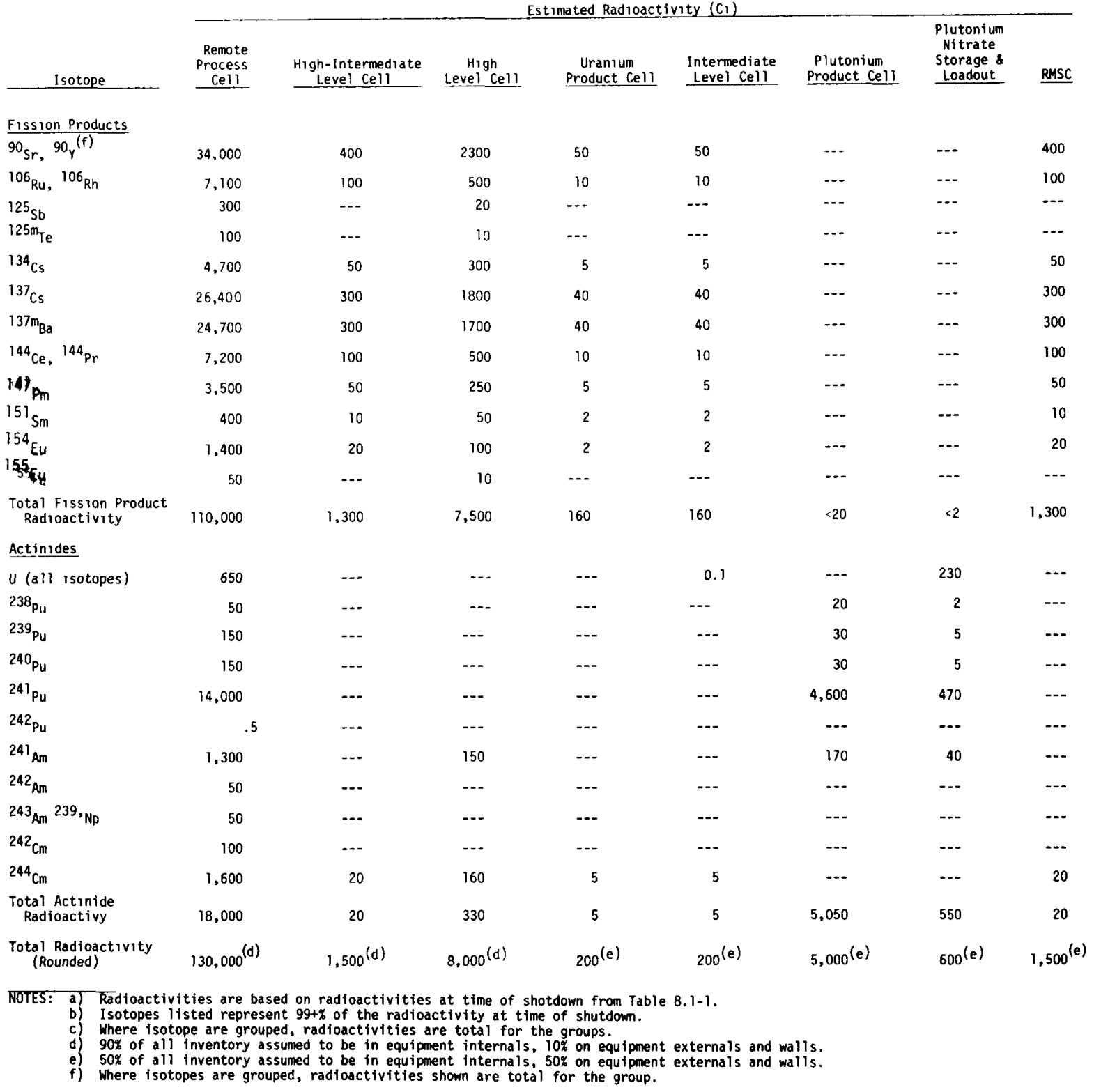


The radioactivity listed is that associated with 2 liters (a) (HWW) solution in the HLC, 2 liters of stream $5^{(a)}$ (HAW) in the HILC, 1 liter of stream 54 (a) $(P C P)$ in the PPC, and 0.2 liter of stream $75^{(a)}$ in the ILC and UPC. A holdup of 24 liters $(a)$ of dissolver solution and 20 iiters $(a)$ of HWW is assumed for the RPC. The radioactivities of the process streams are based on flow sheet data and decontamination factors representative of the Purex process. Based on the information in Table B.3-1 approximately $4.2 \mathrm{~kg}$ of plutonium are estimated to be in the process cells of the main process building before chemical decontamination.

The above assumptions seem reasonable based on previous experience at Hanford. Estimated holdup numbers are stated more accurately than they deserve. They are presented in this fashion to preserve continuity with the rest of this report. These estimates are highly dependent on plant operating philosophy and the values presented represent what is expected to be a typical case for the assumptions used. Actual plant operations could result in values different from those shown.

Table B.3-2 gives the estimated inventories of radionuclides in the process cells following chemical decontamination (see Appendix E.2). The inventories in Table B.3-2 are derived from the estimated inventories at shutdown in Table B.3-1, assuming a chemical decontamination factor (DF) of 2 for concrete and 100 for external surfaces of equipment in all cells. A DF of 1000 for internal surfaces of equipment is expected because the decontamination chemicals are in more intimate contact with metal surfaces for longer periods of time. The amount of plutonium in the process cells is estimated to be approximately $70 \mathrm{gm}$ following chemical decontamination.

\section{B.4 ESTIMATES OF RADIOACTIVITY LEVELS IN HLLW AND ILLW STORAGE TANKS AFTER PLANT SHUTDOWN}

Table B.4-1 contains an estimate of the radioactive contaminants remaining in a HLLW tank at the time of decommissioning. Because of the large inventory of wastes at the time of plant shutdown, four years of decay time

(a) Stream designations refer to those in Figure A.1.4, Volume 2. 
TABLE B.3-2. Estimated Inventory of Major Radionuclides on Process Cell Walls and External Surfaces of Equipment in Process Cells After Chemical Decontamination

\begin{tabular}{|c|c|c|c|c|c|c|c|}
\hline Remote & & & Estimated $R a$ & loactivity ( $C_{1}$ & & & \\
\hline $\begin{array}{l}\text { Relist } \\
\text { Process Cel1 }\end{array}$ & $\begin{array}{l}\text { Mrgnel Cell } \\
\text { Level }\end{array}$ & Level Cell & $\begin{array}{l}\text { Jranium } \\
\text { Product Cell }\end{array}$ & $\begin{array}{l}\text { Intermealate } \\
\text { Level Cell }\end{array}$ & $\begin{array}{l}\text { Plutonium } \\
\text { Product Cell }\end{array}$ & Storage \& Loadout & \& Scrap $\mathrm{Cell}$ \\
\hline
\end{tabular}
Fission Products

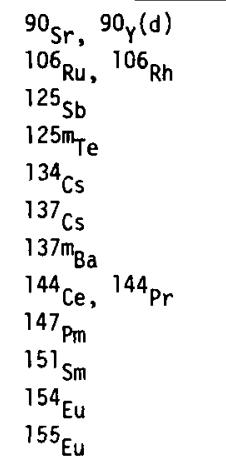

Total Fission Product Radioactivity

1,450
300
13
5
200
1,130
1,060
310
150
17
60
2

\section{$\begin{array}{ll}\text { Plutonium } & \begin{array}{l}\text { Plutonium Nitrate } \\ \text { Pemote Maint } \\ \text { Product Cell }\end{array} \text { Storage \& Loadout } \\ \end{array}$}

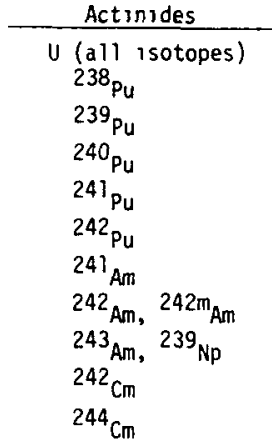

$\begin{array}{rrr}17 & 100 & 11 \\ 5 & 22 & 2 \\ -- & -- & - \\ -- & -- & - \\ 2 & 13 & 1 \\ 13 & 77 & 9 \\ 13 & 73 & 9 \\ 5 & 22 & 2 \\ 2 & 10 & 1 \\ -- & 2 & -- \\ -- & 5 & -- \\ -- & -- & -- \\ 60 & 325 & 35\end{array}$

Total Actinide

Total Radroactivity

(Rounded)

--
--
--
--
--
--
--
--
--
$<1$
$<1$
60

NOFE (a) Based on Table B.2-1

b) Assumes DF of 2 for concrete, 100 for equipment

85\% of contamination on exterete, $15 \%$ is on equipment

(d) Where isotopes are grouped, radioactivities are total for the group 
TABLE B. 4-1. Estimated Inventory of Radionuclides in a HLLW Storage Tank After Removal of Waste

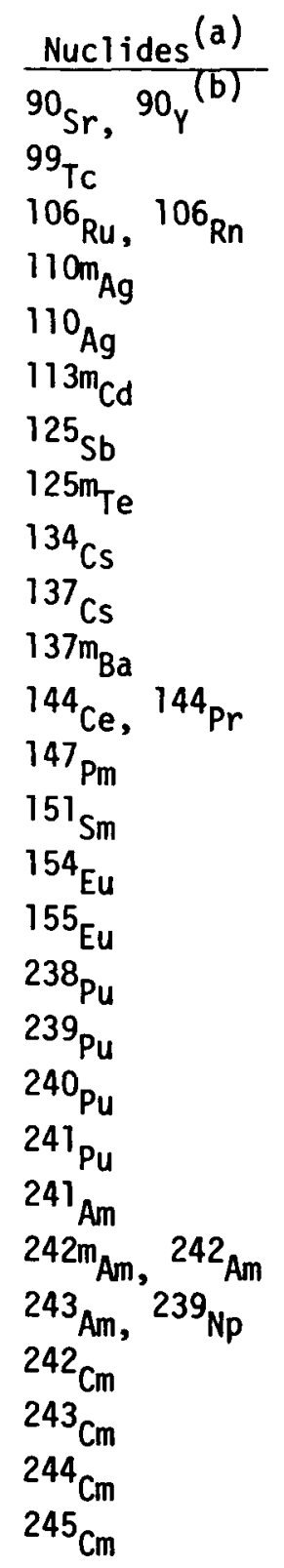

Totals

\begin{tabular}{|c|c|c|}
\hline \multicolumn{3}{|c|}{ Radioactivity (Ci) } \\
\hline $\begin{array}{c}\text { Residual } \\
\text { Waste Solution }\end{array}$ & $\begin{array}{c}\text { Tank } \\
\text { Bottom }\end{array}$ & $\begin{array}{l}\text { Tank Walls } \\
\text { and Internals }\end{array}$ \\
\hline $2.2 E+6$ & $1.1 E+5$ & $8.4 E+3$ \\
\hline $2.7 E+2$ & 1. $3 E+1$ & -- \\
\hline $4.9 E+5$ & $2.4 E+4$ & $1.8 E+3$ \\
\hline $3.1 E+2$ & $1.5 E+1$ & -- \\
\hline $3.9 E+1$ & 1.9 & -- \\
\hline $1.7 F+2$ & 85 & -- \\
\hline
\end{tabular}

4. $3 E+4 \quad 2.1 E+3 \quad 1.6 E+2$

1. $8 \mathrm{E}+4$

$8.7 E+2$

$6.6 \mathrm{E}+1$

6. $3 E+5$

$3.1 E+4$

2. $4 \mathrm{E}+3$

$1.7 E+6$

8. $5 E+4$

$6.6 \mathrm{E}+3$

1. $6 \mathrm{E}+6$

7. $9 E+4$

6. $0 \mathrm{E}+3$

2. $9 E+5$

1. $4 \mathrm{E}+4$

1. $1 E+3$

4. $9 E+5$

2. $4 E+4$

1. $8 \mathrm{E}+3$

2. $4 \mathrm{E}+4$

$1.2 E+3$

$9.2 \mathrm{E}+1$

1. $0 \mathrm{E}+5$

$5.1 E+3$

4. $\mathrm{OE}+2$

$1.8 \mathrm{E}+4$

9. $O E+2$

$6.8 \mathrm{E}+1$

$1.6 \mathrm{E}+3$

$7.6 E+1$

5.8

$3.7 \mathrm{E}+1$

1.8

$1.3 \mathrm{E}+2$

6.4

$1.5 E+4$

$7.3 \mathrm{E}+2$

5. $6 \mathrm{E}+1$

1. $4 \mathrm{E}+4$

7. $1 E+2$

$5.4 \mathrm{E}+1$

1. $9 \mathrm{E}+3$

9. $5 \mathrm{E}+1$

7.2

1. $9 \mathrm{E}+3$

9. $5 \mathrm{E}+1$

7.2

1. $2 \mathrm{E}+3$

5. $9 \mathrm{E}+1$

4.6

1. $8 \mathrm{E}+2$

8.9

1. $2 \mathrm{E}+5$

6. $1 E+3$

4. $6 \mathrm{E}+2$

3. $7 \mathrm{E}+1$

$\frac{1.8}{3.8 \mathrm{E}+5}$

(a) Isotopes listed represent $98+\%$ of the radioactivity in waste processed 1.5 years after reactor discharge and stored 4 years.

(b)

Where isotopes are grouped, radioactivities given are for total for group. 
after reprocessing was assumed for the waste solutions using the isotopic composition in Table B.2-2. Radioactivity levels in the ILLW tanks are expected to be approximately three orders of magnitude lower than in the HLLW tanks.

The radioactivity levels were estimated as discussed in the following subsections.

\section{B.4.1 Radioactivity Levels in Waste Solutions}

Table B.2-2 gives the waste radioactivity from 1 metric ton of fuel, processed 1.5 years after reactor discharge and decayed 4 years in the HLLW storage tank, as $3.84 \times 10^{5} \mathrm{Ci}$. Approximately 570 liters of high-level waste solution are assumed to be generated for each metric ton of fuel processed. These values represent a solution in the tanks with approximately $680 \mathrm{Ci} / \mathrm{liter}$.

\section{B.4.2 Solution Remaining in Tanks After Removal of Waste}

Although the tank floor is sloped $0.42 \mathrm{~cm}$ per horizontal meter $(0.05 \mathrm{in}$. per foot) and the empty-out jets (steam-operated ejector pumps) are located on the low end of the tank floor, the empty-out jets will not remove all the liquid from the HLLW tanks. It is assumed that about $8.9 \mathrm{~cm}(3-1 / 2$ in.) of solution remain in the low end of a HLLW tank after removal of waste; this amounts to 11,600 liters of solution containing $7.9 \times 10^{6} \mathrm{Ci}$ of radioactivity left in each HLLW tank.

Because of its design, the ILLW tank can be pumped out almost completely, leaving very little solution in the tank after pumpdown. The radioactivity resulting from this pump "heel" is insignificant when compared with the levels in the ILLW tank bottom. The radioactivity in these tank "heels" is assumed to be ascribable to decommissioning in this study. Processing of the wastes down to these "heel" levels is considered to be part of plant production operations.

\section{B.4.3 Radioactivity Adhering to Tank Internals}

The HLLW tanks contain about $10,800 \mathrm{~m}$ of 5.08 -cm-diameter Schedule 40 stainless steel pipe coolant coils (see Figure A.4-2). The area of this pipe and the other internal equipment and tank surfaces is about $1900 \mathrm{~m}^{2}$. Contamination of these surfaces after removal of the waste is estimated as equivalent to the amount of radioactivity contained in a thin film $1900 \mathrm{~m}^{2}$ 
by $0.01 \mathrm{~mm}$ thick. This $\mathrm{film}$ is assumed to adhere to the surface and evaporate, thereby leaving its radionuclides deposited on the stainless steel. This basis results in a calculated $1.45 \times 10^{4} \mathrm{Ci}$ of radioactive material adhering to the tank internals and walls. An equal amount of radioactive material is assumed to have built up in crevices and corners on the internals for a total of $2.9 \times 10^{4} \mathrm{Ci}$. Radioactivity on the tank top is assumed to be about $300 \mathrm{Ci}$.

Because the ILLW tanks do not have coolant coils, only radioactivity on tank walls was considered here. Based on the wall area, expected ILLW radioactivities (approximately three orders of magnitude lower concentration than in HLLW) and contamination equivalent to the amount of radioactivity contained in a film of solution $0.01 \mathrm{~mm}$ thick covering the walls, a value of approximately $2 \mathrm{Ci}$ was estimated for the tank walls.

\section{B.4.4 Radioactivity on the Tank Bottoms}

The high-level waste tanks are equipped with air lift circulators and air ballast tank agitators to reduce the amount of solids that settle out on the tank floor. Even so, it is assumed that the radioactivity equivalent to that from 1 MTHM fuel $\left(3.8 \times 10^{5} \mathrm{Ci}\right)$ is deposited on the tank bottom.

As in the previous case, levels in the ILLW tank are taken to be approximately three orders of magnitude lower and are thereby estimated to be $3.8 \times 10^{2} \mathrm{Ci}$.

\section{B.5 ESTIMATES OF RADIOACTIVITY LEVELS IN HLLW AND ILLW STORAGE TANKS FOLLOWING CHEMICAL DECONTAMINATION}

Early in the decommissioning activity, the HLLW and ILLW tanks are chemically decontaminated. Tables B.5-1, B.5-2, and B.5-3 present the estimated radionuclide inventories in the HLLW storage tanks after chemical decontamination for each decommissioning mode. Radioactivity levels in the ILLW tank bottom are taken to be three orders of magnitude lower than in the HLLW tank. Radioactivity levels on the ILLW tank internals and from solution remaining in the tank are expected to be insignificant compared to HLLW tank bottom levels. See Appendix E.3 for more complete details on each decommissioning mode. 
TABLE B.5-1. Estimated Inventory of Radionuclides in a HLLW Storage Tank After Removal of Waste and

Chemical Decontamination for the Layaway Mode

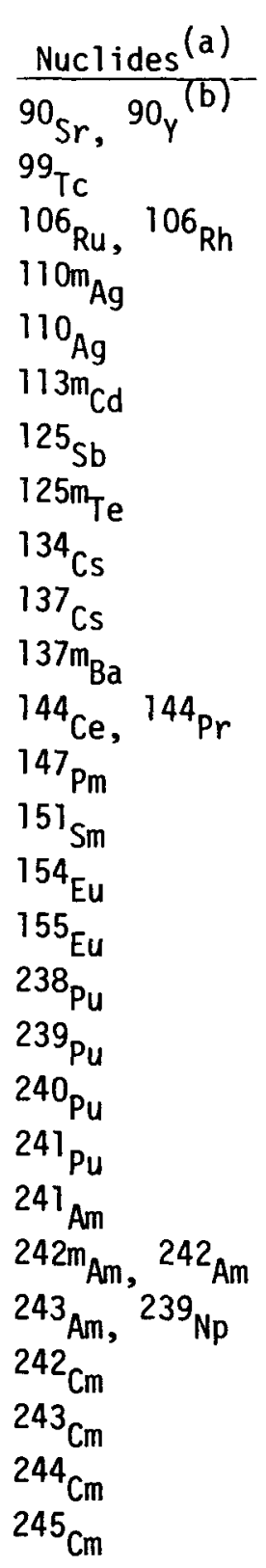

Totals

\begin{tabular}{ccc}
\multicolumn{3}{c}{ Radioactivity $(\mathrm{Ci})$} \\
\hline Residual & Tank & Tank Walls \\
Waste Solution & Bottom & and Internals
\end{tabular}

\section{6. $9 E+3$}

1. $5 E+3$

$2.4 E+1$

8. $4 E+3$

$1.1 E+2$

$1.8 \mathrm{E}+3$

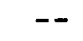

1. $3 E+2$

2.1

1. $6 \mathrm{E}+2$

$5.7 \mathrm{E}+1$

$-$

$6.6 \mathrm{E}+1$

2. $0 \mathrm{E}+3$

3. $1 E+1$

2. $4 \mathrm{E}+3$

5. $3 E+3$

8. $5 E+1$

$6.6 E+3$

$5.0 E+3$

7. $9 \mathrm{E}+1$

6. $\mathrm{OE}+3$

9. $1 \mathrm{E}+2$

1. $4 \mathrm{E}+1$

1. $1 E+3$

1. $5 \mathrm{E}+3$

2. $4 \mathrm{E}+1$

7. $5 \mathrm{E}+1$

1.2

1. $8 \mathrm{E}+3$

3. $1 E+2$

5.1

9. $2 \mathrm{E}+1$

$5.7 \mathrm{E}+1$

5.0

--

4. $O E+2$

$6.8 \mathrm{E}+1$

$-$

5.8

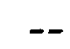

4. $7 \mathrm{E}+1$

--

$-$

$-$

4. $4 \mathrm{E}+1$

--

5. $6 \mathrm{E}+1$

6.0

-

5. $4 \mathrm{E}+1$

6.0

$--$

7.2

4.0

$-$

7.2

4.6

3. $8 E+2$

6.1

4. $6 \mathrm{E}+2$

$\frac{--}{2.5 E+4}$ $\frac{-}{3.8 E+2}$

\section{$2.9 E+4$}

(a) Isotopes listed represent $98+\%$ of the radioactivity in waste from fuel processed 1.5 years after reactor discharge and stored for 4 years.

(b) When isotopes are grouped, radioactivities given are total for group. 
TABLE B.5-3. Estimated Inventory of Radionuclides in a HLLW Storage Tank After Removal of Waste and Chemical Decontamination for the Dismantling Mode

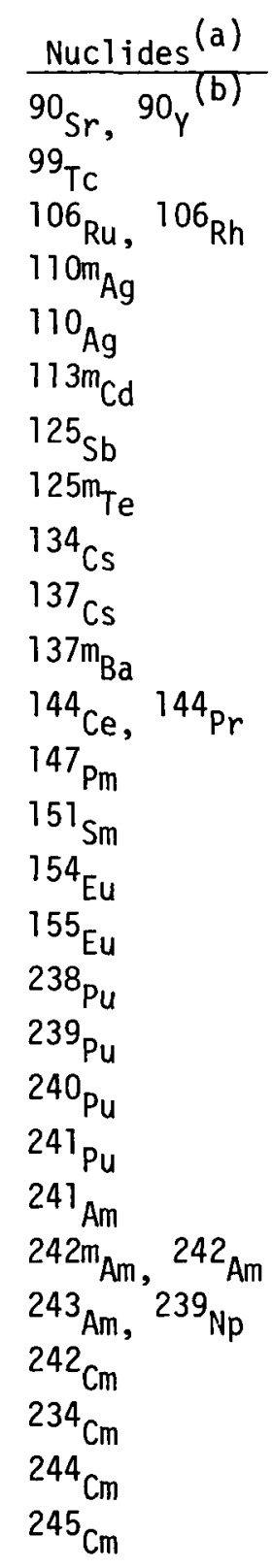

Totals

\begin{tabular}{|c|c|c|}
\hline \multicolumn{3}{|c|}{ Radioactivity (Ci) } \\
\hline $\begin{array}{c}\text { Residual } \\
\text { Waste Solution }\end{array}$ & $\begin{array}{c}\text { Tank } \\
\text { Bottom } \\
\end{array}$ & $\begin{array}{l}\text { Tank Walls } \\
\text { and Internals }\end{array}$ \\
\hline-- & $1.1 E+2$ & $8.4 E+2$ \\
\hline-- & -- & -- \\
\hline-- & $2.4 E+1$ & $1.8 \mathrm{E}+2$ \\
\hline- & -- & -- \\
\hline-- & -- & -- \\
\hline- & -- & -- \\
\hline-- & 2.1 & $1.6 \mathrm{E}+1$ \\
\hline-- & -- & 6.6 \\
\hline-- & $3.1 E+1$ & $2.4 E+2$ \\
\hline-- & $8.5 E+1$ & $6.6 \mathrm{E}+2$ \\
\hline-- & $7.9 E+1$ & $6.0 E+2$ \\
\hline-- & $1.4 \mathrm{E}+1$ & $1.1 E+2$ \\
\hline-- & $2.4 \mathrm{E}+1$ & $1.8 \mathrm{E}+2$ \\
\hline-- & 1.2 & 9.2 \\
\hline-- & 5.1 & $4.0 E+1$ \\
\hline-- & -- & 6.8 \\
\hline-- & -- & -- \\
\hline-- & -- & -- \\
\hline-- & -- & $=-$ \\
\hline-- & -- & 5.6 \\
\hline-- & -- & 5.4 \\
\hline-- & -- & -- \\
\hline-- & -- & -- \\
\hline-- & - & - \\
\hline-- & -- & -- \\
\hline-- & 6.1 & $4.6 \mathrm{E}+1$ \\
\hline-- & -- & $\ldots$ \\
\hline$<5$ & $3.8 E+2$ & $2.9 E+3$ \\
\hline
\end{tabular}

\footnotetext{
(a) Isotopes 1 isted represent $98+\%$ of the radioactivity in waste from fuel processed 1.5 years after reactor discharge and stored for 4 years.

(b) When isotopes are grouped, radioactivities given are total for the group.
} 
B.5.1 Radioactivity Estimates in the Layaway Mode

Table B.5-1 shows the estimated radionuclide inventory following the decontamination flushes called for in the layaway mode. Four flushes using 37,900 liters $(10,000 \mathrm{gal})$ of nitric acid chemically decontaminate the tank bottom and dilute the solution remaining in the HLLW tank. Decontamination factors of 100 for the first flush and 10 for the second flush were assumed for the tank bottom. Subsequent flushes are assumed to provide negligible reduction of radioactivity fixed to the tank bottom and act only to dilute the solution left in the tank.

\section{B.5.2 Radioactivity Estimates in the Protective Storage Mode}

Table B.5-2 presents radioactivity levels in the HLLW tank following chemical decontamination procedures called for in the protective storage mode. In addition to the flushings described in the layaway mode, all remaining waste solution is pumped from the HLLW tank.

\section{B.5.3 Radioactivity Estimates in the Dismantlement Mode}

Table B.5-3 presents the estimated radioactivity levels in the HLLW tank following chemical decontamination procedures for dismantlement. Dismantlement procedures call for flushing the tank as in the two previous modes, plus spraying down the inside of the tank walls and the tank internals with nitric acid (giving an assumed reduction in radioactivity content by a factor of 10), and pumping all remaining waste solution from the tank.

\section{B. 6 WASTE SOLIDIFICATION PLANT RADIONUCLIDE INVENTORIES}

Table B.6-1 presents the total radioactivity of the high-level wastes that result from reprocessing the reference fuel mixture. The column labeled "Radioactivity at Time of Reprocessing" represents the radioactivity of waste from one MTHM of fuel that was reprocessed 1.5 years after reactor discharge and stored for 1.3 years during normal plant operations. The column labeled "Radioactivity at Time of Shutdown" represents the radioactivity of waste from one MTHM of fuel held up in the Waste Solidification Plant (WSP) over its 30-year life (1/30 MTHM held up per year). The remaining columns depict the decay of this held-up material after the WSP is shut down. 
TABLE B.6-1. Radioactivity of HLLW in WSP at Various Times

\begin{tabular}{|c|c|c|c|c|c|c|c|c|}
\hline Nuclide & $\begin{array}{l}\text { Radioactivity at time } \\
\text { of Solidification(a) }\end{array}$ & $\begin{array}{l}\text { Radioactivity at time } \\
\text { of Plant Shutdown (b) } \\
\end{array}$ & $\frac{\operatorname{Rad} 10}{10}$ & $\frac{\text { ctivity at }}{20}$ & $\begin{array}{l}\text { Year Shown } \\
\frac{30}{}\end{array}$ & $\frac{\text { After WSP }}{100}$ & $\begin{array}{l}\text { Shutdown, } \\
500 \\
\end{array}$ & $\frac{C_{1} / \text { MTHM }}{1000}$ \\
\hline \multicolumn{9}{|l|}{$\begin{array}{l}\text { Fission } \\
\text { Products } \\
\end{array}$} \\
\hline \multirow{3}{*}{ 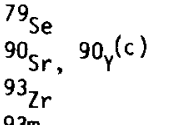 } & $342 \mathrm{E}-1$ & $341 E-1$ & $341 E-1$ & $341 E-7$ & $341 E-1$ & $341 \mathrm{E}-7$ & $341 E-1$ & $340 E-1$ \\
\hline & $117 E+5$ & $830 E+4$ & $648 E+4$ & $507 E+4$ & $396 E+4$ & $704 E+3$ & $183 E-1$ & 00 \\
\hline & 160 & 160 & 160 & 160 & 160 & 160 & 160 & 160 \\
\hline $93 m_{n b}$ & $327 \mathrm{E}-1$ & $948 \mathrm{E}-1$ & 121 & 136 & 146 & 160 & 160 & 160 \\
\hline${ }^{99} \mathrm{TC}$ & $128 E+1$ & $128 E+1$ & $128 E+1$ & $128 E+1$ & $128 \mathrm{E}+1$ & $128 \mathrm{E}+1$ & $128 E+1$ & $128 \mathrm{E}+1$ \\
\hline \multirow{2}{*}{$\begin{array}{l}{ }^{106} \mathrm{Ru},{ }^{106} \mathrm{Rh} \\
{ }^{107} \mathrm{Pd}\end{array}$} & $149 E+4$ & $718 \mathrm{E}+3$ & 726 & $734 E-3$ & $742 E-6$ & 00 & 00 & 00 \\
\hline & $118 \mathrm{E}-1$ & $118 \mathrm{E} I$ & $118 E-1$ & $118 E-1$ & $118 E-1$ & $118 E-1$ & $118 E-1$ & $118 E-1$ \\
\hline \multirow{2}{*}{$\begin{array}{l}110 \mathrm{~m}_{\mathrm{Ag}} \\
110_{\mathrm{Ag}} \\
113 \mathrm{~m}_{\mathrm{Cd}}\end{array}$} & $215 E+2$ & 717 & $324 E-4$ & $146 E-8$ & 00 & 00 & 00 & 00 \\
\hline & $280 E+1$ & $932[1$ & $421 E-5$ & $190 E-9$ & 00 & 00 & 00 & 00 \\
\hline $113 \mathrm{~m} c d$ & 970 & 505 & 308 & 188 & 114 & $358 \mathrm{E}-2$ & $901 E-11$ & 00 \\
\hline $119 m_{S n}$ & $853 E-1$ & $281 E-2$ & $113 E-6$ & $451 E-11$ & 00 & 00 & 00 & 00 \\
\hline & $418 E+3$ & $542 E+2$ & $416 \mathrm{E}+1$ & 320 & $246 \mathrm{E}-1$ & $387 E-9$ & 00 & 00 \\
\hline \multirow{2}{*}{${ }^{1256_{\mathrm{Sn}},{ }^{126 \mathrm{~m}_{\mathrm{Sb}}}}$} & $173 E+3$ & $225 E+2$ & $173 E+1$ & 132 & $102 \mathrm{E}-1$ & $160 \mathrm{E}-9$ & 00 & 00 \\
\hline & 110 & 110 & 110 & 110 & 110 & 110 & 110 & 110 \\
\hline \multirow{2}{*}{${ }^{126} 6_{\mathrm{Sb}}$} & $543 E-1$ & 5 43E 1 & $542 E-1$ & $542 E-1$ & $542 E-1$ & $542 E-1$ & $541 E-1$ & $540 E-1$ \\
\hline & $761 E+4$ & $750 E+3$ & $255 \mathrm{E}+2$ & 861 & $296 \mathrm{E}-1$ & $156 \mathrm{E}-11$ & 00 & 00 \\
\hline \multirow{5}{*}{$\begin{array}{l}135 \mathrm{Cs} \\
137 \mathrm{Cs} \\
137 \mathrm{~m}_{\mathrm{Ba}} \\
{ }^{144} \mathrm{Ce},{ }^{144} \mathrm{Pr} \\
{ }^{147} \mathrm{Pm}\end{array}$} & $312 \mathrm{E}-1$ & $312 \mathrm{E}-1$ & $312 E-1$ & $312 \mathrm{E}-1$ & $312 E-1$ & $312 E-1$ & 3 I2E-1 & $312 E-1$ \\
\hline & $900 E+4$ & $649 E+4$ & $515 E+4$ & $409 E+4$ & $325 \mathrm{E}+4$ & $644 E+3$ & $625 E-1$ & $100 E-1$ \\
\hline & $841 E+4$ & $607 E+4$ & $482 E+4$ & $382 E+4$ & $303 E+4$ & $602 E+3$ & $585 E-1$ & $100 E-1$ \\
\hline & $149 E+5$ & $556 \mathrm{E}+3$ & $748 E-1$ & $101 E-4$ & $136 E-8$ & 00 & 00 & 00 \\
\hline & $487 E+4$ & $613 E+3$ & $436 E+2$ & $309 E+1$ & 202 & $200 E-8$ & 00 & 00 \\
\hline${ }^{151} \mathrm{Sn}$ & $119 E+3$ & $106 E+3$ & $978 E+2$ & $903 E+2$ & $834 E+2$ & $477 E+2$ & $197 \mathrm{E}+1$ & $400 E+1$ \\
\hline${ }^{152} \mathrm{Eu}$ & $144 E+1$ & 685 & 384 & 216 & 121 & $213 E-2$ & $197 \mathrm{E}-12$ & 00 \\
\hline \multirow{3}{*}{$\begin{array}{l}153_{\mathrm{Gd}} \\
154_{\mathrm{Eu}} \\
155_{\mathrm{Eu}}\end{array}$} & 147 & $470 E-2$ & $135 E-6$ & $386 E-11$ & 00 & 00 & 00 & 00 \\
\hline & $574 E+3$ & $321 E+3$ & $208 E+3$ & $35 E+3$ & $876 \mathrm{E}+2$ & $423 E+1$ & $126 \mathrm{E}-6$ & 00 \\
\hline & $252 E+3$ & $219 E+2$ & 476 & $103 E-1$ & $225 \mathrm{E}-3$ & 00 & 00 & 00 \\
\hline FP Subtotal & $729 E+5$ & $240 E+5$ & $168 E+5$ & $132 E+5$ & $104 E+5$ & $201 E+4$ & $397 E+1$ & $188 E+1$ \\
\hline \multicolumn{9}{|l|}{ Actinides } \\
\hline \multirow{2}{*}{$\begin{array}{l}{ }^{237} \mathrm{NP},{ }^{233} \mathrm{Pu} \\
{ }^{238} \mathrm{Pu}\end{array}$} & $802 E-1$ & $808 \mathrm{E}-1$ & $812 E-1$ & $818 E-1$ & $822 E-1$ & $852 E-1$ & $968 \mathrm{E}-1$ & 100 \\
\hline & $707 E+1$ & $727 \mathrm{E}+1$ & $701 E+1$ & $675 E+1$ & $649 \mathrm{E}+1$ & $691 \mathrm{E}+1$ & 808 & 100 \\
\hline $\begin{array}{l}{ }^{239} \mathrm{Pu} \\
240 \mathrm{Pu}\end{array}$ & 180 & 182 & 183 & 185 & 186 & 196 & 245 & 300 \\
\hline $240 \mathrm{Pu}$ & 461 & $120 E+1$ & $154 E+1$ & $177 E+1$ & $193 \mathrm{E}+1$ & $223 E+1$ & $217 E+1$ & $210 E+1$ \\
\hline${ }^{241} \mathrm{Pu}$ & $821 E+2$ & $442 E+2$ & $277 E+2$ & $174 E+2$ & $170 \mathrm{E}+2$ & 588 & 175 & 170 \\
\hline \multirow{3}{*}{$\begin{array}{l}241_{\mathrm{Am}} \\
241_{\mathrm{Am}},{ }^{242 \mathrm{~m}} \mathrm{Am}_{\mathrm{Am}} \\
243{ }_{\mathrm{Am}},{ }^{239_{\mathrm{Np}}} \\
242_{\mathrm{Cm}}\end{array}$} & $710 E+2$ & $706 E+2$ & $700 E+2$ & $693 E+2$ & $684 E+2$ & $615 E+2$ & $325 E+2$ & l $50 \mathrm{E}+2$ \\
\hline & $966 \mathrm{E}+1$ & $902 E+1$ & $862 E+1$ & $824 E+1$ & $786 \mathrm{E}+1$ & $572 E+1$ & 922 & 100 \\
\hline & $946 \mathrm{E}+1$ & $946 E+1$ & $944 \mathrm{E}+1$ & $944 E+1$ & $942 \mathrm{E}+1$ & $936 \mathrm{E}+1$ & $904 \mathrm{E}+1$ & $860 E+1$ \\
\hline \multirow{2}{*}{${ }^{242} \mathrm{Cm}$} & $128 E+3$ & $645 E+1$ & $353 E+1$ & $338 \mathrm{E}+1$ & $323 E+1$ & $234 E+1$ & 378 & $400 E-1$ \\
\hline & 946 & 696 & 560 & 451 & 363 & $798 \mathrm{E}-1$ & $138 \mathrm{E}-4$ & 00 \\
\hline \multirow{2}{*}{$\begin{array}{l}{ }^{244} \mathrm{Cm} \\
{ }^{245} \mathrm{Cm}\end{array}$} & $679 E+3$ & $404 E+3$ & $275 E+3$ & $188 \mathrm{E}+3$ & $128 \mathrm{E}+3$ & $878 E+1$ & $196 \mathrm{E}-5$ & 00 \\
\hline & 182 & 182 & 182 & 182 & 182 & 182 & 181 & 175 \\
\hline${ }^{246} \mathrm{~cm}$ & $341 E-1$ & $340 E-1$ & $340 \mathrm{E}-]$ & $339 \mathrm{E}-1$ & $339 E-1$ & $335 E-1$ & $316 E-1$ & $300 \mathrm{E}-1$ \\
\hline $\begin{array}{l}\text { Actinides } \\
\text { Subtotal }\end{array}$ & $989 E+3$ & $553 E+3$ & $404 E+3$ & $305 E+3$ & $237 \mathrm{E}+3$ & $960 E+2$ & $466 E+2$ & $268 \mathrm{E}+2$ \\
\hline Total & $739 E+5$ & $246 \mathrm{E}+5$ & $172 \mathrm{E}+5$ & $135 E+5$ & $106 E+5$ & $211 E+4$ & $506 \mathrm{E}+2$ & $287 E+2$ \\
\hline
\end{tabular}

NOTES

(a) Radioactivities are based on HLLW radioactivities given in Table B 1-2 and reflect a 3-year cooling period after reprocessing

(b) Based on waste from 1 MTHM fuel held up over the 30-year 11fe of plant (1/30 MTHM held up per year)

(c) When isotopes are grouped, radioactivities are the total for the group 
The Waste Solidification Plant is expected to operate for about 3 years ter the main Fuel Reprocessing Plant shuts down. Flush solutions from the main plant and the waste tanks are processed as they accumulate during this period. Processing of the dilution flushes is expected to clean the equipment internals to low inventories of waste radionuclides.

During routine production operations, two canisters of solidified waste per day are removed from the WVC. Because these canisters are temporarily stored in the FRSS water-filled basins, it is necessary that they be relatively free of contamination on their external surfaces to prevent overloading of the basin filtering system with radioactivity. These routine transfers require that the waste system cells be kept relatively clean.

Table B.6-2 presents an estimate of the amount of radioactive contaminants on internal and external surfaces of process equipment and cell walls after shutdown of the WSP. Contamination of external surfaces in the WVC is expected to be primarily from the dusting that occurs during the operation of the calciner. This dust, smaller than 5 micrometers in mean particle size, will be mainly on external equipment surfaces. It is assumed that the bulk of liquid waste spills that occur during normal plant operation are flushed to the sump and recycled into solidified waste. The in-can melting and glass solidification (before disconnecting) leaves little opportunity for a major buildup of spilled glass. Levels in remaining cells are relatively low because of flushings during normal plant operation. A total of $0.32 \mathrm{~g}$ of plutonium is estimated to be in the WSP before chemical decontamination.

Table B.6-3 presents estimates of the amounts of radioactive contaminants in the WSP cells following chemical decontamination. Decontamination factors of 2 for concrete, 100 for stainless steel, and 1000 for equipment internals were used as for other process equipment. In cells with stainless steel liners, the flushes during plant shutdown are expected to remove much of the surface contamination. In the WVC, much of the contamination remaining in the cell after the plant shutdown flushes is expected to be in the brickwork of the calciner and the in-can melters. Chemical decontamination is expected to be ineffective in removing this material. Similarly, in the CDC, most of the easily removable contaminants will be removed by flushes before decommissioning gins. Following chemical decontamination, a total of $0.14 \mathrm{~g}$ of plutonium estimated to remain in the WSP cells. 
TABLE B.6-2. Estimated Inventory of Major Radionuclides in Cells of WSP After Shutdown

Radionuclides Inventory, $\mathrm{Ci}$

\begin{tabular}{|c|c|c|c|c|}
\hline $\begin{array}{c}\text { Waste } \\
\text { Vitrification } \\
\text { Cell }\end{array}$ & $\begin{array}{c}\text { Canister } \\
\text { Decontamination } \\
\text { Cell }\end{array}$ & $\begin{array}{l}\text { Hot } \\
\text { Pipe } \\
\text { Trench }\end{array}$ & $\begin{array}{l}\text { Hot } \\
\text { Maintenance } \\
\text { Area }\end{array}$ & $\begin{array}{c}\text { Off } \\
\text { Gas } \\
\text { Treatment Cell }\end{array}$ \\
\hline
\end{tabular}

Fission Products

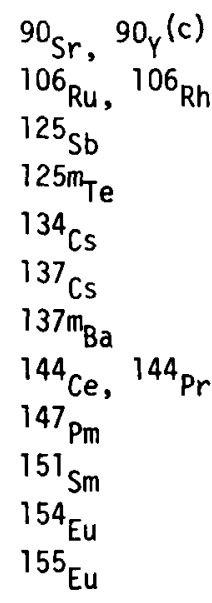

Total FP

Actinides

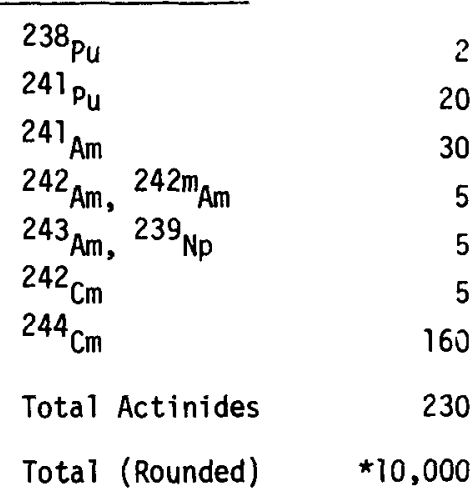

$\begin{array}{rrrr}80 & 110 & 4 & 20 \\ - & 3 & - & - \\ - & - & - & - \\ - & - & - & - \\ - & 5 & 3 & 15 \\ 60 & 85 & 3 & 15 \\ 60 & 80 & - & - \\ - & 2 & - & - \\ - & 7 & - & - \\ - & 1 & - & - \\ - & 4 & - & - \\ - & - & - & - \\ 200 & 297 & 10 & 50\end{array}$

50

(1)

3,400
300
25
20
350
2,600
2,400
250
270
35
140
10
9,800

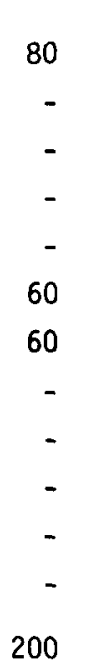

${ }^{\star} 1000 \mathrm{Ci}$ on walls and external surfaces of equipment $4000 \mathrm{Ci}$ on calciner-incanmelter equipment $4500 \mathrm{Ci}$ on equipment internals.

NOTES: a) Based on radioactivities at time of shutdown from Table B.4-1.

b) Isotopes listed represent $99 \%$ of the radioactivity at time of shutdown

c) When isotopes are grouped, radioactivities shown are total for group. 
Nuclide

\section{Fission Products}

$90_{\mathrm{Sr},} 90_{Y}(\mathrm{~b})$

${ }^{106} \mathrm{Ru},{ }^{106} \mathrm{Rh}$

$125 \mathrm{Sb}$

$125 \mathrm{~m} \mathrm{Te}$

${ }^{134} \mathrm{Cs}$

$137 \mathrm{Cs}$

$137 \mathrm{~m}_{\mathrm{Ba}}$

${ }^{144} \mathrm{Ce},{ }^{144} \mathrm{Pr}$

${ }^{147} \mathrm{Pm}$

$157 \mathrm{Sm}$

${ }^{154} \mathrm{Eu}$

${ }^{155} \mathrm{Eu}$

Total F.P.

\section{Actinides}

${ }^{238} \mathrm{Pu}$

$241 \mathrm{Pu}$

$241 \mathrm{Am}$

$242 \mathrm{Am}, 242 \mathrm{~m}_{\mathrm{Am}}$

$243 \mathrm{Am},{ }^{239} \mathrm{~Np}$

${ }^{242} \mathrm{~cm}$

${ }^{244} \mathrm{Cm}$

Total Actinides

Total (Rounded)

\begin{tabular}{ccccc}
\multicolumn{5}{c}{ Radioactivity Inventory, $\mathrm{Ci}^{(\mathrm{a})}$} \\
\hline Waste & Canister & Hot & Hot & Off \\
$\begin{array}{c}\text { Vitrification } \\
\text { Cell }\end{array}$ & $\begin{array}{c}\text { Decontamination } \\
\text { Cell }\end{array}$ & Pipe & Maintenance & Gas \\
& & Trench & Area & Treatment Cell \\
\hline
\end{tabular}

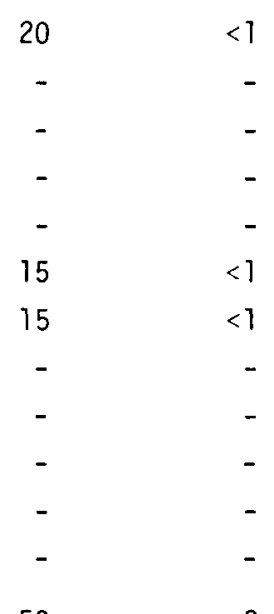

3,915

50

$<3$

$<1$

$<1$

NCTES: a) Based on radioactivities from Table B.4-2 and DF's of 2 for concrete and 100 for stainless steel.

b) When isotopes are grouped, radioactivities shown are total for the group.

c) $10 \mathrm{Ci}$ on cell walls and equipment, $4000 \mathrm{Ci}$ on calciner-incan melter external surfaces. 
0 


\section{REFERENCE SITE - DESCRIPTION AND CONTAMINATION LEVELS}

A reference environment was developed to aid in assessing the public safety and potential environmental effects of conceptually decommissioning an FRP by various alternative methods. Some of the information, namely the meteorology parameters and population distributions, were taken from Appendix I of the ALAP Study (1) for the river site expected for the year 2000. Expected radioactivity contamination levels at the time of plant shutdown are estimated. These were calculated assuming routine releases consistent with 10 CFR 50 Appendix I requirements for the assumed 30 years of plant production operations. The ecological information was derived from the environment of an operating nuclear reactor. (2) The remainder of the information was obtained from a variety of sources or it was developed specifically for this study. All of the information is representative of potential sites for fuel cycle facilities in the midwestern or south mideastern United States.

The animal species identified in the environs of this reference site may not be the same as those identified in site specific statements, however the impact on species including those identified as endangered is not considered to be so markedly different as to obviate the usefulness of this analysis.

Individual features of an actual site for a given nuclear facility may vary from those of the reference site. However, it is believed that this generic approach will result in a more meaningful overall analysis of potential impacts associated with most nuclear fuel cycle facilities. Site specific assessments would be required for individual facilities.

\section{1 SITE LOCATION}

The reference site is located in a rural area with characteristics similar to those found in midwestern or south mideastern United States. The site occupies 4.7 square kilometers ( 1160 acres) in a rectangular shape of 2 kilometers ( 1.24 miles) by 2.35 kilometers ( 1.46 miles). A moderately-sized river runs through one corner of the site. 


\section{C.2 DEMOGRAPHY}

The site is located in a rural area that has relatively low population density, with highest population densities occurring at distances of 16 to 64 kilometers ( 10 to 40 miles) away, and gradually reducing population densities out to 177 kilometers ( 110 miles). The population numbers are given in Table C.2-1. The total population out to 80 kilometers (50 miles) is 3.52 million.

TABLE C.2-1. Population Distribution Around the Reference Site

\begin{tabular}{|c|c|c|c|c|}
\hline$\frac{\text { Distance }}{\text { (miles) }}$ & $\frac{\text { from Facilities }}{\text { (kilometers) }}$ & $\begin{array}{c}\text { Population } \\
\text { Density } \\
\text { (persons/mi } /{ }^{2} \text { ) }\end{array}$ & $\begin{array}{l}\text { Total Population } \\
\text { in Annulus }(a)\end{array}$ & $\begin{array}{l}\text { Cumulative } \\
\text { Population }\end{array}$ \\
\hline $0-1$ & $0-1.6$ & --- & 10 & 10 \\
\hline $1-2$ & $1.6-3.2$ & 226 & $2,130^{(b)}$ & $2,140^{(b)}$ \\
\hline $2-3$ & $3.2-4.8$ & 333 & 5,230 & 7,370 \\
\hline $3-4$ & $4.8-6.4$ & 367 & 7,940 & 15,300 \\
\hline $4-5$ & $6.4-8.0$ & 415 & 11,700 & 27,000 \\
\hline $5-10$ & $8.0-16$ & 379 & 89,300 & 116,000 \\
\hline $10-20$ & $16-32$ & 398 & 375,000 & 491,000 \\
\hline $20-30$ & $32-48$ & 559 & 878,000 & $1,370,000$ \\
\hline $30-40$ & $48-64$ & 469 & $1,030,000$ & $2,400,000$ \\
\hline $40-50$ & $64-80$ & 398 & $1,120,000$ & $3,520,000$ \\
\hline
\end{tabular}

(a) It is assumed that $1 / 16$ of these persons reside within each of the 16 sectors.

(b) Totals are rounded to three significant figures

\section{C.3 LAND ISSE}

The use of any part of the total site area of 4.7 square kilometers (1160 acres) for anything other than for the fuel cycle facility is prohibited. The plant facilities are located inside a much smaller fenced-in 
Ortion ( 0.12 square kilometers, or 30 acres) of the site, with a minimum distance of one kilometer ( 0.6 miles) from the point of plant airborne releases to the outer site boundary (fenced and marked).

In most of the surrounding area about $80 \%$ of the land is used for farming. The main crops in this area, which include all land within 16 kilometers (10 miles) of the site, are soybeans (60\%), corn, oats, and other grain (30\%) and hay $(10 \%)$. It is expected that this area will remain largely agricultural and that the population will not change significantly.

A wildlife refuge is located about 14 to 20 kilometers (9 to 12 miles) from the site. A State Park is located about 10 kilometers ( 6 miles) in the opposite direction, and a State Forest and campground are about 14 kilometers (9 miles) away, near the wildlife refuge.

There are large truck gardens in the area. The nearest dwelling is a farm house located 1.3 kilometers $(0.8$ miles) from the site. A milk cow is kept at this farm and is maintained on fresh pasture 7 months of the year. A family garden is kept for vegetables with a growing season of 5 months. River water is used for irrigation of this farm.

\section{4 WATER USE}

Complete access to natural waterways (except to onsite shorelines) by the public is assumed. The river is used for dipersal of acceptable liquid effluents from the fuel cycle facility. The river is used for irrigation, fishing, boating and other aquatic recreational activities. Its shores are used for hunting and for marinas and docks. It is assumed that one-sixth of the average person's diet comes from food crops irrigated by the river water downstream of the site, and one-third of the maximum exposed individual's food intake is from the same source.

In the vicinity of the plant it is assumed that a limited number of individuals may spend $50 \mathrm{hr} / \mathrm{yr}$ swimming, $50 \mathrm{hr} / \mathrm{yr}$ boating, and may spend $70 \mathrm{hr} / \mathrm{yr}$ fishing on the shoreline obtaining $20 \mathrm{~kg}$ of fish. Essentially no fresh water molluscs or crustacea are taken from the river. Aquatic foods are assumed to be consumed within 24 hours of the time they are caught. 
Drinking water is taken from the river by larger towns and cities. viduals living immediately downstream near the river derive their potable water from wells and not directly from the river. For development of population radiation doses it is assumed that $20 \%$ of the residents within 80 kilometers (50 miles) of the site obtain their drinking water from the reference river. Travel time from the site to the urban water consumer is taken to be 48 hours. It is assumed that each person not in the vicinity of the plant will spend on the average $2 \mathrm{hr} / \mathrm{yr}$ swimming, $4 \mathrm{hr} / \mathrm{yr}$ boating, and $4 \mathrm{hr} / \mathrm{yr}$ on the shoreline downstream of the site. (3) The average per capita fish consumption for this area has been estimated to be $6.9 \mathrm{~kg} / \mathrm{yr} .{ }^{(4)}$ It is assumed that $15 \%$ of this consumption is from fish obtained downstream from the site.

The region has no large commercial fishing operations. Most of the fish catch is caught by local recreational anglers for home consumption.

\section{C.5 GEOLOGY}

The reference site occupies a low bluff that forms a bank of the river running through one corner. Several flat alluvial terraces comprise the main topographic features on the property. These terraces lie at average elevations of 280 to 284 meters (918 to 932 feet) above sea level and, in general, slope away from the river at grades of 2 to $3 \%$. The topography at the site is typical of that in the area and the region.

The rocks that underlie this region, including the reference site, are relatively old. Glaciation probably less than 1,000,000 years ago as well as recent alluvial deposition, has mantled the older rocks with a variety of unconsolidated materials in the form of glacial moraines, glacial outwash plains, glacial till and river bed sediments. This cover of young soils rests upon a surface of glacially carved bedrock consisting of sandstone, shale and granitic rocks. The upper surface of underlying rock can support unit foundation loads up to $73,200 \mathrm{~kg} / \mathrm{m}^{2}\left(15,000 \mathrm{lb} / \mathrm{ft}^{2}\right)$. The bedrock surface is irregular and slopes generally to the east or southeast.

The nearest known or inferred fault is 37 kilometers ( 23 miles) southeast of the site. There is no indication that faulting has affected the area of the site in the last few million years. Within the last 110 years, on 
two earthquakes were recorded as having occurred within 161 kilometers (100 miles) of the site. The first occurred in 1917 and had an intensity of 6 on the Modified Mercalli scale. The epicenter was located about 97 kilometers (60 miles) from the site. The second occurred in 1950 with an estimated intensity of 5 to 6 , and the epicenter was located about 130 kilometers ( 80 miles) from the site. For construction of facilities in this area, the Design Basis Earthquake relates to a horizontal acceleration of $0.25 \mathrm{~g}$.

\section{C.6 HYDROLOGY}

The site lies on the outwash plain of the river running across its corner. This plain is bounded by a glacial moraine containing numerous lakes and swampy areas. Drainage from the moraine converges with drainage from the terraces and swales, and flows generally southeast into the river. The river tributaries close to the site are a creek, 8 kilometers ( 5 miles) northwest, and another creek, 4.8 kilometers ( 3 miles) southeast. Another river flows approximately parallel to the plant site river along a line 6.4 kilometers (4 miles) north of the site, joining the plant-site river 24 kilometers ( 15 miles) downstream from the site.

The natural surface drainage of the immediate site area is mainly to the southwest, away from the river. Surface runoff tends to collect in the depression at the south end of the terrace, where it is bounded by higher ground.

Large supplies of groundwater are available from the plant site river outwash plain alluvium, glacial moraine, and from underlying sandstones in the area. The general course of deep groundwater flow is to the southeast. The regional gradient broadly parallels the trend of the topography and the surface drainage.

The groundwater levels near the site are relatively flat and slope toward the river during normal river stages. During periods of high river flow, there may be some reversal of groundwater flow. These reversals would be of short duration and infiltration of water from the river would be limited. The gradient toward the river is reestablished after the high water recedes. 
River flow information based on 40 years of data from the plant site river gaging station shows an annual average flow rate of $1420 \mathrm{~m}^{3} / \mathrm{sec}(50,000 \mathrm{cfs})$. River flow and temperature data pertinent to the reference site are shown in Figures C.6-1 and C.6-2, respectively.

The river is assumed to be reasonabiy free of pollution as shown in Table C.6-1. It is moderately turbulent during the spring. Little or no stratification of water occurs. There is no tidal influence.

The average river velocity at the site varies between 0.46 and $0.76 \mathrm{~m} / \mathrm{sec}$ $(1.5$ and $2.5 \mathrm{fps})$ for flows below $2000 \mathrm{~m}^{3} / \mathrm{sec}(72,000 \mathrm{cfs})$. The river drops about 3 meters $(10 \mathrm{ft}$ ) from 2.4 kilometers ( 1.5 miles) upstream to 2.4 kilometers ( 1.5 miles) downstream of the site. Rapids frequently occur in this stretch of the river.

The 1-in-1000-years flood would be expected to reach 280 meters (921 ft) MSL (mean sea leve1), and the maximum flow of record (1965) was estimated to have reached 279 meters $(916 \mathrm{ft}$ ) MSL. Normal river stage at the site is about 275 meters ( $905 \mathrm{ft}$ ) MSL, and the site grade is 287 meters ( $942 \mathrm{ft}$ ) MSL.

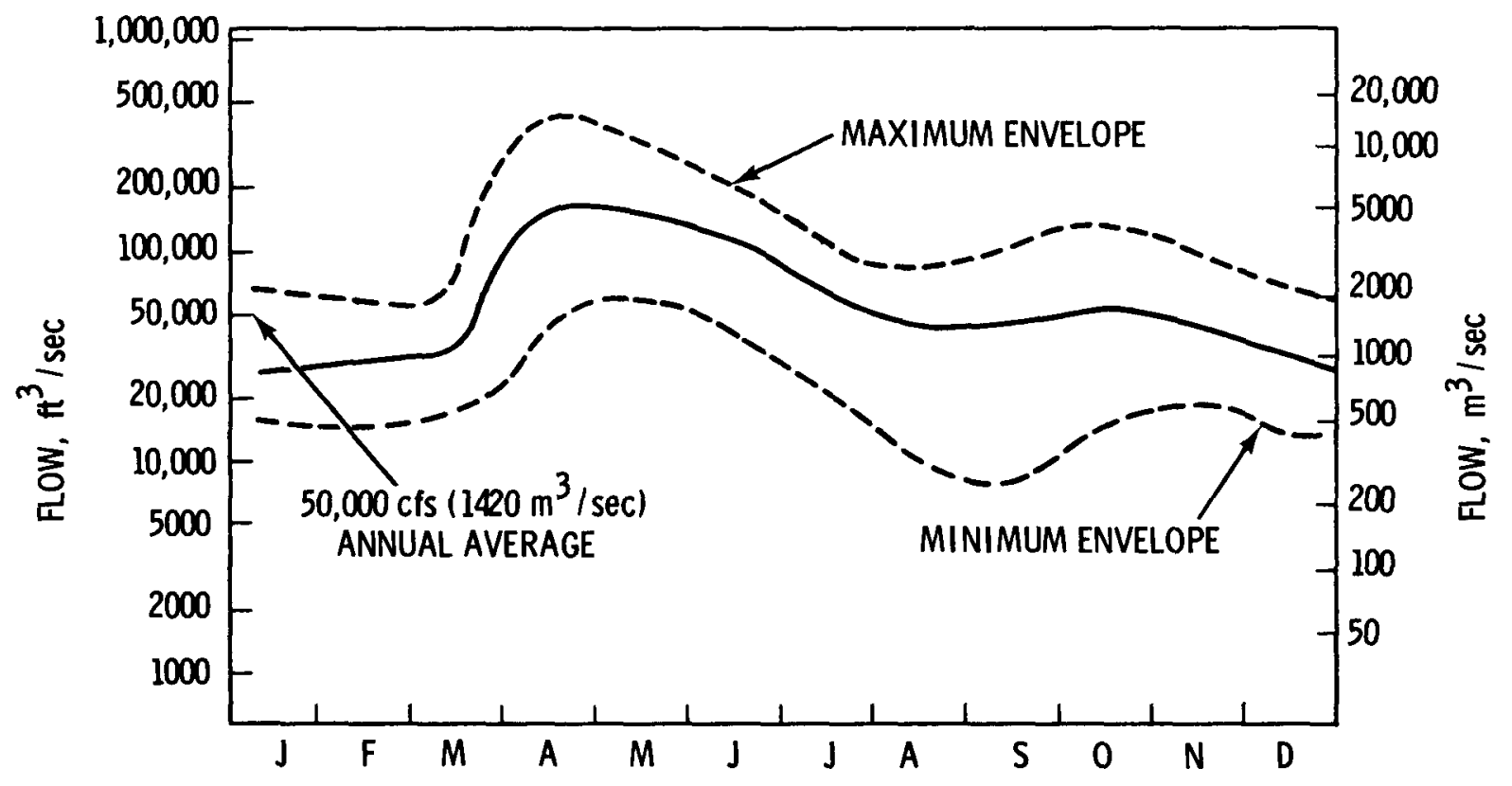

FIGURE C.6-1. Recorded Daily Average and Extreme River Flows at the Reference Site 
TABLE C.6-1. River water Chemistry at the Reference Site (Summary of 12 Monthly Samples)

\begin{tabular}{|c|c|c|c|c|c|}
\hline & Minimum & Maximum & Average & $\begin{array}{l}\text { Standard } \\
\text { Deviation }\end{array}$ & $\begin{array}{l}\text { Number of } \\
\text { Samples }\end{array}$ \\
\hline \multicolumn{6}{|l|}{ Solids (mg/1) } \\
\hline Total & 143 & 216 & 185 & 23.2 & 1212 \\
\hline Dissolved & 125 & 208 & 178 & 27.8 & 12 \\
\hline Suspended & 1.2 & 18.4 & 7.5 & 6.2 & 12 \\
\hline \multicolumn{6}{|l|}{ Hardness (mg/1) } \\
\hline \multicolumn{6}{|l|}{$\left(\right.$ as $\left.\mathrm{CaCO}_{3}\right)$} \\
\hline Total & 98 & 174 & 147 & 24.8 & 12 \\
\hline Calcium & 70 & 120 & 99 & 15.6 & 12 \\
\hline Magnesium & 28 & 58 & 48 & 9.9 & 12 \\
\hline \multicolumn{6}{|l|}{ Alkalinity (ing/1) } \\
\hline \multicolumn{6}{|l|}{$\left(\right.$ as $\left.\mathrm{CaCO}_{2}\right)$} \\
\hline Total & 91 & 165 & 140 & 24.3 & 12 \\
\hline Phenolphthalein & 0 & 12 & 1.8 & 4.1 & 12 \\
\hline \multicolumn{6}{|l|}{ Gases (mg/1) } \\
\hline Free Carbon Dioxide & -- & -- & -- & -- & -- \\
\hline Ammonia-Nitrogen (N) & 0 & 0.09 & 0.02 & 0.03 & 12 \\
\hline \multicolumn{6}{|l|}{ Anions (mg/1) } \\
\hline Carbonate $\left(\mathrm{CO}_{3}^{-2}\right)$ & 0 & 14.4 & 2.10 & 4.96 & 12 \\
\hline Bicarbonate $\left(\mathrm{HCO}_{3}^{-}\right)$ & 111 & 201 & 166 & 29.1 & 12 \\
\hline Hydroxide $(\mathrm{OH}-)$ & -- & -- & -- & -- & -- \\
\hline Chloride $\left(\mathrm{Cl}^{-}\right)$ & 0.30 & 5 & 1.43 & 1.48 & 12 \\
\hline Nitrate-Nitrogen $\left(\mathrm{NO}_{3}^{-}\right)$ & 0.07 & 0.55 & 0.26 & 0.15 & 12 \\
\hline Sulfate $\left(\mathrm{SO}_{4}^{-2}\right)$ & 6.3 & 13.5 & 9.5 & 2.2 & 12 \\
\hline $\begin{array}{l}\text { Phosphorus- } \\
\text { Soluble }\left(\mathrm{PO}_{4}^{-3}\right)\end{array}$ & 0.012 & 0.057 & 0.030 & 0.012 & 12 \\
\hline Silicate $\left(\mathrm{SiO}_{3}^{-2}\right)$ & 3.2 & 12.5 & 7.7 & 3.3 & 12 \\
\hline \multicolumn{6}{|l|}{ Cations $(\mathrm{mg} / 1)$} \\
\hline Calcium $\left(\mathrm{Ca}^{+2}\right)$ & 28 & 48.1 & 39.7 & 6.28 & 12 \\
\hline Magnes ium $\left(\mathrm{Mg}^{+2}\right)$ & 6.8 & 14.1 & 11.6 & 2.4 & 12 \\
\hline Sodium $\left(\mathrm{Na}^{+2}\right)$ & 2.8 & 6.4 & 5.0 & 1.1 & 12 \\
\hline Total Iron $\left(\mathrm{Fe}^{+2}\right)$ & 0.04 & 0.52 & 0.23 & 0.13 & 12 \\
\hline Total Manganese $\left(\mathrm{Mn}^{+2}\right)$ & -- & -- & -- & -- & -- \\
\hline Potassium $\left(k^{+1}\right)$ & -- & -- & -- & -- & -- \\
\hline \multicolumn{6}{|l|}{ Miscellaneous } \\
\hline Color (APHA units) & 20 & 80 & 39 & 22 & 12 \\
\hline Turbidity (JTU) & 1 & 4.5 & 2.53 & 1.48 & 12 \\
\hline Ryznar Index (AT 25 C) & 6.64 & 7.86 & 7.21 & 0.377 & 12 \\
\hline Conductivity (mmhos) & 192 & 350 & 292 & 49.8 & 12 \\
\hline $\mathrm{pH}$ & 7.4 & 8.6 & 8.15 & 0.308 & 12 \\
\hline$B O D(m g / l)$ & 0.9 & 2.5 & 14 & 0.58 & 12 \\
\hline Dissolved Oxygen $(\mathrm{mg} / \mathrm{l})$ & 8 & 15 & 10.6 & 2.1 & 11 \\
\hline Temperature $\left({ }^{\circ} \mathrm{C}\right)$ & 0.5 & 30 & 9.69 & 9.03 & 12 \\
\hline
\end{tabular}




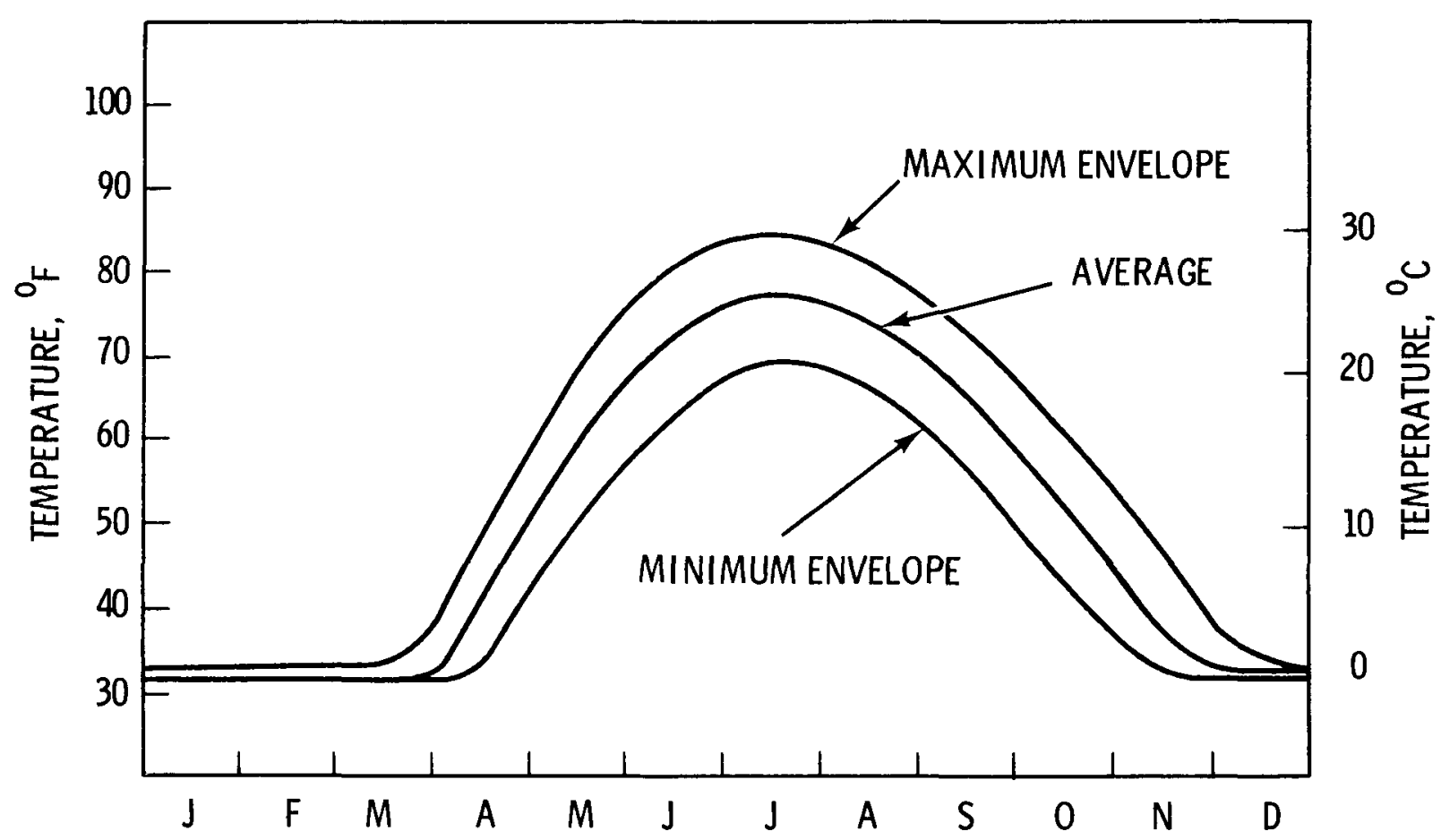

FIGURE C.6-2. Daily Average and Extreme Water Temperatures at the Reference Site

A study was conducted to determine the predicted flood discharge flow and water level at the site resulting from the "maximum probable flood" as defined by the U.S. Army Corps of Engineers. The "maximum probable flood" was estimated to reach a peak stage elevation of 286 meters (939 ft) MSL at the reference site. The peak level at the site would be reached in about 12 days from the onset of the worst combination of conditions resulting in the "maximum probable flood."

The nearest domestic water supply reservoir is fed by the river from an intake about 60 kilometers ( 37 miles) downstream. Under emergency conditions, withdrawal of river water could be suspended for about 48 hours without curtailment of nonessential use. With curtailment of nonessential use, this period could be extended to about 100 hours.

The groundwater table under normal conditions is higher than the river; thus, groundwater and runoff drain to the river. There are numerous shallow 
public wells, 23 to 46 meters ( 75 to $150 \mathrm{ft}$ ) deep, supplying residences and farms along the river terrace. The closest public water supply well is a small city well obtaining water 72 meters $(237 \mathrm{ft}$ ) below ground level, about 4.8 kilometers ( 3 miles) downstream.

The amount and rate of dispersion of effluent materials discharged into a river depend on the flow rate, geometry, bottom roughness, and density gradients. As a result, no single dilution-distance relationship exists that will account for all the possible variations.

The point-source dilution curve initially is inversely proportional to distance and then, after vertical mixing has occurred, the dilution is inversely proportional to the square root of the distance until the limiting effect of the near-side boundary becomes important at about 1,000 meters ( 0.6 miles). The fully mixed situation occurs at a distance of about 50,000 meters ( 30 miles).

Values indicated in Figure C.6-3 are assumed for evaluations of the reference river site in this study, using the case for one nuclear reactor. Adjustments can be made directly to these graphs for other liquid effluent flow rates.

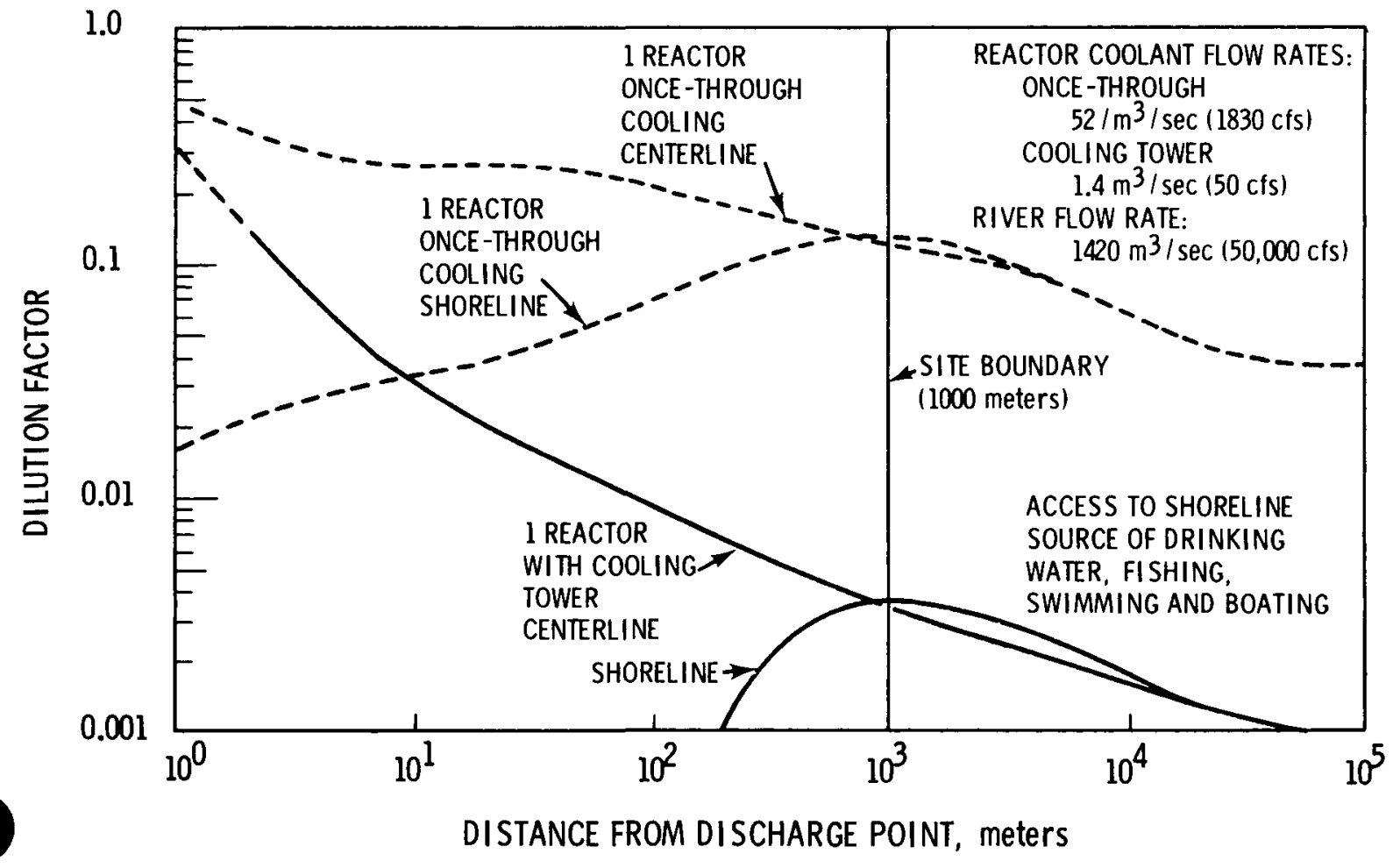

FIGURE C.6-3. Liquid Effluents Dilution for the Reference River 
The estimates to be developed for the concentration of radionuclides in the water downstream of the liquid effluent discharge point in a river are based on the analytical model given in WASH-1258. (1)

\section{C.7 METEOROLOGY}

The site has a typical continental climate. It is characterized by wide variations in temperature, modest winter precipitation, normally ample spring and summer rainfall, and a general tendency to extremes in all climatic features. January is the coldest month and July is the warmest month. Table C.7-1 shows monthly temperature statistics.

\section{IABLE C.7-1. Monthiy Air Temperature Statistics $\left({ }^{\circ} \mathrm{C}\right)$ at the Reference Site}

\begin{tabular}{|c|c|c|c|c|c|c|c|c|c|c|c|c|}
\hline & Jan & $\mathrm{Feb}$ & Mlar & Apr & May & Jun & $\underline{\text { Jul }}$ & Aug & Sep & Oct & Nov & Dec \\
\hline Maximum & -6.1 & -4.4 & 3.3 & 12.8 & 20 & 25 & 28.3 & 26.7 & 22.2 & 15 & 4.4 & -3.3 \\
\hline Minimum & -16.1 & -14.4 & -6.7 & 1.7 & 7.8 & 13.3 & 16.1 & 15 & 10 & 3.9 & -4.4 & -12.2 \\
\hline Mean & -11.1 & -9.4 & -1.7 & 7.2 & 13.9 & 18.9 & 22.2 & 21.1 & 16.1 & 9.4 & 0.0 & -7.8 \\
\hline Extreme Maximum & 15 & 16.1 & 27.8 & 32.8 & 40.6 & 39.4 & 41.7 & 40 & 40.6 & 32.2 & 23.9 & 17.2 \\
\hline Extreme Minimum & -38.9 & -36.7 & -34.4 & -15.6 & -6.7 & 0.6 & 5.6 & 3.3 & -5.6 & -13.3 & -27.8 & -33.9 \\
\hline
\end{tabular}

The number of days with maximum temperatures of $32^{\circ} \mathrm{C}\left(90^{\circ} \mathrm{F}\right)$ and above is estimated to be 12. The number of days with a minimum temperature of $0^{\circ} \mathrm{C}$ $\left(32^{\circ} \mathrm{F}\right)$ or below and $-18^{\circ} \mathrm{C}\left(0^{\circ} \mathrm{F}\right)$ or below is estimated to be 168 and 40 , respectively. The January relative humidities at 7:00 a.m., 1:00 p.m., and 7:00 p.m. are estimated to be 76,68 , and $70 \%$, respectively. The corresponding humidities for July are 86,55 , and $55 \%$. Monthly average humidities are shown in Table C.7-2.

TABLE C.7-2. Mean Monthly Relative Humidity (\%) at the Reference Si.te $\begin{array}{llllllllllll}\text { Jan } & \frac{\text { Feb }}{74} & \frac{\text { Mar }}{75} & \frac{\text { Apr }}{73} & \frac{\text { May }}{66} & \frac{\text { Jun }}{62} & \frac{\text { Jul }}{66} & \frac{\text { Aug }}{68} & \frac{\text { Sep }}{70} & \frac{\text { Oct }}{70} & \frac{\text { Nov }}{66} & \frac{\text { Dec }}{73} \\ 78\end{array}$

The months of May through September have the greatest amounts of precipitation, with an average rainfail during this period of 432 to $457 \mathrm{~mm}$ ( 17 to 18 $70 \%$ of the $610-\mathrm{mm}(24-\mathrm{in}$.$) annual rainfa11. The maximum 24-\mathrm{hr}$ total rainfall 
for the period 1894 through 1965 was $127 \mathrm{~mm}$ (5 in.) and occurred in May. Thunderstorms have an annual frequency of 36 and are the chief source of rain from May through September. Snowfall in the area averages $1070 \mathrm{~mm}$ (42 in.) annually, with occurrences recorded in all months except June, July and August. The extremes in annual snowfall of record are $152 \mathrm{~mm}$ ( 6 in.) minimum and $2235 \mathrm{~mm}$ (88 in.) maximum.

Annually, the winds are predominantly bimodal. This bimodal distribution is characteristic of the seasonal wind distributions as well. The average wind speed for spring is $11 \mathrm{~km} / \mathrm{hr}$ (7 mph) and for the other seasons is about $16 \mathrm{~km} / \mathrm{hr}(10 \mathrm{mph})$. The maximum reported wind speed of $148 \mathrm{~km} / \mathrm{hr}$ (92 mph) was associated with a tornado. Tornadoes and other severe storms occur occasionally. Eight tornadoes were reported from 1916 through 1967 in the county where the site is located. The probability of a tornado striking a given point in this area is about $5 \times 10^{-4}$ per year. For design purposes a wind velocity of $480 \mathrm{~km} / \mathrm{hr}$ ( $300 \mathrm{mph}$ ) is assumed to be associated with tornadoes.

It is estimated that natural fog restricting visibility to 0.4 kilometer $(0.25 \mathrm{mile})$ or less occurs about $30 \mathrm{hr} / \mathrm{yr}$. Icing due to freezing rain can occur between October and April, with an average of one to two storms per year. The mean duration of icing on utility lines is $36 \mathrm{hr}$.

Diffusion climatology comparisons with other locations indicate that the site is typical of the region, with relatively favorable atmospheric dilution conditions prevailing. Frequency of thermal inversion is expected to be about $32 \%$ of the year, and the frequency of thermal stabilities is $19 \%$ slightly stable, $27 \%$ stable, $20 \%$ neutral, and $34 \%$ unstable.

Data from a number of river sites used for nuclear reactors were used to calculate the "typical" annual atmospheric dispersion pattern in an average 22-1/2-degree sector from the site. Disperson factors at selected distances for the average sector were determined from joint-frequency distributions for each site. This was done by calculating the disperson factor, $\bar{\chi} / Q^{\prime}$ for each sector at selected downwind distances and then calculating the average dispersion factor at each distance. In other words, the dispersion factors in those sectors corresponding to overland trajectories were added without regard 
to direction and divided by the number of sectors involved. For river sites all sixteen sectors were used. Thus, an average dispersion factor was obtained for each selected downwind distance for all sixteen sectors.

Standard groups of meteorological data were interpolated from the specific site data. This grouping provided four stability classes based on vertical temperature gradient and five wind speed classes based on the Beaufort wind scale. Vertical temperature gradient classes were based on Regulatory Guide 1.23 (Safety Guide 23); Pasquil1 classes A, B, and C were classified as $B$ (unstable), Pasquill classes $D$ (neutral) and $E$ (slightly stable) were not reclassified, and Pasquill classes $F$ and $G$ were classified as $F$ (moderately stable).

Wind speed data were frequently available at only one height. In this event, the measured values were extrapolated to the 10-m level for building and vent release calculations and to the 100-m level for stack release calculations. Where measurements at two heights were available, the highest was extrapolated to $100 \mathrm{~m}$ and the lowest to $10 \mathrm{~m}$ using a standard power law extrapolation procedure.

Calculations were made for a number of specific sites to yield average air concentrations and average radiation doses versus distance from the release point, i.e., the values represent the average over all of the wind directions that carry the airborne effluents over land. As previously stated, average sector values were used for this study.

Data on the maximum sector and the average of all 16 sectors were avai1able for sixteen sites. (1) These data were used to determine the ratio of the minimum effective dilution (maximum dispersion factor) to the mean sector value, and are applied to the present study.

The value obtained for the ratio of dispersion factor in the maximum sector to the average sector dispersion factor was 2.5, and this value was used for all release heights in this study. Investigation of changes in this ratio with distance from the site determined that it remained essentially constant with distance from the point of release. The dispersion factors for the average sector as a function of height of release and downwind distance are shown in Figure C.7-1. 


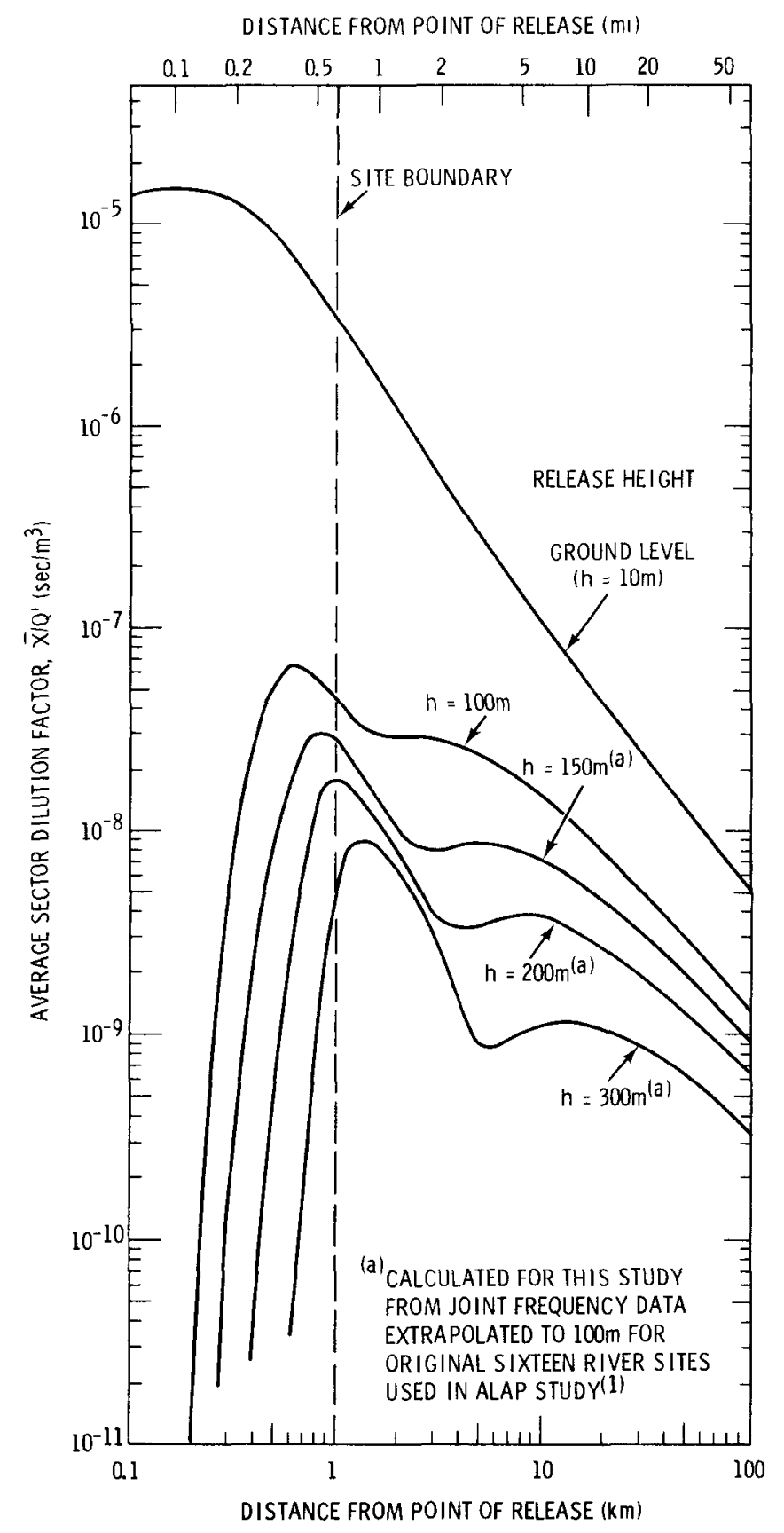

FIGURE C.7-1. Average $\left(\bar{X} / Q^{\prime}\right)$ Values Versus Distance in a Sector from the Reference River Site 
To assess the effect of increased stack height, atmospheric dispersion factors for stack heights of 150,200 and $300 \mathrm{~m}(400,660$, and $980 \mathrm{ft})$ were estimated from the original joint frequency distributions of the 16 reactor sites. These values are also presented in Figure C.7-1.

Where large volumes of heated air are being ejected, the plume rise constant for momentum is estimated to be about $50 \mathrm{~m}^{2} / \mathrm{sec}\left(540 \mathrm{ft}^{2} / \mathrm{sec}\right)$. Assuming an annual average wind speed of 2 to $3 \mathrm{~m} / \mathrm{sec},(4.5$ to $6.7 \mathrm{mph})$ the increase in effective stack height due to momentum would be 20 to 25 meters (66 to $82 \mathrm{ft}$ ). Plume rise due to buoyancy (heat effect) would add at least another 25 to 100 meters ( 82 to $330 \mathrm{ft}$ ) of effective stack height, depending upon the temperature of the exhaust gases. Thus, the $\bar{X} / Q^{\prime}$ values illustrated in Figure $c .7-1$ are larger than they would be if credit had been taken for buoyancy and momentum.

\section{C.8 ECOLOGY}

The description of the ecology at the site is divided into terrestrial and aquatic ecology. These are discussed below under separate subsections.

\section{C.8.1 Terrestrial Ecology}

Less than $20 \%$ of the land within 40 kilometers ( 25 miles) of the plant site is covered with pristine vegetation.

Vegetation in the area was originally identified as supporting a climax deciduous forest. Remnants of the native climax hardwood forest are found on the larger islands, with some lesser stands in isolated pockets along the river bank. Nearly all accessible virgin woodland areas in the region have been burned, cut and plowed. Trees and shrub cover remain stable from year to year except for disturbances from cattle grazing or browsing, clearing, and cutting. Because annual grasses and forbs originate each year from seed, their abundance shows pronounced fluctuation from seasonal and annual changes in environmental conditions, such as rainfall.

The area bordering the river in the vicinity of the plant consists predominantly of a willow-scrub thicket interspaced with cottonwood and poplar, whereas the areas adjacent to the border are largely agricultural crop and grazing land. Many of the terrestrial animals occur in vegetative cover bordering the river, and periodically forage in the adjacent agriculture areas. 
ome areas near the river are inundated by water from small swamps or marshes characterized by cattails (Typhus sp.) and other forms of marsh vegetation.

The shoreline and islands in this reach of the river are heavily utilized by waterfowl and shorebirds. Most waterfowl and shorebirds are migratory, and are present only seasonally, primarily during the summer and fall. The mallard and blue-winged teal are common spring breeders and summer residents. Common marsh birds are the red-winged blackbird, marsh wren, and great-blue heron. A variety of upland game birds and nongame birds utilize riparian habitats for nesting and feeding, as well as for protection from predators and adverse weather.

Bird hunting is mainly directed at waterfowl, both jump shooting and hunting from blinds. This portion of the river is not a preferred hunting area, nor is it used significantly as a resting area for migrating water-fowl. Ruffed grouse are occasionally hunted, but there is little hunting for other birds.

A list of wildlife considered to be rare, endangered, or threatened within the study state is shown in Table C.8-1. The southern bald eagle nests along the Atlantic and Gulf Coasts but moves northward after the nesting season and is occasionally sighted in the study area. The Arctic peregrine falcon nests in the treeless tundra and migrates southward through the midwestern states to the Gulf Coast and South America. The prairie falcon, which nests in other areas, is occasionally sighted in the area. The northern greater prairie chicken is also present at the reference site.

TABLE C.8-1. Wildlife Considered to be Rare, Endangered, or Threatened Within the Reference Site $(6)$

Birds

Southern bald eagle

Arctic peregrine falcon

Prairie falcon

Northern greater prairie chicken 
Some important mammals in the area are listed in Table C.8-2. Squirrel is the principal animal hunted in the area. A one-day season for hunting deer with a gun and a prolonged season for bow and arrow hunting suggest a limited deer population. There is also some hunting of fox and raccoon.

\section{TABLE C.8-2. Some Important Mammals That Are Found Near the Reference Site}

$\begin{array}{lll}\text { Badger } & \text { Gray Squirrel } & \text { Raccoon } \\ \text { Bats } & \text { Ground Squirrels } & \text { Red Fox } \\ \text { Beaver } & \text { Harvest Mouse } & \text { Red Squirrel } \\ \text { Bobcat } & \text { Jumping Mice } & \text { Shrews } \\ \text { Chipmunks } & \text { Mink } & \text { Skunk } \\ \text { Cottontail Rabbit } & \text { Moles } & \text { Voles } \\ \text { Coyote } & \text { Muskrat } & \text { Weasels } \\ \text { Deer Mouse } & \text { Opossum } & \text { Whitetail Deer } \\ \text { Fox Squirrel } & \text { Pocket Gopher } & \text { Whitetail Jackrabbits }\end{array}$

Some important fur bearing animals include raccoon, mink, muskrat, beaver, and fox. Other wide-ranging fur-bearing mammals will probably occur in the vicinity from time to time; especially the coyote, bobcat and possibly the river otter.

Broad-leaved trees characteristic of the study area include oak, elm, basswood, maple and hackberry. These species occur abundantly on the larger islands, with lesser stands in isolated pockets along the river banks. The climax community was probably comprised of maple and basswood. Farming, grazing and logging activities, however, have caused considerable change from the climax vegetation. Most areas that would be in active use at the reference site (e.g., buildings, parking lot) occupy land formerly cultivated. The portion of the site on the far side of the river is in various stages of recovery from weedy species. There is no evidence of the existence of rare or endangered vegetation species at the reference site. 
The soil in the area is thin and varies from sand to silty loam, with an underlay of glacial till. The water table in lower areas is close to the surface, and during river flood these areas are frequently inundated.

The numerous ponds, lakes and swampy areas bounding the site provide nesting areas for waterfowl. Most nest fairly close to water.

\section{C.8.2 Aquatic Ecology}

The shoreline near the site consists of a sand and gravel base that merges with soil and riparian vegetation near the high water line.

The smallest organisms of concern in the river near the proposed site are planktonic forms. The plankton consists of both the photosynthetic phytoplankton and nonphotosynthetic zooplankton. The phytoplankton form the first major link in the aquatic food chain. At the site, phytoplankton originate largely from upstream areas, including impoundments, with some contribution from the periphyton in the immediate area. Diatoms are the principal form of phytoplankton.

The abundance of diatom populations varies in an annual cycle, with the greatest density occurring in late spring and the lowest density in midwinter. Phytoplankton production is influenced by seasonal changes in light intensity, water temperature, and quantities of dissolved nutrients.

The abundance of zooplankton populations also varies in an annual cycle with the greatest density occurring during the summer and fall. The primary habitat of these forms is in the quiet and protected parts of the river. Zooplankton consume primarily phytoplankton and both forms of plankton are utilized as food by certain larger invertebrates and fish.

Diatoms and filamentous green algae dominate the periphyton, or algae communities attached to submerged substrates in the river. The periphyton population appears to be maintained in a subclimax condition, that is, typically in a viable state of recolonization and growth because of erosion by current flows and grazing by aquatic fauna. Seasonal productivity of periphyton corresponds to the annual cycle of phytoplankton growth, being highest in late spring and lowest in midwinter, and is also influenced by light, water emperature, and quantities of dissolved nutrients. Periods of high river 
turbidity and flow have a pronounced impact on periphyton growth, primarily because of siltation and scouring by high velocity currents. Benthic organisms in the river near the site include larvae of aquatic insects, molluscs, and crustacea as the most important producers and consumers. Chironomoids (Diptera, Chironomidae), caddisflies, and mayflies are the dominant insects. Molluscs and crustacea are present.

The density of the benthos varies with substrate type, which in turn is influenced by current flow. Populations include organisms characteristic of the clean, stone riffle areas and others characteristics of sand and silt areas. Generally, the density of the benthos is lower in deep water than in shallow water. Benthic organisms form secondary or intermediate links in the food chain leading to the production of more valuable forms. Aquatic insects are the major food items in the diet of many river fish, and insect larvae are the dominant components of the river drift.

Rooted macrophytes occur in certain areas along the margin of the river. Most of these are emergents such as Thpha and Juncus but some are floating plants such as Potamogeton and Lemna, while a few are submerged plants such as Anarcharis and Ceratophyllum. Biomass of macrophytes varies seasonally, with the greatest concentrations occurring during the summer and fall and the smallest concentrations during the winter. Macrophytes provide food for waterfowl and riparian mammals, shelter for small fish, hiding areas for large fish, and production areas for many microscopic river invertebrates.

Fish form the upper trophic level of aquatic organisms near the proposed site. There are several species of fish known to be present. No significant commercial fishery exists. Sport fishing intensity is greatest in the spring and fall. Most fish spawn in the spring and early summer. Suckers and others have short upriver spawning migrations. Andromous species are present.

None of the fish present is considered to be a rare or endangered species. Sewage wastes released upriver have been subjected to primary and secondary treatment and do not contribute a large amount of pollution in the river. However, the water may contain higher than normal amounts of phosphates and nitrates following periods of high rains due to the influx of agricultural fertilizers. Insecticides from crop spraying are known to be present occasionally in the water at the site, although fish kills from toxic chemicals have yet to be recorded. 


\section{C.9 RADIOLOGICAL CHARACTERISTICS}

In order to make a decision of alternative uses for a site, information is needed on the levels and nature of the radioactive contamination present at the time of decommissioning. This section discusses the potential site radioactive contamination, its origin and expected levels at the time of shutdown of an operating FRP.

Naturaliy occurring radionuclides and radionuclides expected from nuclear weapons testing will be present on any nuclear facility site consistent with the level generally found in the local region. A short discussion on the magnitude of these two sources of radiation is provided for perspective. The following information on these two sources is a distillation of a detailed treatise on the subject found in the UNSCEAR report. (7)

\section{C.9.1 Natural Occurring Radiation}

Natural occurring radiation results from both extraterrestrial and terrestrial sources. Extraterrestrial radiation originates in outer space as cosmic radiation that interacts with particles in the upper atmosphere, emitting radiation to which people on the surface of the earth are exposed. A typical value from this source at sea level is on the order of $30 \mathrm{mrem} / \mathrm{yr}$. The dose rate from this source increases with altitude, being about $120 \mathrm{mrem} / \mathrm{yr}$ in Colorado. (8)

Terrestrial radiation is emitted from radionuclides naturally occurring in varying amounts in soil, rock, the atmosphere and the hydrosphere. This radiation contributes to external exposure and the radionuclides often expose people via food chains and inhalation. Terrestrial radioactivity leads to an internal dose rate of about $20 \mathrm{mrem} /$ year (mostly from ${ }^{40} \mathrm{~K}$ ) and an external dose rate of about $50 \mathrm{mrem} /$ year.

The naturally occurring radionuclides may be classified into two categories: (1) those that are continually produced by the interactions of cosmic rays with matter and (2) those that were originaliy present at the formation of the earth and/or their daughter products (called primordial radionuclides).

\section{C.9.1.1 Cosmic Producted Radionuclides}

A total of twenty radionuclides produced by cosmic rays in the earth's atmosphere have been detected. From the view point of radiation dose only 
${ }^{14} \mathrm{C}$, and, to a lesser extent, ${ }^{3} \mathrm{H}$ (tritium) are of any significance. Tritium occurs naturally in surface waters of the world. Prior to its injection into the biosphere from nuclear tests, levels of $3_{\mathrm{H}}$ in water were approximately $15 \mathrm{pCi} / \mathrm{l}$. Atmospheric testing of nuclear weapons may increase this concentration by as much as a factor of 500 in some regions. Carbon-14 is present in atmospheric carbon dioxide, in the terrestrial biosphere, and in bicarbonates dissolved in sea water.

\section{C.9.1.2 Primordial Radionuclides}

The primordial radionuclides can be divided into those that decay directly to a stable (nonradioactive) nuclide, and those belonging to one of three radioactive decay series headed by ${ }^{238} \mathrm{U},{ }^{235} \mathrm{U}$, or ${ }^{232} \mathrm{Th}$.

Uranium and thorium are widely distributed throughout the earth's crust at about the same radioactivity concentration. Uranium and thorium generally enter the biosphere through soil into plants, and then in herbivorous animals and people. In both series headed by these radionuclides, radon, a gas, escapes to a certain extent from the soil into the atmosphere and decays into particulate solid nuclides that are important contributors to the radioactivity in the environment.

The ${ }^{232}$ Th series is constituted of different isotopes of the same elements of the ${ }^{238} \mathrm{U}$ series, and therefore reacts in the same manner in the environment. Because the ${ }^{235} \mathrm{U} /{ }^{238} \mathrm{U}$ radioactivity ratio in nature is less than 0.05 , the ${ }^{235} \mathrm{U}$ series is much less important than either ${ }^{232}$ Th or ${ }^{238} \mathrm{U}$.

The typical content of uranium-238 in the accessible lithosphere is 2.8 parts per million (ppm). Minute quantities are also found in the atmosphere. In a city, the air concentrations range from 10 to $1,500 \mathrm{pg} / \mathrm{m}^{3}$. Sea water has a relatively uniform ${ }^{238} \mathrm{U}$ concentration of 2 to $3.7 \mu \mathrm{g} / \ell$, but fresh water concentrations vary widely from 0.024 to $200 \mu \mathrm{g} / \mathrm{l}$.

Because, on the average, ${ }^{232} \mathrm{Th}$ and ${ }^{238} \mathrm{U}$ have about the same radioactivity concentration, the daughters ${ }^{226} \mathrm{Ra}$ and ${ }^{228} \mathrm{Ra}$ will also have about the same concentration in soil. In air, particulate radium picked up from the soil has a concentration of about $7 \mathrm{pCi} / \mathrm{l}$. The concentration of radium in sea water is uniform at about $0.05 \mathrm{pCi} / \ell$, but the concentration in fresh water varies from 0.01 to $1 \mathrm{pCi} / \mathrm{l}$. 
Gaseous ${ }^{222} \mathrm{Rn}$ and ${ }^{220} \mathrm{Rn}$ and their short-lived decay products constitute the main part of the radioactivity in air at ground-level. Under normal conditions, the ${ }^{220} \mathrm{Rn}$ and ${ }^{222} \mathrm{Rn}$ concentrations at one meter above the ground range between 0.04 and $0.4 \mathrm{pCi} / 1$ iter. Radon-222 levels in surface waters are typically about $10 \mathrm{pCi} / \mathrm{liter}$. A few thousand picocuries per liter seems to be a typical radioactivity concentration for ${ }^{222} \mathrm{Rn}$ in ground water.

A key nonseries radionuclide of significance is ${ }^{40} \mathrm{~K}$. The radioactivity of $40 \mathrm{~K}$ in soil is, on the average, an order of magnitude higher than that of ${ }^{238} \mathrm{U}$ and ${ }^{232} \mathrm{Th}$. In seawater, ${ }^{40} K$ constitutes the bulk of the radioactivity with a concentration of about $300 \mathrm{pCi} / \mathrm{l}$. (7) Potassium-40 is the main naturally occurring source of internal radiation exposure. Carbon-14 is present in seawater at an average concentration of $0.13 \mathrm{pCi} / \mathrm{l}$. (9)

\section{C.9.2 Radionuclides from Nuclear Weapons Testing}

The primary radionuclides deposited on the earth from global fallout from nuclear weapons testing are ${ }^{3} \mathrm{H},{ }^{14} \mathrm{C},{ }^{60} \mathrm{Co},{ }^{90} \mathrm{Sr},{ }^{137} \mathrm{Cs},{ }^{129} \mathrm{I},{ }^{131_{\mathrm{I}}}$ and plutonium isotopes. Radiation from deposited ${ }^{137} \mathrm{Cs}$ is the main contributor to external dose from radioactive fallout. Contamination levels for these radionuclides vary markedly from region to region and as a function of time. Surface air concentrations and ground contamination are more prominent following periods of atmospheric nuclear testing. Currently, the levels due to fallout are nominal and constant.

\section{C.9.3 Radionuclides from Plant Operation}

Radioactive contamination is expected to be present on the site as a result of effluents released during normal operations over the anticipated plant life of 30 years.

Accidental releases during plant operation are not expected to significantly increase these levels because it is assumed that normal operating practice is to clean up contaminated areas immediately following such events. Estimates of the ground contamination levels were based on the predicted normal operating releases of gaseous effluents for the base case in the ORNL 
ALAP Study $(10)(a)$ for nuclear reprocessing plants and the $\mathrm{UO}_{2}$ fuel cycle case in GESMO (11) (normalized to a 1500 MT/ year plant).

The annual radioactive airborne release rates from the reference FRP assumed in the study are shown in Table C.9-1. Ground deposition from continuous releases from the $100-\mathrm{m}$ stack were estimated using the site meteorological characteristics and standard atmospheric calculation methods. Radioactive decay of the released material was accounted for over the duration of release and following deposition.

The concentration of deposited radionuclides was estimated using an NRC computer model. (12) Constant annual releases were assumed over the 30-year plant life. The effective release height was assumed to be 100 meters (330 ft) with no credit taken for additional plume rise due to either buoyancy or momentum. Meteorological data on joint frequency of wind speed and wind direction by atmospheric stability was from the Barnwel1 Environmental Report. (13) Deposition values reported are representative of the plant area (area within a radius of 1000 meters from the point of release). Offsite contamination levels would be generally lower.

The procedure used to estimate relative deposition rates in the NRC model was based on numerical solutions to the flux-gradient ("K-Theory") diffusion equation. (14) The effluent was not allowed to diffuse beyond a height of 200 meters in a stable condition and 1000 meters in neutral and unstable conditions.

At the ground surface, a partial sink boundary condition involving the deposition velocity was assumed. The wind and eddy diffusivity profiles required as input to the diffusion equation were those presented by Markee. (14) Deposition velocity was allowed to vary with wind speed in accordance with an empirical equation $(15)$ and assuming areal grass density of approximately $70 \mathrm{~g} / \mathrm{m}^{2}$. Resulting deposition velocities were $0.12,1.20$ and $0.88 \mathrm{~cm} / \mathrm{sec}$ for stable, neutral and unstable conditions, respectively.

\footnotetext{
(a) Releases of the base case in Reference 10 were reduced by a factor of 10 in this study to adjust the annual doses to the maximum exposed member of the public to be consistent with the requirements of 10 CFR 50, Appendix I for reactors.
} 
TABLE C.9-1. Estimated Annual Radioactive Atmospheric Release from a 1500 MT/yr Fuel Reprocessing Plant.

\begin{tabular}{|c|c|c|}
\hline Nuclide & Half-Life (days) & Release $\left(C_{1} / y r\right)^{(a)}$ \\
\hline${ }^{89} \mathrm{sr}$ & $505 E+01$ & $26 E-02$ \\
\hline${ }^{90} \mathrm{Sr}$ & $106 E+04$ & $23 E-02$ \\
\hline $90_{Y}$ & $267 E+00$ & $23 E-02$ \\
\hline${ }^{91} 1_{Y}$ & $586 E+01$ & $43 E-02$ \\
\hline${ }^{95} \mathrm{Ar}$ & $655 E+01$ & $75 E-02$ \\
\hline $95_{\mathrm{Nb}}$ & $351 E+01$ & $14 E-01$ \\
\hline${ }^{103}{ }_{\mathrm{Ru}}$ & $396 \mathrm{E}+01$ & $1 \mathrm{IE}-01$ \\
\hline $106 \mathrm{Ru}$ & $369+02$ & $80 E-01$ \\
\hline $110 \mathrm{Ag}$ & $252 E+02$ & $7 \quad 1 E-04$ \\
\hline $125_{\mathrm{Sb}}$ & $996 \mathrm{E}+02$ & $24 E-03$ \\
\hline${ }^{127} \mathrm{Te}$ & 1 O9E +02 & $17 E-03$ \\
\hline${ }^{129} \mathrm{Te}$ & $334 E+01$ & $66 \mathrm{E}-04$ \\
\hline $129_{1}$ & $580 E+09$ & $75 \mathrm{E}-02$ \\
\hline $1311_{1}$ & $804 E+00$ & $18 \mathrm{E}-01$ \\
\hline${ }^{134} \mathrm{Cs}$ & $752 E+02$ & $65 E-02$ \\
\hline${ }^{137} C_{S}$ & $110 E+04$ & $32 \mathrm{E}-02$ \\
\hline${ }^{141} \mathrm{Ce}$ & $325 E+01$ & $4 \mathrm{E}-02$ \\
\hline${ }^{144} \mathrm{Ce}$ & $284+02$ & $23 E-01$ \\
\hline${ }^{147} \mathrm{Pm}$ & $958+02$ & $29 E-02$ \\
\hline${ }^{154} \mathrm{Eu}$ & $314 E+03$ & $21 E-03$ \\
\hline $155_{\mathrm{Eu}}$ & $175 E+03$ & $19 \mathrm{E}-03$ \\
\hline $234_{U}$ & $891 \mathrm{E}+07$ & $23 E-06$ \\
\hline $235 \mathrm{u}$ & $257 \mathrm{~F}+11$ & $51 E-08$ \\
\hline $236 \mathrm{v}$ & $855 E+09$ & $86 \mathrm{E}-07$ \\
\hline $238_{u}$ & $163 E+12$ & $90 E-07$ \\
\hline${ }^{238} \mathrm{Pu}_{\mathrm{u}}$ & $320 E+04$ & $21 E-03$ \\
\hline${ }^{239} \mathrm{Pu}$ & $890 E+06$ & $24 E-04$ \\
\hline${ }^{240} \mathrm{Pu}$ & $239 E+06$ & $36 \mathrm{E}-04$ \\
\hline${ }^{241} \mathrm{Pu}$ & $548 E+03$ & $77 E-02$ \\
\hline${ }^{242} \mathrm{pu}$ & $141 E+08$ & $10 E-06$ \\
\hline $241_{\mathrm{Am}}$ & $158 E+05$ & $47 E-05$ \\
\hline${ }^{243} \mathrm{Am}_{\mathrm{m}}$ & $269 E+06$ & $5 \quad 4 E-06$ \\
\hline $242^{\mathrm{cm}} \mathrm{cm}$ & $163 E+02$ & $5 \mathrm{IE}-03$ \\
\hline${ }^{244} \mathrm{~cm}$ & $653 E+03$ & $71 E-04$ \\
\hline $\begin{array}{l}\text { (a) Rele } \\
\text { by a } \\
\text { dose } \\
\text { cons } \\
\text { for }\end{array}$ & $\begin{array}{l}\text { f the base case } \\
r \text { of } 10 \text { in this } \\
\text { he maximum expos } \\
\text { wi th the requir } \\
\text { rs }\end{array}$ & $\begin{array}{l}\text { ference } 10 \text { were reduced } \\
\text { to adjust the annual } \\
\text { mber of the public to be } \\
5 \text { of } 10 \text { CFR } 50 \text {, Appendix }\end{array}$ \\
\hline
\end{tabular}

The estimated surface concentrations of the individual radionuclides averaged over the entire site are shown in Table C.9-2. The effect of radiation decay of the residual contamination is demonstrated by the site contamination remaining at three decay times following plant shutdown; 10,30 , and 100 years. No credit has been taken in these calculations for any removal echanisms other than radioactive decay. 
TABLE C.9-2. Estimated Maximum Activity of Radionuclides Deposited on the FRP Site Over a 30 year Operating Lifetime

\begin{tabular}{|c|c|c|c|c|}
\hline \multirow[b]{2}{*}{ Nuclide } & \multicolumn{4}{|c|}{$\begin{array}{c}\text { Deposited Radioactivity }\left(\mu \mathrm{Ci} / \mathrm{m}^{2}\right) \text { at } \\
\text { Selected Times After Shutdown }\end{array}$} \\
\hline & Shutdown & 10 Years & 30 Years & 100 Years \\
\hline${ }^{89} \mathrm{Sr}$ & $1.5 E-5$ & $\ldots(a)$ & --- & -- \\
\hline${ }^{90} \mathrm{Sr}$ & $1.4 E-3$ & $1.1 \mathrm{E}-3$ & $6.9 E-4$ & $1.3 E-4$ \\
\hline $90_{Y}$ & 1. $4 \mathrm{E}-3$ & $1.7 E-3$ & $6.9 E-4$ & 1. $3 E-4$ \\
\hline $91_{Y}$ & $2.8 E-5$ & --- & -.- & -. \\
\hline${ }^{95} \mathrm{Zr}$ & $5.5 E-5$ & --- & -- & -- \\
\hline${ }^{95} \mathrm{Nb}$ & $5.5 E-5$ & -- & $\cdots$ & -- \\
\hline${ }^{103} \mathrm{Ru}$ & 4. $9 E-5$ & $\ldots$ & -.- & $\ldots$ \\
\hline${ }^{106}{ }_{\mathrm{Ru}}$ & $2.4 E-3$ & $2.6 \mathrm{E}-6$ & 2. $9 E-12$ & --- \\
\hline${ }^{110} \mathrm{Ag}$ & $2.0 \mathrm{E}-6$ & $8.8 \mathrm{E}-11$ & $\cdots$ & --- \\
\hline${ }^{125} \mathrm{Sb}$ & $2.7 E-5$ & $2.1 E-6$ & $1.3 E-8$ & --- \\
\hline${ }^{127} \mathrm{Te}$ & 2. $1 E-6$ & 1. $7 E-16$ & --- &.- \\
\hline${ }^{129} \mathrm{Te}$ & $2.5 \mathrm{E}-7$ & -- & $\ldots$ & --- \\
\hline${ }^{129} \mathrm{I}$ & $6.4 \mathrm{E}-3$ & $6.4 E-3$ & $6.4 E-3$ & $6.4 E-3$ \\
\hline $131 \mathrm{I}$ & $1.6 \mathrm{E}-5$ & $\cdots$ & -.- & -- \\
\hline${ }^{134} \mathrm{Cs}$ & $5.5 \mathrm{E}-4$ & 1. $9 E-5$ & 2. $3 E-8$ & --- \\
\hline${ }^{137} \mathrm{Cs}$ & 2. $0 \mathrm{E}-3$ & $1.6 E-3$ & 9. $9 \mathrm{E}-4$ & $2.0 \mathrm{E}-4$ \\
\hline${ }^{141} \mathrm{Ce}$ & 5. $1 E-6$ & $\cdots$ & -- & -- \\
\hline${ }^{144} \mathrm{Ce}$ & $7.4 \mathrm{E}-4$ & $9.9 \mathrm{E}-8$ & $1.8 E-15$ & -- \\
\hline${ }^{147} \mathrm{Pm}$ & 3. $1 E-4$ & 2. $2 E-5$ & 1. $1 \mathrm{E}-7$ & $1.0 E-15$ \\
\hline${ }^{154} \mathrm{Eu}$ & $6.8 E-5$ & 3. $O E-5$ & $6.0 \mathrm{E}-6$ & 3. $1 E-8$ \\
\hline${ }^{155} \mathrm{Eu}$ & $3.7 E-5$ & 8. $7 E-6$ & $4.8 E-7$ & $1.9 E-11$ \\
\hline${ }^{234} U$ & $2.0 E-7$ & $2.0 E-7$ & $2.0 E-7$ & $2.0 \mathrm{E}-7$ \\
\hline $235 U$ & $4.4 E-9$ & $4.4 E-9$ & $4.4 \mathrm{E}-9$ & $4.4 E-9$ \\
\hline${ }^{236} U$ & $7.4 E-8$ & $7.4 E-8$ & $7.4 \mathrm{E}-8$ & $7.4 E-8$ \\
\hline $238 u$ & $8.0 E-8$ & $8.0 E-8$ & $8.0 E-8$ & $8.0 E-8$ \\
\hline${ }^{238} \mathrm{Pu}$ & $1.6 E-4$ & 1. $5 E-4$ & 1. $3 E-4$ & 7. $3 E-5$ \\
\hline${ }^{239} \mathrm{Pu}$ & 2. $0 \mathrm{E}-5$ & $2.0 E-5$ & $2.0 E-5$ & $2.0 \mathrm{E}-5$ \\
\hline${ }^{240} \mathrm{Pu}$ & 3. $1 E-5$ & $3.1 E-5$ & 3. $1 E-5$ & $3.0 E-5$ \\
\hline${ }^{241} \mathrm{Pu}$ & 2. $7 E-3$ & $1.3 E-3$ & 3. OE -4 & $1.9 E-6$ \\
\hline${ }^{242} \mathrm{Pu}$ & $8.6 E-8$ & $8.6 E-8$ & $8.6 E-8$ & $8.6 \mathrm{E}-8$ \\
\hline $24 l_{\mathrm{Am}}$ & $1.0 \mathrm{E}-4$ & $1.5 \mathrm{E}-4$ & 1. $9 E-4$ & 1. $9 E-4$ \\
\hline${ }^{243} \mathrm{Am}$ & $4.6 \mathrm{E}-7$ & $4.6 \mathrm{E}-7$ & 4. $6 \mathrm{E}-7$ & $4.6 \mathrm{E}-7$ \\
\hline${ }^{242} \mathrm{~cm}$ & $9.4 \mathrm{E}-6$ & 1. $7 E-12$ & -- & $\cdots$ \\
\hline${ }^{244} \mathrm{Cm}$ & $3.6 \mathrm{E}-5$ & 2. $4 \mathrm{E}-5$ & 1. $1 E-5$ & $7.4 E-7$ \\
\hline
\end{tabular}


At shutdown, the radionuclides with the highest radioactivity are ${ }^{129} \mathrm{I}$, ${ }^{106} \mathrm{Ru},{ }^{241} \mathrm{Pu},{ }^{90} \mathrm{Sr},{ }^{137} \mathrm{Cs}$. For 30 years and longer, ${ }^{129} \mathrm{I},{ }^{90} \mathrm{Sr}$ and ${ }^{137} \mathrm{Cs}$ provide the highest potential radiation doses.

The radioactivity levels calculated for the site are expected to be maximum values. No allowance has been made for normal weathering such as runoff, soil and vegetational coverage, or for resuspension of the deposited material. Except for random concentrations of the contamination, the radioactivity level of the radionuclides is expected to be some fraction of the values in Table C.9-2. For this study, the maximum values were used.

Estimates of site contamination from plant operations have been made by others and are reported here for comparison. The maximum accumulation of transuranic alpha radioactivity for 40 years operation of a FRP reprocessing plutonium recycle fuel were estimated to be $2 \times 10^{-9} \mathrm{Ci} / \mathrm{m}^{2}\left(1.5 \times 10^{-9} \mathrm{Ci} / \mathrm{m}^{2}\right.$ normalized to a $1500 \mathrm{MT} / \mathrm{yr} \mathrm{plant}) .{ }^{(16)}$ For a FRP reprocessing on $1 \mathrm{y} \mathrm{UO}_{2}$ fuel, the radioactivity is expected to be about one-half of the plutonium recycle case, thus about $1 \times 10^{-9} \mathrm{Ci} / \mathrm{m}^{2}$ or about $10^{-3} \mu \mathrm{Ci} / \mathrm{m}^{2}$. This value corresponds approximately to the alpha radioactivity of plutonium calculated in this study: $2.0 \times 10^{-5} \mu \mathrm{Ci} / \mathrm{m}^{2}$. As indicated in Reference 16 , these values are approximately equal to the amount of alpha radioactivity that has accumulated to date from global fallout. 


\section{REFERENCES}

1. U.S. AEC, Final Environmental Statement Concerning Proposed Rule-Making Action: Numberical Guides for Design Objectives and Limiting Conditioning for Operation to Meet the Criteria "As Low As Practicable" for Radioactive Material in Light Water-Cooled Nuclear Power Reactor Effluents, WASH-1258, Directorate of Regulatory Standards, JuTy 1973, Volume 1 of 3, Figure $6 \mathrm{~B}-1$, page $6 \mathrm{~B}-43$ and Figure $6 \mathrm{C}-8$, page $6 \mathrm{C}-12$.

2. U.S. AEC, Final Environmental Statement Related to Operation of Monticello Nuclear Generating Plant, Docket No. 50-263, November 1972, pages II-15 through II-26.

3. U.S. AEC, Final Environmental Statement Concerning Proposed Rule-Making Action: Numberical Guides for Design Objectives and Limiting Conditioning for Operation to Meet the Criteria "As Low As Practicable" for Radioactive Material in Light Water-Cooled Nuclear Power Reactor Effluents, WASH-1258, Directorage of Regulatory Standards, July 1973, Volume 1 of 3, Table 6B-6, page 6B-36.

4. U.S. Nuclear Regulatory Commission, Regulatory Guide 1.109. (For comment), March 1976, Table D-1, pp. 1.109-1.164.

5. Meteorology and Atomic Energy 1968, TID 24190 Edited by D. H. Slade, Juty 1968, page 73 .

6. Bureau of Sport Fisheries and Wildlife Redbook, U.S. Dept. of Interior and the Federal Register.

7. United Nations Scientific Committee on the Effects of Atomic Radiation, Ionizing Radiation: Levels and Effects, Volume 1, United Nations, 1972, pages 29-63.

8. A. W. Kement, Jr., C. R. Miller, R. P. Minx, B. Shleien, Estimates of Ionizing Radiation Doses in the United States 1960-2000, ORP/CSD 72-1 U.S. Environmental Protection Agency, August 1972.

9. National Council on Radiation Protection, National Background Radiation in the U.S., NCRP Report 45, November 1975, page 35.

10. B. C. Finney, et al., Correlation of Radioactive Waste Treatment cost and the Environmental Impact of Waste Effluents in the Nuclear Fuel Cycle for Use in Establishing "As Low As Practicable" Guides - Nuclear Fuel Reprocessing", ORNL-TM-4901, May 1975. Table 4.2, page 95.

11. Final Generic Environmental Statement on the Use of Recycle Plutonium in Mixed Oxide Fuel for Light Water Reactors, NUREG-0002, USNRC, August 1976, Volume 3, Tab7e IV E-8, page IV E-24. 
J. F. Sagendorf and J. T. Goll, X0QDOQ - Program for the Meteorological Evaluation of Routine Effluent Releases at Nuclear Power Stations, Draft NRC Report, December 1976.

13. Environmental Report. Barnwell Nuclear Fuel Plant, Docket No. 50-332, A7lied Chemical Nuclear Products, Inc., November T971, Appendix IV, p. 18.

14. E. H. Markee, Jr., A Parametric Study of Gaseous Plume Depletion by Ground Surface Adsorption, USAEC Meteorological Information Meeting, AECL-2787, 1967, pp. 602-613.

15. C. A. Pelletier and J. D. Zimbrick, "Kinetics of Environmental Radioiodine Transport Through the Milk-Food Chain," in Environmental Surveillance in the Vicinity of Nuclear Facilities, W. C. Reining, Editor, Thomas Publishers, Springfield, IL, 1970.

16. Final Generic Environmental Statement of the Use of Recycle Plutonium in Mixed Oxide Fuel for Light Water Reactors, NUREG-0002, USNRC, August 1976, Volume 3, Section 3.3, page IV E-35. 
0

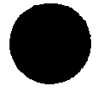




\section{DERIVATION OF RESIDUAL RADIOACTIVE CONTAMINATION LEVELS}

A review of existing guidelines and regulations has led to the conclusion that there is a need to derive acceptable residual contamination levels that are generally applicable to decommissioned nuclear facilities and sites. It is the purpose of this Appendix to provide the supporting information for developing the proposed disposition criteria in Section 6, Volume 1.

\section{D.1 EXISTING GUIDANCE}

There are no unique regulations or specific guidance on acceptable maximum annual dose to individuals living on or near a decommissioned site. Some guidance currently exists on levels of radioactive surface contamination that are acceptable to the USNRC for termination of operating licenses. $(1,2)$ Guidance suggested by others $(3-8)$ is specifically directed toward a type of facility or accidental situations involving radioactivity.

Guidance which could be interpreted as a dose limit recommendation for this study includes:

1. Recommendations of International Committee on Radiation Protection (ICRP), Publication $9^{(9)}$

2. Surgeon General's Guidelines (DHEW) (10)

3. Appendix I of 10 CFR 50, Guides on Design Objectives for Light-WaterCooled Nuclear Power Reactors (NRC) (17)

4. Federal Guidance for the Environmental Limits of Plutonium Contamination in Soil, DRAFT (EPA) (12)

5. 40 CFR 190, Environmental Radiation Protection Requirements for Normal Operations of Activities in the Uranium Fuel Cycle (EPA). (13)

The ICRP recommended that the maximum annual whole-body exposure of the general public to external gamma radiation be 1 imited to $500 \mathrm{mrem} /$ year. ${ }^{(9)}$ This excludes background radiation and the exposure incurred under medical treatment.

For dwellings constructed on or with uranium mine tailings, the Surgeon neral of the United States Public Health Service (USPHS) recommended the 
graded action levels 1 isted in Table $0.1-1^{(10)}$ for external gamma radiation.

TABLE D.1-1. U. S. Public Health Service Recommendations

for Reducing External Exposures Due to

Radioactive Contamination

External Gamma Radiation(a)

1. Less than $0.05 \mathrm{mR} / \mathrm{hr}$

2. From 0.05 to $0.1 \mathrm{mR} / \mathrm{hr}$

3. Greater than $0.1 \mathrm{mR} / \mathrm{hr}$
Recommendation

No action indicated.

Remedial action may be suggested.

Remedial action indicated.

(a) Exposures in addition to background.

In the case of a 24-hr/day occupancy, levels 1 and 3 result in exposures of about $400 \mathrm{mR} / \mathrm{yr}$ and $900 \mathrm{mR} / \mathrm{yr}$, respectively.

In Appendix I of 10 CFR 50, it is stated in part: (11)

A. The calculated annual total quantity of all radioactive

- material above background(b) to be released from each

light-water-cooled nuclear power reactor to unrestricted

areas wi1l not result in an estimated annual dose or dose

commitment from liquid effluents for any individual in

an unrestricted area from all pathways of exposure in

excess of 3 millirems to the total body or 10 millirems

to any organ.

B.1. The calculated annual total quantity of all radioactive material above background to be released from each 1 ightwater-cooled nuclear power reactor to the atmosphere will not result in an estimated annual air dose from gaseous effluents at any location near ground level which could be occupied by individuals in unrestricted areas in excess of 10 millirads for gamma radiation or 20 millirads for beta radiation.

2. Notwithstanding the guidance of paragraph B.1:

(a) The Commission may specify, as guidance on design objectives, a lower quantity of radioactive material above background to be released to the atmosphere if

(b) Background means radioactive materials in the environment and in the effluents from light-water-cooled power reactors not generated in, or attributable to, the reactors of which specific account is required in determining design objectives. 
it appears that the use of the design objectives in paragraph B.l is likely to result in an estimated annual external dose from gaseous effluents to any individual in an unrestricted area in excess of 5 millirems to the total body; and

(b) Design objectives based upon a higher quantity of radioactive material above background to be released to the atmosphere than the quantity specified in paragraph B. 1 will be deemed to meet the requirements for keeping levels of radioactive material in gaseous effluents as low as is reasonably achievable if the applicant provides reasonable assurance that the proposed higher quantity will not result in an estimated annual external dose from gaseous effluents to any individual in unrestricted areas in excess of 5 millirems to the total body or 15 millirems to the skin.

C. The calculated annual total quantity of all radioactive iodine and radioactive material in particulate form above background to be released from each light-water-cooled nuclear power reactor in effluents to the atmosphere will not result in an estimated annual dose or dose commitment from such radioactive iodine and radioactive material in particulate form for any individual in an unrestricted area from all pathways of exposure in excess of 15 millirems to any organ.

EPA Draft Guidance on Plutonium in Soil states: (12)

Calculation of the numerical value for the proposed guidance(a) is as follows:

a. The rationale for the proposed guidance is based on a balancing of risks on a societal basis. For regulatory purposes, an incremental risk assumption of one per million per year is assumed to represent an acceptable limit for large population groups, where risk assumption is involuntary and the population segment affected may not be the principal beneficiary.

b. A population averaged risk estimate of 40 cancers per million man-lung-rem exposure is inverted to an individual probability basis. The segmental doses to other organs are included to give an overall risk correlation of 10 mrem (lung)/year equivalent to an excess risk of $1 \times 10^{-6}$ cancers/person-year.

c. The lung dose of $10 \mathrm{mrem} /$ year is equated to a corresponding air concentration by use of dosimetric relationships based on the recommendations of the ICRP Task Group on Lung Dynamics.

At the time of this writing, EPA's draft guidance has been revised but it is not available for reference. 
The environmental standard proposed by EPA on the uranium fuel cycle states in part:(13)

Subpart B--Environmental Standards for the Uranium Fuel Cycle 190.10 Standards for Normal Operations.

(a) The annual dose equivalent shall not exceed 25 millirems to the whole body, $75 \mathrm{millirems}$ to the thyroid, and $25 \mathrm{milli-}$ rems to any other organ of any member of the public as the result of exposure to planned discharges of radioactive materials, radon and its daughters excepted, to the general environment from uranium fuel cycle operations and radiation from these operations.

In summary, two of the recommendations fall in the 400 to $500 \mathrm{mrem} / \mathrm{yr}$ range, $(9,10)$ The remaining dose rate limits for which there is documented guidance range from 3 to $75 \mathrm{mrem} / \mathrm{yr} .(11,12,13)$

It is not within the scope of this study to recommend dose limits for the exposure of members of the public to radioactive materials. Therefore, acceptable residual contamination levels have been calculated for a range of possible dose rate limits, based upon the rationale and guidance just discussed. It is reasonable to expect that if dose limits are promulgated uniquely for the control of public exposure from decommissioned nuclear facilities, that they will probably fall in the range of the lower values, namely 1 to $25 \mathrm{mrem} / \mathrm{yr}$. For this reason, example disposition criteria have been developed for the reference FRP for this range of annual dose limits as a demonstration of the methodology. In the analysis, the annual dose limits are assumed to apply to any organ of the maximum exposed individual. The selection of this range of possible dose rate limits is not intended nor should it be implied as a recommendation for limiting the exposure of members of the public to residual contamination at decommissioned nuclear facilities. 


\section{D.2 TECHNICAL APPROACH}

The basic premise for disposition criteria calculated in this study is that no member of the public will receive a dose at a rate in excess of the selected maximum annual dose criterion (i.e., 1 to $25 \mathrm{mrem} / \mathrm{yr}$ in this study). That is, under no foreseeable circumstance will the predicted dose rate to any member of the public be permitted to exceed the dose rate specified for unrestricted release. Where higher dose rates are predicted, the potential exposure will need to be controlled by means of "special conditions" imposed on the release of property; i.e., conditionally released as defined in Volume I, Section 6.

\section{D.2.1 Residual Radioactive Contamination Levels}

Radioactive contamination is expected to be present in the reference facility and on the generic site as a result of normal operations and resulting effluents released over the anticipated plant 1 ife of 30 years.

\section{D.2.1.1 Site}

Estimates of the ground contamination levels at the site were based on the predicted normal operating releases of gaseous effluents as discussed in Appendix C.

Ground deposition from continuous releases from the $100 \mathrm{~m}$ stack were estimated using the site meteorological characteristics and state-of-theart atmospheric calculation methods. Radioactive decay of the released material was accounted for over the duration of release and following deposition. The resulting surface contamination levels by radionuclide are listed in Appendix C, Table C.9-2. For a more complete discussion of this calculation, see Appendix C, Section C.9.3.

\section{D.2.1.2 Reference Fuel Reprocessing Plant}

Dose rate factors were calculated by assuming that surfaces in the reference FRP were contaminated to one $\mathrm{Ci} / \mathrm{m}^{2}$. Relative isotopic compositions of the contamination at selected times of planned decommissioning are listed in Table $0.2-1$. These compositions are based on inventories in the remote process cell after decontamination as described in Appendix B.3. 


\section{D.2.2 Dose Calculations}

The models and computer codes used for calculating doses from the exposure pathways evaluated in this study are described in Appendix F.4.

\section{D.2.2.1 Site}

The annual dose was calculated to each of several organs of reference for all pathways shown by experience to be significant, for each year following the initial exposure. For some of the organs, the dose rate increases initially with time of exposure then decreases as both radioactive decay and biological half-times dictate. For example, the annual dose to bone from inhalation of resuspended contamination would not be expected to peak until several years after the initial inhalation exposure. of course, other pathways will have an effect on how the dose rate to bone varies with time and this was accounted for.

Annual doses for an unrestricted use of the site at each of several times after shutdown are 1 isted in Table D.2-2. For unrestricted release, it was assumed that the site was used for agricultural purposes and the ground contamination, listed in Table C.9-2, Appendix C, was uniformly mixed in the soil to a depth of $15 \mathrm{~cm}$ ( $n 6$ inches). The resuspension layer was assumed to be $1 \mathrm{~cm}(\mathrm{~N} / 2$ inch) with no credit taken for weathering. The resuspension factor was assumed to decrease with time as discussed in Volume 1 , Section 6 . These assumptions result in maximizing the annual dose. It is obvious from Table D.2-2 that the annual doses to the thyroid gland and bone are controlling, with the maximum annual dose occurring at times after the intake commences, of 1 and 3 years, respectively.

Annual doses for a conditional release of the site were also calculated. The basis for a conditional release was prohibition of growing farm crops or grazing food animals on the released site. It was assumed in this case that the ground contamination at site was undisturbed, thereby remaining on the soil surface at the levels listed in Table C.9-2, Appendix C. Again 
no credit was taken for weathering, and the resuspension factor was treated exactly as in the unrestricted release case. The resulting maximum annual doses for conditional release at each of several times after shutdown are listed in Table D.2-3. The primary exposure pathway in this case is from external radiation emanating from the contaminated ground, although inhalation exposure is a major contributor. As before, the doses to the thyroid gland and bone are controlling; however, the doses to all the organs considered are lower as a result of eliminating the ingestion path. For the thyroid gland and bone the doses are lower by at least a factor of ten.

\section{D.2.2.2 Reference Fuel Reprocessing Plant}

The annual dose to several organs of reference was calculated for the inhalation and submersion pathways plus direct exposure to contaminated surfaces. The maximum annual doses and the time (after exposure begins) that they occur are listed in Table D.2-4. As discussed previously, the doses are normalized to a surface contamination level of one $\mu \mathrm{Ci} / \mathrm{m}^{2}$. Air concentrations in enclosed spaces from material resuspended from contaminated surfaces were based on a resuspension factor of $5 \times 10^{-6}$ per meter, as discussed in Volume 1, Section 6 . The annual doses from both the inhalation and submersion pathways were based on the resulting air concentrations.

The dose from direct exposure to contaminated surfaces was calculated assuming a room size sufficiently large that the external exposure would be dominated by exposure to floor contamination. In other words, the additional dose that results from exposure to the wall and ceiling surfaces is assumed to be minor compared to the dose from exposure to the floor.

From Table D.2-4, it can be seen that the dose to the lungs and bone is controlling with the maximum annual dose occurring at times of 1 and 32 years, respectively, after the exposure begins. The maximum annual dose to these organs is practically unchanged with time after shutdown, even when decommissioning is contemplated at 100 years.

\section{D.2.3 Allowable Residual Contamination Levels}

Residual contamination levels at the generic site, Table C.9-2 (Appendix C) and the corresponding maximum annual dose, Tables D.2-2 and 
D.2-3, establishes a relationship between organ dose and ground contamination levels at selected times after shutdown of the reference FRP. This relationship is used to establish the allowable residual contamination levels for both Unrestricted and Conditional Use categories corresponding to desired limits placed on the maximum annual dose. As previously stated, it is not the purpose of this study to recommend such a limit; therefore, allowable residual contamination levels were calculated for a range of possible limits, specifically 1 and $25 \mathrm{mrem} / \mathrm{yr}$. The resulting values for unrestricted and conditional release are listed in Volume 1 (see Tables 6.4-1 and 6.4-3, Section 6).

For surface contamination in the reference FRP, the maximum annual doses, Table D.2-4 were calculated assuming a residual surface contamination level of one $\mu \mathrm{Ci} / \mathrm{m}^{2}$ of the composition listed in Table $0.2-1$. The relationship, thus established, was then used to derive allowable residual contamination levels in exactly the same manner as was previously described for the site contamination. The resulting allowable residual surface contamination levels are listed in Volume 1 (see Table 6.4-5). 
TABLE D.2-1. Isotopic Composition of Radioactive Surface Contamination in the Reference FRP

Radionuclide

Sr-90
$Y-90$
Ru-106+d (a)
Sb-125+d
Te-125m
$\mathrm{Cs}-134$
$\mathrm{Cs}-137+d$
$\mathrm{Ce}-144+d$
$\mathrm{Pm}-147$
$\mathrm{Sm}-151$
$\mathrm{Eu}-154$
$\mathrm{Eu}-155$
$\mathrm{Pu}-238$
$\mathrm{Pu}-239$
$\mathrm{Pu}-240$
$\mathrm{Pu}-241$
$\mathrm{Pu}-242$
$\mathrm{Am}-241$
$\mathrm{Am}-242 \mathrm{~m}$
$\mathrm{Am}-243$
$\mathrm{Cm}-242$
$\mathrm{Cm}-244$

TOTAL
Surface Contamination, $\mu \mathrm{C} i / \mathrm{m}^{2}$ at Times After Shutdown of:

\begin{tabular}{|c|c|c|c|}
\hline Shutdown & 10 Years & 30 Years & 100 Years \\
\hline $\begin{array}{l}1.2 \mathrm{E}-1 \\
1.2 \mathrm{E}-1\end{array}$ & $\begin{array}{l}1.5 \mathrm{E}-1 \\
1.5 \mathrm{E}-1\end{array}$ & $\begin{array}{l}1.6 \mathrm{E}-1 \\
1.6 \mathrm{E}-1\end{array}$ & $\begin{array}{l}1.4 \mathrm{E}-1 \\
1.4 \mathrm{E}-1\end{array}$ \\
\hline $5.2 \mathrm{E}-2$ & 8.0E-5 & -- & -- \\
\hline $2.2 \mathrm{E}-3$ & $2.6 \mathrm{E}-4$ & -- & -- \\
\hline $7.3 E-4$ & $--\quad$ (b) & -- & -- \\
\hline $3.4 \mathrm{E}-2$ & $1.8 \mathrm{E}-3$ & $=-$ & -- \\
\hline $1.9 \mathrm{E}-1$ & $2.4 \mathrm{E}-1$ & $2.5 \mathrm{E}-1$ & $2.4 \mathrm{E}-1$ \\
\hline $5.3 \mathrm{E}-2$ & $\overline{-}$ & -- & -- \\
\hline $2.6 \mathrm{E}-2$ & $2.8 \mathrm{E}-3$ & , & $\overline{7}$ \\
\hline $\begin{array}{r}2.9 \mathrm{E}-3 \\
0 \mathrm{~F}-2\end{array}$ & $4.2 E-3$ & $6.1 \mathrm{E}-3$ & $1.7 \mathrm{E}-2$ \\
\hline $\begin{array}{l}1.0 \mathrm{E}-2 \\
3.6 \mathrm{E}-4\end{array}$ & $\begin{array}{l}7.1 \mathrm{E}-3 \\
1.0 \mathrm{E}-4\end{array}$ & $\begin{array}{c}2.4 \mathrm{E}-3 \\
--\end{array}$ & $\begin{array}{c}4.0 E-5 \\
---\end{array}$ \\
\hline $4.7 \mathrm{E}-3$ & $4.3 \mathrm{E}-3$ & $9.7 E-3$ & $2.7 E-2$ \\
\hline $3.6 \mathrm{E}-4$ & $6.0 \mathrm{E}-4$ & $9.0 \mathrm{E}-4$ & $4.6 \mathrm{E}-3$ \\
\hline $1.1 \mathrm{E}-3$ & $1.7 \mathrm{E}-3$ & $2.8 \mathrm{E}-3$ & $1.4 \mathrm{E}-2$ \\
\hline $1.0 \mathrm{E}-1$ & $1.0 \mathrm{E}-1$ & $7.0 \mathrm{E}-2$ & $1.3 \mathrm{E}-2$ \\
\hline $3.6 \mathrm{E}-6$ & $5.7 \mathrm{E}-6$ & 1.0E-5 & $4.6 \mathrm{E}-5$ \\
\hline $9.5 E-3$ & $1.4 \mathrm{E}-2$ & 2.0E-2 & $1.0 \mathrm{E}-1$ \\
\hline $3.6 \mathrm{E}-4$ & $5.0 E-4$ & $8.0 \mathrm{E}-4$ & $2.9 \mathrm{E}-3$ \\
\hline $3.6 E-4$ & $6.0 \mathrm{E}-4$ & $9.0 \mathrm{E}-4$ & $4.5 \mathrm{E}-3$ \\
\hline $7.3 \mathrm{E}-4$ & -- & -- & -- \\
\hline $1.2 \mathrm{E}-2$ & $1.2 \mathrm{E}-2$ & $9.5 \mathrm{E}-3$ & $3.0 \mathrm{E}-3$ \\
\hline
\end{tabular}

$1.5 \mathrm{E}-1$

$1.5 \mathrm{E}-1$

8. $0 \mathrm{E}-5$

. $6 \mathrm{E}-4$

$1.8 \mathrm{E}-3$

$2.8 \mathrm{E}-3$

$4.2 \mathrm{E}-3$

$7.1 \mathrm{E}-3$

$1.0 \mathrm{E}-4$

$4.3 \mathrm{E}-3$

$6.0 \mathrm{E}-4$

$1.7 \mathrm{E}-3$

$1.0 \mathrm{E}-1$

$5.7 \mathrm{E}-6$

$1.4 \mathrm{E}-2$

$5.0 \mathrm{E}-4$

$6.1 \mathrm{E}-3$

$1.7 \mathrm{E}-2$

$--$

$--$

$9.7 E-3$

4. $6 \mathrm{E}-3$

2. $8 \mathrm{E}-3$

1. $4 \mathrm{E}-2$

4. $6 \mathrm{E}-5$

1. $0 \mathrm{E}-1$

2. $9 \mathrm{E}-3$

$1 . \overline{2 E-2}$

1.0

1.0

1.0

(a) plus daughters

(b) dash indicates values less than $10^{-6}$ 
TABLE D.2-2a. Maximum Annual Dose to Selected Organs of Reference

(Site Decommissioned at Shutdown)

Organ of

Reference Radionuclide (a)

Maximum Annual Dose, mrem via:

\begin{tabular}{|c|c|c|c|c|c|c|}
\hline & & Ingestion & Inhalation & Ground (b & Air Submersion & A11 Pathways \\
\hline \multirow{2}{*}{$\begin{array}{l}\text { Thyroid } \\
\text { a } 1 \text { year (c) }\end{array}$} & $I-129$ & $2.4 \mathrm{E}+0$ & $1.1 \mathrm{E}-4$ & $1.7 E-3$ & $6.8 \mathrm{E}-10$ & $2.4 E+0$ \\
\hline & A11 & $2.4 \mathrm{E}+0$ & $1.1 \mathrm{E}-4$ & 1. $3 \mathrm{E}-2$ & $3.3 E-8$ & $2.4 E+0$ \\
\hline \multirow[t]{2}{*}{$\begin{array}{l}\text { Lung } \\
\text { a } 1 \text { year }\end{array}$} & $\begin{array}{l}\text { Zr-95+d (d) } \\
N b-95 \\
R u-106+d \\
I-129 \\
C s-134 \\
\text { Cs }-137+d \\
\text { Ce-144+d } \\
\text { Eu-154 }\end{array}$ & $\begin{array}{l}--(e) \\
-- \\
-- \\
-- \\
4.0 \bar{E}-5 \\
1.0 \mathrm{E}-4 \\
-- \\
-- \\
\end{array}$ & $\begin{array}{c}5.0 \mathrm{E}-8 \\
1.5 \mathrm{E}-8 \\
9.5 \mathrm{E}-6 \\
-- \\
1.9 \mathrm{E}-8 \\
4.9 \mathrm{E}-8 \\
2.4 \mathrm{E}-6 \\
1.2 \mathrm{E}-7 \\
\end{array}$ & $\begin{array}{l}1.6 \mathrm{E}-4 \\
1.6 \mathrm{E}-4 \\
2.1 \mathrm{E}-3 \\
1.7 \mathrm{E}-3 \\
3.8 \mathrm{E}-3 \\
4.8 \mathrm{E}-3 \\
1.3 \mathrm{E}-4 \\
3.0 \mathrm{E}-4 \\
\end{array}$ & $\begin{array}{l}2.2 \mathrm{E}-10 \\
2.1 \mathrm{E}-10 \\
2.5 \mathrm{E}-9 \\
6.8 \mathrm{E}-10 \\
4.2 \mathrm{E}-9 \\
5.5 \mathrm{E}-9 \\
1.7 \mathrm{E}-10 \\
1.8 \mathrm{E}-8 \\
\end{array}$ & $\begin{array}{l}1.6 \mathrm{E}-4 \\
1.6 \mathrm{E}-4 \\
2.2 \mathrm{E}-3 \\
1.7 \mathrm{E}-3 \\
3.8 \mathrm{E}-3 \\
4.9 \mathrm{E}-3 \\
1.4 \mathrm{E}-4 \\
3.0 \mathrm{E}-4 \\
\end{array}$ \\
\hline & Al1 & 1. $4 \mathrm{E}-4$ & $9.6 E-5$ & $1.3 \mathrm{E}-2$ & $3.3 E-8$ & $1.4 \mathrm{E}-2$ \\
\hline \multirow[t]{2}{*}{$\begin{array}{l}\text { Whole Body } \\
\text { a } 2 \text { years }\end{array}$} & $\begin{array}{l}S r-90+d \\
I-129 \\
C s-134 \\
C s-137+d\end{array}$ & $\begin{array}{l}5.1 \mathrm{E}-2 \\
3.0 \mathrm{E}-3 \\
1.5 \mathrm{E}-4 \\
6.3 \mathrm{E}-4 \\
\end{array}$ & $\begin{array}{l}5.8 E-8 \\
1.0 E-7 \\
3.0 E-8 \\
2.1 E-7 \\
\end{array}$ & $\begin{array}{c}-\overline{-} \\
1.7 \mathrm{E}-3 \\
9.9 \mathrm{E}-4 \\
4.3 \mathrm{E}-3 \\
\end{array}$ & $\begin{array}{l}1.3 \mathrm{E}-12 \\
5.0 \mathrm{E}-10 \\
8.0 \mathrm{E}-10 \\
3.6 \mathrm{E}-9 \\
\end{array}$ & $\begin{array}{l}5.1 \mathrm{E}-2 \\
4.6 \mathrm{E}-3 \\
1.1 \mathrm{E}-3 \\
5.0 \mathrm{E}-3 \\
\end{array}$ \\
\hline & A11 & $5.5 \mathrm{E}-2$ & $1.2 \mathrm{E}-6$ & $7.4 \mathrm{E}-3$ & $1.5 E-8$ & $6.2 E-2$ \\
\hline \multirow[t]{2}{*}{$\begin{array}{l}\text { Bone } \\
\text { 0 } 3 \text { years }\end{array}$} & $\begin{array}{l}S r-90+d \\
I-129 \\
C s-137+d\end{array}$ & $\begin{array}{l}2.1 \mathrm{E}-1 \\
1.6 \mathrm{E}-3 \\
5.8 \mathrm{E}-4 \\
\end{array}$ & $\begin{array}{l}8.8 E-7 \\
5.4 E-8 \\
1.9 E-7 \\
\end{array}$ & $\begin{array}{r}\overline{--} \\
1.7 E-3 \\
4.0 E-3 \\
\end{array}$ & $\begin{array}{l}1.2 \mathrm{E}-12 \\
5.0 \mathrm{E}-10 \\
3.3 \mathrm{E}-9 \\
\end{array}$ & $\begin{array}{l}2.1 \mathrm{E}-1 \\
3.2 \mathrm{E}-3 \\
4.5 \mathrm{E}-3 \\
\end{array}$ \\
\hline & Al1 & $2.1 E-1$ & $2.7 E-5$ & $6.1 E-3$ & $1.1 E-8$ & $2.1 E-1$ \\
\hline \multicolumn{7}{|c|}{$\begin{array}{l}\text { (a) The dose from all radionuclides in the inventory is calculated and included in the total but only those } \\
\text { radionuclides that contribute more than one percent of total from all pathways are listed. }\end{array}$} \\
\hline
\end{tabular}


TABLE D.2-2b. Maximum Annual Dose to Selected Organs of Reference

(Site Decommissioned 10 Years After Shutdown)

Organ of

Reference Radionuclide (a)

\begin{tabular}{|c|c|c|c|c|c|c|}
\hline & & Ingestion & Inhalation & Ground (b) & Air Submersion & All Pathways \\
\hline \multirow{2}{*}{$\begin{array}{l}\text { Thyroid } \\
1 \text { year }(c)\end{array}$} & $I-129$ & $2.4 E+0$ & $1.1 \mathrm{E}-4$ & $1.7 \mathrm{E}-3$ & $6.8 \mathrm{E}-10$ & $2.4 \mathrm{E}+0$ \\
\hline & A11 & $2.4 E+0$ & $1.1 \mathrm{E}-4$ & $5.7 E-3$ & $1.4 E-8$ & $2.4 E+0$ \\
\hline \multirow[t]{2}{*}{$\begin{array}{l}\text { Lung } \\
\text { o } 1 \text { year }\end{array}$} & $\begin{array}{l}\mathrm{I}-129 \\
\text { Cs }-134 \\
\text { Cs }-137+d(d) \\
\text { Eu-154 }\end{array}$ & $\begin{array}{l}--(e) \\
1.4 \mathrm{E}-6 \\
8.2 \mathrm{E}-5 \\
-- \\
\end{array}$ & $\begin{array}{l}6 . \overline{6 \mathrm{E}-10} \\
3.9 \mathrm{E}-8 \\
5.1 \mathrm{E}-8 \\
\end{array}$ & $\begin{array}{l}1.7 \mathrm{E}-3 \\
1.3 \mathrm{E}-4 \\
3.8 \mathrm{E}-3 \\
1.4 \mathrm{E}-4 \\
\end{array}$ & $\begin{array}{l}6.8 \mathrm{E}-10 \\
1.5 \mathrm{E}-10 \\
4.3 \mathrm{E}-9 \\
8.1 \mathrm{E}-9 \\
\end{array}$ & $\begin{array}{l}1.7 \mathrm{E}-3 \\
1.3 \mathrm{E}-4 \\
3.9 \mathrm{E}-3 \\
1.4 \mathrm{E}-4 \\
\end{array}$ \\
\hline & Al1 & $8.3 E-5$ & $8.3 E-5$ & $5.7 E-3$ & $1.4 \mathrm{E}-8$ & $5.9 E-3$ \\
\hline \multirow[t]{2}{*}{$\begin{array}{l}\text { Whole Body } \\
\text { d } 3 \text { years }\end{array}$} & $\begin{array}{l}S r-90+d \\
I-129 \\
C s-137+d\end{array}$ & $\begin{array}{l}4.1 \mathrm{E}-2 \\
3.0 \mathrm{E}-3 \\
4.5 \mathrm{E}-4 \\
\end{array}$ & $\begin{array}{l}4.3 E-8 \\
1.0 E-7 \\
1.5 E-7 \\
\end{array}$ & $\begin{array}{l}-\overline{7} \\
1.7 \mathrm{E}-3 \\
3.1 \mathrm{E}-3 \\
\end{array}$ & $\begin{array}{l}9.4 \mathrm{E}-13 \\
5.0 \mathrm{E}-10 \\
2.6 \mathrm{E}-9 \\
\end{array}$ & $\begin{array}{l}4.1 \mathrm{E}-2 \\
4.6 \mathrm{E}-3 \\
3.6 \mathrm{E}-3 \\
\end{array}$ \\
\hline & A11 & $4.4 E-2$ & $1.3 E-6$ & $4.9 E-3$ & $6.3 E-9$ & $4.9 \mathrm{E}-2$ \\
\hline \multirow[t]{2}{*}{$\begin{array}{l}\text { Bone } \\
\text { a } 3 \text { years }\end{array}$} & $\begin{array}{l}S r-90+d \\
I-129 \\
C s-137+d\end{array}$ & $\begin{array}{l}1.6 \mathrm{E}-1 \\
1.6 \mathrm{E}-3 \\
4.6 \mathrm{E}-4 \\
\end{array}$ & $\begin{array}{l}6.9 \mathrm{E}-7 \\
5.4 \mathrm{E}-8 \\
1.5 \mathrm{E}-7 \\
\end{array}$ & $\begin{array}{l}-\overline{-} \\
1.7 E-3 \\
3.1 E-3 \\
\end{array}$ & $\begin{array}{l}9.4 \mathrm{E}-13 \\
5.0 \mathrm{E}-10 \\
2.6 \mathrm{E}-9 \\
\end{array}$ & $\begin{array}{l}1.6 \mathrm{E}-1 \\
3.2 \mathrm{E}-3 \\
3.6 \mathrm{E}-3 \\
\end{array}$ \\
\hline & A11 & $1.6 \mathrm{E}-1$ & $2.6 \mathrm{E}-5$ & $4.9 E-3$ & $6.3 E-9$ & $1.7 \mathrm{E}-1$ \\
\hline
\end{tabular}

(a) The dose from all radionuclides in the inventory is calculated and included in the total but only those radionuclides that contribute more than one percent of total from all pathways are listed.

(b) External radiation from contaminated ground.

(c) The time at which the dose-rate peaks after the exposure starts.

(d) Plus daughter radionuclides.

(e) Dash indicates values less than $10^{-13} \mathrm{mrem} /$ year. 
TABLE D.2-2c. Maximum Annual Dose to Selected Organs of Reference

(Site Decommissioned 30 Years After Shutdown)

Organ of

Reference

$\frac{i}{\sim}$

\begin{tabular}{|c|c|c|c|c|c|c|}
\hline \multirow{2}{*}{ Netcicine } & \multirow[t]{2}{*}{ 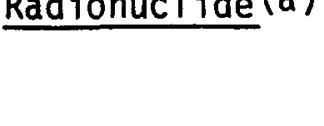 } & \\
\hline & & Ingestion & Inhalation & Ground (b) & Air Submersion & All Pathways \\
\hline \multirow{2}{*}{$\begin{array}{l}\text { Thyroid } \\
\text { a } 1 \text { year }(c)\end{array}$} & $I-129$ & $2.4 E+0$ & $1.1 \mathrm{E}-4$ & $1.7 \mathrm{E}-3$ & $6.8 \mathrm{E}-10$ & $2.4 \mathrm{E}+0$ \\
\hline & A11 & $\overline{2.4 E+0}$ & $\overline{1.1 \mathrm{E}-4}$ & $\overline{4.1 E-3}$ & $\overline{5.1 \mathrm{E}-9}$ & $\overline{2.4 \mathrm{E}+0}$ \\
\hline \multirow[t]{2}{*}{$\begin{array}{l}\text { Lung } \\
\text { a } 1 \text { year }\end{array}$} & $\begin{array}{l}I-129 \\
C s-137+d(d) \\
A m-241\end{array}$ & $\begin{array}{c}--(e) \\
5.2 E-5 \\
-- \\
\end{array}$ & $\begin{array}{r}--- \\
2.5 \mathrm{E}-8 \\
3.2 \mathrm{E}-5 \\
\end{array}$ & $\begin{array}{l}1.7 \mathrm{E}-3 \\
2.4 \mathrm{E}-3 \\
1.9 \mathrm{E}-5 \\
\end{array}$ & $\begin{array}{l}6.8 \mathrm{E}-10 \\
2.7 \mathrm{E}-9 \\
2.0 \mathrm{E}-11 \\
\end{array}$ & $\begin{array}{l}1.7 \mathrm{E}-3 \\
2.4 \mathrm{E}-3 \\
5.2 \mathrm{E}-5 \\
\end{array}$ \\
\hline & A11 & $\overline{5.2 E-5}$ & $\overline{8.1 E-5}$ & $\overline{4.1 E-3}$ & $\overline{5.1 E-9}$ & $\overline{4.2 E-3}$ \\
\hline \multirow[t]{2}{*}{$\begin{array}{l}\text { Whole Body } \\
\text { a } 3 \text { years }\end{array}$} & $\begin{array}{l}\text { Sr }-90+d \\
I-129 \\
\text { Cs }-137+d\end{array}$ & $\begin{array}{l}2.5 \mathrm{E}-2 \\
3.0 \mathrm{E}-3 \\
2.9 \mathrm{E}-4 \\
\end{array}$ & $\begin{array}{l}2.7 \mathrm{E}-8 \\
1.0 \mathrm{E}-7 \\
9.4 \mathrm{E}-8 \\
\end{array}$ & $\begin{array}{r}-\overline{-} \\
1.7 \mathrm{E}-3 \\
2.0 \mathrm{E}-3 \\
\end{array}$ & $\begin{array}{l}5.8 \mathrm{E}-13 \\
5.0 \mathrm{E}-10 \\
1.7 \mathrm{E}-9 \\
\end{array}$ & $\begin{array}{l}2.5 \mathrm{E}-2 \\
4.6 \mathrm{E}-3 \\
2.3 \mathrm{E}-3 \\
\end{array}$ \\
\hline & A11 & $2.8 \mathrm{E}-2$ & $1.2 \mathrm{E}-6$ & $3.7 \mathrm{E}-3$ & $\overline{2.8 E-9}$ & $\overline{3.2 \mathrm{E}-2}$ \\
\hline \multirow[t]{2}{*}{$\begin{array}{l}\text { Bone } \\
\text { a } 3 \text { years }\end{array}$} & $\begin{array}{l}\text { Sr-90+d } \\
I-129 \\
\text { Cs-137+d }\end{array}$ & $\begin{array}{l}1.0 \mathrm{E}-1 \\
1.6 \mathrm{E}-3 \\
2.9 \mathrm{E}-4 \\
\end{array}$ & $\begin{array}{l}4.3 \mathrm{E}-7 \\
5.4 \mathrm{E}-8 \\
9.5 \mathrm{E}-8 \\
\end{array}$ & $\begin{array}{r}-\overline{-} \\
1.7 \mathrm{E}-3 \\
2.0 \mathrm{E}-3 \\
\end{array}$ & $\begin{array}{l}5.8 \mathrm{E}-13 \\
5.0 \mathrm{E}-10 \\
1.7 \mathrm{E}-9\end{array}$ & $\begin{array}{l}1.0 \mathrm{E}-1 \\
3.2 \mathrm{E}-3 \\
2.3 \mathrm{E}-3 \\
\end{array}$ \\
\hline & Al1 & $\overline{1.0 \mathrm{E}-1}$ & $\overline{2.4 \mathrm{E}-5}$ & $\overline{3.7 \mathrm{E}-3}$ & $\overline{2.8 \mathrm{E}-9}$ & 1.1E-1 \\
\hline
\end{tabular}

(a) The dose from all radionuclides in the inventory is calculated and included in the total but only those radionuclides that contribute more than one percent of total from all pathways are listed.

(b) External radiation from contaminated ground.

(c) The time at which the dose rate peaks after the exposure starts.

Plus daughter radionuclides.

Dash indicates values less than $10^{-13} \mathrm{mrem} / \mathrm{year}$. 
Organ of Reference

Radionuclide (a)

Maximum Annual Dose, mrem via:

\begin{tabular}{|c|c|c|c|c|c|c|}
\hline & & Ingestion & Inhalation & Ground (b) & Air Submersion & All Pathways \\
\hline \multirow{2}{*}{$\begin{array}{l}\text { Thyroid } \\
\text { a } 1 \text { year (c) }\end{array}$} & $I-129$ & $2.4 \mathrm{E}+0$ & $1.1 \mathrm{E}-4$ & $1.7 \mathrm{E}-3$ & $6.8 \mathrm{E}-10$ & $2.4 \mathrm{E}+0$ \\
\hline & A11 & $\overline{2.4 E+0}$ & $\overline{1.1 E-4}$ & $\overline{2.2 E-3}$ & $7.3 E-9$ & $\overline{2.4 E+0}$ \\
\hline \multirow[t]{2}{*}{$\begin{array}{l}\text { Lung } \\
\text { a } 1 \text { year }\end{array}$} & $\begin{array}{l}I-129 \\
C s-137+d(d) \\
A m-241\end{array}$ & $\begin{array}{c}--(e) \\
1.0 E-5 \\
--\end{array}$ & $\begin{array}{l}4 .- \\
4.9 E-9 \\
3.4 E-5 \\
\end{array}$ & $\begin{array}{l}1.7 \mathrm{E}-3 \\
4.8 \mathrm{E}-4 \\
2.0 \mathrm{E}-5\end{array}$ & $\begin{array}{l}6.8 \mathrm{E}-10 \\
5.5 \mathrm{E}-10 \\
2.1 \mathrm{E}-11\end{array}$ & $\begin{array}{l}1.7 \mathrm{E}-3 \\
4.9 \mathrm{E}-4 \\
5.4 \mathrm{E}-5 \\
\end{array}$ \\
\hline & A11 & $1.0 \mathrm{E}-5$ & $6.5 E-5$ & $2.2 E-3$ & $\overline{1.3 \mathrm{E}-9}$ & $2.2 \mathrm{E}-3$ \\
\hline \multirow[t]{2}{*}{$\begin{array}{l}\text { Whole Body } \\
\text { a } 3 \text { years }\end{array}$} & $\begin{array}{l}\text { Sr }-90+d \\
I-129 \\
\text { Cs }-137+d\end{array}$ & $\begin{array}{l}4.7 \mathrm{E}-3 \\
3.0 \mathrm{E}-3 \\
5.7 \mathrm{E}-5 \\
\end{array}$ & $\begin{array}{l}5.1 \mathrm{E}-9 \\
1.0 \mathrm{E}-7 \\
1.9 \mathrm{E}-8 \\
\end{array}$ & $\begin{array}{l}1 . \overline{7}-3 \\
4.0 \mathrm{E}-4 \\
\end{array}$ & $\begin{array}{l}1.1 \mathrm{E}-13 \\
5.0 \mathrm{E}-10 \\
3.3 \mathrm{E}-10 \\
\end{array}$ & $\begin{array}{l}4.7 \mathrm{E}-3 \\
4.6 \mathrm{E}-3 \\
4.5 \mathrm{E}-4 \\
\end{array}$ \\
\hline & Aा1 & $7.8 \mathrm{E}-3$ & $1.0 \mathrm{E}-6$ & $2.1 E-3$ & $8.4 \mathrm{E}-10$ & $9.9 E-3$ \\
\hline \multirow[t]{2}{*}{$\begin{array}{l}\text { Bone } \\
\text { o } 3 \text { years }\end{array}$} & $\begin{array}{l}S r-90+d \\
I-129 \\
\text { Cs }-137+d\end{array}$ & $\begin{array}{l}1.9 \mathrm{E}-2 \\
1.6 \mathrm{E}-3 \\
5.8 \mathrm{E}-5 \\
\end{array}$ & $\begin{array}{l}8.1 \mathrm{E}-8 \\
5.4 \mathrm{E}-8 \\
1.9 \mathrm{E}-8 \\
\end{array}$ & $\begin{array}{l}1 .- \\
1.7 \mathrm{E}-3 \\
4.0 \mathrm{E}-4 \\
\end{array}$ & $\begin{array}{l}1.1 \mathrm{E}-13 \\
5.0 \mathrm{E}-10 \\
3.3 \mathrm{E}-10 \\
\end{array}$ & $\begin{array}{l}1.9 \mathrm{E}-2 \\
3.2 \mathrm{E}-3 \\
4.5 \mathrm{E}-4 \\
\end{array}$ \\
\hline & A11 & $\overline{2.0 E-2}$ & $\overline{2.0 \mathrm{E}-5}$ & $2.1 E-3$ & $\overline{8.4 E-10}$ & $\overline{2.3 \mathrm{E}-2}$ \\
\hline
\end{tabular}

(a) The dose from all radionuclides in the inventory is calculated and included in the total but only those radionuclides that contribute more than one percent of total from all pathways are listed.

(b) External radiation from contaminated ground.

(c) The time at which the dose rate peaks after the exposure starts.

(d) Plus daughter radionuclides.

(e) Dash indicates values less than $10^{-13} \mathrm{mrem} /$ year. 
TABLE D.2-3a. Maximum Annual Dose to Selected Organs of Reference

(Site Decommissioned at Shutdown - Conditional Use))

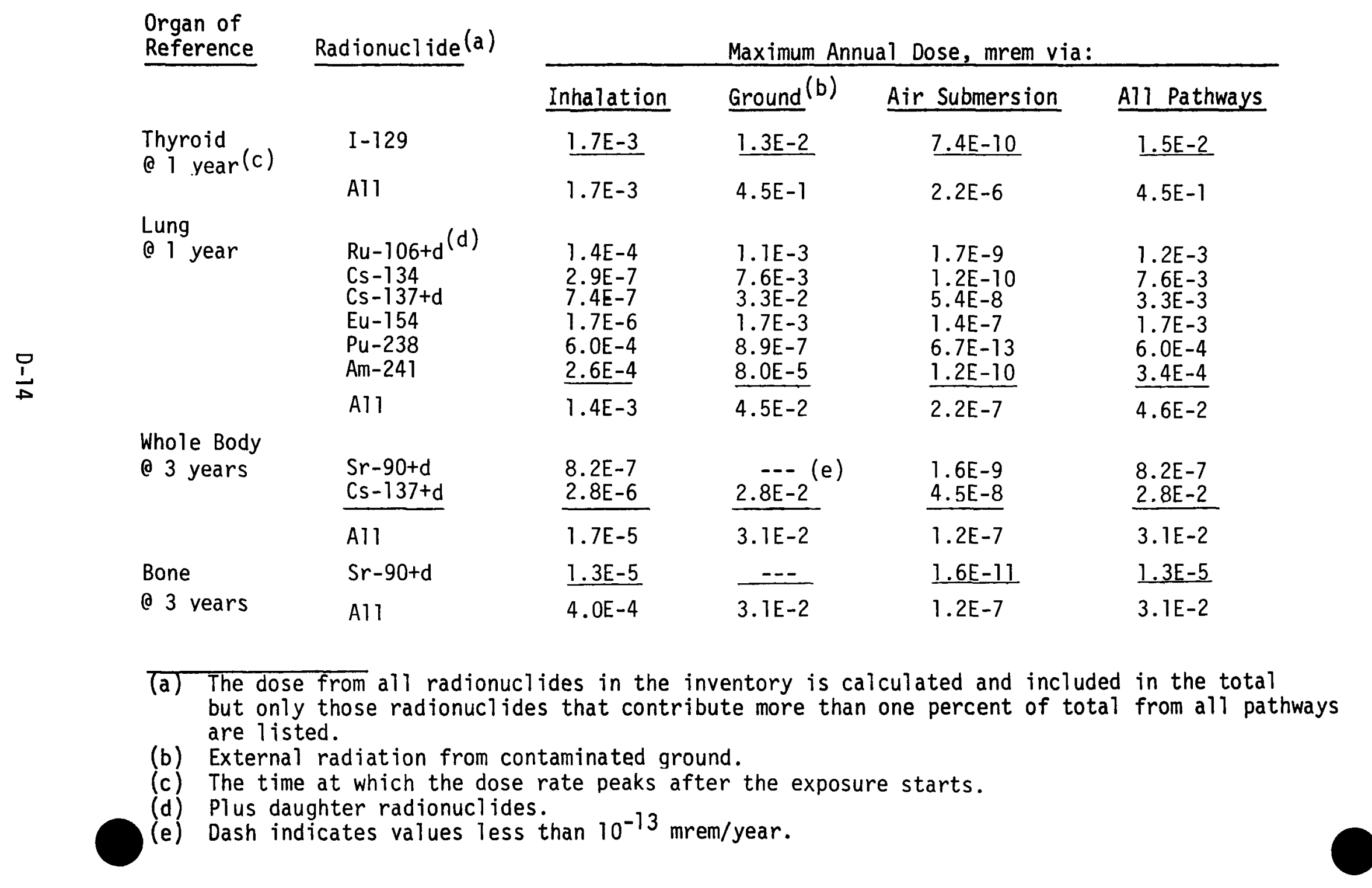


TABLE D.2-3b. Maximum Annual Dose to Selected Organs of Reference

(Site Decommissioned 10 Years After Shutdown - Conditional Use)

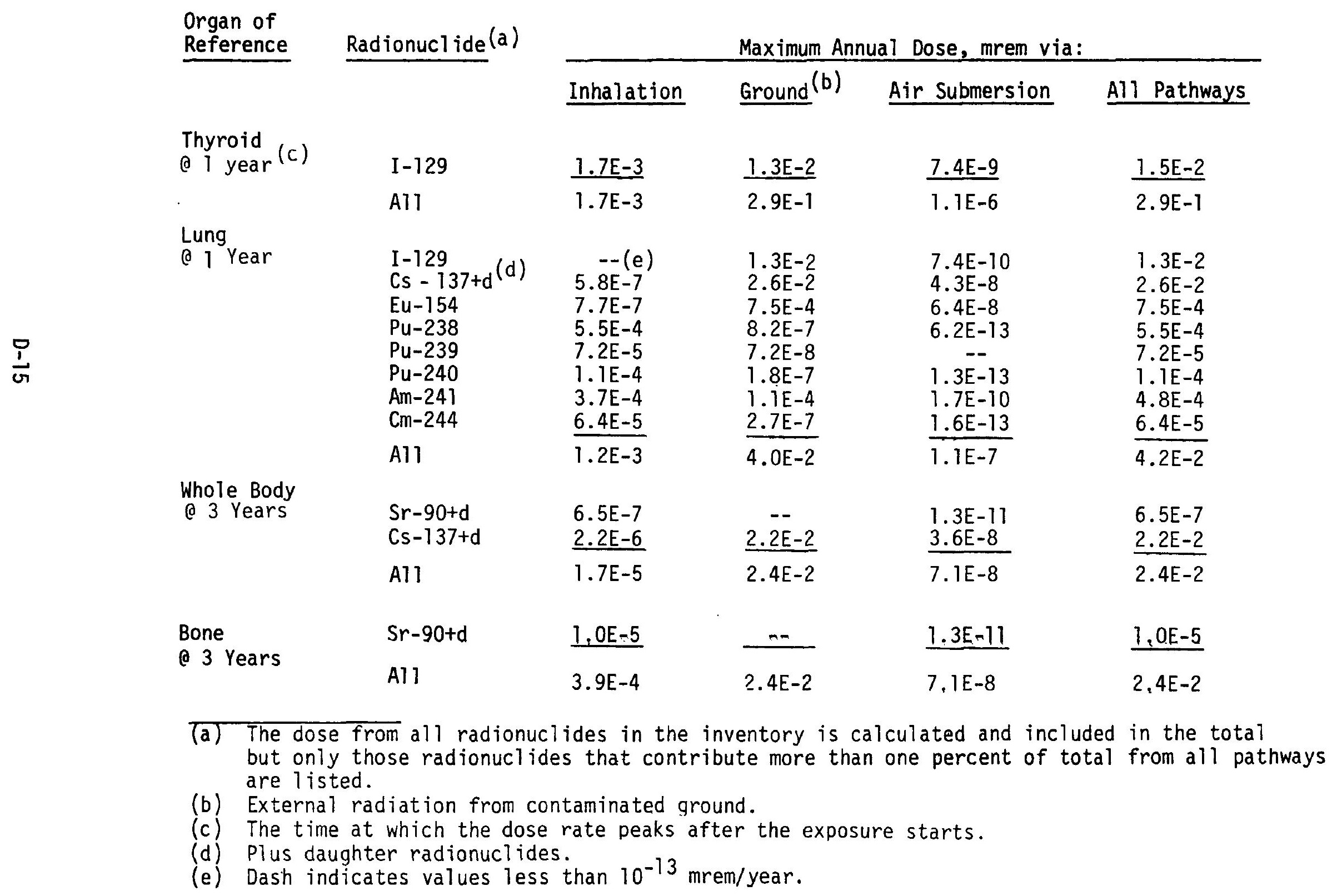




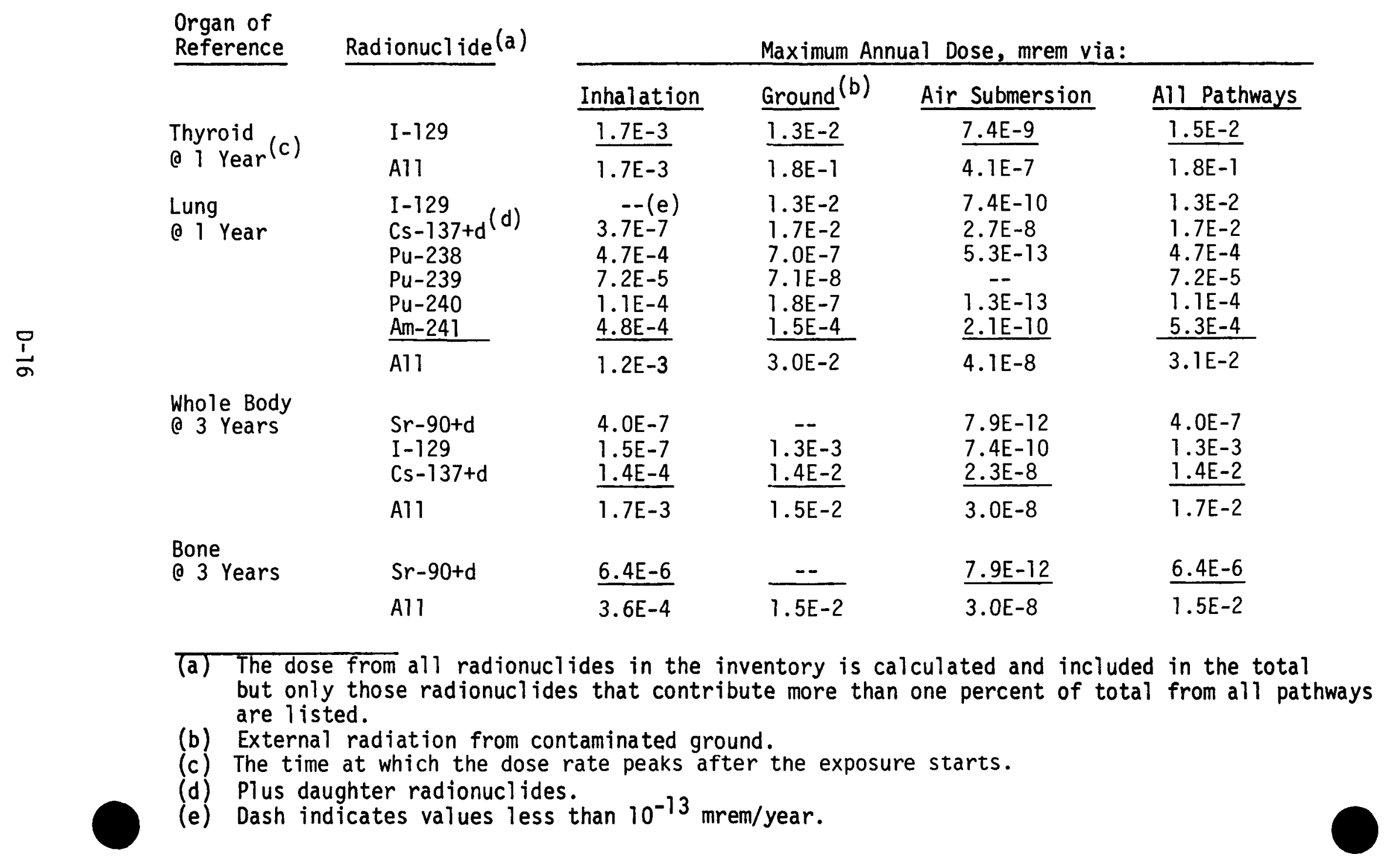




\begin{tabular}{|c|c|c|c|c|c|}
\hline \multirow[t]{2}{*}{$\begin{array}{l}\text { Organ of } \\
\text { Reference } \\
\end{array}$} & \multirow[t]{2}{*}{$\underline{\text { Radionuclide }}^{(a)}$} & \multicolumn{4}{|c|}{ Maximum Annual Dose, mrem via: } \\
\hline & & Inhalation & Ground $^{(b)}$ & Air Submersion & All Pathways \\
\hline \multirow{2}{*}{$\begin{array}{l}\text { Thyroid } \\
\text { a I Year (c) }\end{array}$} & $I-129$ & $\underline{1.7 \mathrm{E}-3}$ & $1.3 \mathrm{E}-2$ & $7.4 \mathrm{E}-9$ & $\underline{1.5 E-2}$ \\
\hline & Al1 & $1.7 E-3$ & $4.8 E-2$ & $6.4 E-8$ & $5.0 \mathrm{E}-2$ \\
\hline \multirow{3}{*}{$\begin{array}{l}\text { Lung } \\
\text { C I Year }\end{array}$} & & & & & \\
\hline & $\begin{array}{l}I-129 \\
C s-137+d(d) \\
P u-238 \\
P u-239 \\
P u-240 \\
\mathrm{Am}-241\end{array}$ & $\begin{array}{l}7 .-(e) \\
7.4 \mathrm{E}-8 \\
2.7 \mathrm{E}-4 \\
7.2 \mathrm{E}-5 \\
1.1 \mathrm{E}-4 \\
5.0 \mathrm{E}-4 \\
\end{array}$ & $\begin{array}{l}1.3 \mathrm{E}-2 \\
3.3 \mathrm{E}-3 \\
4.0 \mathrm{E}-7 \\
7.1 \mathrm{E}-8 \\
1.7 \mathrm{E}-7 \\
1.5 \mathrm{E}-4 \\
\end{array}$ & $\begin{array}{l}7.4 \mathrm{E}-10 \\
5.4 \mathrm{E}-9 \\
3.1 \mathrm{E}-13 \\
-\overline{-} \\
1.3 \mathrm{E}-13 \\
2.2 \mathrm{E}-10 \\
\end{array}$ & $\begin{array}{l}1.3 \mathrm{E}-2 \\
3.3 \mathrm{E}-3 \\
2.7 \mathrm{E}-4 \\
7.2 \mathrm{E}-5 \\
1.1 \mathrm{E}-4 \\
6.5 \mathrm{E}-4 \\
\end{array}$ \\
\hline & A11 & $9.6 E-4$ & $1.6 \mathrm{E}-2$ & $6.4 E-9$ & $1.7 E-2$ \\
\hline \multirow[t]{2}{*}{$\begin{array}{l}\text { Whole Body } \\
\text { o } 3 \text { Years }\end{array}$} & $\begin{array}{l}\text { Sr }-90+d \\
I-129 \\
\text { Cs }-137+d\end{array}$ & $\begin{array}{l}7.5 E-8 \\
1.5 E-7 \\
2.8 E-7 \\
\end{array}$ & $\begin{array}{c}-\overline{-} \\
1.3 E-3 \\
2.8 E-3 \\
\end{array}$ & $\begin{array}{l}1.5 \mathrm{E}-12 \\
7.4 \mathrm{E}-10 \\
4.5 \mathrm{E}-9 \\
\end{array}$ & $\begin{array}{l}7.5 E-8 \\
1.3 E-3 \\
2.8 E-3 \\
\end{array}$ \\
\hline & A11 & $1.4 \mathrm{E}-5$ & $4.2 E-3$ & $5.5 E-9$ & $4.2 E-3$ \\
\hline \multirow[t]{2}{*}{$\begin{array}{l}\text { Bone } \\
\text { a } 3 \text { Years }\end{array}$} & $S r-90+d$ & $1.2 \mathrm{E}-4$ & -- & $1.5 \mathrm{E}-12$ & $1.2 \mathrm{E}-4$ \\
\hline & A11 & $2.9 E-4$ & $4.2 E-3$ & $5.5 E-9$ & $4.5 \mathrm{E}-3$ \\
\hline \multicolumn{6}{|c|}{$\begin{array}{l}\text { (a) The dose from all radionuclides in the inventory is calculated and included in the total } \\
\text { but only those radionuclides that contribute more than one percent of total from all pathways } \\
\text { are } 1 \text { isted. } \\
\text { (b) External radiation from contaminated ground. } \\
\text { (c) The time at which the dose rate peaks after the exposure starts. } \\
\text { (d) Plus daughter radionuclides. } \\
\text { (e) Dash indicates values } 7 \text { ess than } 10^{-13} \mathrm{mrem} / \text { year. }\end{array}$} \\
\hline
\end{tabular}


TABLE D.2-4a. Normal ized Maximum Annual Dose to Selected Organs of Reference (Facility Decommissioned at Shutdown)

Organ of
Reference

\begin{tabular}{|c|c|c|c|}
\hline Inhalation & Floor (b) & Air Submersion & All Pathways \\
\hline $\begin{array}{l}2.3 \mathrm{E}-3 \\
6.5 \mathrm{E}-2 \\
4.5 \mathrm{E}-4 \\
3.8 \mathrm{E}-2 \\
1.5 \mathrm{E}+0 \\
6.9 \mathrm{E}-2 \\
\end{array}$ & $\begin{array}{l}3.1 \mathrm{E}-2 \\
5.6 \mathrm{E}-1 \\
3.7 \mathrm{E}-2 \\
4.7 \mathrm{E}-6 \\
1.3 \mathrm{E}-2 \\
2.1 \mathrm{E}-5 \\
\end{array}$ & $\begin{array}{l}4.0 \mathrm{E}-5 \\
7.6 \mathrm{E}-4 \\
2.6 \mathrm{E}-3 \\
3.0 \mathrm{E}-9 \\
1.6 \mathrm{E}-5 \\
1.1 \mathrm{E}-8 \\
\end{array}$ & $\begin{array}{l}3.3 \mathrm{E}-2 \\
6.2 \mathrm{E}-1 \\
4.0 \mathrm{E}-2 \\
3.8 \mathrm{E}-2 \\
1.5 \mathrm{E}+0 \\
6.9 \mathrm{E}-2 \\
\end{array}$ \\
\hline $1.7 E+0$ & $6.4 \mathrm{E}-1$ & $3.7 E-3$ & $2.4 E+0$ \\
\hline
\end{tabular}

Thyroid

a 1 year

Whole Body
o 8 years $(c)$

$\mathrm{Cs}-134$
$\mathrm{Cs}-137+\mathrm{d}$
$\mathrm{Eu}-154$
$\mathrm{Pu}-238$
$\mathrm{Am}-241$
$\mathrm{Cm}-244$
$\mathrm{~A} 11$

$\mathrm{Ru}-106+\mathrm{d}$

Cs-134

Cs $-137+d$

Ce-144+d

Eu-154

Am-241

$-\ldots(\mathrm{e})$

$6.7 \mathrm{E}-2$

$1.2 \mathrm{E}-4$

$6.1 \mathrm{E}-2$

-- $3.2 \mathrm{E}-1$

-- $6.6 \mathrm{E}-1$

$5.8 \mathrm{E}-4$

$3.2 \mathrm{E}-1$

-- $\quad 1.3 \mathrm{E}-2$

1.2E-3

$6.6 \mathrm{E}-1$

-- $\quad 6.6 \mathrm{E}-2$

2. $8 \mathrm{E}-5$

1. $3 \mathrm{E}-2$

$--$

A1 1

$1.3 \mathrm{E}-2$

$6.4 \mathrm{E}-3$

$7.2 \mathrm{E}-2$

$2.2 \mathrm{E}-5$

$1.3 \mathrm{E}-2$

$8.7 \mathrm{E}-3$

$1.2 \mathrm{E}+0$

Lung

a 1 year

Sr-90+d

$\mathrm{Ru}-106+\mathrm{d}$

1. $4 \mathrm{E}+0$

$1.1 \mathrm{E}+0$

$3.8 \mathrm{E}-7$

1. $4 \mathrm{E}+0$

$\mathrm{Pu}-238$

$6.6 \mathrm{E}-1$

6.]E-2

$1.2 \mathrm{E}-4$

7.2E-1

$\mathrm{Pu}-240$

4.1E+0

5. $0 \mathrm{E}-6$

4. $4 \mathrm{E}-9$

$4.1 \mathrm{E}+0$

Am-241

9. $6 \mathrm{E}-1$

$1.2 \mathrm{E}-6$

$1.0 \mathrm{E}-9$

9.6E-1

Cm-244

$5.3 E+7$

$1.3 \mathrm{E}-2$

2. $2 \mathrm{E}-5$

$5.3 \mathrm{E}+1$

$\underline{7.1 E+0}$

$1.9 \mathrm{E}-8$

$7.1 E+0$

A1 1

$6.9 \mathrm{E}+1$

$8.7 \mathrm{E}-3$

$7.0 \mathrm{E}+1$

Bone

(a) 32 years

Pu-238

$1.4 \mathrm{E}+0$

$1.1 E+0$

2.5E-9

$1.4 \mathrm{E}+0$

$\mathrm{Pu}-240$

1. $2 \mathrm{E}+0$

$3.9 \mathrm{E}-6$

7. $6 \mathrm{E}-10$

$1.2 E+0$

Am-241

$\underline{4.7 E+1}$

$\frac{1.5 \mathrm{E}-5}{1.0 \mathrm{E}-3}$

$4.7 \mathrm{E}+1$

A1 1

$5.1 \mathrm{E}+1$

$\frac{1.2 \mathrm{E}-2}{3.4 \mathrm{E}-1}$

$5.1 \mathrm{E}+1$

\footnotetext{
(a) The dose includes contributions from all radionuclides in the source term but only those radionuclides contributing more than one percent of the total are list

(b) External radiation from contaminated floor.

(c) The time at which the dose rate peaks after the exposure starts.

(d) Plus daughters

(e) Dash indicates values less than $10^{-10} \mathrm{mrem} /$ year.
} 
TABLE D.2-4b. Normalized Maximum Annual Dose to Selected Organs of Reference (Facility Decommissioned 10 Years After Shutdown)

Maximum Annual Dose, mrem per $\mu \mathrm{Ci} / \mathrm{m}^{2}$ via:

\begin{tabular}{|c|c|c|c|c|c|}
\hline \multirow[b]{2}{*}{$\begin{array}{l}\text { nole Body } \\
10 \text { years }(c)\end{array}$} & & Inhalation & Floor(b) & Air Submersion & All Pathways \\
\hline & $\begin{array}{l}\mathrm{Cs}-137+d(\mathrm{~d}) \\
\mathrm{Pu}-238 \\
\mathrm{Am}-241 \\
\mathrm{Cm}-244\end{array}$ & $\begin{array}{l}5.0 \mathrm{E}-2 \\
3.6 \mathrm{E}-2 \\
1.5 \mathrm{E}+0 \\
4.4 \mathrm{E}-2 \\
\end{array}$ & $\begin{array}{l}4.3 \mathrm{E}-1 \\
4.3 \mathrm{E}-6 \\
1.3 \mathrm{E}-2 \\
1.4 \mathrm{E}-5 \\
\end{array}$ & $\begin{array}{l}5.8 \mathrm{E}-4 \\
2.7 \mathrm{E}-9 \\
1.6 \mathrm{E}-5 \\
6.8 \mathrm{E}-9 \\
\end{array}$ & $\begin{array}{l}4.8 \mathrm{E}-1 \\
3.6 \mathrm{E}-2 \\
1.6 \mathrm{E}+0 \\
4.4 \mathrm{E}-2 \\
\end{array}$ \\
\hline \multirow[b]{2}{*}{$\begin{array}{l}\text { hyroid } \\
1 \text { yedr }\end{array}$} & Al1 & $1.7 E+0$ & $4.6 \mathrm{E}-1$ & $1.8 \mathrm{E}-3$ & $2.2 E+0$ \\
\hline & $\begin{array}{l}\text { Cs }-134 \\
\text { Cs }-137+d \\
\text { Eu-154 } \\
\text { Am-241 }\end{array}$ & $\begin{array}{l}--(e) \\
-- \\
-- \\
-- \\
\end{array}$ & $\begin{array}{l}1.2 \mathrm{E}-2 \\
5.3 \mathrm{E}-1 \\
2.9 \mathrm{E}-2 \\
1.3 \mathrm{E}-2 \\
\end{array}$ & $\begin{array}{l}2.1 \mathrm{E}-5 \\
9.9 \mathrm{E}-4 \\
2.9 \mathrm{E}-3 \\
2.2 \mathrm{E}-5 \\
\end{array}$ & $\begin{array}{l}1.2 \mathrm{E}-2 \\
5.3 \mathrm{E}-1 \\
3.2 \mathrm{E}-2 \\
1.3 \mathrm{E}-2 \\
\end{array}$ \\
\hline \multirow[b]{2}{*}{${ }_{1}^{\text {ung }}$ year } & A11 & $1.2 \mathrm{E}-8$ & $5.8 \mathrm{E}-1$ & $4.2 E-3$ & $\overline{5.9 \mathrm{E}-1}$ \\
\hline & $\begin{array}{l}\mathrm{Sr}-90+\mathrm{d} \\
\mathrm{Pu}-238 \\
\mathrm{Pu}-240 \\
\mathrm{Am}-247 \\
\mathrm{Cm}-244\end{array}$ & $\begin{array}{l}1.1 \mathrm{E}+0 \\
3.8 \mathrm{E}+0 \\
9.6 \mathrm{E}-1 \\
5.3 \mathrm{E}+1 \\
4.9 \mathrm{E}+0 \\
\end{array}$ & $\begin{array}{l}4 .- \\
4.6 \mathrm{E}-6 \\
1.2 \mathrm{E}-6 \\
1.3 \mathrm{E}-2 \\
1.9 \mathrm{E}-5 \\
\end{array}$ & $\begin{array}{l}3.1 \mathrm{E}-7 \\
4.0 \mathrm{E}-9 \\
1.0 \mathrm{E}-9 \\
2.2 \mathrm{E}-5 \\
1.3 \mathrm{E}-8 \\
\end{array}$ & $\begin{array}{l}1.1 \mathrm{E}+0 \\
3.8 \mathrm{E}+0 \\
9.6 \mathrm{E}-1 \\
5.3 \mathrm{E}+1 \\
4.9 \mathrm{E}+0 \\
\end{array}$ \\
\hline \multirow{3}{*}{$\begin{array}{l}\text { one } \\
33 \text { years }\end{array}$} & A11 & $6.5 \mathrm{E}+1$ & $5.8 \mathrm{E}-1$ & $4.2 E-3$ & $6.5 \mathrm{E}+1$ \\
\hline & $\begin{array}{l}\mathrm{Pu}-238 \\
\mathrm{Pu}-240 \\
\mathrm{Am}-241\end{array}$ & $\begin{array}{l}1.3 \mathrm{E}+0 \\
1.2 \mathrm{E}+0 \\
4.7 \mathrm{E}+1 \\
\end{array}$ & $\begin{array}{l}3.6 \mathrm{E}-6 \\
1.2 \mathrm{E}-6 \\
1.2 \mathrm{E}-2 \\
\end{array}$ & $\begin{array}{l}2.3 \mathrm{E}-9 \\
7.6 \mathrm{E}-10 \\
1.5 \mathrm{E}-5 \\
\end{array}$ & $\begin{array}{l}1.3 \mathrm{E}+0 \\
1.2 \mathrm{E}+0 \\
4.7 \mathrm{E}+1 \\
\end{array}$ \\
\hline & All & $5.1 E+1$ & $2.7 \mathrm{E}-1$ & $7.1 \mathrm{E}-4$ & $5.1 \mathrm{E}+1$ \\
\hline
\end{tabular}

1) The dose includes contributions from all radionuclides in the source term but only those radionuclides contributing more than one percent of the total are listed

)) External radiation from contaminated floor.

:) The time at which the dose rate peaks after the exposure starts.

1) us daughters

?) Uash indicates values less than $10^{-10} \mathrm{mrem} / \mathrm{year}$. 
TABLE D.2-4c. Normalized Maximum Annual Dose to Selected Organs of Reference (Facility Decommissioned 30 Years After Shutdown)

Organ of Reference $\underline{\text { Radionuclide }}^{(a)}$

Maximum Annual Dose, mrem per $\mu \mathrm{Ci} / \mathrm{m}^{2}$ via:

\begin{tabular}{|c|c|c|c|c|c|}
\hline & & Inhalation & Floor (b) & Air Submersion & All Pathways \\
\hline \multirow[t]{2}{*}{$\begin{array}{l}\text { Whole Body } \\
\text { a } 11 \text { years }(c)\end{array}$} & $\begin{array}{l}\mathrm{Cs}-137+\mathrm{d}(\mathrm{d}) \\
\mathrm{Pu}-238 \\
\mathrm{Am}-241 \\
\mathrm{Cm}-244\end{array}$ & $\begin{array}{l}3.0 \mathrm{E}-2 \\
3.1 \mathrm{E}-2 \\
1.5 \mathrm{E}+0 \\
1.9 \mathrm{E}-2 \\
\end{array}$ & $\begin{array}{l}2.6 \mathrm{E}-1 \\
3.6 \mathrm{E}-6 \\
1.3 \mathrm{E}-2 \\
5.9 \mathrm{E}-6 \\
\end{array}$ & $\begin{array}{l}3.7 \mathrm{E}-4 \\
2.3 \mathrm{E}-9 \\
1.5 \mathrm{E}-5 \\
3.0 \mathrm{E}-9 \\
\end{array}$ & $\begin{array}{l}2.9 \mathrm{E}-1 \\
3.1 \mathrm{E}-2 \\
1.5 \mathrm{E}+0 \\
1.9 \mathrm{E}-2 \\
\end{array}$ \\
\hline & Al1 & $1.6 \mathrm{E}+0$ & $2.8 \mathrm{E}-1$ & $7.5 \mathrm{E}-4$ & $1.9 E+0$ \\
\hline \multirow[t]{2}{*}{$\begin{array}{l}\text { Thyroid } \\
\text { a } 1 \text { yeár }\end{array}$} & $\begin{array}{l}\text { Cs }-137+d \\
E u-154 \\
A m-241\end{array}$ & $\begin{array}{l}--(e) \\
-- \\
--\end{array}$ & $\begin{array}{l}3.3 \mathrm{E}-1 \\
6.1 \mathrm{E}-3 \\
1.3 \mathrm{E}-2\end{array}$ & $\begin{array}{l}6.7 \mathrm{E}-4 \\
5.9 \mathrm{E}-4 \\
2.1 \mathrm{E}-5 \\
\end{array}$ & $\begin{array}{l}3.3 \mathrm{E}-1 \\
6.7 \mathrm{E}-3 \\
1.3 \mathrm{E}-2 \\
\end{array}$ \\
\hline & Al1 & -- & $\overline{3.5 \mathrm{E}-1}$ & $1.5 \mathrm{E}-3$ & $3.5 E-1$ \\
\hline \multirow[t]{2}{*}{$\begin{array}{l}\text { Lung } \\
\text { a } 1 \text { year }\end{array}$} & $\begin{array}{l}\mathrm{Sr}-90+\mathrm{d} \\
\mathrm{Pu}-238 \\
\mathrm{Pu}-240 \\
\mathrm{Am}-241 \\
\mathrm{Cm}-244\end{array}$ & $\begin{array}{l}6.8 \mathrm{E}-1 \\
3.2 \mathrm{E}+0 \\
9.6 \mathrm{E}-1 \\
5.2 \mathrm{E}+1 \\
2.2 \mathrm{E}+0 \\
\end{array}$ & $\begin{array}{l}--- \\
3.9 \mathrm{E}-6 \\
1.2 \mathrm{E}-6 \\
1.3 \mathrm{E}-2 \\
8.7 \mathrm{E}-6 \\
\end{array}$ & $\begin{array}{l}1.9 E-7 \\
3.4 E-9 \\
1.0 E-9 \\
2.1 E-5 \\
6.0 E-9 \\
\end{array}$ & $\begin{array}{l}6.8 \mathrm{E}-1 \\
3.2 \mathrm{E}+0 \\
9.6 \mathrm{E}-1 \\
5.2 \mathrm{E}+1 \\
2.2 \mathrm{E}+0 \\
\end{array}$ \\
\hline & A11 & $6.0 \mathrm{E}+1$ & $\overline{3.5 \mathrm{E}-1}$ & $1.5 \mathrm{E}-3$ & $6.0 E+1$ \\
\hline \multirow[t]{2}{*}{$\begin{array}{l}\text { Bone } \\
\text { a } 34 \text { years }\end{array}$} & $\begin{array}{l}\mathrm{Pu}-238 \\
\mathrm{Pu}-240 \\
\mathrm{Am}-241\end{array}$ & $\begin{array}{l}1.1 \mathrm{E}+0 \\
1.2 \mathrm{E}+0 \\
4.6 \mathrm{E}+1 \\
\end{array}$ & $\begin{array}{l}3.0 \mathrm{E}-6 \\
1.2 \mathrm{E}-6 \\
1.2 \mathrm{E}-2 \\
\end{array}$ & $\begin{array}{l}1.9 \mathrm{E}-9 \\
7.6 \mathrm{E}-10 \\
1.5 \mathrm{E}-5 \\
\end{array}$ & $\begin{array}{l}1.1 \mathrm{E}+0 \\
1.2 \mathrm{E}+0 \\
4.6 \mathrm{E}+1 \\
\end{array}$ \\
\hline & A11 & $4.9 E+1$ & $1.7 \mathrm{E}-1$ & $4.2 \mathrm{E}-4$ & $5.0 E+1$ \\
\hline
\end{tabular}


TABLE D.2-4d. Normalized Maximum Annual Dose to Selected Organs of Reference (Facility Decommissioned 100 Years After Shutdown)

Irgan of

ieference Radionuclide (a

\section{Inhalation}

Cs $-137+d(d)$

$\mathrm{Pu}-238$

$\mathrm{Pu}-240$

Am-241

A11

Cs $-137+d$

Am-241

A 11

6.5E-3

1. $8 \mathrm{E}-2$

$2.1 \mathrm{E}-2$

$1.4 \mathrm{E}+0$

$1.4 \mathrm{E}+0$

\section{Max}

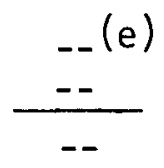

1. $9 \mathrm{E}+0$

9.6E-1

$4.7 E+1$

$5.1 \mathrm{E}+1$

$6.3 \mathrm{E}-1$

1. $2 \mathrm{E}+0$

$4.2 E+1$

$\mathrm{Pu}-238$

$\mathrm{Pu}-240$

Am-241

Al 1

$4.4 \mathrm{E}+1$

\begin{tabular}{l}
$5.6 \mathrm{E}-2$ \\
$2.0 \mathrm{E}-6$ \\
$1.2 \mathrm{E}-6$ \\
$1.1 \mathrm{E}-2$ \\
\hline $6.8 \mathrm{E}-2$
\end{tabular}

7.6E-2

$\frac{1.1 E-2}{8.8 E-2}$

8.8E-2

\section{2. $3 \mathrm{E}-6$}

1. $2 \mathrm{E}-6$

$1.1 \mathrm{E}-2$

8. $8 \mathrm{E}-2$

1.7E-6

$1.2 \mathrm{E}-6$

$1.1 \mathrm{E}-2$

$4.5 \mathrm{E}-2$
Air Submersion

\begin{tabular}{l}
$7.6 \mathrm{E}-5$ \\
$1.3 \mathrm{E}-9$ \\
$7.6 \mathrm{E}-10$ \\
$1.4 \mathrm{E}-5$ \\
\hline $2.2 \mathrm{E}-4$
\end{tabular}

\begin{tabular}{l}
$1.4 E-4$ \\
$1.9 E-5$ \\
\hline $3.6 E-4$
\end{tabular}

2. $0 \mathrm{E}-9$

1. $0 \mathrm{E}-9$

$1.9 \mathrm{E}-5$

$3.6 \mathrm{E}-4$

1.1E-9

7. $6 \mathrm{E}-10$

$\frac{1.3 \mathrm{E}-5}{1.8 \mathrm{E}-4}$
All Pathways

6. $3 E-2$

$1.8 \mathrm{E}-2$

2.1E-2

$1.4 E+0$

1. $5 \mathrm{E}+0$

7.6E-2

$\frac{1.1 \mathrm{E}-2}{8.8 \mathrm{E}-2}$

1. $9 \mathrm{E}+0$

$9.6 \mathrm{E}-1$

$\frac{4.7 E+1}{5.7 E+1}$

6.3E-1

1. $2 \mathrm{E}+0$

$\frac{4.2 \mathrm{E}+1}{4.4 \mathrm{E}+1}$

$T$ The dose includes contributions from all radionuclides in the source term but only those radionuclides contributing more than one percent of the total are 1 isted.

1) External radiation from contaminated floor.

) time at which the dose rate peaks after the exposure starts.

1) Trus daughters

) Dash indicates values less than 10-10 mrem/year. 


\section{REFERENCES}

1. U. S. Nuclear Regulatory Commission, Termination of Operating Licenses for Nuclear Reactors. Regulatory Guide 1.86, June 1974.

2. U. S. Nuclear Regulatory Commission, Guidelines for Decontamination of Facilities and Equipment Prior to Release for Unrestricted Use or Termination of Licenses for Byproduct, Source or Special Nuclear Material, November 1976.

3. Code of Federal Regulations, Title 10, Part 49, "Transportation," Superintendent of Documents, GPO, Washington, DC 20555, 1976.

4. U. S. Energy Research and Development Administration, "Prevention Control and Abatement of Air and Water Pollution " U. S. ERDA Manual, Chapter 0510, Apri1 2, 1975.

5. J. W. Healy, A Proposed Interim Standard for Plutonium in Soils, LA-5483-MS, Los Alamos Scientific Laboratory, Los A7amos, NM, January, 1974.

6. C. E. Guthrie and J. P. Nichols, Theoretical Possibilities and Consequences of Major Accidents in $233 \mathrm{U}$ and ${ }^{239} \mathrm{Pu}$ Fuel Fabrication and Radioisotope Processing PTants, ORNL-3447, Oak Ridge National Laboratory, Oak Ridge, TN 37830, April 1964.

7. A. J. Hazle and Bert L. Crist, Colorado's Plutonium-in-Soil Standard, Colorado Department of Health, Óccupational and Radiological Health Division, Denver, C0, 1975.

8. ANSI Standard N328 (Draft) Control of Radioactive Surface Contamination on Materials, Equipment and Facilities to be Released for Uncontrolled Use, 1976

9. "Recommendations of the International Commission on Radiological Protection," ICRP Publication 9, Pergamon Press, London, 1966.

10. Surgeon General, U. S. Public Health Service, Surgeon General's Guidelines, "Use of Uranium Mill Tailings for Constructive Purposes." Hearings before the Subcommittee on Raw Materials of the Joint Committee on Atomic Energy, October 28 and 29, 1971, pp. 52-54, 1971.

11. Code of Federal Regulations, Title 10, Part 50, Appendix I, "Licensing of Production and Utilization Facilities," Superintendent of Documents, GP0, Washington, DC 20555, 1976.

12. Federal Guidance for the Environmental Limits of Plutonium Contamination in Soils (Draft), Environmental Protection Agency, 1976

13. Code of Federal Regulations, Title 40, Part 190, "Environmental Radia tion Protection Standards for Nuclear Power Operations," Superintendent of Documents, GPO, Washington, DC 20555, January 1977. 
APPENDIX E

\section{DECOMMISSIONING MODE DETAILS}

The details presented in this appendix are intended to amplify information presented in Section 7.0 of Volume 1. For ease of reference, the second digit of the sub-appendix number matches with the second digit of the corresponding subsection in Volume 1 (e.g. E.1 and 7.1 both deal with activities in the planning and preparation phase, E.2 and 7.2 cover decontamination methods, E. 3 and 7.3 describe the dismantlement mode, etc.).

\section{E.1 QUALITY ASSURANCE PROGRAM}

To meet the Quality Assurance (QA) regulations imposed upon it, this complex project requires QA planning from the earliest stages. As each detailed procedure is developed, the QA needs are included. A review of QA functions for decommissioning is presented below.

\section{- Methods Review}

Whenever a decommissioning procedure is written, peer reviews of the procedures are made and documented. The reviews assure that the planning includes suitable controls for application to physics, radiation, safety, accident, security, thermal, stress, $Q A / Q C$, and hydraulic analyses. The controls include other checks, tests, and formal design reviews as necessary. Other aspects of planning which are reviewed are reliability criteria, the choice of test methods, and the choice of processes or materials. Also receiving documented review is the margin of safety established for procedures, equipment, or structures.

\section{- Procurement Document Control}

The project's suppliers, including the fixed-price contractors and the shipping cask vendors, are selected from a list of qualified suppliers. QA inspections of the vendor's plant may be needed to place new firms on the qualified list. 
Procurement Document Control is a QA procedure to verify that any QA requirements for specified hardware or services are identified in procurement documents or purchase orders. This includes references to applicable drawings, specifications, standards, codes, regulations, required records, test data, certifications, and qualifications of personnel or procedures. Special handling, shipping, or packaging requirements are also identified to vendors. This control is applied to any supplier of the specific devices and equipment vital to the project, such as environmental monitoring equipment, safety and shielding devices, radiation detection equipment, chemicals, and explosives.

- Work Instructions, Procedures, and Drawings

This QA requirement establishes formal documentation of work instructions, procedures, and drawings, and sets the sequence of action for preparation, review, approval, and control of information. The persons responsible for the work sequences are clearly identified. This QA procedure assures that the latest revision of drawings, plans and work instructions are at each work place. Changes in the decommissioning procedures receive equivalent scrutiny and QA approval as original planning.

- Document Control

Document control verifies that all essential documentation receives review, approval, release, change and distribution control. QA procedures will be set up to purge the system of obsolete or erroneous information.

- Identification and Control of Procured Items

This QA procedure establishes a program of supplier source inspection for vendors of critical items. (Also see the Inspection and Test Section.) Records, such as certification of conformance, are required from vendors to show they meet the QA requirements. This procedure also assures that purchased materials or items are inspected on receipt. Items must be sufficiently identified to allow proper identification for use or segregation of nonconforming items. The shelf life of chemicals must be clearly stated.

- Special Processes

These controls apply to unusual work procedures. This decommissioning project has several tasks in this category; for example, large-scale chemical 
decontamination work and the use of explosive charges. Special provisions are made to identify and control any unusual processes using reviews and audits.

\section{- Inspection and Test}

These are requirements assuring that all items produced for the project are properly inspected or verified. Inspections in the vendor's plant may be necessary for some items. Adequate inspection instructions are prepared, and inspection records are prepared and retained.

Verification QA procedures assure inspection of each essential decommissioning operation as well.

- Calibration

A11 measurements require the use of properly calibrated equipment. Therefore, a $Q A$ system of calibration control is used to assure instrument reading validity. The accuracy requirements and tolerances for the project measurements are identified. The prime example of equipment with calibration requirements is radiation monitoring devices. Instruments that monitor vital services will probably have calibration procedures already in place. For this equipment, the existing $Q A$ calibration needs are maintained.

- Shipping and Receiving

These $Q A$ procedures identify special instruction for handling, packaging, shipping, receiving, storing and marking of components for decommissioning. Included are radioactive shipments that require written QA procedures for each package type, specifying all steps in the package inspection, preparation, loading, and closing. Signed check lists are used. Package seals must be carefully verified on contaminated units for which no additional outside packaging is used.

\section{- Operating Status}

Sufficient $Q A$ identification must be applied to prevent the inadvertent operation of systems no longer functional, or the use of discrepant items. Restricted use may be necessary in many cases, such as pumps, which may not have been fully removed from service. Nonconformances are identified, and the records are retained as part of the project records. 
- Special Quality Assurance Records

A QA index of records and their required retention periods is maintained. These records include operating logs, results of reviews, inspections, tests, audits, material analyses, monitoring or work performance, records of orientation, training and qualifications of personnel, procedures, drawings, specifications, criteria documents, procurement documents, shipping records, nonconformance and corrective action reports, and audit reports. Extensive records or dose rate surveys are needed.

- Quality Auditing

Regular audits verify that each of the QA procedures is being followed. Examples include witnessing radioactive shipments, calibration audits, verification that the correct procedures were used, vendor inspections, receiving and storage inspections, and audits for complete QA procedures and record retention.

\section{E.2 DECONTAMINATION METHODS}

There are currently a number of techniques available for removing radioactive contamination from the: surfaces of process equipment and facility structures. Most techniques can be placed in one of two categories: mechanical or chemical decontamination. The subsections below describe the methods used in this study for decontaminating the facility.

\section{E.2.1 Chemical Decontamination Techniques}

A variety of flush chemicals and sequences of flushes have proved effective in removing contamination from chemical separations plants. Those used in this study are discussed in the following subsections.

\section{E.2.1.1 Internal Chemical Decontamination of Equipment}

The procedure presented below is typical of those used to flush the internals of process equipment.

1. Install temporary directional gamma detectors at strategic locations in each process area. These detectors should be capable of remote positioning and providing capability for spectrographic analysis. 
2. Conduct a remote survey of the process cells with the directional gamma detectors to establish pre-flush radiation levels and gamma spectra.

3. Mix the required solutions in the central decontamination system tanks.

4. Make the temporary connections necessary to introduce the solutions into the process equipment.

5. Introduce a $50 \% \mathrm{HNO}_{3}$ solution at $80^{\circ} \mathrm{C}$ into the system in the sequence presented in the protective storage plan.

6. Activate air sparging and recirculation systems and carry out the flush. Digest the flush within the vessels a minimum of 4 hours. Operate vessel equipment such as puisers, pumps, jets, instrument pipes, etc., to provide good contact with the solutions. (Thirty minutes is sufficient for water flushes.)

7. Sample the decontamination solution at existing sample points at regular intervals during the flush. Analyze the solution for dissolved contaminants. Monitor the vessel and appurtenances with the directional gamma detectors.

8. When the flush has achieved maximum results, remove the solution to the high-level or intermediate-level waste concentrator, concentrate $i t$, and send it to the tank farm.

9. Conduct a similar flush with water at $80^{\circ} \mathrm{C}$ to remove remaining decontamination solution. Concentrate this material and send it to the tank farm.

10. Introduce a solution of $20 \% \mathrm{NaOH}-2 \%$ tartaric acid at $80^{\circ} \mathrm{C}$ into the system and repeat steps 2 and 6-9. (This solution removes selected elements such as zirconium and niobium that resist acid flushes.)

11. Introduce a solution of $3 \% \mathrm{HF}-20 \% \mathrm{HNO}_{3}$ at $80^{\circ} \mathrm{C}$ into the system and repeat steps 2 and 6-9. This solution is corrosive to stainless steel and should remove most residual contamination. Because of its corrosiveness, the flushing times should be shorter than with other chemical decontaminating agents.

12. Repeat step 9. 
These procedures will normally clean the internals of the process equipment in most areas. There may be some areas which require additional treatments. The methods used in these areas will depend on the particular circumstances encountered. Some procedures which might be used are given below:

A. If the spectrographic data indicate the presence of ruthenium isotopes, a solution of $4 \% \mathrm{KMnO}_{4}-1 \% \mathrm{NaOH}$ may be used.

B. A solution of $0.025 \mathrm{M} \mathrm{KF}-0.1 \mathrm{M} \mathrm{AlNO}_{3}$ may be added to remove plutonium and silicate deposits that result from the use of technical grade process chemicals.

C. Many sludge deposits may be removed by the addition of $20 \% \mathrm{HNO}_{3}-6 \% \mathrm{AlF}_{3}$.

D. A solution of $5 \%$ oxalic acid- $3 \% \mathrm{HNO}_{3}$ at $60^{\circ} \mathrm{C}$ is effective for removing $\mathrm{MnO}_{2}$ and some residual fission products. This solution might be used in areas where the corrosive effects of $\mathrm{HF}-\mathrm{HNO}_{3}$ are not desirable.

It is estimated that chemical decontamination of the process equipment and process cells will generate about $1.14 \times 10^{6}$ liters $(300,000$ gal) of contaminated solutions. The volume of this waste will be reduced on the plant's waste storage system for eventual solidification and disposal. The volume of waste transferred to the liquid waste storage system is estimated to be 380,000 liters $(100,000$ gal $)$.

Flushing of the internals of process piping is done using similar procedures, but by flowing the solutions through the pipes.

\section{E.2.1.2 Chemical Decontamination of Cel1 Walls and External Surfaces of Equipment}

Decontamination of the cell walls and external surfaces of the process equipment typically begins with the introduction of a $50 \% \mathrm{HNO}_{3}$ solution, first through the mist system and then through rotating high pressure sprayers. After a hot water or steam spray flush, a short $3 \% \mathrm{HF}-20 \% \mathrm{HNO}_{3}$ solution is introduced by the dual spraying system, also followed rapidly by several hot water flushes. This basic flush sequence is repeated as necessary. Following the final water flush, the sumps are flushed with $\mathrm{HNO}_{3}$ and water, and the cells are allowed to dry. The decontamination solution collected from these 
Derations is concentrated and transferred to the waste storage tank farm. Information from the gamma detectors determine if other external flushes are desired.

\section{E.2.1.3 Other Surface Cleaning Procedures}

Removal of contamination from sealed surfaces such as painted walls and floors, tank exteriors, etc., can be accomplished using a variety of techniques. For small quantities of loose contamination on floors, simple granular sweeping compounds can be effective. For more tenacious contaminants, various cleansing compounds can be utilized. Several proprietary decontamination solutions are available. Ordinary household detergents are effective but produce sizable quantities of waste water to process and cause foaming during concentration. Aerosol-type foaming cleansers can be effective and do not require large volumes of waste water, but their use produces sizable quantities of contaminated wiping material to dispose of.

Variable pressure, high velocity water jets can be used effectively for some types of surface decontamination work. The devices can be operated by one man, at pressures up to 300 atmospheres (4500 psig), using a hand-held jet lance. On those surfaces for which the water jet is effective, the jet is a rapid decontamination method. Its use produces significant volumes of contaminated waste water. This waste water volume can be reduced by recirculation.

If none of the above chemical techniques are successful in removing surface contamination, the most likely alternative is to mechanically remove the surface itself.

\section{E.2.2 Mechanical Decontamination Techniques}

Concrete surfaces throughout the facility will be contaminated to a depth of a few centimeters. These concrete surfaces cannot be cleaned chemically to unrestricted use levels. The surface materials must be removed mechanically and packaged for disposal.

Several criteria must be considered when selecting a mechanical decontamination method for a particular location. The method should facilitate ontrol of airborne contamination and minimize spread of contamination. The 
method should minimize the potential for personnel exposure, and the size and weight of removed materials must be controlled to facilitate packaging and shipping for disposal.

The various methods available for removal of concrete and steel are listed in Table E.2-1 together with the advantages and disadvantages of each. of particular interest are the explosives techniques for use on concrete walls, and the rock-splitting techniques for localized removal of concrete surfaces.

\section{E.2.2.1 Rock Splitting and Hammering}

The modified rock splitting tool described in Section E.3.6.2 is the principal device used in this study for removal of contaminated concrete surfaces. Use of this device permits localized removal of concrete surfaces at depths of 5 to 8 centimeters with no explosions and very 1 ittle dust. The principal source of dust is the drilling of the holes in the concrete into which the splitting tool is inserted. Use of one of the portable ventilation enclosures (Section E.3.6.4) will prevent scatter of any contaminated dust. When decontaminating wall surfaces, work should start at the top of the contaminated area, to prevent potential recontamination of the clean surface by falling dust or debris. The material removed will be packaged for disposal.

Electric or pneumatic hammers may also be used, particularly on floor surfaces. These devices have the disadvantage of creating significant quantities of dust and small fragments which might be difficult to contain during the operation and which might readily recontaminate the areas being cleaned.

\section{E.2.2.2 Mechanical Decontamination with Explosives}

The use of explosives has been demonstrated ${ }^{(1)}$ to be a very effective way to remove contaminated concrete. Placement of blasting mats (about $3 \mathrm{~m} \times 3.7 \mathrm{~m}$, weighing $1600 \mathrm{~kg}$ ) over the region being blasted prevents projectiles of debris from penetrating the confinement barriers. Fine fog sprays of water before, during, and after each explosion aid in settling the dust created by the blasts. Typical use of the fog spray has been from 1 minute before to about 15 minutes after blasting. While the blasting sequences are designed to minimize air pressure surges, attention must be given to the building 


\section{TABLE E.2-1 Concrete and Stee 1 Removal Methods}

Removal Method

Flame Cutting
Advantages

- Concrete, steel liner and reinforcing steel may be cut in one operation

- Fast cutting speed

- Adaptable for remote operation

- Adaptable for pivoted circumferential cutting

- Adaptable for cutting on irregular surfaces

- No vibration/shock

- Low noise level

- Controlled rate of material removal

Blasting

Thermic Lance

Core Boring and Rock Splitting
- Removal rate is high where adjacent material damage is not of concern

- Adaptable for cutting irregular surfaces

- Adaptable for remote operation

- Adaptable for the control of size and weight of material particles removed

- Selective removal of specific areas

- Cuts both concrete and steel without difficulty

- Fast "hole punching" speed

- Ideally suited for cutting irregular surfaces

- Remote operation is possible for up to approximately 3 meters

- No vibration/shock

- Low noise level

- Controlled rate of material removal

- Technique is proven and is used extensively in conventional mining operations

- Low noise level

- No toxic gases generated

- Water cooling minimizes airborne particulate material

- Moderate-to-slow cutting speeds

- Material removal rate is controlled
Disadvantages

- Generates copious quantities of toxic gases and smoke. Smoke could potentially spread gross contamination throughout contamination control envelope unless adequately controlled.

- Consumes large quantity of gas

- Requires a starter-hole made by a core drill to provide an outlet gas-flow path

- May cause vibrations and shocks (Vibrational control is possible by limiting maximum charge)

- Requires torch to cut reinforcing steel

- High noise level

- Generates moderate quantities of dust which must be controlled

- Generates moderate quantities of toxic gases and smoke. Smoke could potentially spread gross contamination throughout contamination control envelope unless adequately controlled.

- Requires need for rock jack to break out concrete sections

- Consumes large quantity of bottled oxygen

- Cutting through reinforcing steel or structural steel slows cutting speed and tears diamonds off core drill

- Requires additional operation of torch for reinforcing steel

- Cooling water is required for drilling; water may have to be filtered and recycled

- Not ideally suited for operation on irregular surfaces or in cramped quarters 
ventilation confinement system to prevent surge damage to filter systems, with monitoring of the system to assure its continued integrity.

The first step in explosive decontamination of concrete is to drill holes to hold the explosives. In some areas these holes may be drilled parallel to and about $12 \mathrm{~cm}$ (5 in.) from the surface of the concrete to be removed. The entire length of the surface to be removed must be drilled. Explosives are inserted in the holes and backfilled with sand if necessary to produce the desired blast depth. In other areas, $12 \mathrm{~cm}$ deep holes may be drilled perpendicular to the surface to be removed. The holes can be on $30 \mathrm{~cm}$ centers over the entire surface. The holes are filled with mortar after the explosives are inserted. The explosives used may be of several varieties as shown in Table E.2-2.

Four to five strands of 150 grain blasting cord twisted together and placed in a tube inserted in the hole is an effective explosive. Partial sticks of dynamite also perform adequately. Explosive liquids may be used where it is difficult to insert solids. The size of the area to be blasted at one time is controlled so that in the event of an accident there is an acceptably low potential for damage with the explosives involved. There are never more explosives in the building than are actually being used. A blast series is carried out with the individual charges sequenced so that the shock wave generated by the blast is minimized. Blasting mats are placed over the blast area to prevent the scattering of debris. A water fog spray is used during the blast to minimize dust generation. The blasted area is then inspected for the desired results and surveyed to ensure that all contamination above unrestricted levels has been removed and all explosives have been detonated. The area is then protected by painting or by covering with heavy plastic or canvas to minimize recontamination during subsequent blasts.

Before an area is explosively decontaminated the ventilation system is protected from damage due to overpressurization. In some areas this is accomplished by closing existing dampers during the blast. Normal ventilation may be used in these areas except during the actual blast. In some areas a cover is installed over ventilation openings and removed after the blast. other areas require the use of an auxiliary ventilation system that draws air 
TABLE E.2-2 Types of Explosives for Use in Dismantlement (2)

1. PETN (Pentaerytritol tetranitrate)

This explosive is used in the form of detonating cord. It is primarily used during the blasting of large boreholes up to 5 meters in depth. In addition, it has proved to be effective for surface spalling which requires the removal of about $20 \mathrm{~cm}$ from exposed surfaces.

2. $85 \%$ High Velocity Gelatin Dynamite

This explosive is primarily used in holes ranging in depth from $45 \mathrm{~cm}$ to 1.5 meters, and as a partial loading in some holes when a high concentration of energy is needed in a particular area. Breakage is excellent; however, the explosive does produce a crushed zone around the borehole, thus generating a larger amount of dust than PETN.

3. Cast TNT (High Detonation Pressure Primers)

This explosive is used where a high degree of fragmentation with less heaving effect than conventional dynamite is desired.

4. Binary Energy System (Liquid Explosives)

This explosive is mixed onsite and when not mixed, it is not classed as an explosive in most states. It is used in place of Cast TNT during the spalling of surface contamination and to make shaped charges which can be used to punch holes in high density concrete.

5. Water Gel Explosives

A water gel explosive containing a large amount of aluminum is used as a partial replacement for $85 \%$ dynamite. It has exhibited good shattering characteristics and produced larger-sized rubble than any of the other explosives. Its primary use is in areas with little or no reinforcing rods where larger size rubble is desired.

6. Other Explosives

High strength ammonia dynamite and plastics have been investigated via small scale blasts and the effects indicated that they did not produce the desired results. 
from the blasting area and exhausts through a series of roughing filters into the normal building ventilation system.

In most areas of the reference plant the concrete rubble is removed by loading it into shipping containers with a front end loader with a shielded cab. A water spray is used while the rubble is being loaded to minimize dust generation. To minimize delays during rubble loading in the process cells, the 4.5 MT mobile crane is used to lower empty shipping containers into the cell while the EMS crane lifts the full ones out. Excess debris is sprayed from the full containers as they are lifted through the cell hatch. The filled containers are sealed, surveyed and removed to the cask loading station for shipment.

In some areas, lead glass windows and viewing ports penetrate the walls to be scarfed. These are removed and the openings sealed or otherwise protected from the blast effects before blasting operations begin.

The following is a representative sequence of events for explosive decontamination of concrete:

1. Inspect the ventilation system in the blast area and make necessary modifications to protect it during blasts. Remove or protect any lead glass windows or other penetrations which could be damaged by the blast. Install a protective device over sumps.

2. Drill holes in the pattern directed by the plan.

3. Backfill the holes with sand where necessary to achieve the desired blast depth.

4. Install the blasting mats to prevent the scattering of debris.

5. Move all unnecessary personnel to an area designated as safe from the b]ast.

6. Load the explosives in the holes.

7. Move all remaining personnel to the safe area. Announce on the public address system that a detonation is about to take place. 
8. A health physicist performs a final search of the area to ensure that all personnel are clear and that all accesses to the blast area are secured.

9. Activate the water spray system in the cell to minimize dust generation.

10. Approximately $1 \mathrm{~min}$ before the blast make a final announcement over the public address system.

11. Connect the wires to the detonator.

12. DETONATE!

13. Using the shielded cage or a periscope where radiation levels require, the explosives expert inspects the blast area to verify the desired results, ensure the safety of the area for rubble removel (ensure that the blasting material has completely detonated), and check the rubble accumulation.

14. Survey the scarfed area to ensure that the desired contamination has been removed.

15. Protect the clean area by painting in plutonium contaminated areas and by covering it with heavy plastic or canvas in other areas.

16. Repeats steps 2-15 as necessary until all the concrete has been scarfed from a given process room.

17. When rubble accumulation warrants, lower the front end loader into the area and load the rubble into containers. Lift containers out of the ce11. Water spray is used during rubble removal to minimize dust generation. 


\section{E.3 DISMANTLEMENT MODE SUPPORTING INFORMATION}

The information presented in this section is intended to amplify the procedures discussed in Section 7.4 of Volume 1.

\section{E.3.1 Equipment Removal Operations in the Process Cells of the Main Process} Building

Following chemical decontamination of the process cells in the main process building, equipment is removed from the cells to reduce radiation levels in preparation for mechanical decontamination of the cells. The plant conditions listed below are met before equipment removal operations begin in the process cells:

1. All process solutions are removed from the equipment in the cells. The equipment is decontaminated internally with chemicals and the cell walls and the externals of the process equipment are decontaminated.

2. The 55-MT equipment maintenance station crane is inspected and certified by the vendor or a qualified alternate.

3. Several trial runs of the crane are made to ensure that all personnel are familiar with the equipment removal and transfer procedures.

4. Radiation and industrial safety and emergency procedures are reviewed by all involved personnel and approved.

5. The ventilation equipment, emergency power systems, fire protection equipment and radiation monitoring equipment in the main process building are in service and fully functional.

6. The transfer cask and shipping containers are available in the contact equipment removal station.

7. The cask loading station is prepared for equipment loadout.

8. Continuous air sampling equipment is operating in the contact equipment removal station near the hatch to be opened.

9. The shielded working platform is installed in the contact equipment removal station.

10. All equipment required for the operations in the cell is available. 
E.3.1.1 Removal of Equipment from the Uranium Product Cell (UPC) and the Intermediate-Level Cel1 (ILC)

This section identifies the major steps required to remove and package equipment in the uranium product and intermediate-level cells. The radiation levels anticipated in these cells after chemical decontamination should permit operations by direct contact by personnel.

The cells are surveyed and certified safe for personnel by the health physicist before in-cell operations begin. Hot spots in the cells are shielded locally as necessary. Personnel working in the cells wear protective clothing and appropriate breathing equipment at all times. Health physics personnel observe all operations to ensure that radiation and industrial safety precautions are followed at all times.

- Procedure

Because the uranium product cell and the intermediate-level cell are expected to contain similar contamination levels, the equipment removal techniques are similar for both cells and the procedures that follow apply to both.

First, a working area is cleared by removing the equipment under and around the cell hatch. Next, a scaffold that can be moved easily and whose height is adjustable is placed in the cel1. It is used as a working platform for the remainder of the operations in the cel1. Larger equipment that cannot be reached directly by the EMS crane is lowered to the cell floor by installing a support in the ceiling above it and attaching a cable through the support to the equipment. After being lowered, the equipment is dragged to the area under the hatch and lifted out with the crane. Equipment is generally removed from the top of the cell down and from the hatch outward to the walls. Piping that penetrates into other areas of the building is sealed as it is cut off in the cell. The high-level liquid waste pipe vault that runs from the UPC to the waste tank cells is sealed as soon as possible. Other normal ventilation flow pathways remain open and are used as much as possible. Modifications are made as necessary to ensure adequate ventilation flows. The shielded working platform, although not required for personnel shielding, is kept in place over the open hatch as much as possible to maintain normal 
ventilation air flow patterns. The area around the cell hatch used for loading shipping containers and positioning potentially contaminated equipment is protected with a disposable covering.

\section{- Sequence of Events}

1. Ensure that the ventilation system will provide a negative pressure in the cell relative to the contact equipment removal station when the hatch is removed.

2. Remove the concrete hatch cover from the cell.

3. Conduct a radiation survey of the cell to ensure that levels are safe for extended working periods inside the cell. Install shielding around any hot spots discovered.

4. Using the 55-MT equipment maintenance station crane, position a worker in protective clothing in a crane basket near the first piece of equipment to be removed.

5. Attach a cable to the equipment supported from the 4.5-MT crane.

6. Cut away and remove all piping and other interferences with a plasma torch. Detach the equipment from its installed location and lift it from the cell.

7. Place the equipment in a shipping container inside the transfer cask and install the shipping container lid.

8. Place the lid on the transfer cask.

9. Remove the transfer cask to the cask loading station with the 55-MT equipment maintenance station crane.

10. Remove the shipping container from the transfer cask and place it in the cargo container positioned in the cask loading station.

11. Remove full cargo containers to the fuel receiving and storage station to await shipment to the disposal site.

12. Repeat steps $4-11$ for the remaining equipment located in the vicinity of the hatch in the sequence given in Tables E.3-1 and E.3-2. 


\section{TABLE E.3-1 Uranium Product Ce11 - Order of Removal of Major Pieces of Equipment}

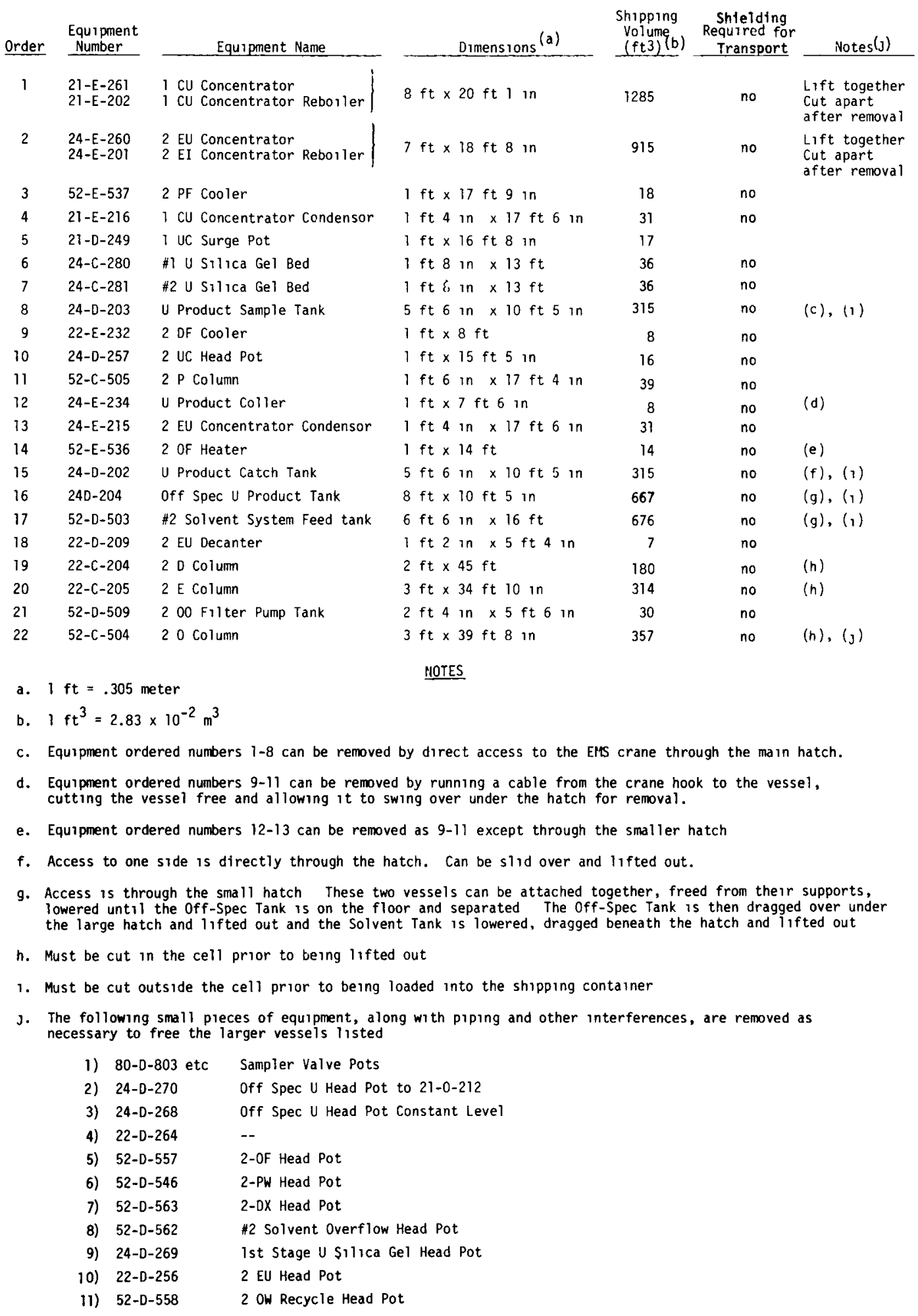




\section{TABLE E.3-2 Intermediate Level Cell - Order of Removal of Major Pieces of Equipment}

\begin{tabular}{|c|c|c|}
\hline Order & $\begin{array}{l}\text { Equipment } \\
\text { Number }\end{array}$ & Equipment Name \\
\hline 1 & $45-C-490$ & $\mathrm{NO}_{2}$ Absorber \\
\hline 2 & $42-E-402$ & LAW Concentrator Reboller \\
\hline 3 & $42-E-461$ & LAW Concentrator \\
\hline 4 & $54-E-515$ & Acid Fractionator Condensor \\
\hline 5 & $54-E-501$ & Acid Fractionator Reboiler \\
\hline 6 & $54-C-550$ & Acid Fractionator \\
\hline 7 & $42-D-445$ & 42-D-406 Head Pot \\
\hline 8 & $45-E-415$ & Vessel off-gas Condensor \\
\hline 9 & $42-D-406$ & LAW Concentrator Feed Tank \\
\hline 10 & $45-0-441$ & Vessel Off-gas KO Pot \\
\hline 11 & $\begin{array}{l}42-D-440 \\
42-F-401\end{array}$ & $\begin{array}{l}\text { Solvent Burner Quench Pot } \\
\text { Waste Solvent Burner }\end{array}$ \\
\hline 12 & $45-K-425$ & \#1 Iodine Scrubber \\
\hline 13 & $45-E-432$ & Off-gas Heater (Elec) \\
\hline 14 & $62-0-605$ & Recovered Acıd Storage Tank \\
\hline 15 & $42-0-402$ & Solvent Burner Feed Tank \\
\hline 16 & $42-D-434$ & LAWB Check Tank \\
\hline 17 & $42-D-401$ & Solvent Batch Strıpping Tank \\
\hline 18 & $45-D-432$ & Vacuum Breaker Tank \\
\hline 19 & $45-E-431$ & Off-gas Heater (Steam) \\
\hline 20 & $45-\mathrm{K}-426$ & \#2 Iodine Scrubber \\
\hline 21 & $54-E-530$ & Recovered Acid Cooler \\
\hline
\end{tabular}

\begin{tabular}{|c|c|c|c|}
\hline Dimensions (a) & $\begin{array}{l}\text { Shrpping } \\
\text { Volume } \\
\left(\mathrm{ft}^{3}\right)(\mathrm{b})\end{array}$ & $\begin{array}{l}\text { Shielding } \\
\text { Required for } \\
\text { Iransport }\end{array}$ & Notes $^{(1)}$ \\
\hline $5 \mathrm{ft} \times 31 \mathrm{ft} 7 \mathrm{in}$ & 790 & no & $(g)$ \\
\hline $4 \mathrm{ft} \times 13 \mathrm{ft} 8 \mathrm{ln}$ & 219 & no & \\
\hline $7 \mathrm{ft} 10 \mathrm{in} \times 20 \mathrm{ft} 8 \mathrm{in}$ & 1268 & no & $(g),(h)$ \\
\hline $2 \mathrm{ft} 8 \mathrm{in} \times 16 \mathrm{ft}$ & 114 & no & (c) \\
\hline $1 \mathrm{ft} 1$ in $\times 9 \mathrm{ft} 5 \mathrm{in}$ & 11 & no & \\
\hline $5 \mathrm{ft} 6 \mathrm{in} \times 38 \mathrm{ft} 8 \mathrm{in}$ & 1170 & no & $(g)$ \\
\hline $6 \mathrm{ft} \times 16 \mathrm{ft} 3 \mathrm{in}$ & 585 & no & (d) \\
\hline $1 \mathrm{ft} 10 \mathrm{in} \times 13 \mathrm{ft}$ & 44 & no & \\
\hline $4 \mathrm{ft} 2 \mathrm{ln} \times 9 \mathrm{ft} 1 \mathrm{in}$ & 158 & no & (e) \\
\hline $6 \mathrm{ft} 1 \mathrm{in} \times 11 \mathrm{ft} 6 \mathrm{in}$ & 426 & no & (e) \\
\hline $5 \mathrm{ft} 11 \mathrm{in} \times 19 \mathrm{ft} 10 \mathrm{in}$ & 694 & no & $\begin{array}{l}\text { Lift together } \\
\text { Separate after } \\
\text { removal }\end{array}$ \\
\hline $3 \mathrm{ft} 6$ in $\times 24 \mathrm{ft} 8 \mathrm{in}$ & 302 & no & (g) \\
\hline $2 \mathrm{ft} 1$ in $\times 6 \mathrm{ft} 3 \mathrm{in}$ & 27 & no & (f) \\
\hline$x 18 \mathrm{ft} 2 \mathrm{in}$ & 977 & no & $(e),(h)$ \\
\hline$x 16 \mathrm{ft} 6 \mathrm{in}$ & 1100 & no & $(e),(h)$ \\
\hline$\times 7 \mathrm{ft} 9 \mathrm{in}$ & 86 & no & (e) \\
\hline$\times 7 \mathrm{ft} 10 \mathrm{in}$ & 110 & no & (e) \\
\hline$x 12 \mathrm{ft} 5 \mathrm{in}$ & 68 & no & (e) \\
\hline$\times 3 \mathrm{ft} 10 \mathrm{in}$ & 8 & no & $(f)$ \\
\hline$\times 30 \mathrm{ft} 11 \mathrm{in}$ & 998 & no & (g) \\
\hline$\times 27 \mathrm{ft} 4 \mathrm{in}$ & 43 & no & $(f),(g),(1)$ \\
\hline
\end{tabular}

a. $1 \mathrm{ft} \quad 305$ meter

\section{NOTES}

b. $1 \mathrm{ft}^{3}-283 \times 10^{-2} \mathrm{~m}^{3}$

c. Equipment number 1-4 can be reached through the hatch with the EllS crane.

d. Equipment numbered 5-7 is close to the hatch. It can be removed by running a cable to the equipment from the crane hook, cutting the equipment free and allowing it to swing over under the hatch for removal.

e. Can be attached and lowered together. The bottom vessel is cut free and dragged to the hatch for $11 \mathrm{fting}$.

f. Close to the floor. Can be dropped and dragged to the hatch.

g. Plust be cut in the cell prior to being lifted out.

h. Must be cut outside the cell prior to being loaded into the shipping container

1. The following small preces of equipment, along with piping and other interferences, are removed as necessary to free the larger vessels listed above
1) $54-D-568$
AF Chloride REmoval Head Pot
2) $42-0-461$
42-D-440 Head Pot
3) $42-0-446$
LAWB Head Pot
4) $45-D-472$
$\mathrm{NO}_{2}$ Absorber Bottoms Head Pot
5) 80-D-810, etc. Sampler Valve Pots 
Lower the movable, adjustable height scaffold into the cell.

14. Proceed with equipment removal as in steps 4-11, positioning the scaffold for cutting and detaching equipment and removing interferences using the sequence in Tables E.3-1 and E.3-2.

15. Install lifting supports in the cell ceiling above the equipment not located near the hatch. Hang the equipment from the ceiling support, and detach it from its normal supports. Lower the equipment to the floor of the cell, slide it to the area beneath the hatch and lift it out.

16. As equipment is removed, seal the piping that penetrates the cell walls.

E.3.1.2 Removal of Equipment from the High-Intermediate-Level Cel1 (HILC) and the High-Level Cel1 (HLC)

This section identifies the major steps required to remove and package the equipment from the high-intermediate-level and high-level cells. Remote methods are used to limit personnel exposure to the anticipated high radiation levels.

A shielded working cage suspended from the EMS crane is used for equipment removal operations in these cells. The cage is conceptually described in Appendix E.3.6. The shielded cage is safety tested each time before it is lowered into the cell. A shielded working platform (also described in Appendix E.3.6) is in place over the cell hatch except when the cage or equipment is being 1 ifted into or out of the cel1. When equipment is being removed, personnel in the contact equipment removal station remain at a safe distance until the equipment has been placed in a shipping container, the lid is in place, and a radiation survey has been taken. Health physics personnel observe all operations to ensure that radiation and industrial safety precautions are observed at all times.

\section{- Procedure}

The high-level cell and the high-intermediate-level cell are expected to contain similar amounts of radioactive contamination upon completion of chemical decontamination. Anticipated radiation levels in these cells prevent dismantlement operations by direct contact with personnel. 
The procedures described below apply to both cells and involve the use or a shielded working cage and a shielded working platform. Once an area beneath the hatch is cleared of equipment by working from the bottom of the cage, the cage is lowered into the cell by the EMS crane and the shielded platform is placed over the hatch. Equipment in the cell is removed as in Section E.3.1.1. Equipment that cannot be reached directly by the crane is removed by drilling a $2.5-\mathrm{cm}$ hole through the cell ceiling from above with a track drill. A cable from the 4.5-MT mobile crane is put through the hole and attached to the equipment. The detached equipment is lowered to the cell floor with the mobile crane, dragged under the hatch, and removed from the cell with the EMS crane. The holes are sealed after they are used. Piping that penetrates the cell walls is sealed after it is severed. Normal ventilation pathways remain open and are used as much as possible. Modifications are made as necessary to ensure adequate ventilation air flows. The area around the hatch that may be exposed to smearable contamination is protected by a disposable covering.

\section{- Sequence of Events}

1. Ensure that the ventilation system will provide a negative pressure in the cell relative to the contact equipment removal station when the hatch is removed.

2. Remove the concrete hatch cover from the cell.

3. Using the 55-MT equipment maintenance station crane, position the shielded cage near the first piece of equipment to be removed.

4. Attach a cable to the equipment supported by the 4.5-MT crane.

5. Using a plasma torch and the shielded cage manipulator arms, cut away and remove all interferences and detach the equipment from its installed location.

6. Remove the equipment from the cell. (Communications between the shielded working cage and the mobile crane are mandatory for this operation.)

7. Remotely place the equipment in a shipping container located inside the transfer cask (located in the CERS) and remotely install the container lid. 
8. Remotely place the lid on the transfer cask and conduct a radiation survey.

9. Remove the transfer cask to the cask loading station with the EMS crane.

10. Remove the shipping container from the transfer cask and place it in a cargo container in the cask loading station.

11. Remove full cargo containers to the fuel receiving and storage station to await shipment.

12. Repeat steps 3-11 for the remaining pieces of equipment using the sequence in Tables E.3.3 and E.3.4.

13. As equipment is removed, severed piping that penetrates the cell walls is sealed.

14. Concurrently with removal of equipment near the hatch use the track drills to bore holes in the cell ceiling above major pieces of equipment that cannot be reached from the hatch with the crane. These pieces of equipment are removed by running a cable from the 4.5-M crane through the hole to the equipment. The equipment is detached with a plasma torch, lowered to the cell floor with the 4.5-MT crane, dragged to the area beneath the cell hatch and removed with the EMS crane. Holes are plugged except when they are in use.

\section{E.3.1.3 Removal of Equipment from the Plutonium Product Cell (PPC)}

This section identifies the major steps required to remove and package the equipment in the plutonium product cel1. The radiation levels anticipated in this cell after chemical decontamination should permit direct contact by personnel in fresh air suits with use of adequate local shielding. The cell will be surveyed and lead-filled rubber sheets hung from the wall for temporary shielding before equipment removal begins. Health physics personnel will observe all operations to ensure that radiation and industrial safety procedures are followed at all times. 


\section{TABLE E.3-3 High-Intermediate Level Cell - Order of Removal}

of Major Pieces of Equipment

\begin{tabular}{|c|c|c|c|c|c|c|}
\hline Order & $\begin{array}{l}\text { Equipment } \\
\text { Number } \\
\end{array}$ & Equipment Name & Dimensions (a) & $\begin{array}{l}\text { Shipping } \\
\text { Volume } \\
\left(\mathrm{ft}^{3}\right)(\mathrm{b})\end{array}$ & $\begin{array}{l}\text { Shielding } \\
\text { Required for } \\
\text { Iransport } \\
\end{array}$ & Notes $(j)$ \\
\hline 1 & $51-0-501$ & Carbonate Diversion Tank & $2 \mathrm{ft} 5$ in. $\times 6 \mathrm{ft}$ & 35 & no & \\
\hline 2 & $\begin{array}{l}43-E-445 \\
43-E-409\end{array}$ & $\begin{array}{l}\text { General Purpose Concentrator } \\
\text { General Purpose Concentrator } \\
\text { Reboiler }\end{array}$ & $7 \mathrm{ft} 8$ in. $\times 15 \mathrm{ft}$ & 882 & no & $\begin{array}{l}\text { Lift together. } \\
\text { Cut apart } \\
\text { after removal. }\end{array}$ \\
\hline 3 & $32-D-307$ & I BP Surge Tank & $4 \mathrm{ft} \times 14 \mathrm{ft} 8 \mathrm{in}$ & 235 & no & \\
\hline 4 & $51-0-502$ & \#1 Solvent System Feed Tank & $8 \mathrm{ft} 2$ in. $\times 16 \mathrm{ft}$ & 1067 & no & (i) \\
\hline 5 & $42-C-401$ & I S Column & $3 \mathrm{ft} \times 31 \mathrm{ft} 7 \mathrm{in}$. & 284 & no & (h), (c) \\
\hline 6 & $51-E-535$ & $1 \mathrm{PF}$ Cooler & $1 \mathrm{ft} 1$ in. $x 18 \mathrm{ft}$ & 21 & no & \\
\hline 7 & $41-E-417$ & HAW Concentrator Condensor & $2 \mathrm{ft} \times 9 \mathrm{ft} 11 \mathrm{in.}$ & 40 & no & \\
\hline 8 & $51-E-532$ & HAX Cooler & 1 ft 5 in. $\times 22$ ft 4 in. & 45 & no & (h) \\
\hline 9 & $51-E-534$ & 1 RF Heater & $1 \mathrm{ft} \times 21 \mathrm{ft} 4 \mathrm{in}$ & 22 & no & (h) \\
\hline 10 & $21-E-236$ & 1 BX Anolyte Cooler & $1 \mathrm{ft} 2$ in. $\times 15 \mathrm{ft}$ & 20 & no & \\
\hline 11 & $42-0-433$ & $1 \mathrm{SF}$ Tank & $3 \mathrm{ft} 9$ in. $\times 14 \mathrm{ft} 8 \mathrm{in}$. & 206 & no & \\
\hline 12 & $21-D-213$ & I BX Anolyte Feed Tank & $2 \mathrm{ft} \times 5 \mathrm{ft}$ & 20 & no & \\
\hline 13 & $43-E-419$ & $\begin{array}{l}\text { General Purpose Concentrator } \\
\text { Condensor }\end{array}$ & $1 \mathrm{ft} 5$ in. $\times 12 \mathrm{ft} 7$ in. & 25 & no & \\
\hline 14 & $51-E-533$ & 1 OF Heater & $1 \mathrm{ft} \times 21 \mathrm{ft}$ & 21 & no & (h) \\
\hline 15 & $51-0-511$ & $\begin{array}{l}\text { Solvent Treatment Waste } \\
\text { Decanter }\end{array}$ & $1 \mathrm{ft} \times 5 \mathrm{ft} 7 \mathrm{in}$. & 6 & no & \\
\hline 16 & $51-0-573$ & Neutralization Pot & $1 \mathrm{ft} 6$ in. $\times 3 \mathrm{ft} 6$ in. & 8 & no & \\
\hline 17 & $51-0-552$ & Solvent Overflow Head Pot & $1 \mathrm{ft} 4$ in. $\times 3 \mathrm{ft} 6$ in. & 6 & no & (d) \\
\hline 18 & $51-C-503$ & I $R$ Column & $2 \mathrm{ft} 10 \mathrm{in.} \times 32 \mathrm{ft} 6 \mathrm{in.}$ & 261 & no & (h) \\
\hline 19 & $51-c-502$ & I P Column & $2 \mathrm{ft} 10 \mathrm{in.} \times 16 \mathrm{ft} 3 \mathrm{in.}$ & 130 & no & \\
\hline 20 & $51-C-501$ & 10 Column & $2 \mathrm{ft}^{\circ} 10 \mathrm{in.} \times 32 \mathrm{ft} 6 \mathrm{in}$. & 261 & no & (h) \\
\hline 21 & $21-C-202$ & $1 \mathrm{BX}$ Column & $2 \mathrm{ft} 10 \mathrm{in.} \times 41 \mathrm{ft}$ & 329 & no & (h) \\
\hline 22 & $21-C-203$ & $1 \mathrm{C}$ Column & $2 \mathrm{ft} 10 \mathrm{in.} \times 34 \mathrm{ft} 4 \mathrm{in}$. & 276 & no & $(h)$ \\
\hline 23 & $\begin{array}{r}21-E-235 \\
(A \& B)\end{array}$ & HSP Cooler & $2 \mathrm{ft} 10 \mathrm{in.} \times 27 \mathrm{ft} \mathrm{l}$ in. & 217 & no & (h) \\
\hline 24 & $45-D-442$ & Dissolver Off-gas KO Pot & $2 \mathrm{ft} 6$ in. $\times 5 \mathrm{ft}$ & 31 & no & \\
\hline 25 & $21-D-210$ & I BU Recycle Tank & $3 \mathrm{ft} 6$ in. $\times 7 \mathrm{ft} 8$ in. & 94 & no & \\
\hline 26 & $51-D-507$ & 100 Filter Pump Tank & $2 \mathrm{ft} 7$ in. $\times 5 \mathrm{ft} 2$ in. & 35 & no & May be attached \\
\hline 27 & 43-D-409 & GPW Check Tank & $2 \mathrm{ft} 10$ in. $\times 6 \mathrm{ft} 8 \mathrm{in.}$ & 54 & no & $\begin{array}{l}\text { and lowered } \\
\text { together. }\end{array}$ \\
\hline 28 & $32-E-337$ & I BP Heater & $4 \mathrm{in.} \times 20 \mathrm{ft} 6 \mathrm{in.}$ & 2 & no & $(e),(h)$ \\
\hline 29 & $45-E-416$ & DOG Condensor & $1 \mathrm{ft} \times 9 \mathrm{ft}$ & 9 & no & \\
\hline 30 & $43-D-411$ & $\begin{array}{l}\text { Sump Collection Tank } \\
\text { Decanter }\end{array}$ & $1 \mathrm{ft} 8$ in. $\times 5 \mathrm{ft} 10$ in. & 16 & no & \\
\hline 31 & $21-0-212$ & 1 Cu Decanter & $1 \mathrm{ft} 2$ in. $\times 5 \mathrm{ft} 2$ in. & 7 & no & (f) \\
\hline 32 & $21-E-233$ & HAF Cooler & $1 \mathrm{ft} \times 16 \mathrm{ft} 10 \mathrm{in}$ & 17 & no & (f) \\
\hline 33 & $21-0-211$ & HAW Decanter & $7 \mathrm{ft} \times 5 \mathrm{ft}$ & 245 & no & (f) \\
\hline 34 & $21-E-230$ & HAP Heater & $8 \mathrm{in.} \times 21 \mathrm{ft}$ & 9 & no & (h) \\
\hline 35 & $21-C-201$ & HS Column & I ft 10 in. $x 46 \mathrm{ft} 9$ in. & 157 & no & $(g),(h),(j)$ \\
\hline
\end{tabular}




\section{NOTES TO TABLE E.3-3}

a. $1 \mathrm{ft}=.305$ meter

b. $1 \mathrm{ft}^{3}=2.83 \times 10^{-2} \mathrm{~m}^{3}$

c. Equipment numbered 1-5 can be removed by direct access to the EMS crane through the cel1 hatch

d. Equipment numbered 6-17 is within about $2 \mathrm{~m}$ of the edge of the hatch. It can be removed by using the manipulator to run a cable to the equipment from the crane hook, cutting the equipment loose and swinging it over under the hatch for $11 \mathrm{fting}$.

e. Access to cable from crane hook through the hole left by IBX electrocell.

f. Access to cable from crane hook through the hole left by HA contactor.

g. Equipment numbered $18-30$ required a special hole in the cell ceiling for removal.

h. Must be cut inside the cell pror to being lifted out.

1. Must be cut outside the cell prior to being loaded into the shipping container.

3. The following small pleces of equipment, along with piping and other interferences, are removed as necessary to free the larger vessels listed above
1) 2l-0-267 1 BAW Head Pot
2) 51-D-515 51-D-502 Head Pot
3) 42-0-466 15 Column Feed Pot
4) 51-D-550 I RW Recycle Head Pot
5) 51-0-548 I RF Head Pot
6) 51-D-544 1 OW Diversion Head Pot
7) 51-0-540 $10 \mathrm{~F}$ Head Pot
8) 42-0-464 I S Column Head Pot
9) 21-D-272 1 BU Head Pot to 1 BU Recycle Tank
10) 42-D-471 Solvent Burner Feed Tank Head Pot
11) 43-D-443 6 PW Check Tank Head Pot
12) 51-0-572 Waste Solvent Head Pot
13) $51-0-571 \quad 15 \times$ Head Pot
14) 32-D-365 Pu Rework Head Pot to $1 \mathrm{BP}$
15) 51-D-516 51-D-502 Recycle Head Pot
16) 41-D-456 HWD Reflux Head Pot
17) $51-0-541 \quad 1$ OW Recycle Head Pot
18) 21-0-246 1 BU Head Pot
19) 51-D-556 HAX Head Pot
20) 21-D-242 HAP Head Pot
21) 21-D-262 $1 \mathrm{CU}$ Head Pot
22) 21-0-271 1 BU Recycle Head Pot
23) 51-D-569 ---
24) 80-D-808, Sampler Valve Pots 


\section{TABLE E.3-4 High Level Cel1 - Order of Removal of Major Pieces of Equipment}

\begin{tabular}{ccl} 
Order & $\begin{array}{c}\text { Equipment } \\
\text { Number }\end{array}$ & \multicolumn{1}{c}{ Equipment Name } \\
\hline 1 & $61-D-602$ & Dissolver Acid Surge Tank \\
2 & $61-D-617$ & Hull Rinse Surge Tank \\
3 & $18-D-101$ & Accountability Tank \\
4 & $17-D-113$ & Feed Surge Tank \\
5 & $15-0-141$ & \#2 Dissolver Head Pot Tank \\
6 & $15-D-142$ & \#3 Dissolver Head Pot Tank \\
7 & $15-D-143$ & \#4 Dissolver Head Pot Tank \\
8 & $15-D-140$ & \#1 Dissolver Head Pot Tank \\
9 & $15-D-108$ & \#2 Dissolver Transfer Tank \\
10 & $15-D-107$ & \#1 Dissolver Transfer Tank \\
11 & $15-D-109$ & \#3 Dissolver Transfer Tank \\
12 & $15-D-112$ & \#4 Dissolver Transfer Tank \\
13 & $21-D-201$ & HA Feed Tank \\
14 & $17-D-104$ & \#2 Feed Adjust Tank \\
15 & $17-D-111$ & Dissolver Flush Accumulator \\
16 & $17-D-103$ & \#1 Feed Adjust Tank \\
17 & $43-E-421$ & GPC Feed Tank Reflux \\
18 & $43-0-408$ & GP Condensor \\
19 & $43-D-412$ & Sump Collectron Tank \\
20 & $41-D-405$ & HWW Sample Tank \\
21 & $41-D-404$ & HWW Catch Tank \\
22 & $41-D-417$ & HAW Surge Tank \\
23 & $43-E-418$ & Sump Collectron Tank \\
& & Condensor
\end{tabular}

a. $1 \mathrm{ft}=.305$ meter

b. $1 \mathrm{ft}^{3}=2.83 \times 10^{-2} \mathrm{~m}^{3}$

c. Equipment numbered $1-9$ can be reached by direct access with the EHS crane through the hatch.

d. Equipment numbered 10-21 is within $15 \mathrm{~m}$ of the hatch It can be removed by running a cable from the equipment to the crane hook, cutting the equipment loose and allowing it to swing over under the hatch for removal

e. Requires a hole in the cell celling for removal

f. Can be lowered with a cable through the hole left by the removal of the centrifuge

g. Must be cut in the cell prior to being 11 fted out

h. Must be cut up outside the cell prior to being loaded into the shipping container

1. The following small equipment is removed as necessary, along with piping and other interferences, to free the larger vessels listed above:
1) 61-D-656 Hull Rinse Mix Feed Head Pot
2) 61-D-655 Hull Rinse Constant Level Head Pot
3) 61-D-659 \#1 Dissolver Ac1d Head Pot
4) 61-D-660 \#2 Dissolver Acrd Head Pot
5) 61-D-661 \#3 Dissolver Acid Head Pot
6) 61-D-663 Dissolver Hull Rinse Seal Head Pot
7) 80-0-801 Sampler Vaive Pots

Shipping Shielding

Volume Required for

$\left(\mathrm{ft}^{3}\right)(b)$ Iransport

$5 \mathrm{ft} 10 \mathrm{in} . \times 9 \mathrm{ft} 10 \mathrm{in} . \quad 335$ yes

202 yes

561 yes

(h)

no

no

no

no (c)

no

no

no

yes

(h)

$6 \mathrm{ft} \times 15 \mathrm{ft} 8 \mathrm{in} . \quad 564$ no

$6 \mathrm{ft} \times 16 \mathrm{ft} 2 \mathrm{in} . \quad 582$ no

$6 \mathrm{ft} \times 15 \mathrm{ft} 8 \mathrm{in} \quad 564$ no

$8 \mathrm{ft} \times 15 \mathrm{ft} \mathrm{lm} .965$ no (h)

$\mathrm{ft} 4 \mathrm{in} . \times 15 \mathrm{ft} 5 \mathrm{in} . \quad 829$ no

$3 \mathrm{ft} 6 \mathrm{in} . \times 15 \mathrm{ft} 4 \mathrm{in} \quad 188$ yes (d)

ft 2 in. $x 11 \mathrm{ft} 5 \mathrm{in.} 198$ yes (e)

9 in $x 30 \mathrm{ft} 6$ in 17 yes (f), (g), (1)

NOTES
982 yes 
- Health and Safety Requirements

1. Personnel working in the cell will be in fresh air suits at all times. The air supply equipment for the fresh air suits shall be connected to a primary circuit of the emergency electrical power system.

2. The building ventilation system, all radiation protection and monitoring systems, building isolation systems, fire protection systems and emergency power systems shall be operable. Modifications are made as necessary to these safety systems to ensure that they function properly at all times.

3. The cell shall be surveyed, temporary shielding emplaced as necessary, and certified safe for personnel by the health physics technician prior to commencement of in-cell operations.

4. The contact radiation dose from each piece of equipment shall be determined before it is removed from the cell.

5. The shielded working platform will be in position over the open hatch above the cell whenever possible.

- Procedure

The equipment in the plutonium product cell is small and widely spaced because of nuclear criticality considerations. This facilitates equipment removal. Relatively large amounts of plutonium contamination are expected. The adjustable height scaffold is used to position workers for operations in the cell.

The EMS crane does not serve this cell. Plant production procedures are used to lift the hatch cover from the cell. As in the other cells, equipment removal begins with the pieces immediately below the hatch, proceeding downward and outward from the hatch opening. A mobile crane is used to lift equipment from the cell. There are two pieces of equipment directly below the cell hatch. They must be removed prior to placing the scaffold in the cell. They are supported by a cable from an I-beam placed over the hatch opening while being detached by a worker in a crane bucket suspended from the mobile 
crane. The equipment is removed from the cell with the mobile crane after the worker is lifted out of the cell. Major pieces of equipment not located near the hatch are removed as in the uranium product and intermediate-level cells by installing a support above them and attaching a support cable.

Smearable Pu levels should be low after chemical decontamination. Incell surveys of equipment are made to verify this. Where there are significant amounts of smearable contamination on the equipment, a fixative agent is applied to the equipment as it is lifted out of the cel1. It is expected that this will not be required frequently. The equipment is lifted from the ce11, placed in an air-tight shipping container and the lid is sealed. The work area around the hatch is protected from contamination by a disposable covering. Normal ventilation pathways are used where possible. The ventilation pathways are altered as necessary to insure that there is adequate ventilation air flow into and out of the cell. The shielded working platform is placed over the hatch opening to provide more normal ventilation flow rates.

\section{- Sequence of Events}

1. Ensure that the ventilation system will provide a negative pressure in the cell relative to the contact equipment removal station when the hatch cover is removed.

2. Remove the hatch cover using plant production procedures.

3. Conduct a radiation survey of the cell to ensure that radiation levels will permit extended periods of time working in the cell. Lead-filled rubber sheets are used as necessary to cover walls and equipment not being worked on to reduce radiation levels.

4. Position a support I-beam across the hatch opening above the first piece of equipment to be removed.

5. Using the 4.5-MT mobile crane, position a worker in a crane basket near the first piece of equipment to be removed.

6. Attach a support cable from the beam to the equipment. 
7. Cut away and remove a 11 piping and interferences and detach the equipment from its supports with a plasma torch.

8. Lift out the worker.

9. Remove the piece of equipment with the 4.5-MT crane. Place the equipment in an air-tight shipping container positioned under the EMS crane. Seal the lid of the container.

10. Conduct a survey to ensure that the container is free of external contamination. Perform spot decontamination on the container as necessary.

11. Remove the shipping container to the cask loading station with the EMS crane. Prepare the container for shipment in a cargo container.

12. Repeat steps 4 through 11 for the remaining euqipment under the hatch in the order given in Table E.3.5.

13. Place the scaffold in the cell and position it near the next piece of equipment to be removed.

14. Proceed with equipment removal in the order given in Table E.3.5. Install supports above equipment, attach support cables, detach the equipment from its supports, lower it to the floor and slide it to the area beneath the hatch for removal. Package and transfer the equipment as in steps 9 through 11 .

15. As equipment is removed, severed piping that penetrates the cell walls is sealed.

E.3.1.4 Removal of Equipment from and Decontamination of the Plutonium Nitrate Storage and Loadout Area (PNSL)

This section identifies the major steps required to remove the equipment from the plutonium nitrate storage and loadout area and to decontaminate the walls, floor and ceiling. The radiation levels that are anticipated in this area should permit direct contact by personnel in fresh air suits. The plutonium nitrate cells are surveyed for radiation levels before equipment 


\section{TABLE E.3-5. Plutonium Product Cell - Order of Removal of Major Pieces of Equipment}

\begin{tabular}{|c|c|c|c|c|c|c|}
\hline $\begin{array}{l}\text { Order } \\
\text { Number }\end{array}$ & $\begin{array}{l}\text { Equipment } \\
\text { Number } \\
\end{array}$ & Equipment Name & Dimensions (a) & $\begin{array}{c}\text { Shipping } \\
\text { Volume } \\
\left(\mathrm{ft}^{3}\right)(\mathrm{b}) \\
\end{array}$ & $\begin{array}{r}\text { Approximate } \\
\text { Contact Dose } \\
\text { Rate (mR/hr) } \\
\end{array}$ & Notes $(h)$ \\
\hline 1 & $\begin{array}{l}34-E-336 \\
34-E-360\end{array}$ & $\begin{array}{l}\text { 3-P Concentrator } \\
\text { 3-P Concentrator Reboller }\end{array}$ & $4 \mathrm{ft} 6$ in $\times 13 \mathrm{ft} 9$ in & 278 & no & Lift together \\
\hline 2 & $33-C-309$ & 3 PS Diluent Wash Column & $7 \mathrm{in} \times 17 \mathrm{ft}$ & 6 & no & (c) \\
\hline 3 & $32-E-315$ & Pu Vent Cooler & $7 \mathrm{in} \times 10 \mathrm{ft} 10 \mathrm{in}$ & 4 & no & \\
\hline 4 & $32-0-343$ & Pu Vent KO Pot & $3 \mathrm{ft} 6 \mathrm{in} \times 3 \mathrm{ft}$ & 37 & no & \\
\hline 5 & $33-\epsilon-303$ & 3-A Column & $3 \mathrm{ft} 5$ in $\times 43 \mathrm{ft} 7 \mathrm{in}$ & 509 & no & (g) \\
\hline 6 & $32-0-301$ & Pu Rework Tank & $4 \mathrm{ft} \times 15 \mathrm{ft} 5 \mathrm{in}$ & 247 & no & \\
\hline 7 & $33-C-306$ & 3-B Column & $4 \mathrm{ft} \times 46 \mathrm{ft} 3 \mathrm{ln}$ & 740 & no & (g) \\
\hline 8 & $32-C-301$ & 2-A Column & $3 \mathrm{ft} 5 \mathrm{ln} \times 43 \mathrm{ft} 7 \mathrm{ln}$ & 509 & no & $(g)$ \\
\hline 9 & $32-c-302$ & $2-8$ Column & $3 \mathrm{ft} 5 \mathrm{in} \times 30 \mathrm{ft} 3 \mathrm{in}$ & 353 & no & (g) \\
\hline 10 & $33-E-333$ & 2 BP Exchanger & $8 \mathrm{in} \times 2 \mathrm{ft} 8 \mathrm{in} \times 18 \mathrm{ft} 6 \mathrm{in}$. & 33 & no & \\
\hline 11 & $34-E-334$ & 3-P Concentrator Condensor & $1 \mathrm{ft} \times 1 \mathrm{ft} 4 \mathrm{in} \times 21 \mathrm{ft} 2 \mathrm{ln}$ & 28 & no & (g) \\
\hline 12 & $32-E-332$ & 2 AF Exchanger & $1 \mathrm{ft} \times 1 \mathrm{ft} 4$ in $\times 21 \mathrm{ft} 2 \mathrm{in}$ & 28 & no & $(d),(g)$ \\
\hline 13 & -- & Concrete SIab Shield & $4 \mathrm{in} \times 5 \mathrm{ft} 9 \mathrm{in} \times 5 \mathrm{ft} 6 \mathrm{in}$ & 10 & no & (e) \\
\hline 14 & $35-D-377$ & $\begin{array}{l}\text { Pu Product } 100 \text { \& Measuring } \\
\text { Tank }\end{array}$ & $2-1 / 4$ in $\times 4 \mathrm{ft} 9 \mathrm{in} \times 5 \mathrm{ft}$ & 4 & no & \\
\hline 15 & -- & Concrete Slab Shield & $4 \mathrm{ln} \times 8 \mathrm{ft} 6 \mathrm{in} \times 6 \mathrm{ft} 6 \mathrm{ln}$ & 18 & no & \\
\hline 16 & $34-0-303$ & Pu Product Sample Tank & $2-1 / 4$ in $\times 7 \mathrm{ft} 6$ in $\times 6 \mathrm{ft}$ & 8 & no & \\
\hline 17 & -- & Concrete Slab Sheld & $4 \mathrm{ln} \times 8 \mathrm{ft} 6 \mathrm{in} \times 11 \mathrm{ft} 10 \mathrm{in}$ & 33 & no & \\
\hline 18 & $35-D-305$ & Pu Product Storage Tank & $\begin{array}{l}2-1 / 4 \text { in } x>f \mathrm{ft} 6 \text { in } x \\
11 \mathrm{ft} 4 \text { in }\end{array}$ & 15 & no & \\
\hline 19 & -- & Concrete Slab Shield & $4 \mathrm{ln} \times 8 \mathrm{ft} 6 \mathrm{in} \times 11 \mathrm{ft} 10 \mathrm{~m}$ & 33 & no & \\
\hline 20 & $35-D-304$ & Pu Product Storage Tank & $\begin{array}{c}2-1 / 4 \text { in } x \quad 7 \text { ft } 6 \text { in } x \\
11 \text { ft } 4 \text { in }\end{array}$ & 15 & no & \\
\hline 21 & -- & Concrete Slab Shield & $4 \mathrm{ln} \times 8 \mathrm{ft} 6 \mathrm{ln} \times 11 \mathrm{ft} 10 \mathrm{in}$ & 33 & no & \\
\hline 22 & $35-D-306$ & Pu Product Storage Tank & $\begin{array}{l}2-1 / 4 \text { in } x>\text { ft } 6 \text { in } x \\
11 \mathrm{ft} 4 \text { in }\end{array}$ & 15 & no & \\
\hline 23 & -- & Concrete Slab Shield & $4 \mathrm{ln} \times 4 \mathrm{ft} 6$ in $\times 6 \mathrm{ft} 4 \mathrm{in}$ & 9 & no & \\
\hline 24 & $34-0-302$ & Pu Product Catch Tank & $2-1 / 4 \times 3 \mathrm{ft} 6 \mathrm{in} \times 5 \mathrm{ft} 10 \mathrm{in}$ & 4 & no & $\langle f\rangle$ \\
\hline 25 & $34-G-301$ & Pu Catch Tank Pump & $\cdots$ & 1 & no & \\
\hline 26 & $34-G-302$ & Pu Product Pump & $\cdots$ & 1 & no & \\
\hline 27 & $34-G-303$ & Pu Product Pump & $\cdots$ & 1 & no & \\
\hline 28 & $34-G-304$ & Pu Product Pump & -- & 1 & no & $(h)$ \\
\hline
\end{tabular}

(a) $1 \mathrm{ft}=0305 \mathrm{~m}$

(b) $1 \mathrm{ft}^{\mathrm{s}}=283 \times 10^{-2} \mathrm{~m}^{3}$

(c) Equipment ordered 1 and 2 can be removed directly through the hatch

(d) The order of number 10 and 12 may be reversed if rigging is easier

(e) All concrete shield slabs sit directly in front of the tank which they precede on the list

(f) The order of removal of the tanks and shields may vary to make the rigging easier

(g) Must be cut up in the cell prior to being lifted out

(h) The following small equipment is removed as necessary along with all piping and other interferences to free the larger vessels listed above
1) $33-D-374$
3 PSP Head Dot
9) $51-0-554$
3 AX Head Pot
2) $33-0-375 \quad 3 \mathrm{SW}$ Head Pot
10) 32-D-361 2 AW Head Pot
3) $80-0-839$ etc Sampler Valve Pots
11) 32-D-364 Pu Rework Head Pot to I SF
4) $33-D-348$
3 AW Head Pot
12) 33-D-350 $3 \mathrm{BW}$ Head Pot
5) $33-D-370$
3 BSP Head Pot
13) $32-D-346 \quad 2$ BP Head Pot
6) $33-D-354$
3 BP Diversion Head Pot
14) $32-0-3402$ AF Head Pot
7) 51-D-553 3 BS Head Pot
15) 34-0-378 3 PD KO Pot
8) $33-0-380$
Pu Recycle Head Pot
16) $51-D-5562$ AX Head Pot 
emoval operations begin. Health physics personnel observe all operations to assure that radiation and industrial safety procedures are observed at all times.

\section{- Procedure}

This area consists of plutonium nitrate cells Number 1 and 2; the plutonium nitrate operating station containing pump, valve and loadout glove boxes; a control area and a cooling water area. Relatively high Pu contamination is anticipated. There is no access into the plutonium nitrate cells large enough to allow removal of the storage tanks and neutron shields. Therefore, the tanks and shields are sectioned inside the cells and removed through penetrations in the north wall of each cell. A fixative is sprayed on the outside of the tanks and shields before removal from the cell to help prevent any surface contamination from becoming airborne.

Before the tanks and shields are removed from the PNC's, it is necessary to remove the glove boxes. The glove boxes are cleaned internally with chemicals, sprayed internally with a fixative, equipment is removed from the boxes and the fronts of the boxes are sectioned and removed. Removal of the glove boxes allows the penetration through the walls of the PNC's to be made.

Equipment in the cooling water area and control area is disassembled and surveyed and packaged for disposal dejending upon the results of radiation survey. Contaminated equipment is moved to the PNSA for packaging and shipment. Filters, fans and ducting are considered contaminated for disposal purposes.

It is necessary to decontaminate the walls, floor, and ceiling in this area after the equipment has been removed. A survey is conducted in the cooling water area, the control area, the storage area and the operating station. Spot decontamination methods are used to remove the expected localized and low contamination level. The walls in the plutonium nitrate cells may contain wide spread contamination. These walls are scarfed using explosives. Drilling and rock splitting are used on the ceiling. The stainless floor liner is sectioned and removed and the underlying concrete decontaminated as necessary. 
As a result of the access penetrations that must be made, modifications are made to the ventilation system as necessary to ensure adequate air flows.

- Sequence of Events

1. Decontaminate, disassemble, and survey the equipment in the PNSA. Package and dispose of the equipment as appropriate.

2. Flush plutonium storage (slab) tanks and glove boxes with nitric acid and water as necessary.

3. Apply a nonflammable coating to the floor and walls of the PNOG and to the interior surfaces of the glove boxes. This will fix residual contamination and prevent it from becoming airborne. The glove boxes are cleaned using a vacuum cleaner with nuclear criticality-safe dimensions and acid-soaked, nondegradable sponges before the coating is applied.

4. Cut all pipes and seal all wall penetration from the glove boxes to the PNC's.

5. Remove the piping, pumps, and other equipment from the glove boxes in the plutonium nitrate operating station. The equipment is bagged out of the glove boxes using existing procedures and placed in airtight shipping containers.

6. Section and package the fronts of the pump, valve, and loadout glove boxes.

7. Using a jackhammer, cut openings in the north walls of PNC Nos. 1 and 2. The existing air locks are used to prevent the spread of airborne contamination.

8. Section and package the slab tanks and neturon shields using a portable power saw. The slab tanks are sectioned into 1.22 meter $x$ 2.44 meter ( $4 \mathrm{ft} \times 8 \mathrm{ft}$ ) pieces, sprayed with a nonflammable coating, removed from the PNC's and loaded into shipping containers in the PNSA. Neutron shields are similarly sectioned, spray coated, and prepared for surface burial. 
9. As the tanks and shields are removed from the cells, the floor is covered with a painted $0.64-\mathrm{cm}(1 / 4-i n$.$) steel decking to minimize$ the spread of contamination that remains on the floor liner.

10. Disassemble and survey the equipment in the cooling water area, the control area and the storage area. Dispose of the material as appropriate.

11. Survey the walls, floor ceiling in the PNOS, CWA, PNCA and the PNSA. Remove any contamination discovered.

12. Seal the penetrations between the PNOS and the PN cells.

13. Decontaminate the concrete walls and ceiling in the plutonium nitrate cells using explosives and rock splitters.

14. Decontaminate and remove the temporary decking from the cells.

15. Remove and section the stainless steel floor liner, package it and remove it for shipment. To avoid airborne plutonium contamination, the entire liner is vacuumed using the vacuum cleaner with nuclear criticality-safe dimensions, the cutting pattern is marked off with tape and the entire liner is sprayed with a fixative agent. The tape is removed and the cutting areas are cleaned with sponges soaked in decontamination solution before cutting begins. Underlying concrete is spot decontaminated by mechanical means as necessary.

16. Detach and remove the air filters and the air coolers for circulating air, and all potentially contaminated ventilation duct work. Filters are bagged out using plant production procedures. Contaminated duct work is filled with foam, sectioned with an air operated hacksaw, sprayed with a fixative agent and removed for packaging. Ventilation ducktwork is temporaily rerouted as necessary during these operations to provide proper contamination control. 
E.3.1.5 Removal of Equipment from the Remote Process Cell (RPC), the Remote Maintenance and Scrap Cel1 (RMSC), and the Crane and Equipment Maintenance Gallery (CEMG)

This section identifies the major steps required to remove and package the equipment from the remote process cell, the remote maintenance and scrap ce11, and the crane and equipment maintenance gallery. The work in the remote process cell and remote maintenance and scrap cell is carried out by remote methods, using the maintenance equipment installed in the cells. Direct personnel contact methods should be possible in the crane and equipment maintenance gallery.

- Procedure

Remote Process Ce11

Relatively high radiation levels are expected on the equipment in this cel1. Plant production procedures and the installed remote maintenance equipment are used to remove the equipment from this cel1. The 31-MT maintenance crane is used to support the equipment, and the installed power manipulator is used to support and maneuver the plasma torch to cut and detach the equipment. Installed shielding windows provide personnel viewing. The opening between the RPC and the FRSS is sealed before equipment removal operations begin.

Access to the remote process cell is via a horizontally-sliding shield door into the crane and equipment maintenance gallery. Detached equipment is removed to the CEMG using the maintenance crane or the hull transfer crane. In the CEMG, removed equipment is placed in a shipping container within a transfer cask, the lid of the container and the cask are sealed, and a radiation survey is taken. Personnel remain shielded from this operation by using the shielding window and master-slave manipulator in the wall of the CEMG. The transfer cask is lifted from the CEMG using the EMS crane and removed to the cask loading station where the shipping container is prepared for shipment. Detached equipment requiring segmentation is transferred to the RMSC and segmented and packaged using installed equipment. Equipment is removed in the order given in Table E.3.6. 


\section{TABLE E.3-6. Remote Process Cell - Order of Removal of Major Pieces of Equipment}

\begin{tabular}{|c|c|c|c|c|c|c|}
\hline $\begin{array}{l}\text { Order } \\
\text { Number }\end{array}$ & $\begin{array}{l}\text { Equipment } \\
\text { Number }\end{array}$ & Equipment Name & Dimensions $(a)$ & $\begin{array}{l}\text { Shipping } \\
\text { volume } \\
\left(\mathrm{ft}^{3}\right)(\mathrm{b})\end{array}$ & $\begin{array}{l}\text { Shielding Required } \\
\text { for Transport }\end{array}$ & Notes \\
\hline 1 & $12-T-105 A / B$ & Dissolver Basket Storage Rack & $\cdots$ & 18 & no & \\
\hline 2 & $15-k-154$ & \#1 Dissolver Screen Pot & $x 6 \mathrm{ft} 9 \mathrm{in}$ & 12 & yes & \\
\hline 3 & $15-E-132$ & \#1 Dissolver Heater/Cooler & $1 \mathrm{ft} 4 \mathrm{in} \times 5 \mathrm{ft} 3 \mathrm{in}$ & 9 & yes & \\
\hline 4 & $15-C-101$ & $\# 1$ Dissolver & $3 \mathrm{ft} 2 \mathrm{in} \times 15 \mathrm{ft} 7 \mathrm{in}$ & 156 & yes & \\
\hline 5 & $15-k-155$ & \#2 Dissolver Screen Pot & $1 \mathrm{ft} 4$ in $\times 6 \mathrm{ft} 9$ in & 12 & yes & \\
\hline 6 & $15-E-133$ & \#2 Dissolver Heater/Cooler & $1 \mathrm{ft} 4 \mathrm{in} \times 5 \mathrm{ft} 3 \mathrm{ln}$ & 9 & yes & \\
\hline 7 & $15-C-102$ & \#2 Dissolver & $3 \mathrm{ft} 2 \mathrm{in} \times 15 \mathrm{ft} 7 \mathrm{in}$ & 156 & yes & \\
\hline 8 & $15-k-156$ & \#3 Dissolver Screen Pot & $1 \mathrm{ft} 4 \mathrm{ln} \times 6 \mathrm{ft} 9 \mathrm{in}$ & 12 & yes & \\
\hline 9 & $15-E-134$ & \#3 Dissolver Heater/Cooler & $1 \mathrm{ft} 4 \mathrm{in} \times 5 \mathrm{ft} 3 \mathrm{in}$ & 9 & yes & \\
\hline 10 & $15-C-103$ & \#3 Dissolver & $3 \mathrm{ft} 2$ in $\times 15 \mathrm{ft} 7 \mathrm{in}$ & 156 & yes & \\
\hline 11 & $14-6-101$ & Shear & $5 \mathrm{ft} \times 5 \mathrm{ft} 6 \mathrm{in} \times 10 \mathrm{ft}$ & 275 & yes & \\
\hline 12 & $14-\gamma-106$ & $\begin{array}{l}\text { Shear Magazine Transition } \\
\text { Section }\end{array}$ & $\cdots$ & 2 & no & \\
\hline 13 & $14-Y-105$ & Shear Feed Magazıne & $13 \mathrm{ft} 7$ in $\times 1 \mathrm{ft} 6$ in & 31 & no & \\
\hline 14 & $14-Y-107$ & $\begin{array}{l}\text { Shear Feed Chain and Magazine } \\
\text { and Drive Section Extending } \\
\text { into Cell }\end{array}$ & $\begin{array}{l}3 \mathrm{ft} \times 3 \mathrm{ft} 8 \text { in } x \\
1 \mathrm{ft} 6 \\
6\end{array}$ & 17 & no & \\
\hline 15 & $14-Y-104$ & Shear Support Frame & --- & 10 & no & \\
\hline 16 & $15-Y-152$ & Diverter & $8 \mathrm{ft} 9$ in $\times 11 \mathrm{ft} 1 \mathrm{in}$ & 848 & yes & (c) \\
\hline 17 & $13-T-107$ & Fuel Transfer Table & -- & 36 & no & \\
\hline 18 & $06-T-015$ & Fuel Transfer Conveyor & --- & 36 & no & \\
\hline 19 & $41-E-401$ & HAW Concentrator Reboiler & $4 \mathrm{ft} \times 13 \mathrm{ft} 2 \mathrm{ln}$ & 211 & yes & \\
\hline 20 & $41-E-460$ & HAW Concentrator & $6 \mathrm{ft} 4 \mathrm{in} \times 19 \mathrm{ft} 1 \mathrm{in}$ & 765 & yes & (c) \\
\hline 21 & $12-T-103$ & Basket Crane & $\cdots$ & 500 & no & (c) \\
\hline 22 & $46-T-403$ & Hull Monitor & --- & 50 & no & \\
\hline 23 & $46-T-401$ & Dissolver Basket Dumper & --- & 50 & yes & (c) \\
\hline 24 & $12-T-102$ & 35-Ton Maintenance Crane & --- & 750 & no & (c) \\
\hline 25 & $12-T-104$ & Power Manipulator & --- & 750 & no & (c) \\
\hline
\end{tabular}

(a) $1 \mathrm{ft}=0305 \mathrm{~m}$

(b) $1 \mathrm{ft}^{3}=283 \times 10^{-2} \mathrm{~m}^{3}$

(c) Must be cut outside the cell prior to being loaded in the shipping container 
Piping and other penetrations through the cell walls are sealed after they are cut. After all equipment has been removed, the cranes and power manipulator are run into the CEMG for use there. Shielding windows are removed or protected after all process equipment has been removed in preparation for structural decontamination operations.

\section{Remote Maintenance and Scrap Cell}

The radiation levels anticipated in this cell may require remote operations. The installed crane, power manipulators and viewing windows are used for removing the equipment from this cell. The equipment is lifted and moved in the cell using the installed crane, and removed from the cell through the hatch into the CEMG with the EMS crane. In the CEMG the equipment is placed in a shipping container within a cask, sealed and removed to the cask loading station for shipment. Equipment is removed in the order given in Table E.3.7. After all equipment has been removed, shielding windows, periscope wall tubes and master-slave manipulators are removed, and the respective wall penetrations sealed in preparation for the later removal of the cell liner.

\section{TABLE E.3-7. Remote Maintenance and Scrap Cell - Order of} Removal of Major Pieces of Equipment

\begin{tabular}{|c|c|c|c|c|c|c|}
\hline $\begin{array}{l}\text { Order } \\
\text { Number }\end{array}$ & $\begin{array}{l}\text { Equipment } \\
\text { Number }\end{array}$ & Equipment Name & Dimensions $^{(a)}$ & $\begin{array}{c}\text { Shipping } \\
\text { Volume } \\
(\mathrm{ft} 3)^{(b)} \\
\end{array}$ & $\begin{array}{l}\text { Shielding Required } \\
\text { for Transport } \\
\end{array}$ & Notes \\
\hline 1 & --- & $6 \mathrm{Hull}$ Disposal Containers & $3 \mathrm{ft} \times 7 \mathrm{ft} 4 \mathrm{in}$. & 396 & yes & \\
\hline 2 & $46-T-435$ & $\begin{array}{l}\text { Portable Cover Rack for Hull } \\
\text { Disposal Containers }\end{array}$ & $4 \mathrm{ft} \times 4 \mathrm{ft} 6 \mathrm{in}$. & 18 & no & \\
\hline 3 & $47-T-432$ & SAC Waste Retainer & $2 \mathrm{ft} \times 2 \mathrm{ft} 3 \mathrm{in}$. & 9 & no & \\
\hline 4 & $47-T-431$ & SAC Waste Chute & $4 \mathrm{ft} \times 10$ in. $\times 1 \mathrm{ft} 3$ in. & 8 & no & \\
\hline 5 & $46-T-402$ & Hull Transfer Car & $10 \mathrm{ft} \times 7 \mathrm{ft} \times 3 \mathrm{ft} 6 \mathrm{in}$ & 245 & no & \\
\hline 6 & $86-T-865$ & Removable Work Table & $\begin{array}{l}12 \mathrm{ft} \times 6 \mathrm{ft} 6 \text { in. } x \\
8 \mathrm{ft} 8 \mathrm{in} .\end{array}$ & 100 & no & $(c)$ \\
\hline 7 & $75-K-732$ & Mist Eliminator & $6 \mathrm{ft} \times 4 \mathrm{in} . \times 3 \mathrm{ft}$ & 120 & no & \\
\hline 8 & $87-V-803$ & TV Camera & -- & 1 & no & \\
\hline 9 & $86-T-840$ & Maintenance Crane & -- & 750 & no & (c) \\
\hline 10 & $86-T-827$ & Power Manipulator and Bridge & --- & 750 & no & (c) \\
\hline
\end{tabular}

\footnotetext{
(a) $1 \mathrm{ft}=0.305 \mathrm{~m}$

(b) $1 \mathrm{ft}^{3}=2.83 \times 10^{-2} \mathrm{~m}^{3}$

(c) Must be cut outside the cell prior to loading in the shipping container.
} 


\section{Crane and Equipment Maintenance Gallery}

This area is used routinely for work by direct contact by personnel because the expected radiation levels are low. The floor is protected with a disposable covering during equipment removal operations in the remote cells. CEMG equipment consists of a workbench, a crane maintenance platform, a strongback and an ultrasonic cleaning tank. Equipment that is not needed during operations in the remote cells is removed prior to the commencement of operations. The remainder is packaged and removed afterward. The power manipulator and the 31-MT ton crane from the remote process cell remain in this area to be used for the structural decontamination operations in the remote process cell.

\section{E.3.1.6 Glove Box Removal}

The following procedures are used for packaging and removing glove boxes:

1. Using plant production maintenance procedures, remove and package all contaminated equipment and debris from the glove box.

2. Vacuum the interior of the glove box with a criticality-safe vacuum cleaner.

3. Wipe down the interior steel surfaces with a sponge soaked in decontamination solution.

4. Completely fill each glove box with foam-in-place polyurethane.

5. Erect a small plastic greenhouse or portable filtered enclosure around the glove box.

6. Where possible separate adjacent glove boxes and disconnect all attachments. (Large glove boxes are sectioned with an air-operated hack saw.)

7. Cut the polyurethane foam at the separation point and place a cover over the exposed ends.

8. Place the glove boxes in shipping containers. 


\section{E.3.2 Sequence of Events for Filter Niche Decommissioning}

The filter niche is decommissioned via the following sequence of events:

1. Isolate the filter niche from any sources of potentially contaminated air.

2. Remove and package the filters using plant production maintenance procedures.

3. Chemically decontaminate the stainless steel liner, if necessary, using swabs or sponges. (This operation, performed at the end of the process building chemical decontamination phase may need to be repeated here.)

4. Conduct a radiation survey of the filter niche liner. Install temporary shielding over any hot spots.

5. Using a jackhammer make an additional penetration through the filter niche ceiling.

6. Position a shipping container in the lower viewing and operating station.

7. Section the stainless steel liner with a plasma torch to fit $1.22 \mathrm{~m}$ by $2.44 \mathrm{~m}$ ( $4 \mathrm{ft}$ by $8 \mathrm{ft}$ ) shipping containers. Remove the sections and place them in the shipping container using the installed monorail hoist or a portable crane.

8. Place the lid on the shipping container. Move it to the area beneath the hatch into the cask loading station, lift it into the cask loading station with the EMS crane and prepare it for shipment.

9. Repeat Steps 7 and 8 until the stainless steel liner has been completely removed. Work from clean areas toward the acess penetrations.

10. Survey the exposed concrete and spot decontaminate it mechanically as necessary.

11. Survey the lower viewing and operating station and decontaminate it as necessary. 


\section{E.3.3 Sequence of Events for the Dismantlement of the Liquid Waste Storage Facility}

The following sequence of events are used in the dismantlement of the liquid waste storage tank farm.

\section{E.3.3.1 Sequence of Events for Dismantlement of the Waste Tank Equipment Galley (WTEG)}

1. Chemically decontaminate all areas of the building with the exception of the cold areas. Many areas, such as the waste tank diverter cell (WTDC), have built-in chemical decontamination spray systems. These areas are sprayed until radiation levels are reduced sufficiently to allow contact operations on the equipment in these areas.

2. Remove coolant pumps and related equipment.

3. A strippable coating is applied to all surfaces in the area formerly occupied by the coolant pumps. This area is used as a work area for sectioning and packaging equipment removed from the WTDC.

4. Remove and package off-gas treatment equipment and piping.

5. Portable scaffolding is lowered into the WTDC through the existing man-hole. Piping above the two diverters is severed and removed using contact methods and the portable scaffold.

6. Cut a two-meter by two-meter hole in the WTEG concrete floor (WTDC ceiling) directly above the HLLW diverter.

7. The HLLW diverter is cut from it supports and associated piping, and lifted out of the cell. The diverter is surveyed for radiation and further decontaminated as necessary. It is then packaged for shipment and disposal.

8. The second diverter is cut free from all supports and piping, dragged to the position formerly occupied by the HLLW diverter and removed from the cel1. The second diverter is surveyed, packaged and shipped in the same manner as was the first. 
9. Cap a11 pipes leading to the waste tanks.

10. A11 piping and equipment remaining in the WTDC is removed.

11. Section, remove, and package the WTDC stainless steel cell liners. This procedure is similar to that used in the PNSL (Appendix E.3.1.4).

12. Survey the WTDC. Any contamination found on the underlying concrete in the WTDC is mechanically decontaminated using explosives or drilling and rock splitting.

13. Survey and mechanically decontaminate the hot area of the WTEG. Techniques are those used in the WTDC.

14. Decontaminate the building ventilation system. Methods used to decontaminate the main process building ventilation system are used here.

15. Decontaminate the work area.

16. Demolish the remainder of the WTEG building.

17. Perform final radiation survey of the WTEG.

\section{E.3.3.2 Sequence of Events for the Dismantlement of the ILLW Tank and HLLW Tanks}

1. Empty the tanks by processing the high-level waste through the waste solidification facility. The waste solution heels remaining in the tanks when decommissioning begins are consolidated in the last tanks to be decontaminated. The ILLW tank is used to collect contaminated solutions generated during decommissioning.

2. As each tank is emptied, introduce 33,000 liters $(10,000$ gal) of concentrated (50\%) nitric acid into the tank to dissolve deposits on the tank bottom and dilute the residual liquid waste solution that cannot be removed using the installed pump-out jets. Circulate the solutions using the installed spraging equipment and pump the tank down 
to the "residual" level with the installed pumps. Repeat this procedure or modified procedures until flushing becomes ineffective (assumed 2 times for ILLW tank and 4 times for each HLLW tank).

3. Isolate the tank farm from the main process building. Reroute the waste tank off gas and waste tank vault vent system to the waste solidification facility. Remove the pipe vault from the main process building to the tank farm.

4. After the four tanks have been emptied and the heels flushed, decontaminate and demolish the waste tank equipment gallery. (See

Section E.3.3.1)

5. Dismantle the ILLW tank. The procedure is similar to the one described in the sequence below for the high-level waste tanks. This tank is decommissioned first to evaluate equipment and gain experience before proceeding to the more difficult HLLW tanks. The radiation levels in the ILLW tank are approximately 1000 times lower than the HLLW tanks. Installation of decontamination sprayers through the ceiling of the waste tank vault is not required for the ILLW tank. Following the heel flush, the ILLW tank is pumped dry using a long shaft pump installed in the existing vault user.

6. Excavate a working area on top of the concrete vaults of all tanks. The holes are dug using a large backhoe. The sides of the holes are sprayed with concrete. (Caution must be exercised during excavation to ensure that the vault riser containing the 4-in. riser from the tank is not disturbed.

7. Clean the exposed concrete vault tops and paint them with a strippable coating to facilitate removal of contamination that might occur during dismantlement operations. This coating is replaced as necessary until the operations in the tank are completed. 
8. Install temporary shielding on the vault tops as necessary to reduce radiation dose rates to levels that permit working on the vault top for prolonged periods of time.

9. Make 25 penetrations for decontamination sprayers through the roof of each HLLW vault and tank top. The location of the penetrations is shown in Figure E.3-1. The penetrations are made by core dril1ing a $5-\mathrm{cm}\left(2-\right.$ in. $_{\text {) }}$ hole in the vault top, cutting a hole in the tank top and sealing a capped pipe in the hole. Drilling operations are done inside a small portable greenhouse. The air pressure in the tank is maintained below the level in the greenhouse during these operations.

10. Chemically decontaminate the tanks internals. A decontamination mist of $3 \% \mathrm{HF}-20 \% \mathrm{HNO}_{3}$ is first sprayed into the tank through nozzles inserted through the penetrations. This is followed by decontamination with rotating high-pressure decontamination sprayers inserted through the penetrations to provide maximum coverage for the decontamination spray. The decontamination solution is pumped out of the tank and is followed by a short water spray. This sequence is repeated twice. It is expected that an overall decontamination factor of about 10 will be achieved on the tank internals using these procedures. These sprays also serve as the final two heel flushes for the HLLW tanks.

11. Reseal all the penetrations when chemical decontamination operations are complete.

12. Erect the greenhouse building over the excavation site at HLLW Tank \#3 and prepare it for equipment removal operations. Connect the auxiliary ventilation system to an existing penetration into the tank.

13. Remove the vault riser and $10-\mathrm{cm}$ (4-in.) tank riser and seal the penetration into the vault. 


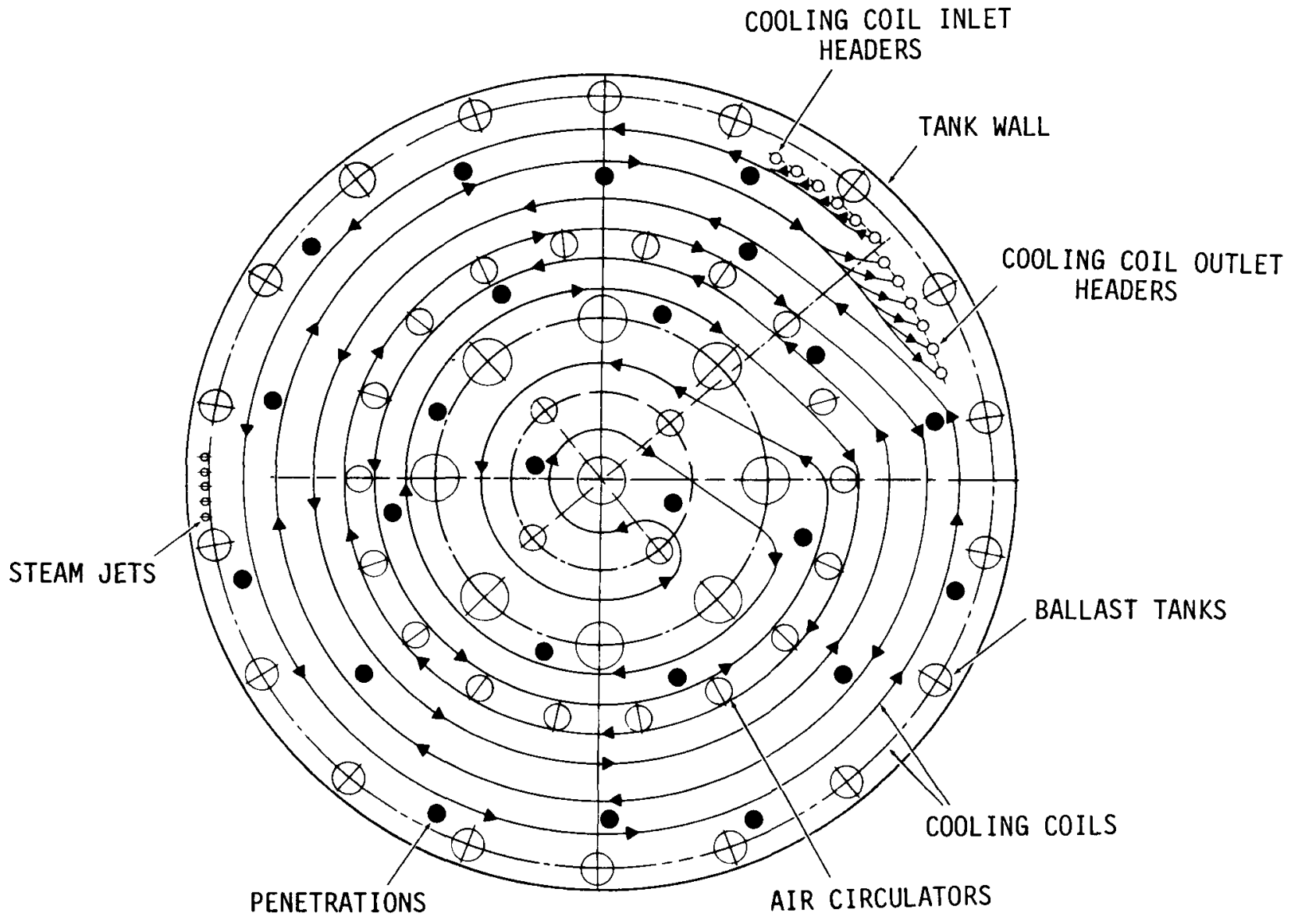

FIGURE E.3-1. Location of Spray Penetrations for HLLW Tank Decontamination

14. Core drill a 10-cm (4-in.) hole through the vault top above the lowest spot in the tank. Seal a 10-cm (4-in.) capped pipe in the hole. Penetrate the tank top below the hole and install a submersible pump to extract the residual solution from the tank. The pump discharge runs through an air-tight seal in the pipe cap.

15. Using a track drill, bore $2.5-\mathrm{cm}(1-\mathrm{in}$.$) holes 30 \mathrm{~cm}(1 \mathrm{ft})$ apart outlining the two roughly radial cuts in the first 3 meter $\times 3$ meter (10 ft by $10 \mathrm{ft}$ ) concrete section of the vault top to be removed (see Figure E.3-2). Use explosives to remove the concrete between 


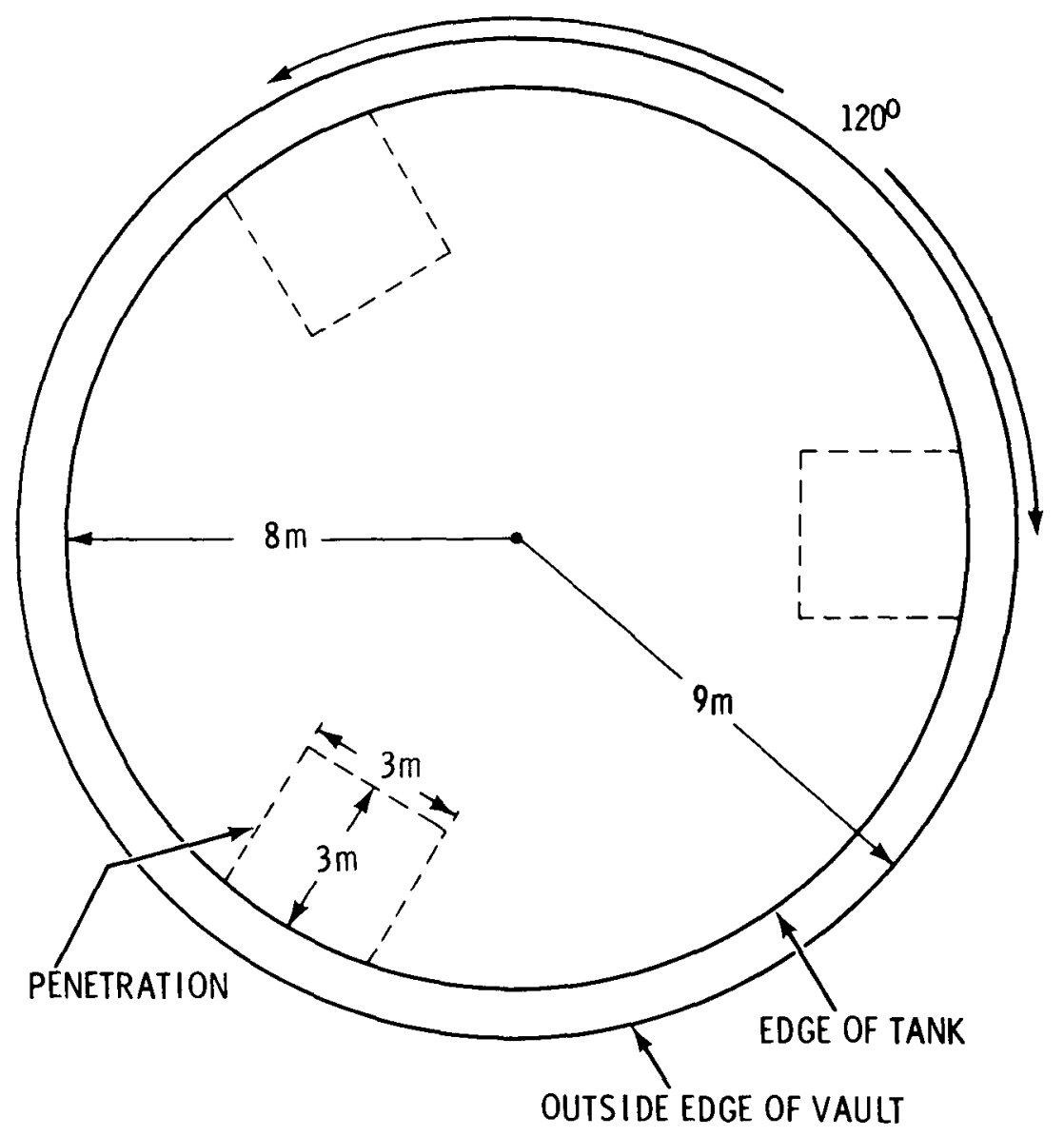

FIGURE E.3-2. Waste Tank Vault Top Penetrations

the holes. Cut the exposed reinforcing bar with a plasma torch. Attach a lifting/supporting device and support the block from the greenhouse crane. Use a track drill, explosives, and plasma torch to separate the other two sides of the slab. Lift the block off with the greenhouse crane. (Caution must be exercised during these operations to ensure that the top of the waste tank is not penetrated.) Break up the vault top and place in container for disposal of the contaminated concrete. 
16. Install a shielded working platform similar to the one described in Appendix E.3.6 over the opening in the concrete. This platform remains in place except when objects are being lifted into or out of the tank.

17. Using a plasma torch, remove several small sections of the exposed tank top. Use the openings to reach inside and sever any connections from the tank internals to the section of tank top beneath the opening. Remove the tank top beneath the opening. (This is a remote operation by personnel protected by the shielded working platform and shielded cage.)

18. Attach the crane hook to the first section of internals to be removed. Detach this section with a plasma torch and lift it out of the tank into a shipping container in a transfer cask. Place the lid on the shipping container and transfer cask. Remove the cask to the greenhouse and prepare the shipping container for shipment.

19. Sections of tank internals are monitored as they are removed from the tank. Sections found to be highly contaminated are either decontaminated in place using a portable decontamination sprayer, or taken to the special decontamination area of the greenhouse and cleaned.

20. Repeat steps 18 and 19 until sufficient space has been cleaned to lower the shielded working cage into the tank. Work downward into the tank to the tank bottom.

21. Continue decontaminating and removing the tank internals until about one-third of the tank has been cleared. Since the process for getting the cage in and out of the tank is time consuming, it is desirable that the cage remain in the cell for as long a working period as possible. It may be necessary for the cage operator to attach cables to the individual sections of internals as he frees them. These cables would run out to the working platform and could be used to drag and lift the sections out when the cage is removed. 
22. Install and seal a shield over the opening into the tank vault.

23. Make the next penetration into the tank vault and tank top as in step 15 through 17.

24. Remove the tank internals accessible to this opening as in steps 18 through 21 .

25. Make the last large penetration and proceed as above.

26. Survey the tank ceiling, wall and floor and chemically decontaminate them if necessary using the portable decontamination solution spray nozzle and the shielded cage.

27. Remove the submersible pump installed in step 14 .

28. Section the tank top with a plasma torch and remove it.

29. Starting at the top, section and remove the tank walls.

30. Section and remove the tank floor.

31. Section and remove the vault liner. Mechanically decontaminate the underlying concrete as necessary.

32. Mechanically decontaminate the top of the tank vault as necessary.

33. Excavate to the top of HLLW tank \#2.

34. Move the greenhouse building over HLLW tank \#2 and proceed as in step 13 through 32 . Remove the piping and pipe vaults as they become exposed. It may be necessary to construct temporary pipe runs to carry the decontamination solution to the desired place. Doublewalled stainless steel pipes are used for this purpose. The pipes are buried to provide shielding and are equipped with leak monitoring devices between the inner and outer walls. After dismantlement of the WSP begins, the small amounts of chemical solutions used for local decontamination are transferred to a storage tank and solidified by an outside contractor.

35. Drill drainage holes in the bottom of the tank vault and backfill when decontamination of the vault is complete. 
36. Dismantle HLLW tank \#1.

37. Decontaminate, dismantle and remove the greenhouse building.

\section{E.3.4 Dismantlement Details for the Waste Solidification Plant (WSP)}

Dismantlement of the WSP does not begin until all chemical decontamination solutions from the tank farm have been solidified. A brief description of the procedures used to dismantle the WSP were presented in Section 7.3.4 of Volume 1 ; a more detailed description of the sequence is presented here.

\section{- Sequence of Events}

1. After final pumpout of chemical decontamination solutions from HLLW tank \#1, the hot pipe trench connecting the tank farm to the WSP is dismantled. The pipes are chemically decontaminated internally, cut at both ends, and pulled into the WSP, where they are sectioned to fit into shipping containers.

2. Chemically decontaminate the HPT. A traveling high-pressure sprayer is pulled through the trench to decontaminate it.

3. Seal off the HPT where it enters the WSP.

4. Remove those portions of the HPT exterior to the WSP. Temporary but high-quality greenhouses are used to isolate sections of the trench from the atmosphere while the trench and liner are being removed and packaged for disposal.

5. Perform final chemical flushes of WSP process equipment and cell walls using standard techniques and installed equipment. Mist eliminators are installed at the ventilation exhaust points to prevent damage to ventilation system filters. Used chemical decontamination solutions are routed to the calciner feed tank.

6. Solidify the chemical decontamination solutions produced in step 5 . Transfer the cylinders of solidified waste to the FRSS using normal plant production procedures. 
7. Deactivate utilities (electricity, steam, air water) to process equipment not required to be in operation during dismantlement.

8. Remove the equipment, piping and other hardware from the WVC. Norma? remote maintenance procedures are used where possible to remove equipment to the HMC for disassembly and packaging. A plasma torch is used to cut equipment free from piping and support brackets. All operations are performed remotely using the CVC cranes and installed mainpulators and viewing windows. A portable enclosure with filtered ventilation exhaust is used during cutting operations to reduce the spreac of airborne contamination.

9. Piping that penetrates cell walls is sealed at both ends and left in place. The sealed sections of pipe are removed during the building demolition operations.

10. The in-can-melters and calciner are cut up in the HMC to fit waste containers acceptable at the waste repository. The outer shell of this equipment is sectioned with a plasma torch. Underlying insulation is then stripped out. Ceramic insulation is broken up by dri11ing and rocksplitting, if necessary, and removed. The inner vessel, interior piping and other hardware is sectioned as necessary with a plasma torch. The sectioned equipment is placed in waste disposal containers and removed through the HMC shielding door for offsite shipment. Debris is removed from the HMC floor using a specially designed vacuum cleaning system.

11. Drain the can transfer aisle between the CDC and the FRSS and seal off both ends with welded steel plates.

12. Remove the equipment, piping and other hardware from the canister decontamination cubicle. Temporary shielding is remotely installed over hot areas using the installed cranes, manipulators and shielding windows. Contact methods are then used for equipment removal. Equipment is cut with plasma torches, taken out of the cell through the access plugs to the warm service gallery, packaged and removed for offsite shipment. 
13. Remove the equipment, piping and hardware from the off-gas treatment ce11. Equipment with excessive radiation levels is removed to the HMC remotely using the installed shielding windows and manipulators. Temporary shielding is installed over hot areas and remaining equipment is removed through the OGTC ceiling hatch to the HMC using the HMC crane, sectioned with a plasma torch as necessary, packaged and removed for offsite shipment.

14. Remove the stainless steel liner from the WVC. Conduct a radiation survey of the cell. After remote installation of temporary shielding over hot areas, liner removal is performed by contact methods. Manipulators are removed and sleeves plugged and protective covers are placed over shielding windows before liner removal begins. The liner is sectioned in place using plasma torches and packaged in the HMC for offsite shipment. Liner removal generally proceeds from the top of the cell toward the bottom. The crane rails are the final item removed from the cell. Concrete under the liner is decontaminated as necessary using drilling and rock-splitting techniques. (Explosives may be used if large areas of concrete must be decontaminated.) The concrete surrounding the anchors holding the liner to the concrete wall are expected to have the highest potential for contamination. Roughing filters and additional filters in the ventailation system are installed.

15. Remove the liners from the CDC and OGTC and decontaminate underlying concrete using procedures similar to those described above for the WVC.

16. Remove the equipment and other hardware and the cell liner from the HMC using techniques similar to those described above for the other cells. Use the special vacuum cleaning system to clean the cell, and wash down surfaces with swabs soaked in decontamination solution.

17. Conduct a radiation survey of the remaining galleries and operating areas of the WSP and decontaminate them as necessary. Contamination is expected to be localized. Contaminated equipment or piping is 
removed using standard maintenance techniques or cut and removed with a portable plasma torch. Contaminated concrete is removed using drilling and rock-splitting or by jackhammering.

18. Decontaminate the ventilation system. HEPA and roughing filters are removed using normal production operational maintenance procedures. A temporary HEPA filtered ventilation system bypass exhausting into the ventilation trench to the VFS is installed during decontamination operations in the WSP ventilation system. Ventilation ductwork is sectioned, sealed at both ends, packaged and removed. Stainless steel liners are removed from ventilation trenches by sectioning in place with a plasma torch. Contact operations are expected to be used for ventilation system decontamination after ventilation filters have been removed.

19. Seal off the WSP ventilation trench where it enters the VFS. Decontaminate the ventilation trench using techniques similar to those described previously for the hot pipe trench.

20. Conduct final radiation surveys of the WSP. The building is demolished with the other decontaminated facilities on the site during the demolition and site restoration phase.

\section{E.3.5 Sequence of Events Fuel Receiving and Storage Station (FRSS)}

The following sequence of events is used in this study to decommission the fuel receiving and storage station:

1. Ensure that the water filtration and deionization system is operating at maximum efficiency.

2. Operate the pool water recirculation, deionization and filtration systems until the radioactivity in the pool water has been reduced to levels that will permit release of the water to the nearby river, consistent with the concept of ALARA. Compliance with federal and local water quality standards is determined by analysis of the 
quality standards is determined by analysis of the deionized pool water before it is released to the environment. It is estimated that this operation will require about 100 days using the installed deionization equipment. Additional equipment will be installed if necessary to reduce radioactivity to the desired levels.

3. Isolate the FRSS ventilation system from the main process building.

4. Drain the pools. The deionized pool water is pumped to the onsite water reservoir for subsequent release to the river or vaporized in the acid fractionator overhead vaporizer and released to the atmosphere. As the poots are drained, wash down the exposed surfaces with a high-pressure water or steam spray and paint them with a nonflammable water-based paint. As soon as it is exposed, the opening between the remote process cell and the fuel transfer pool is sealed with a stainless steel plate bolted to the concrete wall. This plate remains in place until decommissioning operations in the RPC and FRSS have been completed.

5. Radioactive particulates will have accumulated on the bottom of the storage pools over the lifetime of the plant. Most of these particulates are removed with an underwater vacuum cleaner when about $1.5 \mathrm{~m}$ of water remains in the pools. The bulk of the particulates are collected in filters placed on the vacuum discharge. The remainder of the water in the pools is then drained. The pool floor is chemically decontamined with a high-pressure water sprayer and then painted.

6. Beginning with the fuel transfer pool, detach equipment with a plasma torch and load it into a shipping container with the canister crane. Large equipment is sectioned in place before being loaded into a container.

7. Place the lid on the shipping container, transfer it to the vehicle unloading bay and prepare it for shipment. 
8. Remove the equipment in the various areas in the following order:

1) fuel storage pool, 2) cask unloading pools No. 1 and No. 2,

3) decontamination pit, 4) test and decontamination pit.

9. Remove and package the quipment and piping in the deionization area. If flammable deionization materials are used in this system, mechanical devices (saws) are used for cutting operations.

10. Decontaminate the walls and floor of the deionization areas as necessary.

11. At this point the area is converted into a temporary storage area for cargo containers awaiting shipment. The succeeding steps are carried out when this capability is no longer needed.

12. Remove and section the stainless steel liners in the storage pools and decontamination pits, working from the top of the pool toward the bottom. The 1 iners are cut to fit into $1.22 \mathrm{~m}$ by $2.44 \mathrm{~m}(4 \mathrm{ft}$ by $8 \mathrm{ft}$ ) shipping containers.

13. Survey the exposed concrete for radiation and remove contaminated areas by drilling and rock-splitting or with jackhammers.

14. Conduct a comprehensive survey of the remaining areas of the building. Remove and package any contaminated material discovered.

15. Remove and package all contaminated ductwork in the building and decontaminate the ventilation unit. Temporary rerouting of ventilation ductwork may be required to ensure proper contamination control.

16. Decontaminate the two vehicle unloading bays.

17. Conduct a final radiation survey of the fuel receiving and storage station.

18. Demolish the FRSS when the rest of the facility is demolished. 


\section{E.3.6 Special Equipment and Material Requirements}

A number of peripheral activities are required to obtain the needed special tools and equipment. These activities include: the development of functional and operational requirements for devices needed in the decommissioning work; the preparation of detailed designs for noncommercially available devices, and modifications to commercially-available equipment; procurement or fabrication of the identified equipment items; and the establishment and use of a mockup facility for use in testing and development of special remotelyoperated equipment or procedures. Most of these activities are carried out during the planning and preparation period.

A listing of special tools and equipment together with their functions is given in Table E.3-8. It is assumed that none of this equipment is avai1able from the facilities' production operations equipment. All equipment required for jobs that are subcontracted are assumed to be furnished by the subcontractor. Descriptions of conceptual specifications for some of the more unique nonstandard devices are presented in the subsections that follow. Speical material requirements are presented in Table E.3-9.

\section{E.3.6.1 Cutting Devices}

The principal devices used in cutting contaminated structures in this study are plasma arc torches and the arc saw. 0xy-acetylene torches are used for some cutting of carbon steels. However, since most of the materials to be cut will be stainless steel, use of the oxy-acetylene torch will be 1 imited.

\section{- Plasma Arc Torch}

Two types of plasma arc cutting torches were considered in this study: the traditional plasma-flame cutting torch (also referred to as constrictedtungsten-arc) and the newer vortex-stabilized arc.

Traditional plasma-arc cutting employs an extremely high temperature, high velocity constricted arc between the electrode in the plasma torch and the piece to be cut. The arc is constricted by passing it through a nozzle with a small diameter orifice. The arc is thereby localized so that its 


\section{TABLE E.3-8. Special Tools and Equipment for Decommissioning}

Portable plasma cutting torch( 3 )
Portable oxy-acetylene cutting torch
Arc saw 4 )
Gulllotine pipe saws
Closed circuit, high resolution tele-
vision systems
Shielded vehycle, scoop or front
end loader( 6 )
High velocity water jets $(7)$
Hydraulic concrete surface spalling
device (rock splitter)
Concrete drills
Electric/pneumatic hammers
Portable enclosures with filtered
ventilation exhaust

Shleided working platform

Contamination confinement greenhouse bullding

Polyurethane foam generator

Submersible pump or long-shaft pump

Radiation detection and analysis system

Electric arc welding machines

Paint sprayers

High security locks

Intrusion alarm system

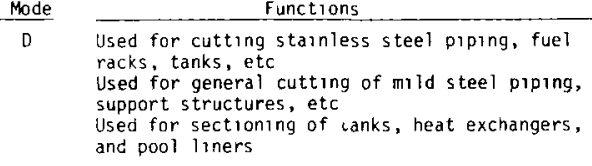

D Used for cutting stainless steel piping, fuel

racks, tanks, etc support structures, etc Used for sectioning of canks, heat exchangers, and pool liners

All Portable power pipe saws for removal of piping

All For observation and control of remote operations in high radiation fields

o For remote packaging of activated concrete rubble, etc See subsequent description in Section $E 366$

All For surface decontamination of piping. tanks and equipment

All For removal of contaminated concrete surfaces See subsequent description in Section E 362

All For drilling holes in concrete as required for surface spalling and volume blasting

D,PS For collecting and filtering air, smoke, fumes, etc , from cutting or other dusty operations on contaminated materials see subsequent description in Section $E$ B 64

A1l Provide personnel with maximum respiratory and surface protection against contamination

D For use over areas being blasted for removal of concrete, prevention of flying missiles, etc

For use after inplant radwaste system has been dismantled

For drilling 1020 meter-deep vertical holes in concrete for explosive surface removal

For personnel use in removing contaminated equipment and concrete from elevated areas

For personnel use in process cells and waste tanks where radiation levels prevent unshielded access see Specifications in Section $E 367$

Used to close openings into process cells and waste tanks, reducing radiation shine to the surroundings See Specifications in Section E 365

D To house decomissioning activities and prevent spread of contamination from openings into waste tanks during operations in the tanks

D For foam-filling of contaminated ventilation ductwork, to fix contamination

D,PS For removing residual heels in waste storage tanks after flushing

All For use in monitoring progress of chemical decontamination processes

All For a variety of welding needs

All For appication of rubber-emulsion paints to $f i x$ contamination on surfaces or to prevent recontamination of cleaned surfaces

L,PS To secure exterior entrances to facility and interior entrances into hazardous areas

L,PS To provide full-time survelllance of facility as protection against intrusion 
TABLE E.3-9. Special Materials for Decommissioning

Material

Polysulfide Adhesive

Double-walled stainless steel piping

Decontamination chemicals

Linear-shaped explosive charges

$\underset{j}{w}$
Mode

PS

PS

Al1

D
Useage

For sealing doors, access plates, etc. into contaminated areas.

For temporary piping between waste tanks for use during flushing and decontamination.

For chemically decontaminating piping, tanks, etc. in place.

For sectioning pipe, tanks, liners, etc.

\author{
Key: \\ D - Dismantlement \\ PS - Protective Storage \\ L - Layaway
}


energy is concentrated upon a small area on the base plate where its intense heat melts the metal.

The gas, which is preheated by the arc, expands and is accelerated as it is forced through the constricting orifice. The metal that is melted is then continuously removed by the jet-like action of the gas stream to form a kerf. The combined heat and force of the arc stream produce a high-quality, smooth, sawlike cut. Where inert gases are used, the cutting process depends upon thermal action alone. When cutting materials such as mild steel and cast iron, increased cutting speeds can be achieved by using oxygen-bearing cutting gases. In this case, the energy obtained by the chemical reaction of oxygen with the base material is added to the arc heat to permit higher cutting speeds. The process can be used to cut any metal. The plasma-arc torch is shown schematically in Figure E.3-3.

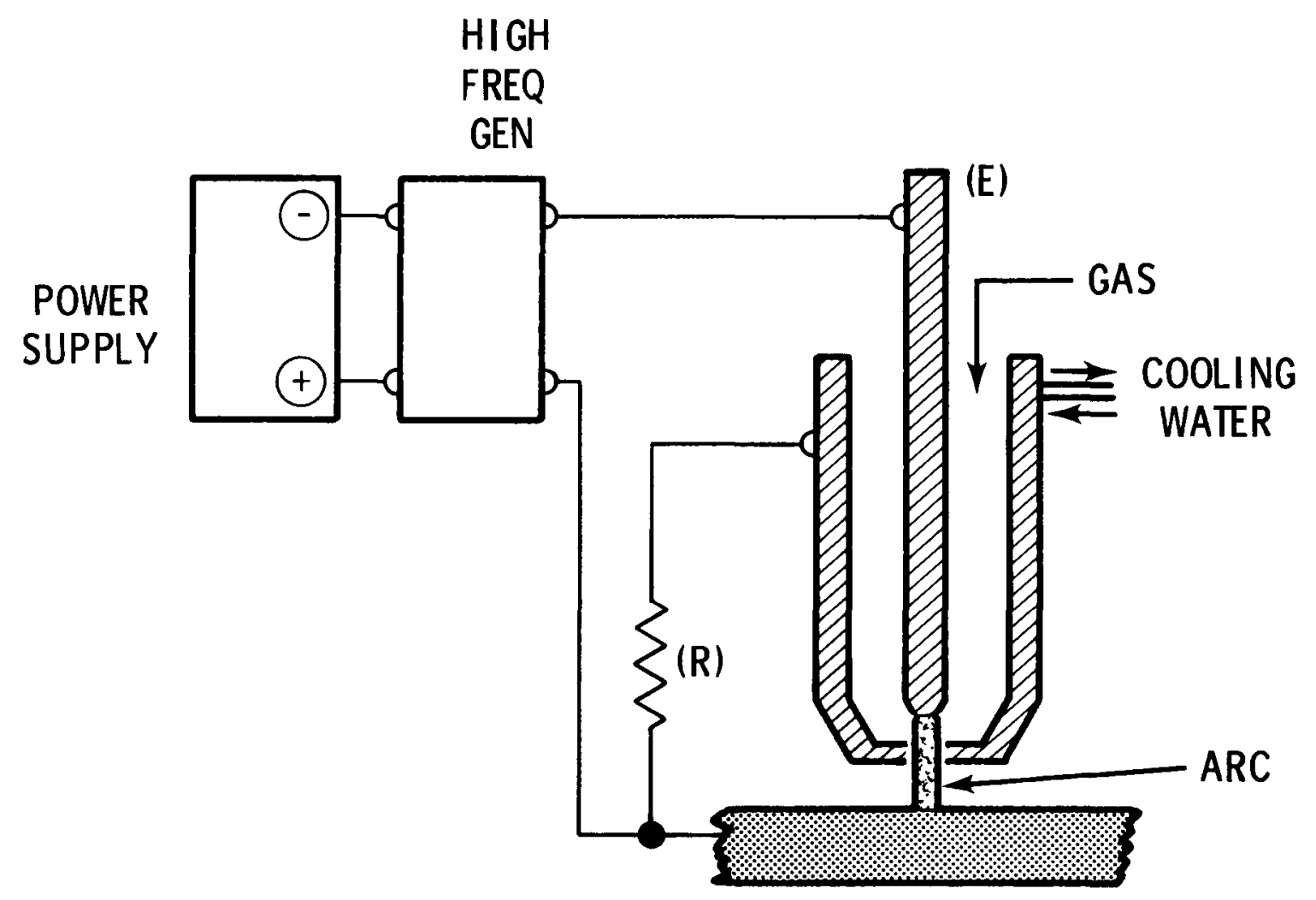

FIGURE E.3.3. Plasma Arc Torch Schematic Diagram 
The electrical circuit is basically the same as used for gas tungsten-arc welding with the exception that a connection is made from the ground and passed through a resistor $(R)$ to the nozzle of the torch. A high-frequency spark is used to complete the circuit between the electrode (E) and the nozzle, thereby producing a pilot arc. This pilot arc is then used to initiate the main arc from the electrode to the work piece. (9)

There are two types of electrode holders and automatic cutting controls. One type is designed for cutting where the torch is manually guided. The other type is for automated cutting where the torch is mounted on an automatic travel mechanism. Water cooling is used to prolong the operating life of the torch electrode and nozzle. Torch surfaces are insulated as completely as possible to prevent the operator from touching an electrically "hot" metallic surface. Gas pressure regulators and flowmeters are required for controlling the flow of cutting gas. A contactor, usually built into the power supply, is necessary for turning power on and off. For automated operation, a travel carriage of the straight-line, circle-cutting or shape-cutting type having the desired speed range is required.

The cutting controls contain relays and solenoid valves to control the flow of cutting gas, to operate the high-frequency power supply required for arc starting and to open and close the cutting power contactor. The controls also provide a flow switch to indicate an adequate flow of cooling water. The machine control provides a means of starting and stopping the carriage on which the torch is mounted.

Arc-constricting nozzles are available in a variety of diameters and shapes. The shape and diameter of the arc-constricting nozzle to be used depends on the application and the electrical current to be used, with high currents requiring larger orifices. Both single port and multiport nozzles have been used for cutting. The multiport nozzles generally have auxiliary ports arranged in a circle around a central orifice.

The torch system used for cutting have open-circuit voltages in the range of 120 to $40 \mathrm{~V}$ direct-current single phase. Heavy-duty cutting requires power 
supplies with 400 open-circuit volts. The high open-circuit voltage is required for severing thick plates and for piercing metal as thick as $5 \mathrm{~cm}$ (2 in.).

Mixtures of argon and hydrogen or nitrogen and hydrogen are generally used for cutting stainless steel, aluminum and other nonferrous metals. Nitrogen and oxygen, supplied separately to the torch and mixed in the torch nozzle, are used for cutting carbon steel, cast iron and alloy steels.

In mechanized operations, the torch standoff distance from the work piece, in air, is set between $0.64 \mathrm{~cm}(1 / 4 \mathrm{in.})$ and $1.6 \mathrm{~cm}(5 / 8 \mathrm{in.})$. The electrical cutting current, gas type and rate of flow are set at values recommended by the manufacturer of the equipment. These values are primarily determined by the type and thickness of the material being cut. After the operator presses a start button to initiate the cutting arc, the sequence of operations is regulated by the cutting control.

For manual operation, the operator selects the gas flow rate and cutting current according to the table of conditions supplied by the manufacturer or as obtained from his own testing and development program. The torch is held over the work piece and the cutting arc is struck by pressing a button on the torch handle. The torch is then manually guided over the work piece. At the end of the cut the arc automatically extinguishes and the control automatically opens the contacts and closes the gas solenoid values. The operator can extinguish the arc at any point simply by moving the torch away from the workpiece.

The plasma cutting process can be used in air or under water. It is especially adaptable to automation when highly radioactive material is to be cut, e.g., the pressure vessel of the Elk River Reactor in Minnesota. (3) As it is not necessary to start the cut at the edge of the plate, the plasma arc torch is particularly adaptable to the piercing and cutting of holes in large plates and vessels. The process is also well adapted to gouging of deep pits in materials including pad washing and scarfing. 
Some typical conditions for mechanized plasma arc cutting of stainless stee 1 in air are given in Table E.3-10.

TABLE E.3-10. Typical Conditions for Plasma Arc Cutting of Stainless Steel

\begin{tabular}{|c|c|c|c|c|}
\hline $\begin{array}{r}\text { Thickr.ess } \\
(i, i .)(a)\end{array}$ & $\begin{array}{l}\text { Speed } \\
\text { (ipm) (a) }\end{array}$ & $\begin{array}{l}\text { Orifice } \\
\text { Diameter } \\
\text { (in.)(a) }\end{array}$ & $\begin{array}{l}\text { Current } \\
\text { (amps) }\end{array}$ & $\begin{array}{l}\text { Gas Flow } \\
(c f h)(b)\end{array}$ \\
\hline$i / 2$ & 100 & $1 / 8$ & 300 & $150 \mathrm{~N}_{2}$ \\
\hline 1 & 50 & $5 / 32$ & 400 & $175 \mathrm{~N}_{2}$ \\
\hline 2 & 20 & $5 / 32$ & 500 & $130 \mathrm{~A}-70 \mathrm{H}$ \\
\hline 3 & 16 & $3 / 16$ & 500 & $130 \mathrm{~A}-70 \mathrm{H}$ \\
\hline 4 & 8 & $3 / 16$ & 500 & $130 \mathrm{~A}-70 \mathrm{H}$ \\
\hline
\end{tabular}

(a) 1 in. $=2.54 \mathrm{~cm}$
(b) 1 cfh $=2.83 \times 10^{-2} \mathrm{~m}^{3} / \mathrm{hr}$
$\mathrm{A}=$ argon gas
$\mathrm{N}_{2}=$ nitrogen gas
$\mathrm{H}_{2}=$ hydrogen gas

The second type of plasma torch considered in this study is the vortexstabilized arc. $(a, b)$ Although this torch was designed mainly for high temperature metalurgical heating, it can be used effectively for cutting. Because the arc is formed entirely inside the torch (not between the tool and workpiece as described above) the arc can remain established with abrupt and severe changes in tool-to-workpiece distances. This makes the vortex stabilized arc an excellent cutting tool when used with remote manipulators and on irregular surfaces.

Plasma is formed when the gas is forced past the arc, heating the gas. The shape of the orifice causes the incoming gas to swirl, forming a vortex. This vortex is used to stabilize the arc. Arcs up to 1.5 meters in length have been produced using this technology.

(a) Private communication: J. F. Johnson, Battelle, Pacific Northwest Laboratories, with George Beitel, Rockwell-Hanford, July 27, 1977.

(b) Private communication: J. F. Johnson, Battelle, Pacific Northwest Laboratories, with Dave Brown, TASC, Raleigh, NC, July 27, 1977. 
Arc Saw

Initial development and demonstration work for an arc saw cutting device has been accomplished. ${ }^{(4)}$ The results indicate that use of the device, particularly in a contaminated equipment volume reduction program, looks very promising and it is assumed that additional development work will provide an even more sophiticated unit that will be available commercially in the near future. It is both an economical and an expedient cutting process relative to other methods.

A prototype arc saw machine was built to swing a $91 \mathrm{~cm}$ (36 in.) diameter, $0.64 \mathrm{~cm}(1 / 4 \mathrm{in.})$ thick copper or mild steel blade with a $11.2 \mathrm{~kW}$ (15 hp) motor. Blade speed was approximately $880 \mathrm{rpm}$ and blade cooling was accomplished by a water spray system installed in the blade guard. However, cutting can be accomplished remotely either in air or underwater while permitting automatic positioning and tracking of the saw blade during cutting operations. All equipment, with the exception of the blades, are commercially available items (modifications are necessary, of course). The blades can be made in any well-equipped machine shop. The arc saw is shown schematically in Figure E.3-4.

The modified power source consists of a $7500 \mathrm{~A}, 80 \mathrm{~V}$ open circuit, $50 \mathrm{~V}$ operating dc power supply of the constant current, constant voltage type. The controls include a recorder to monitor voltage, amperage, blade travel, positioning motor electrical supply, and the necessary positioning controller to permit automatic positioning and tracking of the saw blade during cutting operations.

Low voltage, high amperage current is applied through the arc saw blade to the grounded work piece, thereby melting the base metal while producing a narrow cut. Work piece position changes or vibrations, which would normally bind any other type of saw, merely slows the arc saw's cutting speed with a resultant wider cut being opened to accommodate the shifting motions. This is due to the "electrical leading edge" being transferred from the narrow tip of the blade temporarily to spots on the sides of the blade coming into contact momentarily with the work piece. The difference of potential is thus shifted 


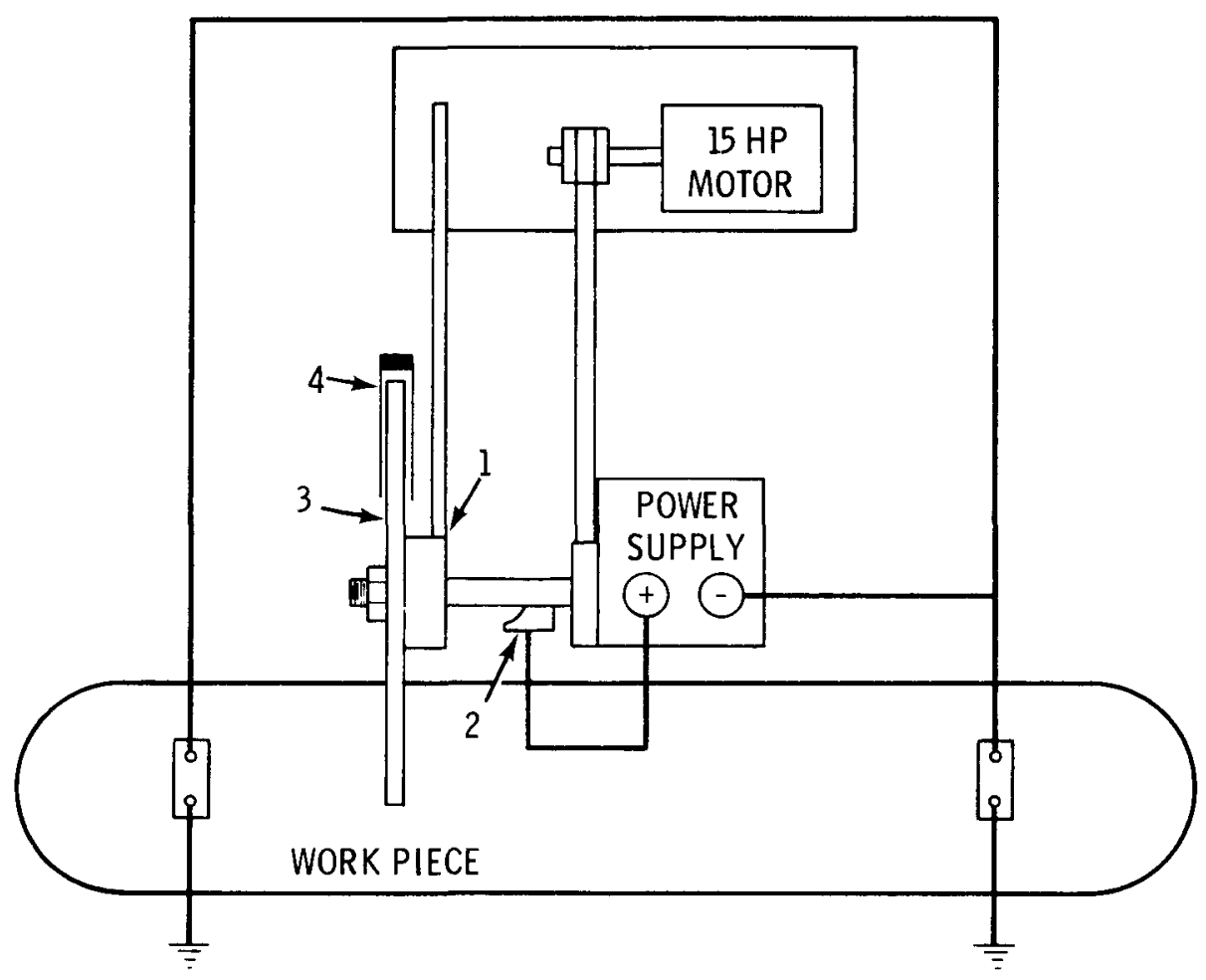

1 BEARING ATTACHED TO, BUT INSULATED FROM ARC BLADE

2 BRUSHES IN CONTACT WITH SHAFT WHICH IS CONNECTED DIRECTLY TO ARC SAW BLADE

3 COPPER OR STEEL ARC SAW BLADE

4 BLADE GUARD WITH WATER SPRAY DEVICE FOR COOLING

\section{FIGURE E.3-4. Arc Saw Schematic Diagram}

to the lateral areas, thus producing the wider cut. As a result, the saw can cut through a variety of materials, pieces, and loose tubes without jamming. Scaling up the saw blades to diameters of approximately 3 meters ( 9 to $10 \mathrm{ft}$ ) for cutting larger diameter heat exchangers, tanks, etc., appears to be feasible. 


\section{E.3.6.2 Tools for Concrete Surface Removal}

Many areas of the plant have concrete surfaces contaminated to a depth such that surface washing with decontamination solutions is ineffective, and removal of the surface layers is the only effective decontamination method. Some tools used in this study for mechanical removal of concrete are described in this section.

- Rock Splitters

Modified rock-splitting tools have been developed to facilitate mechanical decontamination of concrete. An example of such a device is illustrated in Figure E.3-5. The tool consists of a split collar with a sharp triangular ridge around the circumference, mounted on a shaft that has a tapered end. The tapered portion of the shaft is pulled into the split collar by a hydraulic cylinder, forcing the sharp ridges into the concrete, thereby fracturing the concrete locally. The device is fully portable. It weighs about $9 \mathrm{~kg}$ (20 1b) without the hydraulic power unit which supplies the moving force to the hydraulic cylinder, and has dimensions of about $40 \mathrm{~cm}$ (16 in.) in length and about $52 \mathrm{~cm}^{2}$ ( 8 in. ${ }^{2}$ ) area. It can readily be adapted to remote operation.

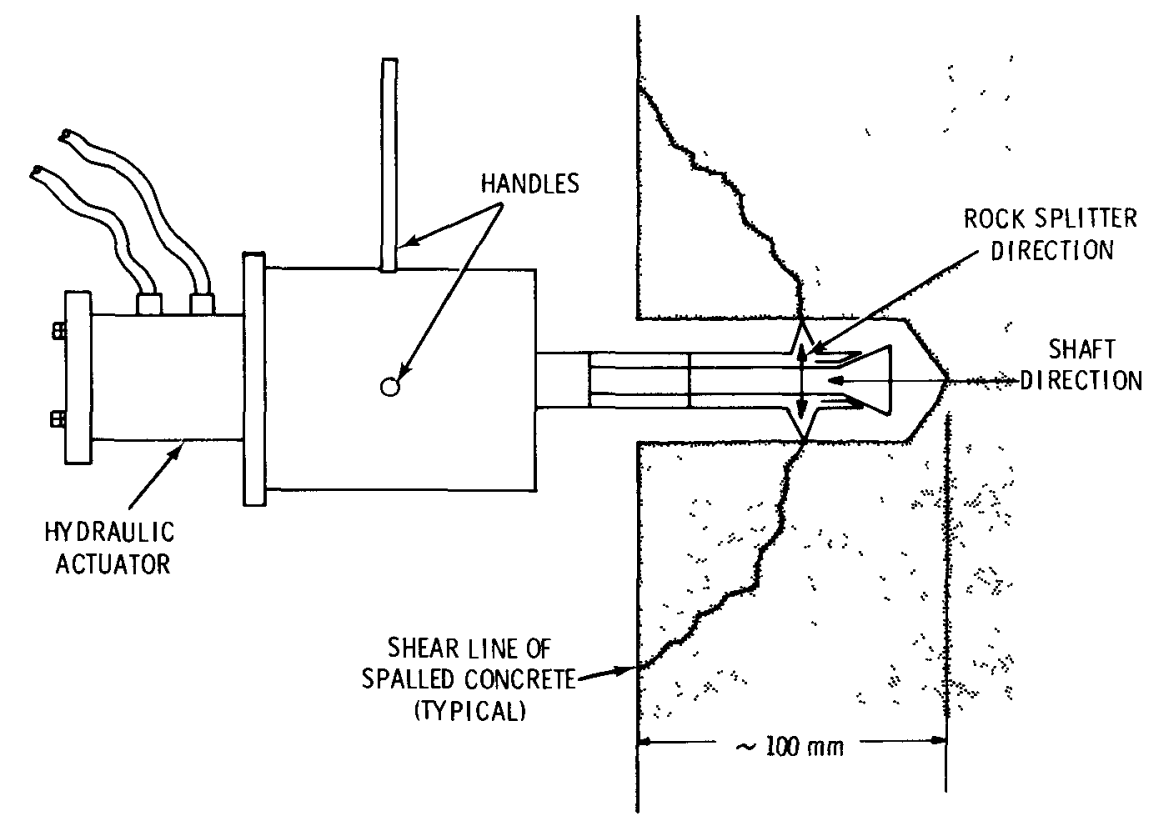

FIGURE E.3-5. Hydraulic Rock-Splitter for Spalling 
A $2.5-\mathrm{cm}$ (1-in.) diameter hole, about $10 \mathrm{~cm}$ (4 in.) in depth, is drilled into the concrete surface. The splitting tool is inserted to the bottom of the hole and the hydraulic actuator forces the sharp edges of the tool into the surrounding concrete, causing the concrete to fracture locally and spall away from the surface.

For rapid removal of large surface areas, several devices can be ganged together with a corresponding set of concrete drills and operated as a unit. The spacing between holes and the pattern of the holes (square or triangular array) are important parameters in the effectiveness of this technique for removing concrete surfaces. Arrangement of the concrete dril1s and the splitting tools into a fixed-geometry array would assure a relatively uniform removal pattern.

\section{- Linear-shaped Charges}

An economic and expedient method for reducing equipment or piping to a physical size that can be further processed or packaged for storage is through the use of remote self-contained explosive charge units. Thus, radiation exposure to personnel is minimized where high radiation levels are involved. The use of shaped charges, i.e., the perforation and cutting of solids by high-velocity and ultra-high-velocity particles under explosive attack, has been used extensively in the last 15 to 25 years. $(10,11)$ Recently, such methods have been used for the removal of activated components and contaminated systems (fuel pool liners) that are not amenable to conventional removal techniques.

Shaped charges usually inside tubular housing with the shape of an inverted "V". This tube is filled with an explosive cyclotrimethylenetrinitramine, commonly called RDX. Figure E.3-6 shows a cross-section of a typical linear-shaped charge. The housing is generally copper but other materials such as aluminum and lead can be used. The melting and subsequent fusing of the housing material with the base material being cut may make the decontamination of those edges very difficult; therefore, in-situ decontamination either chemically or mechanically prior to explosive cutting is recomended to minimize final contamination levels. 


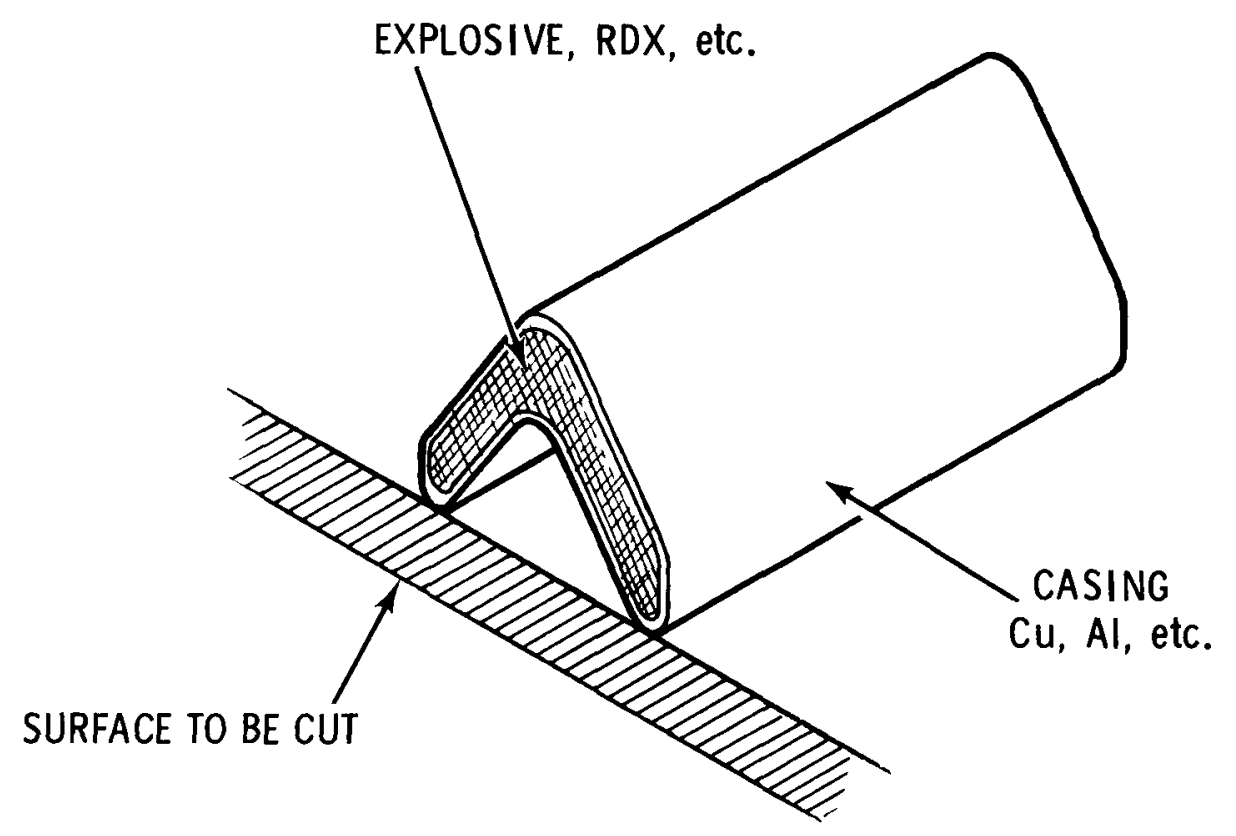

FIGURE E.3-6. Typical Linear-Shaped Charge Section

The charges are usually equipped with detonators that are activated using a priming cord lead having a high explosive core of pentaerythritol tetranitrate, commonly referred to as PETN, which is initiated with an electric blasting cap. Th principle of the shaped charge is that as the detonation wave collapses the inverted "V", the underside of the liner material becomes a jet of extremely hot metal particles traveling at very high velocity toward the surface to be cut.

Automatic clamp-on features are desirable and are available commercially. Charges so designed would pose fewer problems in placement, handling and detonating. The number of charges that can be detonated is limited only by the blast effect on nearby equipment. Shock wave and fragment damage can be reduced appreciably by having blast curtains or metal shields in the vicinity of the detonation. The curtains disrupt the shock wave and stop or slow down the fragments so that any damage would be minimal. 
The feasibility and demonstration of using 1 inear-shaped charges for explosive cutting of such diverse shaped objects as the following has been documented. (13)

- $61 \mathrm{~cm}$ 0.D. $\times 1.6 \mathrm{~cm}$ wall (24 in. 0.D. x 5/8 in. wall) stainless steel pipe

- $10 \mathrm{~cm} \times 10 \mathrm{~cm} \times 0.95 \mathrm{~cm}$ thick (4 in. $\times 4$ in. $\times 3 / 8$ in. thick) angle iron

- $2.5 \mathrm{~cm}(1-$ in.) diameter solid stainless steel bar

- $15 \mathrm{~cm} \times 0.95 \mathrm{~cm}(6$ in. $\times 3 / 8$ in.) thick web "H" beam.

The use and handling of these explosives is limited to experts.

\section{E.3.6.4 Portable Filtered Enclosures}

Many of the cutting operations required for disassembly of the facility have the potential for putting contaminated material into the air. To minimize the hazard to operating personnel and the potential for widespread contamination of the work areas, portable filtered ventilation enclosures are used in this study to confine and collect particulate material produced by the cutting processes. A typical unit is illustrated in Figure E.3-7. A large squirrelcage blower is used to pull air through a high-efficiency particulate air (HEPA) filter preceeded by a fiberglass roughing filter, all of which are mounted on a wheeled cart. A flexible duct couples the cart unit to the enclosure unit where the cutting is done. Another fiberglass roughing filter is installed in the ventilation outlet of the enclosure. The enclosure may have whatever shape best performs the required function at a particular location. A simple rectangular open-faced box will suffice for most applications.

Radiation detection devices are used to monitor the buildup of radioactive material on the filters. The pressure drop across the HEPA filter is monitored to detect increases of particulates built up on the filter. The filters are changed when either the dose rate from the collected radioactive particles or the differential pressure across the HEPA filter reach predetermined levels. 


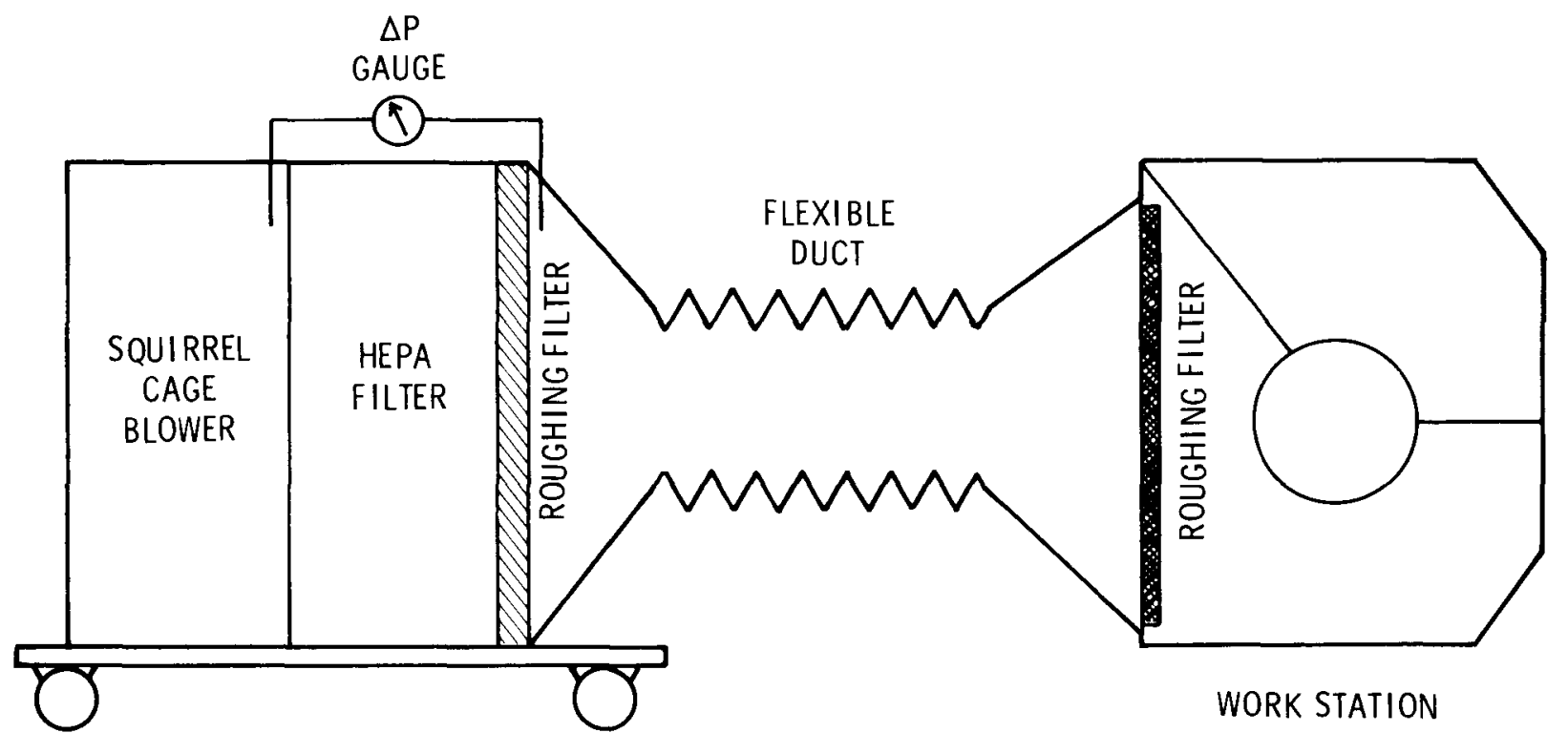

FIGURE E.3-7. Portable Filtered Enclosure

\section{E.3.6.5 Shielded Working Platform}

During mechanical dismantlement in the process cells, the concrete hatch covers are removed for extended periods of time. To prevent radiation overexposure of personnel working near the hatch and to control ventilation flow, a shielded working platform is built that can be positioned over the hatch when the shielded cage is in the cell. This platform decreases the air flow through the hatch opening and allows personnel working around the opening to observe operations in the cell. Shielded working platforms are also used where penetrations are made into the liquid waste tanks. A conceptual drawing of the shielded working platform is presented in Figure E.3-8.

The shielded working platform should have the following characteristics:

1. Adequate shielding (approximately $10 \mathrm{~cm}$ of lead) to allow personnel to work around the hatch and on top of the platform for extended periods of time without accumulating excessive radiation exposures. 

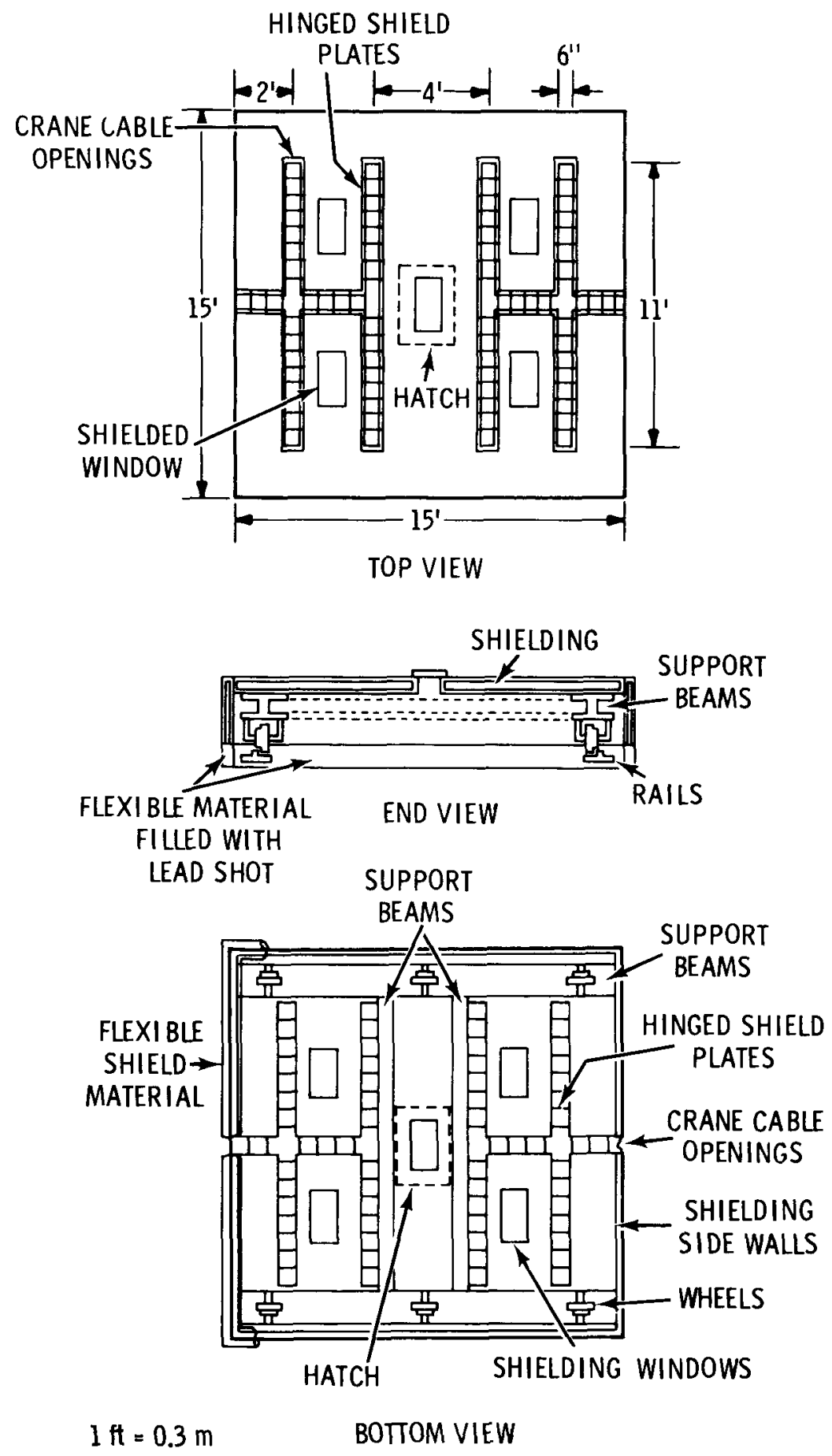

FIGURE E.3-8. Sketch of Shielded Working Platform 
2. Have sufficient size to span a $3.3 \mathrm{~m} \times 3.3 \mathrm{~m}(11 \mathrm{ft} \times 11 \mathrm{ft}$ ) opening ( $3 \mathrm{~m} \times 3 \mathrm{~m}$ in the waste tank farm).

3. Shielding windows to allow personnel on the platform to observe operations below.

4. A means of maneuvering the shielded cage on the EMS crane with the platform in position.

5. A means of maneuvering the platform into position with the shielded cage suspended in the cell from the EMS crane.

6. Be easy to move and be capable of being positioned over any of the hatch openings.

7. A means of shielding the crane cable openings when they are not in use.

8. Allow the shielded cage operator to enter and exit the cage from the platform when the cage is in the cell.

9. Restrict ventilation air flow through the cell hatch to a reasonable level.

\section{E.3.6.6 Front End Loader with Shielded Cab}

It is necessary to remove scarfed concrete rubble from some areas with radiation levels above those allowed for contact operations. A front end loader with a shielded cab is used in these areas. The cab is slightly pressurized and is well sealed to prevent contamination from airborne radionuclides inside the cab. The operator is in a fresh air suit with a selfcontained air supply. The loader itself is a modified verison of a commercially available product and is electrically operated.

The front end loader with shielded cab should have the following characteristics:

1. A cab with adequate shielding to allow the operator to remain for extended periods of time in fields up to $20 \mathrm{R} / \mathrm{hr}$.

2. A means of being lifted with the EMS Crane. 
3. Lead glass viewing windows on three sides and a smaller viewing port in the roof of the cab.

4. An electrical power source.

5. Be small enough to be 1 ifted in and out of a $2.5 \mathrm{~m} \times 2.5 \mathrm{~m}(8 \mathrm{ft} \times 8 \mathrm{ft}$ ) opening.

6. Sufficient maneuverability to operate in confined spaces like the plutonium product cell.

7. A bucket sized and shaped to make loading into the rubble containers easy with a minimum of spilling.

8. A means of keeping the outside of the windows clean when the water spray is operating in the work area.

9. An air monitor and alarm in the cab.

10. A well sealed cab.

11. An emergency means of personnel egress in case of breakdown or power failure.

12. A means of communication between the operator and an out-of-cell staff member.

13. An air monitor to determine contamination levels of the air within the cab.

\section{E.3.6.7 Shielded Working Cage}

Dose levels in some process cells will be too high to allow personnel to work without shielding. The location of the cell hatch covers, and the size and amount of equipment in the cells makes the installation and use of manipulators through the cell walls unfeasible. A portable shielded working cage with manipulator arms can provide the in-cell visibility and flexibility necessary to perform the intricate removal operations in a reasonable time period while minimizing personnel exposure. Similar conditions existing in the high-level waste tank require use of a shielded cage in removing the ternals from the tank. 
The shielded working cage should have the following characteristics:

1. Adequate shielding to allow the operator to work for extended periods of time in areas with radiation levels to $100 \mathrm{R} / \mathrm{hr}$. Less shielding may be required in the cage used in the process building than in the cage for the tank farm. The exact amount of shielding necessary is determined during the planning phase.

2. A method of communications with personnel outside the cell.

3. An air supply and ventilation system that keeps the cage at a positive pressure relative to the air in the cells. (The air supply system is connected to one of the primary circuits of the emergency electrical power system.)

4. An emergency breathing apparatus for use in case of ventilation failure.

5. An emergency means of personnel egress during breakdown or electrical power failure.

6. An air monitor and alarm system to warn the operator in the event that airborne contamination enters the cage.

7. A lead glass viewing window as required and remotely operated television cameras for viewing from the top, bottom, and sides of the cage.

8. Two manipulator arms capable of extending $5.5 \mathrm{~m}$ (18 ft) and supporting $23 \mathrm{~kg}$ (50 1bs) at full extension. Provisions for good manipulation below the cage.

9. A means of suspending the cage from the equipment maintenance station 55-MT (60 ton) crane.

10. Three legs extendible up to $4.25 \mathrm{~m}$ ( $14 \mathrm{ft}$ ) long to provide a stable working platform when the cage is suspended from a crane or sitting on a floor. 
11. A means for retracting the legs and manipulator arms sufficiently to allow the cage to be raised and lowered through an opening $3.25 \mathrm{~m}$ $(10 \mathrm{ft})$ square.

12. An auxiliary lighting system to illuminate work areas.

13. Ports for unforeseen uses.

14. One or more externally mounted television cameras, operable from inside the cage or outside the cell, with a monitor in the cage.

15. Radiation monitors outside the cage which can be positioned using the manipulator arms to take readings at any desired location within reach of the arms.

16. Radiation monitors inside the cage.

17. A means of entry and exit via the shielded working platform when the cage is in the cell. (This door can also be used as an emergency exit. It must be large enough to accommodate an operator wearing emergency breathing apparatus.)

18. A television camera for visual monitoring of the cage operator by staff personnel from outside the cell.

A sketch of one possible configuration of the shielded working cage is shown in Figure E.3-9.

\section{- Operating Procedures}

The shielded cage will become contaminated on the outside while it is suspended in the process cells or waste tanks. It must be decontaminated or "bagged out" of the work area to prevent spreading this contamination. Placement of the cage in the work area and its subsequent removal is time consuming. The operator should perform as many tasks as possible before the cage is removed from the work area.

The following is a typical sequence of operations with the cage in a process cell or waste tank:

1. Check the operation of the cage, particularly the safety systems.

2. Attach the cage to the crane and lower it into the work area. 


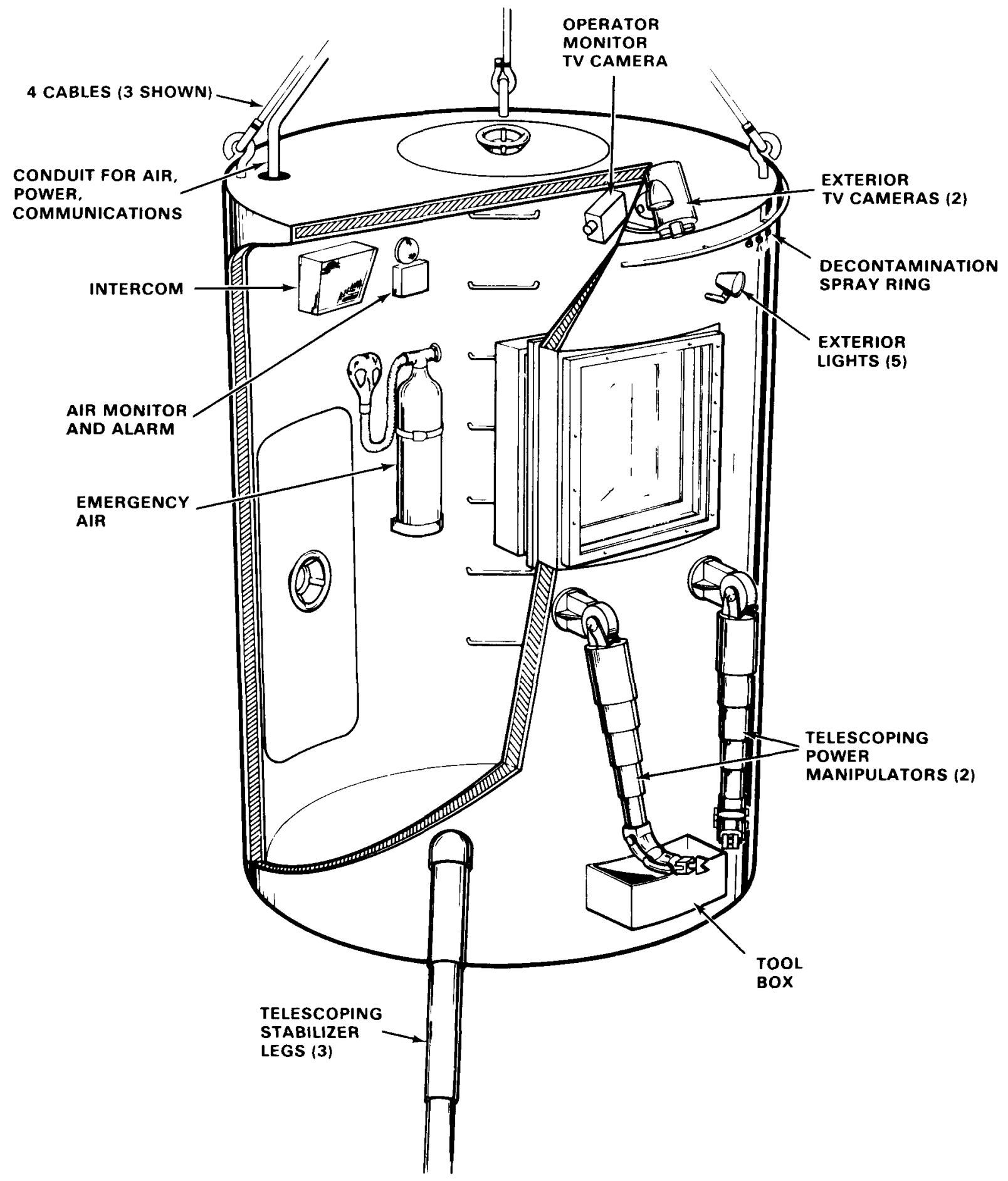

FIGURE E.3-9. Conceptual Sketch of Shielded Working Cage 
3. Place the shielded working platform in position over the opening into the work area.

4. Decontaminate the area around the entry hatch of the cage as necessary.

5. The operator enters the cage through the hatch in the shielded working platform and the hatch in the top of the cage.

6. Position the cage for operations.

7. The operator performs all tasks possible.

8. Position the cage for operation egress.

9. Decontaminate the area around the entry hatch of the cage as necessary.

10. The operator exits through the working platform hatch.

11. Remove the working platform.

12. Remove the cage from the cell, covering it with a material to prevent the spread of contamination if necessary.

\section{E.3.6.8 Greenhouse Building}

To decontaminate and dismantle the waste tanks in this study, the tanks are penetrated from the top and the contaminated equipment is cut out and removed. To prevent the release of radioactivity to the environment and to support the operations in the tanks, a greenhouse building is constructed over the work area. This building is movable so that it can be used to dismantle all four liquid waste storage tanks. It is designed to withstand year-round weather conditions.

Portable buildings which meet all requirements are currently available on the market. These structures are portable and can be erected and dismantled quickly by a smal1 sized crew. (14) 
The greenhouse building should have the following characteristics:

1. Be large enough to span the excavation site over a tank vault and to contain the equipment necessary to conduct the dismantling and decontamination efforts in the tank (about $30 \mathrm{~m}$ by $30 \mathrm{~m}$ ).

2. Be movable from one tank site to another.

3. Be equipped with a 40-MT crane that spans the area over the tank vault top.

4. Contain chemical decontamination facilities including mixing and storage tanks, a high pressure spray system, electropolishing cell, and decontamination tanks with appropriate shielding.

5. A filtered ventilation system that maintains a negative pressure in the building relative to the outside atmosphere even when the building doors are open, provides comfort conditioning of the air in the building, and prevents the release of radioactivity in the exhaust.

6. Contain facilities for packaging contaminated material, preparing it for shipment, and loading it on the transport vehicle.

7. Designed to prevent radioactive releases during year-round weather conditions at the site and to allow operations to be carried out during normally expected weather conditions.

8. Radiation monitoring and alarm systems.

9. Be connected into the site emergency power generation equipment or contain its own emergency power source.

10. Provide capability to install and remove the pumps and other necessary equipment to transfer solutions between the waste tanks after the waste tank equipment gallery has been removed.

11. Provide facilities to repair the equipment in the building and the other equipment used in the waste tank dismantlement and decontamination operations. 
12. Contain an auxiliary filtered ventilation system that can be connected to an existing penetration into a waste tank and maintain a negative pressure in the tank relative to the greenhouse building.

\section{E.3.6.9 Electropolishing Decontamination Station}

Reduction of alpha contamination levels from in excess of $1,000,000 \mathrm{~d} / \mathrm{m}$ per $100 \mathrm{~cm}^{2}$ to background within 10 min has been demonstrated using electropolishing techniques. The utility and versatility of this decontamination method has been shown on a wide variety of alloy compositions and geometries.

Electropolishing is an electrochemical process used to partially dissolve a surface. Two major results occur from electropolishing: first, the surface material (along with the contaminants) is dissolved, and second, the surface of the material is progressively smoothed. This smoothing effect reduces recontamination from the electrolytic solution and allows a simple water rinse as the final step in producing a contamination-free surface.

The process system, shown in simplified form in Figure E.3-10, offers the following advantages over other decontamination processes:

- it can be used for a wide variety of metals, alloys, component geometries, and types of contamination;

- it substantially reduces personnel exposure as well as expense;

- it is rapid and effective;

- it contributes to a significant reduction in the amount of solid waste requiring expensive controlled storage, transportation and burial; and

- it permits the reclamation, reuse, and/or recycling of valuable materials.

Its major disadvantage is that materials to be decontaminated must be small enough to fit inside the tank and must be moved to the tank.

An electropolishing decontamination station could be installed in the facility to perform a final decontamination on contaminated metals. One tank contains the electrolyte and appropriate fixtures. Additional tanks are used for primary rinse water and final rinsing. A large constant voltage dc 


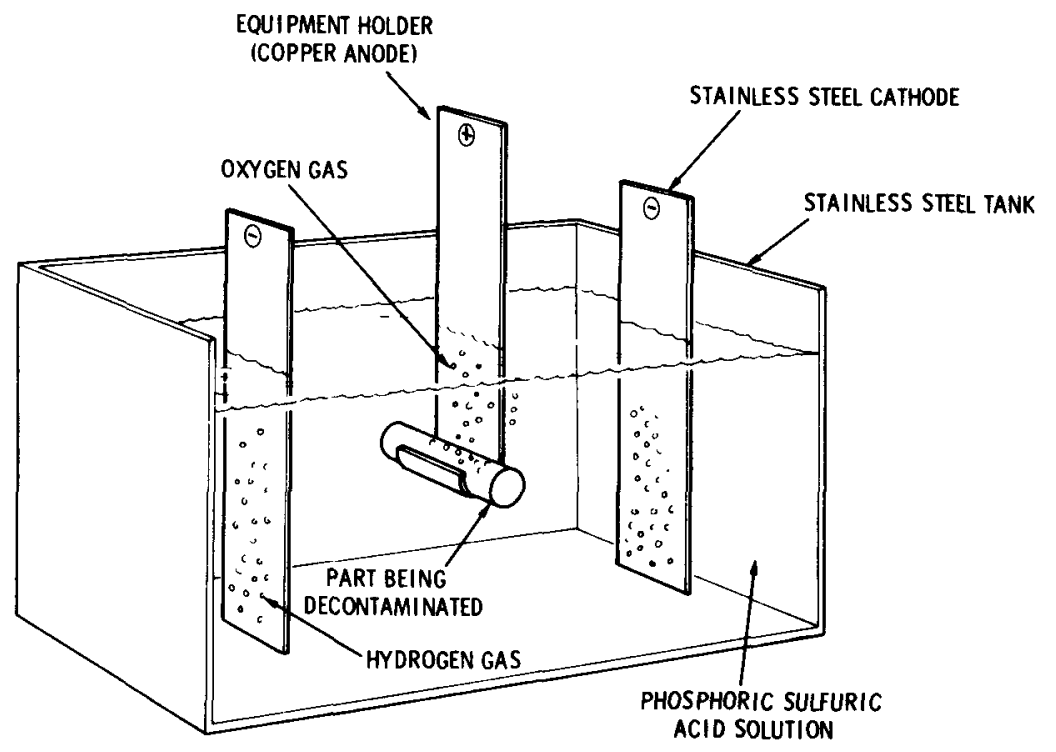

FIGURE E.3-10. Schematic Diagram of Electropolishing Cell

power supply capable of providing up to $10,000 \mathrm{~A}$ at about $10 \mathrm{~V}$ to current level of $0.15 \mathrm{~A} / \mathrm{cm}^{2}$ is needed. A recirculation system is required to provide constant mixing of the electrolyte, on-line filtration of suspended solids, and on-line removal of dissolved metal ions by ion exchange. The ion exchange columns are connected to permit back-flushing and regeneration, with the regeneration solutions piped into the liquid radioactive waste system for treatment and disposal. Sufficient air sweep over the electrolyte tank must be maintained to remove the hydrogen gas that is evolved due to electrolysis during the cleaning process. A power interruption system that is activated upon loss of the air sweep is included to prevent operation of the electropolisher and the accumulation of explosive quantitites of hydrogen gas when the ventilation system is inoperative. 


\section{E.4 PROTECTIVE STORAGE MODE SUPPORTING INFORMATION}

Section 7.4 of Volume 1 briefly described the procedures used to place the reference facility in protective storage. This portion of the appendix supplies additional details of those procedures.

\section{E.4.1 Procedures for Sealing Contaminated Areas}

Portions of the facility that contain significant amounts of radioactive contamination during the surveillance period are isolated from the remainder of the facility. Potential pathways for the migration of contamination from these areas are blocked by the installation of temporary but rugged physical barriers. Possible methods for design and/or construction of these barriers are presented in this section.

Besides acting as a contamination control barrier, the barriers are also designed to discourage unauthorized personnel entry into contaminated areas. Structuraliy substantial barriers are used, and extensive use is made of stainless steel in constructing the barriers to prevent cutting by oxyacetylene torches.

The preferred method of installing the barriers is by welding. This method is used on piping, ventilation ductwork, manipulator sleeves and equipment penetrations. Piping is cut and a circular plate is welded over the open ends. Similar procedures are used for manipulator sleeves and equipment penetrations. Rectangular plates are welded onto ventilation ductwork. A1l welds are inspected by x-ray, dye-penetrant or other appropriate techniques.

A polysulfide adhesive compound is used to seal the perimeter of pipes and other penetrations through the concrete walls into contaminated areas. The polysulfide adhesive is used whenever seals must be formed on concrete surfaces or on metal surfaces where welding is not possibie. This adhesive forms a strong, durable bond with these materials. After it has cured, the adhesive remains flexible, permitting different rates of thermal expansion between two bonded surfaces without breaking the seal. The adhesive can be applied with a spatula or extrusion gun and does not run after application. 
After draining the oil from the windows, shielding windows are protected by covering them with a stainless steel plate sealed to the surrounding concrete with polysulfide adhesive. The plate is bolted to studs placed in the concrete. After the adhesive has been applied to the underlying concrete, the plate is put in place and the bolts are tightened to produce an even seal. The bolts are welded to the studs to discourage unauthorized removal.

Metal doors are secured by welding them to the metal door frame. Spot welds are used where the intent is only to make the door inoperative. Continuous welds are made where an air-tight seal is required. The perimeter of the door jam where it meets the surrounding concrete and other surfaces that cannot be welded is then sealed with polysulfide adhesive.

\section{E.4.2 Decontamination and Isolation Procedures for Glove Boxes, Hoods and the Sample and Analytical Cells}

The procedures given below are used in this study to prepare the glove boxes throughout the facility for protective storage. They are also used for hoods in the hot laboratories.

1. Vacuum the interior of the glove boxes thoroughly using a vacuum cleaner with a criticality-safe geometry.

2. Wipe down the interior surfaces of the glove box and exposed surfaces of equipment and piping with sponges soaked in chemical decontamination solution.

3. Conduct a radiation survey to identify hot areas. Use swabs or a portable decontamination sprayer on spots that resist cleanup.

4. Clean off residue with hot water.

5. Clean out sumps and drains and dry them thoroughly.

6. Apply a nonflammable contamination fixing agent to all interior surfaces.

7. Remove any manipulators and store them in noncombustible containers. Seal all glove ports, shielding windows, manipulator sleeves, etc., with steel plates. (See Appendix E.4.1.) 
8. Remove the ventilation system exhaust filters. All filters are transported offsite for disposal.

9. Weld steel plates over the ventilation intake and exhaust ductwork and install HEPA-filtered vents to the atmosphere in each independentlyisolated area.

Similar procedures are used in the sample and analytical cells. The wipedown phase (Step 2) is eliminated and all eight cells are chemically decontaminated using hot water in a portable high pressure sprayer. A1l operations in the cells can be performed remotely using the master-slave manipulators, the installed passout drawer, and intercell conveyors.

\section{E.4.3 Sequence of Events for Placing the Liquid Waste Storage Facility in Protective Storage}

The following sequence of events is used to place the tank farm in protective storage. Information presented here supplements that given in Section 7.4.3, Volume 1 .

- Sequence of Events

1) When chemical decontamination operations in the main process building have been completed, reroute the waste tank off-gas system and the waste tank cell vent system to the waste solidification plant. The ventilation exhaust from the waste tank equipment gallery is routed directly to the ventilation filter station.

2) Flush all tanks with four successive flushes of 38,000 liters $(10,000$ gal) each of $50 \%$ nitric acid to dilute the pump heel and dissolve most deposits on the tank bottom.

3) Introduce a long shaft pump through the existing penetration to the ILLW tank and remove the residual liquid from the tanks. Dilute any residual acid with 11,000 liters of water and pump the tank empty.

4) Introduce and distribute sufficient inorganic absorbant into the ILLW tank to absorb the residual liquid. 
5) Seal all process piping, instruments, the existing penetration and any other connections to the ILLW tank from the WTEG.

6) Install a temporary double encased underground pipeline from the HLLW tanks to the diverter cell in the WTEG.

7) Excavate to the top of the tank vault HLLW tank No. 3. Install a portable greenhouse and penetrate the vault top and tank top.

8) Install a submersible pump through the penetration and remove the residual liquid from the tank. Pump the residual liquid to the WSP via the WTDC through the temporary pipeline. Dilute residual acid with 11,000 liters of water and pump the tank empty again. Remove the pump and introduce and distribute sufficient inorganic absorbant to absorb any residual liquid.

9) Seal the penetrations to the tank top and tank vault. Backfill the excavation to the vault top.

10) Seal all process piping, instrument and other connections to HLLW tank No. 3 , in the WTEG.

11) Repeat steps 7 through 10 for HLLW tanks Nos. 2 and 1.

12) Install a HEPA filter in the off-gas pipe from each waste tank.

13) Chemically decontaminate off-gas equipment associated piping and the diverter, all in the WTEG.

14) Remove the diverter control mechanisms and place them in the diverter cell.

15) Smearable contamination in all but the hot area of the WTEG is fixed with paint or removed with sponges soaked in decontamination solution.

16) Remove contaminated equipment and piping in WTEG hot area.

17) Seal access openings and equipment penetrations to sample cell.

18) Deactivate all noncontaminated equipment, piping and other systems not needed during interim care. 
19) Drain and remove the fuel oil in the emergency generator fuel tank.

20) Seal the opening into hot area of the WTEG and install a HEPAfiltered vent to the atmosphere.

21) Remove filters and decontaminate ventilation system.

22) Install intrusion alarms and provide remote readout for intrusion, fire, and radiation alarms.

23) Seal building entrances not required for surveillance and maintenance.

24) Deactivate all utilities not needed during interim care period.

25) Perform final radiation survey of WTEG and secure the building.

\section{E.4.4 Sequence of Events for Placing the Waste Solidification Plant in} Protective Storage

A brief discussion of the procedures are given in Section 7.4.4, Volume 1. Additional details of the operations used to place the WSP in protective storage are presented here.

- Sequence of Events

1) Solidify the process waste liquids from chemically decontamination of the main process building, and from diluting the heels and flushing the liquid waste storage tanks.

2) Chemically decontaminate all cell walls utilizing the installed spray systems.

3) Solidify these decontamination solutions (which also serve as flushes of the solidification equipment).

4) Remove all remaining solidified waste canisters to the FRSS for load-out and disposal. Drain and seal the canister transfer aisle that connects the WSP to the FRSS by welding in place a prefabricated steel barrier.

5) Disconnect the electrical supply to the spray calciner and in-can melter furnaces. Disable the umbilical systems used for remote operation of the melters. 
6) Sever and seal all exposed ends of all piping and other equipment that penetrate the walls of the shielded cells.

7) Remove all master-slave manipulators using normal production operating procedures. Store these contaminated items in the hot maintenance cell and weld shut the shielded access door to the HMC.

8) Drain the oil from the shielding windows. Install protective steel barriers over the manipulator sleeves, the transfer locks, and shielding windows. Secure all shielding plugs in place by welding.

9) Remove all contaminated HEPA filters for disposal and install new units in the cells. Isolate the waste vitrification, hot maintenance, canister decontamination and off-gas treatment cells from the FRP ventilation system by welding a steel barrier over the end of the cell ventilation tunnel beneath the shielding plug in the warm service gallery. Install a HEPA filtered vent in the WSG to vent the cells to the atmosphere. Secure the access plug.

10) Remove and/or fix all smearable radioactive contamination that remains in the operating galleries or aisles. Paint any accessible contaminated areas.

11) Deactivate all equipment, piping, utilities and other systems that is not needed during the interim care period.

12) Install an intrusion alarm system. Provide remote alarm readouts for the intrusion, fire, and radiation detection systems.

13) Seal by welding all building entrances that are not required for surveillance and maintenance.

14) Perform the final radiation surveys and secure the WSP building.

\section{E.4.5 Sequence of Events for Placing the FRSS in Protective Storage}

The following procedures are used in this study to prepare the FRSS for protective storage. The procedure was discussed briefly in Section 7.4.5, Volume 1, and is amplified here.

1) Assure that the water filtration and deionization system is opera ting at maximum efficiency. 
2) Operate the pool recirculation, deionization and filtration systems until the radioactivity in the pool water has been reduced to levels that permit release of the water to the environment consistent with the principles of ALARA. Compliance with Federal and local water and air quality standards is determined by analysis of the deionized pool water before it is released to the environment. Deionization of the water is estimated to require about 100 days using the installed deionization equipment. Additional or replacement equipment is installed if necessary to reduce radioactivity to the desired levels.

3) Drain the pools. The water is drained to the water reservoir and subsequently released to local water bodies. As the pools are drained, wash down the exposed surfaces and paint them with a nonflammable water-based paint. As soon as it is exposed, the penetration between the Remote Process Cell and the Fuel Transfer Pool is sealed with a stainless steel plate.

4) When about $1.5 \mathrm{~m}(5 \mathrm{ft})$ of water remains in the pools, remove the radioactive particulates from the pool floor with an underwater vacuum cleaner. The particulates are collected in filters placed on the vacuum discharge. The remainder of the pool water is then drained or evaporated out the main stack and the pool floor is chemically decontaminated with high pressure sprayers and painted.

5) Survey the equipment in the pools. Remove contamination with high pressure water sprays or chemical solutions. Fix contamination that cannot be removed by painting with one coat each of two distinctly colored paints. Equipment that cannot be effectively decontaminated or coated is removed to a process cell for storage.

6) Clean the ion exchange beds, recirculation pumps and water filters, and deactivate the system. Transport any flammable deionization equipment to an offsite disposal area. The remaining contaminated deionization equipment is $\mathrm{placed}$ in a process cell. Decontamination of the remainder of the deionization area as necessary. 
7) Survey and decontaminate the remaining areas of the fuel receiving and storage station as necessary. Deactivate the overhead cranes.

8) Isolate the FRSS ventilation system from the main process building. Install a HEPA-filtered vent to the outside.

9) Install intrusion and fire alarms at designated locations.

10) Weld the vehicle unloading bay doors closed and seal them weather tight. Install high security locks on remaining exterior doors. 


\section{E.5. LAYAWAY MODE SUPPORTING INFORMATION}

Section 7.5 of Volume 1 describes briefly the procedures used to place the reference facility in layaway. This appendix supplies additional details to some of those procedures.

- Decontamination of Glove Boxes and the Sample and Analytical Cells

The procedure given below is used to prepare the glove boxes in the AVOS, PNOS and radioactive laboratories for layaway. Similar procedures are used to decontaminate the hoods in the radioactive laboratories. Procedures used here are similar to those used to place the glove boxes in protective storage.

1) Vacuum the interior thoroughly with a vacuum cleaner that has nuclear criticality-safe geometry.

2) Wipe down the interior surfaces, equipment and piping with sponges soaked in decontamination solution.

3) Conduct a radiation survey to identify hot spots. Use swabs or a portable decontamination sprayer on spots that resist cleanup.

4) Clean off all chemicals and residue with a hot water bath or steam spray.

5) Clean out sumps and drains and dry the area thoroughly.

6) Apply a nonflammable contamination fixing agent to all interior surfaces.

7) Seal all glove ports in glove boxes.

The cleanup of the SAC follows a similar procedure except that the wipedown phase (step 2) is eliminated. All eight cells are decontaminated using the portable high pressure sprayer. All operations in the SACs can be performed remotely using the master-slave manipulators. Transfers can be made using the installed passout drawer and the intercell conveyors. 


\section{E.6 DECOMMISSIONING WASTES AND WASTE DISPOSAL}

Detailed estimates of volumes and weights of concrete rubble, stainless steel liners, process equipment, stainless steel piping, and HEPA and roughing filters from dismantlement of the reference fuel reprocessing plant are presented in Tables E.6.1 through E.6.5. These estimates form the basis for determining packaging and shipping requirements for waste disposal as discussed in Section 7.6 .

In addition to those items tabulated in Tables E.6.1 through E.6.5, the following waste materials also require disposal:

- Fuel Storage Racks

There are 120 fuel storage racks located in the fuel storage basin. Each rack has a volume of $5.6 \mathrm{~m}^{3}$ and weighs $1230 \mathrm{~kg}$. Racks are assumed to be packaged individually for shipment to a commercial burial ground.

- Glove Boxes

There are six glove boxes from the PNSL and SAC areas that must be packaged and shipped as transuranic (TRU) waste, and 15 glove boxes from the laboratory area that can be packaged and shipped as non-TRU waste. Each glove box has a volume of $1 \mathrm{~m}^{3}$ and weighs $820 \mathrm{~kg}$.

- Waste Tanks

The three HLLW tanks and the ILLW tank must be sectioned and packaged for shipment to a deep geologic repository. Assuming the equivalent tank wal1 thickness of $1.25 \mathrm{~cm}(1 / 2$ in.) and allowing for the curvature of the tank sections, the shipping volume calculated for the four tanks is $510 \mathrm{~m}^{3}$ and the weight is $156,000 \mathrm{~kg}$. This includes an allowance of $60 \mathrm{~m}^{3}$ and $10,000 \mathrm{~kg}$ for tank rib structures.

- Solidified Decontamination Liquids

After evaporation to reduce the volume, 680,000 liters $(180,000 \mathrm{gal})$ of liquid wastes from chemical decontamination of the process building and from waste tank flushing remain to be solidified. This waste is processed and packaged at the waste solidification plant (WSP) prior to plant decommissic ing. Waste solutions from flushing the liquid waste storage tanks are 
TABLE E.6.1. Concrete Rubble from Dismantlement of the Reference Fuel Reprocessing Plant
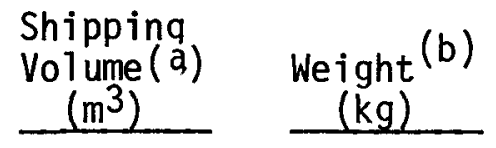

I - TRU Waste

\begin{tabular}{|c|c|c|}
\hline $\mathrm{RPC}$ & 237 & 284,000 \\
\hline RMSC & 10 & 12,700 \\
\hline HLC & 136 & 164,000 \\
\hline HILC & 170 & 204,000 \\
\hline PPC & 49 & 59,000 \\
\hline PNC's & 3 & 3,600 \\
\hline FN & 1 & 1,400 \\
\hline SAC's & 1 & 1,400 \\
\hline Openings in PNC's & 34 & 41,000 \\
\hline WTEG & 3 & 3,600 \\
\hline Access hole to WTDC & 10 & 12,200 \\
\hline WTDC & 5 & 5,500 \\
\hline Openings in Waste Tank Vaults & 5 & 5,500 \\
\hline WVC & 5 & 5,500 \\
\hline $\operatorname{CDC}$ & 2 & 2,500 \\
\hline OGC & 3 & 3,600 \\
\hline HMC & 2 & 2,500 \\
\hline Pipe Trenches & 1 & 1,400 \\
\hline Totals & 677 & 814,000 \\
\hline
\end{tabular}

\section{II - Non-TRU Waste}

$\begin{array}{ccr}\text { ILC } & 164 & 197,000 \\ \text { UPC } & 147 & 176,000 \\ \text { Wal1s of HTG/PEG } & 436 & 522,000 \\ \text { CUP's } & 35 & 42,000 \\ \text { FSP } & 14 & 16,000 \\ \text { FTP } & 25 & 31,000 \\ \text { VFS } & 0.3 & 30 \\ \text { Miscellaneous } & \underline{28} & \frac{34,000}{1,018,000}\end{array}$

(a) Based on a packing fraction of 0,50

(b) Based on a density of $2,400 \mathrm{~kg} / \mathrm{m}^{3}$ 
TABLE E.6.2. Stainless Steel Liners from Dismantlement of the Reference Fuel Reprocessing Plant

\begin{tabular}{|c|c|c|}
\hline Origin & $\begin{array}{l}\text { Shipping } \\
\text { Volume }(a) \\
\left(\mathrm{m}^{3}\right)\end{array}$ & $\begin{array}{r}\text { Weight } \\
(\mathrm{kg})\end{array}$ \\
\hline TRU Waste & & \\
\hline $\mathrm{RPC}$ & 23 & 5,500 \\
\hline RMSC & 86 & 21,000 \\
\hline HLC & 10 & 2,500 \\
\hline HILC & 15 & 3,800 \\
\hline PPC & 8 & 1,900 \\
\hline PNC's & 23 & 5,500 \\
\hline FN & 122 & 30,000 \\
\hline SAC's & 18 & 4,300 \\
\hline WTDC & 36 & 8,800 \\
\hline HLLW Vaults & 265 & 86,000 \\
\hline ILLW Vault & 88 & 28,000 \\
\hline WVC & 133 & 32,000 \\
\hline $\operatorname{CDC}$ & 72 & 18,000 \\
\hline HMC & 50 & 12,000 \\
\hline OGC & 7 & 1,700 \\
\hline Sample Cell (WTEG) & 4 & 1,100 \\
\hline Pipe Trenches & 113 & 28,000 \\
\hline Totals & 1,073 & 290,000 \\
\hline
\end{tabular}

II - Non-TRU Waste

\begin{tabular}{|c|c|c|c|}
\hline ILC & & 15 & 3,500 \\
\hline UPC & & 12 & 2,900 \\
\hline CUP's & & 180 & 44,000 \\
\hline FSP & & 114 & 28,000 \\
\hline FTP & & 129 & 31,000 \\
\hline & Totals & 450 & 109,000 \\
\hline
\end{tabular}

(a) For packaging purposes assume an equivalent thickness of $15 \mathrm{~cm}$ due to bending of the liners during removal. 
TABLE E.6.3. Equipment from Dismantlement of the Reference Fuel Reprocessing Plant

\begin{tabular}{|c|c|c|}
\hline Origin & $\begin{array}{l}\text { Shipping } \\
\text { Volume }(a) \\
\left(\mathrm{m}^{3}\right)\end{array}$ & $\begin{array}{c}\text { Weight } \\
(\mathrm{kg}) \\
\end{array}$ \\
\hline \multicolumn{3}{|l|}{ I - TRU Waste } \\
\hline $\mathrm{RPC}$ & 138 & 111,000 \\
\hline RMSC & 68 & 54,000 \\
\hline HLC & 220 & 176,000 \\
\hline HILC & 148 & 119,000 \\
\hline PPC & 80 & 65,000 \\
\hline PNSL & 34 & 27,000 \\
\hline HLLW Tank Internals & 380 & 304,000 \\
\hline ILLW Tank Internals & 0.5 & 450 \\
\hline WTEG & 17 & 14,000 \\
\hline WSP & 86 & 69,000 \\
\hline PNC Slab Tanks & 44 & 35,000 \\
\hline PNC Neutron Shields & 127 & 102,000 \\
\hline Valves, etc. & 28 & 23,000 \\
\hline Miscellaneous & 136 & 109,000 \\
\hline Totals & 1,570 & $1,208,000$ \\
\hline \multicolumn{3}{|l|}{ II. Non-TRU Waste } \\
\hline ILC & 260 & 209,000 \\
\hline UPC & 150 & 121,000 \\
\hline WTEG & 75 & 60,000 \\
\hline SCG & 8 & 6,800 \\
\hline Valves, etc. & 28 & 23,000 \\
\hline Miscellaneous & 105 & 84,000 \\
\hline Totals & 626 & 504,000 \\
\hline
\end{tabular}

(a) For cylindrical equipment items, the shipping volume is the volume of the rectangular box that an item

(b) Based on an average density of $800 \mathrm{~kg} / \mathrm{m}^{3}$. 
TABLE E.6.4. Stainless Steel Piping from Dismantlement of the Reference Fuel Reprocessing Plant

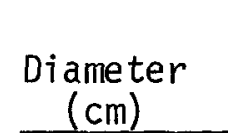

\begin{tabular}{cccc}
$\begin{array}{c}\text { Length } \\
(\mathrm{m})\end{array}$ & $\begin{array}{l}\text { Solid } \\
\text { Volume } \\
\left(\mathrm{m}^{3}\right)\end{array}$ & $\begin{array}{l}\text { Linear } \\
\text { Density } \\
(\mathrm{kg} / \mathrm{m})\end{array}$ & $\begin{array}{c}\text { Shipping } \\
\text { Volume } \\
\left(\mathrm{m}^{3}\right)\end{array}$ \\
\hline
\end{tabular}

I - TRU Waste

$\leq 5$
$5-10$
$10-15$

20

Underground

$10,700 \quad 21$

13.4

42

27.4

36

143,000

$3,400 \quad 18$

8.5

71

17

93,000

550

42

108

84

39,000

1,280

12

53.3

24

138,000

HLLW Tank Internals 31,600

64

$$
\text { Totals }
$$

18

$\frac{255}{458}$

48,000

565,000

$1,030,000$

II - Non-TRU Waste

$<5$
$5-10$
$10-15$
20

8,500

17

13.4

34

115,000

3,400

18

27.4

36

93,000

550

8.5

71

17

39,000

Totals

1,280

42

108

$\frac{32}{169}$

$\frac{138,000}{385,000}$ 
TABLE E.6.5. HEPA and Roughing Filters from Dismantlement of the Reference Fuel Reprocessing Plant

Origin

$$
\begin{aligned}
& \text { Number of Filters } \\
& \text { HEPA's Prefilters } \\
& \hline
\end{aligned}
$$

I - TRU Waste

PPC

Filter Niche (for RPC)

Filter Niche (for RMSC)

Filter Niche (for off-gas)
Contact Cells Housing

Waste Off-gas

WSP Ventilation

WSP Off-gas

Totals

II - Non-TRU Waste

AFS

VFS

WTEG

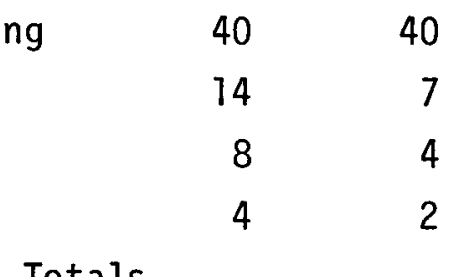

Totals

Totals
Volume

$\left(\mathrm{m}^{3}\right)$

Weight

(kg)
1.1220

$0.7 \quad 145$

$1.7 \quad 365$

$1.2 \quad 255$

$2.0 \quad 380$

$6.8 \quad 1,450$

$2.0 \quad 380$

1.1220

$\frac{0.5}{20} \quad \frac{110}{3,500}$

$9.52,040$

$13.2 \quad 2,840$

$\frac{2.5}{25} \quad \frac{540}{5,400}$ 
estimated to produce a waste volume equivalent to 40,000 liters of HLLW after being processed through the calciner. Based on 0.082 liters of glass per liter of liquid waste and 180 liters of glass per canister $(30 \mathrm{~cm}$ in diameter by $3.1 \mathrm{~m}$ long), a total of 195 canisters of vitrified waste from chemical decontamination operations require shipment as heat-generating high-level waste to a deep geological repository. This number is rounded to 200 for calculating costs.

\section{- $\underline{\text { Trash }}$}

Combustible and noncombustible trash is estimated to be generated at an average rate of two 210-1iter (55-gal) drums per day during the decommissioning of the reference fuel reprocessing plant. One-half of this trash is assumed to be low-level TRU waste requiring disposal at a deep geologic repository, and the other half is assumed to be non-TRU waste which can be shipped to a shallow land burial ground. 


\section{E.7 DECOMMISSIONING MANPOWER REQUIREMENTS}

This section presents amplifying details for the decommissioning manpower requirements presented in Section 7.7 .

\section{E.7.1 Staff Labor Job Descriptions}

Organization charts for the dismantlement, protective storage and layaway support staffs were presented in Figures 7.7-2, 7.7-3 and 7.7-4. A description of the functions performed by key individuals in the dismantlement staff are presented below. Functions for the support staff in protective storage and layaway are similar.

- Project Manager is responsible to corporate management for the complete planning, coordination and supervision of all activities carried out to dismantle the reference fuel reprocessing plant. He directs the project engineer and the health and safety supervisor to ensure that the dismantlement plan is developed and implemented in a safe and cost-effective manner. He provides necessary liaison with regulatory agencies and implements regulatory requirements.

- Health and Safety Supervisor is responsible for recommending policy in matters of radiological and industrial safety and for enforcing these policies when they are approved. He establishes and implements radiological safety, industrial safety and emergency preparedness programs.

- Radiation Safety Specialist advises the Health and Safety Supervisor in matters of radiation safety. He develops and implements the radiological safety program, maintains occupational exposure records, and supervises the safety technicians.

- Laboratory Supervisor is responsible for conducting the environmental and onsite surveillance programs including sampling and analysis. He supervises the operation of the plant analytical laboratory facilities.

- Radioactive Waste Disposal Specialist oversees all shipments of radioactive and nonradioactive materials that leave the site for disposal or transfer to insure that the shipments are properly packaged and decontaminated and 
conform with all applicable Federal, state and local regulations. He arranges with suppliers to provide shipping containers and contracts with carriers to transport all radioactive wastes.

- Industrial Safety Specialist advises the health and safety supervisor in matters of industrial safety. He develops and implements the industrial safety program.

- Security Force Supervisor is responsible for all site security matters. He supervises the dismantlement security force.

- Special Nuclear Material Accounting Specialist is responsible for developing and implementing the decommissioning SNM Safeguards Program. He maintains all SNM records, supervises the SNM technicians monitoring SNM accounting equipment, prepares SNM reports for submittal to regulatory agencies and coordinates with the security force supervisor to provide security for all SNM on the site.

- Project Engineer is responsible for planning, coordinating and carrying out the decomissioning activities in a safe manner. He provides engineering services and detailed procedures necessary to implement the decommissioning plan. He is responsible for the preparation of all routine and special reports and he compiles a chronological history of the entire decommissioning project.

- Plant Operations and Maintenance Supervisor is responsible for operating and maintaining plant equipment and services required to remain in operation during part or all of the decommissioning project. He ensures that the control room and other plant operating areas are manned by qualified personnel when necessary, and through the supply attendants he stocks and disburses tools and expendable supplies.

- Procurement Specialist prepares and expedites procurement orders and purchase requisitions for special tools and equipment required for the decommissioning operations. 
- Project Accountant maintains a complete record of all costs incurred during the decommissioning project. He disburses funds with approval of the project manager.

- Decommissioning Operations Supervisors develop detailed working procedures and supervise the performance of all decommissioning tasks. They write specifications for special equipment and tools that must be procured or fabricated to carry out the decommissioning project and prepare routine and special reports as requested by the project engineer.

- Quality Assurance Specialist prepares the decommissioning quality assurance plan and works with the project manager to implement the quality assurance program. He reports directly to corporate headquarters in quality assurance matters. He supervises the assistant quality assurance specialist and quality assurance clerks who monitor the performance of decommissioning activities and equipment suppliers and provides other QA functions as outlined in Section 7.1 and Appendix E.1.

\section{E.7.2 Details of Decommissioning Worker Manpower Requirement}

Detailed estimates of the number of decommissioning workers and the time required to perform each of the basic decommissioning tasks discussed in Section 7.3 through 7.5 are presented in Tables E.7-1, E.7-2, and E.7-3. These tables form the basis for the overall decommissioning schedules presented in Figures 7.3-1, 7.4-1, and 7.5-1, for dismantiement, protective storage and layaway, respectively, and for the decommissioning worker manpower totals presented in Tables 7.7-4, 7.7-5 and 7.7-6.

The methodology and assumptions used in deriving these manpower tables are discussed in Section 7.7.2. 


\section{TABLE E.7-1. Estimated Decommissioning Worker Manpower Requirements}

for Dismantlement of the Reference Fuel Reprocessing Plant

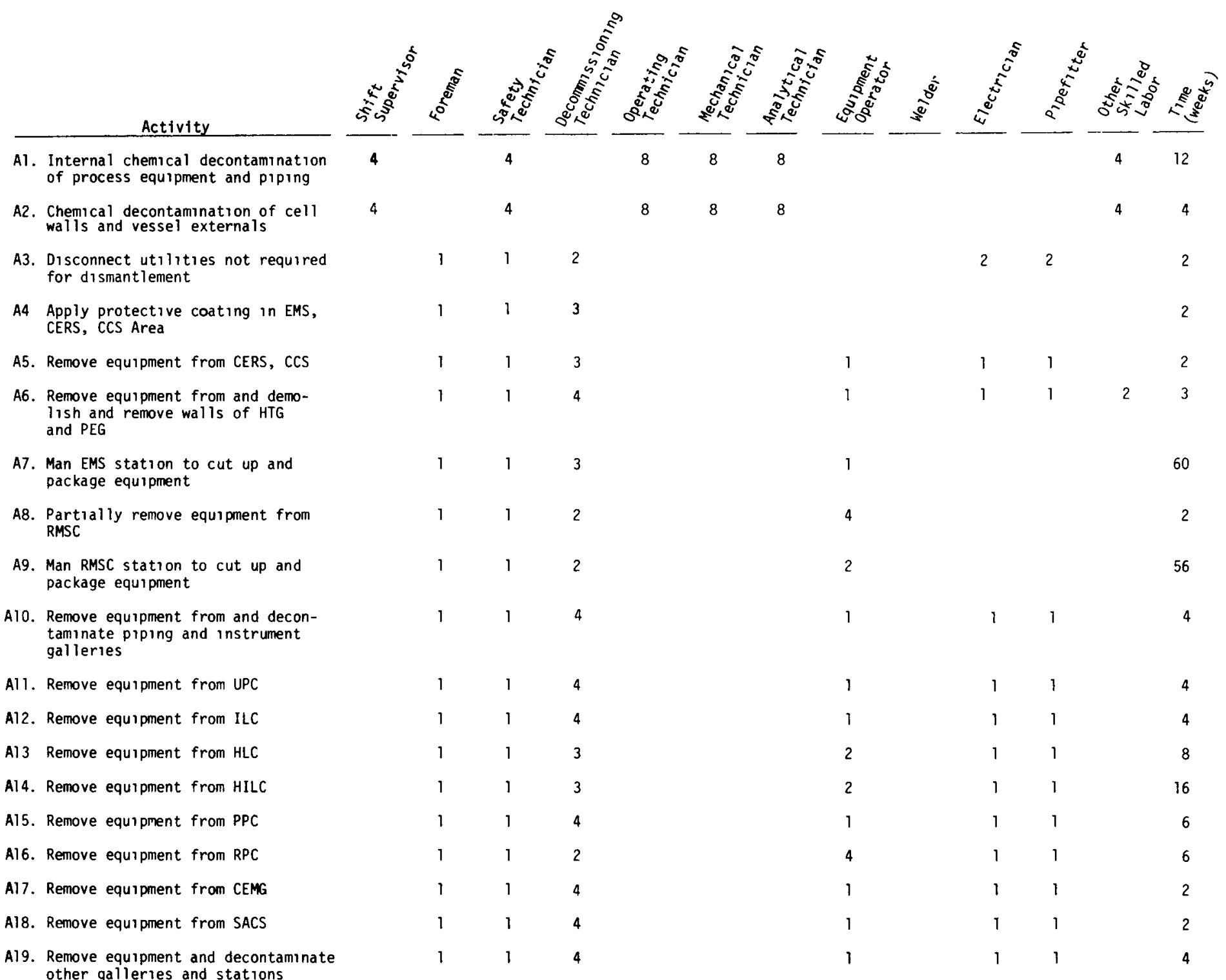


TABLE E.7-1 (contd)

A20. Remove equipment from and decon-

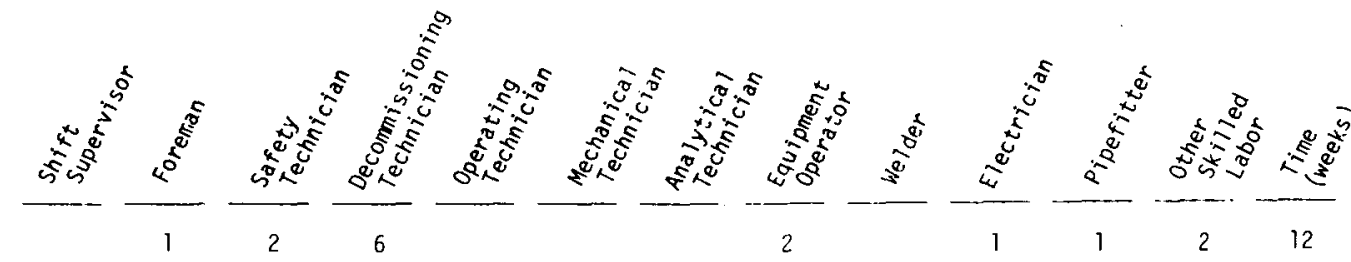
taminate PNSL.

A21. Mechanically decontaminate UPC and remove stainless steel liner

A22. Mechanically decontaminate ILC and remove stainless steel liner

A23. Mechanically decontaminate HLC and remove stainless steel liner

A24. Mechanically decontaminate HILC and remove stainless steel liner

A25. Mechanically decontaminate PPC and remove stainless steel liner

A26. Mechanically decontaminate RPC and remove stainless steel liner

A27. Mechanically decontaminate RMSC and remove stainless steel liner

A28. Mechanically decontaminate CEMG

A29. Decontaminate EMS, CCS, CERS area

A30. Decontaminate CLS

A31. Remove miscellaneous equipment

A32. Remove filtration equipment and decontaminate filter niche, etc.

A33. Decontaminate and remove venti lation ductwork

A34. Decontaminate ventilation trench from lia in Process Eldg. to VFS

A35. Perform final radiation survey of liain Process Building 
TABLE E.7-1 (contd)

Activity

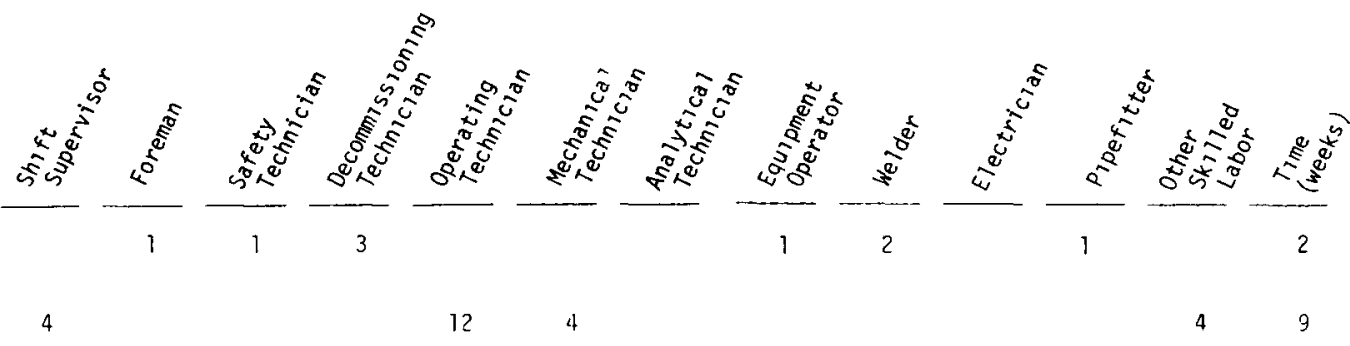

Bl Reroute waste tank far ventilation systems

B2 Flush heel from HLLW tanks and ILLW tank

B3 Decommission WTEG

a) Chemicaliy decontaminate off-gas equioment

b) Chemically decontaminate diverter cell

c) Disconnect utilities not required for dismantlement

d) Remove coolant pumps and apply

e) Remove and package off-gas coolant equipment and piping

f) Sever and remove piping from upper area of diverter tcll

g) Cut $4 m^{2}$ hole in concrete above diverter

h) Remove both diverters

1) Cap pipes leading to waste tanks

J) Remove and package remaining piping in diverter cell

k) Section, remove and package stainless steel liners

1) Survey and mechanically decontaminate diverter cell

m) Remove equipment and mechanically decontaminate sample cell

22

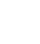

$1 \quad 12$$$
2
$$$$
\begin{array}{lll}
1 & 1
\end{array}
$$$$
1
$$$$
1
$$$$
1
$$

2

$\begin{array}{lll}1 & 1 & 4 \\ 1 & 1\end{array}$

11

$\begin{array}{ll}1 & 1 \\ 1 & 1 \\ 1 & 1 \\ 1 & 1\end{array}$

$\begin{array}{lll}1 & 2 & 1 \\ ? & 1 & 2 \\ 1 & & 1 \\ 1 & 2 & 1\end{array}$




\section{TABLE E.7-1 (contd)}

\section{Activity}

n) Survey and decontaminate hot area of WTEG

0) Remove filters and decommission building ventilation system

p) Remove equipment from cold area and decommission work area q) Perform final radiation survey

B4 Demolish WTEG

B5 Chemically decontamınate tank internals of HLLW tanks

B6 Dismantle and remove pipe vaults

B7 Man station to package material from waste tank decommissioning

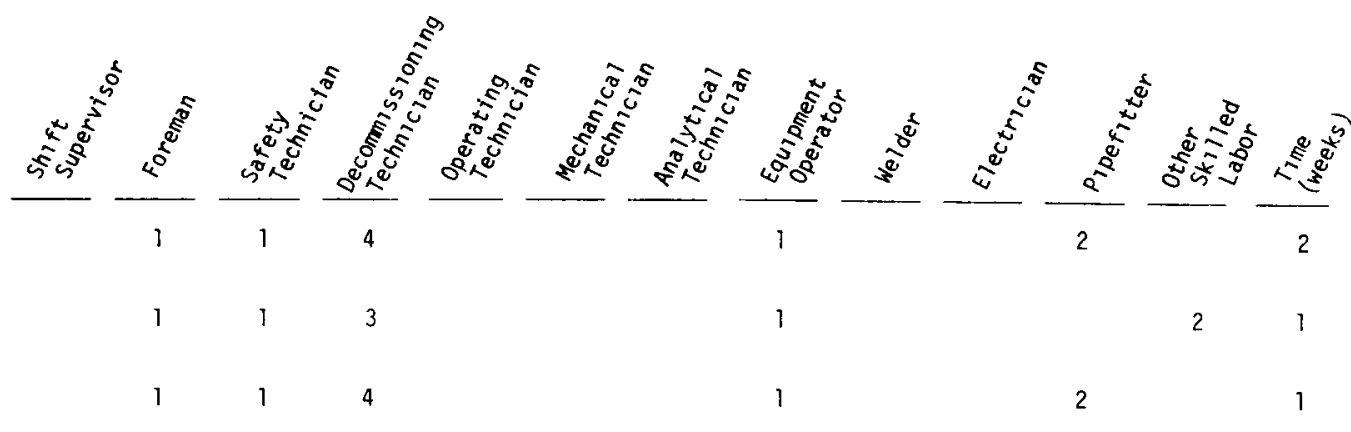

B8 Decommission ILLW tank
a) Install greenhouse
b) Install submersible pump and drain tank
c) Penetrate concrete vault top in 3 places
d) Penetrate tank top in 3 places
e) Section and remove tank internals
f) Section and remove tank
g) Section and remove vault liner
h) Survey vault and decontaminate as necessary

1) Provide drainage holes and backfill cavity

B9 Decommission HLLW Tank \#3
a) Install greenhouse b) Install submersible pump and
drain tank 
TABLE E.7-1 (contd)

\section{Activity}

c) Penetrate concrete vault top in 3 places

d) Penetrate tank top in 3 places

e) Section and remove tank internals

f) Section and remove tank

g) Section and remove vault iner

h) Survey vault and decontamınate as necessary

1) Provide dra inage holes and backfill cavity

B1G. Decommission HLLW Tank \#2

B11 Decommission HLLW Tank \#]

B12 Decontaminate and dismantle greenhouse

Crew at WTEG during storage of liquid decommissioning wastes

Crew to decontaminate HLLW tank sections and tank internals

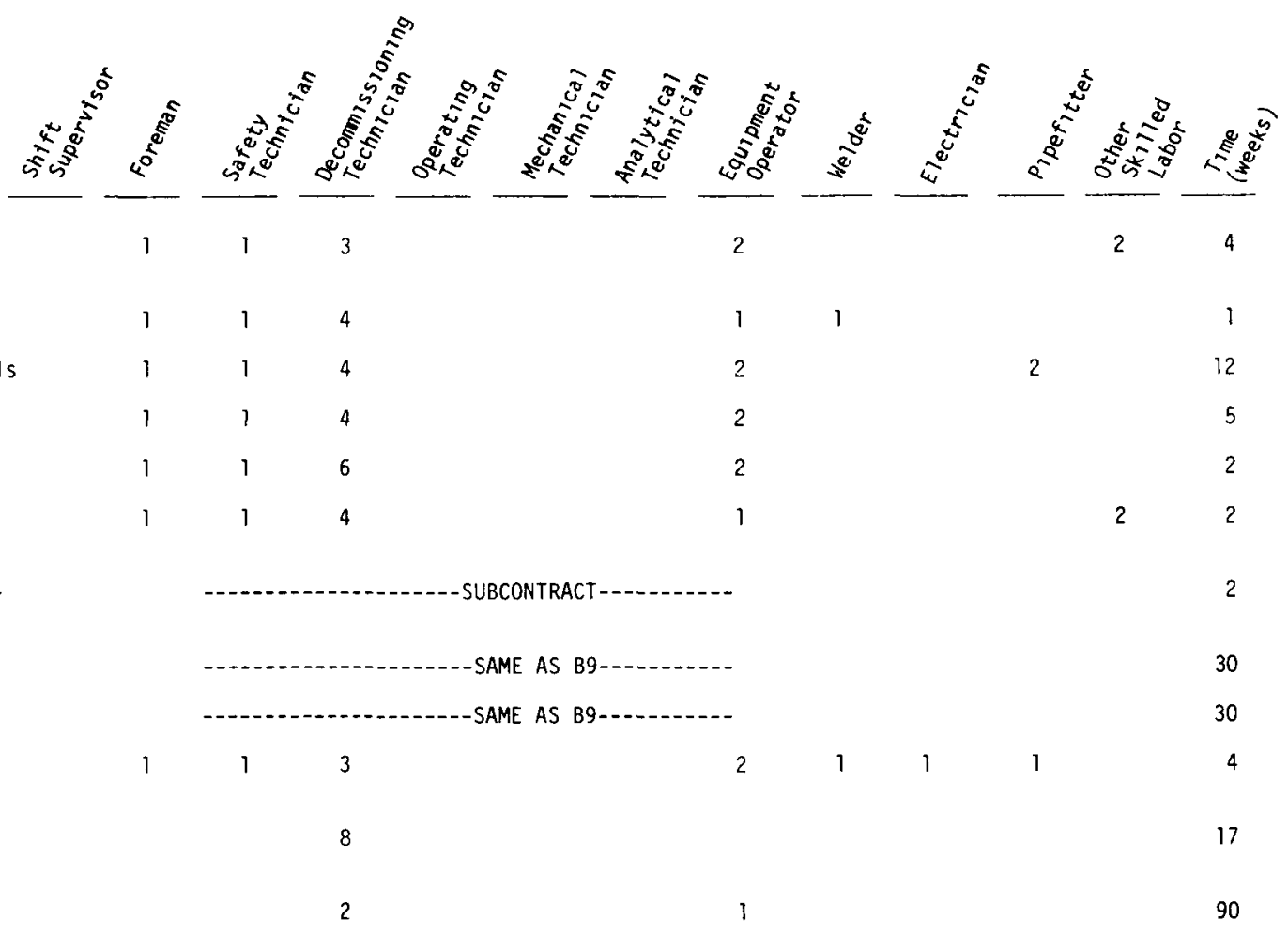


TABLE E.7-1 (contd)

\section{Activity}

Cl Solidify wastes from chemical decontamination and tank flushing

C2 Chemical decontamination of WSP process equipment and piping

C3 Chemical decontamination of cell walls and vessel externals

C4 Solidify solution producted in

C5 Disconnect utrlities not required for dismant lement

C6 Remove equipment, piping and hardware from WVC

C7 Drain and seal can transfer aisle between CDC and FRSS

C8 Remove equipment, piping and hardware from CDC

C9 Remove equipment, piping and hardware from OGTC

C10 Remove liners and shield doors from WVC and decontaminate cell

C11 Remove liners from CDC and OGTC and decontamnate cells

C12 Man sectioning and packagin station in HMC

C13 Remove equipment, hardware and liner from HMC and decontaminate cell

C14 Remove filters and decontaminate WSP ventilation system

Cl5 Survey remaining galleries and decontaminate as necessary

C16 Decontaminate ventilation trench between WSP and VFS

C17 Perform final radiation survey of WSP

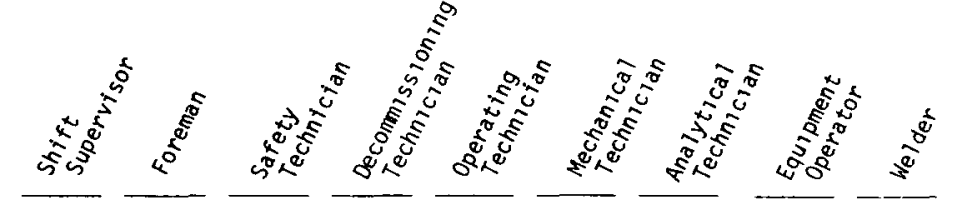

8

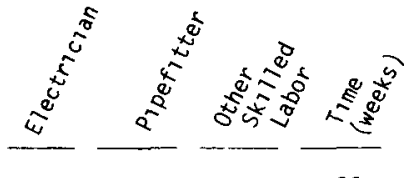

36

-PERFORMED AS PART OF

1 1

3

4

4

4

4

2 
TABLE E.7-1 (contd)

\section{Activity}

D1 Man loadout station in FRSS

D2 Deionize and drain storage pools

D3 Remove storage racks and other equipment

D4 Remove stainless steel pool 1 iners

D5 Mechanically decontaminate pool concrete

D6 Decontaminate other FRSS work areas

D7 Remove filters and decontaminate and remove FRSS ventilation ductwork

D8 Perform final radiation survey of FRSS

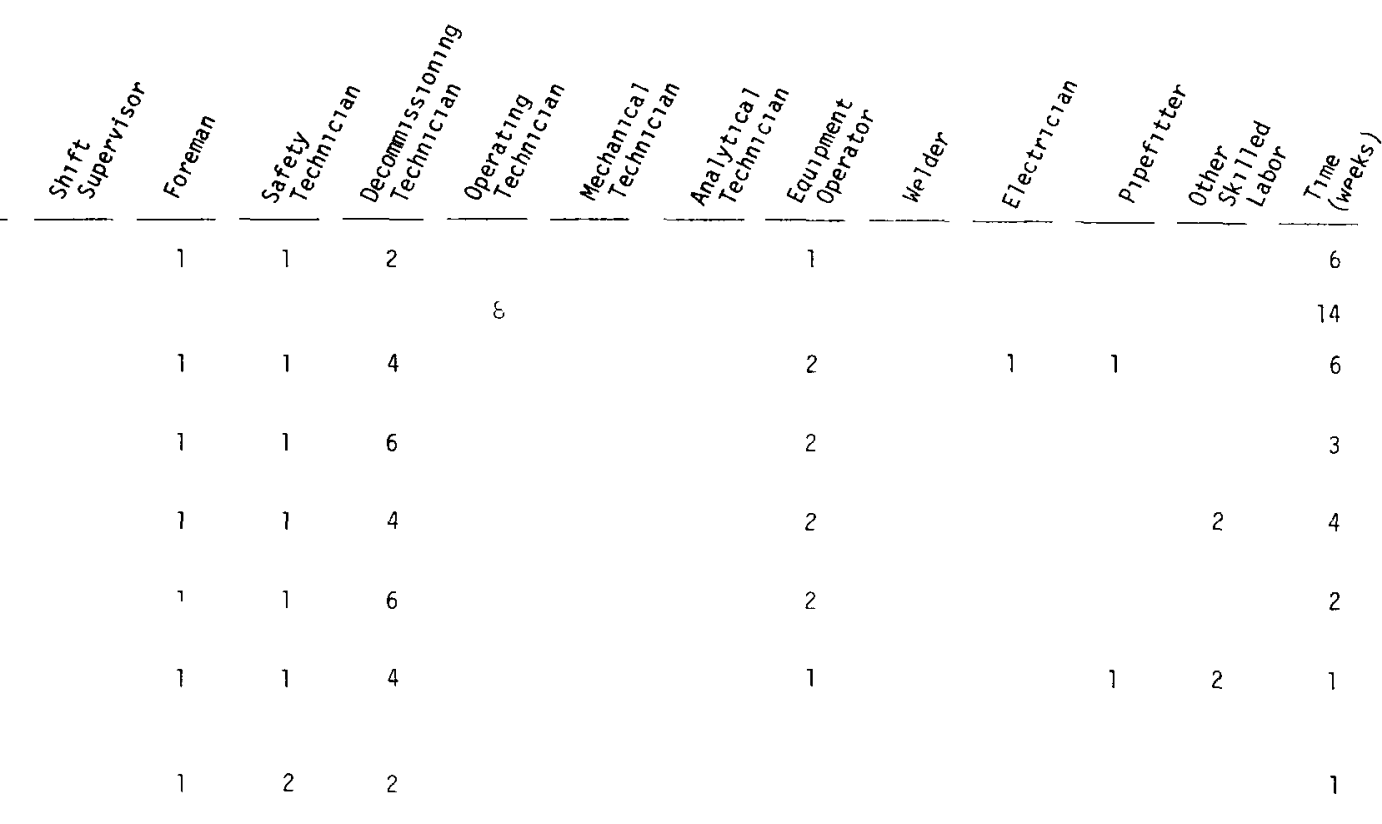




\section{TABLE E.7-1 (contd)}

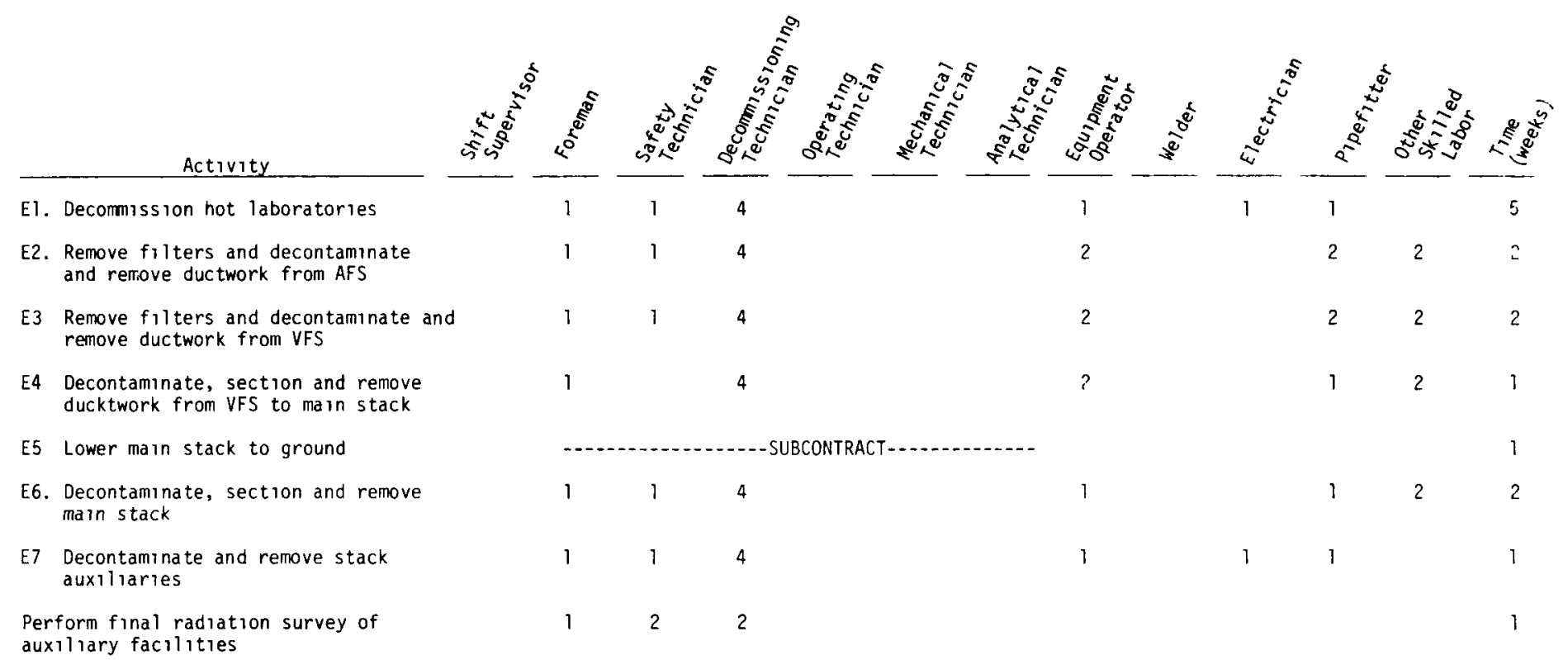


TABLE E.7-2. Estimated Decommissioning Worker Manpower Requirements for Placing the Reference Fuel Reprocessing Plant in

Protective Storage

\section{Activity} of process equipment and piping

A2 Chemical decontamination of cell walls and vessel externals

A3 Remove master-slave manipulators and store in CEMG

A4 Transfer equipment and seal openings from CERS to process cells

A5 Sever and seal penetrations from piping and instrument galleries to process cells

A6 Decontaminate SAC's and glove boxes Seal openings and install covers over windows

A7 Decontaminate PNSL glove boxes Seal openings and install covers over windows

A8 Remove equipment and decontaminate remaining areas and stations

A9 Fix smearable contamination in PPC and PNC's

Al0 Fix smearable contamination in accessible areas

All Deactivate equipment, piping and systems not needed during interim care

A12 Install barriers and seal openings in SCG, HTG/PEG, CEMG and PNC's

A13 Install barriers and seal openings process cells

A14 Isolate pipe trench from Main Process Building to WTEG

A15 Remove filters and decontamınate ventilation system
Al Internal chemical decontamination
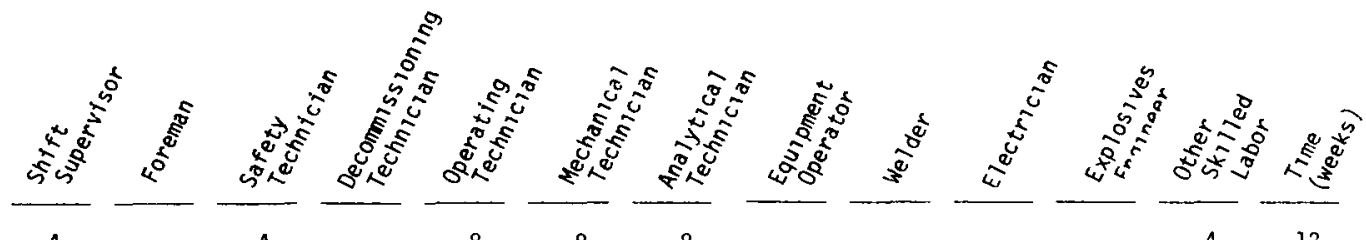

8

$8 \quad 8$

12

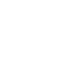

12

14

1

1

16 Deactivate 60-ton crane 


\section{TABLE E.7-2 (contd)}

Al7 Install intruder, fire, and radiation alarm system

A18 Seal bullding entrances not required for surveillance and maintenance

AT9 Deactivate all utilities not needed during interim core

A20 Perform final radiation survey and secure building

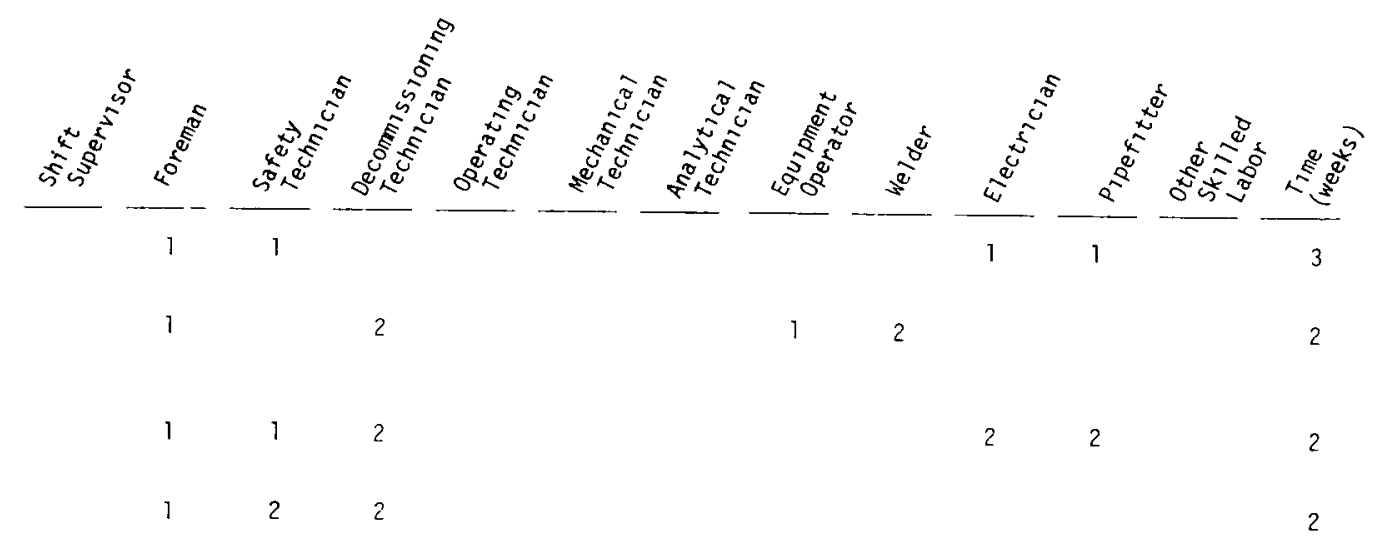

$\underset{\omega}{\frac{T}{\omega}}$ 


\section{TABLE E.7-2 (contd)}

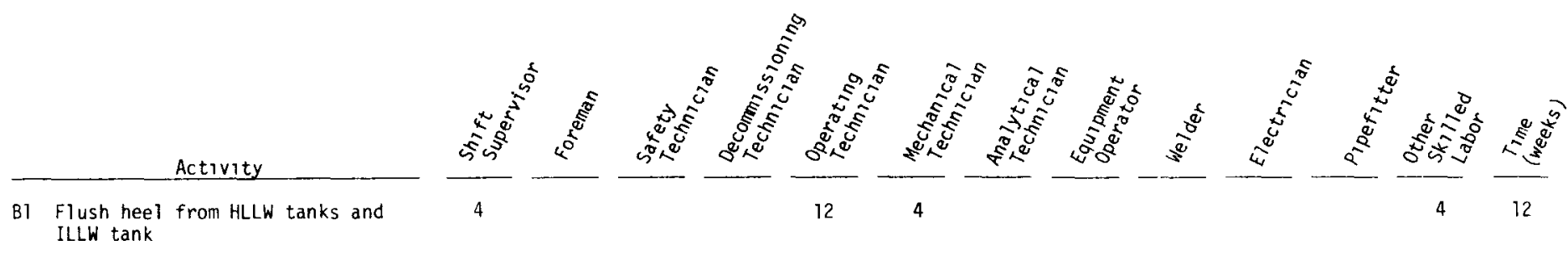

B2 Decommission ILLW tank
a) Install pump through existing hole and pump tank empty
b) Introduce inorganic absorbent
into tank
) Seal penetration to ILLW tank
d) Seal connections to ILLW tank in WTEG

B3 Decommission HLLW Tank \#3
a) Excavate over tank, install greenhouse, and penetrate tank
b) Install pump and pump tank empty
c) Introduce inorganic absorbant into tank d) Seal penetrations to tank top and
tank vault and backfill
e) Sea 7 connections to HLLW Tank \#3 in WTEG

B4 Decommission HLLW Tank \#2

Same as 83

B5 Decommission HLLW Tank \#1

Same as B3

B6 Place WTEG in protective storage
a) Install HEPA filter in off-gas line from each waste tank
b) Chemical decontamination of off-gas equipment and piping
c) Chemrcal decontamination of diverter cell 
d) Remove diverter controls and piace in diverter cell

e) Seal entrance to diverter cell

f) Remove and/or fix smearable contamination in WTEG

g) Remove contamınated equipment to hot area of WTEG

h) Seal openings to sample cell

1) Deactivate equipment, piping, and systems not needed during interim care

j) Drain emergency fuel o1l tank

k) Seal opening to hot area of WTEG

1) Remove filters and decontaminate vent system

m) Instail intruder, fire and radiation alarm system

n) Seal bullding entrances not required for service and ma intenance

o) Deactivate utilities not needed during interim care

p) Perform final rad'ation survey and secure bullding

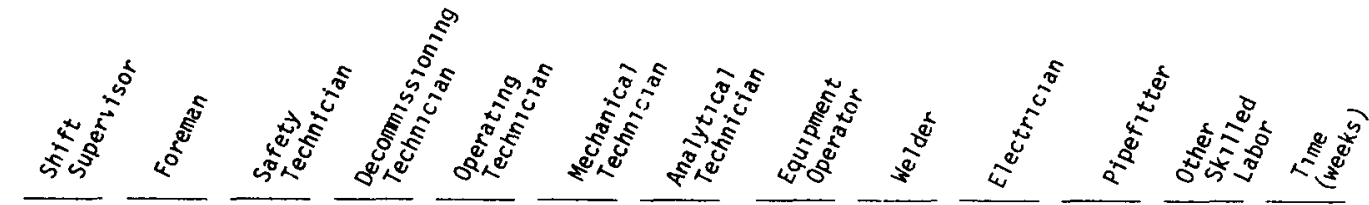
(1)

$\begin{array}{ll}1 & 1 \\ 2 & 2 \\ 1 & 1 \\ 1 & 1 \\ 1 & \end{array}$

G 11

11

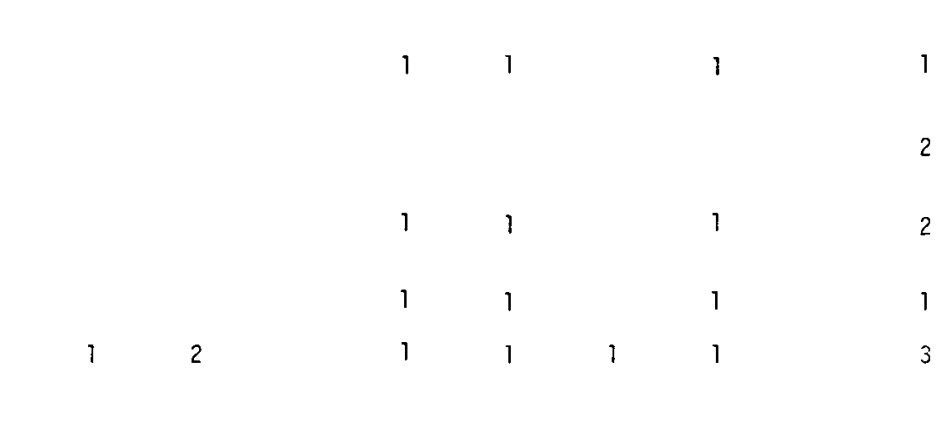

$\begin{array}{lll}1 & 1 & 2\end{array}$

2

2

Crew at WTEG during storage of 11 quid decomissioning wastes 
TABLE E.7-2 (contd)

Cl Solidify liquid wastes from chemical decontamination of FRP and tank farm

C2 Chemical decontamination of cell walls and vessel externals

C3 Solidify wastes from decontamination of WSP

C4 Drain and seal can transfer aisle from COC to FRSS

C5 Disconnect electrical supply to furnaces and disable umbilical systems

C6 Sever and seal piping penetrations of walls into shielded cells

C7 Remove master slave manipulators and store in HMC

C8 Fix smearable contamination in accessible areas

C9 Install plates over manipulator sleeves and shrelding windows weld shield plugs in place

C10 Remove f1lters and decontaminate vent system

C11 Deactivate equipment, piping and systems not
needed during interim care

C12 Install intruder, fire and radiation alarm system

$\mathrm{Cl} 3 \mathrm{Seal}$ entrances not required for surveillance and ma intenance

C14 Deactivate utilities not needed during interim care

15 Perform final radiation survey and secure building
31

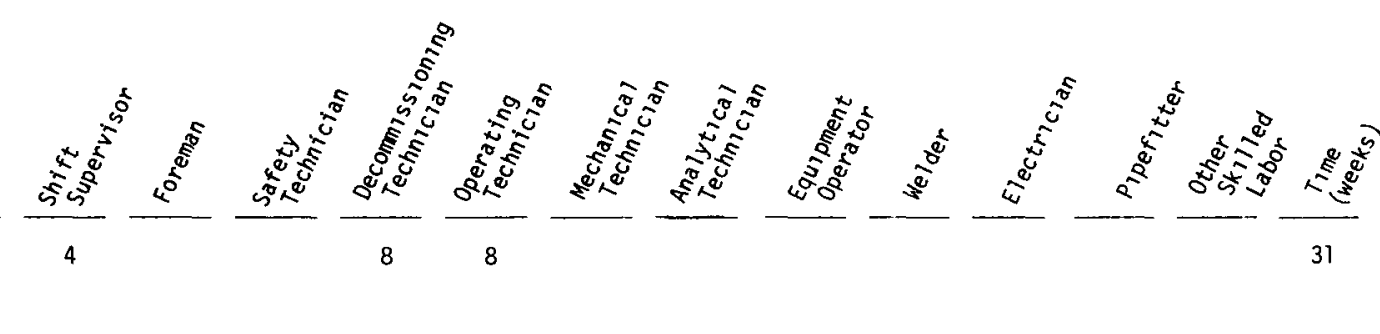

$\begin{array}{ll}1 & 1 \\ 1 & 1 \\ 2 & 2 \\ 1 & 1\end{array}$

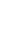




\section{TABLE E.7-2 (contd)}

Activity

D1 Man loadout station in FRSS

D2 Deionize and drain storage pools

D3 Deactivate and decontaminate water treatment system

D4 Fix smearable contamination in pool area

D5 Decontaminate fuel storage racks

D6 Seal access between RPC and fuel transfer pool

07 Fix smearable contamination in other areas and deactivate cranes

D8 Remove filters and decontaminate ventilation systen

D9 Install intruder, fire and radiation alarm systen

D10 Seal and secure access to FRSS

D11 Deactivate utilities not needed for interim care

012 Perform final radiation survey and secure building

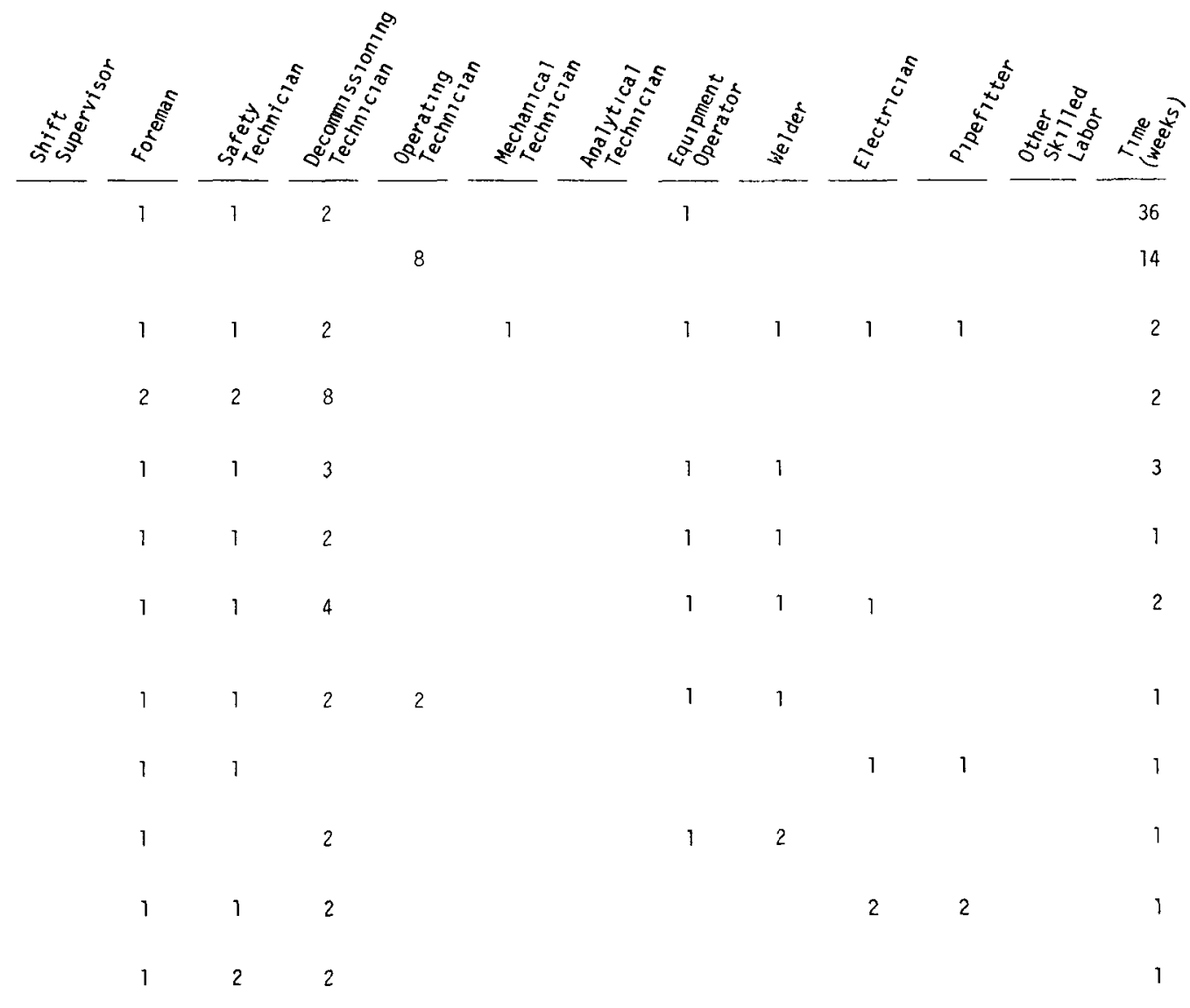




\section{TABLE E. 7-2 (contd)}

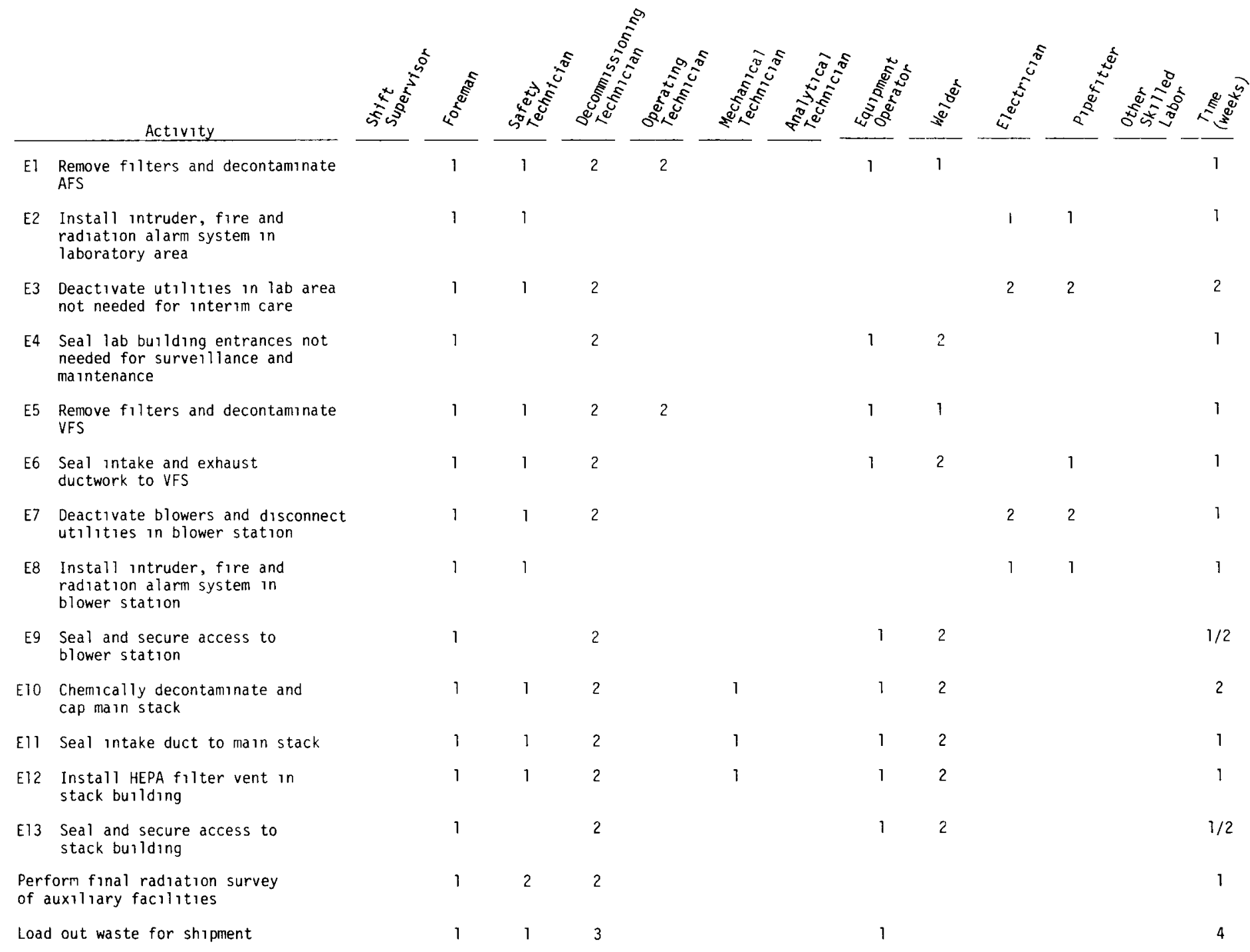


Activity

Al Chemical decontamination of process equipment and piping

A2 Chemical decontamination of cell walls and vessel externals

A3 Fix smearable contamination in accessible areas

A4 Decontaminate SAC's and glaveboxes

A5 Deactivate equipment, piping and systems not needed during interim

A6 Decontaminate vent system and and change out filters

A7 Install intruder, fire and radiation alarm system

A8 Deactivate utilities not needed during interim care

A9 Perform final radiation survey of Main Process Building

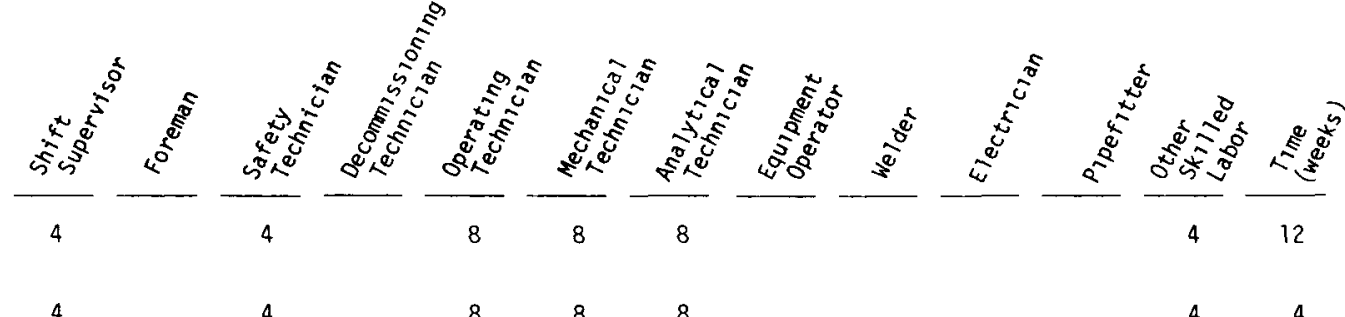

2

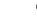




\section{TABLE E.7-3 (contd)}

\begin{tabular}{|c|c|c|c|c|c|c|c|c|c|c|c|c|c|c|}
\hline & Activity & 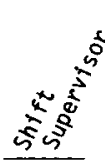 & $4^{50}$ & 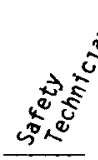 & E & 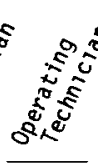 & 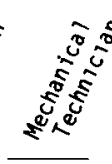 & 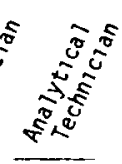 & 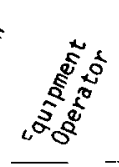 & $\frac{x^{2}}{x^{2}}$ & $\frac{\underbrace{5}}{\underbrace{5}}$ & $\frac{2^{2}}{2^{2}}$ & 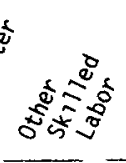 & 害离 \\
\hline$B 1$ & $\begin{array}{l}\text { Flush heel from HLLW tanks and } \\
\text { ILLW tank }\end{array}$ & 4 & & & & 12 & 4 & & & & & & 4 & 12 \\
\hline B2 & $\begin{array}{l}\text { Chemical decontamination of off } \\
\text { gas equipment and diverter cell } \\
\text { in WTEG }\end{array}$ & 1 & & 1 & & 2 & 2 & 2 & & & & & 1 & 2 \\
\hline B3 & $\begin{array}{l}\text { Fix smearable contamination in } \\
\text { accessible areas of WTEG }\end{array}$ & & 2 & 2 & 8 & & & & & & & & & 2 \\
\hline B4 & $\begin{array}{l}\text { Deactivate equipment, piping } \\
\text { and other systems not needed } \\
\text { during interim care }\end{array}$ & & 1 & & 3 & 1 & 2 & & 1 & 1 & 1 & 1 & & 2 \\
\hline B5 & $\begin{array}{l}\text { Decontarinnate vent system and } \\
\text { change out filters }\end{array}$ & & 1 & 1 & 2 & 2 & & & 1 & & & & & 1 \\
\hline B6 & $\begin{array}{l}\text { Install intruder, fire and } \\
\text { radiation alarm system }\end{array}$ & & 1 & 1 & & & & & & & 1 & 1 & & 1 \\
\hline$B 7$ & $\begin{array}{l}\text { Deactivate utilities not } \\
\text { needed during interim care }\end{array}$ & & 1 & 1 & 2 & & & & & & 2 & 2 & & 1 \\
\hline B8 & $\begin{array}{l}\text { Perform final radiation survey } \\
\text { of } 11 \text { quid waste storage facility }\end{array}$ & & 1 & 2 & 2 & & & & & & & & & 1 \\
\hline $\begin{array}{l}\text { Crew } \\
\text { deco }\end{array}$ & $\begin{array}{l}\text { wat wTEG during storage of } \\
\text { ommissioning wastes }\end{array}$ & & & & & 8 & & & & & & & & 17 \\
\hline
\end{tabular}




\section{TABLE E.7-3 (contd)}

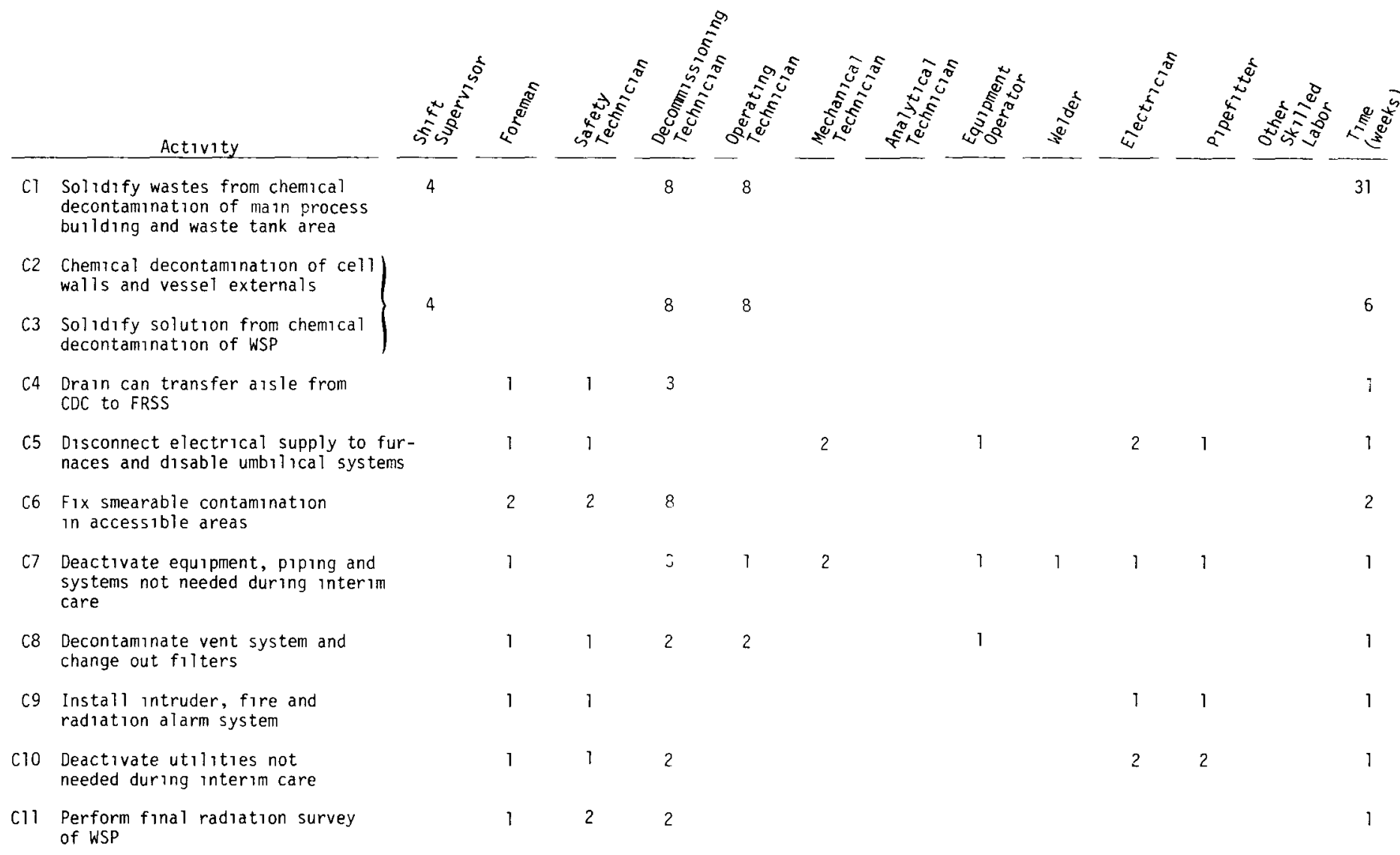


TABLE E.7-3 (contd)

Activity

DI. Man loadout station in FRSS

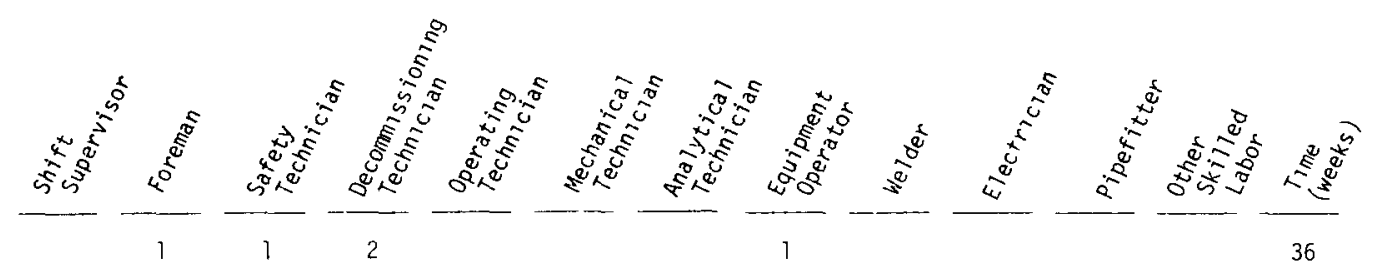

D2. Deionize and drain storage pools

8

D3. Deactıvate and decontaminate water treatment system

D4. Fix smearable contamination in pool area

D5. Decontaminate fuel storage racks

D6. Seal access between RPC and fuel transfer pool

D7. Fix smearable contamination in other areas and disable cranes

D8. Decontaminate vent system and change out filters

D9 Install intruder, fire and radiation alarm system

D10. Deactivate utilities not needed during interim care

D11. Perform final radiation survey of FRSS

$\begin{array}{lll}2 & 2 & 8 \\ 1 & 1 & 3 \\ 1 & 1 & ? \\ 1 & 1 & 4 \\ 1 & 1 & 2 \\ 1 & 1 & \\ 1 & 1 & 2 \\ 1 & 2 & 2\end{array}$




\section{TABLE E.7-3 (contd)}

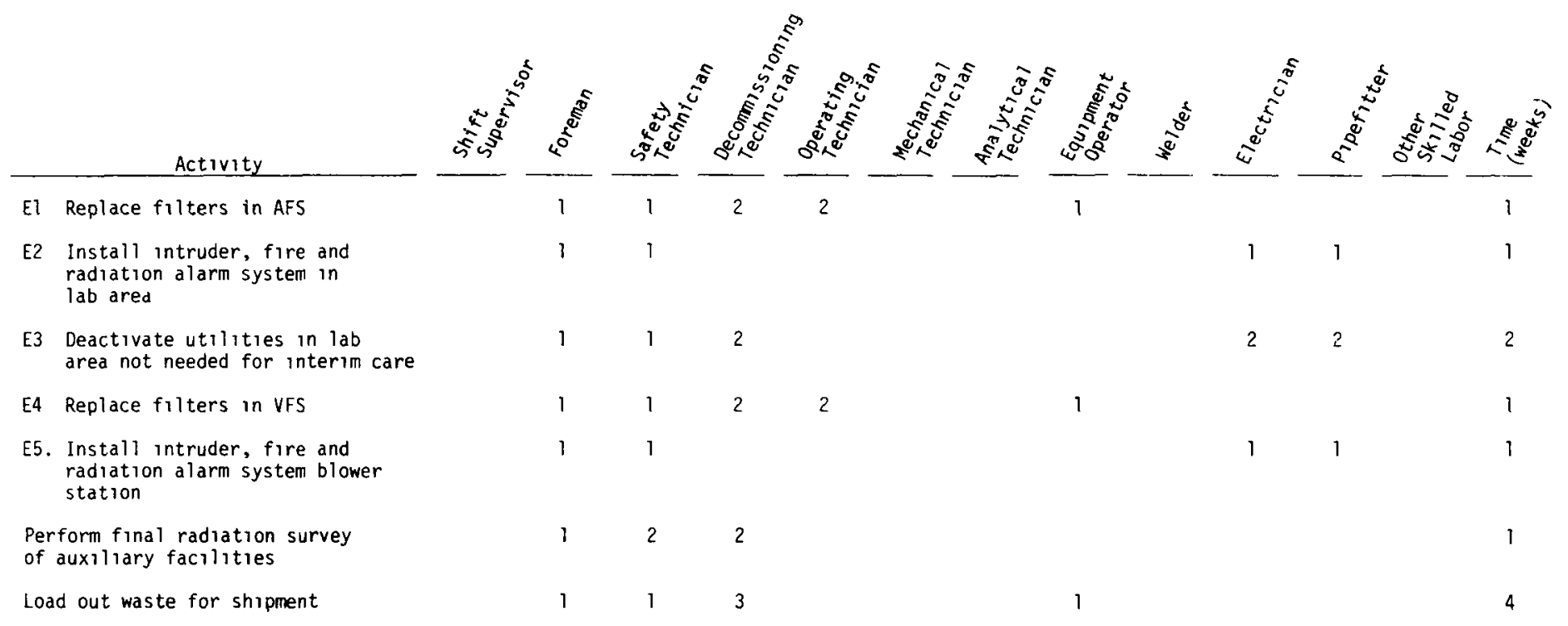




\section{E. 8 COST ESTIMATE DETAILS}

This section provides amplifying details for the cost estimate information presented in Volume I, Section 7.8.

\section{E.8.1 Labor and Subcontractor Cost Details}

Decommissioning labor costs are based on an estimated pay scale for each type of decommissioning employee. Pay scales are based on data from the Bureau of Labor ${ }^{(16)}$ wages for similar occupations on the Hanford Atomic Reservation and pay scales for similar skills in the construction trades. Support staff employees were grouped as much as possible by level of responsibility and decommissioning workers were grouped by skill and experience level and a representative pay scale was assigned to each group using the references cited above. These pay scales are presented in the "Base Pay" column of Table E.8.1. Decommissioning labor costs presented in Tables 7.8-1 through 7.8-6 were computed using the "Owner cost" column of the table. This column gives the base pay increased by $70 \%$ for nonunion employees and $50 \%$ for union employees to account for owner costs such as fringe benefits, taxes and insurance. The key employees listed in the table are assumed to receive incentive pay for remaining until decommissioning activities are completed.

\section{E.8.1.1 Subcontractor Cost Estimates for Dismantlement}

Subcontractor costs for the dismantlement mode were summarized in Table 7.8-7. Details of the items presented in the table are presented below.

- Excavate Overburden from Tanks

The overburden must be removed from the four waste tank vaults for dismantlement of the waste tanks. The excavation is assumed to be performed by a track-mounted backhoe with a $.6 \mathrm{~m}^{3}\left(3 / 4 \mathrm{yd}^{3}\right)$ capacity. Each excavation requires removal of about $960 \mathrm{~m}^{3}$ of soil. Unit excavation costs are from reference 17. The cost to reinforce the sides of each excavation with sprayed gunite has been estimated from reference 2. Gunite is assumed to be sprayed 2 in. thick over a mesh covering the $250 \mathrm{~m}^{2}$ surface of the sides of each excavation. Costs presented are for all four tanks. 
Excavate $3800 \mathrm{~m}^{3} \times 2.50 / \mathrm{m}^{3}$

$\$ 9,500$

Reinforce sides of holes $1000 \mathrm{~m}^{2} \times \$ 20.00 / \mathrm{m}^{2}$

$\frac{20,000}{\$ 30,000}$

TOTAL

- Greenhouse Installation

A large greenhouse is installed over the excavation for each tank before dismantlement activities in the tank begin. The greenhouse is assumed to be a "Sprung Instant Structure" (see Section E.3.6.8). The crew required to disassemble and reassemble the greenhouse is estimated to be composed of the following:

\section{Foreman \\ 5 Laborers \\ 1 Equipment Operator \\ 1 oiler \\ 1 22-MT crane}

The cost for this crew is given in reference 2 as $\$ 960 /$ day. It is estimated that taking down and reinstalling the greenhouse requires 3 weeks time. Including an allowance of $\$ 1,000 /$ move for equipment, materials and site preparation gives a total cost for four moves of $\$ 62,000$.

- Backfill Waste Tank Vaults

Each waste tank vault is backfilled after the waste tank internals, tank walls and vault liner have been removed and the vault decontaminated. It is assumed that 10 drainage holes $45 \mathrm{~cm}$ in diameter are drilled in the floor of each waste tank vault. Vaults and the excavation over the vaults are assumed to be filled by a bulldozer using soil from the site and compacted by air tamping. Concrete rubble from demolition of the Process Building and WTEG may also be used as fill. All unit costs are from reference 17 . Cost totals for all four tanks are presented.

Drilling 40 holes $\times \$ 700 /$ hole

Backfill tank vaults $4600 \mathrm{~m}^{3} \times \$ 3.40 / \mathrm{m}^{3} \quad 16,000$

Backfill excavations $3800 \mathrm{~m}^{3} \times \$ 3.40 / \mathrm{m}^{3} \quad \frac{13,000}{\$ 57,000}$ 
TABLE E.8-1. Estimated Base Pay Rates and Owner Costs for Decormissioning Employees

Employee

\section{Project Manager(a) \\ Project Engineer (a)}

Health \& Safety Supervisor(a)

Quality Assurance Specialist ${ }^{(a)}$

Decommissioning Operations Supervisor $(a)$

Plant Operations \& Maintenance Supervisor $(a)$

Radiation Safety Specialist(a)

Industrial Safety Specialjsf(a)

SNM Accounting Specialist

Accountant (a)

Radioactive Waste Disposal Specialist

Procurement Specialist(a)

Security Force Supervisor

Laboratory Supervisor

Assistant QA Specialist

Secretary

Radiowaste Disposal Clerk

QA Clerk

Radiation Exposure Records Clerk

Procurement Clerk

Supply Clerk

Custodian

Foreman (a)

Shift Supervisor (a)

Decommissioning Technician (a)

operating Technician(a)

Mechanical Technician

Equipment Operator(a)

Maintenance Technician

Welder

Pipefitter

Electrician

Instrument Technician

Safety Technician

SNM Accounting Technician

Analytical Technician

Engineering Technician

Chemical Makeup Operator

Security Guard

Explosives Engineer

Explosives Technician

Safety Review Committee Members
Annual Base Pay

34,000

29,000

29,000

25,000

25,000

25,000

20,000

20,000

20,000

18,000

15,000

15,000

15,000

15,000

15,000

8,000

8,000

8,000

8,000

8,000

8,000

8,000

22,000

22,000

20,000

20,000

20,000

20,000

20,000

20,000

20,000

20,000

20,000

13,000

13,000

13,000

13,000

12,000

12,000

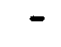

$-$
Owner Cost

58,000

49,000

49,000

42,000

42,000

42,000

34,000

34,000

34,000

31,000

26,000

26,000

26,000

26,000

26,000

12,000

12,000

12,000

12,000

12,000

12,000

12,000

33,000

33,000

30,000

30,000

30,000

30,000

30,000

30,000

30,000

30,000

30,000

20,000

20,000

20,000

20,000

18,000

18,000

$300 / d a$

$250 /$ da

$400 / d i$

(a) Key employees assumed to receive incentive pay.

(b) Work as consultants on a daily rate basis.

(c) Work as consultants on a daily rate basis. An allowance for travel and living expenses is also included. 
- Lower 100-m Stack

The cost to take down the 100-m stack is presented below. The operation is assumed to take 2 weeks using two 200 -ton cranes with $450-\mathrm{ft}$ booms. All costs are from reference 2 .

\begin{tabular}{llr} 
Crane Rental $-3,000 / \mathrm{wk} \times 4$ weeks & $\$ 12,000$ \\
Operators (2) $16.00 / \mathrm{hr} \times 160 \mathrm{hr}$ & 2,600 \\
Oilers (2) $11.55 / \mathrm{hr} \times 160 \mathrm{hr}$ & 1,900 \\
Foreman $\quad 15.70 / \mathrm{hr} \times 80 \mathrm{hr}$ & 1,300 \\
Welder $\quad 15.45 / \mathrm{hr} \times 8 \mathrm{hr}$ & 100 \\
Riggers (4) $14.00 / \mathrm{hr} \times 320 \mathrm{hr}$ & 4,500 \\
Laborers (2) $10.60 / \mathrm{hr} \times 160 \mathrm{hr}$ & 1,700 \\
Equipment and Supplies & 500 \\
\multicolumn{2}{|c|}{ TOTAL }
\end{tabular}

- Demolish Structures

An average demolition cost of $\$ 78 / \mathrm{m}^{3}$ of concrete has been used for the large reinforced concrete buildings at the FRP. These costs were estimated by an experienced demolition contractor. The amount of concrete in each building was estimated from the drawings in the facility description (see Appendix A).

Main Process Building

FRSS

Waste Solidification Plant

Waste Tank Equipment Gallery TOTAL

$$
\begin{array}{rr}
16,700 \mathrm{~m}^{3} \times \$ 78 / \mathrm{m}^{3} & \$ 1,300,000 \\
8,300 \mathrm{~m}^{3} \times \$ 78 / \mathrm{m}^{3} & 650,000 \\
2,500 \mathrm{~m}^{3} \times \$ 78 / \mathrm{m}^{3} & 200,000 \\
1,900 \mathrm{~m}^{3} \times \$ 78 / \mathrm{m}^{3} & 150,000 \\
\hline & \$ 2,300,000
\end{array}
$$

\section{- Backfill Cavities}

Building cavities are backfilled when demolition is completed. Bulldozer backfill of all cavities using soil from the site is assumed. It is assumed that compaction of the backfilled soil is not required. Concrete rubble from building demolition may also be used as fill. Backfill unit 
costs are from reference 17. Cavity volumes are estimated from the facility drawings in Appendix A.

$$
\text { Backfill } 70,000 \mathrm{~m}^{3} \times \$ .45 / \mathrm{m}^{3} \quad \$ 32,000
$$

\section{- Site Restoration}

Site restoration activities are assumed to consist of removing above grade concrete pads and roads, grading and leveling the site, and planting native vegetation. These activities are estimated to require 4 weeks time using the equipment and labor listed below. All unit costs are from reference 17.

\begin{tabular}{|c|c|c|}
\hline Scraper & $\$ 2,000 /$ wk $\times 3$ weeks & $\$ 6,000$ \\
\hline Dozer and Ripper & $1,500 /$ wk $\times 3$ weeks & 4,500 \\
\hline Grader & $450 /$ wk $\times 3$ weeks & 1,400 \\
\hline Jackhammers and Compressor & $600 /$ wk $\times 1$ week & 600 \\
\hline Dump Trucks (2) & $360 /$ wk $\times 6$ weeks & 2,200 \\
\hline Loader & $900 /$ wk $\times 3$ weeks & 2,700 \\
\hline Equipment Operators (4) & $580 /$ wk $\times 12$ weeks & 7,000 \\
\hline Oilers (2) & $460 /$ wk $\times 6$ weeks & 2,800 \\
\hline Laborers (3) & $430 /$ wk $\times 6$ weeks & 2,600 \\
\hline Foreman & $600 /$ wk $\times 4$ weeks & 2,400 \\
\hline Fine Grading, Seeding, Fertilizing & $.80 / \mathrm{m}^{2} \times 120,000 \mathrm{~m}^{2}$ & $\frac{96,000}{\$ 128,000}$ \\
\hline
\end{tabular}

\section{E.8.1.2 Subcontractor Costs for Protective Storage}

Subcontractor costs for protective storage were summarized in Table 7.8-8. Details of the items presented in the table are given below.

- Install Alarm Systems and Remote Readout Capabilities

The cost of alarm system installation and wiring for remote readouts is estimated using a standard electrical crew from reference 17. This crew consists of the following:

\section{Foreman}

3 Electricians

2 Helpers 
The cost for this crew is $\$ 640 /$ day. This task is estimated to require 5 weeks for the main process building and FRSS, and 2 weeks each for the WTEG, WSP and auxiliary facilities. Total cost of this activity, including $\$ 1,000$ for miscellaneous equipment and supplies used by the subcontractor is $\$ 36,000$.

- Excavate to Top of HLLW Tanks

A portion of each HLLW tank vault is uncovered to permit penetration of the tank to pump out residual waste solutions. It is assumed that $75 \mathrm{~m}^{3}$ of soil is excavated from each tank at a cost of $\$ 2.50 / \mathrm{m}^{3}$. (17) Reinforcing the sides of each excavation with sprayed concrete is estimated to cost $\$ 1,700$ per excavation. (See excavation costs for dismantlement.) Backfilling costs are estimated as before at $\$ 3.40 / \mathrm{m}^{3}$. The total excavation and backfilling costs for the three tanks are $\$ 8,000$.

- Install Greenhouse

A small portable greenhouse is placed over the excavated portion of the HLLW tank as a contamination control enclosure. Installation of this greenhouse is estimated to require a crew of:

1 Foreman

4 Laborers

1 Equipment Operator

1 oiler

1 22-MT Crane.

Cost for this crew is $\$ 880 /$ day. Assuming that each move of the greenhouse requires 2 days, total greenhouse installation costs for the three tanks. are $\$ 5,000$.

- Weld Inspection

Welding is used in many places to isolate a contaminated area from its surroundings. It is assumed that these welds will require third party inspection as part of the quality assurance program. Estimated cost of this activity is $\$ 25,000$. 


\section{- Change Facility Electrical Service}

Electricity requirements at the facility are nominal after protective storage has been completed. It is assumed that the large electrical service for the plant is changed to a small service towards the end of the protective storage period. This task is estimated to require 3 weeks using the standard electrical crew described above. Cost of materials is estimated at $\$ 10,000$. Total cost for this task is then $\$ 20,000$.

\section{E.8.1.3 Subcontractor Costs for Deferred Dismantlement}

Subcontractor costs for deferred dismantlement were presented in Tables 7.8-21 and 7.8-22. Bases for these estimates are discussed below.

- Refurbish Ventilation and Emergency Electrical Systems

Before deferred dismantlement following protective storage can begin, the ventilation system and the emergency electrical system must be restored. Labor costs for this job are based on the following crew:

1 Foreman

3 Electricians

2 Helpers

1 Equipment Operator

1 Light Crane

2 Millwrights

Cost for this crew is $\$ 1,060 /$ day. (17) The refurbishing operation is estimated to require 8 weeks. Equipment and material costs are estimated at $\$ 100,000$, based on replacement of much of the original equipment. Total cost for this operation is $\$ 150,000$.

- Install Larger Electrical Service to Plant

Electricity requirements during dismantlement are significantly larger than during interim care. Installation of a larger electrical service is estimated to require 4 weeks time using the crew described above (less the two millwrights). Cost of this crew is $\$ 840 /$ day. (17) Equipment and material costs are estimated to be $\$ 20,000$. Total cost of this activity is $\$ 37,000$. 
- Refurbish Cranes

Cost of this activity is estimated to be $\$ 100,000$. This is based on the assumption that a significant portion of the crane cables, controllers and motors will require replacement after receiving no maintenance over an extended interim care period.

- Install Temporary Electrical Service to Supply Dismantlement Equipment

It is assumed that the existing electrical system in the plant will not be usable after an extended interim care period. Cost of installing a temporary system to supply dismantlement equipment is based on use of the standard electrical crew of:

1 Foreman

3 Electricians

2 Helpers

Cost of this crew is $\$ 640 /$ day. (17) This activity is estimated to require 3 weeks time. The cost of equipment and materials is estimated to be $\$ 10,000$. Total cost of this activity is $\$ 20,000$.

\section{E.8.2 Special Equipment Costs}

Performance of the decommissioning activities described in Volume 1, Section 7 , requires the acquisition of some specialized decommissioning equipment that is not available from suppliers as a standard item. Cost estimates for this equipment are presented in this section.

\section{E.8.2.1 Dismantlement Special Equipment Costs}

Cost estimates for specialized dismantlement equipment presented in Table 7.8-9 are given below. Most cost estimates are based on engineering judgment.

\section{- Greenhouse Construction}

The cost of the special greenhouse used to cover the waste tanks during dismantlement is summarized below. Building cost is based on a $36 \mathrm{~m} \times 55 \mathrm{~m}$ "Sprung Instant Structure."(14) This building consists of an aluminum framework 
covered with a PVC-coated nylon fabric. The building is weather-proof and capable of withstanding $225 \mathrm{~km} / \mathrm{hr}$ winds. All other costs are based on engineering judgment. The cost of the decontamination facilities are estimated assuming that an electropolishing unit is installed. The facility is assumed to be designed and contructed by a subcontractor according to specifications developed by the dismantlement staff.

\begin{tabular}{lr} 
Engineering Costs & $\$ 50,000$ \\
Building Costs & 150,000 \\
Equipment & 150,000 \\
\hline Cranes & 100,000 \\
Chemical Decontamination Facilities & 100,000 \\
Ventilation System & 25,000 \\
Waste Packaging and Loadout Facilities & 50,000 \\
Radiation Monitoring Equipment and Alarms & 70,000 \\
Emergency Power System & 25,000 \\
Pumps and Piping & 25,000 \\
Repair Shop & $\$ 750,000$ \\
Subtotal & 190,000 \\
Subcontractor Overhead and Profit & $\$ 940,000$
\end{tabular}

- Modified Rock Splitters

Conventional rock splitters with power supply can be purchased for about $\$ 4,000$. The cost of a modified rock splitter used for concrete scarfing is estimated to be $\$ 8,000$.

\section{- Shielded Crane}

The cost of a normal 5-MT crane is approximately $\$ 25,000$. The cost to modify the crane to provide shielding to the operator in radiation zones is estimated to be $\$ 75,000$. Total cost for this item is $\$ 100,000$. 
- Shielded Front End Loader

The cost of a normal front end loader is approximately $\$ 13,500$. The cost to modify the loader to run on batteries and to provide radiation shielding for the operator is estimated to be $\$ 40,000$. Total cost for this item is $\$ 54,000$.

- Shielded Working Cage

Engineering and development costs for the cage are estimated to be $\$ 100,000$. Construction costs for the cage, including special equipment in the cage, are estimated to be $\$ 350,000$. Total costs for the cage are $\$ 450,000$.

- Shielded Working Platform

Engineering and development costs are estimated to be $\$ 50,000$. Construction costs are estimated at $\$ 180,000$. Total costs for the platform are $\$ 230,000$.

- HEPA Filter Replacement

Replacement of HEPA and roughing filters after chemical decontamination is estimated to cost $\$ 200 /$ filter, including installation and testing. It is estimated that about 500 filters require replacement. Total cost for filter replacement is $\$ 100,000$.

\section{E.8.3 Waste Management Costs}

The cost of packaging, shipping and disposing of the wastes from immediate dismantlement of each facility in the reference FRP are presented in Table E.8-2. These costs are based on the waste management unit cost data presented in Table 7.8-12 and the waste volumes presented in Appendix E.6. 
TABLE E.8-2. Packaging, Shipping, and Waste Disposal Costs

By Facility for FRP Immediate Dismantlement(a)

IRU Waste Management Costs (1000 1975 Dollars)

\begin{tabular}{|c|c|c|c|c|c|c|c|c|c|c|c|c|c|}
\hline & $\begin{array}{l}\text { Concrete } \\
\text { Rubble } \\
\end{array}$ & $\begin{array}{c}\text { Stainless } \\
\text { Steel } \\
\text { Plate } \\
\end{array}$ & $\begin{array}{r}\text { Equip \& } \\
\text { P1ping } \\
\text { (Unshielded) } \\
\end{array}$ & $\begin{array}{r}\text { Equip \& } \\
\text { Piping } \\
\text { (Shielded) } \\
\end{array}$ & $\begin{array}{r}\text { Waste } \\
\text { Tank } \\
\text { Sections } \\
\end{array}$ & $\begin{array}{c}\text { Filters }{ }^{(b)} \\
\text { (Unshielded) }\end{array}$ & $\begin{array}{c}\text { Filters } \\
\text { (Shielded) }\end{array}$ & $\begin{array}{l}\text { Giove } \\
\text { Boxes } \\
\end{array}$ & $\begin{array}{l}\text { Solidified } \\
\text { Decontamin } \\
\text { Liquids }(b) \\
\end{array}$ & $\operatorname{Irash}(b, c)$ & Subtotal & $\begin{array}{c}\text { Owner } \\
\text { Overhead }\end{array}$ & Total \\
\hline Process Building & 1710 & 740 & 2170 & 5200 & - & 25 & 170 & 30 & 4000 & 300 & 14,000 & 1400 & 15,000 \\
\hline Liquid Waste Storage & 60 & 1230 & 2130 & - & 1300 & 15 & - & - & 900 & 300 & 6,000 & 600 & 6,600 \\
\hline $\begin{array}{l}\text { Waste Solidification } \\
\text { Plant }\end{array}$ & 30 & 630 & 300 & - & - & 10 & - & - & - & 200 & 1,000 & 100 & 1,100 \\
\hline $\begin{array}{l}\text { Fuel Recelving \& } \\
\text { Storage Station }\end{array}$ & - & - & - & - & - & - & - & - & - & - & 0 & - & 0 \\
\hline Auxiliary Facilities & - & - & - & - & - & - & - & - & - & - & 0 & - & 0 \\
\hline
\end{tabular}

Non-TRU Waste Management Costs (1000 1975 Dollars)

\begin{tabular}{|c|c|c|c|c|c|c|c|c|c|c|}
\hline Process Building & 245 & 10 & 140 & - & 2 & 3 & 30 & 430 & 43 & 470 \\
\hline Lıquid Waste Storage & - & - & 35 & - & 1 & - & - & 35 & 3 & 38 \\
\hline $\begin{array}{l}\text { Waste Solidification } \\
\text { Plant }\end{array}$ & - & - & - & - & - & - & - & 0 & - & 0 \\
\hline $\begin{array}{l}\text { Fuel Receiving \& } \\
\text { Storage Station }\end{array}$ & 25 & 100 & 20 & 100 & - & - & 20 & 265 & 26 & 290 \\
\hline Auxiliary Facilities & 1 & - & 75 & - & 2 & - & 20 & 40 & 4 & 44 \\
\hline
\end{tabular}
(a) Costs for deferred dismantlement are the same as for immediate dismantlement except that there are no waste handing
charges for solidified decontamination ilquids

(b) These costs are also incurred for protective storage and iayaway
(c) Costs for protective storage and layaway are one-half those for immediate dismantlement 


\section{REFERENCES}

1. J. F. Nemec and K. G. Anderson, Demolition of Radioactive and Contaminated Concrete and Structures by Use of Explosives, Presented at 1974 Annual Meeting of the American Nuclear Society, Philadelphia, PA, June 1974.

2. Dupont Blaster's Handbook, 15th Edition, 1969.

3. Final Program Report on Dismantling of Elk River Reactor, C00-651-93, September 1974.

4. M. P. Schlienger and G. A. Beitel, Topical Report: Arc Saw Testing, Atlantic Richfield Hanford Co., Richland, WA, ARH-LD-147, February 18, 1976.

5. Brochures from E. H. Wachs Co., Wheeling, IL.

6. G. R. Bainbridge, Decommissioning of Nuclear Facilities, A Review of Status, IAEA, October 1973.

7. J. Barton Carver, "New Uses for Cleaning with Water," Power, May 1976.

8. Nucleonics Week, June 24, 1976.

9. Welding Handbook, Sixth Edition; Section Three, Part A: "Welding, Cutting and Related Processes." Published by the American Welding Society, 1970.

10. Dupont Blaster's Handbook, 15th Edition, 1969.

11. M. A. Cook, The Science of High Explosives, American Chemical Society Monograph Series, Reinhold Book Corporation, New York, NY, 1968.

12. D. D. Kog, V. D. Linse, and S. J. Basham, Jr., "Use of Linear Shaped Explosive Charges for Reactor Dismantiing," Tran. Am. Nucl. Soc., 22, $635,1975$.

13. J. D. Kaser and J. 0. Vining, Size Reduction of Large Contaminated Process Equipment Using Explosive-Shaped Charges, BNWL-B-192, Battelle, Pacific Northwest Laboratories, Richland, WA, November 1972.

14. Brochure furnished by Sprung Instant Structures, Ltd., Calgary, Alberta, Canada.

15. H. W. Arrowsmith, W. C. Budke, and R. P. Allen, Electropolishing as a

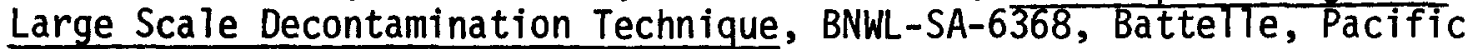
Northwest Laboratories, Richland, WA, to be published. 
16. Bureau of Labor Statistics Bulletin, March 1975, U.S. Department of Labor, Washington, DC.

17. R. S. Godfrey, ed., Building Construction Cost Data 1975, R. S. Means Co., Duxbury, MA, 1974. 


\section{APPENDIX F \\ DECOMMISSIONING SAFETY ASSESSMENT DETAILS}

This appendix contains detailed information on the assumptions, methoas, and calculations used to assess the safety impacts of decommissioning a reference fuel reprocessing plant discussed in Section 8 of Volume 1. The four sections of this appendix include: key assumptions used in the safety assessment, safety impacts of decommissioning activities, safety impacts of transportation activities, and radiation dose models.

\section{F.1 KEY ASSUMPTIONS USED IN THE SAFETY ASSESSMENT}

The following list of assumptions are essential to performing the safety analysis. They are used throughout Section 8 and this Appendix in quantifying the safety impacts.

1. The assumptions listed in Sections 3.3 and 8.2 apply to this section.

2. For all decommissioning modes, the process solutions are emptied and flushed from all piping, equipment and sumps. A11 process chemicals not needed for decommissioning are removed.

3. Systems used during subsequent decommissioning phases are functional and their operability is confirmed.

4. The particle removal efficiency of one HEPA filter is $99.95 \%$ giving a transmission factor of $5 \times 10^{-4}$. The transmission factor for one roughing and two HEPA filters in series is $2.5 \times 10^{-7}(10 \%$ removal efficiency for the roughing filter and $99.95 \%$ and $99.5 \%$ for the HEPAs). During decommissioning operations it is assumed that the HEPA filters are tested on a regular basis to assure the above efficiencies.

5. Chemical decontamination factors are assumed to be 2 for concrete, 100 for exterior decontamination of FRP equipment, 1000 for interior flushing of FRP equipment, 100 for first flush of HLLW tank bottoms and 10 for second flush of HLLW tank bottoms and 10 for decontamination spray of HLLW tank internals and walls. 
6. The aerosol mass concentration that can be supported by turbulent air flow conditions at most operational area exhaust outlets is $10 \mathrm{mi} 11$ igrams $/ \mathrm{m}^{3}$.

7. Local airborne contamination control systems for cutting, drilling and blasting operations are $90 \%$ efficient.

8. The principal mechanism for release of radionuclides from chemical decontamination operations is the entrainment of liquid droplets in the ventilation air. The amount of material airborne and its radionuclide concentration are a function of such variables as contamination level, solubility, contact time, etc. A $10 \mathrm{mg} / \mathrm{m}^{3}$ suspension of liquid droplets with the radionuclide concentration of the bulk liquid is typically assumed.

9. In the occupational dose calculations all personnel are assumed to be experienced radiation zone workers. The low range of the dose rates in the FRP process cells shown in Table 5.4-1 were used.

10. External radiation exposure from transportation operations are based on the maximum allowable dose rates for shipment in exclusive use vehicles.

11. The cummulative dose to the public from truck and rail shipments is based on population and dose per mile values given in Wash-1238 (see reference 16).

12. Atmospheric conditions given in NRC Regulatory Guide 1.3 (see reference 29) for a 0 to 8 hour release are used for the radiation dose calculations for accidental releases. For accidents at the FRP site a maximum individual is assumed to be located at one kilometer. For transportation accidents a maximum individual is assumed to be located at 100 meters.

\section{F.2 SAFETY IMPACTS OF DECOMMISSIONING ACTIVITIES}

Safety impacts of decommissioning activities include the potential release of radioactive material to the environment and subsequent radiation dose to the public, radiation dose to decommissioning personnel, the potentral release of chemical pollutants, and construction/industrial accidents. 


\section{F.2.1 Releases of Radioactive Material to the Environment}

Releases of radioactive material from normal decommissioning operations and from potential accidents are described in this section.

\section{F.2.1.1 Releases of Radioactive Material from Normal Decommissioning}

Table F.2-1 summarizes the release of radioactive material for normal decommissioning operations. The assumptions and calculations for this table are given in this section.

A. Releases during Planning and Preparation. The activities which comprise the planning and preparation phases of decommissioning are described in Section 7.1, Volume 1. Only one activity, a comprehensive radiation survey of the facility, appears to have any potential for release of radioactive material.

\section{FRP Main Process Building (MPB)}

Smearable radioactive particles lying on a hard, impermeable surface can be injected into the air by mechanical entrainment. $(1,2)$ Resuspension factors $(\mathrm{a})$ on the order of $5 \times 10^{-5}$ to $10^{-6} \mathrm{~m}^{-1}$ have been reported from walking over contaminated surfaces at various speeds. (1) Personnel access to areas of high radiation levels is limited and inspections of any area with readings greater than $1 \mathrm{R} / \mathrm{hr}$ are not likely. The extent of area outside the process cells contaminated to this level would also be severely limited. A radiation level of $1 \mathrm{mR} / \mathrm{hr}$ would be approximated by a surface contamination level of $15 \mathrm{mCi} / \mathrm{m}^{2}$. Using the higher resuspension factor of $5 \times 10^{-5} \mathrm{~m}^{-1}$ would indicate airborne concentrations of radionuclides as high as $7 \times 10^{-4}$ $\mathrm{mCi} / \mathrm{m}^{3}$. This concentration is only found as the individual crosses the surface. Thus, only a portion of the total volume of the space of concern attains the estimated concentration. Therefore, it is estimated that inspections of contaminated areas prior to cessation of operation would not

(a) Resuspension factor, $\mathrm{K}^{(3)}$

$$
K\left(\mathrm{~m}^{-1}\right)=\frac{\text { Airborne concentration (units } \left./ \mathrm{m}^{3}\right)}{\text { Contamination level (units } \left./ \mathrm{m}^{2}\right)}
$$


TABLE F.2-1. Estimated Release of Radioactive Material from Normal Decomissioning Activities

\begin{tabular}{lllll} 
& Reference & Total & Total \\
Unit Release to & Released to & Released to \\
Reference & Ventilation & Ventilation & Atmosphere, \\
Facility & Unit & System, CI & System, CI & CI \\
\hline
\end{tabular}

Plannıng \& Preparation Phase

Inspection/Contamınation Survey

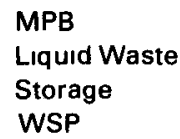

Decontamınation \& Decommıssıonıng Phase

1 Process Vessel - Fill \& Sparge

2 Pump \& Dilute

3 Recirculation of Solution through Pipıng \& Process Equip

4 High Pressure, Moving Spray

2 Removal of Surface Layer of Contaminated Concrete
a Drıllıng \& Blastıng
b Drillıng \& Rock Splıttıng

c Jackhammerıng

d Chippıng

e Paintıng

$\frac{\text { Janıtorıal Technıques }}{1 \text { Vacuumıng }}$

2 Swabbıng

3 Sweepıng

Filter Replacement

\begin{tabular}{|c|c|c|c|c|}
\hline $\begin{array}{l}\text { MPB } \\
\text { Liquid Waste }\end{array}$ & RPC & $47 \mathrm{E}-2^{(a)}$ & 037 & $93 E-8$ \\
\hline Storage & WTDC & $12 \mathrm{E}-3$ & $12 E-3$ & $30 \mathrm{E}-10$ \\
\hline $\begin{array}{l}\text { WSP } \\
\text { Liquid Waste }\end{array}$ & WVC & $18 \mathrm{E}-3$ & $18 E-3$ & $45 \mathrm{E}-10$ \\
\hline Storage & HLLW Tank & 29 & 120 & 29 E-6 \\
\hline - & - & - & 一 & - \\
\hline MPB & $\begin{array}{l}\text { RPC } \\
\text { Filter Niche }\end{array}$ & $\begin{array}{l}099 \\
61 \mathrm{E}-2\end{array}$ & $\begin{array}{l}79 \\
61 \mathrm{E}-2\end{array}$ & $\begin{array}{l}20 \text { E-6 } \\
31 \text { E-5 }\end{array}$ \\
\hline Liquid Waste & & & & \\
\hline Storage & $\begin{array}{l}\text { HLLW Tank } \\
\text { WTEG/WTDC }\end{array}$ & $\begin{array}{ll}0 & 15 \\
0 & 26\end{array}$ & $\begin{array}{l}06 \\
026\end{array}$ & $\begin{array}{l}30 \mathrm{E}-4 \\
64 \mathrm{E}-8\end{array}$ \\
\hline WSP & WSP & 32 E-2 & 010 & $25 \mathrm{E}-8$ \\
\hline
\end{tabular}

$\begin{array}{lllll}\begin{array}{l}\text { MPB } \\ \text { Liquid Waste }\end{array} & \text { RPC } & 67 \mathrm{E}-2 & 054 & 13 \mathrm{E}-7 \\ \text { Storage } & \text { HLLW Tank } & 082 & 33 & 17 \mathrm{E}-3 \\ \text { WSP } & \text { WTEG/WTDC } & 15 \mathrm{E}-2 & 15 \mathrm{E}-2 & 38 \mathrm{E}-9 \\ & \text { WVC } & 60 & 60 & 15 \mathrm{E}-5 \\ & & & \\ \text { MPB } & \text { RPC } & 132 & 110 & 27 \mathrm{E}-6 \\ \text { MPB } & \text { RPC Cellıng } & 10 & 8 & 20 \mathrm{E}-6 \\ \text { Liquid Waste } \\ \text { Storage } & \text { WTEG/WTDC } & 35 & 35 & 90 \mathrm{E}-7 \\ \text { WSP } & \text { WVC } & 029 & 087 & 22 \mathrm{E}-7 \\ - & - & - & - & - \\ - & - & - & - & -\end{array}$

$\begin{array}{lllll}\text { MPB } & \text { SAC } & 5 \mathrm{E}-3 & 004 & 10 \mathrm{E}-8 \\ \text { WSP } & \mathrm{HMC} & 015 & 015 & 38 \mathrm{E}-8 \\ - & - & - & - & - \\ - & - & - & - & - \\ & & & & \\ \text { MPB } & - & & 28 \mathrm{E}-2 & 14 \mathrm{E}-5 \\ \text { LWS } & - & - & 19 \mathrm{E}-2 & 95 \mathrm{E}-6 \\ \text { WSP } & - & - & 61 \mathrm{E}-2 & 31 \mathrm{E}-5\end{array}$

$\begin{array}{ll}15 \mathrm{E}-2 & 38 \mathrm{E}-9 \\ 012 & 30 \mathrm{E}-8 \\ 15 \mathrm{E}-2 & 38 \mathrm{E}-9\end{array}$

$25 \mathrm{E}-8$

Physical Decontamınation Technıques

Removal of Metal by Plasma Torch Cutting

$19 \mathrm{E}-2$

95 E-6

(a) $47 \mathrm{E}-2=47 \times 10^{-2}$ 
result in a measurable increase in the routine airborne release during operations. A total of approximately $15 \mathrm{mCi}\left(\sim 20,000 \mathrm{~m}^{3}\right.$ of air at $7 \times 10^{-4}$ $\mathrm{mCi} / \mathrm{m}^{3}$ ) could be released to the building ventilation and exhaust system as a result of the inspection of contaminated areas. The material passes through two sets of HEPA filters with a transmission factor of $2.5 \times 10^{-7}$, thus a release of $3.8 \times 10^{-9} \mathrm{Ci}$ to the atmosphere is postulated.

2. Reference Unit - Waste Tank Equipment Gallery (WTEG)

The estimated inventory for the "intermediate" zone of the WTEG is $<100 \mathrm{Ci}$ (see Table 5.4-1 in Volume 1). The nominal surface contamination level of the floor is estimated to be $36 \mathrm{mCi} / \mathrm{m}^{2}$. The "intermediate" zone must be entered to survey the "hot" zone and WTDC. Since the floor is more likely to be contaminated than the ceiling or walls, the nominal surface contamination was increased to $70 \mathrm{mCi} / \mathrm{m}^{2}$ for this calculation. The volume of the WTEG "intermediate" zone is approximately $34,000 \mathrm{~m}^{3}$. Under thr assumptions used previously, $120 \mathrm{mCi}$ are released to the building vr. ilation system during the inspection/radiation survey of the WTEG/WTDC and $3.5 \times 10^{-8}$ $\mathrm{Ci}$ are released to the atmosphere.

3. Waste Solidification Plant (WSP)

It is assumed that the same criteria for access of personnel to contaminated areas will be used in the WSP as in the MPB. The air flow through the WSP is approximately $1 / 4$ of that through the MPB. The assumption of a radionuclide release equivalent to that of the $M$ in is conservative, and thus a release of $15 \mathrm{mCi}$ to the $\mathrm{WS}^{r}$ ventilation system with a release of $3.8 \times 10^{-9} \mathrm{Ci}$ to the atmosphere is postulated.

\section{B. Releases from Chemical Dec:ntamination Techniques}

Various aqueous solutions are used to remove radioactive contamination from the :terior and exterior surfaces of process piping and vessels and exposed concrete and metal surfaces of the FRP. The composition of the decontamination solutions and the details of the techniques are given in Section 7.2 , Volume 1 . 


\section{Process Vessels - Fill and Sparge Technique}

Vessels are filled with a warm nitric acid solution (30\%) and the interior is "scrubbed' by recirculating the liquid or by air sparging.

The primary mechanism for the release of radioactivity under these conditions appears to be the entrainment of liquid droplets formed by the breakup of liquid films on the surface of the solution. This is especially true if air sparging is used as a means of liquid agitation. If air is introduced at the rate of 1 cubic meter per $\min (35.3 \mathrm{cfm})$, the velocity of air would be 0.009 meters per second $(0.03 \mathrm{fps})$ in a vessel the size of the HAW concentrator. "...At superficial air velocities of less than 0.046 meters per sec $(0.15 \mathrm{fps})$... aerosols formed by the vigorous mixing of a solution in air are metastable and have a concentration in the order of $10 \mathrm{mg} / \mathrm{m}^{3}$." ${ }^{(4)}$ Assuming a density of $1 \mathrm{~g} / \mathrm{ml}$ for the solution, $10 \mathrm{mg}$ is approximately $0.01 \mathrm{ml}$. Thus $0.01 \mathrm{ml} / \mathrm{min}$ of vessel liquid is entrained from the process vessels and is routed through the vessel off-gas treatment system.

- Reference Unit - Equipment in the Remote Processing Cell (RPC)

Ninety percent of the $130,000 \mathrm{Ci}$ of the residual radionuclide inventory is estimated to be on the interior surfaces of the equipment in the RPC (see Table B.3-1). The process vessel with highest inventory of residual radioactivity is the HAW concentrator with an estimated volume of 6,000 liters. For the purposes of this calculation, it is assumed that the $117,000 \mathrm{Ci}$ is contained in the equivalent of $12 \mathrm{HAW}$ concentrators, each requiring four hours of sparging using an air flow rate of $1 \mathrm{~m}^{3} / \mathrm{min}$ to attain the DF of 1,000 assumed for the chemical decontamination of vessel internals (Section 7.2). The nominal concentration of the radionuclides in the decontamination solution is $117,000 \mathrm{Ci} \div 72,000$ liters $=1.62 \mathrm{Ci} / 1$ iter or $1.62 \mathrm{mCi} / \mathrm{ml}$. If $0.01 \mathrm{ml}$ is entrained in each cubic meter of sparge air, $28.8 \mathrm{ml}$ of liquid containing $46.6 \mathrm{mCi}$ are released in the sparge air during the chemical decontamination of the equipment in the RPC.

Eight MPB process cells are listed in Table B.4-1 that have significant residual inventories of radionuclides. The amount of residual radionuclides on the equipment internals in these cells range from less than 1/2300 to 
1/16 of that estimated for the equipment in the RPC. The total release of radionuclides to the building ventilation system from chemical decontamination of process equipment in the MPB was conservatively estimated by multiplying the RPC release by eight, or $0.37 \mathrm{Ci}$.

Since not all the vessels are vented to the DOG or VOG systems, only the removal efficiency of two HEPA filters in series (a transmission factor of $2.5 \times 10^{-7}$ is used) in the ventilation system is assumed. The estimated release to the atmosphere is $9.3 \times 10^{-8} \mathrm{Ci}$.

- Reference Unit - Equipment in the Waste Tank Equipment Gallery (WTEG)/ Waste Tank Diverter Cell (WTDC)

It is postulated that $50 \%$ of the residual radionuclide inventory of $5,000 \mathrm{Ci}$ in the WTDC is associated with the interior surfaces of the two diverter tanks. No significant quantities of residual radionuclides are postulated for the gas treatment equipment in the "hot zone" of the WTEG.

The diverter tanks are assumed to be slightly smaller than the HAW concentrator, requiring 5,000 liters each for chemical decontamination. Using the calculational format and assumptions above ("Fill and Sparge." Reference Unit-Equipment in the RPC), $4.8 \mathrm{ml}$ of decontamination solution containing $1.2 \mathrm{mCi}$ of radioactivity is released to the building ventilation system and $3.0 \times 10^{-10} \mathrm{Ci}$ are released to the atmosphere from this activity.

- Reference Unit - Equipment in the Waste Vitrification Cell (WVC)

The number of items in the WVC to which this technique can be applied is limited. Table B.6-2 indicates that $4500 \mathrm{Ci}$ are on WVC equipment internals. Using the assumptions that were used for equipment in the RPC but reducing the number of vessels to six, the estimated airborne release to the building ventilation system during the chemical decontamination of the equipment in the WVC is $1.8 \mathrm{mCi}$. The estimated release to the atmosphere is $4.5 \times 10^{-10} \mathrm{Ci}$.

Residual radionuclide inventories are much smaller in other cells in the WSP. The quantity of equipment (especially equipment normally used to process high level liquids) is limited. Furthermore, when the equipment in the WSP is ready for chemical decontamination, large volumes of concentrated decontamination solution will have been processed, thus diminishing 
radionuclide content. Thus, the release from the WVC equipment decontamina tion is assumed to represent the total from the waste solidification facility.

2. Emptying and Decontamination of High Level Liquid Waste Storage TanksPump and Dilute

- Reference Unit - High Level Liquid Waste Storage Tank (HLLW)

The "heel" (residual material which cannot be pumped from the tanks by existing jets) remaining in a storage tank is diluted by the addition of 38,000 liters of nitric acid (which also aids in dissolving material at the bottom of the tank). The mixture is pumped from the vessel using the existing jets, again leaving a "heel". This dilution operation differs somewhat for the three decommissioning modes considered in this study. For protective storage and layaway the HLLW tanks are decontaminated by four successive flushes and pumpdowns. For dismantlement the final two heel flushes are introduced by high pressure sprays. The spray operations are treated in part 4 of this section.

The anticipated residual radionuclide inventory at shutdown in $7.9 \times$ $10^{6} \mathrm{Ci}$ (see Table B.4-1). The total volume of the tanks is $1300 \mathrm{~m}^{3}$. If it is assumed that the volume of the tank during each dilution is filled with an aerosol of mass concentration of $10 \mathrm{mg} / \mathrm{m}^{3(4)}$ composed of liquid drops with the same radioactivity concentration as the bulk liquid, the activities released to the off-gas system during the four dilutions are $2.2,0.51,0.12$ and $0.028 \mathrm{Ci}$ respectively. Thus, it is anticipated that $2.9 \mathrm{Ci}$ of radioactivity is released to the building ventilation system during application of this technique to a single HLLW tank. This value is also assumed to be the same for the pump and dilute operation for dismantlement.

A total of $3 \mathrm{HLLW}$ plus 1 ILLW tanks require emptying/decontamination. The total release during this activity in the liquid waste storage area is conservatively assumed to be $11.6 \mathrm{Ci}$ to the building ventilation system and $2.9 \times 10^{-6} \mathrm{Ci}$ to the atmosphere (assumes transmission through 2 HEPA filters in series prior to release). 
3. Recirculation of Solution through Piping and Process Equipment

Interiors of piping are decontaminated by the recirculation of flush solutions. To be effective, the liquid contacting the surface must be continually replenished and the pipe or equipment must be completely full to ensure all surfaces are decontaminated. The only points at which an air space is found over the liquid is in the makeup and receiving tanks. Thus, the potential for routine airborne release is believed small and the quantities of radionuclides made airborne are insignificant.

\section{High Pressure, Moving Spray}

Most cells within the prototype facility are assumed to be equipped with two types of spraying systems for chemical decontamination. These systems are: a) low flow "fog" nozzle fixed in place near the ceiling of the cells to wet down surfaces, and b) a rotating, high pressure spray that can be lowered into the cell to "scrub" surfaces with a high-pressure jet. Both systems are connected to the central mixing and distribution system within the process building. It is also assumed that portable high-pressure sprays can be used in most other locations within the facility.

The principal mechanism for radioactivity entrainment in air during these operations appears to be through the suspension of liquid droplets containing contamination. These droplets of contaminated liquid may be formed by the impaction of a high-pressure jet upon a liquid film containing dissolved radioactivity, which may be coating contaminated surfaces. The spray particles from the "mist" nozzles are assumed to be too small to possess sufficient force to produce film breakup and are assumed merely to wet surfaces.

The quantity of radioactivity in the liquid aerosols is influenced by many factors such as: quantity of radioactivity on various surfaces, ability of liquid to dissolve the radioactivity, contact time between liquid and surfaces, etc. Large variations in each factor can be anticipated between cells and even within a single cell. The quantity of liquid droplets entrained in the air passing through a process cell is dependent on the quantity and size distribution of the droplets made airborne, and the velocity and direction of the exhaust flow. Because of the uncertainties in many of the factors mentioned above, evaluation of all the factors for each cell did not seem 
warranted. Rather, a conservative value was derived by using the most contaminated area in which each operation is conducted as representative of the airborne release of radioactivity to the facility ventilation system during the operation in any cell.

This technique is assumed to be used in two flow configurations: 1) in process cells with flow-through ventilation, and 2) in waste storage tanks where only "in-leakage" creates flow through the volume containing airborne material. The postulated airborne release calculation is discussed below.

- Reference Unit - Remote Process Cell

The highest contamination level after plant shutdown, 130,000 $\mathrm{Ci}$, is found in the Remote Process Ce11 (see Table B.3-1). Ninety percent of this radioactive contamination is distributed over vessel internals. Of the remainder, $11,050 \mathrm{Ci}$ (8.5\% of the total) is assumed to be distributed on concrete surfaces (primarily as leaks or spills on the walls adjacent to certain pieces of equipment) and $1950 \mathrm{Ci}(1.5 \%$ of the total) is on the exterior surfaces of piping and equipment and on the stainless steel floor liner. It is further assumed that $50 \%$ of the radioactivity on the concrete surfaces and almost all the contamination on exterior surfaces of piping and equipment and on the floor is solubilized and removed in the decontamination solutions. Assuming a $191 \mathrm{iter} / \mathrm{min}(5 \mathrm{gpm})$ flow and a 60 minute cycle, $7475 \mathrm{Ci}$ of radioactivity will be found in 1140 liters of solution. The nominal concentration is $6.6 \mathrm{mCi} / \mathrm{ml}(24.9 \mathrm{Ci} / \mathrm{gal})$.

The detailed spray characteristics of the rotating high-pressure spray are not well defined. Since the function of this spray is to "scrub" contamination from various surfaces using hydraulic forces, it must reach most all areas of the cell. To achieve this objective, it is assumed that the spray is primarily a high-pressure coherent jet which does not produce small droplets. Data are not available to define the quantity or characteristics of the droplets formed. Thus, the conservative assumption is made that a sufficient quantity of droplets is generated to maintain a concentration of $10 \mathrm{mg} / \mathrm{m}^{3}$ (the maximum mass concentration anticipated at air velocities less than $0.15 \mathrm{fps}$ ) in gases exhausted from the cel1. (4) It is further assumed 
hat the aerosol contains the normal concentration of radioactivity of the bulk liquid, or $6.6 \mathrm{mCi} / \mathrm{ml}$. The flow through the RPC is $250 \mathrm{~m}^{3} / \mathrm{min}(8800 \mathrm{cfm})$. Thus $16.5 \mathrm{mCi} / \mathrm{min}$ are released to the ventilation and exhaust system during this operation or, $990 \mathrm{mCi}$ during the postulated 60-min cycle. By conservatively assuming that chemical decontamination of each process cell produces a release the same as that of the RPC, the estimated total routine release during process cell spray decontamination operations is $8 \times 990 \mathrm{mCi}$, or $7.9 \mathrm{Ci}$ to the ventilation system. After passing through two HEPAs in series, a release of $2 \times 10^{-6} \mathrm{Ci}$ is calculated to reach the atmosphere.

- Reference Unit - Filter Niche

As much as $200 \mathrm{Ci}$ (see Table 5.4-1 of Volume 1) could be accumulated in the filter niche. If a high pressure spray at a rate of 19 liters/min ( $5 \mathrm{gpm}$ ) is used for $60 \mathrm{~min}$, the nominal concentration of radionuclides in the decontaminating liquid is approximately $0.17 \mathrm{mCi} / \mathrm{ml}$. The normal exhaust flow is approximately $600 \mathrm{~m}^{3} / \mathrm{min}(21,000 \mathrm{cfm})$. Conservatively assuming this flow is not reduced during decontamination operations and assuming $10 \mathrm{mg}$ of liquid can be entrained in each cubic meter of air, $61 \mathrm{mC} i$ of radionuclides could reach the single stage of HEPA filters in the VFS or auxiliary system. Using a transmission factor of $5 \times 10^{-4}$ for a single stage of HEPA filtration, a total of $3.1 \times 10^{-5} \mathrm{Ci}$ could be released from the FRP from this operation.

- Reference Unit - High Level Liquid Waste Storage Tank

The final two heel flushes of the HLLW tanks are introduced through high pressure, low flow rate spray nozzles installed through the tank tops. Containment is provided by a greenhouse erected over the partially exposed tank. Filtered air is drawn through the greenhouse and into the HLLW tank, thereby maintaining a slightly negative pressure from the tank to the atmosphere. A means of exhausting air from the HLLW tank to the ventilation and exhaust system is temporarily installed to maintain a negative pressure in the tank in relationship to the greenhouse. The flow rate is low.

After pumpdown, it is anticipated that a total of $8.3 \times 10^{6} \mathrm{Ci}$ of radioactivity may remain in the bottom of a HLLW tank in the form of liquid and sludge and material adhering to the walls $\left(289 \mathrm{~m}^{2}\right)$ and internal equipment primarily the cooling tubes with a surface area of $1900 \mathrm{~m}^{2}$ ). The anticipated 
contamination levels of the interior tank walls and equipment are given in Appendix B.4, Table B.4-1. A total of $2.9 \times 10^{4} \mathrm{Ci}$ are assumed on the tank sides and internal equipment.

Radioactivity can be made airborne in the HLLW tanks during chemical decontamination by the impact of the high-pressure spray on wetted surfaces. The air velocity in the tank is low since only the quantity of air required to maintain a negative pressure is extracted. If the air is extracted near the top of the vessel (the most probable location for leaks), very little flow is anticipated in the tank to lift droplets generated deeper in the tank. Thus, assuming an airborne concentration of $10 \mathrm{mg} / \mathrm{m}^{3(4)}$ in the exhaust gases is conservative. If a flow of $28.4 \mathrm{~m}^{3} / \mathrm{min}(1000 \mathrm{cfm})$ is assumed, $0.284 \mathrm{ml} / \mathrm{min}$ of liquid are released to the ventilation and exhaust system.

The radioactivity present in the liquid is a function of the effectiveness of the decontamination technique and the volume involved. The surface area involved in ceiling, walls and prping is large and a long time cycle is required to assure adequate spray coverage.

Two spray cycles approximately $13 \mathrm{hrs}$ each are used in the dismantlement mode for HLLW decontamination. For both cycles $26,100 \mathrm{Ci}$ (the difference in calculated inventories on tank walls and internals shown in Tables B.4-1 and $B .5-3)$ are dissolved in 76,000 liters resulting in a nominal concentration of $0.34 \mathrm{Ci} / 1 \mathrm{iter}$. For the $26 \mathrm{hr}$ spray period $0.15 \mathrm{Ci}$ will reach the exhaust HEPA (transmission factor of $5 \times 10^{-4}$ ) resulting in a release of $7.5 \times 10^{-5} \mathrm{Ci}$ to the atmosphere. For the three HLLW and one ILLW tanks a conservative estimate of the total release is four times this value, or $3 \times 10^{-4} \mathrm{Ci}$ to the atmosphere.

- Reference Unit - Waste Tank Equipment Gallery (WTEG) Waste Tank Diverter Cel1 (WTDC)

Residual radionuclide inventories of $2500 \mathrm{Ci},<1000 \mathrm{Ci}$, and $<100 \mathrm{Ci}$ are estimated for the external surfaces of equipment and walls of the WTDC, the "hot," and the "intermediate" zones of the WTEG (see Table 5.4-1 in Volume 1). These areas are assumed to be decontaminated by the "High Pressure, Moving Spray" technique using installed or portable equipment. 
Assuming the same procedures and 60 minute time cycle as previously described, the radionuclide release in the "hot" zone of the WTEG is calculated as follows:

- Residual Radionuclide Inventory: $1000 \mathrm{Ci}$

$850 \mathrm{Ci}$ on concrete walls (DF $=2$ )

$150 \mathrm{Ci}$ on equipment $(\mathrm{DF}=100)$

- Nominal Concentration of Radionuclides in Liquid: $573.5 \mathrm{Ci} / 1135.5$ liters $=0.505 \mathrm{Ci} / 1 \mathrm{iter}$

- Liquid Entrained in Exhaust Flow: $360 \mathrm{~m}^{3} / \mathrm{min} \times 0.01 \mathrm{ml} / \mathrm{m}^{3} \times 60 \mathrm{~min}$ $=216 \mathrm{ml}$

- Radionuclides Released to Building Ventilation: $0.505 \mathrm{mCi} / \mathrm{ml} \times 216 \mathrm{ml}$ $=109 \mathrm{mCi}$.

The residual inventory in the "intermediate" zone of the WTEG is one-tenth that of the "hot" zone with an exhaust rate of $566 \mathrm{~m}^{3} / \mathrm{min}$ giving an estimated release to the building ventilation system of $17.3 \mathrm{mC}$.

The WTDC is completely lined with stainless steel and the entire residual radionuclide inventory of $2500 \mathrm{C} i$ is assumed to behave as if it were on equipment. A DF of 100 is assumed for chemical decontamination. The exhaust rate is $100 \mathrm{~m}^{3} / \mathrm{min}$ with a nominal concentration of radionuclides in the solution of $2.18 \mathrm{Ci} / 1$ iter. The estimated release to the building ventilation system from chemical decontamination of all three areas is $0.257 \mathrm{Ci}$, giving a release to the atmosphere of $6.4 \times 10^{-8} \mathrm{Ci}$.

- Reference Unit - Waste Vitrification Cell (WVC)

The WVC is estimated to have the largest residual radionuclide inventory in the Waste Solidification Plant - 10,000 Ci (see Table B.6-2). Only $1000 \mathrm{Ci}$ of this is estimated to be on the stainless steel liner and on the external surfaces of equipment. Using installed equipment and the same assumption described in a previous section (High Pressure Moving Spray, Reference UnitRemote Processing Cel1, a 60 min spray cycle at 18.9 liters/min with a chemical DF of 100) the nominal concentration of radionuclides in the liquid is $0.87 \mathrm{Ci} / 1$ iter. Since the airflow in the WVC is $10 \mathrm{w}, 60.6 \mathrm{~m}^{3} / \mathrm{min}$, the mass concentration entrained in the exhaust is assumed to be no larger than that 
postulated for this technique in the RPC $-10 \mathrm{mg} / \mathrm{m}^{3}$. Thus, it is estimat that $31.7 \mathrm{mCi}$ of radioactivity are released to the building ventilation system during application of this technique to chemically decontaminate the WVC. Material released to the building ventilation system during this operation must be transmitted through two banks of HEPA filters prior to release. Thus it is estimated that $7.9 \times 10^{-9} \mathrm{Ci}$ are released to the atmosphere.

There are five other stainless steel lined cells in the WSP (see Table A.5-1) that may contain residual radionuclide inventories and require chemical decontamination - Hot Pipe Trench (HPT), Canister Decontamination Cubicle (CDC), Off Gas Treatment Cell (OGTC), Hot Maintenance Cell (HMC), and the Cell Ventilation Tunnel (CVT). The estimated residual radionuclide inventories for these cells are listed in Table B.6-2. Their total is $500 \mathrm{Ci}$, about half the radioactivity estimated on the walls of the WVC. The exhaust flow rates through the OGTC and the HMC are 6 and 3 times that in the WVC but their estimated inventory is only $60 \mathrm{Ci}$. Assuming a release of twice that estimated for the WVC for chemically decontaminating all the remaining cells is considered to be conservative. Thus, it is estimated that $100 \mathrm{mCi}$ is released to the building ventilation system and $2.5 \times 10^{-8} \mathrm{Ci}$ is released to the application of the high-pressure moving spray technique.

C. Releases from Equipment Removal and Physical Decontamination Techniques. After chemical decontamination, additional decommissioning operations include equipment removal by cutting with a plasma torch and physical decontamination of concrete surfaces by blasting, drilling, rock splitting, jackhammering and chipping. The details of these techniques are given in Sections 7.2 and 7.3 of Volume 1 .

1. Removal of Metal by Cutting with a Plasma Torch

Metal items can be cut by vaporization of all material (including residual radionuclides) in a $0.32 \mathrm{~cm}$ ( $1 / 8$ in.) swath by a plasma torch. A local airborne contamination control system (vacuum) near the source is used with an assumed efficiency of at least $90 \%$.

- Reference Unit - Equipment and Floor Liner of Remote Process Cell

It was assumed in a previous section (Chemical Decontamination of Process Vessels by the Fill and Sparge Technique, Reference Unit - Equipmen 
(n RPC) that the residual inventory of radionuclides on the interior of equipment in the RPC was the equivalent of 12 HAW concentrators. The HAW concentrator is $1.6 \mathrm{~m}$ in diameter by $5.5 \mathrm{~m}$ tal1, and irregular in shape. It's surface area is estimated to be $60 \mathrm{~m}^{2}$. Assuming a DF of 1000 for the chemical decontamination of vessel internals, $117 \mathrm{C} j$ is thus estimated to be on $720 \mathrm{~m}^{2}$ of interior surfaces yielding a nominal surface level of $117 \mathrm{Ci} \div$ $720 \mathrm{~m}^{2}=0.162 \mathrm{ci} / \mathrm{m}^{2}$. The external contamination level is $\left(1.9 \mathrm{Ci} \div 720 \mathrm{~m}^{2}\right)$ $0.00264 \mathrm{Ci} / \mathrm{m}^{2}$, giving a total surface contamination level of $0.165 \mathrm{Ci} / \mathrm{m}^{2}$. When dealing with limited areas, the influence of "hot spots" (areas of unusually high radioactivity) can change the airborne release and a value twice the nominal value $\left(0.33 \mathrm{ci} / \mathrm{m}^{2}\right)$ is used in these calculations.

Pipes and hardware must be cut free to allow for removal of the equipment. Additional segmentation of pipe is also required for packaging. It is assumed that disconnecting each of the 12 vessels will require the cutting of both ends of the equivalent of ten $5 \mathrm{~cm}(2-i n$.$) diameter, Schedule 40$, pipes, or 240 cuts. Clearing the cel1 and segmentation for packaging will require twice that number of cuts ( 480 cuts) for a total of 720 cuts. The pipe is assumed to be contaminated to the same level as the vessel itself. The cal. culations of the radionuclide releases are:

1) surface area vaporized in cutting: average diameter of pipe $=$ $5.54 \mathrm{~cm}$; circumference of pipe $=\pi d=3.14 \times 5.54 \mathrm{~cm}=17.4 \mathrm{~cm}$; surface area per cut $=17.4 \mathrm{~cm} \times 0.32 \mathrm{~cm}=5.57 \mathrm{~cm}^{2} /$ cut; total surface area vaporized $=720 \times 5.57 \mathrm{~cm}^{2}=0.401 \mathrm{~m}^{2}$.

2) residual inventory released to the building ventilation by cutting: $0.33 \mathrm{Ci} / \mathrm{m}^{2} \times 0.4 \mathrm{~m}^{2} \times 0.1=0.0132 \mathrm{Ci}$.

Bulkier equipment requires segmentation to fit into packages acceptable at Federal repositories. In cutting the equivalent of 12 HAW concentrators to fit into shipping packages, it is estimated that the radionuclides on $1.64 \mathrm{~m}^{2}$ would be released. Thus, $0.054 \mathrm{Ci}$ are released to the building ventilation system.

Segmentation of the floor liner is not anticipated to add significantly to the radionuclide release from this operation. The estimated surface contamiation level is less than one-tenth of that estimated for piping and equipment. 
Assuming that plasma torch cuttirig in all eight process cells releases. quantities of radionuclides comparable to those estimated for the RPC, the total radionuclide release during use of this technique in the FRP is conservatively estimated to be $(0.0672 \mathrm{Ci} \times 8) 0.54 \mathrm{Ci}$ to building ventilation system and $1.3 \times 10^{-7} \mathrm{Ci}$ to the atmosphere.

- Reference Unit - High Leve1 Liquid Waste (HLLW) Storage Tank

The HLLW storage tanks represent the largest accumulation of radionuclides in the reprocessing complex but are not physically part of the main process building. All operations involving work on contaminated surfaces are to be performed under a temporarily installed "greenhouse." A filtered ventilation system provides a negative pressure in the building relative to the outside atmosphere. In addition, an auxiliary filtered ventilation system is connected to an existing penetration into the waste tank and maintains a negative pressure in the tank relative to the "greenhouse." Thus, airborne material must migrate against a pressure gradient to the "greenhouse" before it is in jeopardy of release to the environment. Consequently, the most likely path of release is through the auxiliary tank ventilation system. For conservatism, it is assumed that any material released to the vesse 1 atmosphere would eventually reach the exhaust filters of the auxiliary ventilation system.

A detailed procedure and sequence for this operation is given in Volume 1, Section 7.3.3. Once an opening has been established into a vessel, the internal equipment and piping is removed. Based on information given in Table B.5-3 a contamination level of $1.5 \mathrm{Ci} / \mathrm{m}^{2}$ is assumed. An estimated 4500 cuts are required to segment the $5 \mathrm{~cm}$ ( 2 in.) pipe cooling coils into 475 sections to fit into $1.2 \mathrm{~m} \times 1.2 \mathrm{~m} \times 2.4 \mathrm{~m}(4 \mathrm{ft} \times 4 \mathrm{ft} \times 8 \mathrm{ft})$ containers. Assuming $10 \%$ of material vaporized is released, segmentation of the cooling tubes is estimated to release $0.38 \mathrm{Ci}$ of radioactivity in $8.6 \mathrm{~kg}$ (19 1b) of stainless steel. Segmentation of other internal piping is estimated to release an additional $10 \%$ of this amount, or $0.038 \mathrm{Ci}$ of radioactivity in $0.86 \mathrm{~kg}(1.9 \mathrm{lb})$ of stainless steel. A total of $0.4 \mathrm{Ci}$ of radioactivity in $24 \mathrm{~kg}(52 \mathrm{lb})$ of stainless steel are released during the segmentation of the walls, floor and ceiling. Thus $0.82 \mathrm{Ci}$ of radioactivity in $33 \mathrm{~kg}$ (73 1b) 
ff stainless steel are estimated to be released to the auxiliary ventilation system during this operation. Assuming three HLLW and one ILLW storage tanks, a conservative estimate of the routine release for plasma torch cutting of liquid waste storage tanks is $3.3 \mathrm{Ci}$ to the auxiliary ventilation system and $1.7 \times 10^{-3} \mathrm{Ci}$ to the atmosphere.

- Reference Unit - Equipment, Piping, and Floor Liner of Waste Tank Equipment Gallery (WTEG)/Waste Tank Diverter Cell (WTDC)

Items in the three areas-- "hot" and "intermediate" zones of the WTEG and the WTDC--made of metal will be disconnected and segmented to fit into appropriate shipping containers by a plasma torch with a local airborne contamination control system. The nominal surface contamination level of materials in the sections vary by their origin and the presence/absence of internal contamination.

The postulated radioactivity levels of the various materials used to estimate radionuclide releases is double the normal value to compensate for "hot spots." After chemical decontamination, levels are:

Equipment and pipe WTEG "hot" zone - $30 \mathrm{mCi} / \mathrm{m}^{2}$

Equipment and pipe WTEG "intermediate" zone $-3 \mathrm{mCi} / \mathrm{m}^{2}$

Equipment and pipe WTDC - $190 \mathrm{mCi} / \mathrm{m}^{2}$

Floor liner WTDC $-150 \mathrm{mCi} / \mathrm{m}^{2}$.

The "intermediate" zone of the WTEG contains the most equipment of the three areas and it was assumed that the equivalent of 480 cuts of $5-\mathrm{cm}$ diameter pipe were required to disconnect the equipment and segment the pipe for shipment. The equipment is non-transuranic, non-high level waste and does not require additional segmentation for shipment. This activity is calculated to release $0.8 \mathrm{mCi}$ of radioactivity to the building ventilation system. The same operation was assumed to require 100 cuts (1ess equipment) in the "hot" zone and release $0.17 \mathrm{mCi}$ to the ventilation system.

The equipment and floor liner in the WTDC is considered to be high-level waste and require segmentation. The total release including 100 pipe cuts is estimated to be $14.3 \mathrm{mCi}$ to the ventilation system. Thus, it is estimated that plasma torch operations in the WTED/WTDC release a total of $15 \mathrm{mCi}$ of radioactivity to the building ventilation system and $3.8 \times 10^{-9} \mathrm{Ci}$ to the atmosphere. 
- Reference Unit - Piping, Liner, and Equipment of Waste Vitrification Cel1 (WVC)

After chemical decontamination a residual radionuclide inventory of $4000 \mathrm{C} i$ is estimated for the equipment in the WVC (see Table B.6-2). The entire inventory is assumed to be involved with the annular portions of three pieces of equipment--the calciner and two in-can melters. It is assumed that the residual radionuclides are distributed evenly among the three pieces of equipment and that $75 \%$ of the radioactivity is associated with the ceramic insulator material. Radionuclides released during plasma torch cutting in the WVC are those principally associated with the highly contaminated, degraded, ceramic insulator material that is exposed during segmentation of the calciner and in-can melter furnaces.

It is assumed that as much as $20 \%$ of the radioactivity present could be made airborne during segmentation and removal of the equipment. Ninety percent of this airborne material is collected by the local airborne contamination system. Thus $3000 \mathrm{Ci} \times 0.2 \times 0.1=60 \mathrm{Ci}$ of radioactivity are released to the building ventilation system during this entire operation and $1.5 \times 10^{-5} \mathrm{Ci}$ are released to the atmosphere after filteration through two banks of HEPA filters.

The residual radionuclide inventory for all other areas in the WSP are estimated to be at least 2 orders of magnitude less (see Table B.6-3). Plasma torch cutting generally affects only a minute fraction of the surface area (and thus the surface contamination) involved. The radionuclide releases calculated for segmentation of the piping and equipment in all other areas of the WSP are insignificant by comparison.

- Reference Unit - Contaminated Equipment and Piping Outside of Process Cells (Layaway and Protective Storage)

All equipment outside process cells that cannot be chemically decontaminated to acceptable levels is detached and placed in process cells. It is anticipated that the equipment will be detached in the most expeditious manner consistent with good practices and transferred as single units. Much of the detachment can be accomplished by unbolting or cutting support structures with relatively low levels of contamination. The principal 
Urce of airborne radioactivity is the cutting of internally contaminated piping joining the equipment to the process. It is anticipated that the level of contamination is low to moderate since it will exist in areas used by processing personnel.

The contamination levels which can be tolerated in equipment outside process cells is much less than that for equipment inside process cells. The HAW concentrator was used as a basis for estimating the potential airborne release during removal and segmentation of process equipment by cutting with a plasma torch. A contamination level of $0.165 \mathrm{Ci} / \mathrm{m}^{2}$ was estimated for this piece of equipment. A radiation source of this high level in an area to which personnel have direct access would constitute a serious potential hazard during the operating phase and would be removed. The maximum internal contamination level which would result in a tolerable radiation reading appears to be at least 1 order of magnitude less than that estimated for the HAW concentrator. For this evaluation, the surface contamination of the equipment and piping to be removed is assumed to be $0.02 \mathrm{ci} / \mathrm{m}^{2}$. It is further assumed that the equivalent of 100 five-cm (2-in.) diameter pipes must be cut to remove the equipment and piping (a total of 200 clits). On this basis, $2.2 \mathrm{mCi}$ of radioactivity are vaporized during the cutting. The local airborne contamination control mechanism is assumed to be $90 \%$ effective. Thus, it is estimated that $0.22 \mathrm{mCi}$ of radioactivity are released to the building ventilation and exhaust system during the application of this technique. This results in a release of $5.5 \times 10^{-11} \mathrm{Ci}$ to the atmosphere.

- Reference Unit - Incidental Cutting in Waste Tank Equipment Gallery for Layaway or Protective Storage Mode

Equipment and piping outside the "hot" zone that cannot be satisfactorily decontaminated must be removed by cutting with a plasma torch and stored in the "hot" zone. The residual radionuclide contamination level of equipment in the "intermediate" zone of the WTEG was estimated to be $3 \mathrm{mCi} / \mathrm{m}^{2}$ (see earlier discussion in this section, "Reference Unit - Equipment, Piping and Floor Liner of WTEG/WTDC"). Since the intent is to remove excess contamination, cutting is assumed to be in areas of nominal contamination level. suming it is necessary to cut the equivalent of 50 five-cm diameter pipes 
(with Local Airborne Contamination Control), $0.017 \mathrm{mCi}$ of radionuclides released to the building ventilation system and $4.2 \times 10^{-12} \mathrm{Ci}$ are released to the atmosphere from this operation.

- Reference Unit - Waste Solidification Plant - Contaminated Equipment and Piping Outside Process Cells (Layaway and Protective Storage)

The exact size and number of piping and equipment which must be removed in the WSP are not known. A release identical to the WTEG is assumed. This results in a release of $4.2 \times 10^{-12} \mathrm{Ci}$ to the atmosphere.

2. Removal of Surface Layer of Contaminated Concrete (Scarfing)

a. Drilling and Blasting. Reference Unit - Remote Process Cell (RPC)

Horizontal Drilling. If the holes for explosives are drilled horizontally into the wall from the contaminated surface, some contaminated solid particles will become airborne in the cell and challenge the exhaust filters The surface area of these walls are $351 \mathrm{~m}^{2}$ and $58 \mathrm{~m}^{2}$, respectively. The holes are $2.54 \mathrm{~cm}$ in diameter $\times 12.7 \mathrm{~cm}$ deep on $10 \mathrm{~cm}$ centers and a total of 39,000 are required for the two walls. This gives a surface area affected by drilling of $20 \mathrm{~m}^{2}$ that contains $130 \mathrm{Ci}$ of radioactivity.

Approximately $2.5 \mathrm{~m}^{3}$ of concrete with a mass of $6000 \mathrm{~kg}$ would be removed by this drilling. The radioactivity concentration for this drilling operation is $22 \mu \mathrm{Ci} / \mathrm{g}$ of concrete removed.

A similar set of techniques was successfully used in the dismantlement of the Elk River Reactor. The highest weekly average concentration of dust was around $10 \mathrm{mg} / \mathrm{m}^{3}$ during removal of the biological shield using explosives. (5) At a ventilation flow of $306 \mathrm{~m}^{3} / \mathrm{min}(10,800 \mathrm{cfm})$ (7.5 air changes/ $\mathrm{hr}$ ), $3.1 \mathrm{~g} / \mathrm{min}$ could be carried off at a mass concentration of $10 \mathrm{mg} / \mathrm{m}^{3}$. Not all the material generated is small enough to be carried by the low air velocities in the cell at this ventilation rate $-0.046 \mathrm{~m} / \mathrm{sec}(0.15 \mathrm{ft} / \mathrm{sec})$. The time span of the operation further limits the quantity of the dust that can be released. If we assumed $10 \%$ of the material escaping the local dust control system can be entrained in the ventilation flow, $60 \mathrm{~kg}$ of concrete dust containing $1.32 \mathrm{Ci}$ of radioactivity could be released to the cell ventilation during this operation. Assuming eight cells with this relea 
sults in a conservative estimate of routine release from drilling of $11 \mathrm{Ci}$ to the ventilation system. After passing through a prefilter plus two HEPAs in series, $2.7 \times 10^{-6} \mathrm{Ci}$ is calculated to be released to the atmosphere.

Blasting in Remote Process Cell. The quantity and size distribution of the concrete particles generated during blasting is not known. It is assumed the entire volume of the $\operatorname{RPC}\left(2460 \mathrm{~m}^{3}\right)$ is filled with the maximum airborne concentration of dust $\left(10 \mathrm{mg} / \mathrm{m}^{3}\right)$ with the nominal radioactivity concentration of the dust calculated for drilling $(22 \mu \mathrm{Ci} / \mathrm{g})$. Thus, $24.6 \mathrm{~g}$ of dust containing $0.54 \mathrm{mCi}$ of radioactivity are made airborne per explosion. Assuming 20 explosions are used to scarf all the contaminated concrete surfaces in the $\mathrm{RPC}, 492 \mathrm{~g}$ of concrete dust containing $10.8 \mathrm{mCi}$ of radioactivity are released during this operation. Assuming a comparable release for each of the eight cells, a conservative estimate of routine release from blasting operations is $86 \mathrm{mC} i$ to the cell vent system. After passing through one roughing plus two HEPA filters in series, the release is $2.2 \times 10^{-8} \mathrm{Ci}$ to the atmosphere.

Drilling and Using Modified Rocksplitter

- Reference Unit - Ceiling of RPC

The principal anticipated use of this technique is for removing concrete from the ceiling of process cells. Holes $2.54 \mathrm{~cm}$ in diameter on $10 \mathrm{~cm}$ centers are drilled through the ceiling from above. A modified rock splitter is inserted from above and an average depth of $2.54 \mathrm{~cm}$ of the contaminated surface is removed.

The surface contamination level on the ceiling will be an order of magnitude lower than the nominal level of the walls. Using the RPC as the reference process cell, its ceiling is estimated to have $654 \mathrm{mCi} / \mathrm{m}^{2}$ of contamination.

A total of 14,490 holes are required in the RPC ceiling area of $150 \mathrm{~m}^{2}$. The 14,490 holes would encompass a total surface area of $6.54 \mathrm{~m}^{2}$. At the above mentioned surface contamination levels, $4.8 \mathrm{Ci}$ of radioactivity are involved. Since the holes are drilled down through $1.22 \mathrm{~m}$ of concrete, the volume and mass of concrete involved with the radioactivity are unknown. til the contaminated surface in the cell is penetrated, the dust and debris 
is released to the area above the cell. Upon cell penetration, the mate generated will fall into the cell by gravity, aided by differential pressure between the cell and the area above the cell. It is believed that only a thin layer of concrete would be contaminated. A layer $0.64 \mathrm{~cm}$ thick was arbitrarily chosen. Thus, a volume of $466 \mathrm{~cm}^{3}$ with a mass of $112 \mathrm{~kg}$ of concrete contains the $4.8 \mathrm{Ci}$. The nominal radioactivity concentration of the concrete would be $43 \mu \mathrm{Ci} / \mathrm{g}$. Assuming $20 \%$ of the dust generated eludes the collection system rather than $10 \%$ (due to the added effect of gravity and differential pressure) and is of the particle size to remain airborne, $22.5 \mathrm{~kg}$ of concrete dust containing $0.97 \mathrm{Ci}$ of radioactivity could be released to the cell ventilation during this operation.

After all the holes have been drilled, modified rock splitters are inserted and the contaminated surface is scarfed to a nominal depth of $2.5 \mathrm{~cm}$ (1 in.). The rubble generated will be caught in baskets or netting positione directly under the work area. A fine water spray is used to attenuate the airborne release of dust. The nominal calculated surface contamination is $654 \mathrm{mCi} / \mathrm{m}^{2}$ and the mass involved to a depth of $2.54 \mathrm{~cm}$ is $9.1 \times 10^{3} \mathrm{~kg}$ $\left(2 \times 10^{4} \mathrm{lb}\right)$ of concrete. It is anticipated that the size of the concrete rubble broken away by this technique would primarily be coarse (inches in diameter) with fine particles generated along cracks. Dust generated is assumed to have the same radioactivity concentration as the nominal value of $10.8 \mu \mathrm{Ci} / \mathrm{g}$.

Assuming air in the ventilation system contains $10 \mathrm{mg} / \mathrm{cu}$ meter, (5) $3.1 \mathrm{~g}$ of concrete dust containing $33.4 \mu \mathrm{Ci}$ of radioactivity are released per minute of operation. Assuming 15 hours of operation for the RPC, $30 \mathrm{mCi}$ would be released from rock splitting operations to the ventilation system. Thus, for drilling and rock splitting operations, $1.0 \mathrm{Ci}$ are released to its cell venti lation system. For eight comparable process cells, a conservative release of $8 \mathrm{Ci}$ is estimated to the ventilation system. After filtration, this results in an atmosphere release of $2 \times 10^{-6} \mathrm{Ci}$.

- Reference Unit - Waste Tank Equipment Gallery (WTEG)/Waste Tank Diverter Cell (WTDC)

Residual inventories of radionuclides are assumed to be on the conc surfaces of the "hot" and "intermediate" zones of the WTEG and under 10\% or 
he area of the stainless steel liner in the WTDC. It is further assumed that only $10 \%$ of the surface area in the "intermediate" zone is contaminated. Thus, the areas involved are small and, in two cases, random. Thus, the drill-rock splitter technique is used.

The surface areas involved and nominal surface contamination levels for the three areas are:

$$
\begin{aligned}
& \text { "intermediate" zone in WTEG }-239 \mathrm{~m}^{2} \text { at } 0.178 \mathrm{Ci} / \mathrm{m}^{2} \\
& \text { "hot" zone in WTEG }-433 \mathrm{~m}^{2} \text { at } 0.982 \mathrm{Ci} / \mathrm{m}^{2} \\
& \text { WTDC }-23.6 \mathrm{~m}^{2} \text { at } 7.44 \mathrm{Ci} / \mathrm{m}^{2} \text {. }
\end{aligned}
$$

The technique, assumptions, and calculations format are described in the initial segment of this section, "Reference Unit - Ceiling of the RPC." Drilling of $23,000,42,000$, and $23405.07 \mathrm{~cm}^{2}$ holes are required for the three areas respectively, releasing $0.21 \mathrm{Ci}, 2.1 \mathrm{Ci}$, and $0.88 \mathrm{Ci}$ to the building ventilation system.

The exhaust flows from the areas of concern are - "intermediate" zone $66 \mathrm{~m}^{3} / \mathrm{min}$, "hot" zone $360 \mathrm{~m}^{3} / \mathrm{min}$, and WTDC $100 \mathrm{~m}^{3} / \mathrm{min}$. The time required to perform the operation in each area was calculated using a work rate of $5.8 \mathrm{~m}^{2} / \mathrm{hr}$ rounded off to the nearest hour. The nominal radionuclide contents of the concrete dust are estimated to be:

$$
\begin{aligned}
& \text { "intermediate" zone }-2.9 \mu \mathrm{Ci} / \mathrm{g} \\
& \text { "hot" zone }-16 \mu \mathrm{Ci} / \mathrm{g} \\
& \text { WTDC - } 122 \mu \mathrm{Ci} / \mathrm{g} .
\end{aligned}
$$

Releases for rock splitting in the three areas are $0.04 \mathrm{Ci}, 0.26 \mathrm{Ci}$, and $0.029 \mathrm{Ci}$, respectively, to the building ventilation system.

The total release from both operations in all three areas is estimated to be $3.5 \mathrm{Ci}$ to the building ventilation system and $9 \times 10^{-7}$ to the atmosphere.

- Drilling and Rock Splitting. Reference Unit - Waste Vitrification Cell

The wall surface area is $873 \mathrm{~m}^{2}$ (see Table A.5-1) and $87.3 \mathrm{~m}^{2}$ of concrete under the stainless steel liner is assumed to be contaminated with radionuclides to the same level as the liner. The residual inventory on the walls and exterior surfaces of equipment, piping, and hardware is $1000 \mathrm{Ci}$ (see Table B.6-2). The surface area of the equipment is estimated to be $300 \mathrm{~m}^{2}$ 
plus $437 \mathrm{~m}^{2}$ for piping and hardware. The total contaminated surface area $1610 \mathrm{~m}^{2}$ giving a nominal surface concentration of radionuclides of $0.621 \mathrm{Ci} / \mathrm{m}^{2}$. The estimated residual inventory associated with concrete surfaces is then calculated as $54.2 \mathrm{Ci}$.

The contamination is assumed to be random (although most likely confined to the lower levels of the WVC). The method chosen to remove the contaminated surface is by drilling/rock splitting. The technique, calculational format and assumptions are described earlier (Drilling and Rock Splititng, Reference Unit - Ceiling of Remote Process Cell).

Drilling. The area is $87.3 \mathrm{~m}^{2}$ and 8451 holes $2.54 \mathrm{~cm}$ in diameter are required. The total surface area involved is $4.6 \mathrm{~m}^{2}$ containing $2.8 \mathrm{Ci}$ of radioactivity. It is estimated that $0.28 \mathrm{Ci}$ is released to the building ventilation system and $7 \times 10^{-8} \mathrm{Ci}$ are released to the atmosphere after filtration.

Rock Splitting. Rock splitting involves the breaking away of the concrete surface to a nominal depth of $2.54 \mathrm{~cm}$. Dust is assumed to have the nominal radionuclide concentration as the bulk concrete $(10.1 \mu \mathrm{Ci} / \mathrm{g})$. A wa mist is used to control the airborne dust. In the previous discussion, entertainment of $10 \mathrm{mg}$ of dust $/ \mathrm{m}^{3}$ of exhaust was postulated. The WVC exhaust flow is assumed to be $60.6 \mathrm{~m} / \mathrm{min}$. Assuming an operational period of 15 hours, as much as $5.5 \mathrm{mCi}$ of radioactivity can be released to the building ventilation system.

Assuming the other cells in the WSP result in a release of twice that of the WVC, the total release of radionuclides during the removal of contaminated concrete surfaces in the WSP is calculated to be $0.87 \mathrm{Ci}$ to the building ventilation system and $2.2 \times 10^{-7} \mathrm{Ci}$ to the atmosphere.

Contaminated Concrete Removal in Other Areas of the Waste Solidification Plant. Three other areas are estimated to have significant inventories of residual radionuclides on concrete surfaces - HPT $20 \mathrm{Ci}$, OGTC $2.5 \mathrm{Ci}$, and the CDC $3.3 \mathrm{Ci}$. Air flow is from the HPT and CDC to the WVC and, therefore, exhaust flow rates and radioactivity contamination levels in the former cells are lower. The air flow through the OGTC is six times that of the WVC but its residual inventory is less than $1 / 20$ th that of the WVC. Using the WVC 
elease as a basis to estimate the same operations in these other cells is thus conservative. The residual inventories in the HMC $(0.67 \mathrm{Ci})$ and galleries are approximately two orders of magnitude less and do not exert any discernable effect on the magnitude of the radionuclide release from the application of this technique in the WSP.

The estimated total release from all areas of the Waste Solidification $\mathrm{Plant}$ is $0.87 \mathrm{Ci}$ to the building ventilation system and $2.2 \times 10^{-7} \mathrm{Ci}$ to the atmosphere.

c. Jackhammering. Reference Unit - Areas Outside Process Cells

A pneumatic jackhammer is used to remove contamination from concrete surfaces for areas of limited size and moderate contamination level. The quantity of suspendable particles generated by this technique is unknown but, since the point of origin (where the top of the jackhammer contacts the concrete surface) is well defined, effective means of controlling airborne release appear possible. Thus, it is anticipated that this technique will esult in the airborne release of significantly lower quantities of radioactivity compared to the other techniques (i.e., less than $1 \%$ of the material generated by blasting). Therefore, releases from these operations are expected to be negligible.

d. Chipping. Reference Unit - Areas Outside Process Cells

This manual technique is utilized on limited areas having low to moderate contamination levels. Such areas will be carefully defined and a fixative applied to hold the contamination in place. Removal starts at the uncontaminated peripheral areas and progresses into contaminated areas. Airborne release is minimal and limited to a small amount of contaminated concrete dust formed during the fracturing of the concrete. Local airborne contamination control devices such as suction tubes are assumed to be used and would be effective in removing dust. Thus, no significant airborne release of contamination is anticipated during the application of this technique.

e. Painting. Reference Unit - Areas Outside Process Cells

Areas that cannot adequately be decontaminated but do not pose a radiation hazard will be painted with at least one coat each of two 
distinctively-colored paints. Contaminated areas being painted have alread been subjected to some treatment and contamination is assumed to be firmly embedded in the concrete. Painting applies a cover over the surface and does not cause relocation of the concrete surface. Thus, no significant airborne release is anticipated during application of this technique.

D. Release from Janitorial Techniques. The janitorial techniques include vacuuming, swabbing with sponges, and sweeping.

1. Vacuuming

- Reference Unit - Sample and Analytical Cell (SAC)

This technique reentrains deposited airborne material either by drawing air across the surface (aerodynamic entrainment) or by scrubbing the deposited material from the surface with stiff bristles (mechanical entrainment) and capture by an air stream. The vacuum cleaner is assumed to exhaust through a HEPA filter. Vacuuming, as a decontamination procedure, is used for the Sample and Analytical Cells (SAC), gloveboxes and hoods. The SACs are $1.8 \mathrm{~m} \times 1.8 \mathrm{~m} \times 3 \mathrm{mtall}(6 \mathrm{ft} \times 6 \mathrm{ft} \times 10 \mathrm{ft}$ ) with a stainless steel liner covering the floor and part way up the wall and are assumed to contain $100 \mathrm{Ci}$ (see Table 5.4-1 in Volume 1). It is anticipated that this technique will not be highly effective in removing radionuclides contaminating the surface due to the presence of a greasy film from the long term condensation of trace organic vapors from the atmosphere. The technique is applied to make subsequent decontamination by sprays more effective by removing trash and lint. Thus, it is assumed that $10 \%$ of the contamination is made airborne and passed into the cleaner collection system. The cleaner exhausts through a HEPA filter. Thus, $10 \% \times 0.05 \%$ or $5 \times 10^{-5}$ of the inventory in the SAC is calculated to be released to the cell ventilation system during vacuuming.

The total inventory involved in the eight SACs is 800 curies and $40 \mathrm{mCi}$ could be released to the HVAC system during vacuuming of all eight cells. This activity results in a release of $1 \times 10^{-8} \mathrm{Ci}$ to the atmosphere.

- Reference Unit - Hot Maintenance Cell

The HMC is to be used to segment and package equipment removed from other cells in the WSP. These activities are potentially dusty, especially 
egmentation of the Calciner and In-Can Melter. It was postulated in a previous discussion ("Plasma Torch Cutting. Reference Unit - Piping, Liner, and Equipment WVC") as much as $3000 \mathrm{Ci}$ may be involved with powdered, degraded, ceramic insulation. The LAC normally used with a plasma torch is only intended to collect condensed metallic vapors and may be overworked by the large quantities of powder involved. Secondary enclosures normally constructed of combustible material would be a fire hazard near a plasma torch and are an obstruction for a remote operation. Thus, it is postulated that as much as $20 \%$ of the radionuclide inventory (600 Ci) could be deposited on the cell surfaces.

Since the metal surfaces are relatively clean from prior chemical decontamination procedures, vacuuming should be more effective than in the SAC and it is assumed $50 \%$ of the material could be removed. Thus, it is estimated that $0.15 \mathrm{Ci}$ are released to the building ventilation system and $3.8 \times 10^{-8} \mathrm{Ci}$ are released to the atmosphere from this operation.

\section{Swabbing Contaminated Surfaces with Mixed Acid Soaked Sponges}

Metal surfaces with acceptably low radiation readings, limited area and accessibility, and which do not have equipment installed for spray decontamination are decontaminated by swabbing with acid proof sponges soaked in mixed acids. There should be little potential for routine airborne release during use of such a technique. Some small liquid drops may be generated during wringing of solution out of the sponges and during wiping activities. The level of contamination in the liquid is expected to be low due to the restrictions on radiation levels for manual operations. Thus, the routine release to the cell ventilation from this source is not considered to be significant.

\section{Sweeping}

Sweeping is a technique used primarily to remove trash and dust from large floor areas that are not highly contaminated. This technique is not applied to areas containing significant quantities of surface contamination Mechanical entrainment is the aerosol generation mechanism. Techniques are vailable to restrain the generation of dust (moisture, oily sawdust, etc.) 
Thus, no significant airborne release of radionuclides is postulated during the application of this technique to decommissioning activities.

\section{E. Isolation and Deactivation of Systems (Layaway and Protective}

Storage). All systems not required for surveillance and maintenance of the MPB are either isolated or deactivated. A1l system having safety functions remain operative. The activities during this phase are principally administrative (tagging, inspections, surveys, etc.). All pipes (except sanitary and fire fighting water) penetrating the outer wall are cut about $20 \mathrm{~cm}$ from the wall and circular steel plates are welded over the exposed ends. The pipes are generally uncontaminated, and no airborne release of radioactivity is anticipated during these operations. For contaminated pipes, the formula described in a previous section can be applied (Removal of Metal by Cutting with Plasma Torch - Reference United Contaminated Equipment and Piping Outside of Process Cells). If the contamination is as assumed in a previous section $\left(0.02 \mathrm{ci} / \mathrm{m}^{2}\right)$ and the equivalent of twenty-five $5 \mathrm{~cm}$ ( 2 in.) diameter pipes are cut at both ends, as much as $0.056 \mathrm{mCi}$ of radioactivity could be released to the building ventilation and exhaust system during these operations. This results in a release of $1.4 \times 10^{-11} \mathrm{C}$ to the atmosphere.

Operations in the liquid waste storage area and the WSP are assumed to double this release. The release from isolation and deactivation activities for the layaway mode is assumed to be a factor of 10 less than protective storage.

- Decontamination and Isolation of Sample and Analytical Cells Gloveboxes

In a previous discussion of the potential routine airborne releases, it was estimated that as much as $40 \mathrm{mCi}$ of radioactivity could be released to the cell exhausts during vacuuming of the 8 SACs. The value is doubled to include potential releases during vacuuming of gloveboxes. No significant airborne releases are anticipated during swabbing of contaminated surfaces using acid-soaked sponges. A release of $80 \mathrm{mCi}$ to the ventilation system results in an atmospheric release of $2 \times 10^{-8} \mathrm{Ci}$. 
- Contact Equipment Removal Station Decontamination, Equipment Removal and Isolation

The pieces of equipment mounted on removable shield plugs in the Contact Equipment Removal Station are withdrawn and the assemblies are stored in a process cell (Protective Storage Mode). The items will have been chemically decontaminated by the cell spray system and should be relatively free of readily entrainable contamination. The equipment is drawn up into specially fabricated plastic bags. Penetrations into the process cell are immediately sealed. Therefore, no significant airborne release of radionuclides is anticipated during this procedure.

- Fuel Receiving and Storage Station Decontamination and Isolation The major steps in decontamination and isolation of the FRSS are:

- Reduce the radioactivity level of pool water where it can be released to the environment.

- Isolate pool and stabilize surface contamination.

- Survey and stablize surface contamination in other FRS work areas.

- Isolate FRSS from remainder of facility.

The radionuclide concentration of the pool water is reduced by cycling the water through existing demineralizers and filters. The concentrations of radionuclides in the water are very low and no significant airborne release of contamination is anticipated. Disposal of demineralization and filtration equipment is done by existing operational procedures. Both resin and filters are damp with water and no significant airborne release is anticipated.

The opening to the RPC is sealed and the contamination in the poot and equipment stabilized. Manual techniques of decontamination and painting are proposed and should not generate significant airborne release. The pool can easily be enclosed and auxiliary contamination control equipment installed. Equipment in the pool's deionization area that cannot be reduced to acceptable levels of contamination is removed and stored in process cells. It is assumed that the operation will involve the equivalent of a single piece of equipment in the RPC and cutting is performed by plasma torch. 
- Filter Stations Decontamination and Isolation

After reduction and immobilization of contamination are accomplished, contaminated areas are isolated by welding shut all penetrations and blanking ventilation and exhaust ducts. HEPA-filtered vents from the FRSS and uncontaminated area of the process building to the outside are installed to allow the building to "breathe." Installation of HEPA vents is done so that it does not compromise the capability of the building to withstand design basis catastrophic natural phenomena. No significant releases are anticipated from this activity.

Isolation of the ventilation and exhaust system is accomplished by welding prefabricated steel plates in the ducts at convenient locations. Areas containing approximately equivalent levels of contamination are isolated as a single area. Only the ducts from the contaminated areas to the initial in-line filters are considered to have a significant level of surface contamination. Since much of the ductwork passes through areas that are accessible to personnel during the operation of the facility and the welding technique used to install the plates is a contact operation, contamination levels must be kept low. The level of surface contamination is conservatively assumed to be $1.5 \mathrm{mCi} / \mathrm{m}^{2}$ (approximately $100 \mathrm{mR} / \mathrm{hr}$ ). The fractional airborne release of $\mathrm{PuO}_{2}$ during heating on a stainless steel plate at $1000^{\circ} \mathrm{C}$ in air flowing at a velocity of up to $100 \mathrm{~cm} / \mathrm{sec}$ is less than $2.5 \times 10^{-4}$. (6) If the airborne release during welding is assumed to be similar and the total surface area heated is equal to $3.8 \mathrm{~m}^{2}$, the total airborne release during this operation is $1.4 \mathrm{mCi}$ of radioactivity to the building exhaust system. This results in a release of $7.0 \times 10^{-7} \mathrm{Ci}$ to the atmosphere.

- Replacement of High Efficiency Particulate Air (HEPA) Filter

All filters are to be replaced and their in-situ efficiency validated prior to release of the facilities to decommissioning personnel. Filter replacement is also done after certain activities such as chemical decontamination of facilities and end of decommissioning phase.

Filter replacement is a routine maintenance technique during the operational phase of the facilities and well established and tested procedures exist. Documentation on the fraction of accumulated inventory dislodged 
luring filter change out has not been identified, but loss of significant quantities would be intolerable and, for large accumulations of radionuclides, readily detectible. Thus, $0.1 \%$ of the radionuclide inventory on the filters is conservatively assumed to be released during filter removal.

The estimated radionuclide inventory accumulated on the first stage of HEPA filters from the beginning of decommissioning activities are shown below:

Through Chem Decon.

MPB

LWS WSP
$8.4 \mathrm{Ci}$

$12 \mathrm{Ci}$

$0.12 \mathrm{Ci}$
Through

Decommissioning

$28 \mathrm{Ci}$

$19 \mathrm{Ci}$

$61 \mathrm{Ci}$

The estimated release of accumulated radionuclides to the backup stage of HEPA filters are:

\begin{tabular}{llc} 
& \multicolumn{1}{c}{$\begin{array}{c}\text { Through } \\
\text { Chem Decon. }\end{array}$} & $\begin{array}{c}\text { Through } \\
\text { Decommissioning }\end{array}$ \\
MPB & $0.0084 \mathrm{Ci}$ & $0.028 \mathrm{Ci}$ \\
LWS & $0.012 \mathrm{Ci}$ & $0.019 \mathrm{Ci}$ \\
WSP & $0.00012 \mathrm{Ci}$ & $0.061 \mathrm{Ci}$
\end{tabular}

The release to the atmosphere from the entire operation is estimated at $5.4 \times 10^{-5} \mathrm{Ci}$.

\section{F. Decommissioning Waste Processing and Handling Operations}

1. Liquid Wastes

Liquid waste storage and solidification operations for chemical decontamination solutions are identical to those for processing high level waste in an operating FRP. The chemical decontamination solutions contain much lower amounts of radionuclides than HLLW. Consequently, the release of radionuclides during chemical decontamination solutions storage and solidification is low compared to that from production operations at the FRP.

The residual heels in the HLLW tanks $\left(210^{7} \mathrm{Ci} /\right.$ tank) contain the highest radionuclide inventory. A total DF of $10^{11}$ is assumed for the spray calciner and its off-gas system based on required performance during production 
operations. Processing the tank heels from three HLLW tanks results in a calculated release of $3 \times 10^{-4} \mathrm{Ci}$ to the building ventilation system and $7.5 \times 10^{-11} \mathrm{Ci}$ to the atmosphere.

2. Solid Wastes

Various types of contaminated solid waste are generated during decommissioning. These include process vessels and piping, ventilation filters, concrete rubble, protective clothing, and rags. A1l process equipment is chemically decontaminated both internally and externally prior to removal. Ventilation filters are bagged in plastic for disposal. Contaminated materials are handled and packaged in plant areas with efficient operating air filtration systems. Thus, the release of radionuclides from normal operations in the handling of solid wastes is expected to be negligible when compared to that from other decommissioning activities.

\section{F.2.1.2 Potential Accidental Releases of Radioactive Material}

Table F.2-2 summarizes the estimated radioactivity released from postulated decommissioning accidents. The detailed calculations and assumption for these releases are given in this section.

1. Temporary Loss of Equipment and Services

- Water

Water is used as a local airborne contamination control technique during certain operations - drilling, rock splitting, jackhammering, etc. In most other instances, loss of water would only result in the possible delay of operations as in chemical decontamination or rinsing. Consequences of the loss of local airborne contamination control is described elsewhere.

- Electricity

The reference FRP has normal emergency electrical power and distribution systems. Thus, a complete loss of electrical service resulting in the loss of confinement is highly unlikely. If it occurs, loss of power during most operations should not result in the loss of major confinement systems, but could result in loss of local airborne contamination control. Simultaneous cessation of operations will also occur. Only during 


\section{TABLE F.2-2 Estimated Radioactivity Released from Postulated Decommissioning Accidents}

1 Temporary Loss of Service

Water

Electricity

Compressed Aır/Gases

Ventilation

Fire Protection

Radiation Monitoring

2 Mixıng of Incompatıble Chemıcals

3 Lıquid Leaks Durıng Transport \& Use/Inadvertent Transfer of Liquids to an Open Line

4 Break in Compressed Aırlıne for Pneumatıc Jackhammer

5 Dropping of Contamınated Concrete Rubble

6 Loss of Local Aırborne Contamınatıon Control System Plasma Torch Cuttıng Drıllıng/Blastıng Drilling/Rock Splitting

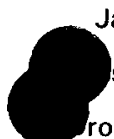
Jackhammerıng s of Blastıng Mat

roppıng Decontamınated Equipment

Durıng Removal

9 Incomplete Clean-up of Exterıor Rubble Contaıners

10 Segmentation by Plasma Torch of Equipment not Chemıcally Decontamınated

11 Fire Involvıng Contamınated Clothing or Combustıbles

12 Detonation of Unused Explosives in Cell

13 Flood Durıng Dismantlıng

14 High Winds Durıng Dismantlıng

15 Fire Durıng Cuttıng with Plasma Torch Outside Process Cell

16 Fire in Ventilation Ducts During Welding

17 'Red Oil' Explosion in HAW Concentrator

18 Fire Involvıng Plywood Shıppıng Contaıners in in Loading Area

19 Filter Fallure During Chemical Decontamınation

20 Tornado

21 Earthquake

22 dons of Filtration Durıng Vacuumıng

not significant

(b) gle Stage of Filtration

(c) nu = not used
Released to Buildıng

Ventılatıon System, $\mathrm{CI}$

\begin{tabular}{|c|c|c|c|c|c|}
\hline & \\
\hline MPB & HLLW & WSP & MPB & HLLW & WSP \\
\hline$n s^{(a)}$ & ns & ns & ns & ns & ns \\
\hline ns & ns & ns & ns & ns & ns \\
\hline ns & ns & ns & ns & ns & ns \\
\hline ns & ns & ns & ns & ns & ns \\
\hline ns & ns & ns & ns & ns & ns \\
\hline ns & ns & ns & & & \\
\hline 60 & ns & ns & $15 \mathrm{E} 6$ & ns & ns \\
\hline 60 & 60 & 12 & $15 \mathrm{E} 6$ & 15 E-6 & $30 \mathrm{E} 7$ \\
\hline
\end{tabular}

ns

ns

ns

ns

ns

ns

ns ns ns

013

13

ns

ns

$55 \mathrm{E}-3 \quad \mathrm{nu}$

ns

ns

38

$\mathrm{nu}(\mathrm{c})$

ns

ns

u

ns

66

ns

38

$18 \mathrm{E}-6$

22 E-5

$22 \mathrm{E}-5$

$45 \mathrm{E}-13$

$11 \mathrm{E}-8$

$56 \mathrm{E}-12$

$\begin{array}{llllll}55 \text { E-3 } & \text { nu } & \text { nu } & 14 \text { E-9 } & \text { nu } & \text { nu } \\ \text { ns } & \text { ns } & \text { ns } & \text { ns } & \text { ns } & \text { ns } \\ \text { ns } & \text { ns } & \text { ns } & \text { ns } & \text { ns } & \text { ns } \\ \text { ns } & \text { ns } & \text { ns } & \text { ns } & \text { ns } & \text { ns }\end{array}$

036

036

036

$18 \mathrm{E}-4$

$18 \mathrm{E}-4$

$18 \mathrm{E}-4$

25

nu

nu

$60 \mathrm{E}-7$

nu

nu

$44 \mathrm{E}-4$

$11 \mathrm{E}-10$

079

$60 \mathrm{E}-2 \quad 001$

ns

$28 \mathrm{E}-2$

ns

ns

33

ns

300
$40 \mathrm{E}-4^{(\mathrm{b})} \quad 60 \mathrm{E}-2 \quad 50 \mathrm{E}-6$

ns $\quad 33$ ns

$31 \mathrm{E}-7$ nu ns $028 \quad n s$ 
jackhammering where the operation is performed by a portable compressed air system can the oepration persist with the loss of electrical service. This occurrence is covered elsewhere.

- Compressed Air/Gases

Loss of compressed air would result in the temporary loss of sparging capability in process and liquid waste storage vessels. Settling of sludge in the waste tanks could increase and some hydrogen gas from the radiolytic decomposition of water could accumulate. Hydrogen gas is lighter and more mobile than air and would tend to rise and be carried off by the ventilation system. For the concentrations of radionuclides in the tanks during decommissioning, some remedial action is expected to be implemented before such concentrations can be reached. Thus, loss of compressed air should not result in any increased airborne release of contamination.

- Ventilation

A temporary loss of forced ventilation could result in an increase in airborne release of contamination. Air would initially be drawn into the facility to tend to equilibrate the normal pressure differentials. Howeve natural draft from the stack would maintain a small flow of air in the proper direction. Eventually, however, some airborne contamination may diffuse backward into nonregulated areas and reach the outside atmosphere. This diffusion, if it occurs, is a slow process. Thus releases should be minor Furthermore, the redundancy built into the FRP ventilation system makes even a temporary loss of ventilation highly improbable.

- Fire Protection

Loss of the fire protection system would result in no airborne consequences without the simultaneous occurrence of a fire. The combination of occurrences is highly unlikely. Even so, portable, nonpowered fire protection systems are available for use in the event of loss of normal fire protection systems.

- Radiation Monitoring

As with the fire protection system, the simultaneous airborne release of radioactivity would be required before any increased consequences woulc arise from the temporary loss of radiation protection. 
Solutions of various chemicals are only found in the process building during chemical decontamination and in the liquid waste storage tanks. If an alkaline chemical and an acidic chemical are mixed, heat is rapidly generated and the liquid can boil violently with aerosol entrainment in the vapor. The decontaminating solutions can contain relatively high inventories of radionuclides (as much as $32.4 \mathrm{Ci} / 1 \mathrm{iter}$ for the first nitric acid rinse of the HAW Concentrator concentrated by a factor of 20). The quantity of aerosols carried in the ventilation flow is controlled by the capacity of the flowing air to carry particles. Assuming a ventilation flow of $308 \mathrm{~m}^{3} / \mathrm{min}$ in the RPC (equivalent to $7.5 \mathrm{air}$ changes $/ \mathrm{hr}$ ), the maximum amount of material airborne would be $3.1 \mathrm{~g}$ of solution containing $100 \mathrm{mC} i$ of radioactivity.

Assuming the condition could persist for 60 min before corrective action is tanken and a sufficient quantity of reactants is available, as much as $6 \mathrm{Ci}$ in $190 \mathrm{~g}$ of liquid could be released to the cell ventilation and exhaust system as a result of such an occurrence. This results in a release of $1.5 \times 10^{-6} \mathrm{Ci}$ to the atmosphere.

3. Inadvertent Transfer of Liquids to an Open Pipe Leaks Liquid During

Transport and Use

Contaminated liquids generated during the chemical decontamination procedure are transported in existing pipes designed to transport radioactive process solutions in the FRP. Such pipes do not pass through nonradiation zones. Thus, if a release does occur, the liquid is released into an unoccupied process area and aerosols generated are processed through the ventilation and exhaust system. Releases exceeding $3.1 \mathrm{~g}$ of liquid containing $100 \mathrm{mC} i$ of radioactivity (from an accident during the first flush of RPC equipment) in a flow of $308 \mathrm{~m}^{3} \mathrm{air} / \mathrm{min}$ are not anticipated. The liquid in excess of the amount airborne would be a decontamination/housekeeping problem. It is assumed that the maximum period such a condition could exist undetected is $60 \mathrm{~min}$. Thus, as much as $6.0 \mathrm{Ci}$ of radioactivity in $190 \mathrm{~g}$ of liquid could be released to the cell ventilation nd exhaust system from such an occurrence. This results in a release of $1.5 \times 10^{-6}$ to the atmosphere. 
Most of the piping carrying high level liquid waste is embedded in soil or encased in trenches, and leaking liquids do not find a ready interface with the atmosphere. One of the few areas where liquids can be released is in the diverter cell. Although concentrations may be high, exhaust ventilation flows are very low, and anticipated releases of radionuclides should not exceed those listed for the FRP.

Highly radioactive liquids are available in the WSP process only as far as the calciner. The exhaust flow in the WVC is approximately $1 / 5$ th the $308 \mathrm{~m}^{3} /$ min 1 isted above. Liquids have approximately the same radioactivity concentrations as above, and therefore, the anticipated release could be as high as $1.2 \mathrm{Ci}$ to the building ventilation system for the scenario 7 isted above and $3.0 \times 10^{-7} \mathrm{Ci}$ to the atmosphere.

4. Break in Compressed Air Line for Pneumatic Jackhammer

Jetting of compressed gases upon powders adhering to surfaces can be an effective method of entraining particles. (7) Such an occurrence could increase the quantity of material airborne in a 7 imited area for a short period of time. Since jackhammering is a manual technique, such a malfunc tion would be immediately evident, the operation would be stopped, and remedial measures promptly implemented. The areas where this technique can be used are limited by the modest radiation levels in which the operator can work. Thus, the accidental airborne release is assumed to be small compared to those estimated for the previous accidents.

5. Dropping of Contaminated Concrete Rubble

Contaminated concrete rubble scarfed from the surface is caught in baskets or nets in the FRP and WSP. If such a container were inadvertently dropped or spilled, the accumulated material could fall to the floor and leave some fine particles adhering to the rubble suspended in the air flow. The quantity of such material should be quite small. The basket/net is not intended to retain fine particles (less the $4.0 \mu \mathrm{m}$ aerodynamic equivalent diameter) and most of the suspendible particles should be entrained in the air during routine operations. Thus, it is anticipated that there would not be a significant increase in airborne contamination as a result of this accident. 
- During Layaway and Protective Storage

Limited quantities of concrete rubble with low to moderate levels of contamination can be generated by drilling/rock splitting and jackhammering. The rubble is manually loaded into 208-1iter (55-gal) drums using a water mist to minimize the generation of dust if required. The drums are sealed before they are transferred from the area, and therefore, any spillage of rubble should be limited to the small quantities handled during manual loading. Since the level of contamination present on most rubble is low, spilling of contaminated concrete rubble should not result in significant airborne release of contamination to the building ventilation system.

\section{Loss of Local Airborne Contamination Control}

- During Plasma Torch Cutting

An LAC mechanism that removes $90 \%$ of the particulate material generated is assumed to be operative during cutting using a plasma torch. Loss of the local air control mechanism could result in the release of essentially all of the material generated to the cell ventilation, increasing the values listed in Table F.2-1 by an order of magnitude.

- In Remote Process Ce11

The value listed for the radionuclides released in the airborne effluents includes several distinct activities - cutting of piping to clear the cell, segmentation of pipe and equipment to fit into shipping packages, etc. Use of the plasma torch is not continuous. The largest quantities of radionuclides are released during the segmentation of piping and it is assumed that all the radioactivity vaporized $(0.132 \mathrm{Ci})$ is released to the building ventilation system and $3.3 \times 10^{-8} \mathrm{Ci}$ passes through two HEPA filters in series and is released to the atmosphere.

- In High-Level Liquid Waste Storage Area

Although segmentation of the internal piping is a lengthy operation requiring an estimated 4500 cuts, it is also a remote operation and system failures may be less readily detected. Taking no credit for natural depletion mechanisms (coagulation, settling, plate-out, etc.), 
as much as $3.8 \mathrm{Ci}$ of radioactivity can be released to the "greenhouse" filtering system from all cuts and $1.9 \times 10^{-3} \mathrm{Ci}$ could be released to the atmosphere via the single stage of HEPA filters.

- In Waste Vitrification Cell

The radionuclide release during plasma torch cutting in the WSP is controlled by the release of highly contaminated, degraded, ceramic insulator exposed during the segmentation of the Calciner and In-Can Melter furnaces. It is assumed as much as $5 \%$ of the $1000 \mathrm{Ci}$ present in a single item of equipment could be released during a single cut. Thus, it is estimated that $50 \mathrm{Ci}$ of radionuclides are released to the building ventilation system and $1.3 \times 10^{-5} \mathrm{Ci}$ released to the atmosphere after filtration.

- During Drilling-Blasting in Main Process Building

The routine airborne release for drilling was estimated partially on the basis of the measured carrying capacity of a ventilation system under similar circumstances ${ }^{(5)}$ and partially on an assumed effectiveness for the local airborne control mechanisms (i.e., blasting mats, water sprays). Thus, it is anticipated that loss of the local airborne control mechanism would only result in a tenfold increase in the airborne release to the cell ventilation system. The routine release was estimated to be $1.32 \mathrm{Ci}$ for drilling holes in all the contaminated walls in the RPC. If the loss of airborne contamination control is assumed to result in the release of 10 times the mass of particles which could be entrained in the air flow, the airborne release to the cell ventilation could be as high as $13 \mathrm{Ci}$. This results in a release of $3.3 \times 10^{-6} \mathrm{Ci}$ to the atmosphere.

- Drilling/Rock Splitting

Although a local airborne contamination control technique (water mist) is specified for this procedure, no credit is taken for its efficiency in the calculation of radionuclides released in the gaseous effluents. Thus, it is estimated that malfunction of this system would not result in an additional release of radionuclides during decommissioning of any facility 
During Scarfing of Contaminated Concrete Surfaces by Pneumatic Jackhammer

This is a manual technique and loss of airborne control would be readily ipparent. Thus, no increase in airborne emission should result from this failure event.

7. Loss of Blasting Mat During Blasting

If the blasting mat were lost during the scarfing of contaminated concrete surfaces, equipment in the process cell could be damaged by missiles not stopped by the mats. The principal equipment items remaining in the cell are the spray nozzles used to aid in controlling airborne material. In this study the cells are assumed to be isolated by ventilation (much reduced cell ventilation flow), or a secondary system is used that is designed to withstand the force generated by the explosion with subsequent exhausting into the normal ventilation system. Thus, even if higher airhornerconcentrations of airborne particles are generated initially, the rborne release to the normal cell ventilation should not increase signifi cantly as a result of the loss of the blasting mats. As in the case of the loss of the water spray discussed before, the release should be less than $250 \mathrm{~g}$ of concrete dust containing $5.5 \mathrm{mCi}$ of radioactivity for the single explosion where the mat was lost. The resultant release to the atmosphere is $1.4 \times 10^{-9} \mathrm{Ci}$.

8. Dropping of Decontaminated Equipment During Removal

Contaminated equipment within process cells or vessels is internally and externally chemically decontaminated prior to removal. Such treatment should have removed most of the readily removable surface contamination, leaving the residual radioactivity tightly incorporated in the metal surfaces. Thus, dropping of the equipment would not result in the airborne release of measurable quantities of radionuclides to the ventilation system.

9. Incomplete Cleanup of Exterior of Rubble Containers

The exterior of containers used to remove contaminated concrete rubble $\mathrm{jm}$ the process cells are to be hosed down to remove loose contaminated terial. If this cleanup is inadvertently omitted, containers carrying 
external particulate contamination can be moved through areas occupied by people and shed some or all the contamination in transport. It is planned that all concrete rubble generated be kept continually damp to reduce potential dusting. Thus, it is anticipated that any contamination shed in transport is in the form of damp clumps and should constitute a housekeeping concern and not a significant airborne release hazard.

10. Segmentation by Plasma Torch of Equipment Not Chemically Decontaminated

If the internal chemical decontamination of equipment and piping were inadvertently omitted, the omission could be undetected by radiation readings in the cell depending upon the background readings. Plasma torch cutting of highly contaminated objects is a remote operation and a major set of cuts such as segmentation of pipes, etc., could be completed before the cause of high stack emissions is traced back to its source. Thus, the estimated releases are based upon the potential residual inventory involved in a complete segment of the activity.

\section{- Remote Process Cell}

Assuming all the piping has not been chemically decontaminated before being cut and segmented, the residual radionuclides on $0.4 \mathrm{~m}^{2}$ would be released by the plasma torch cutting (see "Removal of Metal by Cutting with a Plasma Torch. Reference Unit - RPC"). The nominal surface level of radionuclides for equipment and piping (using the assumption given for RPC equipment in previous discussions) is $165 \mathrm{Ci} / \mathrm{m}^{2}$. Therefore, $6.62 \mathrm{Ci}$ could be released to the building ventilation system by this scenario (assuming LAC is functioning) and $1.7 \times 10^{-6} \mathrm{Ci}$ could be released to the atmosphere.

- High-Level Liquid Waste Storage

The DF (decontamination factor) from chemical flushing of HLLW internals is 100 . The radionuclide release associated with segmentation of the internal piping by plasma torch after chemical decontamination was previously estimated at $0.38 \mathrm{Ci}$. Thus, it is estimated that $38 \mathrm{Ci}$ are released to the building ventilation system from the segmentation of undecontaminated piping and $0.019 \mathrm{Ci}$ are released to the atmosphere (after a single stage of HEPA filtration). 
Waste Vitrification Cell

The maximum estimated routine release is based upon the release of highly contaminated, degraded, ceramic insulator that was not affected by chemical decontamination techniques. Omitting chemical decontamination may increase the radionuclide release in an additional $1 \%$ to $2 \%$ for the entire operation and, due to the uncertainties in the factors and assumptions used, is not considered significant.

11. Fire Inve ing Contaminated Clothing or Combustible Waste

Absorbent materials such as rags or paper wipes are used for a variety of purposes and are discarded after use. Some material that has come into contact with contaminated surfaces can hold small quantities of radionuclides. Likewise, protective clothing (coveralls, caps, hoods, shoe covers, etc.) can become contaminated by use. The contamination levels of both types of material are limited by the radiation exposure permissible to personnel. Other protective devices, such as fresh air suits, can be used in zones with latively high alpha contamination and thus, be contaminated to high levels. ithough many kinds of plastics do not burn readily or are self-extinguishing, plastics are generally considered combustible.

- Main Process Building

Entry into processing cells with high alpha radiation inventories (primarily the PPC) does not occur until after chemical decontamination. Most of the smearable contamination should have been removed by this time. If it is assumed that there is approximately $1 \mathrm{~m}^{2}$ of surface on a fresh air suit and the surface is contaminated to the level of the equipment handled $\left(2.6 \times 10^{7} \mathrm{dpm} / 100 \mathrm{~cm}^{2}\right)$, each suit could be contaminated with $2.6 \times 10^{9} \mathrm{dpm}$. It is postulated that five contaminated fresh air suits mixed with other combustible waste containing and equal amount of radioactivity will ignite and burn in a metal container. The total weight of the combusitles is $20 \mathrm{~kg}(50 \mathrm{lb})(10 \mathrm{~kg}$ plastic and $10 \mathrm{~kg}$ paper). The material burns erratically because of the limited access of oxygen within the container, and therefore, only half its combustion heat content can be eased. Thus, approximately $7.5 \times 10^{4} \mathrm{kcal}$ are released. Such a quantity heat is sufficient to raise the temperature of $2800 \mathrm{~m}^{3}$ of cell air $77^{\circ} \mathrm{C}$. 
This waste contains $2.6 \times 10^{10} \mathrm{dpm}$ of radioactivity. The maximum fractional airborne release measured during the burning of contaminated waste under similar conditions (but without a metal container) was $1.5 \times 10^{-5}$ (8) Thus, it is estimated that as much as $4 \times 10^{6} \mathrm{dpm}$ $\left(1.8 \times 10^{-6} \mathrm{C} i\right)$ could be released to the ventilation system. The release to the atmosphere after filtration is $4.5 \times 10^{-13} \mathrm{Ci}$.

- Liquid Waste Storage Area/Waste Solidification Plant

Contaminated materials from decommissioning activities in the liquid waste storage area/WSP contain only a small fraction of alpha emitters and thus, the amount of contamination is limited by the external dose rate. For the purposes of this calcualtion, it was assumed as much as $150 \mathrm{mCi}$ of radinnuclides could be involved in the combustible waste. Using the scenario described above, $2.2 \times 10^{-5} \mathrm{Ci}$ would be released to the building ventilation system and $1.1 \times 10^{-8} \mathrm{Ci}$ from the HLLW "greenhouse" and $5.6 \times 10^{-12} \mathrm{Ci}$ from the WSP to the atmosphere.

\section{Detonation of Unused Explosives in $\mathrm{Cell}$}

On occasions, individual charges of explosives used to scarf contaminated surfaces may not be detonated upon command. Usually such an occurrence can be detected by a qualified explosives engineer by visual inspection of the surface being scarfed. If an.errant charge were detonated during the inspection when the water spray is turned off and the blasting mat not in place, a temporary high dust loading in the cell could result. A mixture of large and sma11 concrete particles would temporarily pass through a portion of the cell air volume. If the nominal air velocity in the cell is less than $0.043 \mathrm{~m} / \mathrm{sec}$ $(0.15 \mathrm{ft} / \mathrm{hr})$, particles larger than $40 \mu \mathrm{m}$ aerodynamic equivalent diameter will begin to settle out. A quasi-stable airborne concentration of $100 \mathrm{mg} / \mathrm{m}^{3}$ has been estimated for a fine plutonium dioxide powder. (9) Assuming conservatively that the entire volume of the RPC (approximatley $2460 \mathrm{~m}^{3}$ ) could be filled with such a mass loading, as much as $250 \mathrm{~g}$ of concrete dust containing $5.5 \mathrm{mC} i$ of radioactivity would be released as a result of this accident. The release to the atmosphere is $1.4 \times 10^{-9} \mathrm{Ci}$. 
13. Flood During Dismantling

The site is above the 1000-yr flood level. Thus, no release is expected from floods.

14. High Winds During Dismantlement

The MPB, WSP, and WTEG buildings are designed to withstand the Design Basis. Tornado and Earthquake (DBT and DBE) and should withstand the maximum , $e^{2}$ ?d anticipated. All significant quantities of radioactivity are to be Poved from both buildings before any substantial degradation of structural integrity occurs. Therefore, no significant release is anticipated from the buildings due to high winds.

There is a period during the dismantling of the waste tanks where a possible pathway to the atmosphere can be envisioned - after penetration of the waste tank for decontamination and removal of internals. After chemical flushes with nitric acid the inventory of radionuclides in a liquid waste pk is estimated to be $5.5 \times 10^{4} \mathrm{Ci}$. A concrete stabilized passage to the ank vault is constructed for dismantlement. This passage is enclosed by a greenhouse designed to withstand the maximum 100-yr wind. Procedures will call for cessation of operations during high winds. These procedures include sealing (e.g., using caps on the Shielded Work Platform) of any penertrations into the waste tanks. Thus, no significant airborne release of radioactivity is anticipated from this source due to high winds.

15. Fire During Cutting with a Plasma Torch Outside Process Cells (Layaway and Protective Storage)

Some cutting is performed during layaway operations outside the process cells in a relatively uncontaminated area. Cutting is an infrequent occurrence and merits special consideration and preparation. It involves a manual or semiremote procedure during this mode and wi1l, therefore, always have personnel in attendance. As a general rule, the combustible loading in the surrounding area is reduced to essentials (rags, paper, protection) during this activity. The heat from a plasma torch is confined to a narrow area. probability of a major fire during this operation is very remote and the 
materials that could burn would be contaminated to very low levels. Thus, it is anticipated that such an occurrence would not result in significant airborne releases.

16. Fire in Exhaust Ducts During Welding

Sections of the exhaust ducts are isolated near the end of decommissioning operations by welding prepared metal blanks in selected locations. The ducts are chemically decontaminated prior to these operations. Trace quantities of organic vapors in the exhaust may condense upon metal surfaces, and a significant layer could accumulate over the lifetime of the facility. Once a sticky layer begins to accumulate, lint and other combustible particles that can enter the ducts can be readily incorporated in the layer.

Heat sensors (part of the fire protection system) in the area that would be activated by the heat from the welding may be temporarily bypassed during this activity. Since the activity occurs in a potentially contaminated zone, the welder is encumbered with protective devices (clothing, respirator, etc.) that can reduce his sensitivity to his environment. It is conceivable that welding operations could be initiated in an area that contains a quantity of combusible materials capable of supporting a small fire.

It is postulated that combustible materials in the duct are inadvertently ignited by the heat from welding. Since welding in a contact operation, the operations are 7 imited to areas of moderate or low radiation exposure. A value of $100 \mathrm{mR} / \mathrm{hr}$ (approximate surface contamination of $15 \mathrm{mCi} / \mathrm{m}^{2}$ ) was arbitrarily chosen. It is further postulated that $30 \mathrm{~m}$ (100 linear $\mathrm{ft}$ ) of $1.2 \mathrm{~m} \times 1.2 \mathrm{~m}(4 \mathrm{ft} \times 4 \mathrm{ft})$ duct $\left(5.95 \mathrm{~m}^{<}\right.$, of surface) are burned before the fire is brought under control. The inventory of radionuclides in jeopardy is $89.3 \mathrm{mCi}\left(15 \mathrm{mCi} / \mathrm{m}^{2} \times 5.95 \mathrm{~m}^{2}\right)$. As much as $40 \%$ of the inventory of $\mathrm{UO}_{2}$ powder involved in combustible material was entrained with a velocity exceeding $100 \mathrm{~cm} / \mathrm{sec}$ (39.4 fps) drawn through burning material. (10) Thus, it is postulated that as much as $360 \mathrm{mCi}$ of radioactive materials could challenge the final HEPA filter bank as a consequence of this occurrence and $1.8 \times 10^{-4} \mathrm{Ci}$ are released to the a tmosphere. 
17. "Red 0i1" or Other Organic Nitrate Explosion in HAW Concentrator

"Red oil" is a term applied to nitrated organic materials formed with the degradation of process organic liquids. All organic process liquids are planned to be removed from the system prior to use of proposed procedures, but organic materials may be used as decontaminating agents. If some degraded process solvents or organic decontaminating agents are inadvertently left in the HAW and concentrated with a nitric acid flush, a potential exists for the formation of "red $0 i 1 "$ or other organic-nitrate reactions and their detonation.

The most contaminated liquid processed by the HAW Concentrator is the initial acid spray from the chemical decontamination of the RPC $-6.6 \mathrm{Ci} / 1$ iter. A nominal concentration of $10 \mathrm{Ci} / 1 \mathrm{iter}$ is used here for conservatism. The concentrator is assumed to reduce the volume of liquid waste, thus increasing the concentration. If the volume of liquid is concentrated by a factor of 5 prior to the explosion, the liquid would have a radioactivity concentration of $50 \mathrm{ci} / \mathrm{liter}$.

The blast effects of such an explosion with a large amount of material in a commercial FRP was estimated to be equivalent to $1.3 \mathrm{~kg}$ of TNT with a shock wave

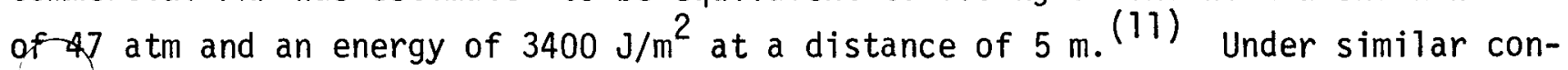
ions as postulated for the reference FRP, filtration capabilities of the ventilation system were estimated to be unimproved. ${ }^{(11)}$ The concentrator is assumed to rupture and all the liquid in the vessel is assumed to be made airborne in the RPC. If an aerosol mass concentration equivalent to light rain is assumed $\left(100 \mathrm{mg} / \mathrm{m}^{3}\right),{ }^{(4)}$ the release to the ventilation system would be $250 \mathrm{ml}$, or $2.5 \mathrm{Ci}$. After passing through the ventilation filters, $6 \times 10^{-7} \mathrm{Ci}$ are released to the atmosphere.

18. Fire Involving Plywood Shipping Container in Loading Area

Only non-TRU, non-high level wastes will be packaged in plywood containers (see Section 7.6). The consequence of fires in all three facility areas has been described in Accident Scenario No. 11 ("Fire Involving Contaminated Clothing or Combustibles"). The basis for the Main Process Building scenario was the waste material generated in the PPC which has high TRU concentrations. It is assumed that 20 boxes of combustible waste containing $150 \mathrm{mCi}$ of non-TRU radionuclides are packed in plywood containers which on fire. Under the assumptions used in Accident Scenario No. 11, 
$4.4 \times 10^{-4} \mathrm{Ci}$ are released to the building ventilation system and $1.1 \times$ $10^{-10} \mathrm{Ci}$ are released to the atmosphere.

19. Filter Failure During Chemical Decontamination of Process Cells

Estimates of the quantity of radionuclides released to the exhaust filters during the chemical decontamination of a11 cells/tanks within the three areas (Main Process Building, liquid waste storage, and WSP) are given in Section F.2.1.1 "Chemical Decontamination by High Pressure, Moving Spray." The values are:

MPB $-7.9 \mathrm{Ci}$
HLLW $-0.6 \mathrm{Ci}$
WSP $-0.1 \mathrm{Ci}$

A11 exhaust filters are replaced and tested at the end of the production operation. The primary source of deposited radionuclides at this point in the decommissioning activities is chemical decontamination. It is assumed that all the released material is collected on the first stage HEPA filter and $10 \%$ of the accumulated inventory is released by the assumed failure of the filter.

A second stage of filtration allows the release of $4.4 \times 10^{-4} \mathrm{Ci}$ and $5.0 \times 10^{-6} \mathrm{Ci}$ to the atmosphere from the Main Process Building and the WSP respectively. Only a single stage of filtration was assumed for the highlevel waste storage area and the released inventory of $0.06 \mathrm{Ci}$ goes directly to the atmosphere.

20. Tornado During Dismantling of HLLW Storage Tank

Large penetrations $3 \mathrm{~m} \times 3 \mathrm{~m}(10 \mathrm{ft} \times 10 \mathrm{ft})$ are not made until dilution flushing of residual liquid, decontamination of the internals and removal of all lquids from the waste tanks are complete.

It is assumed that a tornado would destroy the integrity of the greenhouse, thereby exposing the $3 \mathrm{~m} \times 3 \mathrm{~m}$ (10 ft $\times 10 \mathrm{ft}$ ) penetration to the atmosphere. Any contamination airborne at this time could be released. The gross volume of a waste tank is $1300 \mathrm{~m}^{3}$. If the aerosol concentration is taken to be $10 \mathrm{mg} / \mathrm{m}^{3}$, the total mass airborne would be $13 \mathrm{~g}$ of waste. At 
nominal concentration of the last liquid solution in the tank $(2.1 \mathrm{Ci} /$ Titer or $2.1 \mathrm{mCi} / \mathrm{ml}$ ) and a specific gravity of 1 for the liquid, the radioactivity airborne and released to the atmosphere would be $28 \mathrm{mCi}$.

It is assumed that the vacuum generated by the passage of the tornado over the access hole is not sufficient to effect structural damage to the subgrade metal equipment.

\section{Earthquakes}

As in the case of high winds or tornados, the primary process buildings are designed to withstand a DBE, and no significant degradation of structural integrity is anticipated until all major quantities of radioactivity are removed. No significant release of radioactivity is anticipated from this source.

A potential for radioactivity release may exist after the large penetrations are made in the waste tanks. The "greenhouse" enclosure is assumed to fail from the earthquake. Again, as much as $28 \mathrm{mC} i$ airborne in the vessel

at che time the DBE occurs could be released the the environment. The reainder $(3300 \mathrm{C})$ of the contamination is tightly bound to the metal surfaces, but some could be shaken from the metal due to the violence of the quake. The quantity is unknown but is believed smal1. It is therefore assumed that a fraction of $10^{-3}$ of this radioactivity becomes airborne, or, $3.3 \mathrm{Ci}$. The remainder is assumed to fall to the floor of the waste tank or is buried by the collapse of the structures. Thus, a total of $3.3 \mathrm{Ci}$ could be released from this source as the result of an earthquake.

22. Loss of Filtration During Vacuuming

A vacuum cleaner is used in two areas where significant inventories of residual radionuclides exist: the Sample and Analytical Cells (SAC) in the Main Process Building and the Hot Maintenance Cell (HMC) in the WSP. The quantity of radionuclides assumed to be suspended by applying this technique in a single area (one SAC or the entire HMC) is $1.25 \mathrm{Ci}$ in the SAC and $300 \mathrm{Ci}$ in the HMC (see Section F.2.1.1 "Airborne Effluents, Part D. Janitorial Techniques"). Loss of filtration could release all the suspended material the building ventilation system resulting in $3.1 \times 10^{-7} \mathrm{Ci}$ and $7.5 \times$ ${ }^{-5} \mathrm{Ci}$, respectively, being released to the atmosphere. 


\section{F.2.2 Occupational Radiation Exposure}

Table F.2-3 provides the detailed information for the dismantlement occupational dose estimates presented in Section 8.3.1.1.

\section{F.2.3 Hazardous Chemical Releases During Decommissioning Operations}

Review of the reference fuel reprocessing plant and potential decommissioning-decontamination procedures reveals three potential sources of hazardous chemicals: (1) residuals from plant operation, (2) chemicals employed during decontamination, and (3) stable fission products resulting from decay of residual isotopes. While no material from any of these three sources is likely to pose a significant hazard, some could be of concern if allowed to concentrate. A brief discussion of each major chemical is provided below:

\section{F.2.3.1 Chemical Residuals from Plant Operations}

Chemicals are employed in many of the unit operations performed at a fuel reprocessing plant. Residues from these operations may require attention during decontamination. Most, however, will be at quantity or concentration levels lower than accepted standards and undergo natural transformations which mitigate the hazard. Operations of interest include: dissolution, solvent extraction, organic solvent treatment, secondary recovery extraction, and gaseous waste treatment.

Nitric acid is employed for dissolution purposes. Residuals of this corrosive liquid should be of little concern since they will neutralize by natural processes included contact with soils. Resultant nitrate salts are natural nutrients and will be of concern only if allowed to accumulate in soils to levels where they can leach into ground and surface waters such that concentrations exceed the drinking water 1 imit of $10 \mathrm{mg} / \ell$. This is a highly unlikely condition.

Nitric acid solutions in the FRP sometimes contain gadolinium nitrate. Concentrations are typically too low to be of importance. Gadolinium, however, is relatively toxic. It has been suggested that drinking water should not exceed $0.2 \mathrm{mg} / \mathrm{l}$ and water for the propagation of aquatic life should not exceed $0.015 \mathrm{mg} / \ell$. Gadolinium can be concentrated by a factor of 10,000 
TABLE F.2-3 Estimated Occupational Radiation Doses for Immediate Dismantlement

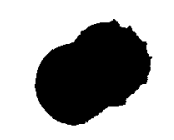

\begin{tabular}{|c|c|c|c|c|c|c|c|c|c|c|c|c|c|c|c|}
\hline \multirow{2}{*}{$\begin{array}{l}\text { Event } \\
\text { Main } \\
\text { Processing } \\
\text { Plant }\end{array}$} & & upervisors & & Decommiss: & ioning Jech & mincians & Satery & Techmociar & & Equipm & Ient Operate & & Cratismen & 8 Miscofle & aneous \\
\hline & $\begin{array}{l}\text { Quverage } \\
\text { Exposure } \\
\text { Rote ure tirre }\end{array}$ & $\begin{array}{l}\text { Total } \\
\text { Exposure } \\
\text { Hours } \\
\end{array}$ & $\begin{array}{l}\text { Dose } \\
\text { Man } \\
\text { Rem } \\
\end{array}$ & $\begin{array}{l}\text { Average } \\
\text { Exposure } \\
\text { Rate imf) }\end{array}$ & $\begin{array}{l}\text { Total } \\
\text { Exposure } \\
\text { Hours } \\
\end{array}$ & $\begin{array}{l}\text { Dose } \\
\text { Man } \\
\text { Rem } \\
\end{array}$ & $\begin{array}{l}\text { Average } \\
\text { Expossure } \\
\text { Rate Imri }\end{array}$ & $\begin{array}{l}\text { Total } \\
\text { Exposure } \\
\text { Mours } \\
\end{array}$ & $\begin{array}{l}\text { Dose } \\
\text { Mon } \\
\text { Aem } \\
\end{array}$ & $\begin{array}{l}\text { Average } \\
\text { Exxosure } \\
\text { Rate Imfr: }\end{array}$ & $\begin{array}{l}\text { Total } \\
\text { Exposure } \\
\text { Hours } \\
\end{array}$ & $\begin{array}{l}\text { Dose } \\
\text { Man } \\
\text { Aem } \\
\end{array}$ & $\begin{array}{l}\text { Average } \\
\text { Exposure } \\
\text { Aate (m) }\end{array}$ & $\begin{array}{l}\text { Toal } \\
\text { Exposure } \\
\text { thours } \\
\end{array}$ & $\begin{array}{l}\text { Dose } \\
\text { Man } \\
\text { Aem } \\
\end{array}$ \\
\hline Imeteres Deccar & : & 384 & 038 & 1 & $\operatorname{sac}$ & 864 & & $38 \mathrm{~A}$ & 038 & & & & 1 & 1040 & 1.4 \\
\hline 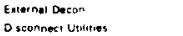 & : & $\begin{array}{r}128 \\
16\end{array}$ & $\begin{array}{l}013 \\
002\end{array}$ & i & 1910 & 191 & i & 128 & 013 & & & & 1 & 480 & $0 \% 8$ \\
\hline 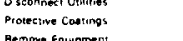 & ! & $\begin{array}{l}16 \\
16\end{array}$ & $\begin{array}{l}002 \\
002\end{array}$ & : & $\begin{array}{l}1700 \\
180\end{array}$ & $\begin{array}{ll}012 \\
018\end{array}$ & $\vdots$ & $\begin{array}{l}16 \\
16\end{array}$ & $\begin{array}{l}\begin{array}{l}002 \\
002\end{array} \\
002\end{array}$ & & & & 1 & 240 & 024 \\
\hline 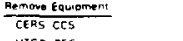 & . & 16 & 002 & 1 & 180. & 018 & . & 16 & & & & & & 120 & 003 \\
\hline $\begin{array}{l}\text { HTGA PEG } \\
\text { TPIC LPIG FPIG }\end{array}$ & i & 24 & 002 & i & 36 & 036 & ' & 24 & 002 & ; & $\infty$ & 009 & i & $\begin{array}{l}120 \\
360\end{array}$ & $\begin{array}{l}012 \\
036\end{array}$ \\
\hline TPIC LA & 1 & $\begin{array}{l}32 \\
32 \\
32\end{array}$ & & ì & $\begin{array}{l}54 \mathrm{c} \\
240\end{array}$ & 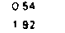 & 10 & $\begin{array}{ll}32 \\
32\end{array}$ & $\begin{array}{l}0.03 \\
0.32\end{array}$ & $\therefore$ & $\begin{array}{l}90 \\
60\end{array}$ & $\begin{array}{l}009 \\
012\end{array}$ & : & $\begin{array}{l}240 \\
120\end{array}$ & $\begin{array}{l}024 \\
096\end{array}$ \\
\hline $\begin{array}{l}\text { ILC } \\
\text { HLC }\end{array}$ & $\therefore$ & 32 & $\begin{array}{l}026 \\
026\end{array}$ & 8 & 240 & $\begin{array}{r}196 \\
192\end{array}$ & 10 & $\begin{array}{l}32 \\
32\end{array}$ & $\begin{array}{l}8.32 \\
0.32\end{array}$ & $\frac{2}{2}$ & $\begin{array}{l}60 \\
60\end{array}$ & $\begin{array}{l}012 \\
012\end{array}$ & 8 & $\begin{array}{l}120 \\
240\end{array}$ & $\begin{array}{l}096 \\
048\end{array}$ \\
\hline $\begin{array}{l}\text { HeC } \\
\text { Mitc }\end{array}$ & & $\begin{array}{c}64 \\
128\end{array}$ & $\begin{array}{l}320 \\
102\end{array}$ & $\begin{array}{c}50 \\
8\end{array}$ & & $\begin{array}{l}180 \\
576\end{array}$ & w & 64 & 448 & 5 & 240 & 120 & 5 & 240 & 120 \\
\hline 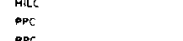 & 10 & $\begin{array}{l}128 \\
48\end{array}$ & $\begin{array}{l}102 \\
048\end{array}$ & $\begin{array}{c}8 \\
10\end{array}$ & $\begin{array}{l}720 \\
360\end{array}$ & $\begin{array}{l}576 \\
366\end{array}$ & $\begin{array}{l}10 \\
10\end{array}$ & $\begin{array}{r}128 \\
48\end{array}$ & $\begin{array}{l}128 \\
0.8 \\
0.8\end{array}$ & $\begin{array}{c}10 \\
3\end{array}$ & ${ }_{90}^{480}$ & 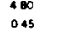 & $\begin{array}{c}10 \\
5\end{array}$ & $\begin{array}{l}480 \\
360\end{array}$ & $\begin{array}{l}400 \\
100 \\
100\end{array}$ \\
\hline $\begin{array}{l}\text { APC } \\
\text { PMSC }\end{array}$ & $\begin{array}{c}75 \\
5\end{array}$ & $\stackrel{48}{24}$ & $\begin{array}{l}360 \\
012\end{array}$ & 3 & $\begin{array}{l}180 \\
9\end{array}$ & $\begin{array}{l}135 \\
0.45\end{array}$ & ${ }_{3}^{100}$ & ${ }_{24}^{88}$ & $\begin{array}{l}880 \\
013\end{array}$ & 10 & 360 & 300 & & & 360 \\
\hline CEMG & $\therefore$ & is & 002 & ? & $\begin{array}{c}x c \\
12 c\end{array}$ & $\begin{array}{l}0.3 \\
0.12\end{array}$ & s. & $\begin{array}{l}24 \\
15 \\
15\end{array}$ & $\begin{array}{l}017 \\
002\end{array}$ & $?$ & ${ }_{\infty}^{180}$ & $\begin{array}{l}0.06 \\
0.06\end{array}$ & , & 200 & 024 \\
\hline $\begin{array}{l}\text { saCs } \\
\text { Golloreses }\end{array}$ & $?_{1}^{5}$ & $\begin{array}{l}18 \\
32\end{array}$ & 009 & 5 & 120 & 060 & 5 & 18 & 009 & 2 & 50 & 012 & 2 & 120 & 024 \\
\hline 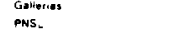 & 15 & 热 & $\begin{array}{l}0.3 \\
144\end{array}$ & 13 & $\begin{array}{l}1800 \\
1080\end{array}$ & $\begin{array}{l}0.08 \\
162 \\
162\end{array}$ & is & $\begin{array}{r}32 \\
192\end{array}$ & $\begin{array}{l}0.03 \\
288 \\
280\end{array}$ & ; & ${ }_{380}^{20}$ & 012 & 2 & 360 & 072 \\
\hline 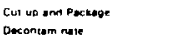 & 8 & 928 & 392 & B & 4350 & $34 \mathrm{~B}$ & 8 & 920 & 342 & 2 & 2680 & $\begin{array}{c}100 \\
532 \\
532\end{array}$ & 2 & 1040 & 288 \\
\hline 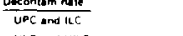 & ${ }^{3}$ & 48 & 014 & 3 & 450 & 135 & 3 & A & 024 & 2 & 720 & ises & 2 & 360 & \\
\hline 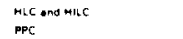 & ${ }_{2}^{20}$ & 64 & 128 & ${ }^{20}$ & 600 & 120 & 20 & 64 & , 28 & 3 & 960 & 20 & 2 & 40 & 年 \\
\hline APC & 25 & 48 & 120 & 25 & $\begin{array}{l}250 \\
450\end{array}$ & 113 & ${ }_{25}^{2}$ & $\begin{array}{l}27 \\
48\end{array}$ & $\begin{array}{l}054 \\
120\end{array}$ & 3 & 720 & 216 & $a^{2}$ & $\begin{array}{l}180 \\
900\end{array}$ & $\begin{array}{l}036 \\
180\end{array}$ \\
\hline RMsc & 3 & 32 & 010 & 3 & 360 & 10 & 3 & 32 & 010 & i & 240 & 024 & ; & & 024 \\
\hline $\begin{array}{l}\text { CEMG } \\
\text { EMS CCS CGAS }\end{array}$ & $\vdots$ & 16 & 002 & i & 240 & 024 & 1 & 16 & 002 & $\therefore$ & 160 & 016 & ' & 120 & 012 \\
\hline as & $i$ & 16 & 002 & ; & 360 & $\begin{array}{l}818 \\
036\end{array}$ & $\vdots$ & $\begin{array}{l}16 \\
16\end{array}$ & $\begin{array}{l}0.02 \\
0.02\end{array}$ & i & $\begin{array}{l}80 \\
80\end{array}$ & $\begin{array}{l}0.08 \\
006\end{array}$ & $\vdots$ & $\infty$ & $\begin{array}{l}006 \\
006\end{array}$ \\
\hline 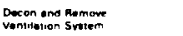 & 2 & co & 016 & 2 & 1680 & 336 & 2 & so & 0.16 & ' & 1200 & 120 & 2 & 420 & om \\
\hline 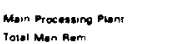 & 241 & & & & & 140 & & & & & & 280 & & & 250 \\
\hline 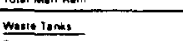 & & & & & & & & & & & & & & & \\
\hline 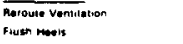 & $\begin{array}{l}2 \\
2\end{array}$ & $\begin{array}{c}16 \\
289\end{array}$ & $\begin{array}{l}003 \\
088\end{array}$ & 2 & .100 & $\begin{array}{l}036 \\
894\end{array}$ & 2 & 16 & 0.03 & 2 & $\infty$ & 012 & $2^{2}$ & $1 \infty$ & 038 \\
\hline 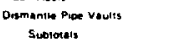 & ; & 72 & $\frac{036}{09}$ & s & 1000 & $\frac{54}{14}$ & 5 & 72 & $\frac{0.36}{039}$ & ' & 270 & 0.27 & $3^{2}$ & 540 & $\begin{array}{l}216 \\
270 \\
277\end{array}$ \\
\hline 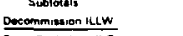 & & & 099 & & & $\underline{1+4}$ & & & 然9 & & & 0.39 & & & $\underline{522}$ \\
\hline 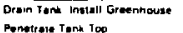 & 2 & 32 & 006 & 2 & 80 & 012 & 2 & 32 & 006 & i & 210 & 021 & 2 & 330 & 000 \\
\hline 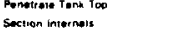 & - & 8 & - 002 & : & ${ }_{\infty}^{800}$ & 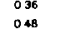 & 8 & ${ }^{24}$ & $\begin{array}{l}002 \\
006\end{array}$ & $i^{1}$ & $\begin{array}{c}240 \\
30\end{array}$ & $\begin{array}{l}024 \\
006\end{array}$ & : & $\begin{array}{c}240 \\
30\end{array}$ & $\begin{array}{l}024 \\
024\end{array}$ \\
\hline Section lank & 8 & 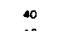 & 032 & $:$ & 300 & 24 & 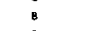 & $\approx$ & 032 & 2 & 150 & 00 & & & 0.4 \\
\hline $\begin{array}{l}\text { Section Inot: } \\
\text { Doconon vout }\end{array}$ & i & 年 & $\begin{array}{l}0,0 \\
001 \\
0.1\end{array}$ & & $\begin{array}{l}100 \\
240\end{array}$ & $\begin{array}{l}090 \\
0.24\end{array}$ & 3 & 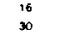 & 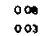 & ' & $\infty$ & 006 & , & 120 & \\
\hline 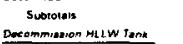 & & & 0.085 & & & .950 & & & $\frac{\overline{0.57}}{2}$ & & & $\underline{007}$ & & & $\frac{\frac{12}{126}}{126}$ \\
\hline Decon internas & 2 & 180 & 032 & 2 & 1000 & 30 & 200 & & 016 & ' & 200 & $\infty$ & 1 & 300 & $0 \infty$ \\
\hline 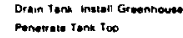 & ; & ${ }_{36}^{32}$ & 018 & 8 & 360 & 100 & 5 & 32 & 018 & ' & 210 & 021 & 2 & $\infty$ & 0.12 \\
\hline 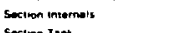 & $:$ & 要 & $\begin{array}{l}807 \\
070\end{array}$ & : & $\begin{array}{l}300 \\
720\end{array}$ & $\begin{array}{l}072 \\
58\end{array}$ & 8 & ${ }_{96}^{36}$ & $\begin{array}{l}0.07 \\
070\end{array}$ & i & 200 & 然 & $\frac{2}{2}$ & $\begin{array}{l}240 \\
720\end{array}$ & 0 \\
\hline 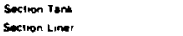 & ; & 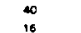 & 032 & : & 300 & 24 & : & 40 & 032 & 2 & iso & $0 \infty$ & & & \\
\hline $\begin{array}{l}\text { Decon vout } \\
\text { Dum }\end{array}$ & & & $\begin{array}{l}0.00 \\
0.02 \\
002\end{array}$ & & $\begin{array}{l}100 \\
240 \\
240\end{array}$ & $\begin{array}{l}0.00 \\
0.024 \\
\end{array}$ & $\vdots$ & is & $\begin{array}{l}0.00 \\
002 \\
0.02\end{array}$ & i & $\infty$ & $\begin{array}{l}\infty \infty \\
\infty \infty \infty\end{array}$ & 1 & 120 & 012 \\
\hline 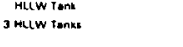 & & & $\frac{\frac{575}{526}}{526}$ & & & $\frac{753}{.165}$ & & & $\frac{159}{477}$ & & & $\frac{321}{983}$ & & & $\frac{726}{738}$ \\
\hline 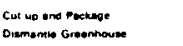 & : & 100 & 67 & - & 0000 & 528 & 8 & $\omega$ & 07 & 2 & 9300 & .00 & & & \\
\hline 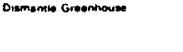 & & 32 & $\frac{003}{10}$ & & $\infty \infty$ & 0.8 & & 32 & $\underline{003}$ & & 300 & 030 & & & \\
\hline weG & & & 0 & & & 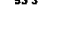 & & & ${ }^{873}$ & & & $\cdots$ & 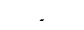 & - & \\
\hline 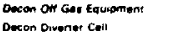 & : & $:$ & oot & : & 100 & $0 \infty$ & 5 & a & oos & & & & $\mathbf{s}$ & 30 & 015 \\
\hline 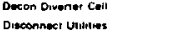 & $i$ & $:$ & 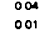 & : & $\begin{array}{c}45 \\
0\end{array}$ & $\begin{array}{l}023 \\
000\end{array}$ & $\begin{array}{c}5 \\
1\end{array}$ & : & 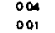 & 1 & 120 & & 5 & 30 & 015 \\
\hline Ramonon Pumper Coner & ; & 8 & 001 & ' & 120 & 012 & i & : & 001 & 1 & 30 & 000 & & & \\
\hline 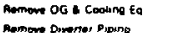 & ${ }_{10}^{2}$ & 32 & 000 & 2 & 400 & 0.60 & 2 & 32 & 000 & 1 & 120 & 012 & & & \\
\hline 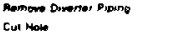 & 2 & $:$ & $\begin{array}{l}0.08 \\
0.02\end{array}$ & $\begin{array}{l}10 \\
2\end{array}$ & $\begin{array}{r}30 \\
120\end{array}$ & $\begin{array}{l}0.030 \\
0.24\end{array}$ & 10 & 8 & 然 & i & $\begin{array}{l}\infty \\
30\end{array}$ & 年 & $\begin{array}{l}10 \\
2\end{array}$ & $\infty$ & $\begin{array}{l}0.00 \\
0.12\end{array}$ \\
\hline Remowe Divoners: & 10 & : & 000 & s & 120 & 000 & 10 & $:$ & $\infty$ & 2 & $\mathbf{3 0}$ & $-\infty$ & 5 & $\infty$ & $\begin{array}{l}812 \\
030\end{array}$ \\
\hline 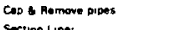 & 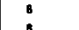 & 12 & 010 & $\therefore$ & 120 & 0,4 & ${ }^{3}$ & 12 & 010 & $\therefore$ & ${ }^{45}$ & 000 & 4 & $\infty$ & 036 \\
\hline 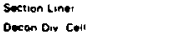 & 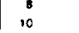 & ${ }^{16}$ & $\begin{array}{l}013 \\
0.006\end{array}$ & $\begin{array}{l}30 \\
10\end{array}$ & $\begin{array}{l}180 \\
120\end{array}$ & $\because 2$ & $\begin{array}{l}8 \\
10\end{array}$ & 10 & 013 & : & $\infty$ & 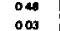 & 10 & $\infty$ & 000 \\
\hline Decon Samonen Cel & 10 & - & 000 & 5 & 120 & 000 & 10 & $:$ & $\infty$ & i & $\infty$ & 003 & 5 & ${ }_{\mathbf{x}}^{\infty}$ & $\begin{array}{l}0.0 \\
015\end{array}$ \\
\hline Deron Hoi ANew WTEG & 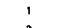 & 16 & 002 & 1 & 240 & 024 & 1 & 16 & 002 & 1 & $\infty$ & 000 & ' & 120 & 0.12 \\
\hline Decomm vonl Snrutum & 2 & 12 & 002 & 2 & 120 & 024 & 2 & 12 & 002 & $i$ & 30 & 000 & 2 & $\infty$ & $\because "$ \\
\hline 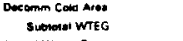 & & & $\frac{001}{0.76}$ & & & $\frac{012}{153}$ & ' & & $\frac{001}{0.76}$ & & & $\frac{003}{110}$ & & & $\frac{\frac{000}{290}}{290}$ \\
\hline 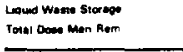 & $\underline{=12}=$ & & $\sqrt[143]{-13}$ & & & 童然 & & & 132 & & & 190 & & & $\underline{10.4}$ \\
\hline 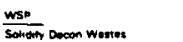 & & 1158 & & & & & & & & & & & & & \\
\hline 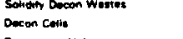 & : & $\begin{array}{l}152 \\
192 \\
192\end{array}$ & $\begin{array}{l}113 \\
0100\end{array}$ & 1 & 20060 & $\begin{array}{l}173 \\
2010\end{array}$ & & & & & & & & & \\
\hline connect Unimuser & $\vdots$ & 18 & 001 & i & 80 & 000 & 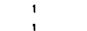 & $\therefore$ & 001 & & & & : & 120 & 012 \\
\hline 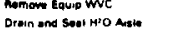 & ; & ${ }^{16}$ & $\begin{array}{l}0.02 \\
0.01\end{array}$ & $i$ & $\begin{aligned} 240 \\
90\end{aligned}$ & 年 & ; & :6 & $\begin{array}{l}0.02 \\
0.01\end{array}$ & 1 & 30 & 003 & ; & & 0 \\
\hline Remonon foula CDC & ; & 18 & 002 & i & 240 & 024 & : & 16 & 002 & i & $\infty$ & 0.00 & i & $\infty$ & $\begin{array}{l}0.00 \\
010\end{array}$ \\
\hline Nomanom EquD OGTC & & 8 & 001 & & 120 & 012 & : & $\therefore$ & 001 & ; & 30 & $\infty$ & & & \\
\hline 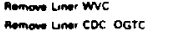 & $:$ & $\$$ & 年 & $:$ & $\begin{array}{l}420 \\
720\end{array}$ & $\begin{array}{l}336 \\
376 \\
576\end{array}$ & $:$ & 8 & 年, & $2^{2}$ & $\begin{array}{l}210 \\
300\end{array}$ & 蓶2 & $2_{2}^{2}$ & 40 & on \\
\hline 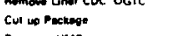 & : & 200 & 100 & : & 750 &.$\infty$ & : & 200 & 100 & ? & 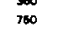 & 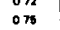 & & & 072 \\
\hline comm nac & 2 & 32 & 000 & 2 & 240 & 040 & 2 & 32 & 000 & i & 240 & 024 & : & 400 & oes \\
\hline 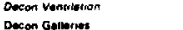 & $?$ & $\begin{array}{l}32 \\
16\end{array}$ & 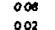 & 2 & 280 & 年 & $?$ & 32 & $\begin{array}{l}000 \\
000\end{array}$ & ; & 240 & 0.34 & $i$ & $+\infty$ & aes \\
\hline 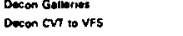 & 2 & 18 & $\begin{array}{l}0.02 \\
0.1\end{array}$ & 2 & ${ }_{30}^{240}$ & $\begin{array}{l}024 \\
012\end{array}$ & $\frac{1}{2}$ & 16 & $\begin{array}{l}802 \\
012\end{array}$ & ; & $\begin{array}{l}120 \\
x\end{array}$ & 年 & ! & $\begin{array}{c}120 \\
30\end{array}$ & 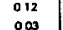 \\
\hline snowout & & & $\frac{4}{437}$ & & & $\frac{30}{379}$ & & & $\frac{314}{314}$ & & & $\frac{0 \omega}{2 \mu}$ & & & $\frac{\frac{0.0}{310}}{310}$ \\
\hline 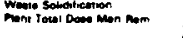 & $\$ 12$ & & & & & & & & & & & & & & \\
\hline 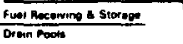 & & & & & & & & & & & & & & & \\
\hline 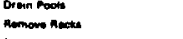 & 5 & & 024 & $\frac{1}{5}$ & $\begin{array}{l}3000 \\
720\end{array}$ & 300 & s & 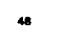 & 024 & ' & & & & & \\
\hline Damon Lnar' & 1 & 24 & 0.02 & i & 540 & 03 & 1 & 24 & $\circ$ & ; & 100 & it & & & \\
\hline D我 & ; & 16 & $\begin{array}{l}0.03 \\
0.02\end{array}$ & : & $=0$ & 告 & ; & ${ }_{10}^{32}$ & & i & $\begin{array}{l}240 \\
120\end{array}$ & 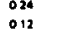 & 1 & $+\infty$ & 0 \\
\hline 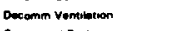 & 2 & 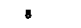 & 001 & 2 & 120 & 024 & 2 & - & 001 & 2 & 30 & 000 & ' & $\infty$ & 000 \\
\hline 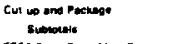 & 3 & 200 & $\frac{0,6}{111}$ & & 2180 & $\frac{\frac{7640}{148}}{140}$ & & & $\frac{0.4}{118}$ & & & $\frac{100}{201}$ & & & $\overline{0.87}$ \\
\hline 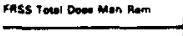 & 1 190 & & & & & & & & & & & & & & \\
\hline 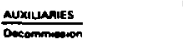 & & & & & & & & & & & & & & & \\
\hline 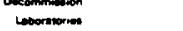 & i & $\infty$ & 00 & ' & & & 1 & $\$$ & & 1 & 100 & & 1 & 300 & $0 \times 0$ \\
\hline & 2 & $\therefore$ & 002 & 3 & 120 & 02 & 2 & $\therefore$ & 00 & : & $\infty$ & 000 & 2 & 200 & 048 \\
\hline $\begin{array}{l}\text { vas } \\
\text { Susucts }\end{array}$ & $?$ & $\begin{array}{l}16 \\
24\end{array}$ & $\begin{array}{l}\text { O03 } \\
0.02\end{array}$ & $?_{1}^{2}$ & 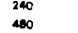 & $\begin{array}{l}0.40 \\
040\end{array}$ & 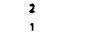 & $\begin{array}{l}18 \\
184\end{array}$ & $\begin{array}{l}0.03 \\
002\end{array}$ & ; & $\begin{array}{l}\infty \\
\infty \\
\infty\end{array}$ & $\begin{array}{l}000 \\
000\end{array}$ &, & 120 & 012 \\
\hline 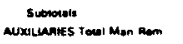 & $\underline{325}$ & & & & & & & & ㅁ11 & & & $\underline{0.33}$ & & & $\overline{0000}$ \\
\hline
\end{tabular}


ants; 1,000 in invertebrates; and 100 in fish. Interactions with soi1 should be sufficiently strong to prevent leaching at hazardous levels. Little is known, however, of the interactions of plants with gadolinium in soil and therefore phytotoxic levels remain unknown.

Solvent extraction is performed with a solution of tributyl phosphate (TBP) in dodecane. TBP is not particularly toxic--the oral $\mathrm{LD}_{50}$ in rats is reported to be $3000 \mathrm{mg} / \mathrm{kg}$ body weight. This would suggest no major threat to drinking water from leaching. The threshold limit value (TLV) in air for an eight-hour day has been set at $5 \mathrm{mg} / \mathrm{m}^{3}$. Direct contact may cause some irritation. Residues of TBP can persist for long periods of time. The organic ester is quite stable to biological and chemical degradation. Hence, some cautions must be taken to avoid buildups of this solvent on materials which may come in direct contact with individuals or which may be exposed to sufficient heat to generate concentrated vapors. Such buildups may result from spills, disposal of spent of off-spec batches of solvent on the soil, or incidental absorption into permeable materials. Dodecane is degradable and should not pose a hazard.

Two reducing agents, hydrazine and hydroxylamine nitrate, may be utilized in conjunction with solvent extraction. While both materials are toxic, they are also highly reactive and therefore should not persist.

Treatment of organic solvents includes washing with nitric acid and sodium carbonate. Considerations pertinent to nitic acid have already been presented. Sodium carbonate poses no significant hazard.

Secondary recovery extraction includes the use of nitrites. These will soon oxidize to the nitrate form and hence be subject to the same considerations suggested for nitric acid.

Gaseous waste treatment involves the use of silver zeolite and mercuric nitrate in addition to nitric acid. As a solid absorbant, the zeolite should be of little concern. The mercury, however, may pose a hazard. Mercury is highly toxic and can be rendered available to various life forms through biological transformation. Hence, even though mercury may be tightly bound soil particles, subsequent transformation to organic forms can release it 
to the atmosphere or water. Mercury should not exceed $0.002 \mathrm{mg} / \ell$ in drinkir water and $0.0002 \mathrm{mg} / \mathrm{l}$ in water with aquatic life. The threshold limit value (TLV) has been set at $0.05 \mathrm{mg} / \mathrm{m}^{3}$ in air for an eight-hour working day. Mercury in soil should be maintained below $0.15 \mathrm{ppm}$ in soil if crops are to be grown. These restrictive limits reflect mercury's high potential for bioaccumulation as well as its toxicity. While residuals are unlikely to be high enough to cause real concern, the potential for buildups from spills, soil disposal practices, or impregnated surfaces should be considered.

Generally speaking, hazardous chemical residuals from operation of chemical separations facilities should not be a major factor during decontamination. Of the potential residuals, concentrations of TBP and mercury deserve the greatest attention. These may be particularly important if spills or soil dispoal practices occurred during operation. Permeable materials mav also be impregnated at hazardous levels.

\section{F.2.3.2 Chemical Residuals from Decontamination Agents}

Recommended decontamination procedures include the use of chemical reagents which may leave residuals. It is, therefore, advisable to review these in light of any hazards which may subsequently develop. Most of the proposed chemicals are subject to chemical reaction and/or neutralization and therefore are not of major significance.

First-phase decontamination includes the use of tartaric acid, caustic, and hydrofluoric acid in additon to nitric acid. of these, the caustic will be used to neutralize the acids, leaving innocuous salts. Tartaric acid is also nonpersistent and poses no real toxic hazard. Hydrofluoric acid may be of concern. It is the most hazardous of the chemicals employed. While the acid function is soon neutralized, fluoride residues may pose a hazard via two routes: leaching into ground and surface waters, and entrainment in the air. Concentrations in water should be held below $1.2 \mathrm{mg} / \ell$ for drinking purposes, $2 \mathrm{mg} / \ell$ for general farmstead use, $2 \mathrm{mg} / \ell$ for irrigation water, and $1.5 \mathrm{mg} / \ell$ if exposure to aquatic plants is anticipated. Fluoride should not exceed $1.5 \mathrm{mg} / \mathrm{l}$ if viable aquatic communities are to be sustained. In air, fluoride can damage plants if concentrations exceed $0.5 \mu \mathrm{g} / \mathrm{m}^{3}$. Fluorides can also damage plants if present in acid soils. The 
imit for worker exposure during eight-hour days is $2 \mathrm{mg} / \mathrm{m}^{3}$. It is unlikely that residues will reach these critical levels and thus threaten the quality of soil or water unless spilled during decontamination.

The second phase of decontamination will involve permanganate, aluminum, and oxalic acid as well as fluorides and nitrates. For the most part, these materials pose no hazard. Permanganates rapidly oxidize in the presence of organics to insoluble manganese dioxides. Similarly, oxalic acid is biodegradable. Aluminum is not particularly hazardous and is not likely to be present at significant levels.

Therefore, under normal circumstances, residues from decontamination procedures are not likely to pose a hazard. The major concern, if any, relates to fluoride residuals. At the same time, the potential for deposits of mercury (off-gas treatment solution), TBP (solvent extraction), and lead from shielding suggests that an operational hazard may develop during decontamination if heat sources are utilized which could volatilize toxic vapors. Where this potential exists, breathing protection devices are advisable.

ilarly, when sandblasting or other dust-generating activities are initiated, safeguards against suspended fluorides are recommended.

\section{F.2.3.3 Stable Isotope Decay Products}

In dealing with radioisotopes contaminated materials, it is important to note that stable end products of the decay process may pose a toxic hazard of their own. To assess this potential, the isotope inventory of a chemical separations facility after chemical decontamination was analyzed. The final inventories were found to be small as can be seen in Table F.2-4.

The lead is of less concern than might be anticipated since it is largely derived from isotopes with extremely long half lives. Hence, actual lead quantities will not reach this maximum level for centuries.

\section{F.2.4 Construction/Industrial Accidents}

Table F.2-5 gives a summary of accident experience for the Atomic Energy Commission in the period 1943-1970 (12) 
TABLE F.2-4. Inventory of Stabie End-Products After Decay of A11 Residuals from Decontamination Procedures

Element

Barium

Zirconium

Neodys ium

Samarium

Molybdenum

Palladium

Lead

\begin{tabular}{c} 
Tota] (quantity \\
\hline (mg) \\
\hline$<1365$ \\
$<541$ \\
$<140$ \\
$<88$ \\
$<3$ \\
$<80$ \\
$<3419$
\end{tabular}

TABLE F.2-5. Construction/Industrial Accident Frequencies (12)

\begin{tabular}{|c|c|c|}
\hline & & $\begin{array}{c}\text { Frequency } \\
\text { (Accident } / 10^{6} \text { Man-Hours) }\end{array}$ \\
\hline Accident Category & Job C'lassification & $\begin{array}{c}1943-70 \\
28 \text { Year Average }\end{array}$ \\
\hline \multirow[t]{3}{*}{ Lost Time Injuries: } & Heavy Construction & 10 \\
\hline & All Construction & 5.36 \\
\hline & AEC Operations & 2.12 \\
\hline \multirow[t]{3}{*}{ Fatalities: } & Construction & 0.042 \\
\hline & AEC Operations & 0.023 \\
\hline & Government Functions & 0.004 \\
\hline
\end{tabular}

\section{F.3 TRANSPORTATION SAFETY}

This section provides the background and details for transportation safety impacts of decommissioning the reference RFP presented in Vol. 1, Section 8.0.

\section{F.3.1 Procedures and Standards for Transporting Radioactive Wastes}

All shipments containing nonexempt. ${ }^{(a)}$ quantities of radioactive material

${ }^{(a)}$ Some radioactive shipments are exempt from the packaging, labeling and shipping requirements of Title 49, Part 173 of the Code of Federal Regulations. Exemption is based on quantity primarily and on several other ditions outlined in 49 CFR 173.391 . 
regulated by the U.S. Department of Transportation (DOT) and the Nuclear Regulatory Commission (NRC). Standards and criteria for packaging and transportation are contained in Title $49^{(13)}$ and Title $10^{(14)}$ of the Code of Federal Regulations.

Radioactive materials are classified for transportation purposes into one of seven transport groups (10 CFR 71, Appendix C) according to their potential hazard if released to the environment. Transport Group $I$ is the most restrictive. Plutonium and other transuranic elements are in this transport group. Transport Group VII is the least restrictive. Materials such as tritium gas, with a low potential for health effects, are placed in Group VII. Most isotopes from the fissioning of uranium are in Tranport Group III or Transport Group IV.

For radioactive material belonging to a specific transport group, the type of packaging required depdnds on both the specific activity and the total quantity of material being shipped. Classification by quantity is in terms of exempt, Type A, Type B, or large quantity. Table F.3-1 lists

e curie limits associated with these quantity specifications for radioisotopes in each of the seven transport groups.

TABLE F.3-1. Quantity Limits for the Seven Transport Groups

Transport

Group

I

II

III

IV

V

VI

VII

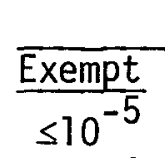

$\leq 10^{-4}$

$\leq 10^{-3}$

$\leq 10^{-3}$

$\leq 10^{-3}$

$\leq 10^{-3}$

$\leq 25$

Activity Level, $\mathrm{Ci}$

\begin{tabular}{lll}
\multicolumn{4}{c}{ Activity Level, Ci } \\
\cline { 1 - 1 }$>\frac{\text { Type A }}{>10^{-5} \text { to } 10^{-3}}$ & $>10^{-3}$ to 20 & Large Quantity \\
$>10^{-4}$ to $5 \times 10^{-2}$ & $>0.05$ to 20 & $>20$ \\
$>10^{-3}$ to 3 & $>3$ to 200 & $>200$ \\
$>10^{-3}$ to 20 & $>20$ to 200 & $>200$ \\
$>10^{-3}$ to 20 & $>20$ to 5000 & $>5000$ \\
$>10^{-3}$ to $10^{3}$ & $>10^{3}$ to $5 \times 10^{4}$ & $>5 \times 10^{4}$ \\
$>25$ to $10^{3}$ & $>10^{3}$ to $5 \times 10^{4}$ & $>5 \times 10^{4}$
\end{tabular}

Most non-TRU waste shipments from the dismantlement of a FRP are ciassified as low-specific-activity (LSA) material (10 CFR 71.4 (g). LSA pments are considered to pose a negligible risk to public health. 
If the radioactivity in a waste shipment is essentially distributed unifd with a concentration of not more than $0.1 \mu \mathrm{Ci} / \mathrm{g}$ of Group I material, or $5 \mu \mathrm{Ci} / \mathrm{g}$ of Group II material, or $300 \mu \mathrm{Ci} / \mathrm{g}$ of Group III or IV material, the waste qualifies as low-specific-activity material. Externally contaminated nonradioactive materials may be considered as low-specific-activity provided that the radioactive contamination averaged over $1 \mathrm{~m}^{2}$ does not exceed $0.1 \mu \mathrm{Ci} / \mathrm{cm}^{2}$ of Group I radionuclides or $1.0 \mu \mathrm{Ci} / \mathrm{cm}^{2}$ for others.

Low-specific-activity material shipped in exclusive use vehicles is exempt from most of the packaging requirements of Title 49 of the Code of Federal Regulations [see 49 CFR 173.392 (b)]. Basically only strong, tight packaging that will not leak in normal transport is required. The radiation dose limits of 49 CRF 173.393 are still applicable, however (see Section 8.3.2.1 of this study).

In accident situations involving LSA packaging, protection to the general public and to transportation workers is based on a limitation of package contents rather than on the accident resistance of the packaging. For packages of LSA material, established activity limits are based on a concept set fq by the International Atomic Energy Agency ${ }^{(15)}$ that, from a radiotoxicity point of view, LSA materials should be inherently safe, i.e., it is inconceivable that, under any circumstances arising in transport, a person could ingest enough material to give rise to a signficiant radiation hazard.

If the specific activity of a shipment exceeds LSA limits but the total number of curies is within Type A limits, then Type A packaging is required for the transport of the material. In accordance with DOT Specification $7 A$ (49 CFR 178.350), a Type A container must meet the standard construction requirements for packages in 49 CRF 173.24 and 49 CFR 173.393. The package must also prevent loss or dispersal of its radioactive contents and retain its radioactive shielding efficiency if subjected to a series of tests designed to simulate package stresses associated with normal transport. The Type A packaging test series is outlined in 49 CFR 173.398 (b) and includes impact, puncture and compression tests, a vibration test, a water spray test, pressure tests and thermal tests. Typical Type A packaging includes steel drums (for example, the Specification $17 \mathrm{C}$ 55-gal drum), wooden boxes, and steel boxes (MLM 2228). 
Shipments of TRU waste destined for Federal custody are presumed to contain large enough inventories of Group I radionuclides that they qualify as Type $B$ or Large Quantity shipments and must therefore be transported in Type B packaging. In addition to meeting the standards for a Type A package, a Type $B$ package must be able to survive a series of hypothetical accident test conditions with essentially no loss of shielding capability (see 10 CFR 71.36 and 10 CFR 71 , Appendix B). The test sequence for Type B packages is designed to simulate the damage that might be expected in a severe accident situation.

Non-high level TRU waste will be packaged in steel drums and steel boxes and shipped in overpacks which meet Type B package standards. The accident protection provided by these overpacks will enable a shipment to withstand all but very severe, highly unusual accidents. High activity shipments and shipments of solidified residue from chemical decontamination will be packaged in steel cylinders and shipped in massive, shielded casks that meet Type B package standards. These casks will likewise withstand all but very severe, highty unusual accidents.

\section{F.3.2 Radiological Transportation Safety Impacts}

\section{F.3.2.1 Radiological Effects of Normal Transportation Operations}

Radioactive waste shipments from dismantlement of an FRP will be made in exclusive use vehicles. Department of Transportation regulations (49 CFR 173.393) set the following limits on radiation levels associated with exclusive use vehicle shipments:

- $1000 \mathrm{mR} / \mathrm{hr}$ at $0.91 \mathrm{~m}(3 \mathrm{ft}$ ) from the external surface of the package (provided the package is transported in a closed vehicle)

- $200 \mathrm{mR} / \mathrm{hr}$ at the external surface of the vehicle

- $10 \mathrm{mR} / \mathrm{hr}$ at any point $1.8 \mathrm{~m}(6 \mathrm{ft})$ from the vehicle

- $2 \mathrm{mR} / \mathrm{hr}$ at any normally occupied position in the vehicle.

DOT regulations (49 CFR $173.393(\mathrm{~h})$ ) require the absence of significant removable surface radioactive contamination on the external accessible surfaces of packages when they are shipped. Levels of removable contamination on the surfaces are determined by a wipe test. The regulations consider that 
the level is "not significant" if the radioactivity on the wipe does not exceed $10^{-11} \mathrm{Ci} / \mathrm{cm}^{2}$ for beta-gamma emitters and $10^{-12} \mathrm{Ci} / \mathrm{cm}^{2}$ for alpha emitters. Any fixed contamination of the surface is also limited by the external-radiation-level restrictions discussed in the previous paragraph.

Limitations on package and vehicle dose rates and on surface contamination levels are designed to minimize the radiological effects of normal transport operations.

Estimates are given in Section 8.0 of the routine radiation doses from rail and truck transport of decommissioning wastes. The method used for this estimate is based on that of WASH-1238. (16) The dose calculations are based on maximum allowable dose rates for shipment in exclusive use vehicles and are therefore conservative. The number of rail and truck shipments are taken from Section 7.6. In addition the following assumptions are made:

1) Two truck drivers during a 500 mile trip would probably spend no more than $12 \mathrm{hr}$ inside the cab and $1 \mathrm{hr}$ outside the cab at an average distance of $3 \mathrm{ft}$ from the truck.

2) Normal truck servicing enroute would require that two garagemen spend no more than $10 \mathrm{~min}$ in the vicinity of the truck cab.

3) Onlookers from the general public might be exposed to radiation when a truck stops for fuel or for the drivers to eat. The onlooker dose is calculated on the basis that 10 people spend an average of 3 min each at a distance of $3 \mathrm{ft}$ from a shipment.

4) The cumulative dose to the general public from truck shipments is based on a population dose of $2 \times 10^{-5} \mathrm{man}-\mathrm{rem} / \mathrm{mile} .^{(16)}$

5) Train brakemen would probably spend $10 \mathrm{~min}$ in the vicinity of a special train shipment during each stop. Assume an exposure rate of $25 \mathrm{mrem} / \mathrm{hr}$ at an average distance of $3 \mathrm{ft}$ from the train. Assume two brakemen at each stop and a stop every 100 miles.

6) The onlooker dose for train shipments is based on an onlooker population of 20 people who each spend 3 min at an average distance of $6 \mathrm{ft}$ from a shipment. 
The cumulative dose to the general public from rail shipments is based on a population dose of $8 \times 10^{-5} \mathrm{man}-\mathrm{rem} / \mathrm{mile}$ for a special train of four cars. (16)

\section{F.3.2.2 Radiological Effects of Potential Transportation Accidents}

Transportation accidents have a wide range of severities. Most accidents occur at low vehicle speeds and have relatively minor consequences. In general, as speed increases, accident severity also increases. However, accident severity is not a function of vehicle speed only. 0ther factors such as the type of accident, the kind of equipment involved, and the location of the accident can have an important bearing on accident severity.

Furthermore, damage to a package in a transport accident is not directly related to accident severity. In a series of accidents of the same severity, or in a single accident involving a number of packages, damage to packages may vary from none to extensive. In relatively minor accidents, serious damage to packages can occur from impacts on sharp objects or from being struck by other cargo. Conversely, even in very severe accidents, damage to packages may be minimal.

A 1972 study (WASH-1238)(16) has analyzed the probability of rail and truck accidents based on accident data supplied by the U.S. Department of Transportation. Accidents are classified by severity into five categories as functions of vehicle speed and fire duration. The five categories and their associated probabilities for both rail and truck accidents are shown in Table F.3-2.

Truck Shipment of non-TRU Waste. Minor accidents are not likely to result in a loss of containment or a release of radioactivity from truck shipments of non-TRU waste. A small percentage of accidents of moderate severity are postulated to result in a breach of package containment and a release of material. Perhaps $10 \%$ of accidents in the severe category would not result in a loss of containment.

The radioactive contamination in compacted and uncompacted trash usually will not be released as the result of an accident involving only echanical forces. Pieces of contaminated clothing, etc., may be spread around, but the contamination is bound on the inert materials. Radioactivity 
TABLE F.3-2. Transportation Accident Severity Categories

\begin{tabular}{|c|c|c|c|c|}
\hline \multirow[b]{2}{*}{ Severity } & \multirow{2}{*}{$\begin{array}{c}\text { Vehicle } \\
\text { Speed, } \\
\text { mph } \\
\end{array}$} & \multirow{2}{*}{$\begin{array}{c}\text { Fire } \\
\text { Duration, } \\
\text { hr } \\
\end{array}$} & \multicolumn{2}{|c|}{$\begin{array}{c}\text { Probability } \\
\text { Per Vehicle Mile }\end{array}$} \\
\hline & & & & Truck \\
\hline \multirow[t]{4}{*}{ Minor } & $0-30$ & $<1 / 2$ & $6 \times 10^{-9}$ & $6 \times 10^{-9}$ \\
\hline & $0-30$ & 0 & $4.7 \times 10^{-7}$ & $4 \times 10^{-7}$ \\
\hline & $30-50$ & 0 & $2.6 \times 10^{-7}$ & $9 \times 10^{-7}$ \\
\hline & & Total & $7.4 \times 10^{-7}$ & $1.3 \times 10^{-6}$ \\
\hline \multirow[t]{5}{*}{ Moderate } & $0-30$ & $1 / 2-1$ & $9.3 \times 10^{-10}$ & $5 \times 10^{-11}$ \\
\hline & $30-50$ & $<1 / 2$ & $3.3 \times 10^{-9}$ & $1 \times 10^{-8}$ \\
\hline & $50-70$ & $<1 / 2$ & $9.9 \times 10^{-10}$ & $5 \times 10^{-9}$ \\
\hline & $50-70$ & 0 & $7.5 \times 10^{-8}$ & $3 \times 10^{-7}$ \\
\hline & & Total & $8.0 \times 10^{-8}$ & $3.1 \times 10^{-7}$ \\
\hline \multirow[t]{7}{*}{ Severe } & $0-30$ & $>1$ & $7.0 \times 10^{-11}$ & $5 \times 10^{-12}$ \\
\hline & $30-50$ & $>1$ & $3.9 \times 10^{-11}$ & $1 \times 10^{-11}$ \\
\hline & $30-50$ & $1 / 2-1$ & $5.1 \times 10^{-10}$ & $6 \times 10^{-12}$ \\
\hline & $50-70$ & $1 / 2-1$ & $1.5 \times 10^{-10}$ & $6 \times 10^{-12}$ \\
\hline & $>70$ & $<1 / 2$ & $1 \times 10^{-17}$ & $1 \times 10^{-10}$ \\
\hline & $>70$ & 0 & $8 \times 10^{-10}$ & $1 \times 10^{-10}$ \\
\hline & & Total & $1.5 \times 10^{-9}$ & $8.2 \times 10^{-9}$ \\
\hline \multirow[t]{3}{*}{ Extra Severe } & $50-70$ & $>1$ & $1.1 \times 10^{-11}$ & $6 \times 10^{-13}$ \\
\hline & $>70$ & $1 / 2-1$ & $1.6 \times 10^{-12}$ & $2 \times 10^{-13}$ \\
\hline & & Total & $1.3 \times 10^{-71}$ & $8 \times 10^{-13}$ \\
\hline \multirow[t]{2}{*}{ Extreme } & $>70$ & 1 & $1.2 \times 10^{-13}$ & $2 \times 10^{-14}$ \\
\hline & & Total & $1.2 \times 10^{-13}$ & $2 \times 10^{-74}$ \\
\hline
\end{tabular}


ssociated with compacted or uncompacted trash is unlikely to be released unless there is a fire or unless the radioactivity is washed out by water. It has been estimated (WASH-1238) (16) that if combustible waste burned in an open fire only a small fraction of the activity would be widely dispersed. Most of the activity, perhaps as much as $99 \%$, would remain in the ashes.

A severe mechanical impact that resulted in breach of a container of concrete rubble would cause some dispersion of material. However, most of the material would return to the ground within a few hundred feet of the point of release. The release fraction for respirable material is estimated to be less than $10^{-3}$. Cement is noncumbustible and the effects of a fire would be very limited.

Decontamination of process equipment, stainless steel plate and other items of metal scrap would result in the removal of all loosely held surface contamination prior to shipment. The most likely result of a transportation accident involving contaminated metal parts would be a release of semivolatile surface contamination as the result of a high temperature fire.

Rail Shipment of TRU Waste. TRU waste shipments will be made in casks or overpacks that meet Type B package standards. The accident protection provided by these packages will enable a shipment to withstand all but very severe, highly unusual accidents. Only the most severe impact and longest fire is assumed to provide a mechanism such that some activity might be lost. Because the material being transported is solid and, for the most part, noncombustible, the fraction of respirable material released in a severe accident which ruptures a shipping container is expected to be small. Release fractions in very severe accidents are expected to be less than $10^{-6}$.

Mitigating the Consequences of Transportation Accidents. In a transportation accident involving radioactive materials, carriers are required to follow DOT-prescribed procedures designed to mitigate the consequences. DOT regulations require prompt reporting of any transportation incident involving shipment of radioactive material in which fire, breakage, spillage, or suspected radioactive contamination occurs. The regulations also specity guidelines for remedial actions in the case of actual or suspected release of radioactivity from a shipping container. 
An intergovernmental radiological assistance program (ERDA-10) provides personnel equipped to monitor radiation and trained to act as advisors to aid in radiological incidents such as a transportation accident involving nuclear material. In the event of a transportation accident, trained personnel from the interagency radiological assistance program are available to assist local public safety and transport carrier officials in the following activities:

- to evaluate the radiological hazard

- to minimize the spread of contamination

- to minimize exposure to workers and the general public

- to provide information to the public to allay undue public alarm and to assist in the orderly conduct of emergency activities

- to assist in carrying out necessary recovery operations.

\section{F.3.3 Nonradiological Transportation Safety Impacts}

The principal nonradiological transportation safety impact is the potential for injuries and fatalities from the transportation accident. Table F.3-3 provides a summary of transportation accident statistics for truck, rail, and barge transportation operations.

TABLE F.3-3 Nonradiation Transportation Accident Statistics (16)

\section{Frequency}

\begin{tabular}{|c|c|c|c|c|}
\hline Mode & $\begin{array}{l}\text { Date } \\
\text { Year }\end{array}$ & $\begin{array}{c}\text { (Accidents/vehicle- } \\
\text { kilometer) }\end{array}$ & $\begin{array}{l}\text { Injuries/ } \\
\text { Accident }\end{array}$ & $\begin{array}{l}\text { Fatalities/ } \\
\text { Accident }\end{array}$ \\
\hline Truck & 1969 & $1.1 \times 10^{-6}$ & 0.51 & 0.03 \\
\hline Rail & 1969 & $0.9 \times 10^{-7(a)}$ & 2.7 & 0.2 \\
\hline Barge & 1970 & $0.9 \times 10^{-6}$ & 0.6 & 0.0 \\
\hline
\end{tabular}

(a) Single rail car. 


\section{RADIATION DOSE MODELS}

This section lists the models, assumptions, parameters, and bases that were used to assess the radiation dose consequence of decommissioning the reference FRP by the dismantlement, protective storage, and layaway decommissioning modes.

\section{F.4.1 Models For Estimating Normal Radiation Dose to Man}

The fundamental relation for calculation of radiation dose to man from the environmental pathways is given as follows for any radionuclide:

$$
R_{i p r}=C_{i p} U_{p} D_{i p r}
$$

where:

$R_{i p r}=$ the radiation dose or dose commitment from nuclide $i$ via pathway $p$ to organ $r$

$c_{i p}=$ the concentration of nuclide $i$ in the media of pathway $p$

$U_{p}=$ the exposure rate or intake rate associated with pathway $p$, and

$D_{i p r}=$ a radiation dose or dose commitment factor: a factor for a given nuclide $i$, pathway $p$ and organ $r$ that converts a given concentration of the radionuclide and the intake rate of that radionuclide to the radiation dose or dose commitment.

The three terms comprising Equation 1 are discussed in the following subsections.

\section{F.4.1.1 Radionuclide Concentrations in the Environment $-\left(C_{i p}\right)$}

Individual equations tailored to each specific exposure pathway were derived from Equation 1. The principal difference among pathways is the manner in which the radionuclide concentrations are calculated. This section develops the set of equations required for the pathway models used in this study.

Radionuclide concentrations in air, water, soil or food are calculated as an integral part of computerized models developed for dose calculations. $(18,19)$ Concentrations in water, aquatic foods, farm products, on shoreline sediment, and in soil are calculated from the radionuclide release rates, the effluent flow rate, the mixing and dilution in the irrigation water, irrigation rate, 
facility lifetime (to determine long-term soil buildup), and decay time between nuclide release and produce consumption. Concentrations in air, farm product, and soil are generated from radionuclide release rates, deposition rates, and uptake parameters, and atmospheric dispersion.

\section{F.4.1.2 Average Radiation Exposure and/or Intake by Man - (Usages, U}

Hours of exposure to external sources of radiation and intake rates of ingested water and food are assigned. For the radiation dose estimates for large population groups, the usages of the average adult are multiplied by the size of the population involved.

\section{F.4.1.3 Radiation Dose Factors - ( $\left.D_{i p r}\right)$}

Equations for calculating internal radiation dose or dose commitment factors were derived from those given by the ICRP for body burdens and Maximum Permissible Concentrations (MPC) of each radionuclide ${ }^{(20)}$ and have been published previously. $(18,21,22,23)$ other dose factors used were calculated in a manner similar to that discussed in Reference 22. Effective decay energies for the nuclides were calculated from the ICRP model, which assumes all of a given radionuclide is in the center of a spherical organ with an appropriate effective radius. Radiation dose factors have units of mrem in the first year per $\mathrm{pC} i$ taken into the body during that year either via ingestion or inhalation. Radiation dose commitment factors have units of mrem/50-yr per $\mathrm{pCi}$ taken into the body in the first year.

The radiation dose factors for external exposure to air and water were derived using the basic assumption that the contaminated medium is large enough to be considered an "infinite volume" relative to the range of the emitted radiations. Under that assumption the energy emitted per gram of medium is equivalent to the energy absorbed per gram of medium. Conversion from MeV per disintegration per gram to rem is made by correcting for the difference in energy absorption between air or water and body tissue, the quality factor of the radiation under consideration, and for the physical geometry of each specific exposure situation.

The radiation dose from submersion in air or immersion in water is an external dose either to the skin, or to both the skin and total body, depending 
on the penetrating power of the radiation emitted. Only beta and gamma radiation, which could penetrate $7 \mathrm{mg} / \mathrm{cm}^{2}$ of tissue, were considered in calculating skin dose. Gamma radiation dose at a $5-\mathrm{cm}$ depth in tissue was used for calculating external dose to the total body (and for internal organs). These radiation dose factors have units of mrem/hr per $\mathrm{pCi} / \mathrm{m}^{3}$ of air and $\mathrm{mrem} / \mathrm{hr}$ per $\mathrm{pCi} / \mathrm{l}$ of water.

Material deposited onto the ground represents a fairly large, nearly uniform, thin sheet of contamination. The factors for converting surface contamination in $\mathrm{pCi} / \mathrm{m}^{2}$ to gamma dose $1 \mathrm{~m}$ above a uniformly contaminated plane have been described. $(18,22)$ Dose factors for exposure to soil (or river sediment) have units of $\mathrm{mrem} / \mathrm{hr}$ per $\mathrm{pCi} / \mathrm{m}^{2}$ surface.

For external exposure, the 50-year dose commitment is equal to the first year dose.

\section{F.4.1.4 Food Pathway Equations}

Farm Products

The model presented for estimating the transfer of radionuclides (except for ${ }^{3} \mathrm{H}$ and ${ }^{14} \mathrm{C}$ ) from irrigation water or from air to plants through both leaves and soil to food products was originally derived by soldat ${ }^{(22)}$ for a study of the potential radiation doses to people from a nuclear power complex in the year 2000. A more detailed treatment of the specific model used (including that for ${ }^{3} \mathrm{H}$ and ${ }^{14} \mathrm{C}$ ) can be found in Baker, Hoenes and Soldat. (24)

- Deposition on Food Products

The source of radionuclide contamination deposited on foods may be either water used for sprinkler irrigation or the atmosphere.

a) Deposition From Irrigation Water

$$
d_{i}=C_{i w} I
$$

where:

$$
d_{i}=\text { deposition rate or flux }\left[p C i /\left(m^{2} d\right)\right] \text { of radionuclide } i
$$


$c_{i w}=$ concentration of radionuclide $i$ in water used for irrigation $(\mathrm{pC} i / \ell)$

$I=$ irrigation rate $\left.\left[\ell / \mathrm{m}^{2} \mathrm{~d}\right)\right]$. Amount of water sprinkled on unit area of field in one day.

b) Deposition Directly from Atmosphere

$$
d_{i}=86,400 X_{i} v_{d i}
$$

where:

$$
\begin{aligned}
86,400 & =\text { dimensional conversion factor }(\mathrm{sec} / \mathrm{d}) \\
V_{d i} & =\text { deposition "velocity" of radionuclide } i(\mathrm{~m} / \mathrm{sec}) \\
\bar{x}_{i} & =\text { annual average air concentration }\left(\mathrm{pC} i / \mathrm{m}^{3}\right) \text { of radionuclide } i
\end{aligned}
$$

- Concentration in Vegetation

The concentration of radioactive material in vegetation resulting from deposition onto plant foliage and uptake from the soil of prior depositions on the ground is given in Equation 3.

$$
c_{i v}=d_{i}\left[\frac{r T_{v}\left(1-e^{-\lambda} E i t_{e}\right)}{Y_{v}{ }_{E i}}+\frac{B_{j v}\left(1-e^{-\lambda} t_{b}\right)}{P \lambda_{i}}\right] e^{-\lambda_{i} t_{h}}
$$

where:

$c_{i v}=$ concentration of radionuclide $i$ in edible portion of plant, ( $\mathrm{pC} \mathrm{i} / \mathrm{kg}$ )

$r=$ fraction of deposition retained on plant (dimensionless), taken to be 0.25

$T_{v}=$ factor for translocation of externally deposited radionuclides to edible parts of plants (dimensionless). For simplicity

it is taken to be independent of radionuclide and is assumed to be 1 for leafy vegetables and fresh forage, and 0.1 for all other produce, including grain. (Reference 21 lists values of this parameter, which vary with nuclide.)

$\lambda_{i}=$ radiological decay constant for radionuclide $i\left(d^{-1}\right)$.

$\lambda_{E i}=$ effective removal constant of radionuclide $i$ from plant $\left(d^{-1}\right)$ $\lambda_{E j}=\lambda_{i}+\lambda_{w}$, where $\lambda_{w}=$ weathering removal constant $=$ $0.693 / 14\left(d^{-1}\right)$ 
$Y_{V}=$ plant yield $\left[\mathrm{kg}\right.$ (wet weight) $\left./ \mathrm{m}^{2}\right]$

$B_{i v}=$ concentration factor for plant uptake of nuclide $i$ from soil [pCi/kg (wet weight) per pCi/kg (dry soil)]

$t_{b}=$ time for buildup of radionuclide in soil (d), taken to be 30 years if the source of the radionuclide is an operating nuclear facility

$P=$ soil "surface density" $\left[\mathrm{kg}\left(\mathrm{dry}\right.\right.$ soil $\left.\left./ \mathrm{m}^{2}\right)\right]$. Assuming a uniform mixing of all radionuclides in a plowlayer $15 \mathrm{~cm}$ deep, $P$ has a value of $224 \mathrm{~kg} / \mathrm{m}^{2}$

$t_{h}=$ holdup time $(d)$. The time between harvest and consumption of the food.

The first term inside the brackets relates to the concentration derived from direct deposition on foliage during the growing season, whereas the second term relates to uptake from soil and reflects the deposition throughout the time from start of deposition until harvest of the plant.

- Concentration in Animal Products

The radionuclide concentration in an animal product such as meat, milk or eggs is dependent on the amount of contaminated feed or forage eaten by the animal and its intake of contaminated water. The following equation describes this calculation. (24)

$$
c_{i a}=S_{i a} \quad C_{i F} Q_{F}+C_{i a w} Q_{a w}
$$

where:

$C_{i a}=$ concentration of radionuclide $i$ in animal product $(\mathrm{pC} i / \ell)$ or ( $\mathrm{pCi} / \mathrm{kg}$ )

$S_{i a}=$ transfer coefficient of radionuclide $i$ from daily intake of animal to edible portion of animal product $[\mathrm{pCi} / 2(\mathrm{mi}] \mathrm{k})$ per $\mathrm{pCi} / \mathrm{d}]$ or $[\mathrm{pCi} / \mathrm{kg}$ (animal product) per $\mathrm{pCi} / \mathrm{d}]$

$C_{i F}=$ concentration of nuclide $i$ in feed or forage $(\mathrm{pCi} / \mathrm{kg})$ calculated from Equation (3) above

$Q_{F}=$ consumption rate of contaminated feed or forage by animal $(\mathrm{kg} / \mathrm{d})$ 
$C_{i a w}=$ concentration of nuclide $i$ in water consumed by animals ( $\left.p C i / l\right)$ assumed usually to be equal to $c_{i w}$, and

$Q_{W}=$ consumption rate of contaminated water by animal $(l / d)$.

The second set of terms in the brackets in Equation 4 is ommitted if the animal does not drink contaminated water. Animal consumption rates normally assumed are given in Table F.4-1. (24)

TABLE F.4-1. Consumption Rates of Feed and Water by Farm Animals

\begin{tabular}{|c|c|c|}
\hline & $\begin{array}{l}\text { Feed or Forage } \\
(\mathrm{kg} / \text { day }) \mathrm{O}_{\mathrm{F}}\end{array}$ & $\begin{array}{c}\text { Water } \\
\text { (l/day), } 0_{a w}\end{array}$ \\
\hline Milk Cow & 55 (Fresh Forage) & 60 \\
\hline Beef Cattle & 68 (Dry Feed) & 50 \\
\hline Pig & 4.2 (Dry Feed) & 10 \\
\hline Poultry (chickens) & 0.12 (Dry Feed) & 0.3 \\
\hline
\end{tabular}

Values for various plant concentration factors and animal product transfer coefficients for the elements considered are given in Table F.4-2. Plant concentration factors were taken originally from UCRL-50163, Part IV ${ }^{(25)}$ and supplemented with radionuclide data as explained in HERMES. (21) Coefficients of transfer from feed to animal products for a limited number of radionuclides are available in the literature. For those where data were lacking, comparisons were made with the behavior of chemically similar elements in man and animals. In some instances, identified with an asterisk in Table F.4-2, the value used was set to $9.9 \times 10^{-4}$ when specific data were unavailable.

- Tritium and Carbon-14 Mode1

The concentration of ${ }^{3} \mathrm{H}$ and ${ }^{14} \mathrm{C}$ in environmental media (soil, plants and animal products) is assumed to have the same specific radioactivity ( $\mathrm{pCi}$ of nuclide per $\mathrm{kg}$ of stable element) as the contaminating medium (air or water) The fractional content of hydrogen or carbon in a plant or animal product is then used to compute the concentration of tritium or ${ }^{14} \mathrm{C}$ in the food product under consideration. Hydrogen content in both the water and the 
TABLE F.4-2. Plant Concentration Factors and Animal Product Transfer Coefficients

\begin{tabular}{|c|c|c|c|c|c|c|}
\hline Eloment & $\begin{array}{c}\mathrm{Plant} / \text { Soil } \\
\text { (Dinnsionless) }\end{array}$ & $\begin{array}{l}\text { Egg/feed } \\
(\mathrm{d} a / \text { rg) }\end{array}$ & $\begin{array}{l}\text { Milk/Grass } \\
\text { (day/g) } \\
\end{array}$ & $\begin{array}{l}\text { Becf.'recd } \\
(\operatorname{sax}, \mathrm{kg})\end{array}$ & $\begin{array}{l}\text { Pork/Feed } \\
(\text { day/rici }) \\
\end{array}$ & $\begin{array}{c}\text { Poultry/Fecd } \\
(\mathrm{day} / \mathrm{l} \text { ) }\end{array}$ \\
\hline & $\cdots B_{i v} \cdots \cdots$ & & & $-\cdots-5 \quad-a$ & & - \\
\hline Be & $4.7 E-04$ & $2.0 E-02$ & 2.0F:-06 & $8.0 E-04$ & $2.0 E-02$ & $4.02-01$ \\
\hline N & $7.5 \mathrm{E}+50$ & $9.9 E-04 *$ & $1.1 \mathrm{E}-02$ & $9.9 E-04$ & $9.95-04$ & $9.9 E-04$ \\
\hline $\mathbf{F}$ & $2.0 E-C 2$ & $9.95-04$ & $7.05-03$ & $2.01-02$ & $9.0 \mathrm{E}-32$ & $9.9 E-04$ \\
\hline na & $5.0 E-32$ & $2.08-01$ & $4.0 \mathrm{E}-02$ & $5.01-02$ & $2.02-01$ & $1.05-02$ \\
\hline P & $5.0 E+.1$ & $1.0 \ddot{E}+01$ & $1.2 \mathrm{E}-02$ & $5.01-02$ & $5.4 y-01$ & $2.95-02$ \\
\hline Ca & $4.0 \mathrm{E}-32$ & $1.0 E+00$ & $8.0 \mathrm{E}-03$ & $3.3 I-03$ & $3.3 \pm-03$ & $3.3 E-03$ \\
\hline $\mathrm{sc}$ & $1.1 E-33$ & $9.9 E-04$ & 2. $5 E-06$ & $6.01-03$ & $1.05-02$ & $4.0 \mathrm{E}-03$ \\
\hline $\mathrm{Cr}$ & $2.5 E-31$ & $9.9 E-04$ & $1.3 E-03$ & $9.9 \mathrm{I}-04$ & $9.9 E-04$ & $9.98-04$ \\
\hline Mn & $3.0 E-.22$ & $2.0 \mathrm{E}-02$ & $1.05-04$ & $5.01-03$ & $2.0 E-02$ & $1.25-01$ \\
\hline Fe & $4.0 D-1 j 4$ & $1.0 \equiv-01$ & $6.0 \mathrm{E}-04$ & $2.0 \mathrm{E}-02$ & $5.0=-03$ & $1.05-03$ \\
\hline co & $9.4 \mathrm{E}-03$ & $1.0 E-01$ & $5.05-04$ & $1.0 E-03$ & $5.05-03$ & $1.0 \mathrm{E}-03$ \\
\hline$w i$ & $2.9 E-1,2$ & $2.0 \mathrm{E}-01$ & $3.4 E-03$ & $1 . O E-03$ & $5.0 E-03$ & $1.0 E-03$ \\
\hline $\mathrm{Cu}$ & $2.3 F-(1)$ & $2.0 E-01$ & $7.0 \mathrm{E}-03$ & $1.0 E-02$ & $1.5 E-02$ & $2.0 E-03$ \\
\hline $\mathrm{zn}_{\mathrm{n}}$ & $4.0 \mathrm{E}-(1)$ & $4.0 \mathrm{E}-03$ & $6.0 E-03$ & $5.0 E-02$ & $2.6 E-02$ & $2.0 \mathrm{E}-03$ \\
\hline $\mathrm{Se}$ & 1. $3 E+100$ & $2.1 E+00$ & $2.3 E-02$ & $1.0 E+00$ & $4.5 E-01$ & $3.7 E-02$ \\
\hline $\mathrm{Br}$ & 7. $(E-) 1$. & $1.65+00$ & $2.5 E-02$ & $2.0 E-02$ & $9.0 \bar{E}-02$ & $4.0 \mathrm{E}-03$ \\
\hline $\mathrm{Rb}$ & $2.3 E-1) 1$ & $3.0 \mathrm{E}-00$ & $1.08-02$ & $1.5 \mathrm{E}-01$ & $2.0 \mathrm{E}-01$ & $2.0 E+00$ \\
\hline Sr & $2.0 \mathrm{E}-6,1$ & $4.0 E-01$ & $1.5 E-03$ & $3.0 \mathrm{E}-04$ & $7.3=-03$ & $9.0 \mathrm{E}-04$ \\
\hline $\mathrm{Y}$ & $2.5 \mathrm{E}-0.3$ & $5.0=-04$ & $5.0 E-O G$ & $5.0 \mathrm{E}-03$ & $5.05-03$ & $5.0 E-04$ \\
\hline $2 x$ & $2.7 \mathrm{E}-0.4$ & $1.2 \mathrm{E}-03$ & $2.5 \mathrm{E}-06$ & $5.0 E-01$ & $1.0 \mathrm{E}-03$ & $1.0 E-04$ \\
\hline $\mathrm{Nb}$ & $9.4 \mathrm{E}-03$ & $1.25-03$ & $1.2 \mathrm{E}-03$ & $5.05-04$ & $1.05-03$ & 1.05-04 \\
\hline Mo & $1.3 \mathrm{E}-01$ & $4.05-01$ & $4.0 \mathrm{E}-03$ & $1.0 E-02$ & $2.0=-02$ & 2. CE- 03 \\
\hline TC & $2.5 E-01$ & $9.9 E-04$ & $1.2 \mathrm{E}-02$ & $9.9 E-04$ & $9.9 \mathrm{~F}-04$ & $9.9 E-04$ \\
\hline$R u$ & 1. $0 E-\sqrt{2}$ & $4.0 E-03$ & $5.0 \mathrm{E}-02$ & $1.05-03$ & $5.0 \mathrm{E}-03$ & $3.0 E-04$ \\
\hline $\mathrm{Rh}$ & 2. $3 E+C 1$ & $4.0 \equiv-03$ & 5. $0 E-03$ & $1.05-03$ & $5.02-03$ & $3.0 E-04$ \\
\hline $\mathrm{Pa}$ & $5.0 E+00$ & $4.0 E-03$ & $5.0 \mathrm{E}-03$ & $1.0 E-03$ & $5.0 \%-03$ & $3.0 E-04$ \\
\hline$\lambda g$ & 1. $5 E-0 !$ & $9.9 E-04$ & $2.5 E-02$ & $9.9 E \times 04$ & $9.95-04$ & $\therefore 9 E-04$ \\
\hline cả & 3. $0 \mathrm{E}-0 \mathrm{~L}$ & $9.9 E-04$ & $6.2 \mathrm{E}-05$ & $1.6 \mathrm{E}-02$ & 1. $6 \mathrm{E}-02$ & $1.6 E-02$ \\
\hline Sn & $2.5 E-03$ & $9.9 \bar{E}-04$ & 1. $3 \mathrm{E}-03$ & $9.9 E-04$ & $9.9 E-04$ & 9.9E-OA \\
\hline Sb & 1. $1 E-0$ ? & $7.0 E-02$ & $7.5 \mathrm{E}-04$ & $3.02-03$ & $7.05-03$ & $6.0 \mathrm{E}-03$ \\
\hline Te & $3.35+50$ & $4.0 E-01$ & $5.0 \mathrm{E}-04$ & $5.0 \mathrm{~L}-02$ & $1.05-02$ & $1.05-02$ \\
\hline I & $2.0 E-02$ & $1.65+00$ & $1.0 \mathrm{E}-02$ & $2.0 E \cdot 02$ & $9.0 \mathrm{E}-02$ & 4.0E-03 \\
\hline cs & $2.0 E-03$ & $6.0 E-01$ & $5.02-03$ & $3.0 \mathrm{E} \cdot 02$ & $2.6 \mathrm{E}-01$ & $4.55+00$ \\
\hline $\mathrm{Ba}$ & $5.0 E-03$ & $1.05-01$ & $4.05-04$ & $5.0 \mathrm{E} \cdot 04$ & 2. $0 \mathrm{E}-02$ & $5.0 E-04$ \\
\hline La & $2.5 E-03$ & $2.05-03$ & $2.5 E-06$ & $5.0 \mathrm{E} \cdot 03$ & $5.05-03$ & $4.0 \mathrm{~F}-03$ \\
\hline $\mathrm{Ce}$ & $5.0 E-01$ & $3.08-03$ & $1.0 \mathrm{E}-05$ & $1.05 \cdot 03$ & $5.0 E-03$ & $6.0 E-04$ \\
\hline $\mathrm{Pr}$ & $2.5 \mathrm{E}-0 \mathrm{i}$ & $4.0 E-03$ & 2. $5 E-06$ & $5.0 \mathrm{E} \cdot 03$ & $5.0 \mathrm{E}-03$ & $1.0 E-03$ \\
\hline Nd & 2. SE-OS & $2.0 \mathrm{E}-04$ & $2.5 \mathrm{E}-06$ & $5.0 \mathrm{E} \cdot 03$ & $5.0 \Sigma-03$ & $4.05-03$ \\
\hline $\mathrm{Pm}_{\mathrm{m}}$ & $2.5 \mathrm{E}-0.3$ & $7.0 \mathrm{E}-03$ & $2.5 E-06$ & $5.0 E \cdot 03$ & 5. $0.2-03$ & $1.0 E-04$ \\
\hline $\operatorname{Sin}$ & $2.55-0.3$ & $7.0 E-03$ & $2.5 \Sigma-06$ & 5.05 .03 & $5.0 \mathrm{E}-03$ & $4.0 \mathrm{E}-03$ \\
\hline Eu & $2.5 \mathrm{E}-0 \mathrm{~S}$ & $7.01:-03$ & $2.5 E-06$ & $5.01-03$ & $5.0 E-03$ & $4.0 E-03$ \\
\hline $\mathrm{rb}$ & $2.65-0=$ & $7.05-03$ & $2.5 \mathrm{E}-06$ & $5.0 \mathrm{E}-03$ & $5.05-03$ & $4.05-03$ \\
\hline 110 & $2.61-0.7$ & $7.05-03$ & $2.5 \mathrm{E}-06$ & $5.0 E-03$ & $5.0 E-03$ & $4.05-03$ \\
\hline $\mathrm{W}$ & $1.8 \mathrm{E}-0:$ & $9.9 E-04$ & $2.5 E-04$ & $9.9 E-04$ & $9.9 E-04$ & $9.9 E-04$ \\
\hline $\mathrm{Pb}$ & $6.8 \mathrm{~L}-02$ & $9.9 E-04$ & $1.05-05$ & $9.9 E-04$ & $9.9 \mathrm{I}-04$ & $9.9 k-04$ \\
\hline$B i$ & $\{.5 \pi-0]$ & $9.9 \mathrm{E}-04$ & $2.5 E-04$ & $9.9 E-04$ & $9.91-04$ & $9.95 .-04$ \\
\hline po & $9.0 F-0 ?$ & $9 . S E-O 4$ & $1.25-04$ & $9.91-04$ & $9.9 r-04$ & $9.91-08$ \\
\hline $\mathrm{Ra}$ & I.AE-OS & $2.0 \Gamma-05$ & $2.01-04$ & $9.9 \pi-04$ & $9.91-0.4$ & $9.91-04$ \\
\hline$\lambda c$ & $2.5 \Gamma-03$ & $2.02-03$ & $2.5 F-O C$ & 5. CE: -03 & $1.0 \mathrm{~L}-02$ & $4.02-03$ \\
\hline$T h$ & 4.2L-0 & $2.05-03$ & $2.58-06$ & $5.05-03$ & $2.0 \mathrm{Or}-02$ & $4.05-03$ \\
\hline $\mathrm{Pa}$ & $2.5 B-0.3$ & $2.05-03$ & $2.5 E-06$ & $5.0 E-33$ & $1.0:-02$ & $4.0 r-03$ \\
\hline u & $2.55-03$ & $3.4 \%-01$ & G.05-04 & $5.01-03$ & 6.0T-04 & $3.2 c-03$ \\
\hline Np & $2.5 \Gamma-0 \vdots$ & $2.05-03$ & $2.51-06$ & $5.02:-03$ & $1.05-02$ & $4.0[-03$ \\
\hline $\mathrm{Pu}$ & 2. $51:-04$ & $2.0 E-03$ & $2.51-08$ & $5.0 E-03$ & $1.0 \mathrm{I}:-02$ & 4.0r-03 \\
\hline$\lambda_{m}$ & 2. $5 t-0 i$ & $2.05-03$ & $2.5 E-06$ & $5.0 \mathrm{r}:-73$ & 1.01-02 & $4.0:-03$ \\
\hline $\mathrm{cm}$ & 2.55 .03 & $2.0 \%-03$ & 2. $5 F-O G$ & $5.02-03$ & $2.01-02$ & $4.0[-0]$ \\
\hline $\mathrm{Cr}$ & $2.5 t ;-03$ & $2.05-03$ & $7.38:-07$ & $5.02-03$ & $1.02-02$ & 4.01:-03 \\
\hline
\end{tabular}

*Where value was unknown, a default value of $9.9 \mathrm{E}-04$ was used. 
nonwater (dry) portion of the food product is used to calculate the tritium concentration. It is assumed that animals obtain all their carbon through ingestion of plants.

When ${ }^{14} C$ is present only in the water used for irrigation it is difficult to model the transfer of this nuclide to vegetation, because plants acquire most of their carbon from the air. At this time the transfer rate of carbon from the water to the air or soil has not been determined. It was therefore conservatively assumed that plants obtain all their carbon from the irrigation water. Such an assumption could lead to concentrations of ${ }^{14} \mathrm{C}$ in plants that are high by an order of magnitude or more. To date no operating nuclear facilities have been identified that specify releases of ${ }^{14} \mathrm{C}$ in their liquid effluents. Table F.4-3 1 ists the parameters used in the computer program for tritium and ${ }^{14} \mathrm{C} .{ }^{(24)}$ These values may be altered from site-specific data.

TABLE F.4-3. Calculation of Fractions of Hydrogen and Carbon in Environmental Media, Vegetation, and Animal Products

\begin{tabular}{|c|c|c|c|c|c|}
\hline Food or Fodder & Water & $\begin{array}{l}\text { Carbon } \\
\text { (dry) }\end{array}$ & $\begin{array}{l}\text { Hydrogen } \\
\text { (dry) }\end{array}$ & $\begin{array}{l}\text { Carbon }(a) \\
\text { (wet) } \\
\end{array}$ & $\begin{array}{l}\text { Hydrogen (b) } \\
\text { (wet) }\end{array}$ \\
\hline & $f_{w}$ & $f_{c}$ & $f_{h}$ & $F_{c v}, F_{c a}$ & $F_{h v}, F_{h a}$ \\
\hline $\begin{array}{l}\text { Fresh Fruits, Vege } \\
\text { tables and Grass }\end{array}$ & 0.80 & 0.45 & 0.062 & 0.090 & 0.10 \\
\hline $\begin{array}{l}\text { Grain and Stored } \\
\text { Animal Feed }\end{array}$ & 0.12 & 0.45 & 0.062 & 0.40 & 0.068 \\
\hline Eggs & 0.75 & 0.60 & 0.092 & 0.15 & 0.11 \\
\hline Milk & 0.88 & 0.58 & 0.083 & 0.070 & 0.11 \\
\hline Beef & 0.60 & 0.60 & 0.094 & 0.24 & 0.10 \\
\hline Pork & 0.50 & 0.66 & 0.10 & 0.33 & 0.11 \\
\hline Poultry & 0.70 & 0.67 & 0.087 & 0.20 & 0.10 \\
\hline $\begin{array}{l}\text { Absolute Humidity. } \\
\text { Concentration of } \\
\text { Concentration of }\end{array}$ & $\begin{array}{l}\text { on in wa } \\
\text { n in a } i\end{array}$ & $\begin{aligned} \cdot & 0.0 \\
\text { er. } & 2.0 \\
. & 1.6\end{aligned}$ & $\begin{array}{l}8 \mathrm{l} / \mathrm{m}^{3} \\
\times 10^{-} 5 \mathrm{~kg} / \\
\times 10^{-4} \mathrm{~kg} /\end{array}$ & & \\
\hline \multicolumn{6}{|c|}{$\begin{array}{l}\text { (a) } F_{C v} \text { or } F_{c a}=f_{c}\left(1-f_{w}\right) \\
\text { (b) } F_{h v} \text { or } F_{h a}=f_{w} / 9+f_{h}\left(1-f_{W}\right) \\
\text { (c) Assumes a typical bicarbonate concentration of } 100 \mathrm{mg} / \ell \\
\text { (d) Assumes a typical atmospheric } \mathrm{CO}_{2} \text { concentration of } 320 \mathrm{ppm}_{v}\end{array}$} \\
\hline
\end{tabular}


a) The Concentration of Tritium in Vegetation is:

$$
c_{1 v}=\left(c_{1 w}\right)(9)\left(F_{h v}\right)(a)
$$

where:

$$
\begin{aligned}
C_{1 w}= & \text { concentration of tritium in the environmental water }(p C i / l) \\
= & \text { concentration in irrigation water (for water release) } \\
= & p C i{ }^{3} \mathrm{H} / \mathrm{m}^{3} \text { air: absolute humidity }\left(\ell / \mathrm{m}^{3}\right) \text { (for airborne } \\
& \text { release) } \\
9= & \text { ratio of the mass of water to the mass of hydrogen } \\
F_{h v}= & \text { fraction of hydrogen in total vegetation (see Table } \mathrm{F} .4-3 \text { ). }
\end{aligned}
$$

b) The Concentration of Tritium in the Animal Product is:

$$
c_{1 a}=\left[\frac{c_{1 F} Q_{F}+c_{1 a w} Q_{a w}}{F_{h F} Q_{F}+Q_{a w} / 9}\right] F_{h a}
$$

where:

$C_{1 F}=$ concentration of tritium in feed or forage $(\mathrm{pCi} / \mathrm{kg})$ calculated by Equation 5 above, where now $C_{1 F}=C_{1 v}$

$F_{h F}=$ fraction of hydrogen in animal feed, where now $F_{h f}=F_{h v}$ (grain)

$F_{\text {ha }}=$ fraction of hydrogen in animal product (see Table F.4-3)

$\mathrm{C}_{\text {law }}=$ concentration tritium in animal drinking water (set to 0 unless there is a release to water).

c) Similarly, the Concentration of ${ }^{14} \mathrm{C}$ in Vegetation is:

$$
c_{3 V}=c_{3 W} F_{C V}(a)
$$

where:

$$
\begin{aligned}
C_{3 w}= & \text { concentration of }{ }^{14} \mathrm{C} \text { in the environmental media divided by } \\
& \text { carbon concentration in that media ( } \mathrm{pCi}{ }^{14} \mathrm{C} / \mathrm{kg} \text { carbon) } \\
= & \mathrm{pCi}{ }^{14} \mathrm{C} / \ell \text { divided by carbon concentration in irrigation water } \\
& (\mathrm{kg} / \mathrm{l}) \text { for water release }
\end{aligned}
$$

(a) The subscribt 1 refers to tritium which is the first nuclide in the isotope listing; similarly the subscript 3 in Equation 7 refers to the $14 \mathrm{C}$. 

$=\mathrm{pCi}{ }^{14} \mathrm{C} / \mathrm{m}^{3}$ divided by carbon concentration in air $\left(\mathrm{kg} / \mathrm{m}^{3}\right)$ for air release
$F_{c v}=$ fraction of carbon in total vegetation

d) The Concentration of ${ }^{14} \mathrm{C}$ in the Animal Product is:

$$
c_{3 a}=\left[\frac{c_{3 F} Q_{F}+c_{3 a w} Q_{a w}}{F_{c F} Q_{F}+F_{c w} Q_{a w}}\right] F_{c a}
$$

For an air release $C_{3 a w}=0$ and since $F_{C W}$ is very small compared to $\mathrm{F}_{\mathrm{cf}}$, Equation 8 reduces to:

$$
c_{3 a}=c_{3 F}\left(\frac{F_{c a}}{F_{c f}}\right)
$$

- Radiation Dose Calculations for Man

The dose radiation dose, $\mathrm{R}_{\mathrm{vr}}$, in mrem to a person consuming vegetation is:

$$
R_{v r}=\sum_{i=1}^{n} c_{i v} u_{v} D_{i r}
$$

Similarly the radiation dose from consuming a particular animal product is:

$$
R_{a r}=\sum_{i=1}^{n} c_{i a} U_{a} D_{i r}
$$

where:

$$
\begin{aligned}
U_{v}, U_{a}= & \text { annual consumption of contaminated vegetable or animal pro- } \\
& \text { ducts in } \mathrm{kg}
\end{aligned}
$$

The exposure is assumed to result from one-year's chronic (continual) ingestion at a uniform rate for routine releases.

(a) The subscript 1 refers to tritium which is the first nuclide in the isotope listing; similarly the subscript 3 in Equation 7 refers to the $14 \mathrm{C}$. 


\section{F.4.1.5 Air Submersion}

The formulas used to calculate doses from air submersion are given below:

$$
R_{p r}(x, \Theta, d)=U_{p} \quad \sum_{i=1}^{n} \chi_{i} D_{i p r}^{\prime}
$$

where:

$$
\begin{aligned}
R_{p r}(x, \Theta, d)= & \text { the external dose rate from } n \text { nuclides via pathway } p \text { to organ } \\
& r \text { of a person located a point } x \text { meters from the source in a } \\
& \text { direction } d \text { averaged over a sector width of } \Theta \text { radians (mrem/ } \\
& y r) \\
U_{p}= & 8766 \mathrm{hr} / \mathrm{yr} \text { for air submersion, and } \\
D_{i p r}^{-}= & \text {dose rate factor for nuclide } i\left(\mathrm{mrem} / \mathrm{hr} \text { per } \mathrm{pCi} / \mathrm{m}^{3}\right) \text { based on a } \\
& \text { half infinite cloud geometry and corrected for the fractional } \\
& \text { penetration of beta and gamma radiations to the appropriate } \\
& \text { tissue depth }\left(7 \times 10^{-3} \mathrm{~cm} \text { for } \mathrm{skin}, 5 \mathrm{~cm}\right. \text { for total body) } \\
\mathbb{Z}_{i}= & \text { annual average concentration }\left(\mathrm{pCi} / \mathrm{m}^{3}\right) \text { of isotope } i \text { at point } \\
& (x, \Theta, d)
\end{aligned}
$$

Equation 12 yields the yearly external dose to a person located at point $(x, \Theta, d)$. The population dose in man-rem/yr is determined by multiplying the dose from Equation 12 by the population located within the sector of the annulus of concern. Values of the dose at point $(x, \theta, d)$ are assumed to be applicable to all individuals located in the annular sector containing that point.

\section{F.4.1.6 Inhalation}

The equation used to calculate air inhalation doses is given by

$$
R_{i p r}=\sum_{i=1}^{n} 10^{12} D_{i p r} \nabla_{i} Q_{i} B
$$

where: 
$10^{12}=$ conversion constant $(\mathrm{pC} i / \mathrm{C} i)$

$\bar{X}_{i}=$ atmospheric dilution factor at point of exposure $\left(\mathrm{s} / \mathrm{m}^{3}\right)$

$Q_{i}=$ release or release rate of nuclide $i$ ( $\mathrm{C} i$ or $\mathrm{C} i / \mathrm{y}$ )

$B=$ ventilation rate of individual exposed [for chronic release, $B=2.31 \times 10^{-4} \mathrm{~m}^{3} / \mathrm{s}$; for acute release $0-8 \mathrm{hr} ., B=3.47 \times 10^{-4} \mathrm{~m}^{3} / \mathrm{s}$ ]

More information on the models used for calculating radiation doses may be found in References 18, 24, and 25.

F.4.2. Model and Calculations for Radiation Exposure Rates in Process Cells

Exposure rates in various cells were calculated using the radioactive material in the cell and the surface area of the contaminated interior. Calculations were made for the remote process cell, high-intermediate-level cel1, high-level cel1, plutonium product cell and the waste vitrification ce11. Exposure rates for other locations were estimated based on these calculations. Table 5.4-1 summarizes the results of these calculations and estimates.

For each of the process cells considered, a cube of equivalent volume was determined. The total interior surface area was calculated and the radioactivity was assumed to be spread evenly on walls, ceiling and floor. In the plutonium product cell, contamination was spread on the walls and ceiling, because the floor has a stainless steel liner, and therefore, should have only small amounts of residual contamination.

The exposure rate was calculated at a point one meter above the floor in the center of the room. Photon flux was determined using disk source geometry as described in Reference 27. Conversion from flux to dose was made using information provided in Reference 28. For fission product spectrum, an energy of $0.6 \mathrm{MeV}$ was assumed. The energy used for the plutonium product cell was $17 \mathrm{keV}$. In the plutonium product cel1, attenuation of the gamma and $x$-rays was taken into consideration.

Bremmsstralung and neutron radiation was considered where applicable, but no significant dose was attributable to these sources. 


\section{F.4.3 Application of Radiation Dose Models}

The radiological impact from the release of radioactive materials during normal decommissioning operations in a reference fuel reprocessing plant was calculated using the information outlined in this section. It was assumed that airborne releases of radioactive material constituted the principal radiological hazard to man. These releases occurred both at ground level and from a $100-m$ stack. Four different radionuclide mixtures were assumed to be released during normal decontamination and decommissioning operations, and these mixtures formed the distribution of radionuclides in source terms for all subsequent radiation dose calculations. These mixtures are listed in Tables F.4-4 F.4-5, F.4-6, and Table F.4-7. Radiation doses factors were calculated for a unit (1 Curie) release of the appropriate mixture of radionuclides. The radiation dose for a specific case was then calculated by multiplying the appropriate unit dose factor by the amount postulated to be released (in Curies) from a particular operation or potential accident.

\section{F.4.3.1 Normal Decommissioning Operational Releases}

Radiation doses resulting from material released during normal decommissioning operations were calculated for a maximum exposed member of the public and for the total population within 80 kilometers (50 miles) of the site. The pathways analyzed for normal operational radionuclide releases were inhalation, air submersion, ingestion of farm products, and exposure to contaminated ground. The first year dose and fifty-year dose commitment were calculated for a one-year chronic intake of radioactive materials as discussed in the previous sections.

The parameters used for calculating radiation doses via ingestion of farm farm products are listed in Table F.4-8. The maximum individual was exposed to contaminated ground $12 \mathrm{hr} /$ day and the average individual for $6 \mathrm{hr} /$ day. 
TABLE F.4-4. Unit Release for FRP During Decommissioning (Typified by the Remote Process (ell)

Radionuclide Curies Radionuclide Curies

\begin{tabular}{|c|c|c|c|}
\hline${ }^{90} \mathrm{Sr}$ & $1.6 \mathrm{E}-1$ & ${ }^{155} \mathrm{Eu}$ & $4.5 E-4$ \\
\hline $90_{Y}$ & $1.6 \mathrm{E}-1$ & ${ }^{239} \mathrm{~Np}$ & 2. $3 \mathrm{E}-4$ \\
\hline $106_{\mathrm{Ru}}$ & $6.8 \mathrm{E}-2$ & ${ }^{238} \mathrm{Pu}$ & $6.4 \mathrm{E}-3$ \\
\hline${ }^{125} \mathrm{Sb}$ & 2. $9 E-3$ & ${ }^{239} \mathrm{Pu}$ & $4.5 E-4$ \\
\hline${ }^{125 \mathrm{~m}_{\mathrm{Te}}}$ & 1.1E-3 & ${ }^{240} \mathrm{Pu}$ & $1.6 \mathrm{E}-3$ \\
\hline${ }^{134} \mathrm{Cs}$ & $4.5 \mathrm{E}-2$ & ${ }^{241} \mathrm{Pu}$ & $1.4 \mathrm{E}-1$ \\
\hline${ }^{137}$ Cs & $2.6 \mathrm{E}-1$ & ${ }^{241} \mathrm{Am}$ & $1.2 \mathrm{E}-2$ \\
\hline${ }^{144} \mathrm{Ce}$ & $3.5 E-2$ & $242 m_{A m}$ & 4. $5 \mathrm{E}-4$ \\
\hline${ }^{144} \mathrm{Pr}$ & $3.5 \mathrm{E}-2$ & ${ }^{243} \mathrm{Am}$ & 2. $3 \mathrm{E}-4$ \\
\hline${ }^{147} \mathrm{Pm}$ & $3.4 \mathrm{E}-2$ & ${ }^{242} \mathrm{~cm}$ & 1. TE-3 \\
\hline${ }^{151_{\mathrm{Sm}}}$ & $3.9 \mathrm{E}-3$ & ${ }^{244} \mathrm{Cm}$ & 1. $6 \mathrm{E}-2$ \\
\hline & $1.4 \mathrm{E}-2$ & & \\
\hline & & Total & 1.0 \\
\hline
\end{tabular}

TABLE F.4-5. Unit Release from the FRP During Decommissioning (Typified by the High Level Liquid Waste Tanks)

Radionuclide Curies Radionuclide Curies

$\begin{array}{llll}{ }^{90} \mathrm{Sr} & 1.8 \mathrm{E}-1 & { }^{154} \mathrm{Eu} & 1.7 \mathrm{E}-2 \\ 90_{\mathrm{Y}} & 1.8 \mathrm{E}-1 & { }^{155} \mathrm{Eu} & 3.0 \mathrm{E}-3 \\ { }^{106} \mathrm{Ru} & 7.7 \mathrm{E}-2 & { }^{239} \mathrm{~Np} & 1.5 \mathrm{E}-4 \\ { }^{125} \mathrm{Sb} & 6.8 \mathrm{E}-3 & { }^{238} \mathrm{Pu} & 2.6 \mathrm{E}-4 \\ { }^{125 m_{\mathrm{Te}}} & 2.8 \mathrm{E}-3 & { }^{241} \mathrm{Pu} & 2.3 \mathrm{E}-3 \\ { }^{134} \mathrm{Cs} & 1.0 \mathrm{E}-1 & { }^{241} \mathrm{Am} & 2.3 \mathrm{E}-3 \\ { }^{137} \mathrm{Cs} & 2.8 \mathrm{E}-1 & { }^{242 \mathrm{~m}_{\mathrm{Am}}} & 3.0 \mathrm{E}-4 \\ { }^{144} \mathrm{Ce} & 2.3 \mathrm{E}-2 & { }^{243} \mathrm{Am} & 1.5 \mathrm{E}-4 \\ { }^{144} \mathrm{Pr} & 2.3 \mathrm{E}-2 & { }^{242} \mathrm{Cm} & 2.0 \mathrm{E}-4 \\ { }^{147} \mathrm{Pm} & 7.7 \mathrm{E}-2 & { }^{244} \mathrm{Cm} & 2.0 \mathrm{E}-2 \\ { }^{151} \mathrm{Sm} & 4.0 \mathrm{E}-3 & & \\ & & \text { Total } & 1.0\end{array}$


TABLE F.4-6. Unit Release from the FRP During Decommissioning (Typified by Plutonium Product Cel1)

\begin{tabular}{|c|c|}
\hline Radionucl ide & Curies \\
\hline${ }^{238} \mathrm{Pu}$ & $4.6 \mathrm{E}-2$ \\
\hline${ }^{239} \mathrm{Pu}$ & $4.6 \mathrm{E}-3$ \\
\hline${ }^{240} \mathrm{Pu}$ & $6.4 \mathrm{E}-3$ \\
\hline $241_{\mathrm{Pu}}$ & $9.1 E-1$ \\
\hline${ }^{241} 1_{A m}$ & $3.2 \mathrm{E}-2$ \\
\hline Total & 1.0 \\
\hline
\end{tabular}

TABLE F.4-7. Unit Release from the FRP During Decommissioning (Typified by Waste Solidification Plant)

Radionuclide Curies $\underline{\text { Radionuclide }}$

\begin{tabular}{|c|c|c|c|}
\hline${ }^{90} \mathrm{Sr}$ & $2.4 \mathrm{E}-1$ & ${ }^{154} \mathrm{Eu}$ & $1.9 \mathrm{E}-2$ \\
\hline $90_{Y}$ & $2.4 \mathrm{E}-1$ & ${ }^{155} \mathrm{Eu}$ & $3.4 \mathrm{E}-4$ \\
\hline${ }^{106} \mathrm{Ru}$ & $1.3 \mathrm{E}-2$ & ${ }^{238} \mathrm{Pu}$ & $3.4 \mathrm{E}-4$ \\
\hline${ }^{125} \mathrm{Sb}$ & $2.7 \mathrm{E}-3$ & ${ }^{239} \mathrm{~Np}$ & 1.7E-4 \\
\hline${ }^{125 m_{\mathrm{Te}}}$ & $1.3 \mathrm{E}-3$ & ${ }^{241} \mathrm{Pu}$ & 2.7E-3 \\
\hline${ }^{134} \mathrm{Cs}$ & 2.7E-2 & ${ }^{24]_{A m}}$ & $4.0 \mathrm{E}-3$ \\
\hline${ }^{137} \mathrm{Cs}$ & $3.8 \mathrm{E}-1$ & $242 m_{A m}$ & $3.4 \mathrm{E}-4$ \\
\hline${ }^{144} \mathrm{Ce}$ & $4.2 E-3$ & ${ }^{243} \mathrm{Am}$ & $1.7 \mathrm{E}-4$ \\
\hline${ }^{144} \mathrm{Pr}$ & $4.2 \mathrm{E}-3$ & ${ }^{242} \mathrm{~cm}$ & $3.4 \mathrm{E}-4$ \\
\hline${ }^{147} \mathrm{Pm}$ & 2. $3 \mathrm{E}-2$ & ${ }^{244} \mathrm{Cm}$ & $2.4 \mathrm{E}-2$ \\
\hline${ }^{151} \mathrm{Sm}$ & $5.4 E-3$ & & \\
\hline & & Total & 1.0 \\
\hline
\end{tabular}


TABLE F.4-8. Parameters Used for Calculation of Radiation Doses from Consumption of Foods

\begin{tabular}{|c|c|c|c|c|c|}
\hline \multirow[b]{2}{*}{ Food } & \multirow{2}{*}{$\begin{array}{l}\text { Holdup } \\
\text { (days) }\end{array}$} & \multicolumn{2}{|c|}{$\begin{array}{c}\text { Consumptipn } \\
\left.(\mathrm{kg} / \mathrm{y})^{(a)}\right)^{n}\end{array}$} & \multirow{2}{*}{$\begin{array}{r}\text { Yield } \\
\left(\mathrm{kg} / \mathrm{m}^{2}\right) \\
\end{array}$} & \multirow{2}{*}{$\begin{array}{l}\text { Growing } \\
\text { Period } \\
\text { (days) }\end{array}$} \\
\hline & & M.I. & Avg. & & \\
\hline Leafy vegetables & 1 & 30 & 15 & 1.5 & 90 \\
\hline $\begin{array}{l}\text { Other above } \\
\text { ground veg. }\end{array}$ & 1 & 30 & 15 & 0.7 & 60 \\
\hline Potatoes & 10 & 110 & 100 & 4 & 90 \\
\hline $\begin{array}{l}\text { Other root } \\
\text { vegetables }\end{array}$ & 1 & 72 & 17 & 5 & 90 \\
\hline Berries & 1 & 30 & 6 & 2.7 & 60 \\
\hline Melons & 1 & 40 & 8 & 0.8 & 90 \\
\hline Orchard fruit & 10 & 265 & 60 & 1.7 & 90 \\
\hline Wheat & 10 & 80 & 72 & 0.72 & 90 \\
\hline Other grain & 1 & 8.3 & 7.5 & 1.4 & 90 \\
\hline Eggs & 1 & 30 & 20 & $0.84^{(c)}$ & 90 \\
\hline Milk & 1 & $274^{(b)}$ & $232^{(b)}$ & $1.3^{(c)}$ & 30 \\
\hline Beef & 15 & 40 & 40 & $0.84^{(c)}$ & 90 \\
\hline Pork & 15 & 40 & 30 & $0.84^{(c)}$ & 90 \\
\hline Poultry & 1 & 18 & 8.5 & $0.84^{(c)}$ & 90 \\
\hline
\end{tabular}

(a) Only that fraction of the diet grown locally and therefore potentially contaminated is listed.

(b) Units of liters/year

(c) Yield of animal feeds, i.e., grain or pasture grass.

The maximum individual is assumed to reside one kilometer from the site where the atmospheric dilution factors were estimated to be $1.0 \times 10^{-7} \mathrm{~s} / \mathrm{m}^{3}$ for elevated releases and $8.0 \times 10^{-6} \mathrm{~s} / \mathrm{m}^{3}$ for ground level releases. These dilution factors were derived by multiplying the average dilution factor taken from Volume 2, Section C.7, Figure C.7-1 by 2.5 to adjust for the maximum sector. The atmosphere dilution factors for calculations of doses to large population groups were $3.4 \times 10^{-9} \mathrm{~s} / \mathrm{m}^{3}$ for elevated releases and $2.7 \times 10^{-7} \mathrm{~s} / \mathrm{m}^{3}$ for ground level releases. 
The radiation doses and dose commitments to the maximum individual from elevated releases of the mixtures previously discussed are listed in Tables F.4-1 F.4-10, F.4-11 and F.4-12. The doses and dose commitments to the large population group from these releases are listed in Tables F.4-13, F.4-14, F.4-15 and F.4-16. To compute doses from a ground level release, divide the $\bar{X} / Q^{\prime}$ for ground level by the $\bar{X} / Q^{\prime}$ for elevated releases (Table C.7-1) and multiply the values in Tables F.4-13 through F.4-16 by this ratio.

TABLE F.4-9. Chronic Radiation Doses and Dose Commitments to the Maximum Individual Due to 100-Meter-High Releases Typified by Those in the Remote Process Cel1

\begin{tabular}{|c|c|c|c|c|}
\hline \multirow[b]{2}{*}{ Pathway } & \multicolumn{4}{|c|}{ lst Year Dose (mrem) } \\
\hline & Total Body & GI-LLI & Bone & Lung \\
\hline Inhalation & $6.4 \mathrm{E}-4$ & $9.0 \mathrm{E}-4$ & $7.4 \mathrm{E}-3$ & $3.9 \mathrm{E}-2$ \\
\hline Ingestion & $3.7 \mathrm{E}-3$ & $7.1 \mathrm{E}-3$ & $6.7 \mathrm{E}-3$ & $3.7 \mathrm{E}-4$ \\
\hline iternal & $7.8 \mathrm{E}-4$ & $(7.8 E-4)$ & $(7.8 E-4)$ & $(7.8 \mathrm{E}-4$ \\
\hline \multirow[t]{2}{*}{ Total } & $.1 E-3$ & $9.6 \mathrm{E}-3$ & $1.5 \mathrm{E}-2$ & $4.0 \mathrm{E}-2$ \\
\hline & \multicolumn{4}{|c|}{ 50-Year Dose Commitment (mrem) } \\
\hline Inhalation & $5.4 \mathrm{E}-2$ & $9.0 E-4$ & $1.3 \mathrm{E}+0$ & $8.4 \mathrm{E}-2$ \\
\hline Ingestion & $5.4 \mathrm{E}-2$ & $7.9 \mathrm{E}-3$ & $2.1 \mathrm{E}-1$ & $6.7 \mathrm{E}-4$ \\
\hline External & $7.8 \mathrm{E}-4$ & $(7.8 \mathrm{E}-4)$ & $(7.8 E-4)$ & $(7.8 \mathrm{E}-$ \\
\hline Total & $1.1 \mathrm{E}-1$ & $9.6 \mathrm{E}-3$ & $1.5 \mathrm{E}+0$ & $8.5 E-2$ \\
\hline
\end{tabular}


TABLE F.4-10. Chronic Radiation Doses and Dose Commitments to the Maximum Individual from 100-Meter-High Releases Typified by Those from the High Level Liquid Waste Tanks

\begin{tabular}{|c|c|c|c|c|}
\hline \multirow[b]{2}{*}{ Pathway } & \multicolumn{4}{|c|}{ Ist Year Dose (mrem) } \\
\hline & Total Body & GI-LLI & Bone & Lung \\
\hline Inhalation & $6.1 E-4$ & $9.6 \mathrm{E}-4$ & $4.2 E-3$ & $2.4 \mathrm{E}-2$ \\
\hline Ingestion & $4.7 E-3$ & $8.6 \mathrm{E}-3$ & 7.7E-3 & $4.8 \mathrm{E}-4$ \\
\hline External & $1.1 E-3$ & $(1.1 E-3)$ & $(1.7 \mathrm{E}-3)$ & $(1.1 E-3)$ \\
\hline \multirow[t]{2}{*}{ Total } & $6.4 \mathrm{E}-3$ & $1.1 E-2$ & $1.3 E-2$ & $2.6 \mathrm{E}-2$ \\
\hline & \multicolumn{4}{|c|}{ 50-Year Dose Commitment (mrem) } \\
\hline Inhalation & $2.5 \mathrm{E}-2$ & $9.6 \mathrm{E}-4$ & 4. $7 \mathrm{E}-1$ & 4. $1 E-2$ \\
\hline Ingestion & $6.7 \mathrm{E}-2$ & $8.6 E-3$ & $2.3 \mathrm{E}-1$ & $8.6 \mathrm{E}-4$ \\
\hline External & $1.1 \mathrm{E}-3$ & $(1.1 E-3)$ & $(1.1 \mathrm{E}-3)$ & $(1.1 \mathrm{E}-3)$ \\
\hline Total & 8.7E-2 & $1.1 \mathrm{E}-2$ & $6.4 \mathrm{E}-1$ & $4.3 \mathrm{E}-2$ \\
\hline
\end{tabular}

TABLE F.4-11. Chronic Radiation Doses and Dose Commitments to the Maximum Individual from 100-Meter-High Releases Typified by Those from the Plutonium Product Cell

\begin{tabular}{|c|c|c|c|c|}
\hline \multirow[b]{2}{*}{ Pathway } & \multicolumn{4}{|c|}{ Ist Year Dose (mrem) } \\
\hline & Total Body & GI-LLI & Bone & Lung \\
\hline Inhalation & $7.1 \mathrm{E}-4$ & $1.1 \mathrm{E}-4$ & $2.1 \mathrm{E}-2$ & $9.4 \mathrm{E}-2$ \\
\hline Ingestion & $4.0 \mathrm{E}-6$ & $6.8 E-4$ & $1.1 \mathrm{E}-4$ & -- \\
\hline External & 4. $4 E-6$ & $(4.4 E-6)$ & $(4.4 E-6)$ & $(4.4 E-6)$ \\
\hline \multirow[t]{2}{*}{ Total } & 7. $2 \mathrm{E}-4$ & $7.9 E-4$ & 2.1E-2 & $9.4 \mathrm{E}-2$ \\
\hline & \multicolumn{4}{|c|}{ 50-Year Dose Commitment (mrem) } \\
\hline Inhalation & $1.7 \mathrm{E}-1$ & $1.1 \mathrm{E}-4$ & $5.8 \mathrm{E}+0$ & $2.9 \mathrm{E}-1$ \\
\hline Ingestion & $2.7 E-4$ & $6.8 \mathrm{E}-4$ & 7. $1 \mathrm{E}-3$ & -- \\
\hline External & $4.4 \mathrm{E}-6$ & $(4.4 E-6)$ & $(4.4 E-6)$ & $(4.4 E-6)$ \\
\hline Total & $1.7 \mathrm{E}-1$ & $7.9 \mathrm{E}-4$ & $5.8 E+0$ & $2.9 \mathrm{E}-1$ \\
\hline
\end{tabular}


TABLE F.4-12. Chronic Radiation Doses and Dose Commitments to the Maximum Individual From 100-Meter-High Releases Typified by Those from the Waste Solidification Plant (WVC)

\begin{tabular}{|c|c|c|c|c|}
\hline \multirow[b]{2}{*}{ Pathway } & \multicolumn{4}{|c|}{ lst Year Dose (mrem) } \\
\hline & Total Body & GI-LLI & Bone & Lung \\
\hline Inhalation & $6.5 E-4$ & $9.6 \mathrm{E}-4$ & $5.2 E-3$ & 2. $9 \mathrm{E}-2$ \\
\hline Ingestion & $4.9 E-3$ & $9.6 \mathrm{E}-3$ & $9.7 E-3$ & 4.7E-4 \\
\hline External & $9.2 E-4$ & $(9.2 E-4)$ & $(9.2 E-4)$ & $(9.2 E-4)$ \\
\hline \multirow[t]{2}{*}{ Total } & $6.5 \mathrm{E}-3$ & 1. $1 \mathrm{E}-2$ & $1.6 \mathrm{E}-2$ & $3.0 \mathrm{E}-2$ \\
\hline & \multicolumn{4}{|c|}{ 50-Year Dose Commitment (mrem) } \\
\hline Inhalation & $3.2 \mathrm{E}-2$ & $9.6 \mathrm{E}-r$ & $5.3 \mathrm{E}-1$ & $4.9 \mathrm{E}-2$ \\
\hline Ingestion & $7.9 \mathrm{E}-2$ & $9.6 E-3$ & $3.1 \mathrm{E}-1$ & $8.7 E-4$ \\
\hline External & $9.2 E-4$ & $(9.2 E-4)$ & $(9.2 E-4)$ & $(9.2 E-4)$ \\
\hline Total & $1.1 \mathrm{E}-1$ & $1.1 \mathrm{E}-2$ & $8.4 \mathrm{E}-1$ & $5.1 E-2$ \\
\hline
\end{tabular}

TABLE F.4-13. Chronic Radiation Doses and Dose Commitments to the Large Population Groups from 100-Meter-High Releases Typified by Those from the Remote Process Cell

\begin{tabular}{|c|c|c|c|c|}
\hline \multirow[b]{2}{*}{ Pathway } & \multicolumn{4}{|c|}{ 1st Year Dose (person-rem) } \\
\hline & Total Body & GI-LLI & Bone & Lung \\
\hline Inhalation & $7.7 \mathrm{E}-2$ & $1.1 \mathrm{E}-1$ & $8.8 \mathrm{E}-1$ & $4.6 \mathrm{E}+0$ \\
\hline Ingestion & $2.8 \mathrm{E}-1$ & 4. $9 \mathrm{E}-1$ & 4. $6 \mathrm{E}-1$ & $3.0 \mathrm{E}-2$ \\
\hline External & $4.8 \mathrm{E}-2$ & $(4.8 E-2)$ & $(4.8 \mathrm{E}-2)$ & $(4.8 E-2)$ \\
\hline \multirow[t]{2}{*}{ Total } & $4.1 E-1$ & $6.5 \mathrm{E}-1$ & $1.4 \mathrm{E}+0$ & $4.7 \mathrm{E}+0$ \\
\hline & \multicolumn{4}{|c|}{ 50-Year Dose Commitment (person-rem) } \\
\hline
\end{tabular}

$\begin{array}{cllll}\text { Inhalation } & 6.5 \mathrm{E}+0 & 1.1 \mathrm{E}-1 & 1.6 \mathrm{E}+2 & 1.0 \mathrm{E}+1 \\ \text { Ingestion } & 3.4 \mathrm{E}+0 & 4.9 \mathrm{E}-1 & 1.3 \mathrm{E}+1 & 5.4 \mathrm{E}-2 \\ \text { External } & 4.8 \mathrm{E}-2 & (4.8 \mathrm{E}-2) & (4.8 \mathrm{E}-2) & (4.8 \mathrm{E}-2) \\ \text { Total } & 1.0 \mathrm{E}+1 & 6.5 \mathrm{E}-1 & 1.7 \mathrm{E}+2 & 1.0 \mathrm{E}+1\end{array}$


TABLE F.4-14. Chronic Radiation Doses and Dose Commitments to the Large Population Group from 100-Meter-High Releases Typified by Those from the High Level Liquid Waste Tanks

\begin{tabular}{|c|c|c|c|c|}
\hline \multirow[b]{2}{*}{ Pathway } & \multicolumn{4}{|c|}{ 1st Year Dose (person-rem) } \\
\hline & Total Body & GI-LLI & Bone & Lung \\
\hline Inhalation & 7.3E-2 & $1.1 \mathrm{E}-1$ & $5.1 E-1$ & 2. $9 E+0$ \\
\hline Ingestion & $3.5 \mathrm{E}-1$ & $5.3 \mathrm{E}-1$ & $5.3 E-1$ & 3. $8 \mathrm{E}-2$ \\
\hline cternal & 6. $7 \mathrm{E}-2$ & $(6.7 E-2)$ & $(6.7 E-2)$ & $(6.7 E-2)$ \\
\hline \multirow[t]{2}{*}{ Total } & $4.9 \mathrm{E}-1$ & 7. 1E-1 & $1.1 E+0$ & $3.0 E+0$ \\
\hline & \multicolumn{4}{|c|}{ 50-Year Dose Commitment (person-rem) } \\
\hline Inhalation & $3.0 \mathrm{E}+0$ & 1.1E-1 & $4.9 \mathrm{E}+1$ & $4.9 \mathrm{E}+0$ \\
\hline Ingestion & $3.9 \mathrm{E}+0$ & $5.3 \mathrm{E}-1$ & $1.5 \mathrm{E}+1$ & $6.9 \mathrm{E}-2$ \\
\hline External & $6.7 \mathrm{E}-2$ & $(6.7 E-2)$ & $(6.7 E-2)$ & $(6.7 E-2)$ \\
\hline Total & 7.01 & 7. IE-1 & $6.4 \mathrm{E}+1$ & $5.0 E+0$ \\
\hline
\end{tabular}

TABLE F.4-15. Chronic Radiation Doses and Dose Commitments to the Large Population Group from 100-Meter-High Releases Typified by Those from the Plutonium Product Cell

\begin{tabular}{c} 
Pathway \\
\hline Inhalation \\
Ingestion \\
External \\
Total
\end{tabular}

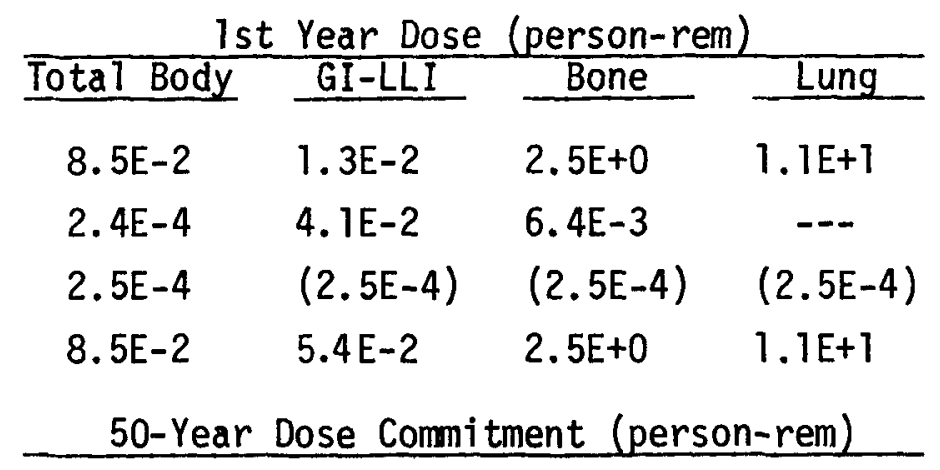

Inhalation

2. $0 \mathrm{E}+1 \quad$ 1. $3 \mathrm{E}-2 \quad 7.0 \mathrm{E}+2 \quad 3.4 \mathrm{E}+1$

Ingestion

$1.6 \mathrm{E}-2$

4. $1 \mathrm{E}-2$

4. 3E-1

External

2. $5 \mathrm{E}-4$

(2.5E-4)

(2.5E-4)

(2.5E-4)

Total

2. $0 E+1$

5. $4 \mathrm{E}-2$

$7.0 \mathrm{E}+2$

$3.4 \mathrm{E}+1$ 
TABLE F.4-16. Chronic Radiation Doses and Dose Commitments to the Large Population Group from 100-Meter-High Releases Typified by Those from the Waste Solidification Plant (WVC)

\begin{tabular}{|c|c|c|c|c|}
\hline \multirow[b]{2}{*}{ Pathway } & \multicolumn{4}{|c|}{ 1st Year Dose (person-rem) } \\
\hline & Total Body & GI-LLI & Bone & Lung \\
\hline Inhalation & $7.8 \mathrm{E}-2$ & $1.1 \mathrm{E}-1$ & $6.3 \mathrm{E}-1$ & $3.4 \mathrm{E}+0$ \\
\hline Ingestion & $3.6 E-1$ & $6.0 \mathrm{E}-1$ & $6.6 \mathrm{E}-1$ & $3.8 \mathrm{E}-2$ \\
\hline Externa 1 & $2.7 \mathrm{E}-1$ & $(2.1 E-1)$ & $(2.1 \mathrm{E}-1)$ & $(2.1 E-1)$ \\
\hline \multirow[t]{2}{*}{ Total } & $6.5 \mathrm{E}-1$ & $9.2 \mathrm{E}-1$ & $1.5 \mathrm{E}+0$ & $3.6 \mathrm{E}+0$ \\
\hline & \multicolumn{4}{|c|}{ 50-Year Dose Commitment (person-rem) } \\
\hline Inhalation & $3.8 \mathrm{E}+0$ & 1.1E-1 & $6.3 \mathrm{E}+1$ & $5.9 \mathrm{E}+0$ \\
\hline Ingestion & $5.1 E+0$ & $6.0 \mathrm{E}-1$ & $1.9 \mathrm{E}+1$ & $7.1 \mathrm{E}-2$ \\
\hline Externa1 & $2.7 \mathrm{E}-1$ & $(2.7 E-1)$ & $(2.1 \mathrm{E}-1)$ & $(2.1 \mathrm{E}-1)$ \\
\hline Total & $9.1 E+0$ & $9.2 \mathrm{E}-1$ & $8.2 E+1$ & $6.2 E+0$ \\
\hline
\end{tabular}

\section{F.4.3.2 Postulated Accidental Releases}

Radiation doses from postulated accidental releases during decommissioning operations were calculated only for the maximum individual. The first-year dose and the fifty-year dose commitment were calculated for an acute (short-time) exposure to airborne radioactive material. The pathways analyzed for accidental releases were air submersion and inhalation. Because of the short time interval of an accidental release, the food pathway contribution to radiation dose was neglected. Mixtures given in Tables F.4-4, F.4-5, F.4-6, and F.4-7 were also used to compute the doses.

The maximum individual was assumed to reside one kilometer from the site where the atmospheric dilution factors were was assumed to be $1.5 \times 10^{-5} \mathrm{~s} / \mathrm{m}^{3}$ for elevated releases and $4.3 \times 10^{-4} \mathrm{~s} / \mathrm{m}^{3}$ for ground level releases. These dilution factors were taken from Regulatory Guide 1.3 for release time as long as 8 hours release time. (29)

The radiation dose and dose commitment factors used were computed as discussed in previous sections. The ventilation rate $\left(3.47 \times 10^{-4} \mathrm{~m}^{3} / \mathrm{s}\right)$ given in legulatory Guide $1.3^{(29)}$ was used in computing inhalation doses. 
The radiation doses and dose commitments to the maximum individual from elevated accidental releases are listed in Tables F.4-17 to F.4-20.

TABLE F.4-17. Radiation Doses and Dose Commitments to the Maximum Individual from 100-Meter-High Accidental Releases Typified by Those from the Remote Process Cel1

\begin{tabular}{|c|c|c|c|c|}
\hline \multirow[b]{2}{*}{ Pathway } & \multicolumn{4}{|c|}{ 1st Year Dose (mrem) } \\
\hline & Total Body & GI-LLI & Bone & Lung \\
\hline Inhalation & $3.1 E-1$ & $2.0 \mathrm{E}-1$ & $4.4 \mathrm{E}+0$ & $1.4 E+1$ \\
\hline External & $3.6 \mathrm{E}-3$ & $(3.6 E-3)$ & $(3.6 \mathrm{E}-3)$ & $(3.6 \mathrm{E}-3)$ \\
\hline \multirow[t]{2}{*}{ Total } & $3.1 E-1$ & $2.0 \mathrm{E}-1$ & $4.4 \mathrm{E}+0$ & $1.4 \mathrm{E}+1$ \\
\hline & \multicolumn{4}{|c|}{ 50-Year Dose Commitment (mrem) } \\
\hline Inhalation & $1.2 E+1$ & $2.0 E-1$ & $3.0 E+2$ & $1.9 E+1$ \\
\hline External & $3.6 \mathrm{E}-3$ & $(3.6 \mathrm{E}-3)$ & $(3.6 \mathrm{E}-3)$ & $(3.6 \mathrm{E}-3)$ \\
\hline Total & $1.2 E+1$ & $2.0 \mathrm{E}-1$ & $3.0 E+2$ & $1.9 E+1$ \\
\hline
\end{tabular}

TABLE F.4-18. Radiation Doses and Dose Commitments to the Maximum Individual from 100-Meter-High Accidental Releases Typified by Those from the High Level Liquid Waste Tanks

\begin{tabular}{|c|c|c|c|c|}
\hline \multirow[b]{2}{*}{ Pathway } & \multicolumn{4}{|c|}{ 1st Year Dose (mrem) } \\
\hline & Total Body & GI-LLI & Bone & Lung \\
\hline Inhalation & $2.7 \mathrm{E}-1$ & $2.2 \mathrm{E}-1$ & 2. $4 \mathrm{E}+0$ & $8.1 E+0$ \\
\hline External & $4.6 \mathrm{E}-3$ & $(4.6 \mathrm{E}-3)$ & $(4.6 E-3)$ & $(4.6 E-3)$ \\
\hline \multirow[t]{2}{*}{ Total } & $2.7 \mathrm{E}-1$ & $2.2 E-1$ & $2.4 E+0$ & $8.1 E+0$ \\
\hline & \multicolumn{4}{|c|}{ 50-Year Dose Commitment (mrem) } \\
\hline Inhalation & $5.6 \mathrm{E}+0$ & $2.2 E-1$ & $9.3 E+1$ & $9.3 E+0$ \\
\hline Externa 1 & $4.6 \mathrm{E}-3$ & $(4.6 \mathrm{E}-3)$ & $(4.6 E-3)$ & $(4.6 \mathrm{E}-3)$ \\
\hline Total & $5.6 \mathrm{E}+0$ & $2.2 E-1$ & $9.3 E+1$ & $9.3 E+0$ \\
\hline
\end{tabular}


TABLE F.4-19. Radiation Doses and Dose Commitments to the Maximum Individual from 100-Meter-High Accidental Releases Typified by Those from the Plutonium Product Cell

\begin{tabular}{|c|c|c|c|c|}
\hline \multirow[b]{2}{*}{ Pathway } & \multicolumn{4}{|c|}{ 1st Year Dose (mrem) } \\
\hline & Total Body & GI-LLI & Bone & Lung \\
\hline Inhalation & $4.3 \mathrm{E}-1$ & $2.5 \mathrm{E}-2$ & 1. $3 E+1$ & $3.6 \mathrm{E}+1$ \\
\hline External & 2. $5 E-6$ & $(2.5 E-6)$ & $(2.5 E-6)$ & $(2.5 E-6)$ \\
\hline \multirow[t]{2}{*}{ Total } & $4.3 \mathrm{E}-1$ & $2.5 \mathrm{E}-2$ & $1.3 E+1$ & $3.6 E+1$ \\
\hline & \multicolumn{4}{|c|}{ 50-Year Dose Commitment (mrem) } \\
\hline Inhalation & $3.8 \mathrm{E}+1$ & $2.5 \mathrm{E}-2$ & 1. $3 E+3$ & $6.4 \mathrm{E}+1$ \\
\hline External & $2.5 \mathrm{E}-6$ & $(2.5 E-6)$ & 2.5E-6) & $(2.5 E-6)$ \\
\hline Total & $3.8 E+1$ & $2.5 \mathrm{E}-2$ & 1. $3 E+3$ & $6.4 E+1$ \\
\hline
\end{tabular}

TABLE F.4-20. Radiation Doses and Dose Commitments to the Maximum Individual From 100-Meter-High Accidental Releases Typified by Those from the Waste Solidification Plant (WVC)

\begin{tabular}{c} 
Pathway \\
\hline Inhalation \\
External \\
Total
\end{tabular}

\begin{tabular}{|c|c|c|c|}
\hline \multicolumn{4}{|c|}{ 1st Year Dose (mrem) } \\
\hline Total Body & GI-LLI & Bone & Lung \\
\hline $3.0 E-1$ & $2.2 \mathrm{E}-1$ & $3.0 E+0$ & $9.6 \mathrm{E}+0$ \\
\hline $4.7 E-3$ & (4.7E-3) & $(4.7 \mathrm{E}-3)$ & $(4.7 E-3)$ \\
\hline $3.0 \mathrm{E}-1$ & $2.2 \mathrm{E}-1$ & 3. $0 \mathrm{E}+0$ & $9.6 \mathrm{E}+0$ \\
\hline \multicolumn{4}{|c|}{ 50-Year Dose Commitment (mrem) } \\
\hline $7.2 E+0$ & 2.2E-1 & $1.2 E+2$ & $1.1 E+1$ \\
\hline $4.7 E-3$ & $(4.7 E-3)$ & $(4.7 E-3)$ & $(4.7 E-3)$ \\
\hline $7.2 E+0$ & 2.2E-1 & $1.2 \mathrm{E}+2$ & $1.1 \mathrm{E}+1$ \\
\hline
\end{tabular}

\section{F.4.4 Effect of Radioactive Decay on Radiation Dose Calculations}

Figures F.4-1 through F.4-8 give the relative first year and fifty year dose commitment to selected organș for various FRP area radionuclide inventories as a function of time since shut down. A reference release of $10^{-3}$ of the total inventory for each FRP area was arbitrarily assumed. 


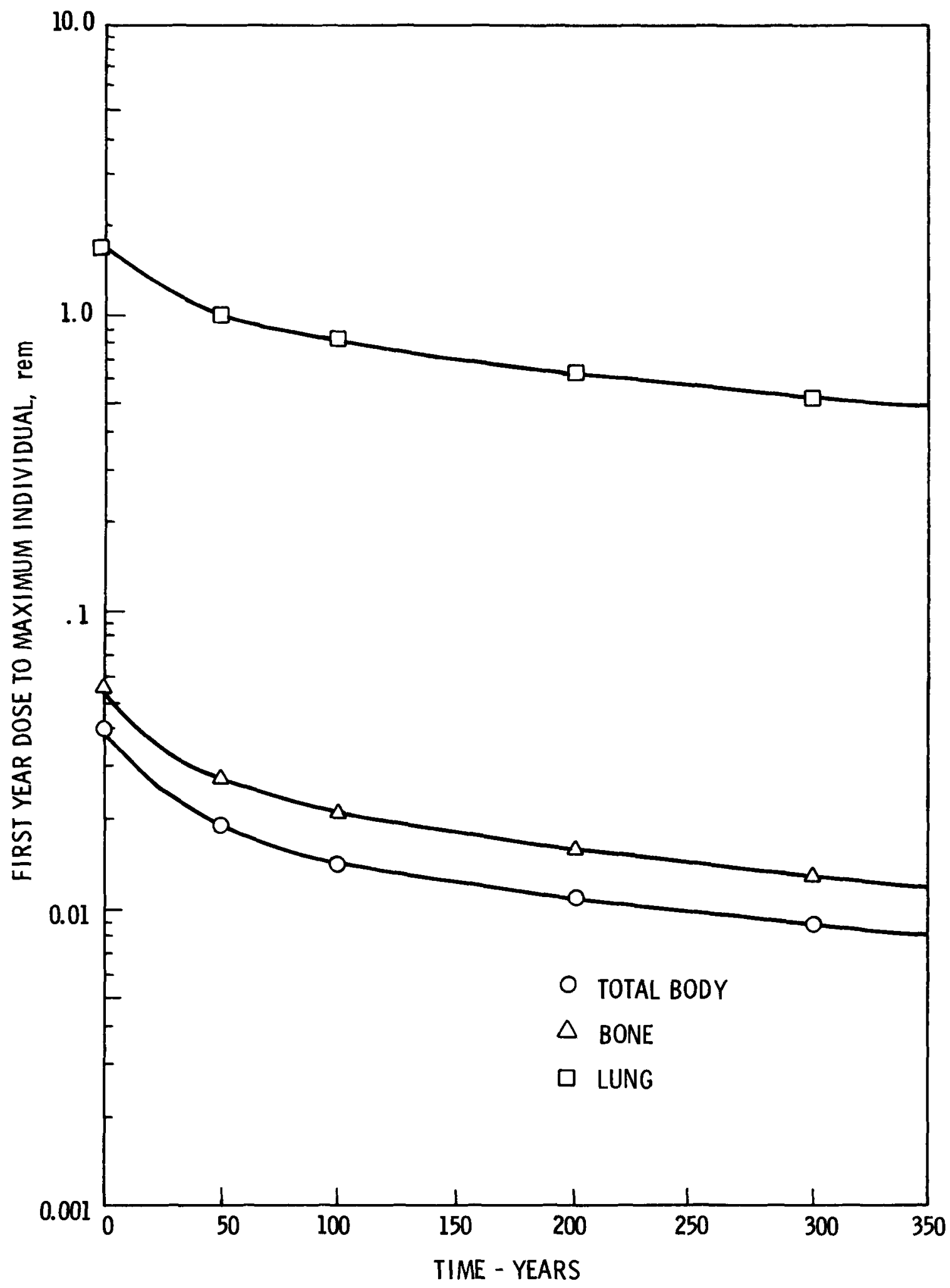

FIGURE F.4-1. First Year Radiation Dose for a Reference Release from the Remote Process Cell 


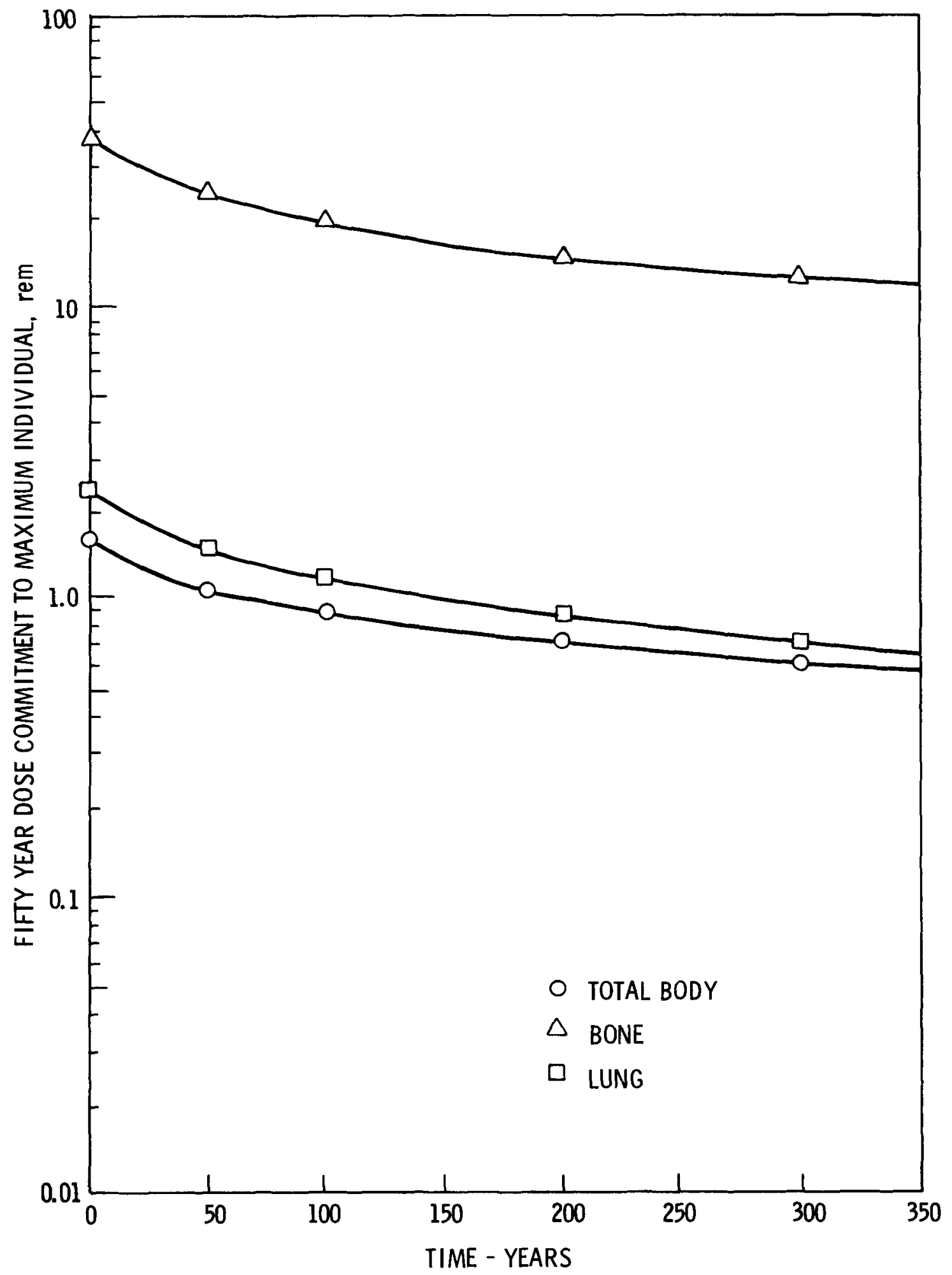

FIGURE F.4-2. Fifty Year Radiation Dose Commitment for a Reference Release from the Remote Process Cell 


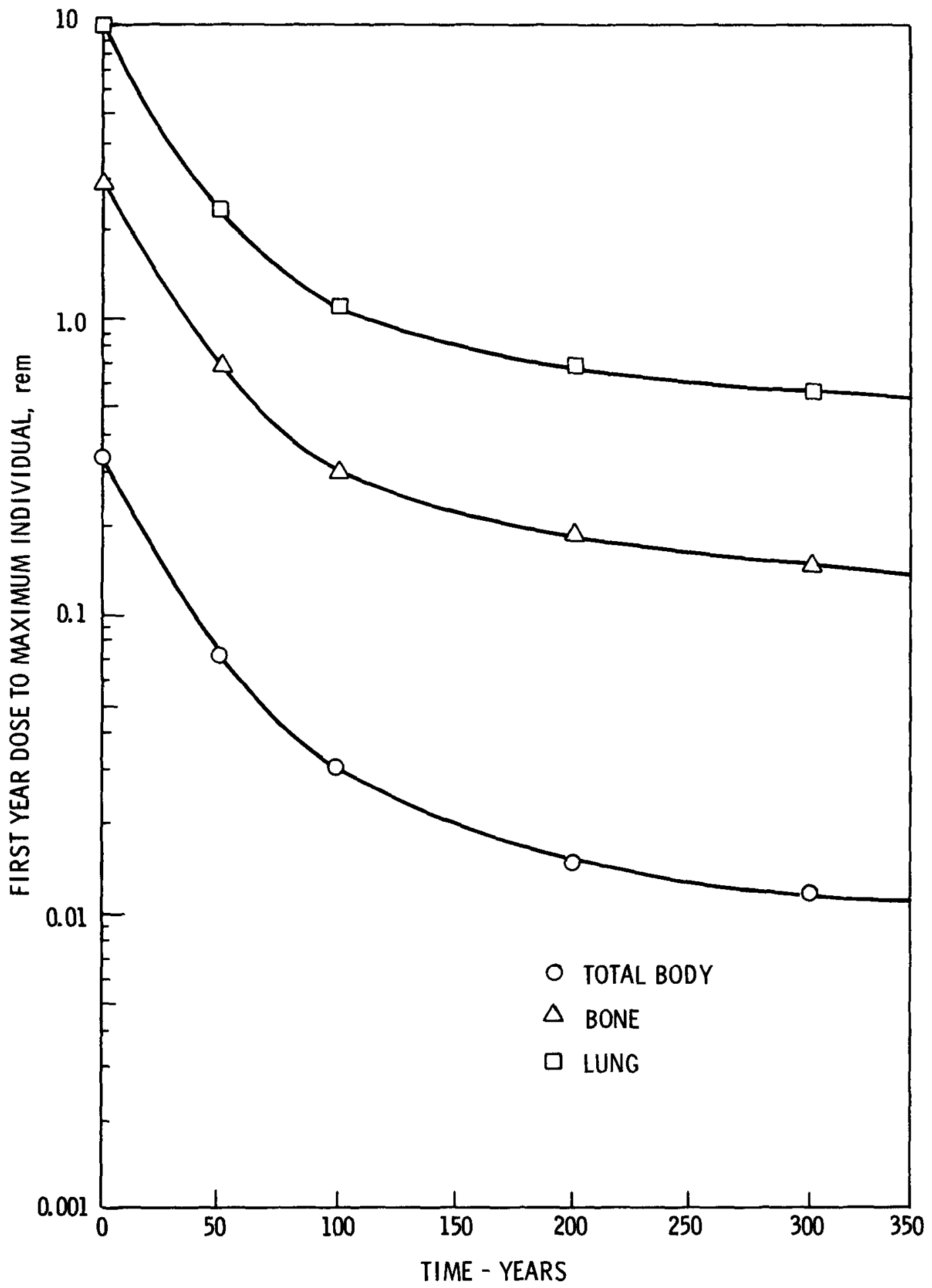

FIGURE F.4-3. First Year Radiation Dose for a Reference Release for a High-Level Waste Storage Tank 


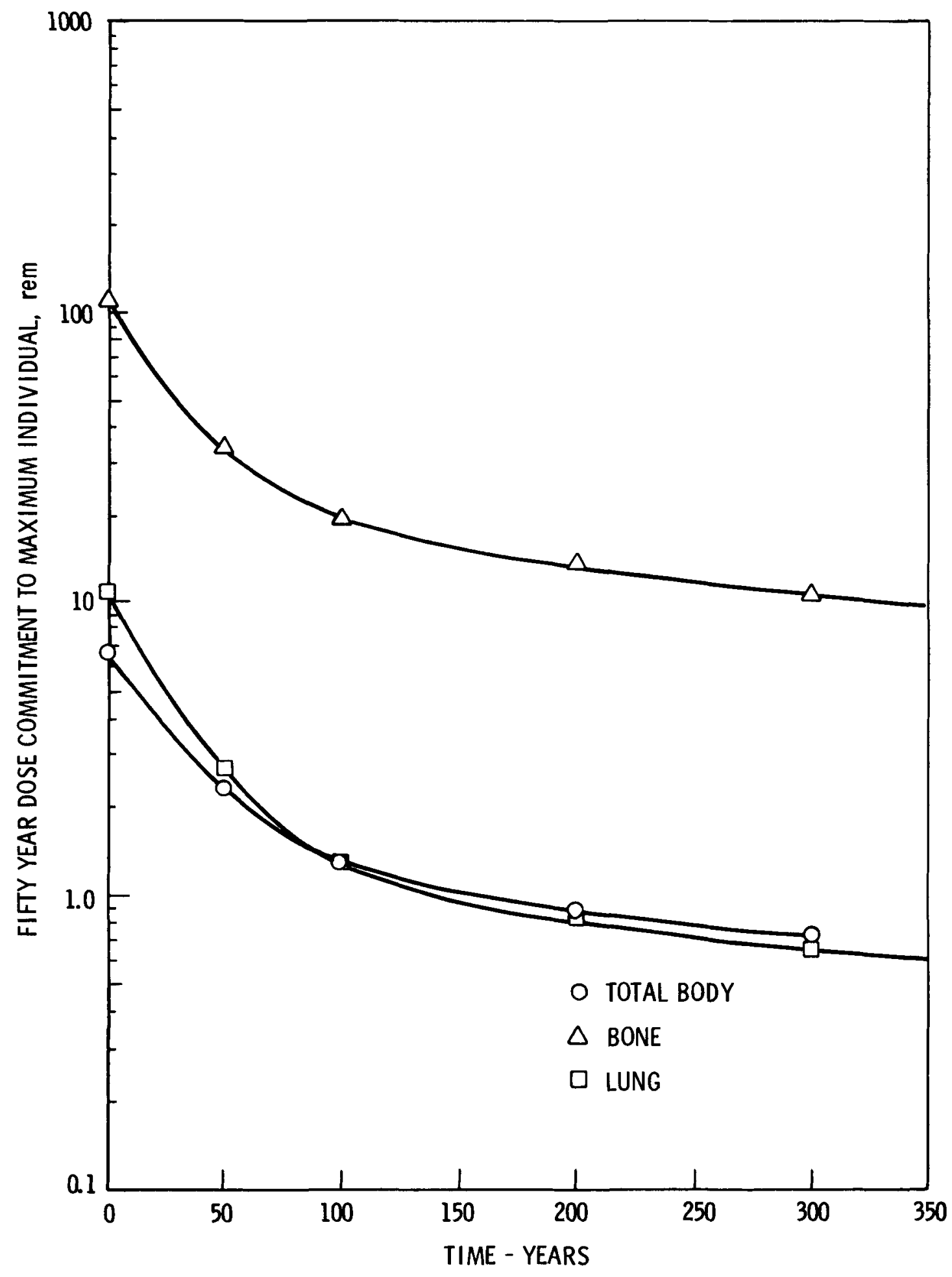

FIGURE F.4-4. Fifty Year Radiation Dose Commitment for a Reference Release from a HighLevel Waste Storage Tank 


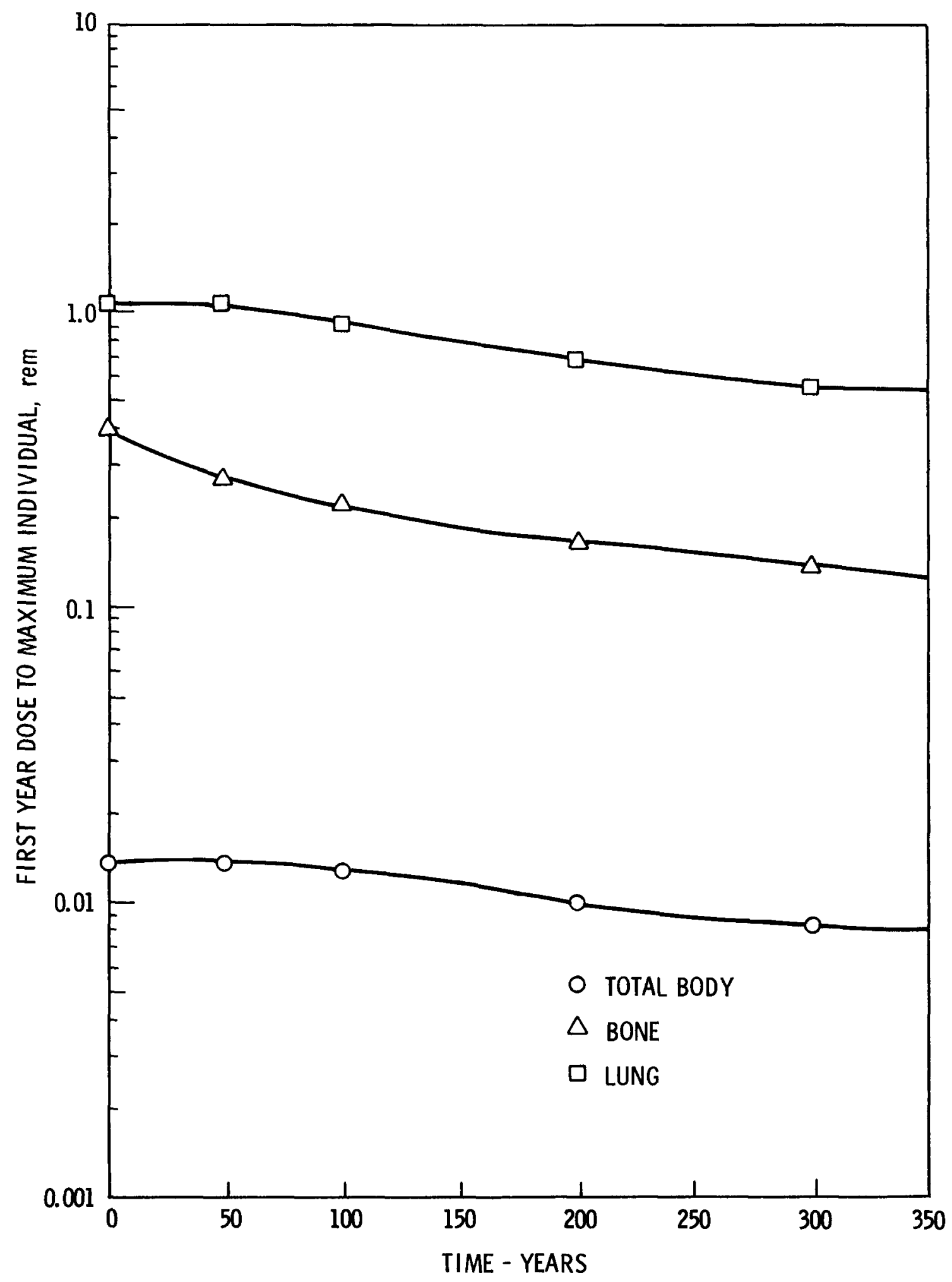

FIGURE F.4-5. First Year Radiation Dose for a Reference Release from the Plutonium Product Cell 


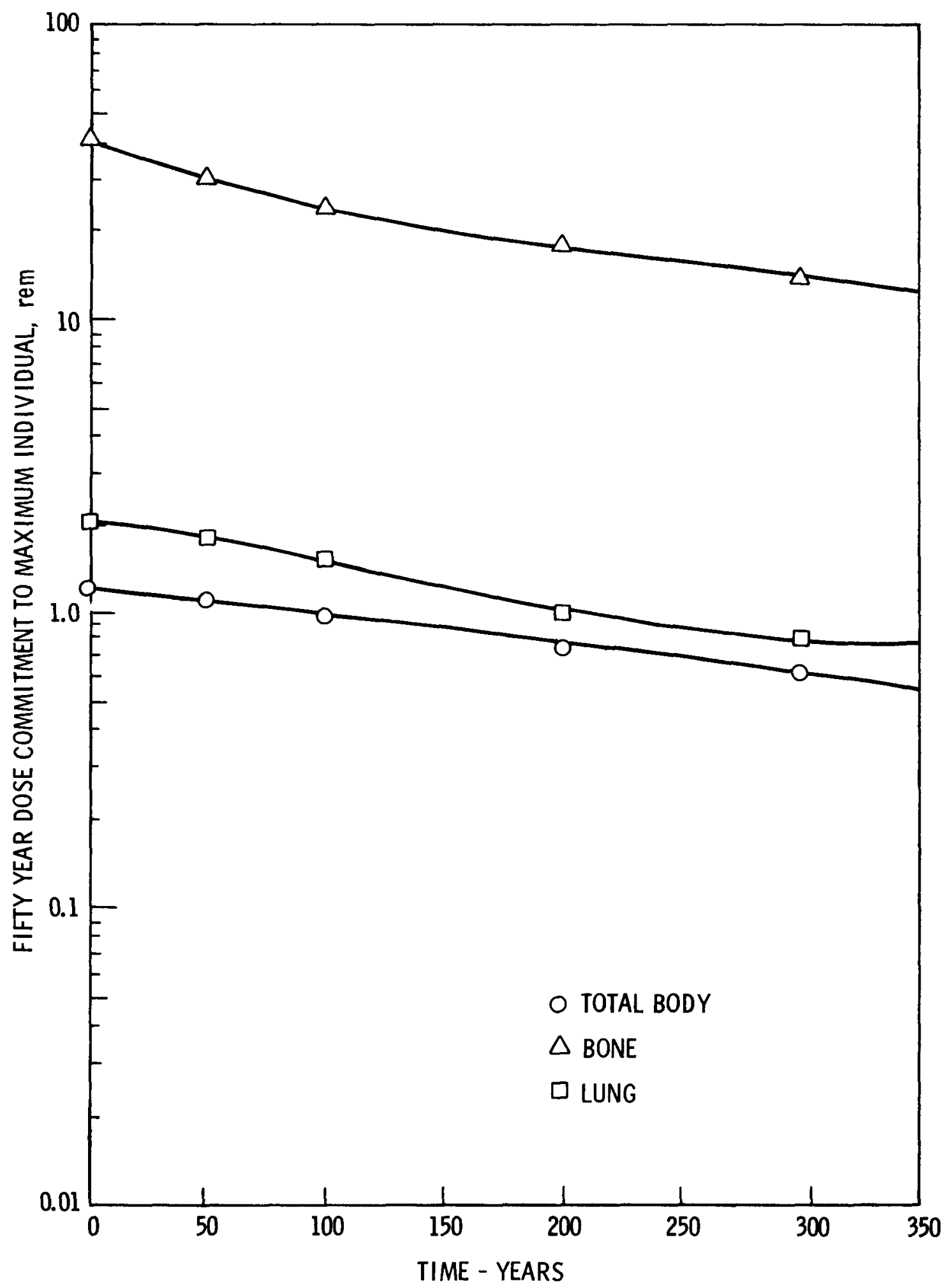

FIGURE F.4-6. Fifty Year Radiation Dose Commitment for a Reference Release from the Plutonium Product Cell 


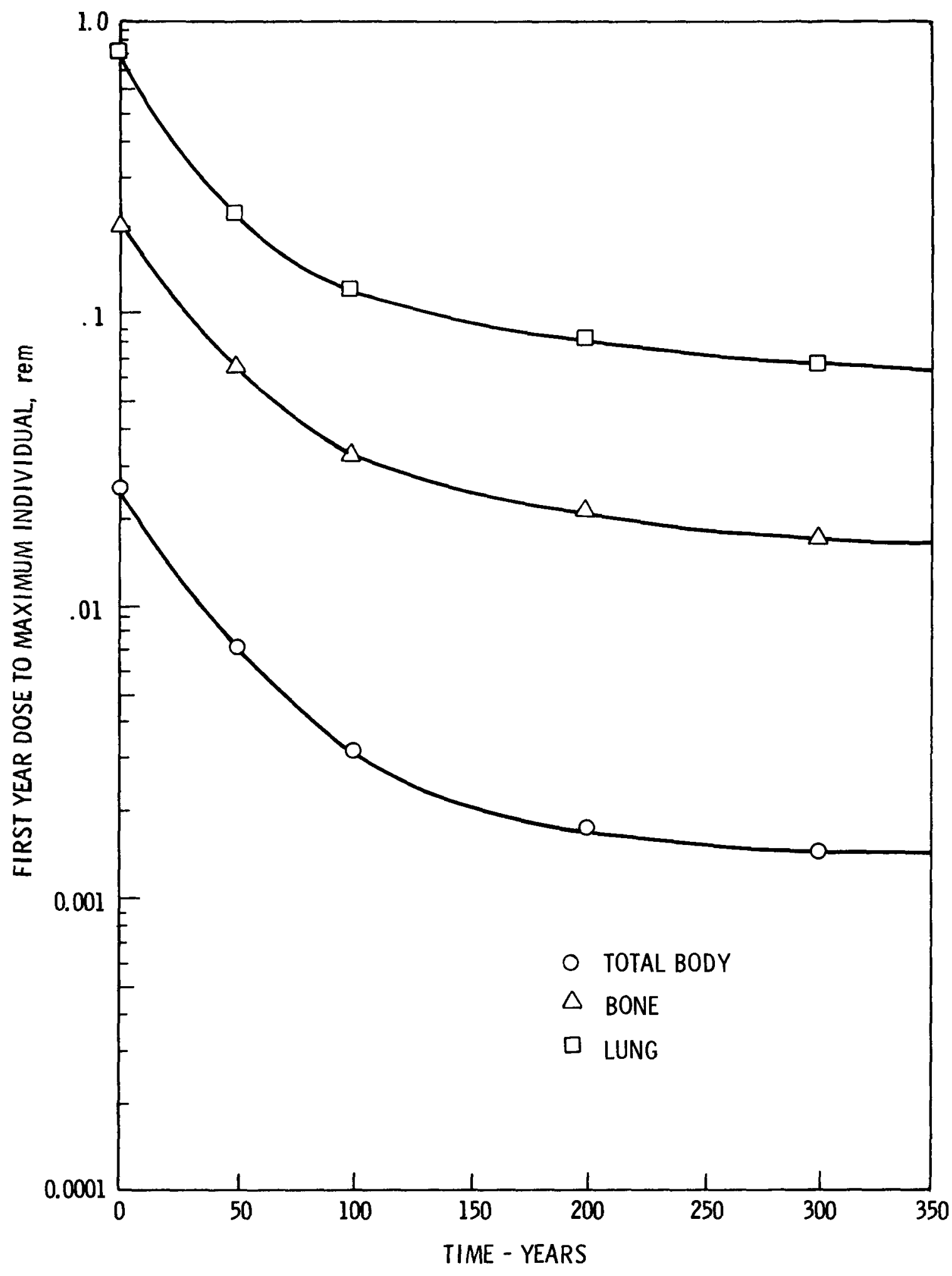

FIGURE F.4-7. First Year Radiation Dose for a Reference Release from the Waste Solidification Plant 


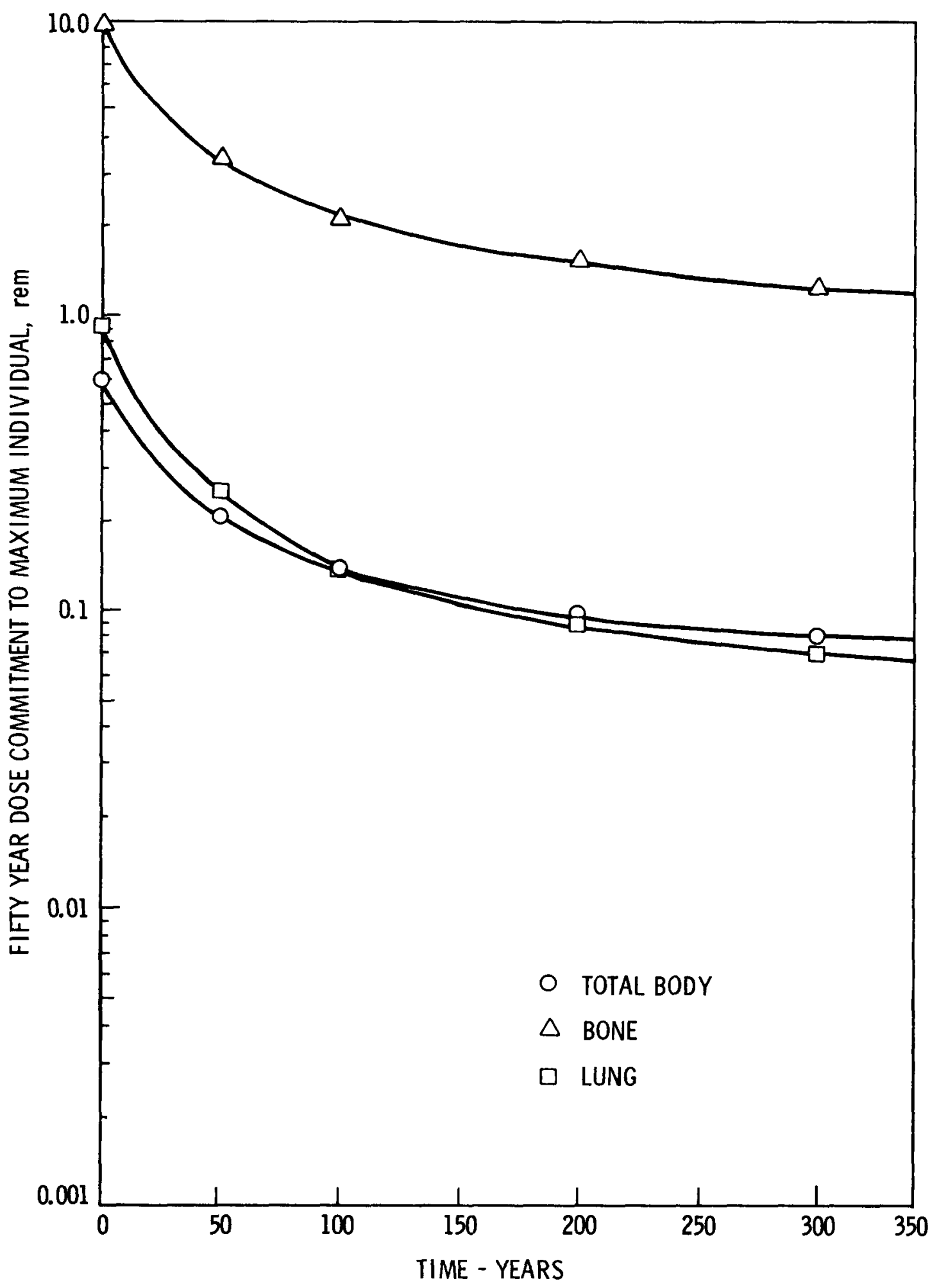

FIGURE F.4-8. Fifty Year Radiation Dose Commitment for a Reference Release from the Waste Solidification Plant 


\section{REFERENCES}

1. I. S. Jones and S. F. Pond, "Some Experiments to Determine the Resuspension Factor of Plutonium from Various Surfaces," Surface Contamination. Pergamon Press, NY, 1967, p. 83.

2. H. Glaubermann, W. B. Bootman and J. J. Breslin, "Studies on the Significance of Surface Contamination," Surface Contamination. Pergamon Press, NY, 1967, p. 169.

3. K. Stewart, "The Resuspension of Particulate Materials from Surfaces," Surface Contamination. Pergamon Press, NY, 1967, p. 63.

4. Staff, Siting of Fuel Reprocessing Plants and Waste Management Facilities. ORNL-4457, Oak Ridge Nationa 7 Laboratory, Oak Ridge, TN, JuTy 1970, p. $8-47$.

5. D. McConnon and J. F. Nemec, Experiences in Decontamination/Decommissioning of the Elk River Reactor. United Power Associates, Elk Rivers, MN, ApriT 1974. Paper presented to Second AEC Environmental Protection Conference, Albuquerque, NM, April 16-19, 1974, Figure 11.

6. J. Mishima, L. C. Schwendiman, and C. A. Radasch, Plutonium Release Studies III. Release from Heated Plutonium Bearing Powders. BNWL-786, Bat telle, Pacific Northwest Laboratories, Richland, WA, JuTy 1968, p. 19.

7. B. R. Fish, R. L. Walker, G. N. Royster, and J. L. Thompson, "Redispersion of Settled Particulates," Surface Contamination. B. R. Fish, ed., Pergamon Press, NY, 1967, p. 75.

8. J. Mishima and L. C. Schwendimann, Fractional Airborne of Uranium Representing Plutonium During the Burning of Contaminated Waste. BNWL-1730, Battelle, Pacific Northwest Laboratories, Richland, WA, June 1975, p. C.12.

9. J. M. Selby et al., Considerations in the Assessment of the Consequences of Effluents from Mixed Oxide Fuel Fabrication Plants. BNWL-1697, Rev. 1, Battelle, Pacific Northwest Laboratories, Richland, WA, October 1970, p. 6.

10. J. Mishima and L. C. Schwendiman. The Amount and Characteristics of Plutonium Made Airborne Under Thermal Stress. BNWL-SA-3379, Battelle, Pacific Northwest Laboratories, Richland, WA, October 1970, P. 6.

11. Questions and Answers. Allied Gulf Nuclear Services, Inc., Barnwell Nuclear Fuel Plant PSAR. 
12. Operational Accidents and Radiation Exposures Experienced Within the USAEC 1943-1970, WASH-1192, 1971.

13. Title 49, Transportation, Parts 170-189, Code of Federal Regulations, Office of the Federal Register, General Services Administration, January 1977.

14. Title 10, Energy, Part 71, Code of Federal Regulations, Office of the Federal Register, General Services Administration, January 1977.

15. Fairbairn, Atomic Energy Review, Vor. II, p. 843, 1973.

16. Directorate of Regulatory Standards, Environmental Safety of Transportation of Radioactive Materials to and From Nuclear Power Plants, WASH-1238, U.S. Atomic Energy Commission, Washington, DC, 1972.

17. Intragency Radiological Assistance P1an, ERDA-10, Energy Research and Development Administration, Washington, DC, April 1975.

18. Soldat, J. K., et al, Models and Computer Codes for Evaluating Environmental Radiation Doses, USAEC Report BNWL-1754, Pacific Northwest Laboratory, Richland, WA, February 1974.

19. Baker, D. A., User Guide For Computer Program Food, USERDA Report BNWL-2209 Pacific Northwest Laboratories, Richland, WA, February 1977.

20. International Commission on Radiological Protection, Report of ICRP Committee II on Permissible Dose for Internal Radiation, ICRP Publication 2, Pergamon Press, NY, 1959.

21. Fletcher, J. F. and W. L. Dotson (compilers), HERMES - Digital Computer Code for Estimating Regional Radiological Effects from the Nuclear Power Industry, USAEC Report HEDL-TME-71-169, Hanford Engineering Development Laboratory, Richland, WA, 1971.

22. Soldat, J. K., Modeling of Environmental Pathways and Radiation Doses from Nuclear Facilities, USAEC Report BNWL-SA-3939, Pacific Northwest Laboratory Richland, WA, 1971.

23. Hoenes, G. R., and J. K. Soldat, Age-Specific Radiation Doses Commitment Factors for a One Year Chronic Intake, NU-Reg. 0172, a report for the U.S. Nuclear Regulatory Commission, to be publishedas a supplement to Regulatory Guide 1.109 . 
24. Baker, D. A., G. R. Hoenes and J. K. Soldat, "FOOD - An Interactive Code to Calculate Internal Radiation Doses from Contaminated Food Products", in Environmental Modeling and Simulation, Proceedings of a conference held in Cincinnati, OH, April 20-22, 1976, pp. 204-208, EPA, Washington, DC, 1976.

25. Brenchley, D. L., J. K. Soldat, J. A. McNeese, E. C. Watson, Environmental Assessment Methodology for the Nuclear Fuel Cycle, USERDA Report BNWL-2219, Pacific Northwest Laboratory, Richland, WA, JuTy 1977.

26. Ng. Y. C., et al., Prediction of the Maximum Dosage to Man from the Fallout of Nuclear Devices - IV, Handbook for Estimating the Maximum Internal Dose from Radionuclides Released to the Biosphere, USAEC Report, UCRL-50164, Lawrence Radiation Laboratory, University of California, Livermore, CA, 1968.

27. Engineering Compendium on Radiation Shielding Volume I: Shielding

Fundamentals and Methods, Chapter 6, "Extended Radiation Sources (Point Kernal Ingregations)", by E. P. Blizzard, A. Foderaro, N. G. Gosseu, and E. E. Kovalev, pp. 363-368, edited by R. G. Jaequer, C. P. Blizzard A. B. Chitton, M. Grotenhuis, A. Hönig, Th. A. Jaequer, and H. H. Eisenlohr.

28. Radiological Health Handbook, U.S. Department of Health, Education and Welfare, U.S. Public Health Service, Revised edition January 1970, U.S. Gov't Printing Office, p. 132.

29. Directorate of Regulatory Standards, Assumptions Used for Evaluating the Potential Radiological Consequences of a Loss of Coolant Accident for Boiling Water Reactors, Regulatory Guide 1.3, USAEC, Washington DC, üune 1974 . 
FINANCIAL CONSIDERATIONS IN DECOMMISSIONING

This appendix contains information in support of Section 10 of Volume 1, Alternative Approaches to Financing Decomissioning. Included are definitions of important terms, derivations of expressions needed to eyaluate costs for comparisons, and some illustrative calculations of costs, as well as some ration ale for selection of interest and discount rates for use in these calculations.

\section{G. 1 DEFINITION OF TERMS}

Interest Rate

Inflation Rate

Discount Rate

Present Value of Money
The rate of return on capital invested in normal securities, i.e., bonds, certificates of deposit, and similar financial instruments The rate of increase in cost of goods and services, on an annual basis, as determined from the nation's economic indicators by the Federal Department of Labor.

The rate of return on capital that could have been realized in alternative investments, if the money were not committed to the plan being evaluated, i.e., the opportunity cost of alternative investments. This cost is equivalent to the weighted average cost of capita1. (1) For an investor-owned corporation, the weighted average cost of capital should reflect the corporation's cost for debt and equity capital and the proportions of debt, equity, and retained earnings which are used for capital investments. (2)

When different business activities require disbursement of funds over different time frames, it is difficult to compare the 
actual cost of each activity to the sponsoring organization. One generally accepted method of placing these various disbursements on a common basis is to compute the value of those disbursements in terms of current dollars, i.e., the present value of money to be paid out or received at some time other than the present. For an investor, "the present value of a future payment or series of payments is the present investment necessary to secure the promise of that future payment or series of payments, with interest at a given rate. "(3)

\section{G.2 DERIVATIONS OF RELATIONSHIPS FOR COST COMPARISONS}

The goal of each of the three approaches to providing financing for decommissioning as discussed in Section 10 of Volume 1 , is to have the appropriate amount of money available when it is needed for decommissioning. In this section, the expressions used to compare the costs of the different approaches are derived.

Let $i$ be the available interest rate/interest period,

$j$ be the inflation rate over the same time period,

$k$ be the discount rate over the same time period,

$n$ be the number of time periods considered,

$P$ be the present value of a sum of money,

$S$ be the sum of money which is equivalent to $P$ when $P$ is compounded over $n$ time periods with an interest rate $i$.

Option I - Payment of Decommissioning Costs After Plant Shutdown (Pay When Incurred)

The present value of a sum of money, $S$, to be paid $n$ years later is given by:

$$
P=\frac{S}{(1+k)^{n}}
$$


If the amount $S$ (the estimated decommissioning costs) is escalated by inflatic the present value of $S$ (for Option I) becomes:

$$
P_{I}=\frac{s(1+j)^{n}}{(1+k)^{n}}
$$

Option II - Creation of a Sinking Fund with Annual Payments (Annual Payment Sinking Fund)

In this case, the estimated costs, $S$, escalated for inflation are paid by the creation of a sinking fund that receives payments each year of facility operation. At the end of the first year of the plant's life an amount $R_{0}$ is paid into the sinking fund. No interest is earned during the first year. At the end of the second year of operation $R_{0}(7+j)$ is paid into the fund. During the second year $(i)\left(R_{0}\right)$ interest is earned on the invested fund. Thus, at the end of the second year the fund has a total of $R_{0}+R_{0}(1+j)+i R_{0}$ dollars.

A closed form expression for the amount of money in the fund can be deriv by considering each year's payment as a separate sinking fund. Thus, the firs year's payment will be $R_{0}(1+i)$ at the end of year two years, $R_{0}(1+i)(1+i)$ at $t$ end of year three, and so on. At the end of the thirtieth year of operations will total $R_{0}(1+i)^{n-1}$, or $R_{0}(1+i)^{29}$, dollars. Similarly the second year payme $R_{0}(1+j)$ will earn compounded interest for 28 years and will ultimately total $R_{0}(1+j)(1+i)^{n-2}$, or $R_{0}(1+j)(1+i)^{28}$. The total value of the sinking fund at th end of year $n$ must be equal to the anticipated decommissioning costs in dollar of the year of shutdown, as given by:

$$
S(1+j)^{n}=R_{0} \sum_{a=1}^{n}(1+j)^{a-1}(1+i)^{n-a} .
$$

The initial payment is:

$$
R_{0}=\left[\frac{s(1+j)^{n}}{\sum_{a=1}^{n}(1+j)^{a-1}(1+i)^{n-a}}\right],
$$

and the $b^{\text {th }}$ annual payment will be:

$$
R_{b}=R_{0}(1+j)^{b-1} \text {. }
$$


The present value of the $b^{\text {th }}$ annual payment is:

$$
P_{b}=R_{0} \frac{(1+j)^{b-1}}{(1+k)^{b}} \text {. }
$$

Thus, the present value of the series of payments is:

$$
P_{I I}=R_{0} \sum_{b=1}^{n} \frac{(1+j)^{b-1}}{(1+k)^{b}}=\left[\frac{s(1+j)^{n}}{\sum_{a=1}^{n}(1+j)^{a-1}(1+i)^{n-a}}\right] \sum_{b=1}^{n} \frac{(1+j)^{b-1}}{(1+k)^{b}}
$$

Option III - Payment of Estimated Decommissioning Costs into a Trust Fund at Facility Startup (Prepaid Sinking Fund)

In this case the full amount of the estimated costs, $S$, is deposited into a trust account when the facility begins operation. After one year the amount in the account will be $S(1+i)$ and the amount required to meet the estimated costs will be $S(1+j)$. Thus, the difference between these amounts, $S(j-i)$ is refunded if $i>j$ or an additional payment is required if $j>i$. The amount present after the adjustment is made is just $S(1+j)$ at the end of year one. The present value of the trust account is given by:

$$
P_{1}=s+\frac{s(j-i)}{(1+k)}
$$

After the second year, the amount present after adjustments is $s(1+j)^{2}$, and the adjustment for that year is $S(1+j)(j-i)$. The present value of the adjusted account is:

$$
P_{2}=s+\frac{s(j-i)}{(1+k)}+\frac{s(1+j)(j-i)}{(1+k)^{2}}
$$

Extension of this series to $n$ years results in the amount present after $n$ years being $S(1+j)^{n}$ as required, the adjustment for that year is $S(1+j)^{n-1}(j-i)$, and the present value of the adjusted account is

$$
s+\frac{S(j-i)}{(1+k)}+\frac{S(1+j)(j-i)}{(1+k)^{2}}+\cdots+\frac{s(1+j)^{n-1}(j-i)}{(1+k)^{n}}
$$


or

$$
P_{\text {III }}=S\left\{1+(j-i) \sum_{a=1}^{n} \frac{(1+j)^{a-1}}{(1+k)^{a}}\right\}
$$

When $i=j$, this expression reduces to just $S$. When $i>j, P$ is less than $S$ due $t_{1}$ the refunds which are appropriately discounted, and when $j>i, P$ is greater thal -S due to the discounted additional payments which are required.

\section{G. 3 RATIONALE FOR SELECTION OF INTEREST AND DISCOUNT RATES USED IN COST COMPARISON CALCULATIONS}

The cost of capital will generally be different for different types of corporations. For investor-owned utilities, the cost of capital can be approx mated by the overall rate of return allowed by the state utility regulatory commission, ${ }^{(4)}$ currently in the $8-10 \%$ range. For example, Minnesota Power and Light was recently allowed a $9.57 \%$ overall rate of return, ${ }^{(5)}$ Pacific Power anc Light $9.17 \%,(6)$ and Montana-Dakotas Utilities $8.66 \%$.

Publicly-owned utilities have no equity financing and their cost of capita can be approximated by using the interest rates on their long-term bonds. Thes rates are generally lower than can be obtained on investor-owned utility bonds since the interest payments are not subject to Federal income taxes. For example, Washington Public Power Supply System AAA bonds, due in the year 2012, pay $5.70 \%$ interest.

An overall review of the financing alternatives for nuclear fuel cycle facilities should include all three categories of ownership (publicly-owned utility, investor-owned utility, and investor-owned corporation) and the respec tive percentages of each facility type owned by each category. Essentially all commercial non-reactor nuclear facilities are owned by investor-owned corporations. About $87 \%$ of 211 nuclear power reactors presently operating or planned in the U.S. are owned by investor-owned utilities, with the remaining 13\% owned by publicly-owned utilities. (8) The number of commercial non-reactor nuclear facilities is very small compared with the number of reactors involved. Thus, the discount rate should be weighted heavily toward the rate appropriate for 
investor-owned utilities, or in the $8-10 \%$ range. Interest rates obtainable frof stable, secure investments are generally several percentage points less than the current discount rates, reflecting the lower risk involved, or in the $6-8 \%$ range.

\section{G.4 CALCULATION OF ANNUAL COSTS FOR SINKING FUNDS}

The bth annual payment required into the sinking fund for Option II can be computed from

$$
R_{b}=\frac{s(1+j)^{n}}{\sum_{a=1}^{n}(1+j)^{a-1}(1+i)^{n-a}}(1+j)^{b-1}
$$

This expression has been evaluated for $S=\$ 56$ million, and for values of $i$ and $j$ ranging from $4 \%$ to $10 \%$, and $n=30$ years.

Some representative values are given in the following table:

TABLE G.4-1. Annual Sinking Fund Payments (Option II) in Millions of Dollars

Estimated Costs $=\$ 56$ million, Facility Operating Life $=30$ years

\begin{tabular}{|c|c|c|c|c|c|}
\hline \multirow[b]{2}{*}{$i=4 \%$} & \multirow[b]{2}{*}{ Year } & \multicolumn{4}{|c|}{ Inflation Rate } \\
\hline & & $4 \%$ & $6 \%$ & $8 \%$ & $10 \%$ \\
\hline & 1 & 1.941 & 2.573 & 3.306 & 4.127 \\
\hline & 5 & 2.271 & 3.248 & 4.497 & 6.043 \\
\hline & 10 & 2.763 & 4.348 & 6.608 & 9.732 \\
\hline & 15 & 3.362 & 5.817 & 9.708 & 15.673 \\
\hline & 20 & 4.090 & 7.784 & 14.265 & 25.241 \\
\hline & 25 & 4.976 & 10.418 & 20.959 & 40.651 \\
\hline & 30 & 4.055 & 13.941 & 30.797 & 65.469 \\
\hline
\end{tabular}

Cumulative Fund Total

$\$ 181.630 \quad \$ 321.636 \quad \$ 563.509 \quad \$ 977.167$ 
TABLE G.4-1. Annual Sinking Fund Payments (Option II) in Millions of Dollars (cont'd)

\begin{tabular}{|c|c|c|c|c|c|}
\hline \multirow[b]{2}{*}{$i=8 \%$} & \multirow[b]{2}{*}{ Year } & \multicolumn{4}{|c|}{ Inflation Rate } \\
\hline & & $4 \%$ & $6 \%$ & $8 \%$ & $10 \%$ \\
\hline & 1 & 1.066 & 1.490 & 2.016 & 2.646 \\
\hline & 5 & 1.246 & 1.880 & 2.742 & 3.874 \\
\hline & 10 & 1.517 & 2.517 & 4.030 & 6.238 \\
\hline & 15 & 1.845 & 3.367 & 5.921 & 10.048 \\
\hline & 20 & 2.245 & 4.505 & 8.700 & 16.181 \\
\hline & 25 & 2.730 & 6.031 & 12.783 & 26.060 \\
\hline & 30 & 3.323 & 8.069 & 18.784 & 41.969 \\
\hline $\begin{array}{l}\text { Cumulat } \\
\text { Tota }\end{array}$ & ve Fun & $\$ 181.630$ & $\$ 321.636$ & $\$ 563.509$ & $\$ 977.169$ \\
\hline
\end{tabular}

The $b^{\text {th }}$ annual adjustment to the prepaid sinking fund can be computed from

$$
R_{b}=S(j-i)(1+j)^{b-1}
$$

This expression has been evaluated for values of $i=8 \%$ and $j=4,6,8$. and $10 \%$, $S=\$ 56$ million, and $b$ ranging from 1 to 30 years. Some representation values ar given in Table G.4-2.

TABLE G.4-2. Annual Adjustments to the Prepaid Sinking Fund (Option III) in Millions of Dollars

Estimated Costs $=\$ 56$ million Facility Operating Life $=30$ years

\begin{tabular}{|c|c|c|c|c|c|}
\hline \multirow[b]{2}{*}{$i=8 \%$} & \multirow[b]{2}{*}{ Year } & \multicolumn{4}{|c|}{ Inflation Rate } \\
\hline & & $4 \%$ & $6 \%$ & $8 \%$ & $10 \%$ \\
\hline & 1 & -2.240 & -1.120 & 0 & +1.120 \\
\hline & 5 & -2.620 & -1.498 & 0 & +1.639 \\
\hline & 10 & -3.189 & -1.892 & 0 & +2.640 \\
\hline & 15 & -3.879 & -3.389 & 0 & +6.849 \\
\hline & 25 & -5.743 & -4.534 & 0 & +11.032 \\
\hline & 30 & -6.986 & -6.068 & 0 & +17.767 \\
\hline
\end{tabular}

Cumulative Fund

Total

$101.630 \quad \$ 321.636 \quad \$ 563.509 \quad \$ 977.167$ 


\section{REFERENCES}

1. R. W. Johnson, Capital Budgeting, Wadsworth Publishing Co. Inc, Belmont, CA, pp 48, 1970.

2. W. G. Lewellen, The Cost of Capital, Wadsworth Publishing Co. Inc. Beimont, CA, $196 \overline{9}$.

3. E. L. Grant, W. G. Ireson and R. S. Leavenworth, Principles of Engineering Economy, 6th edition, The Ronald Press Co., New York, 1976.

4. Ibid, pp 487.

5. Electrical Week, McGraw-Hi11, January 3, 1977, pp. 4.

6. Electrical Week, McGraw-Hi11, January 17, 1977, pp. 7.

7. Electrical Week, McGraw-Hi11, May 23, 1977, pp. 9.

8. World List of Nuclear Power Plants, Nuclear News Buyers Guide, pp. 58-63, February 1977. 